
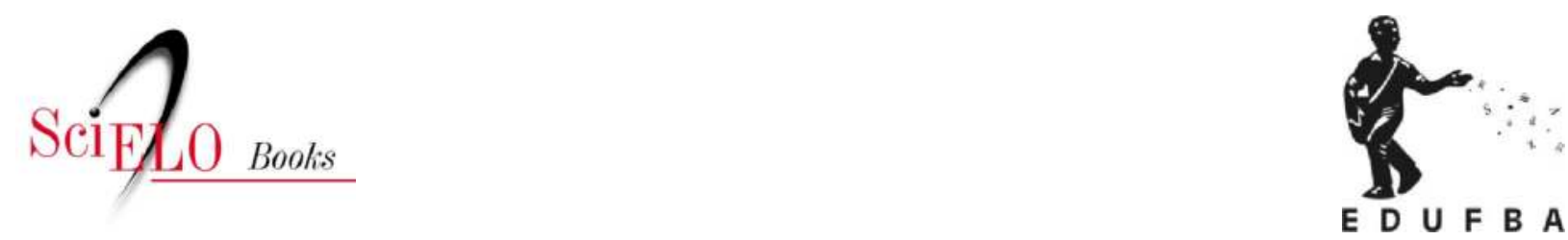

\title{
Europa, França e Bahia
}

difusão e adaptação de modelos urbanos (Paris, Rio e Salvador)

\author{
Eloísa Petti Pinheiro
}

PINHEIRO, EP. Europa, França e Bahia: difusão e adaptação de modelos urbanos (Paris, Rio e Salvador) [online]. 2nd ed. Salvador: EDUFBA, 2011, 368p. ISBN 978-85-232-1191-2. Available

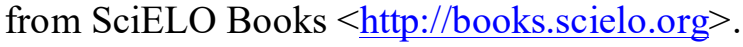

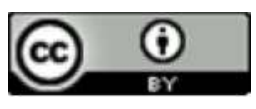

All the contents of this work, except where otherwise noted, is licensed under a Creative Commons Attribution 4.0 International license.

Todo o conteúdo deste trabalho, exceto quando houver ressalva, é publicado sob a licença Creative Commons Atribição 4.0.

Todo el contenido de esta obra, excepto donde se indique lo contrario, está bajo licencia de la licencia Creative Commons Reconocimento 4.0. 


\section{Europa, França e Bahia difusão e adaptação de modelos urbanos \\ (Paris, Rio e Salvador)}

$2^{\mathrm{a}}$ Edição 
UNIVERSIDADE FEDERAL DA BAHIA

REITORA

Dora Leal Rosa

VICE-REITOR

Luiz Rogério Bastos Leal

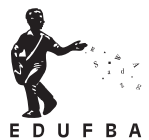

EDITORA DA UNIVERSIDADE FEDERAL DA BAHIA

DIRETORA

Flávia Goullart Mota Garcia Rosa

CONSELHO EDITORIAL

Alberto Brum Novaes

Angelo Szaniecki Perret Serpa

Caiuby Álves da Costa

Charbel Niño El Hani

Cleise Furtado Mendes

Dante Eustachio Lucchesi Ramacciotti

Evelina de Carvalho Sá Hoisel

José Teixeira Cavalcante Filho

Maria Vidal de Negreiros Camargo

\section{fapesb 胃}

Fundação de Amparo

à Pesquisa do Estado da Bahia 
Eloísa Petti Pinheiro

\section{Europa, França e Bahia difusão e adaptação de modelos urbanos (Paris, Rio e Salvador)}

$2^{\mathrm{a}}$ Edição

EDUFBA

Salvador

2011 
(C)2002 by Eloísa Petti Pinheiro.

Direitos para esta edição cedidos à Editora da Universidade Federal da Bahia.

Feito o depósito legal.

2a Edição: 2011

Projeto Gráfico, Editoração e Arte Final

Gabriela Nascimento

Revisão

$1^{\text {a Revisão }}$

Simone de Pinho Lima

Revisão Técnica

Marlene Lage Cajazeira Ramos

Revisão Final

Ana Maria de Carvalho Luz (1 ${ }^{\text {a }}$ Edição)

Biblioteca Central - UFBA

Pinheiro, Eloísa Petti.

Europa, França e Bahia : difusão e adaptação de modelos urbanos (Paris, Rio e Salvador) / Eloísa Petti Pinheiro. - 2 ed. - Salvador : EDUFBA, 2011.

366 p. il.

ISBN 987-85-232-0790-8

Trabalho apresentado originalmente como tese de doutorado.

1. Haussmann, Georges Eugene, Barão, 1809-1991 - Contribuições em renovação urbana. 2. Paris - Modelos arquitetônicos - Sec. XIX. 3. Rio de Janeiro (RJ) - Modelos arquitetônicos - Sec. XIX. 4. Salvador (BA) - Planejamento urbano - Sec. XIX. 5. Salvador (BA) - Projetos e plantas. 6. Salvador (BA) - História. 7. Cidades e vilas - Planejamento Urbano. I. Título.

CDD: 711.4

Editora filiada à
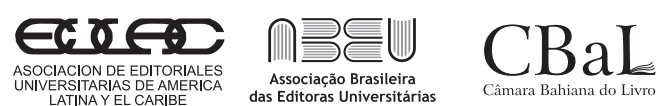

Editora da UFBA

Rua Barão de Jeremoabo

$\mathrm{s} / \mathrm{n}$ - Campus de Ondina

40170-115 - Salvador - Bahia

Tel.: +55 71 3283-6164

Fax: +55 71 3283-6160

www.edufba.ufba.br

edufba@ufba.br 


\section{Oropa, França e Bahia}

$E$ as naus de Manuel Furtado

herança de sua tia?

- Continuam, mar em fora, navegando noite e dia...

Caminham para "Pasárgada", para o reino da poesia.

Herdou-as Manuel Bandeira, que ante minha choradeira, me deu a menor que havia!

- As eternas Naus-do-Sonho, de "Oropa, França e Baía"...

Ascenso Ferreira, 1955

\section{Um Canto que saiu das Senzalas}

O rei mandou me chamar O rei mandou me chamar Para casar com sua filha Só de dote ele me dava Só de dote ele me dava

Oropa, França e Bahia

Me (a)lembrei do meu ranchinho

Da roça, do meu feijão

Hum! Hum!

O rei mandou me chamar...

Ah, seu rei, não quero não

Hum! Hum!

(Motivo dos pretos do Recôncavo Baiano)

Anônimo 



\section{À minha família Ao meu pai Maurício À minha mãe Therezinha Ao meu irmão Roberto}

E a Clarinha que chegou para completar a família. 



\author{
Prefácio $2^{\text {a }}$ Edição 11 \\ Prefácio $\mathbf{1}^{\text {a }}$ Edição 15 \\ Apresentação 21
}

Um comentário inicial 25

Parte I. O Estudo

Capítulo 1. O debate sobre as reformas urbanas 37

Algumas reflexões $\quad 38$

Sobre os processos urbanos $\quad 40$

Sobre estratégias e teorias urbanísticas $\quad 47$

Sobre as reformas urbanas $\quad 53$

Os argumentos para intervir $\quad 56$

Por que intervir 57

Como intervir 60

Para que intervir $\quad 62$

Capítulo 2. Haussmannização ou haussmannizações? 67

Antecedentes de um modelo 69

A implantação de um modelo 76

A difusão de um modelo 83

\section{Parte II. Os Casos}

Capítulo 3. O caso do Rio de Janeiro 91

A capital do País 91

Conhecendo a cidade do século XIX 92

(Trans)formando a cidade $\quad 100$

Alguns projetos para a cidade $\quad 111$ 
Prefácio $2^{\mathrm{a}}$ edição

\section{De Barcelona a Rio, del mar al mar}

\section{De Ciudad Olímpica a Ciudad Olímpica}

Era el otoño del año 1993, y el lugar no podía ser más adecuado, en el aula de la primera clase de un máster de historia urbana. La ciudad, Barcelona. Ese día tuve la gran suerte de sentarme al lado de una estudiante que acababa de llegar de Brasil. Apenas hablaba castellano y nadie le había contado que en Barcelona se hablaba, también, catalán. El profesor utilizaba esta lengua en su primera clase y Eloísa estaba desconcertada. Había llegado para quedarse cuatro años que, en ese momento, parecía mucho tiempo, y regresar a su país con la tesis doctoral. Había elegido Barcelona porque era una ciudad con mar, ella no podría vivir sin el mar. Había nacido en Rio de Janeiro y vivía en Salvador de Bahía. El mar siempre, por todas partes. Además Barcelona era la ciudad postolímpica y le interesaba entender y vivir la transformación que supuso para la ciudad los juegos olímpicos del 92. Quién nos iba a decir, años después, cuando la profesora Eloísa ya es una investigadora de reconocido prestigio y un referente en el mundo académico de su país, que Rio estaría preparando una cita olímpica. Dos ciudades con mar, dos ciudades olímpicas.

Ese día, en esa aula, la profesora Eloísa, inicio este libro. Un libro que es la culminación de una de sus líneas de investigación, convirtiéndola en 
una de las mayores especialistas de la historia de esas dos ciudades, Rio de Janeiro y Salvador de Bahía. Y ese día, en esa aula tuve la suerte de sentarme a su lado y de empezar a descubrir un país, una cultura y unas gentes que ya no me abandonarían. Hay encuentros que amplían miradas y horizontes, que enriquecen y nutren. Esa fue mi suerte. Desde entonces Brasil es un país que acompaña mi trayectoria vital y que hasta ese momento conocía muy poco. Y aunque ahora parezca extraño, porque Brasil se está situando en entre los países de referencia internacional, entonces era una país lejano, casi ignorado. Aunque durante las olimpiadas en Barcelona supimos que tenían la mejor afición del mundo. Ningún otro país tuvo una afición, más alegre, entregada y solidaria con sus deportistas, que Brasil. En ese recorrido que me ha llevado a conocer un país enorme, la profesora Eloísa ha estado siempre allí, formando parte de esa afición particular que con el mismo entusiasmo y fidelidad a su país, contando, mostrando lugares y paisajes, sugeriendo músicas y libros. Y de estos, dos que me han emocionado, Cidade Partida de Zuenir Ventura y Brasil, País de futuro de Stefan Zweig.

En aquella aula aprendimos historia urbana y aprendimos a mirar las ciudades de otro modo. Porque las ciudades son, para la profesora Eloísa, su locus profesional, pero también una de sus referencias vitales. De aquella aula salimos con un alto nivel de conocimiento sobre las transformaciones urbanas de los últimos dos siglos, especialmente de la ciudad de Barcelona. Y desde esa comprensión, podemos ver la ciudad de un modo más profundo. Aprender a valorar lo que hoy ofrece estos lugares urbanos, sus proyectos de futuro, sus ausencias y sus presencias.

En un mundo urbano como el actual en las ciudades nos jugamos el futuro, por eso es tan importante reconocer su pasado, entender sus transformaciones, intuir sus fracasos. Las políticas urbanas son las que más pueden cambiar la vida cotidiana de los ciudadanos: las políticas de vivienda, de transporte, la cohesión social, la reducción de la pobreza, el derecho al trabajo, el incremento de las tasas de escolarización, todo esto y mucho más se concreta en los entorno urbanos. Si la ciudad no tiene proyectos o estos fracasan las políticas sectoriales no pueden desarrollarse pues no existe el entorno adecuado para que cristalicen. Las ciudades son actores del futuro, son agentes políticos de primer orden y siempre han estado y están en transformación. Unos cambios que requieren modelos urbanos, ciudades que guíen a otras. En el XIX la ciudad era París, como muy bien explica el libro de la profesora Eloísa, a finales del siglo XX Barcelona irrumpió con un modelo urbano propio que consolidó con los Juegos del 92, y muchas ciu- 
dades copiándolo lo mejoraron. En este momento las ciudades de América Latina ganan protagonismo en la constelación de ciudades en el mundo. De ellas salen ideas y propuestas que las pueden situar en la estela de las urbes que marcan caminos de futuro. Muchas de ellas se están reinventando y se consolidan en el mapa internacional.

Todo ello en idas y venidas de ideas, de energías, de profesionales y académicos que van y vienen cargando en sus maletas y en sus mentes nuevas sabidurías, apostando por pensamientos transformadores, ensanchando mentes, intensificando conocimiento. Y en eso está la profesora Eloísa, desde aquel lejano 1993, en ampliar el conocimiento sobre la transformación de las ciudades, en contarnos la adaptación de los modelos urbanos que se dieron en el siglo XIX en París, Rio y en Salvador. Y también en difundir el conocimiento de Barcelona en Brasil y al revés, de Brasil en Barcelona. La profesora Eloísa, es un puente entre dos mundos que, sin ella nos conoceríamos mucho menos. Agradecerle pues con estas notas preliminares que nos haya ayudado a ensanchar horizontes, a establecer pasarelas de saberes entre estos dos mares, entre estas dos ciudades. Porque ya nada de Barcelona le es ajeno, habla nuestros dos idiomas, el catalán y el castellano, y se ha convertido en una carioca de Barcelona o en una barcelonesa de Río de Janeiro.

Dra. Carme Miralles-Guasch

Profesora de Geografía Urbana de la Universidad Autónoma de Barcelona

Mayo de 2011 

Prefácio $1^{\mathrm{a}}$ Edição

\section{Caminhos da}

Construção do

\section{Urbanismo no Brasil}

Discutindo as relações entre a reforma de Paris desenvolvida pelo Barão Haussmann em meados do século XIX, a reforma capitaneada por Pereira Passos no Rio de Janeiro, no início do século XX, e aquela ocorrida em Salvador durante a primeira gestão do Governador José Joaquim Seabra (1912-1916), Eloísa Petti Pinheiro aprofunda um aspecto sobre o qual a bibliografia brasileira tem recorrentemente aludido, embora com pouco desenvolvimento na demonstração das possíveis relações entre essas operações. Ao fazê-lo, ela não apenas enriquece nossa bibliografia, com uma perspectiva comparada ainda pouco usual na historiografia brasileira, sobre a cidade e o urbanismo, como nos mostra também as complexas relações entre a nascente cultura urbanística brasileira e a experiência parisiense que, embora sem nunca ter sido teorizada, brilha mais do que qualquer outra como a inspiração - mais ou menos próxima, mais ou menos longínqua - de um grande número de intervenções mundo afora.

Europa, França e Bahia situa-se entre duas vertentes de pesquisa que se desenvolvem com muita nitidez no Brasil desde o final dos anos 1980: a dos estudos sobre o processo de modernização das cidades brasileiras e aquela sobre a constituição de um pensamento e de uma prática urbanística 
${ }^{1}$ Ver, p. ex., os diversos textos publicados em COQUERYVIDROVITCH, Catherine; GOERG, Odile (Org.). La ville européenne outre mers: un modèle conquérant? Paris: L'Harmattan, 1996, e, em particular, o de Odile Goerg e Chantal Chanson-Jabeur.

2 PICON, Antoine. Racionalidade técnica e utopia: a gênese da haussmannização. In: SALGUEIRO, Heliana Angotti (Org.). Cidades capitais do século XIX. São Paulo: EDUSP, 2001. p. 65-101. no país. Para além da meticulosa comparação entre o que move, o que explica, o que inspira e a maneira como acontece cada uma das intervenções que ela estuda, assinalando o que as aproxima e o que as afasta, o estudo de Eloísa Petti Pinheiro oferece-nos a oportunidade de refletir sobre aspectos ou questões ainda relativamente pouco trabalhados pela historiografia brasileira, como é o caso dos caminhos de constituição de uma cultura técnica no Brasil.

A cidade europeia sempre inspirou criações urbanas na América, tanto ao Norte quanto ao Sul, desde os primórdios da colonização, num processo que ganha nova dimensão quando coincidem a emergência do urbanismo como disciplina autônoma e o apogeu do imperialismo. Uma série de trabalhos, desenvolvidos, sobretudo no exterior, vem discutindo os mecanismos dessa transferência e da adaptação de modelos estrangeiros fora dos seus contextos originais, revelando-nos a plasticidade e a adaptabilidade dessas transposições, bem como os instrumentos que as viabilizam. ${ }^{1}$ Apesar da influência haussmanniana poder ser relativizada no caso do Rio e, sobretudo, no caso de Salvador, ela ocupa um papel fundamental na formação, no Brasil, de uma cultura técnica relativa à cidade, entre a $2^{\mathrm{a}}$. metade do século XIX e as $1^{\mathrm{a}}$.S décadas do século XX. Mais do que um modelo, como demonstra Eloísa, ela é referência e fonte de inspiração que se manifesta de diversas maneiras. Uma delas - seguindo a argumentação de Antoine Picon - parece ter sido talvez mais importante do que a reforma propriamente dita, referindo-se ao tipo de conhecimento técnico que estava se desenvolvendo naquele momento e que dispunha das transformações em curso na cidade de Paris como de um privilegiado laboratório de experiências. ${ }^{2}$

Integrantes da elite intelectual brasileira, engenheiros e arquitetos situavam-se na órbita da cultura francesa, que moldava sua visão de mundo e suas abordagens profissionais de diversas maneiras: do ensino calcado em moldes franceses, em sua maior parte, e do acesso a uma bibliografia técnica, cujos avanços eram seguidos bastante de perto, às visitas a Paris que formavam e atualizavam o repertório técnico desses profissionais. Se técnicos daqui acorriam a Paris em busca de formação e de referências, os de lá encontravam aqui possibilidades de atuação profissional e de experimentação de suas ideias, além de reconhecimento oficial, numa série de presenças que, em momentos distintos e com inserções variadas, participaram de experiências essenciais da história do urbanismo brasileiro entre o final do século XIX e as primeiras décadas do século XX, como a construção de Belo Horizonte ou os grandes debates sobre a modernização do Rio nos anos 20 e 30, quando da presença no Brasil de Agache e Le Corbusier. Apenas atendo-nos ao período 
estudado por Eloísa e à experiência haussmanniana, vale a pena lembrar a presença de Bouvard, que chega ao Brasil em 1911, radicando-se por algum tempo em São Paulo, após ter trabalhado no serviço de arquitetura da administração parisiense justamente no momento de consolidação da reforma de Haussmann. Ou ainda a de Paul Villon, discípulo e colaborador de Alphand, engenheiro politécnico responsável pelos parques e jardins e pela arborização de Paris durante a reforma haussmanniana, e que, depois de trabalhar com Glaziou no Rio de Janeiro, participa de importantes projetos durante a construção de Belo Horizonte, como o do Parque Municipal, inspirado nos parques parisienses criados por Haussmann.

Se a influência francesa, de uma maneira geral, e a da Paris haussmanniana, em particular, foram referência essencial na formação da cultura técnica brasileira, podemos perceber, por outro lado, que a este lastro irão incorporar-se outras referências, num processo complexo onde articulam-se aportes de diversas naturezas e origens, ajudando a configurar intervenções em nossas cidades, a moldar o perfil de instituições de ensino ou a estruturar o pensamento de nossos urbanistas. Bons exemplos deste processo complexo de delineamento de paradigmas não faltam, como demonstram a própria construção de Belo Horizonte; ${ }^{3}$ a estruturação do ensino politécnico em São Paulo, onde o paradigma da formação francesa parece ceder lugar ao modelo germânico; ou ainda, a diversidade das referências teóricas e práticas de que lançavam mão técnicos como o engenheiro Saturnino de Brito em seu pioneiro trabalho em diversas cidades brasileiras. ${ }^{4}$

O estudo dos processos de construção da disciplina no Brasil e dos mecanismos de difusão e de reelaboração das ideias que a configuraram revela-nos seus complexos e polimórficos caminhos, num processo no qual parecem se inter-relacionar, na estruturação do pensamento de um determinado autor ou no delineamento de uma determinada intervenção, diferentes formas de ver a cidade e de propostas de como nela intervir. No período que fecha o trabalho de Eloísa, quando ela se refere às propostas de Agache e de Le Corbusier para o Rio de Janeiro, ou à pioneira ação do Escritório do Plano de Urbanismo da Cidade de Salvador (EPUCS), é possível percebermos como esses dois momentos - 0 das tensões pela consolidação do Movimento Moderno no país e o da estruturação de uma experiência que marcou a história do urbanismo em Salvador - revelam os meandros do processo acima mencionado. 0 primeiro desses momentos mostra-nos como o urbanismo modernista brasileiro parece incluir tanto adesões claras e extremamente afinadas com o pensamento corbuseano, como nos casos de Affonso Eduardo
${ }_{3}^{3}$ GOMES, Marco Aurélio A. de Filgueiras; LIMA, Fábio José Martins de. Pensamento e prática urbanística em Belo Horizonte, 1895-1961. In: LEME, Maria Cristina da Silva. Urbanismo no Brasil, 1895-1965. São Paulo: Nobel, 1999, p. 121.

${ }^{4}$ Cf., p.ex., os trabalhos de Carlos Roberto Monteiro de Andrade sobre Saturnino de Brito e Camillo Sitte. 
${ }^{5}$ Cf. GOMES, Marco Aurélio A. de Filgueiras; LIMA, Fábio José Martins de. Urbanismo modernista no Brasil: revisitando suas articulações internacionais. Comunicação apresentada no IV Seminário DOCOMOMOMO Brasil. Viçosa; Cataguases, 30/10 a 03/11/2001.

${ }^{6}$ REZENDE, Vera F. O urbanismo modernista na Cidade do Rio de Janeiro: ideias, projetos e realizações. Comunicação apresentada no IV Seminário DOCOMOMOMO Brasil. Viçosa; Cataguases, 30/10 a 03/11/2001.

7 PONTUAL, Virgínia. A cidade e o bem comum: o engenheiro Antônio Bezerra Baltar no Recife dos anos 50. In: IX Encontro Nacional da ANPUR, 2001, Rio de Janeiro. Anais... Rio de Janeiro, 2001, v. 2, p.797-809.

${ }^{8} \mathrm{Cf}$. ANELLI, Renato. Arquitetura e cidade na obra de Rino Levi. In: V Seminário de História da Cidade e do Urbanismo. 1998, Campinas. Anais.. Campinas: PUC, 1998. 1 CD

9 FERNANDES, Ana; SAMPAIO, Heliodório; GOMES, Marco Aurélio A. de Filgueiras. A constituição do urbanismo moderno na Bahia (1900-1960). In: CARDOSO, Luiz Antonio Fernandes; OLIVEIRA, Olívia Fernandes de (Org.). (Re)Discutindo o modernismo: universalidade e diversidade do Movimento Moderno em Arquitetura e Urbanismo no Brasil. Salvador: Mestrado em Arquitetura e Urbanismo da UFBA, 1997. p. 201-213.
Reidy e de Lúcio Costa (o que não exclui, evidentemente, a riqueza da contribuição e das interpretações individuais desses arquitetos), quanto situações em que a incorporação parcial de ideias defendidas pelo Movimento Moderno trabalhava articuladamente a outras formas de compreensão da cidade e de premissas para a intervenção, configurando aproximações diversas, parciais, fragmentárias do ideário propagado pelos CIAMs, em aliança com outras tendências. ${ }^{5}$ É o que nos mostram casos como o de Adalberto Szilard que, no Rio de Janeiro dos anos 40 e 50, vai tentar conciliar e estabelecer uma síntese entre propostas tão diversas quanto as de Le Corbusier, Saarinen, Bardet, Wright ou Hegermann, em busca de um referencial para a intervenção na cidade existente; ${ }^{6}$ ou o caso, igualmente revelador, de Antonio Baltar que, no Recife, vai beber tanto na fonte do movimento Economia e Humanismo, liderado pelo Padre Lebret, quanto nos ensinamentos do $\mathrm{CIAM}^{7}$ ou ainda, o do então jovem arquiteto Rino Levi que, nos anos 20, busca estruturar um pensamento crítico com relação à cidade brasileira a partir de uma leitura das ideias corbuseanas, dos princípios da Edilizia cittadina, de Piacentini, e dos ensinamentos de Gustavo Giovannni sobre arte e técnica. ${ }^{8}$ Quanto ao processo de planejamento utilizado pelo EPUCS e sua proposta para Salvador, pode-se perceber, ao lado de alguns aspectos da Cidade Radiosa, de Le Corbusier, como a de uma grande estação de transbordo central; uma forte presença do pensamento de Geddes, através da preocupação com um extenso survey sobre as condições gerais da cidade; do de Burgess, através da formulação centrada na cidade mononuclear e concêntrica; e do de Hénard, no que diz respeito à lógica radioconcêntrica. ${ }^{9}$

Além de contribuir para o nosso conhecimento sobre os mecanismos de transferência das ideias constitutivas da disciplina, este livro nos permite ainda refletir sobre como o urbanismo insere-se no quadro mais amplo das questões culturais no Brasil. Apesar de as intervenções ocorridas no primeiro ciclo de modernização de nossas cidades buscarem readequar o espaço urbano às exigências de uma nova realidade econômica (como expressam com clareza as reformas portuárias ou a reestruturação viária propiciada pelos novos meios de transporte em função do desenvolvimento da indústria), é fácil perceber como a estética urbana acaba tornando-se elemento central no projeto de inserção do Brasil no mundo ocidental e no concerto das chamadas "nações civilizadas". É um pouco como se, na falta de mudanças estruturais que, em outros países, caracterizaram o processo de modernização urbana, o "mimetismo formal" pudesse criar a almejada mudança na imagem do país que desejava emergir como parte integrante do mundo ocidental e civilizado. 
Neste sentido, se a cidade europeia, seus traçados, suas formas de gestão e sua arquitetura sempre foram importantes referências para a cidade brasileira, cabe indagarmo-nos sobre os momentos em que vozes, sem dúvida desafinadas com relação ao pensamento dominante, tentaram conceber as cidades brasileiras a partir de uma identidade diferente daquela fornecida pelo mimetismo com a Europa desenvolvida. No primeiro ciclo de modernização urbana esta questão não se colocava. A palavra de ordem era a negação do passado e a substituição de tudo aquilo que pudesse ter alguma relação com a herança colonial, escravista ou negra, quer esta se manifestasse através da arquitetura, do desenho urbano ou dos hábitos dos citadinos. 0 embate, iniciado nos anos 30, em torno da querela "antigo versus moderno", opondo os higienistas e os "progressistas" a todo custo, em sua sanha destruidora, aos "regionalistas", preocupados em defender uma herança que começava a ser valorizada, pode ser considerado uma referência no questionamento da inexorabilidade das transformações impostas às cidades brasileiras, ainda que, muitas vezes, tais posições viessem marcadas pelo conservadorismo. Numa perspectiva totalmente diferente, vale a pena fazer uma outra referência a Rino Levi, desta vez a propósito de seu famoso manifesto publicado n' 0 Estado de São Paulo, em 1925, no qual ele defendia a necessidade de se conceber cidades "...com alma brasileira", com “...um caráter diferente das da Europa”. São apenas alguns exemplos que nos lembram que, na história do urbanismo, o estudo da polifonia a partir da qual a disciplina se construiu, deve sempre vir acompanhado pela preocupação com as dissonâncias...

Dentre muitas outras, estas são apenas algumas das questões que este livro, que tenho o privilégio e a profunda satisfação de apresentar, virá, em muito boa hora, nos ajudar a discutir.

\section{Marco Aurélio A. de Filgueiras Gomes}

Prof. Titular da Faculdade de Arquitetura da UFBA 



\section{Apresentação}

Este livro é resultado da minha tese de doutoramento defendida na Escuela Técnica Superior de Arquitectura de Barcelona da Universidad Politécnica de Cataluña, em 1998, submetida à apreciação dos Professores Horácio Capel Saez, Fernando Alvarez Prozorovich, Fernando de Teran Troyano, Marco Aurélio A. de Filgueiras Gomes e José Luis Oyón Bañales e orientada pelo Professor Francisco Javier Monclús Fraga. A todos agradeço, pois, com suas pertinentes observações, colaboraram para uma melhor apresentação deste texto acadêmico.

A Marco Aurélio, um agradecimento especial, não só por seus comentários em relação à tese e ao livro, mas por todas as observações que tem feito, desde quando fui sua aluna até hoje, quando dividimos a mesma sala de aula.

A Monclús, por sua orientação segura e pelo apoio e incentivo dado no período em que estive em Barcelona.

Pela realização do doutorado, em Barcelona, agradeço ao CNPq, pela bolsa concedida, e à Faculdade de Arquitetura da Universidade Federal da Bahia, pela liberação dos compromissos acadêmicos podendo, assim, dedicar-me exclusivamente ao curso. 
Pela edição deste livro, começo agradecendo à Profa. Ana Fernandes, por acreditar na qualidade do trabalho e indicá-lo para publicação. Agradeço à diretora da EDUFBA, Flávia di Garcia Rosa, e sua equipe, pela viabilização desta publicação. Um agradecimento especial à Gabriela, pelo projeto gráfico cuidadoso que deu formato a este livro.

Não poderia deixar de agradecer a todos os amigos que partilharam os momentos de tensão, e também os de alívio, as angústias e incertezas durante a elaboração da tese e que, certamente, compartilham comigo a alegria de ver este livro publicado.

As inquietações que encontram-se neste estudo, fazem parte das minhas pesquisas ao longo da vida acadêmica. Já no curso de graduação, realizado na Faculdade de Arquitetura e Urbanismo da Universidade Federal do Rio de Janeiro, as questões sobre o estudo de cidades estavam presente. Durante os anos de graduação, percebi que o tema me atraía, emocionava e decidi, ao graduar-me, dar continuidade aos meus estudos aprofundando o tema de cidades.

Por dois anos investiguei as transformações do centro da cidade do Salvador a partir do ponto de vista institucional. Nesse período, mergulhei na documentação da Repartição de Obras Públicas do Estado da Bahia para entender o processo de transformação da cidade entre os anos 1850-1920.

O produto final, com a orientação do Prof. Marco Aurélio, foi um trabalho apresentado como dissertação de mestrado junto ao Programa de Pós-Graduação em Arquitetura e Urbanismo da Faculdade de Arquitetura da Universidade Federal da Bahia (FAUFBA), em 1992. Ao final da defesa, frente a uma banca, havia conseguido o título de Mestre em Arquitetura e Urbanismo. Mas, será que estava satisfeita com o final do trabalho? A resposta foi sim e não. Na realidade, o final da pesquisa deixou-me com mais vontade de entender como as cidades se estruturam, se constróem, se produzem. A história da cidade e do urbanismo despertava, cada vez mais, meu interesse. Vários caminhos se abriram à minha frente, outras inquietações surgiam e haviam outras metodologias de análise. A perspectiva comparada era uma delas.

Havia trabalhado com a cidade do Salvador e suas intervenções públicas, faltava agora entender, e comparar, o que houve em Salvador, com outras cidades. Em alguns momentos da pesquisa para a dissertação de mestrado, encontramos o termo haussmannização para denominar as intervenções na cidade do Salvador entre os anos 1912-1916. Encontrei muitas referências ao processo de reforma urbana ocorrido no Rio de Janeiro, entre os anos 1902-1906. Muitas dessas asseguravam que houve uma cópia do Rio e, algumas, até mesmo fazem referência à Paris. 
Com isso, surge uma nova pergunta: houve mesmo uma cópia da Paris do Segundo Império, meio século depois, numa cidade com uma realidade tão distinta? Quais foram os determinantes que levaram o Barão Haussmann e o Imperador Napoleão III a intervir no tecido urbano de Paris? Em Salvador, foram os mesmos? Não haveriam ali outros fatores decisivos que levariam a uma intervenção independente da reforma urbana em Paris? Como as referências francesas criavam a imagem das cidades brasileiras?

Este livro é o resultado da busca pelas respostas a essas perguntas que ficaram abertas. Através de uma análise comparada, minha pesquisa pautou-se em duas possibilidades: uma possível apropriação dos modelos urbanos europeus em Salvador ou a implementação de um urbanismo local determinado por fatores próprios, mas, que de alguma forma, fazem referência ao Rio de Janeiro e, através deste, à Paris e à Europa. 0 período estudado, o século XIX até a década de 30 do século XX, corresponde ao período onde as referências francesas povoavam o imaginário do povo brasileiro. Fechamos nosso limite temporal quando estas referências começam a mudar, sem, contudo, apontar para a perspectiva de uma cidade brasileira, com nossas próprias referências.

O trabalho com cidades do século XIX e primeira metade do XX, faz parte das preocupações da Linha de Pesquisa em História da Cidade e do Urbanismo do Programa de Pós-Graduação em Arquitetura e Urbanismo da FAUFBA, onde venho desenvolvendo minhas atividades acadêmicas. Também procura preencher uma lacuna nos estudos sobre as cidades brasileiras e, em específico, Salvador no período estudado.

Finalizando, nem todas as questões foram respondidas, pois, ao finalizar o livro, outras surgiram e continuo buscando encontrá-las. Isso não significa que o trabalho esteja incompleto. Pelo contrário, sinto-me satisfeita com o resultado. Afinal, a busca por respostas sempre existirá, e sempre estarei pronta a ir buscá-las.

Gostaria que aqueles que um dia consultarem este livro soubessem o quão prazeroso me foi fazê-lo e como é gratificante vê-lo publicado. Espero que cada um de vocês, leitores, possa apreciá-lo e que as informações aqui contidas possam, de alguma forma, responder algumas de suas indagações. Dessa forma, toda minha busca não terá sido em vão.

\section{Eloísa Petti Pinheiro}




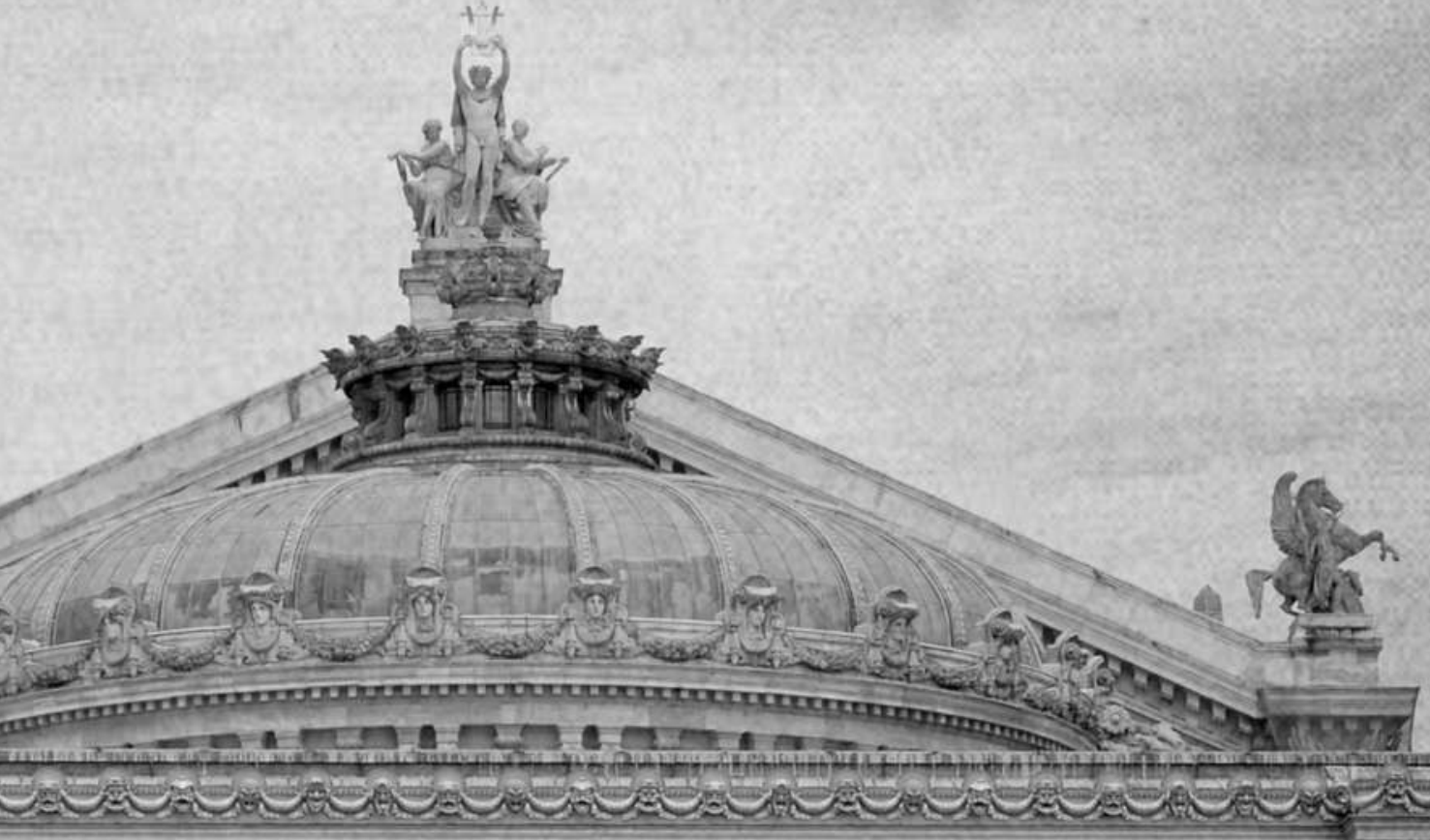

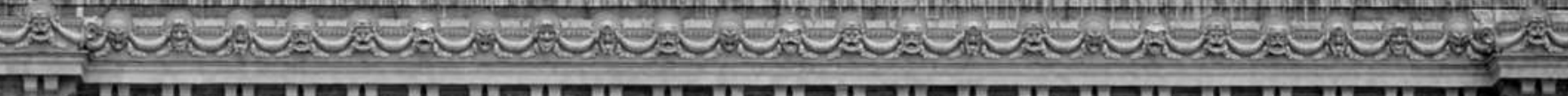

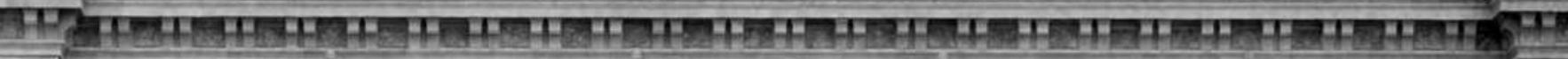

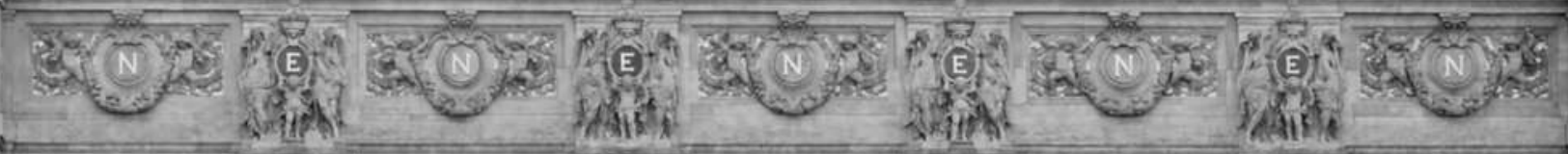

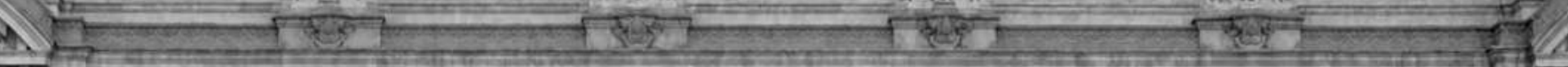

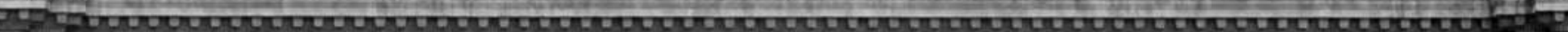

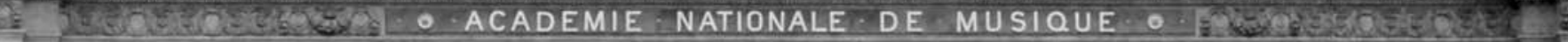

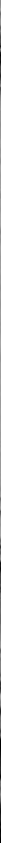




\section{Um comentário inicial}

Por todo o século XIX e princípios do século XX, são introduzidas mudanças importantes na estrutura das cidades, gerando a necessidade de reformas urbanas, ${ }^{1}$ para adaptação a novas realidades. Uma das reformas urbanas mais conhecidas é a realizada em Paris, durante o Second Empire (Segundo Império, 1852-1870), sob as ordens de Napoleão III e sob o comando do prefeito do Departamento do Sena, Georges-Eugène Haussmann, o Barão Haussmann. Essa reforma é feita através de um conjunto de intervenções, entre os anos de 1853 e 1870, conhecidas como "haussmannização", ${ }^{2}$ que vieram a influenciar numerosas outras reformas nas mais diversas cidades do mundo.

A haussmannização é um tema que se mantém atual. Os estudos sobre as obras realizadas pelo Barão Haussmann continuam suscitando discussões que geram novas interpretações sobre intervenções, sua forma de implantação, seu momento histórico, suas consequências e, principalmente, sua difusão como modelo. Nas últimas duas décadas, o tema volta à tona. São realizadas exposições sobre suas obras, são escritos livros e publicados artigos que discutem seus objetivos e seus métodos e são elaboradas novas teses que questionam se a "haussmannização" é um modelo adotado ou adaptado por outras cidades.

\footnotetext{
${ }^{1}$ Entende-se como reforma urbana o conjunto das intervenções realizadas no tecido urbano existente, transformando sua malha, introduzindo melhoramentos, principalmente na infraestrutura, e delineando um novo modelo ideológico e cultural.

20 termo "haussmannização" é um neologismo que adotaremos, neste estudo, por introduzir uma ideia cujo conteúdo é de fundamental importância para seu desenvolvimento. Também adotaremos suas derivações: o adjetivo "haussmanniano" e o verbo

"haussmannizar". Advertimos que o termo não é uma invenção nossa, mas que vem sendo utilizado por outros autores, brasileiros e estrangeiros, principalmente pelos franceses, muitos dos quais fazem parte da bibliografia utilizada neste livro.
} 
3 "Um prefeito é algo mais do que um tapa-buracos, ou um rasgador de avenidas. É também um engenheiro social, embora nem sempre se dê conta disso. Tome-se o caso de um famoso prefeito - o Haussmann, que governou Paris na segunda metade do século passado. Haussmann rasgou avenidas - os chamados grandes bulevares - e abriu perspectivas. Modernizou a cidade. A Paris que se conhece hoje é ainda a Paris de Haussmann, bela, monumental e lógica". (TOLEDO, 1996, p. 142)
A Paris haussmanniana continua cativando a todos e, ainda hoje, serve como exemplo de administração municipal, quando se coloca em prática a transformação de uma cidade qualquer, através de intervenções. Em maio de 1996, por exemplo, Roberto Pompeu de Toledo, em artigo sobre a campanha eleitoral para a Prefeitura do Rio de Janeiro, refere-se a Haussmann, considerando que um prefeito deve ser mais do que um mero rasgador de avenidas: deve ser, também, um engenheiro social. ${ }^{3}$

A difícil arte da construção de cidades, da estruturação de um espaço coerente para os cidadãos, é tema de debate desde o século XIX. A urbanização existe como processo quando parte de uma população passa a viver aglomerada, dedicando-se a outras atividades que não às primárias. A cidade, então, permanece dependente do campo, apesar de dominá-lo, uma vez que esse produz, para ela e sob seu comando, alimentos e insumos industriais. Esse processo existe ao longo da história da humanidade, mas intensifica-se a partir da Revolução Industrial na Europa, o que, no Brasil e na América Latina, só acontece no século XX.

Dessa forma, as sociedades organizam-se em centros urbanos, que adquirem certas características, tais como crescimento demográfico e construtivo, expansão das áreas urbanizadas, transformação do meio rural uma vez que aldeias se transformam em cidades -, dominação das classes sociais rurais pelos citadinos e predominância de práticas sociais geradoras de cultura urbana.

A estruturação social não existe sem espaço. E a natureza social implica ser o espaço da cidade necessariamente histórico, posicionado em marcos temporais, geográficos e culturais. Ou seja, o espaço é sempre concreto, possuindo qualidades físicas, e, não sendo um fenômeno estático, encontra-se em permanente transformação.

Os urbanistas - quer os que planejam espaços totalmente novos, como Ildefons Cerdà e seu projeto de ensanche para Barcelona, ou Lúcio Costa e seu plano piloto para Brasília, quer os que propõem intervenções em espaços construídos como Camillo Sitte ou Saturnino de Brito - sempre buscam a criação de espaços utópicos, perfeitos, cidades ideais, muitas vezes sem levar em consideração a população que deles irá apropriar-se ou sem incluí-la como parte do projeto.

Num encontro imaginário entre Ildefons Cerdà e Lúcio Costa, Philippe Panerai chama a atenção para as dificuldades que surgem ao se propor a construção de uma cidade nova, assinalando as diferenças propostas para a cidade do século XIX e a cidade do movimento moderno, a cidade para os 
pedestres e a cidade para os automóveis. Os fragmentos reproduzidos abaixo são ilustrativos dessas dificuldades. Após passar toda a manhã caminhando do setor hoteleiro até a Praça dos Três Poderes em Brasília, Cerdà e seu ajudante Joan encontram-se com Lúcio Costa e Oscar Niemeyer. (PANERAI, 1987, p. 100)

Niemeyer: Lamento muito, porque não me preveniram. Eu poderia ter ido buscá-los de carro. É uma loucura percorrer tudo isto a pé.

Cerdà: Vós sabeis, na minha idade, adquirem-se algumas manias. Eu gosto muito de descobrir as cidades caminhando tranqüilamente. Isto permite compreender muitas coisas. Mas, diga-me, como fazem as pessoas que não possuem automóvel?

Em outro momento, os quatro encontram-se à mesa de um bar numa das superquadras de Brasília. (PANERAI, 1987, p. 100)

Cerdà: (sorrindo) É um pouco daquilo que eu imaginava em meu primeiro plano para Barcelona, o centro não construído com jardins coletivos, interligando os quarteirões. Vós o fizestes e isto me interessa ver no que vai dar.

Niemeyer: Costa conseguiu convencer a todos, para que sua idéia fosse respeitada e isto está acontecendo. De fato, aboliu-se a propriedade privada do solo. O solo pertence a todos e pode-se cruzar a cidade, a pé, em todos os sentidos.

Joan: Eu me pergunto se esta idéia sedutora conseguirá manter-se por muito tempo convivendo com a prática dos habitantes.

Costa: Tanto tempo quanto a administração municipal fizer respeitar o código de urbanismo.

Cerdà: Ah! sim, o código...

Costa: As cidades se fazem com os códigos.

Joan: E com os habitantes.

Costa: Para ou com, that is the question.

A questão continua em aberto. A projetação e a construção de cidades pressupõem a dificuldade de conciliar uma boa forma com as necessidades de sua população, ou seja, o desafio de desenhar uma cidade está em construir, harmoniosamente, as experiências no espaço, ao longo do tempo. A cidade é formada por uma série de espaços articulados, relacionados entre si, cada um possuindo qualidades particulares. Nesse sentido, o objetivo do projeto é 
atingir a população que vai usar esses espaços e se mover por eles, mexendo com suas emoções e sua sensibilidade e fazendo com que essas experiências sejam continuamente harmoniosas, a cada instante e sob todos os pontos de vista. Nessa busca, técnicos e cidadãos se entrecruzam em busca da forma urbana ideal.

O estudo das cidades - a formação e o desenvolvimento das áreas urbanas planejadas e as reformas nas de formação espontânea - revela-nos, dessa forma, uma grande variedade de problemas. Estudar a história da cidade - especialidade relativamente nova, introduzida no Brasil, nas últimas décadas - é descobrir a riqueza de realidades e de problemas. 0 interesse em estudar a cidade e o urbano deve-se a uma tentativa de preencher um vazio, de aprofundar questões que ainda existem na história das cidades brasileiras, em busca de novas discussões teóricas e metodológicas para a compreensão dos processos de estruturação urbana.

Este trabalho insere-se nesse contexto, focaliza a reforma urbana e a formação da cidade moderna, - processo pelo qual passam diversas cidades em todo o mundo -, também no Brasil, ao longo do século XIX, como também em princípios do século XX, em função da necessidade de adequar-se o espaço urbano às necessidades da modernização. Nesse processo, gera-se um novo campo disciplinar, onde se encontra a gênese do pensamento urbanístico moderno, produzido através da definição das esferas de atuação das intervenções públicas e privadas que provocam mudanças nos modos de vida e nas identidades sociais.

A formação das cidades brasileiras é um tema que nos interessa e sobre o qual trabalhamos há alguns anos. Como arquitetos e pesquisadores de cidades, a observação é inerente às nossas vidas. Ao chegar a um espaço qualquer, nossos olhos não só olham como também observam, analisam, questionam, traduzem e interpretam. Ao caminhar por uma cidade, percebemos que ela não é apenas um emaranhado de ruas, de construções e de gente, mas também é um espaço onde podemos ler a história, a sua história. As cidades, pois, sempre nos despertam a curiosidade e nos instigam para entender como, porque e quando se formaram seus espaços, desvendando assim, sua história.

A observação nos ensina que as cidades são distintas entre si e dentro de si. Cada trecho de cidade tem seu traçado, sua trama, sua característica e sua história. A combinação de muitos fatores faz com que elas tenham seu próprio caráter, seus signos, seus símbolos e seus sinais, indicadores das mudanças ocorridas em anos ou séculos anteriores e reveladores de 
sua história. Em suma, a cidade é o reflexo do tempo, das ideologias, das políticas e da sociedade.

No caso de Salvador, não é diferente. Caminhar por ela, observando-a atentamente, desperta-nos o interesse em entender sua forma e em conhecer sua história. São muitas as questões sobre o seu crescimento, sobre a definição de seus vetores de expansão e sobre a produção de seu espaço urbano moderno. Essas questões têm sido objeto de nossa atenção e de estudo e, em dois momentos distintos, resultaram numa dissertação de mestrado (PINHEIRO, 1992) - em que analisamos as intervenções públicas, sob o ponto de vista institucional, realizadas na cidade do Salvador entre 1850 e 1920 - e uma tese de doutorado (PINHEIRO, 1998), em que ampliamos nosso campo de pesquisa e buscamos entender os modelos urbanos que influenciaram as reformas urbanas do Rio de Janeiro e de Salvador nas primeiras décadas do século XX.

Este trabalho, originado da tese de doutorado, dá continuidade às nossas pesquisas e focaliza os processos de reforma urbana e de modernização que ocorrem tanto na cidade do Rio de Janeiro como na cidade do Salvador, tendo em vista a análise de uma possível adaptação de um modelo urbano europeu às cidades brasileiras, mais especificamente, as possíveis influências do processo de transformação da cidade de Paris, pelas mãos do Barão Haussmann, sobre o processo ocorrido no Brasil.

Nas cidades brasileiras, a reforma urbana realiza-se em princípios do século $X X$, constituindo o ápice de um longo processo que começa, a partir da metade do século XIX, a mudar a imagem das áreas urbanas, a fim de adaptá-las aos novos ideais modernos e higiênicos, decorrentes do avanço científico, de novas tecnologias e de novas ideologias. Com o advento das modernas teorias urbanas, pois, muda-se a forma de estruturar, de pensar, de ver e de viver a cidade.

Nesse período, as cidades brasileiras ainda mantêm um traçado colonial, muitas ainda são irregulares, sem alinhamento retilíneo, com casas construídas entre empenas (sem espaços intermediários) e densamente povoadas. Além disso, mantêm heranças do tempo da escravidão, quando tanto o espaço urbano como o espaço doméstico funcionavam simultaneamente com base na mão-de-obra escrava.

A historiografia urbana brasileira faz referência à haussmannização pela qual passam algumas cidades, principalmente o Rio de Janeiro, que realiza sua reforma urbana entre os anos 1902 e 1906. A cidade, então capital do Brasil, ${ }^{4}$ muda sua imagem, buscando modernizar-se e transformar sua estrutura, num processo de mutação urbana classificado por muitos dos que a estudam como um processo de haussmannização. Essas intervenções buscam
${ }^{4}$ O Rio de Janeiro foi a capital do Brasil - do Vice-Reino, do Império e da República -, entre 1763 e 1960. 
transformar o Rio numa cidade limpa, higiênica, salubre, bonita, burguesa, baseada nos moldes europeus e digna de ser uma capital.

Por sua vez, Salvador também realiza, entre 1912 e 1916, uma importante reforma urbana, para adaptar-se às novas exigências de uma cidade moderna. Interessa-nos, portanto, neste estudo, desvendar o processo de modernização dessas duas cidades, identificar o tipo de intervenção que nelas se realizou, suas causas e consequências, bem como os vínculos dessas reformas com o que se denomina de haussmannização.

O ponto de partida para a investigação que dá suporte a este trabalho foi a hipótese de que a reforma de Salvador não recebe diretamente as influências da reforma parisiense, mas se espelha na do Rio de Janeiro como modelo. Nesse sentido, consideramos, a priori, que, a partir de Paris, difunde-se uma forma diferenciada (nova?), um estilo de intervir no tecido urbano construído, que se difunde como modelo. No Brasil, a Capital Federal adapta esse modelo à sua realidade, transformando-o numa forma particular de intervir em seus próprios espaços. Num segundo momento, essa nova forma adaptada difunde-se pelo País, influenciando e incentivando outras cidades a realizarem suas reformas urbanas.

Duas partes constituem este livro. Na primeira - 0 estudo - discorremos sobre a questão urbana e as reformas urbanas, as novas interpretações e os novos questionamentos relativos ao tema nas últimas décadas. Nela, os processos urbanos, as tradições urbanísticas e as reformas urbanas constituem os pontos focalizados na discussão atual sobre a História da Cidade. Em seguida, analisamos os argumentos utilizados para justificar as intervenções nos espaços construídos e apresentamos as reformas parisienses, analisamos a haussmannização, sua implantação e difusão como modelo, a partir de autores que trabalham com esse tema. Finalmente, demarcamos os parâmetros em que se baseiam as análises dos estudos de caso.

Na segunda parte - Os casos -, Rio de Janeiro e Salvador constituem o foco central do estudo. Nela, inicialmente, são analisadas as transformações da cidade do Rio de Janeiro desde princípios do século XIX, com a chegada da família real ao Brasil, até 1930, e a passagem de Le Corbusier por terras cariocas. Apesar do longo período abordado, a ênfase direciona-se para a reforma urbana dirigida pelo Prefeito Francisco Pereira Passos, entre os anos 1902 e 1906. O percurso que empreendemos pelo século XIX permite entender como se estrutura a cidade colonial-escravista e as transformações introduzidas no espaço urbano que preparam as intervenções do início do século XX. A seguir, analisamos e interpretamos a reforma urbana de Pereira 
Passos - a fim de identificar as influências recebidas do urbanismo europeu, com as adaptações feitas para a realidade brasileira - os projetos urbanísticos e as intervenções realizadas até 1930. São, então, definidos os modelos utilizados e identificados possíveis pontos de contato entre a reforma carioca e a parisiense, bem como a consagração do Rio de Janeiro como modelo para as demais cidades brasileiras, entre elas Salvador.

Aqui, o nosso foco desloca-se para a cidade do Salvador, uma das cidades mais antigas do Brasil, para que se possam comparar e identificar, de forma mais objetiva, as semelhanças e diferenças entre as duas cidades. Do mesmo modo que o Rio, Salvador cresce e desenvolve-se de forma não planejada, com um traçado típico colonial, organizando-se em função da mão-de-obra escrava. Essa é a cidade que chega ao século XX, quando é alvo de uma reforma urbana, para inserir-se no mundo das cidades modernas e civilizadas. Empreendemos aqui, também, um percurso ao longo do século XIX, para caracterizar os modos de vida da cidade colonial e escravista, para, em seguida, centrar a análise na reforma urbana realizada no governo de José Joaquim Seabra (1912-1916), sob a influência do Rio de Janeiro. Coadjuvante das intervenções cariocas realizadas por Pereira Passos, ao ser investido no cargo de governador do Estado da Bahia, Seabra adapta o que presenciou no Rio e dá início ao processo de transformação da sua capital, Salvador. Segue-se uma análise das mudanças urbanas e das propostas feitas para a cidade até 1935, quando se realiza a Semana de Urbanismo, responsável pela introdução de uma nova forma de ver a cidade e de nela intervir. Ao longo dessa análise, está presente o nosso objetivo de identificar as possíveis influências do Rio e de Paris no projeto de modernização da cidade do Salvador.

As análises dos fatos e as comparações com as outras cidades nos conduzem a tecer algumas observações sobre nossas inquietações iniciais, que fazem parte da última parte deste estudo - Um comentário final - onde se encontram as conclusões e considerações finais sobre o tema.

Para o desenvolvimento deste estudo, trabalhamos com a documentação disponível em arquivos e bibliotecas de Paris, Rio de Janeiro, Salvador, São Paulo e Barcelona, onde realizamos o Programa de Doutorado Historia de la Arquitectura, Historia Urbana da Universidad Politécnica de Cataluña. Ter acesso às informações referentes à história das cidades do Rio e de Paris não representou dificuldade alguma, devido à extensa bibliografia existente e à disponibilidade da documentação necessária. 0 mesmo não ocorreu em relação às informações referentes à cidade do Salvador que, diferentemente 
das outras cidades, não possui muitos estudos sobre o tema, além da pouca documentação existente, pois uma parte desapareceu e outra não se encontra disponível. Foi consultada a documentação acessível, apesar de limitada.

Nas pesquisas bibliográficas e iconográficas, percorremos, na Bibliothèque Nacionale de France, os setores cartes et plans, périodiques, estampes e imprimés, e a Bibliothèque Publique d'Information do Centre Georges Pompidou, em Paris. Na cidade do Rio, realizamos as principais pesquisas na Biblioteca Nacional, no Arquivo Nacional e no Arquivo Geral da Cidade do Rio de Janeiro. Foi visitada a biblioteca do Instituto Histórico e Geográfico Brasileiro (IHGB) e a do Instituto de Pesquisa e Planejamento Urbano e Regional (IPPUR) da Universidade Federal do Rio de Janeiro (UFRJ).

As principais fontes pesquisadas sobre a cidade do Salvador foram encontradas no Arquivo Histórico da Prefeitura Municipal de Salvador, no Arquivo Público do Estado da Bahia, na Biblioteca Central do Estado da Bahia, na Biblioteca Central da Universidade Federal da Bahia (UFBA) e em outras bibliotecas da UFBA, como a do Centro de Estudos de Arquitetura na Bahia (CEAB) e a do Programa de Pós-Graduação em Arquitetura e Urbanismo (PPG-AU). Outros acervos importantes foram consultados, como os da Faculdade de Arquitetura e Urbanismo da Universidade de São Paulo (FAUUSP), da biblioteca do Instituto do Patrimônio Artístico e Cultural do Estado da Bahia (IPAC) e do Instituto Geográfico e Histórico da Bahia (IGHB). Conversas com pesquisadores que têm a cidade como seu objeto de estudo também foram de grande utilidade no desenvolvimento do trabalho.

Não nos moveu, na realização deste estudo, a intenção de lançar novos questionamentos ou analisar as reformas de Haussmann em Paris, mas focalizar a haussmannização como possível modelo difundido e adaptado à realidade brasileira, especialmente nos casos do Rio de Janeiro e de Salvador. 



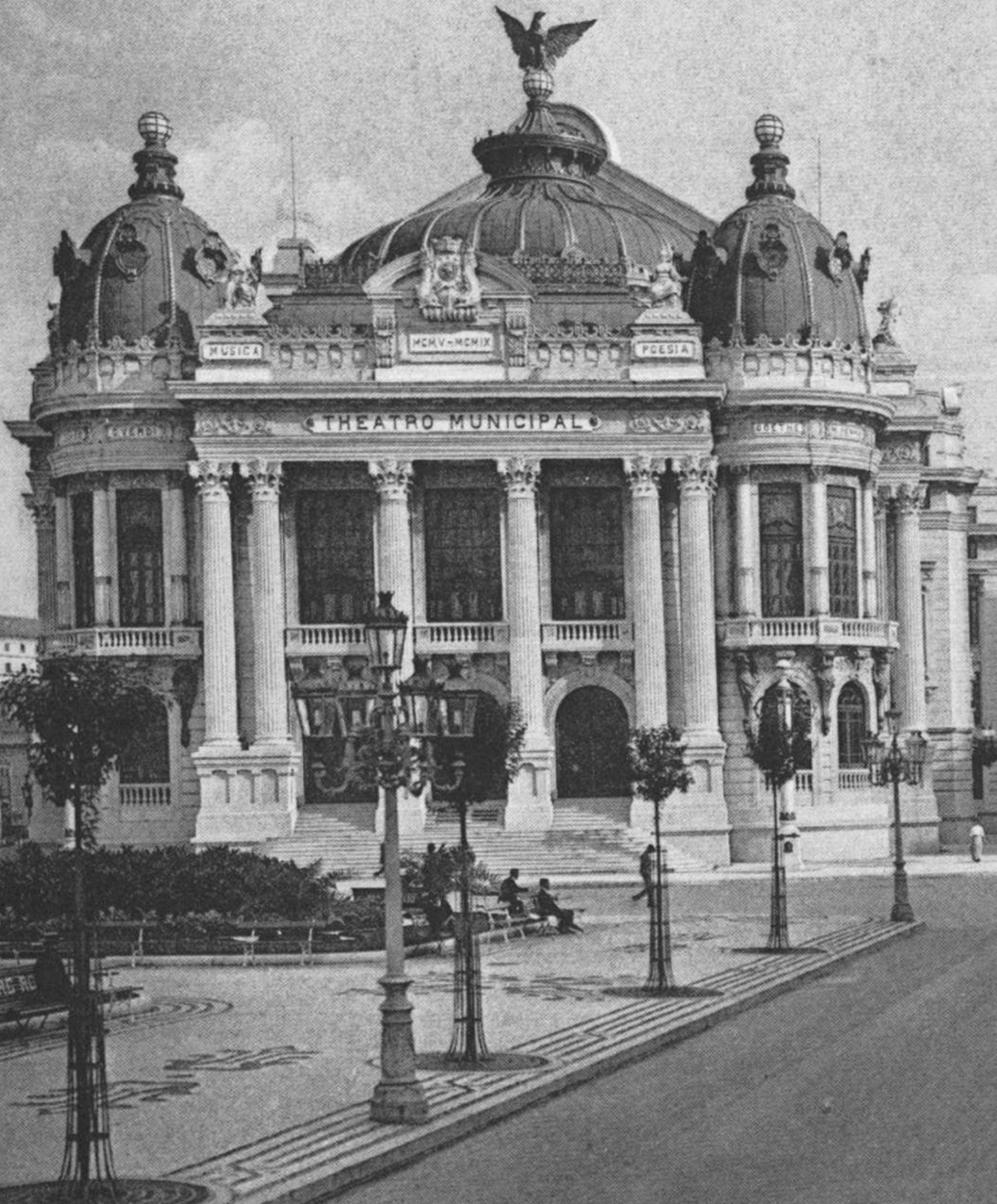




\section{Parte I O Estudo}

Mas a cidade não conta o seu passado, ela o contém como as linhas da mão, escrito nos ângulos das ruas, nas grades das janelas, nos corrimãos das escadas, nas antenas dos pára-raios, nos mastros das bandeiras, cada segmento riscado por arranhões, serradelas, entalhes, esfoladuras.

(Calvino, 1990). 

Capítulo 1

\section{O debate sobre as reformas urbanas}

A preocupação da época contemporânea com as questões urbanísticas vem de finais do século XVIII, quando as cidades passam por processos de transformação social, econômica, cultural e urbanística, associados às mudanças advindas da Revolução Industrial, que está na base de algumas das transformações da sociedade e das cidades na Europa. As novas tecnologias introduzidas mudam as relações dentro das áreas urbanas, diminuem as distâncias e melhoram o saneamento, o que implica uma renovação do espaço urbano, com rápidas alterações no modo de vida urbano, no uso do solo, nas relações de produção e na própria estruturação da sociedade.

São grandes mudanças que se materializam quando, nas cidades industriais, a acumulação capitalista passa do comércio à exploração industrial e, nas cidades portuárias e comerciais, novas funções de um mercado internacional desenvolvem-se, produzindo, como consequência, uma desordem nas áreas urbanas. Seus novos símbolos são as chaminés, a ferrovia e os bairros miseráveis.

$\mathrm{O}$ crescimento urbano e o incremento demográfico, muito rápidos no século XIX, mudam a paisagem da cidade transformando-a num ambiente caótico e desordenado, sendo necessário buscar soluções através de reflexões 
sobre o processo pelo qual passam. Na primeira metade do século XIX, são feitas as primeiras observações sobre o urbano, dando-se uma atenção especial aos problemas sociais. A princípio, as considerações baseiam-se nas acusações dos moralistas contra os maus hábitos da população, nas preocupações com as condições de vida dos pobres nas cidades e nos relatórios dos sanitaristas sobre a saúde das classes populares.

A discussão sobre esses temas, nas últimas décadas, tem o urbano como um novo campo do saber e o discurso urbanístico como uma nova disciplina, cujo objetivo são os estudos sobre os novos modos de produção da cidade. Desde meados do século XIX até hoje, os debates sobre o tema desenvolvem-se por diferentes ângulos, diversos matizes e de distintas formas, o que caracteriza a interdisciplinaridade do tema.

Arquitetos, historiadores da arte e da arquitetura, sociólogos, geógrafos e antropólogos pesquisam a história da cidade, levantam novas questões e rediscutem paradigmas, sempre tentando entender como evoluem as cidades e como se processam as reformas e intervenções no espaço urbano para adaptá-lo a uma nova sociedade e a um novo modo de vida. 0 grande interesse pelo período compreendido entre princípios do século XIX e a Primeira Grande Guerra deve-se ao fato de ser essa uma época em que se estabelecem as bases da cidade moderna em que hoje vivemos. 0 estudo desse momento-chave leva-nos a entender melhor a civilização urbana contemporânea. É nessa fase que se produzem mudanças estruturais, econômicas, físicas e sociais que fazem das cidades um novo campo de experimentos e uma nova área de atuação.

\section{Algumas reflexões}

As aproximações históricas do fenômeno urbano despertam grande interesse em pesquisadores das mais variadas especialidades, já que a análise do processo de urbanização ajuda a compreender a realidade e os problemas das metrópoles modernas. O século XIX é testemunha de uma mudança no mundo urbano que, a uma grande velocidade, faz das cidades organismos complexos, onde se estruturam os espaços e a sociedade. É tal o impacto da urbanização nesse século, que, em consequência, surge uma nova teoria, uma nova disciplina - o Urbanismo -, que tem a pretensão de entender e ordenar o crescimento das cidades. É um século de mudanças estruturais significativas, 
transformadoras da realidade e que, até hoje, nos instigam a adentrar nessas questões, para entender as causas e consequências desse processo. Faremos, aqui, algumas reflexões sobre os principais temas abordados por autores que têm a questão urbana como seu tema central de investigação.

Considera-se o século XIX como o século da industrialização e da rápida urbanização. As mudanças que se produzem nas cidades industriais transformam-se em objeto de observação e campo de investigação. Muitos escritores da época têm como tema esses processos de transformação. Edgar Allan Poe, Charles Baudelaire, Victor Hugo, Eugène Süe, Charles Dickens, Honoré de Balzac, Émile Zola, dentre outros, descrevem esses ambientes urbanos, colocando em evidência os problemas e as misérias que eclodem nos centros urbanos. Os pesquisadores e reformadores sociais como Edwin Chadwick, Frédéric le Play e Engels também escrevem sobre as cidades. Os sanitaristas e médicos introduzem a teoria dos miasmas ${ }^{1}$ e alardeiam a necessidade de circulação de ar. Outros que se interessam pelo tema são os filantropos como Robert Owen e os utópicos como Etienne Cabet.

De princípios do século XX até nossos dias, muitos outros estudos analisam e interpretam a evolução física das cidades, o processo de urbanização e suas consequências. Não pretendemos nos estender nessas reflexões, apenas introduzir o leitor nas últimas questões levantadas por pesquisadores, no que se refere à história da cidade. Num primeiro momento, tratamos dos processos urbanos - suas mudanças espaciais, como eles se desenvolvem, suas consequências na estrutura urbana e na vida dos habitantes e a necessidade de intervir para assegurar a cidade como espaço viável. Em seguida, abordamos as estratégias e teorias urbanísticas desde o momento em que, diante do novo fenômeno urbano, inicia-se uma busca de fórmulas para projetar novos espaços ou para adaptar a antiga cidade às novas exigências da moderna sociedade, até a ocasião em que se constitui uma nova disciplina, um novo campo do saber - o Urbanismo. Finalmente, analisamos as reformas urbanas como processos que dão às antigas cidades a possibilidade de continuar existindo através de intervenções e mudanças, e nesse contexto, refletimos sobre a implantação de modelos e de planos específicos, sempre em busca da forma ideal de cidade. 
${ }^{2} \mathrm{O}$ interesse pelo tema manifesta-se com a publicação do livro de DYOS (1971), e com a formação do grupo Urban History Group na Inglaterra.

${ }^{3}$ A reunião, denominada Città preindustriale e città del capitalismo, é o primeiro passo para enfrentar o grande tema da urbanidade na Europa.

${ }^{4}$ Os Simpósios de História Urbana da América Latina realizam-se em Buenos Aires, em 1966, em Stuttgart, em 1968, em Lima, em 1970 e em Roma, em 1972. O primeiro Seminário de História da Cidade e do Urbanismo que ocorre no Brasil acontece em 1990, em Salvador/ $\mathrm{BA}$, onde se discutem as construções intelectuais que surgem do processo de modernização urbana no século XIX e princípios do século XX. A cada dois anos, acontece uma nova edição desse Seminário (1992, Salvador; 1994, São Carlos; 1996, Rio de Janeiro; 1998, Campinas e 2000, Natal).

\section{Sobre os processos urbanos}

No século $X X$, as pesquisas sobre os processos urbanos do século XIX tomam impulso. A partir da década de 60, na Inglaterra e nos Estados Unidos, elas evoluem de forma rápida, incluindo estudos comparativos entre as cidades dos dois países. ${ }^{2} \mathrm{O}$ crescente interesse pelo tema deve-se ao fato da industrialização e da urbanização no século XIX serem processos que mudam de forma radical a organização espacial das cidades e a relação entre as classes e grupos dentro da sociedade urbanizada. Comparam-se os processos urbanos do século XIX com os atuais e estudam-se as consequências do rápido crescimento urbano que ainda se fazem presentes na metrópole moderna. A esses dois pontos somam-se a disponibilidade e a quantidade de fontes e dados, o que incentiva os pesquisadores a construir relações e interpretações sobre o período.

Nos anos 70, permanece aberta a questão da relevância do fenômeno urbano, que muda o sistema de cidades nos últimos 100 anos. Na Europa e no resto do mundo, realizam-se reuniões, investigações e publicações sobre o tema. Na Itália, um grupo de estudiosos de diversas especialidades e formações reúne-se em Sorrento, em 1973, ${ }^{3}$ levantando a necessidade do debate sobre a História da Cidade ou História Urbana. É evidente, ainda, a necessidade de dar continuidade, em âmbito internacional, através de pesquisas, ao confronto das metodologias, à análise das tradições historiográficas e ao estudo de inúmeras questões. Em 1977, forma-se, em Paris, o Groupe de travail international d'histoire urbaine e, nesse mesmo ano, realiza-se, em Londres, o First International Conference on the History of Urban and Regional Planning, cujo maior interesse se concentra no período de fundação do moderno planejamento, num século de rápida urbanização e industrialização que culmina na Primeira Grande Guerra.

A dinâmica dos processos urbanos na América Latina também é tema de simpósios e reuniões a partir dos anos $60,{ }^{4}$ onde são discutidos e analisados diferentes aspectos da vida urbana e tratados os aspectos temporais relativos ao momento da independência dos países ibero-americanos da Espanha e de Portugal no século XIX.

A princípio, não há clareza sobre o campo de estudo, o objeto ou os métodos da História Urbana e da História da Cidade. Para o grupo de norte-americanos do New Urban History, tais iniciativas ou estudos decorrem, provavelmente, apenas do interesse de alguns historiadores sociais e econômicos, que não pretendem decifrar a evolução da cidade em si, nem 
procuram variáveis urbanas na história. É a História Urbana - estudos sobre os processos sociais na cidade, a história na cidade, as histórias que acontecem no ambiente urbano. Para os ingleses, deve-se dar uma explicação histórica essencialmente urbana, e sua meta principal é explicar a cidade através da relação entre espaço urbano e a sociedade que o habita. É a História da Cidade - sua forma e estrutura espacial. (MONCLÚS FRAGA; OYÓN BAÑALES, 1990, p. 588 $)^{5}$

A História da Cidade, pois, tem como objeto de estudo a configuração espacial convertida em fonte onde se pode ler a história da organização do espaço e da sociedade. Alguns estudos buscam encontrar os pontos definidores e os métodos mais adequados para a História da Cidade, ou seja, procuram uma variável essencialmente urbana. ${ }^{6}$

\section{Urbanização e redes urbanas}

A urbanização não é um fenômeno que se vincule sempre à industrialização, mas, na era industrial, desenvolve-se de forma mais rápida. Londres já é uma grande cidade antes da industrialização que, quando se inicia, utiliza-se da estrutura urbana existente, promovendo uma aceleração do processo de urbanização. A industrialização tem seu caráter urbano, já que faz da cidade sua base territorial, nela concentrando capital e força de trabalho. Pode-se falar em processo de urbanização já na Idade Média e no início da Idade Moderna, com características próprias e distintas daquelas da era industrial. Também pode ser identificada a formação de redes urbanas europeias, que, entretanto, não se constituem necessariamente num sistema em escala continental.

Para entender a urbanização, é necessário enfocar temas como o incremento da demografia urbana, a transferência da população do campo para a cidade e a mudança da relação demográfica urbano-rural. Também é preciso entender as relações e intercâmbios entre as cidades, dentro de um circuito que configure um sistema urbano.

Os estudos sobre urbanização não se restringem à análise da cidade, nem do sistema de cidades. Tampouco se pode entender o fenômeno da urbanização isolado do seu contexto. No caso da América Latina, a urbanização acontece vinculada a processos econômicos que não são resultantes da industrialização, pois as cidades latino-americanas nascem a serviço das relações internacionais com os países mais desenvolvidos, e isso faz com que seu processo de urbanização seja uma variável dependente, resultante de sua incorporação no mercado mundial. (SANTOS, 1982a) Acresce que, desde o seu descobrimento,
${ }^{5}$ Maurício de Abreu (1998, p. 13) considera a história urbana como a história das atividades que se realizam na cidade, no ambiente urbano de um modo geral, e a história da cidade seria a história dos processos sociais que se materializam de forma mais objetiva.

${ }^{6}$ Juan Luis Piñon considera que as ideias que conduzem à construção da cidade se reproduzem a partir de si mesmas, segundo lógicas reconhecíveis, e que o estudo dos fenômenos urbanos depende da posição relativa que ocupam em relação a outros fenômenos adotados como referência, ou seja, que a análise histórica urbana se situa na esfera metodológica da comparação. (PIÑON, 1993, p. 5) 
a ocupação territorial da América Latina foi desigual e irregular, dependente da conjugação de causas físicas, estratégicas, políticas e econômicas.

O esquema de urbanização pouco muda depois da independência dos países latino-americanos, ao longo do século XIX, mantendo-se o mesmo que foi estabelecido durante o período colonial, inclusive com a hierarquia dos centros entre si. Ocorrem lutas internas depois da emancipação até a formação de uma burocracia nacional, através de uma organização lenta. Os núcleos afastados entre si ficam isolados, além de haver outras dificuldades de deslocamento, o que dificulta o intercâmbio. Para atenuar o problema, a política comercial incentiva a primazia das cidades principais, com concentração de atividades administrativas e comerciais num só ponto em cada país. São os primeiros passos para a formação das metrópoles latino-americanas. A organização e a ocupação do espaço, assentadas na centralização do desenvolvimento em torno da capital, tem sua base econômica na agricultura, na pecuária e na mineração, antes que na manufatura. 0 domínio econômico e político exercido pelas capitais ibero-americanas sobre as demais áreas dos seus países faz com que haja uma supremacia total dessas capitais, o que leva à hipertrofia urbana e destaca o fenômeno da macrocefalia, presente em quase todos os países. (LOU; BENASAYAG, 1992, p. 170-171)

Sobre os processos urbanos no Brasil, alguns pontos merecem destaque. Antes do século XIX, o território brasileiro é formado de subespaços que evoluem segundo lógicas próprias, ditadas pelas relações com o mundo exterior. Esse panorama muda na segunda metade do século XIX, quando a produção do café faz do estado de São Paulo um polo dinâmico, com a implantação de ferrovias, a melhoria dos portos e a criação de meios de comunicação, o que contribui para a implementação de uma nova fluidez nessa parte do território brasileiro, uma vez que ali estão os influxos do comércio internacional, as formas capitalistas de produção, trabalho, intercâmbio e consumo que fazem efetiva essa fluidez. (SANTOS, 1996, p. 26-27)

A expansão da agricultura comercial e a exploração mineral são fatores que definem o assentamento da população e determinam a configuração das cidades, no litoral ou no interior. A mecanização da produção, nas áreas agrícolas e minerais, dá impulso e uma nova lógica ao processo. Em finais do século XIX, ocorre uma aceleração do processo de urbanização, já que, segundo os dados dos censos, em $1872,5,9 \%$ da população brasileira é urbana, passando a 9,4\% em 1900, depois a 10,7\% em 1920 e a $31,24 \%$ em 1940. A urbanização brasileira mantém sua característica costeira até meados da década de 60 do século XX, quando também se interioriza. Em finais dessa década, a população urbana supera a rural. 


\section{Morfologia e crescimento urbano}

Adotando a definição de morfologia como a forma da cidade e a disposição dos elementos urbanos, mas sem deixar de considerar a distribuição dos grupos sociais e das funções na cidade (RONCAYOLO, 1988, p. 65), pode-se estudar o tema através da análise da forma total da cidade e do crescimento da área urbana, ou trabalhar com partes específicas da cidade, como o centro, os bairros, as ruas, os quarteirões, as casas e os equipamentos urbanos.

Mas não basta reconhecer as formas, classificá-las e datá-las. É preciso entender o que influencia no uso do solo e na forma que a cidade assume em função de seu crescimento e de suas transformações totais ou parciais. Também é preciso relacionar a forma da cidade com a sociedade urbana.

Por trás dos elementos urbanos e de sua disposição, existe a tentativa de encontrar a ação da sociedade que os constrói, os utiliza e os interpreta; por trás da distribuição estão o jogo das relações e as mudanças das quais estas relações não são senão a expressão imóvel. (RONCAYOLO, 1988, p. 66) ${ }^{7}$

A evolução da forma urbana passa por um processo complexo de estruturação, no qual intervem fatores de natureza diversa, que vinculam as mudanças morfológicas a determinantes econômicos, sociais e tecnológicos, associados aos elementos essencialmente urbanos. Esses fatores influenciam a definição de novos espaços, como os subúrbios e os novos bairros residenciais afastados do centro, ou a introdução dos novos meios de transporte. Multiplicam ainda as descontinuidades espaciais e temporais e caracterizam a mudança de escala com uma superfície ampliada, onde se agregam, à cidade antiga, novas zonas de trabalho e de residência. Os novos meios de transporte dão viabilidade à expansão territorial e possibilitam o deslocamento entre as áreas funcionais e as residenciais, o que contribui para mudanças na estrutura urbana e na segregação espacial.

Na América Latina, muitos elementos contribuem para a transformação urbana, sendo difícil uma análise que adote uma visão de sua totalidade, o que torna mais viáveis os estudos por países. Esse processo de transformação acontece, geralmente, pela desagregação política e institucional, pela consolidação de poderes centralizadores frente aos regionalismos, pela inserção econômica no mercado mundial e pelo controle através dos portos de comércio exterior, com a consequente planificação da infraestrutura e com aspectos peculiares a cada país. 


\section{Estrutura urbana, divisões sociais e funcionais}

Como e onde se localizam as distintas classes sociais nas cidades europeias, a separação entre os espaços sociais e funcionais, a forma como esses espaços se relacionam entre si e como a população se desloca entre eles são pontos muito estudados e de interesse atual, que podem esclarecer os processos de estruturação das cidades e a formação da sociedade urbana. O principal debate centra-se na importância e nas características das relações existentes entre as estruturas sociais e formas espaciais.

O uso do solo passa a ser um determinante na nova estrutura urbana, quando mudam o valor dos terrenos e suas funções. Na cidade industrial, a nova forma de organização espacial caracteriza-se por notáveis diferenciações funcionais no espaço físico. Escritórios, residências, fábricas, slums e parques organizam-se segundo um esquema elementar, rádio-concêntrico, em torno do núcleo do poder - é o centro terciário-representativo. Esse tende sempre a estender-se e não a reproduzir-se, englobando e transformando as zonas limítrofes com a mesma lei do desenvolvimento inicial. No entorno do centro e das residências das classes ricas, pouco a pouco, incorporam-se faixas cada vez mais largas de zonas mistas, com edifícios industriais e residências operárias, e, assim, as demais faixas são empurradas para um perímetro mais externo, na medida em que o crescimento das atividades comerciais impõe a transformação das zonas que fazem divisa com o núcleo central. (AYMONINO, 1972)

Essa nova organização espacial, que começa a estruturar-se em princípios do século XIX, tem como consequência a segregação social e uma nova divisão funcional. As classes sociais dividem-se no espaço urbano em bairros residenciais diferenciados: os bairros operários distanciam-se e diferenciam-se dos bairros burgueses, cada grupo com suas próprias características e tipologias. As residências distanciam-se dos locais de trabalho, e as diversas funções - moradia, trabalho, lazer - ocupam espaços distintos. Essas são tendências cuja generalização se torna difícil, uma vez que cada cidade do século XIX se desenvolve de forma própria e, como tal, precisa ser analisada nas suas especificidades.

Roncayolo considera que o estudo da divisão social e funcional é um capítulo importante para a História da Cidade, mas de difícil conceituação, uma vez que não se trata de uma simples separação entre residência e trabalho. A divisão funcional responde a exigências técnicas, ao custo dos terrenos e aos benefícios que podem ser obtidos a depender da sua localização. Já a divisão social não se pode resumir apenas à distribuição residencial. "Con- 
tudo, é necessário se perguntar se é possível classificar os modos de vida e de habitação através de uma escala única determinada pela renda ou pela profissão, se é possível um só modelo." (RONCAYOLO, 1988, p. 80)

Também é difícil passar-se do conceito de divisão social e funcional ao de "segregação", assim como conceber-se a relação entre segregação espacial e segregação social. Numa análise histórica, a cidade medieval ${ }^{8}$ já apresenta um agrupamento mais ou menos rígido dos ofícios, que depende da força política da corporação e da cidade. Porém isso não supõe uma separação entre trabalho e residência, nem uma separação de classes sociais. No mesmo espaço, convivem mestres de ofício, aprendizes e ajudantes, distintos níveis sociais. A separação acentua-se na cidade industrial, quando surgem os bairros operários e as zonas industriais. A segregação social também se explica pela nova urbanística, que constrói, nos novos espaços da cidade, sociedades mais homogêneas, seja da elite ou de outra camada social.

São duas as consequências da divisão do espaço: uma é a valorização da "cidade" em relação ao crescimento periférico, associando-se "centralidade" a uma remota herança. A outra é a contraposição entre os bairros novos, que caracterizam a modernidade, e os bairros antigos, abandonados, confusos e superpovoados.

A estrutura interna das urbes latino-americanas também é tema de estudos que focalizam a diferenciação entre essas estruturas, através de uma gradação de situações econômicas, sociais e espaciais inseridas num processo geral de urbanização dependente da América Latina. Mas não podemos generalizar, nem pensar na existência de um modelo típico de cidade latino-americana. Tampouco é possível a definição de tendências evolutivas desse modelo apenas pela presença de uma tipologia comum nos processos de estruturação urbana, representada pelo colapso da estrutura urbana colonial, por movimentos setoriais da elite, por localizações periféricas do tipo "villa miseria-callampa-barriada"9 e por centrais como "cortiço-casa de cômodo". A diferença entre as cidades está nas distintas intensidades e no desenvolvimento temporal diferenciado com que se produzem esses processos.

Dentro do espaço da cidade, o século XIX enseja a formação de constelações de núcleos, a crescente descentralização e a despersonalização dos bairros, apagando a imagem integral da área urbana e as referências de identidade do homem com sua cidade. Muda a relação entre o centro histórico e as novas urbanizações. Em muitas cidades, o centro histórico perde a consistência de núcleo vital ou desaparece, deixando de ser residencial, ou se dilui.
80 mesmo ocorre na cidade colonial brasileira.

${ }^{9}$ Assim são chamados os bairros miseráveis na Argentina, no Chile e no Peru, respectivamente, denominados, no Brasil, de favelas. 
${ }^{10}$ Os livros de Baudelaire foram escritos em meados do século XIX.

${ }^{11}$ Os livros referidos de Benjamin foram escritos no início do século XX. (BENJAMIN, 1972, 1986)

12 Ver capítulo 3 - Baudelaire: 0 modernismo nas ruas.
A estruturação urbana pode ser classificada por diferentes períodos, cada um deles correspondendo a uma etapa de urbanização e colocando em evidência as políticas e ideologias dominantes. Uma dessas etapas é a implantação da cidade burguesa, com reflexos na mudança de sua estrutura social e de sua fisionomia, em consequência do crescimento urbano e de população, da diversificação da população, da multiplicação das atividades, da transformação da paisagem urbana e dos tradicionais costumes e maneiras de pensar dos diversos grupos sociais. As mudanças são mais perceptíveis nas grandes cidades, uma vez que a transformação da estrutura econômica tem repercussão visível nas capitais e nos portos, isto é, na parte que está voltada para o mercado mundial.

O Brasil não fica fora de todo esse processo. Aqui, percebemos que indústrias são incentivadas pelo governo a construir casas "higiênicas" para os operários, junto a seus estabelecimentos. Esse tipo de residência, que se concede ao trabalhador da fábrica, pressupõe uma forma de controle da vida e dos costumes dos empregados por parte dos patrões. A partir de meados do século XIX, os bairros também se especializam, e as classes sociais distribuem-se na área urbana de forma segregada: a classe abastada para um lado e os pobres para o outro.

\section{As imagens da cidade}

Cronistas, escritores literários, higienistas e pesquisadores das Ciências Sociais lidam com imagens e representações da cidade. Desde o século XIX, escritores e médicos, preocupados e assustados com as bruscas mudanças que se produzem em suas cidades, descrevem e denunciam um ambiente que ora parece assustador, ora encantador. A cidade também é objeto de estudo, descrição e análise em trabalhos técnicos, como os que analisam cartografias e iconografias, ou ainda em imagens não técnicas.

É interessante observar que muitos dos textos produzidos, no momento e ao sabor das transformações, são posteriormente retomados, propiciando uma releitura por parte de historiadores, arquitetos e sociólogos. Baudelaire, em algumas de suas obras - O pintor da vida moderna, Spleen de Paris e As Flores do $\mathrm{Ma}^{10}$ - descreve, critica e elogia as transformações que ocorrem em Paris durante o período Haussmann, no Segundo Império. No início do século XX, Walter Benjamin, ${ }^{11}$ com base na obra de Baudelaire, analisa e reinterpreta as transformações da Paris haussmanniana. Mais recentemente, M. Berman (1986) ${ }^{12}$ também usa o trabalho de Baudelaire para sua análise 
sobre a modernidade. Em todas as três épocas, a imagem de Paris em transformação, no século XIX, é o foco principal. ${ }^{13}$

As imagens produzidas pelas transformações urbanas refletem uma gama de reações diferenciadas, que vão da rejeição e de uma visão anti-urbana até admiração, numa visão mais positiva de confiança no progresso e numa vida urbana de qualidade. Muitos recorrem a imagens utópicas, situando as cidades entre realidade, pensamento teórico e imaginação popular, ou seja, uma oscilação entre a cidade real e a cidade sonhada. A imagem da cidade do século XIX, pois, passa por um processo radical de transformação, visualizado de forma descritiva ou iconográfica por artistas, arquitetos, historiadores, escritores, cada um com sua forma própria de representar essa fase de mudança. Mudam, inclusive, os pontos de vista ou os ângulos de visão espacial das cidades. ${ }^{14}$

No caso da América Latina, a imagem das cidades começa a se transformar após o processo de independência, a partir do início do século XIX, principalmente nas capitais dos novos países, onde é promovido um novo ordenamento, traduzido em resultados urbanísticos. Se a estruturação das cidades latino-americanas não se assemelha à das cidades europeias, pelo menos há a introdução de novos elementos de estrutura urbana, como as alamedas, os bulevares, os eixos internos e os novos edifícios representativos. Essas novas imagens e representações das cidades são analisadas e interpretadas por distintos profissionais, de formas diversas, sob variados pontos de vista - da Cultura, da Psicologia, do Urbanismo, da História, da Literatura e da Filosofia -, focalizando o urbano como paisagem, ou como local de multidões, ou como espaço do desejo, ou como possibilidade de civilização.

\section{Sobre estratégias e teorias urbanísticas}

Se os processos de transformação urbana são um campo vasto de pesquisas, as formas de intervir na cidade também se constituem em matéria de reflexão. As estratégias e teorias urbanísticas do século XIX e princípios do século XX constituem a base de muitos estudos que buscam entender como se estrutura esse novo campo do saber, o Urbanismo, como se desenvolvem e se aplicam as novas teorias elaboradas e quais são suas consequências. O nascimento do Urbanismo como um campo do saber e sua formulação teórica representam uma reação frente às condições a que chegam as cidades

\footnotetext{
${ }^{13}$ Um exemplo recente é o livro de Sandra Jatahy Pesavento (1999), que analisa as transformações imagéticas das três cidades no século XIX e princípios do século XX através dos escritos e crônicas da época.

${ }^{14}$ Um exemplo é o da cidade amuralhada, que poderia ser retratada da distância de um balão, e necessita da fotografia e do avião no início do século XX.

Hoje, as metrópoles, são melhor representadas por uma foto de satélite.
} 
${ }^{15}$ Segundo a autora, o termo "urbanismo" é um neologismo proposto por Ildefons Cerdà em sua Teoría General de la Urbanización de 1867 e introduzido na França por $\mathrm{H}$. Prost na primeira década do século XX. (CHOAY, 1994)
- aumento de população, crescimento de área, insalubridade e epidemias -, motivadoras de mudanças estruturais para adaptação aos novos padrões exigidos pela sociedade.

Esse novo objeto de estudo, o espaço da cidade, desenvolve-se durante todo o século XIX, quando se torna evidente a necessidade de traçar estratégias para intervir nos antigos e estruturar os recentes ambientes urbanos. 0 caos instaurado nas urbes sustenta os argumentos para que se tomem providências para ordenar a desordem instalada: num mesmo espaço, circulam os carros e os pedestres, criam-se animais e brincam as crianças; não existe separação entre zonas industriais e zonas residenciais; a fumaça está por toda parte; a sujeira é uma constante e as epidemias atingem todas as classes sociais. Segundo Benevolo (1992, p. 7), essa é a origem do Urbanismo moderno.

O urbanismo moderno não nasce ao mesmo tempo que os processos técnicos e econômicos que fazem surgir a cidade industrial e a transformam, mas forma-se num período posterior, quando os efeitos quantitativos das transformações em curso já são evidentes e quando os ditos efeitos entram em conflito entre si, sendo inevitável uma intervenção reparadora.

A história do urbanismo desperta, hoje, tanto interesse quanto a história da cidade, voltando-se para o paralelismo entre experiências urbanísticas e suas especificidades, não como simples reflexo de experiências externas, mas como resultado da interferência de variáveis políticas, técnicas, sociais e econômicas sobre a ordenação do espaço.

O termo Urbanismo, segundo F. Choay, ${ }^{15}$ tanto pode designar uma nova disciplina com pretensão de ser uma ciência de concepção de cidades, com a possibilidade de manter o controle sobre o fato urbano, como pode corresponder ao movimento que busca organizar e regularizar o crescimento e o movimento dos fluxos demográficos, a mudança de escala dos equipamentos e das construções provocadas pela Revolução Industrial. É indiscutível que a era industrial muda a escala e a complexidade do desenvolvimento urbano. Ao tomar uma forma própria - em decorrência da expansão da sociedade industrial em finais do século XIX - a cidade da era industrial provoca um movimento de observação e de reflexão que dá origem a um novo campo do conhecimento.

A era industrial representa uma transformação radical nos aglomerados urbanos existentes e propicia a formação de novas aglomerações, gerando uma grande desordem na organização espacial e transformando a mentalidade dos habitantes e as iniciativas dos planejadores. Há uma mudança estrutural significativa: ampliam-se os limites da cidade; a população cresce 
rapidamente; a cidade divide-se em produtores e consumidores; os espaços dividem-se em periferia, para fábricas e manufaturas, e o centro de negócios. São introduzidos novos elementos, como as chaminés, a ferrovia e um novo mobiliário urbano. A análise semiológica desses novos componentes introduzidos no ambiente urbano é uma outra forma de entender a evolução do urbanismo e seus complementos.

Pode-se, pois, considerar o Urbanismo uma nova ciência - apesar de já existirem discussões sobre o tema do planejamento antes do século XIX -, focalizada como uma nova teoria, que representa, em essência, uma tomada de consciência da sociedade industrial sobre si mesma, através do questionamento de suas realizações.

Desde as primeiras experiências urbanísticas até a constituição de uma nova disciplina, os focos de reflexão incidem sobre a definição de modelos de intervenção e a classificação das experiências empreendidas no âmbito da cidade industrial. A evolução da urbanística segue em paralelo e articulada com as transformações socioeconômicas e as mudanças de direção política presentes nas novas realidades. ${ }^{16}$ As teorias e propostas multiplicam-se em função da necessidade de soluções para os problemas gerados pelo crescimento acelerado das novas cidades e por sua falta de preparação para essas mudanças. As propostas vão desde começar outra vez, criando novos ambientes totalmente diferentes dos atuais, até tentar resolver cada um dos problemas e remediar seus inconvenientes. No primeiro caso, os teóricos pretendem materializar uma visão de cidade ideal. No segundo, especialistas e funcionários produzem regulamentos sobre questões como higiene e novas instalações, que dão origem à moderna legislação urbanística.

Segundo Choay (1979, p. 1-56), podemos dividir a evolução do urbanismo em três etapas, marcadas pela presença maior ou menor de uma ideologia. A Regularização, ${ }^{17}$ correspondente ao processo analítico em que se busca a boa forma. O Pré-urbanismo, de caráter sintético, que fundamenta suas propostas em argumentos ideológicos, abrigando duas correntes principais: a progressista, que propõe um objeto urbano separado, cujos componentes estandardizados se distribuem pelo espaço segundo uma ordem funcional e geométrica, e a culturalista, compacta e multifuncional, que se concentra em objetivos humanistas. Finalmente, a etapa do Urbanismo, que segue as principais correntes do Pré-urbanismo, com a inclusão da figura do arquiteto-urbanista, quando o planejamento de cidades "se acredita" uma ciência. (CHOAY, [197-], p. 109-110)
${ }^{16}$ Benevolo considera o ano de 1848 como marco ideológico da cultura urbanística, que passa a adotar o paternalismo político da nova direita. (BENEVOLO, 1992)

${ }^{17}$ Regularização é o termo que Haussmann usa em suas memórias, para definir suas intervenções em Paris. (HAUSSMANN, 1979) 
Entretanto, essa categorização não pode ser generalizada, já que cada cidade, ou cada país, caminha de forma distinta ao analisar seus problemas e intervir no espaço construído. No caso das cidades alemãs, por exemplo, são propostos estudos mais profundos dos problemas urbanos e obtém-se, como resultado, a elaboração de um plano regulador e de um dispositivo edilício, os dois instrumentos da urbanística moderna. (PICCINATO, 1993) Essa forma de intervenção tem a gestão urbana como sua base e objetiva a distribuição geral dos serviços sociais, a acessibilidade não diferenciada e um habitat sem desequilíbrios, fraturas ou conflitos. O plano regulador é elaborado para controlar esse espaço e distribuir benefícios urbanos a toda a sociedade, como um instrumento de coordenação entre os distintos elementos. 0 dispositivo edilício, competência das administrações públicas, tem como objetivo desde a expedição de licenças até o controle de habitabilidade, sendo o instrumento executivo do plano, uma norma precisa, construída em torno dos princípios da propriedade individual, que fixa as condições mínimas aceitáveis em termos de higiene, estética e circulação.

$\mathrm{Na}$ era industrial, a cidade, a urbanística e o projeto urbano deixam de coincidir, já que não se pode entender cada um deles através dos outros. Ao nos aprofundarmos nas questões da história do urbanismo, principalmente no período estudado, essa defasagem - entre os processos de transformação urbana e a teoria urbanística - permite descobrir e entender a imagem que a cultura dominante propõe para a cidade e os laços da teoria urbanística com o momento socioeconômico original.

Nas discussões sobre o planejamento urbano, em princípios do século XX, surgem as designações City Planning nos Estados Unidos, Town Planning na Inglaterra, Städteplanung na Alemanha e Urbanisme na França. Esses termos são utilizados para descrever as deliberações ordenadas pela autoridade pública para as intervenções físicas na cidade, ou em parte dela, com o objetivo de estabelecer um eficiente e equilibrado funcionamento, além de criar entornos agradáveis.

A expansão da industrialização e da urbanização, que transforma grande parte da Europa e outras partes do mundo, faz com que o planejamento urbano se converta numa questão cada vez mais internacional. Surge um movimento mundial em relação às questões urbanas, com organizações de cunho formal e informal. Congressos, publicações, visitas e projetos evidenciam a evolução do urbanismo. A primeira revista é publicada em 1904 - Der Städtebau e a Alemanha reconhecida como líder mundial do urbanismo. Em 1908, cria-se a seção de higiene rural e urbana do Musée Social de Paris e, em 1910, 
realiza-se o primeiro congresso mundial de urbanismo organizado pelo Royal Institute of British Architects. Na Alemanha, surgem os planos de ocupação do solo que dividem toda a cidade em zonas com funções e regulamentos particulares. Em torno de 1910, já se usa o termo Zonung (zoning ${ }^{18}$ ou zoneamento). Depois da experiência alemã, o zoning é divulgado através de congressos e manuais.

Modelos e teorias urbanísticas surgem em finais do século XIX e princípios do século XX. Dá-se, por exemplo, a consolidação e a divulgação da Arte Urbana, que alguns autores associam ao "urbanismo artístico" preconizado por Camillo Sitte e outros identificam com a "arte na rua", ou mesmo com as propostas monumentais típicas do movimento City Beautifu/19 dos Estados Unidos. É importante ressaltar a conexão das estratégias de embelezamento e a monumentalidade das cidades europeias com o movimento City Beautiful nos Estados Unidos, pois esses movimentos de embelezamento, que surgem da vontade de converter as cidades em obras de arte, vêm de mais longe, do século XVIII.

Em algumas cidades como Paris, Londres ou Viena, busca-se o embelezamento e a monumentalidade não só com a introdução de elementos decorativos e detalhes, mas, na realidade, com a transformação das próprias cidades em monumentos. Essa tradição monumental tem como modelo os bulevares de Haussmann em Paris, a Regent's Street em Londres e a Ringstrasse em Viena. No século XX, essa tendência reflete-se no orgulho cívico aliado ao impulso comercial dos EUA e nas colônias britânicas da Índia, da África e da Austrália, e culmina na megalomania da Alemanha de Hitler, da Rússia de Stalin, da Itália de Mussolini, da Espanha de Franco e até do Brasil, durante o regime autoritário do Estado Novo.

$\mathrm{Na}$ análise desse movimento, que nasce na Europa, vai aos Estados Unidos e volta à Europa, concluímos tratar-se de um fenômeno de difícil compreensão, pelo seu caráter complexo, multifacetado, em cujo contexto se encontram situações diferenciadas do ponto de vista econômico, social, político, cultural e ideológico. Nele, o que se evidencia como mais importante, comum a todas as situações nas quais se implanta o modelo, é a concentração no monumental e no superficial, além da forma de tratar a arquitetura como símbolo do poder, cuja finalidade é impressionar. (HALL, 1996, p. 273) A essência do movimento está em seus partidários acreditarem na beleza, nos belos edifícios e cenários, e crerem que esses, além da estética, podem mudar a má situação das cidades, combatendo a feiúra e a desordem.
18 Segundo F. Mancuso (1980), o
zoning entra nas leis urbanísticas de
alguns países em princípios do século
XX, como na Suécia (1907), Holanda
(1901) e Inglaterra (1909).

${ }^{19}$ Movimento que tem claras referências haussmannianas. 
${ }^{20}$ Outros congressos continuam se realizando com temas periféricos ao urbanismo. Os Congressos Pan-americanos de Arquitetos realizam-se, o $2^{\circ}$ em Santiago do Chile em 1923, o $3^{\circ} \mathrm{em}$ Buenos Aires em 1927 e o $4^{\circ}$ no Rio de Janeiro em 1930. No Brasil, temos os Congressos Brasileiros de Higiene, $01^{\circ}$ no Rio em 1923 e o $2^{\circ}$ em Belo Horizonte em 1924. Em 1931, realiza-se o Congresso de Habitação de São Paulo.

${ }^{21}$ A Semana de Urbanismo de Salvador, com seus objetivos e resultados, é tratada no capítulo específico sobre essa cidade.
Outra teoria sobre o movimento City Beautiful (WILSON, 1980) defende a existência de uma intenção de combinar beleza com função. Daí a incorporação de profissionais para o desenho e a execução dos projetos. As bases do movimento encontram-se na chamada American Discovery of Europe, em que a Europa representa o progresso, com suas cidades que, sob o modelo clássico, parecem mais dinâmicas do que as da América do Norte, mais limpas, melhor administradas, mais bonitas e onde o crescimento e 0 desenvolvimento estão controlados.

\footnotetext{
Uma eficaz avaliação do movimento City Beautiful deve levar em consideração o modo como seus defensores o interpretam. O movimento foi, primeiro, um esforço para adornar as cidades americanas com beleza, carentes que eram pelas características do século dezenove. Foi, em segundo lugar, um esforço consciente para juntar a beleza clássica com a paisagem natural construída e com elementos funcionais essenciais. Combina apreciação estética com algum conhecimento, e algumas vezes uma percepção aguçada de políticas e legítimas necessidades. Foi, finalmente, amplo em sua força. Concebe a cidade e seus habitantes como um organismo, tendo vida e crescimento suscetíveis de definição, racionalidade e controle. (WILSON, 1980, p. 189)
}

Seguindo também os passos da Europa, a América Latina, antes da institucionalização do urbanismo, tem problemas acarretados pelo crescimento urbano espontâneo, sendo esse o tema de diversas reuniões, conferências, encontros e congressos. Um dos primeiros eventos é o Congresso Médico de Pernambuco, realizado em 1909, em Recife. Nele, das 40 palestras, 20 abordam o tema da reforma social e 5 tratam dos problemas urbanos, uns gerais e outros sobre Recife. Passada uma década, em 1920, realiza-se o Primer Congreso Argentino de Viviendas, organizado pelo Museo Social Argentino, e o Primer Congreso Panamericano de Arquitectos de Montevideo. Nesse último, os arquitetos discutem questões urbanas num fórum internacional e, de suas conclusões, constam a elaboração e a adoção de planos reguladores dos centros urbanos. Propõem também a inclusão de um curso especial de Urbanismo nas Escolas e Faculdades de Arquitetura, e a criação de uma liga Pan-americana de Cidades. ${ }^{20}$

Tendo como tema específico o urbanismo, em 1935, realiza-se o Primer Congreso Argentino de Urbanismo em Buenos Aires, com assuntos como história e evolução urbana, urbanização de cidades, aspectos socioeconômicos e o ensino, e a Semana de Urbanismo de Salvador, que tem como objetivo a elaboração de um plano para incluir a cidade no circuito das cidades civilizadas do mundo. ${ }^{21}$ O Primeiro Congresso Brasileiro de Urbanismo, organizado pelo Departamento de Urbanismo do Centro Carioca de Engenheiros, acontece no 
Rio em 1941, com temas como a regularização do crescimento das cidades e a solução dos problemas das habitações, mas também com a intenção de aumentar a influência dos urbanistas. Paralelamente ao Congresso, realiza-se uma exposição de urbanismo no Museu Nacional de Belas Artes (antiga Escola Nacional de Belas Artes).

O urbanismo brasileiro nasce como uma herança do urbanismo progressista europeu, que nos chega através da França, país que está unido culturalmente ao Brasil desde 1816, quando a Missão Francesa por aqui desembarca. A formação do Urbanismo como disciplina, quer dizer, as circunstâncias que originam as reflexões sobre a cidade e seu espaço, no Brasil, são as mesmas que impulsionam o nascimento do tema da urbanística na Europa e nos Estados Unidos. A definição de um quadro teórico ${ }^{22}$ brasileiro tem suas bases na dependência acadêmica e vincula-se, com efeito retardado, às propostas europeias e norte-americanas.

O primeiro período, na formação do pensamento urbanístico no Brasil, vai de 1895 a 1930.23 Nesse momento, a temática central diz respeito aos planos de intervenção urbana e ao aparecimento de técnicas para resolver as questões da cidade como o saneamento, a circulação e a legislação urbanística. A formação dessa área de conhecimento - o Urbanismo - tem sua origem nos cursos de engenharia civil e engenharia-arquitetura e se mantém nas novas escolas de arquitetura, criadas a partir da década de 40.

A primeira geração de profissionais é constituída de egressos dos cursos de engenharia, das antigas Escolas Militares da Bahia, Pernambuco e Rio de Janeiro, ou da Escola Central do Rio de Janeiro. Alguns realizavam seus cursos no exterior. Esses profissionais ocupam cargos públicos nas estruturas administrativas em formação, nas prefeituras das principais cidades e no governo do estado, no período referido. Também criam e participam, como docentes, das Escolas Politécnicas de Engenharia de São Paulo, Bahia e Rio.

\footnotetext{
${ }^{22}$ Entendemos quadro teórico como o processo de investigar a questão urbana, definir sua problemática, tomar consciência de seus pontos frágeis e buscar soluções.

${ }^{23} \mathrm{O}$ segundo período situa-se entre 1930 e 1950; e o terceiro, entre 1950 e 1964. (LEME, 1999)
}

\section{Sobre as reformas urbanas}

Torna-se especialmente importante, para a análise das reformas urbanas do Rio de Janeiro e de Salvador, entender como as intervenções se realizam, mesmo antes da definição do Urbanismo como uma disciplina, uma ciência ou uma arte. Nesse período, muitas cidades europeias modificam seu tecido urbano com novas ruas, que cortam o espaço medieval, com anéis construídos no local das antigas muralhas, circundando seus centros históricos, ou com a 
criação de novos espaços urbanos além dos baluartes finalmente demolidos. Intervir, pois, na cidade construída, não é uma novidade do século XIX. Os planos de regularização, as intervenções para embelezamento ou a reconstrução do centro urbano são experiências que estão presentes já nos séculos anteriores. Obras como a de Sisto V em Roma, no século XVI, a abertura da Place des Vosges em Paris, no século XVII, ou a reconstrução de Lisboa, no século XVIII, pelo Marquês de Pombal, são só alguns exemplos.

No século XIX, as reformas têm como objetivo resolver os problemas que se apresentam nas cidades industrializadas, ou em consequência da industrialização, que provoca um crescimento desmesurável e sem controle, além de um cenário de epidemias e de revoltas. As reformas podem realizar-se, a princípio, pela necessidade de adaptação da cidade às novas tecnologias, que pretendem melhorar a qualidade de vida urbana para mudar suas ruas visando a implantação dos novos meios de transporte; para instalar as tubulações visando possibilitar o abastecimento de água, de gás e viabilizar a rede de esgoto; para "abrir" as habitações para que entre o ar e a luz. Para construir habitações para a população que chega à cidade e não tem onde acomodar-se. Para destruir os cortiços, alinhar as ruas e mudar a estética das construções. Para sanear os espaços públicos. Ao lado disso tudo, busca-se, também, resolver outros problemas, como a superpopulação, a falta de higiene, as epidemias e a desordem. Em resumo, há que modernizar a cidade. $\mathrm{E}$ isso passa a fazer parte de um projeto político das elites.

Muitas são as estratégias de transformação urbana nas cidades europeias entre 1850 e 1914. A principal diferença entre elas é identificada quando comparamos as cidades anglo-saxônicas com as típicas cidades continentais europeias. As primeiras apresentam um movimento de migração das classes abastadas para os subúrbios, enquanto as últimas revelam um comportamento diferente, ao manter um centro, no qual vive a classe mais rica e onde se localizam os edifícios públicos e as instituições nacionais. Wagenaar (1992, 1997) faz uma comparação entre o desenvolvimento de quatro típicas cidades continentais da Europa - Paris, Bruxelas, Roma e Budapeste -, e o das cidades como Londres e Amsterdã, que se expandem em direção aos subúrbios. Confrontando suas respectivas reformas urbanas, o autor busca entender como os diferentes modelos utilizados para resolver problemas comuns podem ser o resultado de estratégias opostas, devido antes a diferentes administrações e políticas nacionais do que a preferências residenciais.

Definem-se, assim, dois métodos de intervenção, em relação às estruturas urbanas existentes: o deslocamento para os subúrbios, livres das 
restrições municipais, com a criação de novas áreas distantes do centro o plano de extensão; a demolição e a substituição das velhas estruturas o plano de reforma. (MUMFORD, 1982, p. 448)

O projeto de Ildefons Cerdà, para Barcelona, e o do Ring, para Viena, incluem-se na primeira categoria. As ampliações urbanas podem ser interpretadas como a vontade de projetar a totalidade da área urbana e geram o ordenamento morfológico e a organização dos serviços de infraestrutura.

Nos planos de reforma, modifica-se o tecido existente com a abertura de ruas e praças e a introdução de novos elementos, como monumentos ou edificações importantes. Realizam-se dentro dos limites da cidade construída. A abertura da Regent's Street em Londres ou as intervenções parisienses realizadas por Haussmann são exemplos de planos de reforma. Esse tipo de intervenção, nas cidades do século XIX, é pontual, intervenção limitada às novas instalações, à renovação das edificações ou à reestruturação viária, o que contrasta com a ideologia total do plano regulador, que tem a visão global da cidade e trabalha o seu conjunto. 0 plano regulador é introduzido para evitar ações contrárias ao interesse comum, tendo, portanto, um papel ativo na intervenção, visando a corrigir equívocos e situações consideradas incorretas.

Um tema muito estudado e que, segundo alguns autores, volta a estar em evidência são as obras de Haussmann, na Paris do Segundo Império, analisadas sob diversos ângulos. Elas causam um impacto de tal envergadura, que são consideradas modelo para muitas outras reformas urbanas no final do século XIX e durante todo o século XX, não só na França e na Europa, como também em outras partes do mundo, inclusive no Brasil. A Paris haussmanniana é, pois, um marco na história da urbanística moderna, podendo ser definida como um estilo de cidade, pois não é obra de um homem só: nasce antes de Haussmann, vai muito além do Segundo Império e mantém-se com as mesmas características do século XIX, o que se pode considerar como o triunfo de uma inteligente conservação, ou como o fracasso do progresso material. (SUTCLIFFE, 1973) O mais importante é que o tema continua vivo. ${ }^{24}$ Na segunda metade do século XIX, o estilo de vida urbano das maiores concentrações urbanas da América Latina tende a aproximar-se do europeu. Pavimentam-se as ruas das cidades, implantam-se os serviços de infraestrutura urbana e afirmam-se os extratos médios e ricos da população. Em princípios do século XX, produz-se um ciclo de transformações em que se repetem, de alguma forma, os esquemas do urbanismo francês do Segundo Império. Daí alguns autores (ALMANDOZ, 1996; SCOBIE, 1977; BENCHIMOL, 1992; SICA, 1981a) fazerem referência direta à influência haussmanniana nas cidades latino-americanas.
${ }^{24}$ As intervenções de Haussmann em Paris serão abordadas mais detidamente no próximo capítulo, com a análise da haussmannização e da sua influência em outras cidades. 
${ }^{25}$ Também Recife realiza sua reforma urbana. Para o tema: Lubambo (1991) e Outtes (1992).

Sobre um plano de extensão, citamos o estudo de Campos Júnior, (1996), que analisa o projeto de ampliação urbana para a cidade de Vitória/ES, de autoria do Engenheiro Saturnino de Brito em 1896.
No Brasil, como exemplo, podemos citar o caso da cidade de Santos (LANNA, 1996) que, a partir de finais do século XIX, passa a ser o maior porto do País. Sua reforma urbana foi iniciada em 1870, com demolições realizadas sob o pretexto de melhoria do espaço urbano, e na década de 90 desse século, voltou-se para a desobstrução do centro e o crescimento da área urbana, com o planejamento de novos bairros, negando seu passado colonial e buscando padrões europeus de construção de cidade que seus habitantes consideram ideais. Nessa mesma linha, há também o caso de São Paulo, uma cidade reconstruída duas vezes sobre o mesmo assentamento.(TOLEDO, 1983)25

\section{Os argumentos para intervir}

Um dos pontos de discussão, quando analisamos as reformas urbanas, são os argumentos justificadores das transformações propostas, utilizados por governos e investidores. Para defini-los e analisá-los, é preciso entender a realidade das cidades, como vivem seus habitantes e que tipo de cidade se idealiza.

Em meados do século XIX, o caos a que chegam as cidades europeias, como vimos anteriormente, converte a questão urbana num ponto de preocupação dos governantes e da elite. São epidemias e revoltas, crescimento desordenado, explosão demográfica e inadaptação da estrutura medieval às novas exigências da sociedade industrial. Não há dúvidas de que os governantes e a classe dominante desejam adaptar a cidade às novas exigências e ao desejo da burguesia, a nova classe urbana, de modificar o aspecto de desordem das cidades e transformá-las num local para seu desfrute. Nesse processo de intervenção, os governos impõem seus projetos de forma autoritária e utilizam justificativas próprias para demolir edificações e abrir novos eixos, estratégia que se repete em muitas das cidades analisadas.

Além de um aumento de área e de população muito rápidos, as urbes também começam a introduzir, em suas ruas, novos elementos que provocam mudanças sem previsão. São os trens, os bondes, os novos serviços urbanos como abastecimento de água, iluminação e redes de esgoto. São também os novos meios de comunicação como os jornais, o telégrafo e o telefone. As ruas são pavimentadas, separando-se a parte por onde transitam os veículos da calçada, onde transitam os pedestres. Pouco a pouco, os modos de vida urbana mudam, e a sociedade encontra-se no meio de um turbilhão. Instala-se 
a cidade burguesa, a cidade moderna. Berman (1986, p. 15) define muito bem a experiência da modernidade: "Ser moderno é encontrar-se em um ambiente que promete aventura, poder, alegria, crescimento, autotransformação das coisas em redor - mas ao mesmo tempo ameaça destruir tudo o que temos, tudo o que sabemos, tudo o que somos".

Nas cidades capitais, que representam um Estado moderno ou impérios comerciais e industriais, há uma preocupação com o ambiente deteriorado. Recuperar a imagem, ser atraente, mudar a estética, melhorar a circulação de pessoas e de mercadorias, buscar mais salubridade e representar a nova burguesia que assume o poder são os objetivos que conduzem os administradores e investidores a realizar as reformas urbanas no século XIX. A desordem, a sujeira, as ruas estreitas, não apropriadas para os novos meios de transporte, que também impedem a passagem da luz e a circulação do ar, e a falta de estética são alguns dos argumentos que se encontram nos discursos dos dirigentes, quando decidem destruir velhas estruturas e substituí-las por novas, rasgar avenidas e demolir arcaicas edificações.

\section{Por que intervir}

O caos do ambiente urbano, no século XIX, de certa forma, é produzido pelo laissez-faire, pela inexistência de métodos de controle urbanístico. Os relatórios dos médicos, a insalubridade da cidade, que ocasiona taxa de mortalidade muito alta, e as epidemias, que matam milhares de pessoas chamam a atenção da administração pública, que decide intervir para mudar a situação, restaurar a habitabilidade da cidade e substituir a imagem do caos pela da ordem.

0 ritmo de crescimento demográfico ${ }^{26}$ urbano é muito rápido, por volta de $2 \%$ ao ano em Londres, que chega a 2 milhões de habitantes em 1840 e passa de 3 milhões em 1865. (BAIROCH, 1990, p. 228-229) Em outras cidades, a situação não é diferente. Em Paris, a população passa de 900 mil habitantes, em 1830, a aproximadamente 1,3 milhão em 1848. (SICA, 1981a, p. 178) O mesmo acontece em Berlim e Viena. ${ }^{27}$ Na América Latina, a situação não muda muito. Buenos Aires passa de 300 mil habitantes, em 1880, a 1,2 milhão, em 1910 (SCOBIE, 1969, p. 324), e o Rio de Janeiro tem uma taxa de crescimento populacional de 90\% entre 1872 e 1890. (ABREU, 1988, p. 54) Com esse crescimento populacional tão repentino, as
${ }^{26} \mathrm{Um}$ dos motivos para o crescimento demográfico acelerado é a transferência do excedente do campo para a cidade que, com o desenvolvimento industrial, favorece a necessidade de força de trabalho.

${ }^{27} 248$ mil habitantes em 1831 e 431 mil em 1852 em Berlim; 850 mil habitantes em 1870 e 1,6 milhão em 1900 em Viena. SICA, P., op. cit., 1981 a, p. 256 e p. 320 , respectivamente. 
cidades apresentam, de um modo geral, uma imagem de pobreza e miséria, com os detritos e o lixo jogados pelas ruas, uma paisagem deteriorada, típica de uma cidade industrial. "O industrialismo, a principal força criadora do século XIX, produziu o mais degradado ambiente urbano que o mundo jamais vira; na verdade, até mesmo os bairros das classes dominantes eram imundos e congestionados." (MUMFORD, 1982, p. 484)

Nesse ambiente deteriorado, as pessoas perdem a sensibilidade. As moradias são da pior qualidade, não só as dos pobres, como também as construídas para a classe média. Os trabalhadores amontoam-se em velhas casas abandonadas, transformadas em casas de cômodos. Muitas vezes, famílias inteiras vivem num só compartimento. Os resultados dessa aglomeração são a grande concentração de sujeira, os esgotos correndo a céu aberto, os ratos que transmitem a peste bubônica e os piolhos que transmitem o tifo. A falta de asseio e as habitações úmidas e escuras propiciam a proliferação de bactérias e infecções.

A cidade do século XIX chega a essa situação caótica em consequência do liberalismo econômico, da Revolução Industrial e da urbanização acelerada. As mudanças destroem os equilíbrios espaciais e humanos, já que, em muitos casos, provocam o desaparecimento dos vínculos de tipo feudal e comunitário, a liberação do uso do solo e o aproveitamento das economias externas mais imediatas. Segundo Hobsbawm (1996, p. 295), as cidades transformam sua forma, imagem e estrutura pela pressão das construções e do planejamento e pela busca do lucro, mas, nos dois casos, não aceitam a presença dos pobres, mesmo reconhecendo que são um mal necessário. Para os planejadores, os pobres são uma ameaça pública, capazes de criar distúrbios, e, por isso, propõem que seus pontos de concentração sejam eliminados através da abertura de bulevares e avenidas. Dessa forma, os pobres dispersam-se em direção a pontos não especificados, à procura de habitações. Para os empreendedores, os pobres são um mercado que não gera lucro, comparado ao dos ricos, com seus negócios especializados e distritos de comércio e as sólidas casas e apartamentos para a classe média.

Para os pobres, quando não ocupam os distritos centrais das cidades abandonados pelas classes mais altas, são construídas habitações por especuladores e construtores. Como descreve Engels (1985, p. 66, grifos do autor), essas habitações são feitas "[...] sem a menor preocupação com a higiene e o conforto dos habitantes, com a única preocupação de obter o maior lucro possível e de acordo com o princípio: por pior que seja um casebre, há sempre um pobre que não pode pagar um melhor." 
Benévolo (1992) classifica a cidade da era industrial em dois tipos, correspondentes a duas etapas: a cidade liberal, anterior a 1848, que apresenta um ambiente desordenado e inabitável, resultado da superposição de muitas iniciativas públicas e privadas não regulamentadas e não coordenadas; e a cidade pós-liberal, posterior a 1848, quando se assume o controle político da urbe, quando se estabelece um novo modelo de cidade em que se limita a liberdade das iniciativas privadas pela intervenção da administração pública, com regulamentos e execução de obras públicas, o que permite a sua reorganização, usando o argumento do ambiente caótico das cidades industriais. Assim se forma a cidade burguesa, uma cidade onde não há espaço para os pobres. Os novos governos, posteriores a 1848, executam projetos de reformas nas cidades, com intervenções que mudam a sua estética e sua estrutura, transformando-as em cenários onde a população pobre não pode penetrar, e a burguesia sente-se à vontade. Os bulevares de Paris, o Ring de Viena, o ensanche de Barcelona ou a Londres vitoriana são exemplos desse tipo de intervenção realizada durante o século XIX.

Em Paris, o amontoamento e a superpopulação levam o centro a uma situação degradante, transformando velhas construções em locais insalubres e perigosos. As ruas estreitas fazem a circulação difícil, não existe limpeza pública, e a sujeira é uma constante. A velha Paris, medieval e romântica, fica inabitável. As epidemias de cólera matam 50 mil pessoas entre 1832 e 1849, e mais de 11.500 em 1853. (GAILLARD, 1991, p. 122) Paris também é a cidade das revoluções e das barricadas. As conspirações nascem no centro superpovoado, nas ruas estreitas e sinuosas, onde qualquer um pode mover-se e esconder-se com segurança. Nesse ambiente, encontra-se o conspirador, que tem, na boemia parisiense, na vida desregrada e nas tabernas, seu ponto de encontro. Quando Luís Napoleão elege-se presidente da Segunda República, em 1848, o ambiente caracteriza-se pelo movimento conspirador e pelas barricadas da revolução de junho.

Nos anos trinta e quarenta, o mundo das classes honradas faz o amálgama de classes trabalhadoras e classes perigosas [...]. Durante esses vinte anos (que são aqueles das grandes insurreições), uma imigração excessiva fez da capital superpovoada uma 'cidade doente'. Agora, a Paris dos Miseráveis, mais miseráveis ainda, tornou-se uma Paris perigosa, impregnada, 'ninho de crime'. [...] A distância é pequena entre a violência criminal e a revolta social. (ROUGERIE, 1989, p. 49-53, grifos nossos)

A situação de Londres não é muito diferente da de Paris, embora possa ser considerada mais moderna, com seus parques, passeios e áreas verdes. 
${ }^{28}$ Cidades como Montevidéu, Santiago do Chile, Buenos Aires, México,

Caracas, Rio de Janeiro e Salvador são alguns exemplos de cidades que, em finais do século XIX, enfrentam problemas urbanos que justificam as reformas que realizam.
Apesar da abertura do Regent's Street, em princípios do século XIX, que estabelece uma separação entre as ruas e praças, habitadas pela nobreza e pela burguesia, e os becos e casebres, ocupados pelos operários e trabalhadores em geral, a cidade mantém seu aspecto sujo, com uma população pobre e com desempregados pelas ruas. É uma capital gigante, que incha sem planificação, sem uma autoridade municipal única, e que acolhe todo tipo de indústria. É uma cidade cosmopolita, com um porto de grande movimentação, uma população misturada em todos os escalões da sociedade, que abriga grande delinquência e criminalidade. Londres também é cenário de intervenções, com a construção de novos edifícios públicos, parques, regularizações ao longo das margens do Tâmisa, reconstruções na City e a abertura da Kingsway.

Outras cidades europeias também realizam intervenções transformando sua imagem. Viena une seu centro medieval com os subúrbios mais longínquos, através da abertura da Ringstrasse e de um conjunto de edifícios públicos e residências particulares - projetados no local das antigas muralhas e do Glacis. A Viena da Ringstrasse compara-se com a Paris do Second Empire e com a Londres vitoriana. Barcelona resolve seu problema de falta de espaço com a derrubada das fortificações e a projeção de uma grande área em volta do Casco Antiguo, o Ensanche. 0 desenvolvimento industrial acontece quando essa cidade ainda vive dentro das muralhas, e bairros como o Raval se convertem em área industrial e proletária, com graves problemas de habitabilidade e de higiene.

Os problemas das cidades do século XIX são, pois, muito semelhantes, motivando os governantes a reagir com intervenções que ensejam as reformas urbanas. Essa situação não é exclusiva das cidades europeias, pois, nas urbes latino-americanas, são encontradas situações muito semelhantes às que desencadeiam reformas urbanas e intervenções no tecido urbano europeu. ${ }^{28}$

\section{Como intervir}

Como foi visto, duas são as formas básicas de resolver os problemas gerados pela cidade industrial: a expansão, pela construção de espaços novos, ou cidades ideais e a intervenção na cidade construída, através de reformas e modificações nas estruturas existentes.

De uma forma geral, a expansão do tecido urbano divide a cidade em uma área externa, as periferias, e outra interna, o centro. As áreas externas 
são compostas de um tecido urbano mais uniforme e caracterizam-se pela presença de zonas residenciais junto a fábricas e equipamentos de produção. $\mathrm{Na}$ área interna, o centro, encontram-se os equipamentos comerciais e terciários, além do aparato institucional e administrativo. Essa área do centro, um tecido urbano medieval, ou colonial, sofre frequentes transformações, devido ao livre jogo do mercado ou pelo efeito de uma série de intervenções planificadas, que asseguram a máxima liberdade possível aos processos privados de apropriação do espaço e garantem ao ente público o espaço operativo e físico necessário para a prestação de serviços gerais e a implantação das redes de infraestrutura urbana.

Para realizar seus projetos na cidade, os governos aprovam leis que permitam a intervenção no espaço construído. Historicamente, as primeiras são as leis sanitárias, ${ }^{29}$ elaboradas como resposta às más condições de higiene e às epidemias que deixam marcas nas cidades. Na Inglaterra, desde 1832, são aprovadas diretrizes tentando inverter a situação sanitária das cidades, como as Leis dos Pobres (MUMFORD, 1982, p. 491), que propõem, a partir de 1840, uma vigilância mais intensa, através de locais específicos que se ocupem de assistir à saúde dos indigentes, do registro de nascimentos e óbitos e da vacinação pública. Mas essas são medidas paliativas, já que, em geral, a cidade permanece igual e há necessidade de meios mais eficazes de intervenção.

Para mudar essa situação, são aprovadas as leis de desapropriação ${ }^{30}$ por utilidade pública, que, a princípio, são adotadas para a implantação da rede de ferrovias e, depois, utilizadas para os planos urbanísticos dos mais diversos tipos. Na França, a lei de desapropriação de 1850 substitui a de 1841, ampliando as competências do Estado para a desapropriação por insalubridade, e convertendo-se na base das intervenções realizadas por Haussmann em Paris, em meados do século XIX. A partir de 1852, a desapropriação efetua-se através de decreto do poder Imperial e permite, inclusive, a desapropriação dos terrenos que estejam por trás dos lotes localizados nas ruas que se abrem, caso se julgue necessária a construção de habitações salubres.

Além dessas leis, são elaborados, aos poucos, instrumentos de controle para adaptar as instituições públicas às condições de desenvolvimento industrial e à dinâmica do mercado: o regulamento para construções, o parcelamento do solo, as modalidades e tipologias dos equipamentos, o modelo do plano e a definição dos usos.

As mudanças urbanas geralmente começam pela definição de um projeto de infraestrutura, como a abertura de eixos e bulevares para um reagrupamento
${ }^{29} \mathrm{Na}$ Inglaterra, a lei sanitária é de 1848; na França, de 1850 e, na Itália, de 1865.

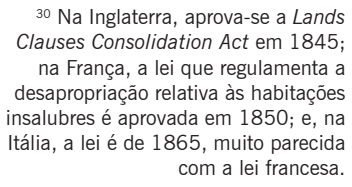

${ }^{30} \mathrm{Na}$ Inglaterra, aprova-se a Lands na França, a lei que regulamenta desapropriação relativa às habitações insalubres é aprovada em 1850; e, na com a lei francesa. 
de setores da cidade, uma das exigências da burguesia para manter o controle unitário da forma da cidade, frente à anarquia do mercado e da produção nos maiores centros metropolitanos e nas capitais. O projeto consiste em configurar os pontos de confluência mais qualificados da nova cidade burguesa, através da construção de ambientes representativos e espaços funcionais.

A Paris do Second Empire é a máxima expressão dessas mudanças urbanas, com as intervenções realizadas sob a autoridade de Napoleão III e as ordens do Prefeito Haussmann. Segundo M. Roncayolo (1989, p. 222223), Paris é o resultado da vontade política em busca da ordem social, do prestígio, do desenvolvimento dos negócios e até de uma reforma autoritária da sociedade. Duas são as causas que justificam essas transformações: em primeiro lugar, estão as epidemias, as revoltas, a obstrução e a depredação do centro; e, em segundo, está o deslocamento das residências e atividades em direção noroeste, com o risco de o centro se tornar obsoleto.

No caso de Paris, a questão do financiamento é outro elemento de importância dentre os instrumentos utilizados para a viabilidade das transformações. A fórmula pensada é a revenda dos terrenos desapropriados aos construtores, depois da abertura das novas ruas e da introdução da infraestrutura pelo governo. Também se recorre a empréstimos, através de um sistema de créditos.

\section{Para que intervir}

Elaboradas as leis e obtida a viabilidade econômica, faz-se necessária uma boa argumentação para que a opinião pública aprove as intervenções. Circular, sanear e embelezar são as três ideias principais, presentes nos discursos que justificam as intervenções nos espaços construídos, embora não sejam as únicas. Há também a questão da ordem pública, o medo das revoltas e a busca da monumentalidade.

Intervir nas cidades não é um fato exclusivo do século XIX. O planejamento barroco, por exemplo, acontece fora do núcleo antigo da cidade, enquanto que, no período moderno, as intervenções ocorrem dentro do centro. Essa mudança de estratégia urbanística justifica-se pelo lado funcional, pois o núcleo central tem problemas de tráfego e deve abrir-se para comunicar-se melhor com os emergentes subúrbios. Por outro lado, os regimes totalitários buscam a revalorização do centro e, para isso, destacam os monumentos existentes e erguem novos, conectando-os através da abertura de eixos majestosos. 
Em Paris, a superpopulação, a insalubridade e o medo de novas revoltas fazem com que Haussmann e Napoleão III desejem uma nova cidade, que supere a antiga estrutura e tenha como suporte dessa transformação a superação dos problemas sanitários e estratégicos, mais do que a busca de um padrão estético. As epidemias justificam as intervenções de caráter sanitário e de arejamento das ruas do centro, enquanto que as barricadas revolucionárias fundamentam a abertura dos bulevares retos e largos, que destroem vielas e casebres e são como um baluarte contra novas insurreições. Na destruição do labirinto medieval, percebe-se a tentativa de sufocar os alvoroços, pois ali vive a população que se destaca por conspirações e revoltas.

Adaptar a cidade às novas exigências geradas pelo rápido crescimento populacional e econômico, modernizando sua estrutura, introduzindo uma nova ordem, é o argumento primeiro utilizado pelos governantes em todas as intervenções. Para viabilizar a mudança, o primeiro passo é criar um adequado sistema de comunicações. A circulação converte-se, assim, num dos argumentos para intervir. As cidades medievais com suas ruas estreitas e sinuosas impedem uma boa fluidez de pessoas e de mercadorias. A introdução dos novos meios de transporte implica a necessidade de ruas mais largas e mais retas para seu perfeito funcionamento. A conjugação de uma nova rede viária e dos novos meios de transporte facilita o deslocamento entre as residências e os postos de trabalho, conecta os novos bairros com o centro e enlaça os novos equipamentos urbanos, a exemplo das estações ferroviárias.

Em Londres, a abertura da Regent's Street, em princípios do século XIX, cria uma artéria norte-sul, com a função de unir os bairros altos aos equipamentos e estabelecimentos públicos de Whitehall e Westminster. Em Paris, o elemento mais importante da nova rede viária proposta por Haussmann é o grande cruzamento - la grande croisée - de dois eixos, norte-sul e leste-oeste, que se cruzam em ângulo reto, e que têm o objetivo de incentivar e promover o centro como núcleo administrativo, comercial e de serviços. Haussmann aposta num centro de fundamental importância para a Grande Paris. Para completar a rede, há os bulevares que se integram, num sistema global de circulação e uma série de ruas diagonais que se abrem para enlaçar os bulevares interiores com os exteriores. Assim, multiplicam-se as grandes circulações concêntricas, facilitando as comunicações com o interior da cidade. As radiais conectam o centro com os novos distritos nos limites da cidade, onde se espera um crescimento de construções residenciais. O sistema de comunicações criado por Haussmann integra as ruas já existentes e utiliza espaços antigos, como a Place de la Concorde, como centros de redistribuição 
de circulação. A nova rede viária também faz a articulação entre as estações de trens e, através delas, conecta Paris com o resto da França.

Entretanto, a boa comunicação entre o centro e os bairros ou entre os bairros não é o único propósito que existe na abertura da nova rede viária. A questão da monumentalidade evidencia-se na intenção de valorizar os monumentos, isolando-os, deixando-os como perspectivas nos extremos das avenidas e bulevares, criando laços visuais entre uns e outros para se obter uma nova imagem da cidade.

Na busca de construção de um novo imaginário social e de uma nova representação da cidade, a salubridade converte-se em outro forte argumento para a intervenção. O objetivo é criar um espaço urbano limpo e ordenado, em substituição aos maus olores e às emanações fétidas da atual cidade. Para obter tal transformação, o meio mais prático é levar a cabo a demolição das edificações definidas como insalubres e a abertura de "corredores" por onde circule 0 ar e penetre a luz.

A salubridade será frequentemente a primeira razão colocada para justificar as aberturas [das novas vias]. Mesmo a monumental avenida da Ópera tem por objetivo confesso sanear (por arrasamento) a Butte des Moulins. Os cortiços substituídos pelas avenidas, o ar pode circular. (PINON, 1991, p. 76)

A abertura de novas vias apresenta-se, pois, como um meio de lutar contra essa situação de insalubridade, já que proporciona a demolição de cortiços e de velhas construções, abrindo espaços mais sadios. Uma das primeiras intervenções na Paris do Segundo Império é a continuação da Rue de Rivoli, iniciada durante o governo de Napoleão Bonaparte, depois Napoleão I (1799-1814), que rasga e destrói os quarteirões mais velhos da Rive Droite, eliminando uma grande parte das antigas casas totalmente insalubres.

Esse problema não se limita às ruas do distrito central. Os bairros miseráveis, o amontoamento, a sujeira e as epidemias fazem de toda a cidade um grande problema sanitário, e até os bairros ricos se veem afetados pelo estado de insalubridade. Essa situação interfere na imagem da cidade, uma imagem que se quer mudar, para que reflita as aspirações da nova cidade, da cidade burguesa.

Paris está cheia de monumentos, belos edifícios públicos, uma coleção de casas particulares elegantes, mas suas ruas continuam sujas, estreitas e perigosas, com antigas residências, antiestéticas e congestionadas. A City de Londres apresenta um aspecto mais moderno pois, após o incêndio de 1666 , suas edificações são reconstruídas de forma uniforme e com tijolos. As novas ruas que enlaçam a City com Westminster são simétricas, retilíneas e largas. 
Apesar disso, o centro ainda mantém a confusão das cidades medievais. Viena, mesmo tendo substituído muitas de suas edificações medievais por novos palácios e edifícios, mantém o mesmo traçado de suas ruas.

As intervenções para o alargamento das ruas e a abertura de avenidas e bulevares permitem a reconstrução de imóveis com novas fachadas, criando uma nova paisagem urbana e uma nova estética. As ruas retas da cidade clássica permitem uma perspectiva que destaca os monumentos eventualmente localizados em suas extremidades. Nas reformas urbanas, a preocupação com a estética, o desenho, a perspectiva, a ornamentação, o traçado urbano e a ordenação da cidade é outro dos argumentos que se apresentam. No século XIX, busca-se transformar as cidades em "obras de arte".

Mas, o que está nas entrelinhas desses argumentos? Existe a vontade da burguesia de apropriar-se do centro e a consequente expulsão dos pobres, e existe a busca da monumentalidade, principalmente nas cidades capitais. Muitos são os exemplos: Paris, Londres, Viena, Barcelona, Florença, Roma, Madrid, as cidades alemãs, além de outras cidades na América e em outras partes do mundo. Mas também existe o medo de revoltas.

A rua reta e larga permite também um melhor deslocamento de tropas, caso se produza uma sublevação, além de (supõe-se) dificultar a construção de barricadas. Será esse o verdadeiro motivo para as intervenções nos espaços densamente construídos das cidades do século XIX? Não há dúvida de que as velhas vielas dos povoados medievais permitem que qualquer pessoa possa se esconder de forma rápida, construir barricadas para impedir o avanço das tropas e de que essa estrutura ajude nas estratégias dos revoltosos. Em Paris, por nove vezes em 25 anos, antes do Segundo Império, levantam-se barricadas e obstrui-se a passagem das milícias.

Pode ser que a planificação retilínea tenha muito mais objetivos estéticos do que militares e tenha sido implantada mais para impor beleza à cidade do que para ajudar no deslocamento das tropas. (SUTCLIFFE, 1993, p. 39) O tema da retificação e "regularização" das ruas e do espaço público é essencial no urbanismo moderno, ainda que finque suas raízes no urbanismo clássico e no barroco.

Na segunda metade do século XVIII, já encontramos referências ao embelezamento do espaço urbano vinculado a objetivos funcionalistas e à reforma da cidade real. O Abade Laugier, em seu Essai sur l'Architecture de 1753, faz referência a três elementos fundamentais para o embelezamento das cidades: as entradas, as ruas e os edifícios. Também indica a necessidade da formação de um plano para ordenar a cidade, no qual se percebe uma 
preocupação funcional, unida a uma visão de conjunto da reforma. No texto de Pierre Patte, Mémoire sur les objects les plus importants de l'architecture de 1769, encontramos preocupações utilitárias e uma discussão sobre os problemas das ruas, consideradas como parte da rede viária. Em seu estudo, coloca os problemas de circulação e higiene, além dos problemas estéticos.

Podemos também definir um argumento econômico, já que as reformas estimulam a geração de empregos, e as novas ruas atraem novos negócios. Um bom sistema de comunicações ajuda a desenvolver as forças produtivas e as relações sociais, acelera o deslocamento de mercadorias, de capital e da população. Nas reformas urbanas realizadas em Paris, existe um argumento político, pois elas são um instrumento que privilegia a política centralizadora de Napoleão III, que vê, na capital francesa, funções nacionais e supranacionais. Não se pode negar sua intenção de fazer de Paris uma capital de prestígio de um Estado moderno e forte. 
Capítulo 2

\section{Haussmannização ou haussmannizações?}

Haussmannização é uma expressão que comporta diversas acepções. Originalmente, refere-se às intervenções realizadas em Paris, no Segundo Império, por ordem de Napoleão III e sob a direção de seu prefeito, Haussmann. Entretanto, mesmo mantendo seu sentido original, o uso dessa expressão expande-se, para referir-se a uma forma de atuação, um estilo urbano, um episódio histórico, um modelo de intervenção urbana numa cidade, inclusive, em momento anterior, às reformas parisienses.

As intervenções urbanas realizadas para a abertura de ruas e de novos espaços em centros densamente construídos não são uma invenção de Haussmann, nem a Paris do Segundo Império é a cidade onde, pela primeira vez, esse tipo de intervenção é realizada. Mesmo antes do Segundo Império, executam-se, em Paris, obras dessa natureza, como as dos prefeitos Claude-Philibert de Rambuteau (1833-1848), Berger (1848-1853) e outras antes, nos tempos de Napoleão I. Desde o século XVI, a rua reta e larga já é considerada superior à sinuosa e estreita, na urbanística francesa, e a percée já é aplicada na França antes de Haussmann. Esse "urbanismo haussmanniano" é reconhecido, por exemplo, na abertura da Rue de Rivoli, sob o comando de Napoleão I, e continua sendo reconhecido nos bulevares da Terceira República. 
Tampouco as reformas de Paris realizam-se por mérito exclusivo de Haussmann. Luís Napoleão (depois proclamado Imperador Napoleão III) projeta suas ideias ainda no exílio, antes de regressar a Paris. Em 1839, em seu ensaio Des Idées Napoléoniennes (BONAPARTE, 1839), já se declara favorável às grandes obras públicas. Em função dos problemas de salubridade, também os higienistas reclamam reformas no centro, a área mais insalubre da cidade. Mas é ao nome de Haussmann que se faz referência, quando se pensa numa reforma urbana direcionada para a abertura de ruas e demolições, num tecido urbano densamente construído, com vistas à criação da cidade burguesa. Para todos os efeitos, a transformação de Paris, a haussmannização, é obra de Georges-Eugène Haussmann.

Entretanto, há os que consideram Haussmann o criador de um estilo, presente após e mesmo antes do Segundo Império, desde que as reformas se realizem nos mesmos moldes daquelas empreendidas na Paris haussmanniana, ou seja, através da abertura de avenidas, a demolição de velhas edificações e o deslocamento da população, sem que o Estado seja o único responsável por ela. (KOSTOF, 1992, p. 271)

Questionamo-nos se Paris se transforma em um modelo para a realização de reformas urbanas em outras cidades que seguem um estilo semelhante ao de Haussmann. Mas será que não existe um modelo para Paris? Muitos autores creem que sim, sendo Londres, cidade onde Napoleão III passa parte do seu exílio, o modelo inspirador da reforma parisiense. Outros consideram que não, pois, em Londres, apesar da abertura da Regent's Street no início do século XIX, não se realizam aberturas drásticas no tecido medieval, já que esse foi destruído no incêndio de 1666. Nesse caso, os modelos podem ser a Roma de Sisto V, a tradição clássica, a Versailles de Le Nôtre, os modelos renascentistas, ou uma expressão tardia do barroco. Esse tipo de arquitetura e de arte urbana já está definido antes de Haussmann, desde Luís XIV, e continua presente após o Segundo Império. Faz-se referência a um pós-haussmannismo na Terceira República e a um neo-haussmannismo, quando, nos últimos anos, esse modo de atuação foi redescoberto após estudos sobre a história das formas urbanas. (LOYER, 1992, p. 192)

Mas, afinal, o que é a haussmannização? Através dos escritos de Haussmann, não se pode chegar a um conceito preciso, uma vez que ele não propõe uma doutrina ou uma teoria de melhorias urbanas. Para F. Choay (1983, p. 166), é o leitor atual de seu trabalho quem busca inferir o método e os princípios gerais por ele assumidos na organização ou reorganização do espaço urbano. É o pesquisador quem busca identificar os elementos componentes 
de sua obra de transformação de Paris e, nela, o que influencia as intervenções em muitas capitais europeias e fora da Europa. 0 próprio Haussmann chama seu trabalho de regularização, que não pretende uma universalidade científica, não se baseia numa crítica social, nem propõe um modelo espacial.

Finalmente, existe um modelo haussmanniano? Se existe, supõe-se que se componha de ideias gerais, de métodos e ações específicas e que haja a possibilidade de sua exportação.

\section{Antecedentes de um modelo}

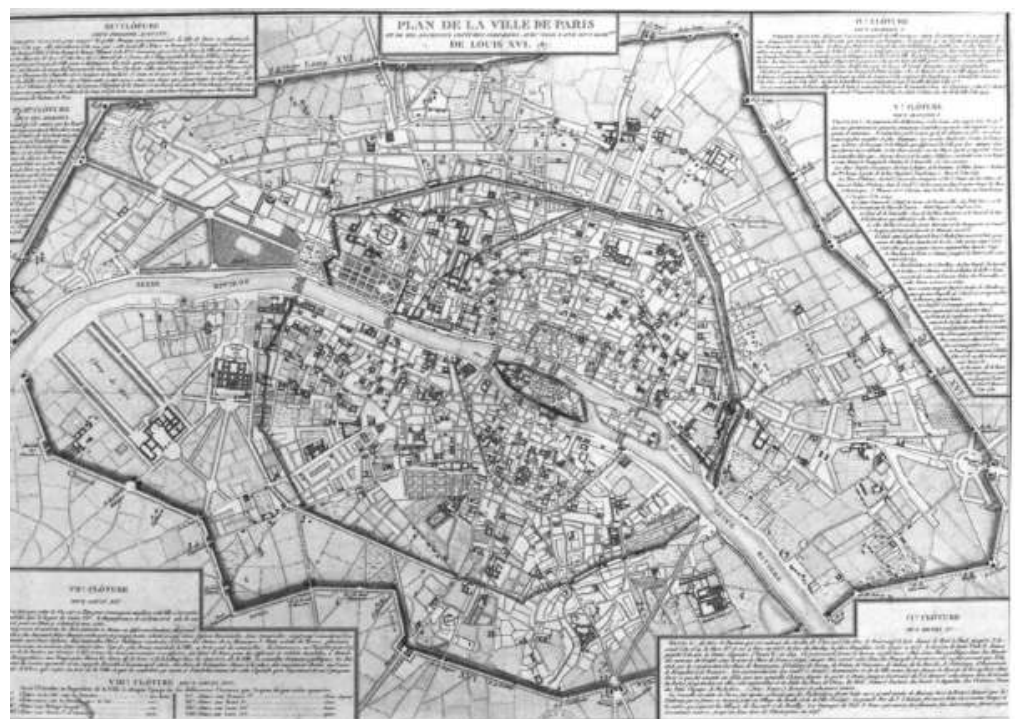

1. Plano de Paris - 1787 - indicando as sucessivas muralhas da cidade, sendo a última a Fermiers Généraux

Paris desenvolve-se no interior de várias linhas de fortificações (Fig. 1), com uma área semicircular na margem direita do Rio Sena e uma muralha do século XIV, que vai da Bastilha até o local onde hoje se encontra a Place de la Concorde. Essa muralha deixa de ter utilidade na época de Luís XIV, que a derruba e a substitui por largas vias arborizadas que acompanham o semicírculo, com muitas árvores. Tais artérias transformam-se nas avenidas mais animadas da cidade, centro de distrações e de comércio. São os boulevards, ${ }^{1}$ destinados a oferecer aos parisienses amplos passeios sombreados, que se
${ }^{1}$ Boulevard significa passagem sobre a muralha de uma cidade fortificada, palavra de origem alemã bol/werk que significa baluarte. (GIEDION, 1958, p.680) 
constituem numa das primeiras e principais características da época, sendo seus traçados ainda fundamentais na rede concêntrica de Paris.

Considera-se que Paris, no século XVII, transforma-se no berço de uma revolução decisiva na urbanística, que se difunde pela Europa e América do Norte. Nessa época, realizaram-se intervenções nos cais ao longo do Rio Sena, transformados em passeios públicos, rodeados de construções altamente valorizadas, o que significa um grande incremento de imóveis para alugar (immeuble à loyer). Algumas dessas estruturas decorrem de um projeto de edifícios projetados num bloco único, como se fossem um só, ao longo da rua.

Com um plano preestabelecido, são abertas ruas largas e arborizadas, praças circulares ou regulares (quadradas, retangulares, triangulares etc.), concebidas para compor a paisagem e colocar em evidência um monumento, definindo uma perspectiva ou uma decoração. De acordo com essa concepção, são projetadas as praças reais (places royales), ou são alargadas praças preexistentes, para dar maior destaque a monumentos existentes.

No que se refere às maiores intervenções do final do século XVII, destacamos a Place de Victories, de 1685, moldura para a estátua do Rei Sol, e a Place Vendôme, de 1697, ambas projetadas por J. Hardouin Mansart. Nessa última, as fachadas são construídas com fundos da Coroa, conforme critérios unificados, e vendidas antes da construção dos edifícios. Outros exemplos são a Place Royale (hoje de Vosges), a Place Dauphine, a Place du Palais-Royal e o alargamento da Place de l'Odéon e o da Place du Panthéon, valorizando seus monumentos. Já no século XVIII, temos a praça dedicada a Luís XV, mais tarde chamada de La Concorde, projetada em 1753 por Jacques Gabriel, moldura para a estátua do rei que Ihe dá nome, e a Rue Royale, também projeto de Gabriel, cujas fachadas também são construídas antes do interior dos edifícios. A novidade e a maestria da solução adotada parecem uma primeira e coerente comprovação das mais atualizadas estéticas da urbanística do século XVIII, que introduzem, na cidade, uma nova relação quantitativa e espacial entre natureza e arquitetura. (SICA, 1982, p. 50)

A construção das places royales não pode ser justificada apenas através da finalidade política de servirem como molduras para as estátuas do rei. Vincula-se, também, a razões de ordem econômica e a um nível mais alto de exigência de eficácia urbana: a construção de uma praça permite realizar uma intervenção localizada e uma adequação funcional, definindo centros comerciais e diretivos da cidade.

Paris muda, cresce, modifica suas formas de apropriação do espaço. Os fossos são cobertos para dar lugar aos bulevares, os terrenos agrícolas são loteados, os antigos arrabaldes são anexados aos bairros centrais, ao tempo 
em que novas periferias se desenvolvem. A nova imagem da cidade se impõe em meados do século XVIII.

Ao longo do século XVIII, junto aos projetos e realizações, surgem também fermentos teóricos e críticos sobre a natureza e a gestão da cidade. Uma parte surge da necessidade de racionalidade e de ordem que vem a reboque dos ideais iluministas. As tensões de classes aludem à necessidade de estabelecer uma nova ordem de conjunto na sociedade. As observações de Voltaire falam da falta de lógica de Paris e de coerência de sua figura urbana. Afirma que Paris carece de praças, de fontes e de mercados e continua conservando ruas muito estreitas e bairros insalubres. Outros autores insistem na necessidade de contar com planos gerais de reestruturação ou do alinhamento interior da cidade. (SICA, 1982, p. 58-59)

Da entrada de Henri IV em Paris (1594) até o ano de 1790 - quando, depois da Revolução de 1789, é elaborado o Plano dos Artistas $^{2}$, que propõe importantes mudanças na cidade, aproveitando os "Bens Nacionais", terras da Coroa e da Igreja desapropriadas pela Convenção Republicana -, são quase dois séculos de transformações na cidade, com a definição de características que ainda hoje reconhecemos nela, como seus tipos de ruas e uma certa concepção de paisagem urbana. Rouleau (1983, p. 64) considera que o urbanismo só entra em Paris com Henri IV.

Organiza-se a paisagem urbana, embelezando e arejando a cidade. 0 esboço medieval da velha Paris vai, aos poucos, juntando-se às realizações que, com sua variedade, definem o urbanismo daquela época, e que representam ainda um dos traços fundamentais da paisagem que nós conhecemos.

O período entre Luís XV e Haussmann - apesar de não ser profundamente estudado, por não apresentar realizações tão espetaculares - é uma época em que as intervenções correspondem às necessidades do momento, acompanhando o crescimento demográfico e a expansão geográfica. Segundo Pierre Pinon (1989, p. 145),

[...] apesar da leveza das políticas urbanas características deste período, a cidade se transforma pela mutação dos programas, pela reformulação dos serviços, pela renovação de fragmentos, pela acumulação de imagens, pela justaposição de 'cidades'.

No período de Napoleão I, a organização urbana é um dos elementos da política de renovação. Uma vez destruídas as amarras feudais, as estruturas urbanas e territoriais são submetidas a uma profunda revisão. A Paris de Napoleão I ainda é uma Paris medieval, tanto em sua estrutura como em seu aspecto, uma cidade labiríntica e pitoresca. Nesse cenário, tem início um vasto programa de obras
${ }^{2}$ Depois da Revolução de 1789 , elabora-se o Plano dos Artistas, um dos planos urbanísticos de Paris, encomendado pela Convenção Republicana a uma comissão de arquitetos e administradores. Esse Plano projeta importantes mudanças, embora atinja basicamente os espaços denominados

"Biens Nationaux", desapropriados da Igreja e da Coroa. Baseia-se em três pontos: uma lei de parcelamento dos "Biens Nationaux"; o primeiro projeto de divisão dos "Biens Nationaux" para a abertura da Rue de Rivoli; e a criação de comissões encarregadas de propor as divisões para todos os "Biens Nationaux" de Paris. (Cf. PINON, 1989, p. 145) 
${ }^{3}$ Passagens são ruas comerciais cobertas, internas aos quarteirões, equipadas com lojas, restaurantes e serviços, abrigados do tempo e do movimento das ruas externas. públicas que, se, por um lado, cria empregos no ramo das construções e modera ou freia as agitações operárias, por outro estimula as iniciativas do capital privado. Essa política de obras públicas envolve a produção de equipamentos civis e produtivos de infraestrutura: estradas, pontes, postos de controle dos rios, portos, mercados, matadouros, cemitérios, rede de esgoto, sistema de abastecimento de água, museus, escolas etc. (Fig. 2, ver caderno de imagens)

A reorganização de Paris talvez fosse o sonho de Napoleão I, um desejo de dar à cidade uma imagem da Roma Clássica, com a restauração simbólica do poder do Império Antigo, ainda que isso também representasse uma continuação da monarquia absoluta. Como militar, Napoleão pensa nos arcos do triunfo e propõe a construção de quatro, entre eles o da Place de l'Etoile, para compor a perspectiva da Avenida dos Champs-Elysées e o do Carrousel, localizado numa praça entre o Louvre e os Jardins de Tuleries.

Napoleão I dá início à abertura da Rue de Rivoli, em 1801, que acompanha os Jardins das Tuleries e o Louvre, uma rua com edificações regulamentadas, desenhadas pelos arquitetos do poder, Charles Percier e P. F. L. Fontaine, com arcadas que formam uma galeria onde se instalam estabelecimentos comerciais e residências. A ideia da arquitetura composta de fachadas uniformes, comportando uma galeria com arcadas, visa a equiparar a Rue de Rivoli ao Palais Royal, que, nessa época, é um dos locais mais animados e atraentes da vida parisiense. Também são abertas ruas que fazem a união da Rue de Rivoli com a Rue de Saint-Honoré, aproveitando os terrenos liberados pelas desapropriações dos bens nacionais.

Do mesmo modo que no século XIX, desde o século XVII, passando pelo Império de Napoleão I e pelo período da Restauração, estão presentes, nos discursos do poder, preocupações com a higiene e com a salubridade da cidade, além da busca de uma melhor rede viária. Gilbert-Joseph-Gaspard Chabrol, Prefeito do Departamento do Sena entre 1812 e 1830, dá início ao alargamento de ruas, visando a uma melhor comunicação dentro da cidade e entre os quarteirões, à segurança pública, ao comércio e também ao embelezamento urbano.

A organização do espaço urbano e das edificações vem atender à demanda de uma nova aristocracia, conduzindo as transformações na cidade em duas direções: a multiplicação de equipamentos aristocrático-burgueses - igrejas, teatros, fontes públicas e "passagens" ${ }^{3}$-, nas áreas centrais, e um crescimento simultâneo de novos bairros, nas faixas externas aos bulevares.

Os novos bairros são produzidos pela iniciativa privada e, neles, o processo é o mesmo: os especuladores adquirem o terreno, grande parte remanescente dos Bens Nacionais, demandam autorização para a abertura de ruas, o loteamento 
da área e a venda dos lotes, construídos ou não. Na margem direita do Rio Sena, entre os bulevares e os Fermiers Généraux, ${ }^{4}$ localizam-se as iniciativas que interessam à aristocracia, mas também se criam alguns bairros destinados

${ }^{4}$ Nova linha de muralhas construída em finais do século XVIII e que abarca também muitos terrenos cultivados. à burguesia. Já os bairros populares, para o proletariado e os artesãos, encontram-se junto ao canal Saint Martin, na zona oriental da cidade.

A Revolução Burguesa de 1830 muda o poder, da aristocracia latifundiária para a burguesia comercial, dando início a uma mudança de atitude em relação à gestão da cidade. A inadequação da estrutura de Paris às novas exigências da política urbanística faz com que a opinião pública demande modificações, ainda que não se consiga realizar uma ação coordenada.

Se, no período de Chabrol, desenvolve-se uma obra modesta mas coerente, na Monarquia de Julho de Luís Felipe (1833-1848), Paris tem um prefeito mais questionável, Rambuteau, com uma certa oposição parlamentar. Só a partir de 1841, pode-se contar com uma lei que melhora o processo de desapropriação. Em 1845, através de um empréstimo para os equipamentos, obras de maior envergadura tomam impulso.

Luís Felipe e seu prefeito Rambuteau empenham-se em transformar a cidade. São abertas 112 ruas, 89 do lado direito e 23 do lado esquerdo do Rio Sena, e outras são alargadas. Árvores são plantadas, passeios são construídos, ruas são recobertas com betume, tubulações de esgoto são implantadas sistematicamente. A iluminação a gás, que começa em 1828, é ampliada, e as grandes artérias são iluminadas. Por ordem de Luís Felipe, uma nova muralha é construída, dessa vez não só em volta de Paris, mas abarcando as cidades vizinhas. É a muralha de Thiers, ou Militar, que tem $36 \mathrm{~km}$ de comprimento. Duas obras importantes desse período são a ordenação da Place de la Concorde, com a instalação do obelisco de Luxor no seu centro, um projeto de Hittorff, e a do novo Hôtel de Ville, ambas em 1836. Além disso, podemos citar as obras de demolição, na Île-de-la-Cité (1832), do gigantesco manicômio-cidade de Charenton (1838-1845) e uma série de obras de embelezamento.

Nas transformações do sistema viário, a intervenção mais importante é o alargamento da Rue de Chanvreire, atual Rue de Rambuteau, na direção leste-oeste. Nesse caso, não se trata de um plano de reestruturação que afete somente edifícios públicos, tampouco de um projeto que se desenvolva fora das áreas urbanizadas ou que corte quarteirões livres no interior da cidade. Consiste num alargamento viário que afeta uma sequência não homogênea de propriedades privadas.

Podemos dizer que uma das mais importantes realizações do período Rambuteau é a implantação de nove linhas ferroviárias radiais, que se 
introduzem furando o bloqueio do arco externo da cidade, e a construção das gares, as estações de trens. A primeira linha ferroviária que une Paris a Saint-Germain é inaugurada em 1837. A instalação de novas linhas férreas principais permite prever o desenvolvimento dos núcleos suburbanos, que suscitam o problema de sua relação com a estrutura existente.

O crescimento demográfico determina a degradação dos bairros velhos, em consequência do congestionamento físico e da ausência de melhorias higiênico-sanitárias. Na mesma área central, potencializam-se as instituições financeiras e comerciais. Paris chega a 1848 com quase 1,3 milhões de habitantes e com 1474 ruas.

A revolução de fevereiro de 1848 exige um governo mais democrático e expressa um sentimento de revolta, devido à corrupção de Luís Felipe e de seus assessores. Há um grande descontentamento dos católicos em relação ao Primeiro-Ministro Guizot, protestante. Ocorre, ainda, a disseminação do socialismo entre o proletariado industrial. A todos esses fatores se soma um forte nacionalismo, fator que suplanta os demais.

Grandes manifestações são realizadas, reivindicando as necessárias reformas. Ao se proibir uma manifestação programada para 22 de fevereiro de 1848, barricadas são erguidas nas ruas, e Luís Felipe abdica em seguida. O governo provisório, eleito em abril e formado por socialistas e republicanos, convoca eleições para a Assembleia Constituinte, mas os resultados decepcionam os socialistas, ocasionando uma nova insurreição em junho do mesmo ano, com a construção de cerca de 400 barricadas do lado direito do rio. A derrota dos rebeldes faz com que a Assembleia aprove uma nova constituição e convoque eleições presidenciais. A repressão, comandada pelo governo provisório, resulta em 5 mil mortes, 15 mil prisões e 4 mil deportações. (GAILLARD, 1991, p. 119)

No governo provisório da Segunda República, instaurada em 1848, Blanc aproxima-se dos métodos de construção do socialismo. No plano da organização da cidade, são propostos os princípios de Charles Fourier, com a criação de um falanstério em cada um dos bairros de Paris. O programa fracassa, com a ruptura do compromisso entre a burguesia e a classe operária, nas jornadas de junho de 1848.

Luís Napoleão, sobrinho de Napoleão Bonaparte, volta de Londres, depois de um exílio de 30 anos - primeiramente entre Alemanha e Suíça, e, depois, na Inglaterra -, e ganha as eleições para a Presidência da França, com votos dos proletários e camponeses. Por não se contentar apenas com a presidência, obtém apoio da maioria da população, através de um plebiscito realizado em dezembro de 1851, para a elaboração de uma nova constituição 
que o transforma em ditador de fato. Novo plebiscito o nomeia Imperador da França, com o nome de Napoleão III, em dezembro de 1852. É o início do Segundo Império, Second Empire, que dura até setembro de 1870.

Ao chegar ao poder na Segunda República, Luís Napoleão já tem claro o papel das classes dominantes e o modo de condução do Estado. Seu ensaio de 1839, anteriormente citado, realça a importância das obras públicas como fator insubstituível de progresso, de coesão social e de crescimento econômico, por potencializar as atividades privadas.

Para Paris, Luís Napoleão tem ideias definidas, baseadas na experiência de Londres, onde os parques e a obra de John Nash, a Regent's Street, fazem-no perceber a importância de realizar intervenções na cidade, a fim de transformá-la na primeira metrópole-capital moderna da Europa. Ao tomar posse, já tem um projeto pronto de estruturação da cidade. "É a contemplação dos 'espaços verdes' da capital do Reino Unido que dá nascimento a isso que nomeamos o 'grande desenho' de Napoleão III: a criação de uma cidade ideal moderna." (TOUTTAIN, 1971, p. 38)

Se Londres foi beneficiada, de certa forma, pelo incêndio de 1666, que permite a abertura de ruas mais largas e mais ventiladas, em Paris são necessárias muitas demolições para a implementação do projeto de cidade moderna e para a implantação de comodidades como abastecimento de água, de gás, de transportes etc. As demolições ocorrem principalmente no centro, ainda medieval, com traçado irregular e ruas estreitas.

Dentre as propostas do projeto, encontra-se a de continuação da Rue de Rivoli até a Bastilha, a substituição de áreas inteiras do leste e do centro, a liberação de quarteirões na Île-de-la-Cité e um plano geral de melhoramentos, além de programas de obras de saneamento urbano, demandados pela sociedade.

As habitações sociais também estão presentes no programa de Luís Napoleão. Em 1850, é construído o falanstério da Rue Rochechouart, a Cité Napoléon, projeto de Gabriel Veugny. Um grupo de casas-modelo é edificado na Avenue Daumesnil e um conjunto residencial, na Avenue de la Bourdonnais. (GAILLARD, 1991, p. 39)

A recuperação econômica de 1851 permite a Luís Napoleão pôr em prática suas ideias e projetos para a transformação da cidade. Constam de seu programa: o cinturão ferroviário de enlace entre os terminais, ${ }^{5}$ a abertura do Carrousel, o término do Louvre, a abertura do Bulevar Strasbourg, a ampliação do mercado de Les Halles e o prolongamento da Rue de Rivoli.

${ }^{5}$ Segundo Gravagnuolo, a rede viária entre as estações de trem, as gares, é obra de Rambuteau. (GRAVAGNUOLO, 1998) Mas Napoleão III encontra resistências do Prefeito Berger, que vacila diante dos grandes gastos necessários para as realizações propostas. Nesse mo- 
mento, Napoleão III decide chamar o experiente Haussmann - que já havia realizado intervenções em Bordeaux - para ocupar o cargo de prefeito do Departamento do Sena.

Ao nomear Georges-Eugène Haussmann, em meados de 1853, a cidade de Paris não passa de uma vila medieval. Segundo Touttain (1997, p. 92),

Esta Paris pitoresca, esta velha Paris cara aos artistas e aos escritores românticos comporta [...] poucos jardins, poucos squares, e apresenta-se como uma cidade incoerente, dotada de monumentos magníficos edificados no curso dos séculos, mas comportando ruas estreitas, sombrias, um emaranhado de becos e muitas habitações 'pitorescas'... mas insalubres.

Já no Guide Baedeker de 1888, encontramos uma descrição de Paris que nos revela o impacto causado à cidade, em seu conjunto, pelas novas ruas largas e de traçado rigoroso. Assim Evenson (1983, p. 24) descreve a Paris de 1888, baseada nesse guia:

Os bulevares e avenidas são acompanhados por largas calçadas. Esses passeios plantados com árvores são animados dia e noite. Os quiosques proliferam-se e ocupam uma parte importante desse espaço para pedestres. Nesses anos que se seguem à renovação haussmanniana, o bulevar tornou-se o símbolo da moda parisiense. A vida urbana é essencialmente pública; a rua é um cenário onde se joga o drama da cidade.

Ao comparar essa descrição com a anterior, indagamo-nos sobre o que aconteceu nesse intervalo de tempo, e a resposta é que as intervenções realizadas no tecido urbano da cidade, comandadas por Haussmann, transformam Paris numa metrópole moderna, modelo para muitas outras cidades.

\section{A implantação de um modelo}

Paris transforma-se numa cidade haussmanniana entre os anos 1853 e 1870. Para realizar essas transformações, unem-se o capital privado e o poder público, que intervêm no tecido urbano com base num modelo funcional de cidade. São obras de implantação de infraestrutura e de serviços necessários para o funcionamento de uma cidade que passa por transformações estruturais produzidas pela Revolução Industrial. São as chamadas obras públicas, como a rede de esgoto, os lampiões a gás da iluminação pública, a rede de abastecimento de água, os aquedutos, os serviços de transporte, os grandes 
parques e os edifícios públicos. Haussmann dá continuidade aos trabalhos iniciados por seus antecessores, com uma diferença: o salto da escala.

As intervenções haussmannianas mudam a maneira de pensar a cidade, tomando como principal elemento a rua e criando uma rede viária composta por um tecido arquitetônico que destrói bairros insalubres e vielas. Expulsam a população residente, melhoram a higiene e a circulação, mudam a imagem da área central, e a cidade prepara-se para um novo modo de vida. A rua do século XIX destrói e modifica a rua medieval. A caixa da rua aumenta, as fachadas são reconstruídas, os trechos irregulares são substituídos por outros com desenho regular, geométrico e reto. Diferentes dos bulevares de Luís XIV - projetados no lugar das antigas muralhas, locais para o desfrute e o passeio -, os bulevares do século XIX, de Haussmann, são artérias criadas para a circulação rápida, o tráfego pesado. 0 espaço haussmanniano é o espaço público - a rua, o passeio, as praças -, o espaço da mobilidade. A originalidade desse projeto está no conceito do sistema de circulação e de respiração, que superpõe malhas hierarquizadas, pertencentes a uma rede em estrela. Esse desenho não resulta num espaço homogêneo, uma vez que se acentua a divisão social entre leste e oeste, entre periferia e centro, mas ainda não se adota a ideia de cidade por setores. A hierarquia do sistema de comunicações muda a ordem de valores. (Fig. 3, ver caderno de imagens)

Daqui para frente, a rua ou o bulevar comandam o imóvel; a percée, o desenho das parcelas; a posição, as funções; o espaço público, o agenciamento dos espaços privados. 0 alinhamento não é mais um procedimento corretivo que respeita o plano. A nova rede viária transforma-se no princípio de organização que se superpõe à cidade antiga ou que regula o agenciamento dos espaços conquistados. A projeção zenital, própria ao engenheiro, abstrai a rede da paisagem urbana e toma o caminho da perspectiva de estilo clássico e da harmonia dos volumes. (RONCAYOLO, 1983b, p. 102)

Na cidade haussmanniana, é introduzida uma nova forma de construção da paisagem urbana. As intervenções no núcleo central tratam o conjunto dos espaços heterogêneos como uma entidade única e o dotam de isotropia. Constrói-se uma imagem urbana mais coerente, com um tipo de arquitetura definida, em que o imóvel se integra no espaço público através de uma projetação regulamentada.

A questão estética busca a qualidade do efeito arquitetônico. Em 1855, Haussmann, numa circular, faz referências à "harmonia a ser instituída nas novas fachadas" (GRAVAGNUOLO, 1998, p. 42-43), indicando a homologação dos elementos construtivos - balcões, molduras, cornijas - como 
norma indispensável a ser somada ao simples controle dimensional de altura e cubagem dos edifícios.

Haussmann dota Paris de bulevares, criando corredores de fachadas uniformes, elementos que constituem peça essencial na estética haussmanniana e em sua estratégia urbana. As avenidas e os bulevares são planejados com o objetivo de que o olhar, de uma extremidade a outra, seja guiado pelas linhas de fuga. A nova monumentalidade conjuga-se com a harmonia entre a política viária e os novos espaços públicos. Haussmann é leal ao espaço urbano, como um cenário onde

[...] as fachadas dos edifícios de apartamentos ao longo das novas ruas portam detalhes mínimos. Suas linhas horizontais foram enfatizadas, e harmonizadas pela intervenção oficial da cidade, para acentuar os efeitos da perspectiva. Estandardização e a falta de decoração minimizam os custos da construção, e o efeito foi saudado como 'moderno'. (SUTCLIFFE, 1993, p. 86)

Em 20 anos, a cidade passa por uma metamorfose jamais vista. A forma de atuar é original, com a abertura de novas vias na periferia, o isolamento de monumentos, o alinhamento de ruas já existentes e os cortes no centro histórico. Não é um processo utópico, pois está de acordo com as possibilidades políticas, financeiras e técnicas da época. A realização dessas transformações torna-se possível pela vontade política de um Chefe de Estado que conhece a necessidade de transformação e de modernização da cidade e que as delega a um operador competente, que busca a ordem social, o prestígio, o desenvolvimento dos negócios e até uma reforma na sociedade. 0 resultado de todo esse movimento é o ajuste da forma do tecido urbano e da forma de convivência. Contudo, mais do que a expressão de uma vontade de mudar, essas transformações são uma resposta à realidade.

\footnotetext{
A haussmannização - a palavra de fato - não é um acidente, ou o capricho de um regime ou a vontade de um príncipe. É antes de tudo uma resposta: ela se estabelece pelas múltiplas pressões que agitam a cidade no início do século, pressão demográfica e pressão econômica que impulsionam o jogo de valores urbanos, o preço do solo ou dos imóveis. A doença e o medo social, o cólera e a revolta não são senão a parte mais visível de uma cidade que se quebra por todos os lados. (RONCAYOLO, 1983b, p. 74)
}

Haussmann considera as questões da grande cidade como problemas técnicos, cujos pontos essenciais são sanear, transportar e equipar. A estrutura urbana adapta-se para receber os novos equipamentos, e Haussmann apoia-se nos engenheiros para realizar sua proposta. Eugène Belgrand é o responsável pelas redes de água e esgoto e pela construção do aqueduto; 
Jean Alphand e Gabriel Davioud responsabilizam-se pelos parques e jardins; Barillet Deschamps traça o plano geral e as linhas das ruas; e Victor Baltard é o chefe do serviço de arquitetura.

Dentro do projeto de intervenções, pode-se dividir a rede viária em três redes, de acordo com a época de execução e a forma de financiamento. A primeira rede (1854-1858) é implantada na época da abertura do grande cruzamento (grande croisée) e do entorno, e metade dela é subvencionada pelo Estado e a outra pelo Município. A segunda rede (1858-1868) é composta pelos grandes sistemas de ruas radiais, como l'Etoile, a Place du Château d'Eau (de la République) e a Place du Trocadéro, e um terço dela é financiado pelo Estado, e dois terços pelo Município. A terceira rede (1868 em diante) prevê os eixos de união dos municípios suburbanos, anexados à Grande Paris em 1860, e outras ruas complementares da segunda rede. Nesse caso, as obras se ressentem da falta de investimentos estatais, sendo executadas com grande dificuldade, com recursos da Prefeitura. (PANERAI, CASTEX; DEPAULE, 1986, p. 26)

Pode-se dizer que, por trás da abertura das ruas haussmannianas, existe a intenção militar de facilitar o acesso a pontos da velha cidade e o deslocamento de tropas dos quartéis, localizados nos cruzamentos, para uma melhor mobilidade em vários sentidos. Entretanto, as ruas projetadas no Plano dos Artistas, em finais do século XVIII, também são retas e sua abertura não é justificada com argumentos da ordem pública. As novas ruas projetadas para os bairros do oeste, como as que saem da Place de l'Etoile, também são retas e não podem ser classificadas como contra-revolucionárias.

Mas será a haussmannização apenas uma intervenção no tecido densamente construído do núcleo central da cidade, transformando-o, mudando seu aspecto, expulsando habitantes de suas ruas, executada por um regime autoritário, com a desculpa da modernização? Em linhas gerais sim, mas ainda existem outras formas de interpretar esse processo.

Segundo Bergeron (1989, p. 281), a Paris haussmanniana é

[...] em primeiro lugar, aquela dos grandes eixos, das belas perspectivas e dos cruzamentos em estrela, sobre a herança histórica e o significado estético ou simbólico e social, do qual tudo já foi dito. Na parte central de Paris, e mais fortemente na margem direita, a rede é solidamente articulada pelos elementos físicos ou históricos da estrutura urbana, tais como o Sena e a Ille de la Cité, ou os bulevares de Luís XIV. Ela une claramente a circulação interna às grandes vias de ligação externa, todas, no mínimo, a qualquer uma entre elas. Conserva-se um caráter inegável de superposição, ao menos é mais do que uma marchetaria, e dá uma unidade e uma nova orientação a um tecido antigo que, em todas as suas partes não recortadas, concilia 
bem seu conteúdo e suas atividades ao novo esquema urbano. Por último, em efeito, ultrapassa a natureza de uma simples rede para situar-se entre os melhores casos ao nível de uma composição [...]

Para Roncayolo (1983b, p. 77), o modelo haussmanniano fundamenta-se num tipo de operação bem definida, viabilizada pela aliança da intervenção pública com as sociedades imobiliárias e de crédito, com o objetivo de promoverem intervenções no tecido construído.

Christiane Blancot (1991, p. 210) define a haussmannização como o símbolo da autoridade administrativa contra a democracia, da norma arquitetônica contra a livre criação, como o símbolo de uma burguesia que atropela o proletariado, fazendo da cidade a sua imagem e semelhança, com uma arquitetura cínica e pretensiosa e uma estética de novo-rico.

Sem dúvida, é uma experiência de intervenção autoritária na cidade, identificada com sua transformação burguesa. Os centros tradicionais constituem seu principal campo de atuação, nos quais se realizam cortes no tecido urbano, com a abertura de ruas e o isolamento de edifícios antigos de grande valor histórico, que passam a ser pontos focais dos novos espaços da cidade. Entretanto, essas intervenções não destroem todo o centro: apenas introduzem novos elementos que Ihe são alheios e mudam sua malha urbana. Ainda, segundo Roncayolo (1994, p. 58),

[...] pelo menos no centro da cidade, as ruas - ruas-corredor, largas avenidas ou cruzamentos - se superpõem ao antigo tecido urbano que subsiste bem ou mal (parcelas e traçados), fragmentado ou conectado com o novo. Salvo exceções, a haussmannização não faz tábula rasa: é trabalho sobre a cidade. Cria deste modo uma espécie de mistura de contato [...]

O sistema planejado por Haussmann é mais complexo e, ao mesmo tempo, mais esquemático do que o da cidade existente. Esse traçado novo tem autonomia com relação ao anterior. Christiane Blancot (1991, p. 212) rebate as críticas de que Haussmann abra suas ruas às cegas, sem levar em consideração a cidade existente, e afirma:

[...] observamos que o traçado preciso busca o contrário, a partir de um projeto definido, levando em consideração as vias públicas existentes e as possibilidades de união dos imóveis novos aos edifícios mais antigos.

O novo traçado da metrópole haussmanniana não é indiferente à estrutura preexistente, sendo o núcleo potencializado como centro político, comercial e social. O centro tradicional revitaliza-se com o grande cruzamento, exaltando 
a área do Hôtel de Ville, sede da prefeitura, como coração metropolitano. Também é significativa a intervenção na Île-de-la-Cité, núcleo baricêntrico da cidade, por razões topográficas e históricas, com a criação de um grande átrio na frente da Notre-Dame, além da abertura de três novas ruas em eixo com três novas pontes e novas construções. Outras obras como l'Opéra, Les Halles, entre outras, produzem uma dupla dinâmica na transformação da cidade: uma tendência centrípeta dos equipamentos civis, terciários e administrativos, e uma tendência centrífuga dos equipamentos considerados "sujos", como os cemitérios, matadouros, manicômios, prisões etc.

Argumentos como segurança e higiene justificam a derrubada de quarteirões insalubres e locais de conspiração, embora haja um argumento subjacente mais forte, que é o de potencializar o valor do solo como mecanismo de expansão urbana e como ciclo gerador de riqueza. As três redes revalorizam as áreas centrais e abrem novas zonas edificáveis. São favorecidas as ofertas de residências de alto nível, sem que seja abordado o problema das casas de baixo custo. Apesar disso, os especuladores veem uma oportunidade de renda na exploração das habitações operárias.

Os novos edifícios residenciais diferenciam-se dos de épocas anteriores. Até o século XVIII, os edifícios burgueses e o habitat aristocrático dividiam o mesmo espaço, afirmando-se, aos poucos, a maison à loyer (casa de aluguel), em que o proprietário reside no pavimento nobre, destinando os demais ao aluguel. A partir da metade do século XIX, essa divisão se vê substituída pelo immeuble de rapport (imóvel para renda), dividido em térreo e sobreloja para comércio ou atividades terciárias, quatro a seis pavimentos de moradias para alugar, e a mansarda para habitação de serviçais ou outros. As diferenças entre os imóveis, no que se refere à classe social dos que neles habitam, encontram-se na localização, no dimensionamento interno e no acabamento das fachadas.

Para conseguir a máxima uniformização da cidade, os planos de intervenção são acompanhados de um rigoroso organograma de reparcelamento, o que garante recompor, num único bloco, as pequenas parcelas. A potencialização máxima dos investimentos é obtida pela planificação da morfologia dos edifícios, com o planejamento tipológico do immeuble a rapport, que se repete ao longo da rua, imprimindo um caráter unitário e reconhecível ao bairro.

Os bairros haussmannianos ${ }^{6}$ misturam funções comerciais e residenciais. As fachadas uniformes, as fileiras de árvores e o denso tecido comercial, formado por cafés, restaurantes e serviços em geral, caracterizam esses novos espaços. Nesse novo traçado, produz-se o espaço da burguesia, esteticamen-

\footnotetext{
${ }^{6} \mathrm{O}$ uso da palavra bairro pode ser imprópria, uma vez que as obras realizadas levantam cortinas de edifícios que ocultam o tecido histórico preexistente, que permanece inalterado por trás dos telões formados pelas novas construções.
} 
te comportado, limpo, sem a presença da população indesejada. Mas essa população continua presente na parte não afetada, na parte de trás, nos quarteirões não derrubados durante as reformas. Restam pedaços da antiga Paris, e a população de baixa renda se vê órfã do poder público.

Intervenções radicais na estrutura urbana não são exclusividade de Paris. Muitas grandes cidades passam por intervenções em busca de modernização, abrem grandes eixos, largas avenidas e destroem quarteirões insalubres no centro. Mas são os trabalhos de Haussmann, em Paris, os que simbolizam esse tipo de ação, pelo fato de as obras impressionarem tanto pela grandeza dos trabalhos executados como pela rapidez com que são feitos. A tudo isso pode-se acrescentar a originalidade, que Marchand (1993, p. 92-93) define em três pontos: a importância dos equipamentos coletivos, a criação de uma cidade burguesa e a produção de um conjunto coerente.

Haussmann copia os equipamentos coletivos de Londres e recupera 0 atraso de Paris em relação a essa cidade. A formação da cidade burguesa é seu principal mérito, uma forma urbana nova e original. A harmonia haussmanniana está na uniformidade das grandes massas e na variedade de detalhes, uma combinação que forma um conjunto esteticamente coerente. A cidade é concebida por hierarquias que controlam volumes, unidades distintas, mas umas pensadas em relação às outras: os imóveis, as ruas, os cruzamentos, os jardins e os quarteirões.

Todo esse movimento tem um outro lado. A cultura popular é excluída dos novos espaços: os teatros populares são demolidos, e os pobres perdem seus espaços de lazer. As demolições no centro provocam uma crise de habitações, favorecem a especulação e agravam a segregação social, uma das consequências das reformas haussmannianas.

Surgem as separações: Paris de um lado, e a periferia de outro; os quarteirões ricos do oeste versus os quarteirões pobres do leste; a rive gauche contra a rive droite. Passa-se da segregação vertical das edificações para a segregação horizontal dos arrondissements. O centro consolida suas funções comerciais, administrativas e financeiras. Também é espaço de lazer, com teatros e locais para o promenade. Nas proximidades, estão os bairros residenciais de luxo, como a área da l'Etoile. Longe do centro, localizam-se os bairros proletários.

A cidade que chamamos de haussmanniana é a cidade burguesa por excelência, o lugar institucional da moderna sociedade burguesa, um espaço que se configura de acordo com a lógica de uma burguesia e se supõe um modelo espacial concreto. É uma vitrina da modernização, antes de ser um centro de produção que se aciona pelo encontro entre um urbanismo autoritário 
e as novas estruturas do capitalismo. Para colocar em prática suas ideias, Haussmann conta com três engrenagens fundamentais: o aparato burocrático, o instrumento legislativo e o sistema financeiro.

As intervenções haussmannianas são um momento de transição para a cidade liberal contemporânea, pois ainda mantêm técnicas de controle da forma urbana herdadas do antigo regime, ao tempo em que são geridas de forma autônoma: os planos realizados pela autoridade pública não são submetidos aos construtores privados. Haussmann detém o poder decisório sobre locais, modos e formas de construir, deixando aos promotores a execução e os lucros dos programas.

A imagem estereotipada de Paris é a haussmanniana. Sempre que pensamos em Paris, a imagem que nos vem à cabeça é a de uma cidade com grandes eixos, belas perspectivas e grandes cruzamentos em estrela. Uma cidade onde o bulevar e o imóvel formam um conjunto indissolúvel. Um modelo para muitas outras cidades que pretendem adaptar-se às novas exigências da vida moderna. A haussmannização associa-se muito mais à estética da cidade, do que à funcionalidade do projeto.

Paris de Haussmann, com seus amplos, elegantes bulevares e vistas astutamente focadas em monumentos, também se tornou um modelo para algo mais - para a vida urbana como uma obra de arte, como uma experiência estética, um espetáculo público sans pareil. É fato evidente que muitos dos seus competidores estão menos interessados nos aspectos funcionais do seu programa do que na urbanidade e universalidade que confere a suas cidades. (KOSTOF, 1992, p. 266-267)

Esse é o paradoxo da haussmannização: seu projeto funcional de cidade fica muito mais conhecido pela criação de uma belle cité.

\section{A difusão de um modelo}

Algumas cidades têm a capacidade de converter-se em exemplo e influenciar outras, que passam a tê-las como modelo, uma vez que "[...] estas cidades místicas exercem uma influência muito além de seus domínios geográficos." (LORTIER, 1995, p. 9)

No século XIX, Paris é considerada um modelo de modernidade, que se divulga nas exposições universais lá realizadas, situação atingida a partir das intervenções haussmannianas. Paris transforma-se, assim, numa cidade 
diferente das outras urbes europeias, por ser a primeira que passa por intensas reformas para adaptar-se às novas condições econômicas e sociais, e por ter construído um novo espaço urbano, mais compatível com os novos tempos e a nova sociedade burguesa.

Essa Paris que nasce das obras do Segundo Império, a Paris haussmanniana, tem, segundo alguns autores, essa capacidade de transformar-se em exemplo e modelo, não só para outras cidades francesas, mas também para muitas outras mais afastadas, como Cairo, Saigon ou Rio de Janeiro.

Os urbanistas e arquitetos do Segundo Império criaram, sem colóquios nem discursos, a cidade mais coerente do mundo, modelo até meados do século $\mathrm{XX}$ de todas as outras capitais, pois vemos, por todas as partes, em todos os lugares, em qualquer ocasião, o gosto pelo embelezamento do espaço público, através da clareza e regularidade dos traçados, dos jardins, dos pontos singulares sublinhados pela arquitetura ou a escultura. (GAILLARD, 1991, p. 140)

O modelo haussmanniano pode revelar-se nos métodos de intervenção utilizados - as ações de Haussmann -, ou na forma final da cidade a configuração das ruas de Paris. Observar Paris e tê-la como exemplo de uma cidade-monumento, que desperta a admiração de todos, é diferente de tê-la como modelo de processo de transformação.

Será a haussmannização efetivamente um modelo? Se for um modelo, deve ser exportável. Pierre Pinon não considera esse modelo totalmente exportável, pois a cidade que o adotasse deveria apresentar as mesmas condições de Paris no momento das intervenções que lá se efetivaram. Por isso, Pinon prefere a referência a um "tipo haussmanniano", que se idealiza, diferente de um "modelo haussmanniano", que se reproduz. "Que o "modelo haussmanniano' não é muito exportável quando consideramos as especificidades de suas operações é um fato", afirma o autor. (PINON, 1995, p. 44-48)

Não há dúvida de que a grande repercussão das obras parisienses faz com que elas sejam admiradas mais pela magnitude de suas artérias e pela capacidade administrativa francesa em enfrentar obras públicas de tamanho vulto, do que pelas demolições e desapropriações efetuadas no centro. O que se admira é a força da obra realizada, a harmonia geral obtida. Suas avenidas e bulevares passam a ser objeto de referência para muitos outros projetos urbanos.

Mas, se o exemplo parisiense penetra em todos os espíritos, é primeiro como uma imagem de uma grandiosa metamorfose, como empreendimento financeiro apostando em especulações (às vezes incertas), não como procedimento específico, não como redes com aberturas brutais. (PINON, 1995, p. 48) 
A haussmannização também está relacionada com o espaço onde se atua, ou seja, o centro histórico denso e confuso. Em muitas das reformas urbanas classificadas como haussmannianas, encontramos alguns elementos específicos semelhantes, tais como as transformações dos quarteirões insalubres, ou considerados como tal, e o enlace de estações de trens ou de pontos importantes da estrutura urbana com centros históricos.

Muito mais do que um modelo para as intervenções em outras cidades, a haussmannização é a base de um novo movimento, o City Beautiful, que revoluciona o desenho urbano nos Estados Unidos em finais do século XIX e que é considerado a versão norte-americana dos embelezamentos haussmannianos.

Para exemplificar alguns dos processos caracterizados como haussmannização do espaço urbano, seguimos a divisão feita por André Lortier (1995, p. 11): o modelo identificado em países limítrofes da França, o que se impõe nas antigas colônias e o que seduz em outras cidades. Incluímos, antes, um comentário a respeito da aplicação do modelo em outras cidades francesas, ainda sob o domínio do Segundo Império.

Roncayolo (1983b, p. 77) afirma que é em Paris que o modelo se constitui, não em Lyon ou Marseille, que também realizam suas reformas urbanas entre 1850 e 1860 . As transformações urbanas em cidades francesas vêm da Segunda República, com a abertura da Rue de Rivoli em Paris e da Rue Centrale em Lyon, continuam durante o Segundo Império e realizam-se também em outras cidades como Lille e Marseille em 1850, Rouen entre 1859 e 1860, Montpellier a partir de 1861, Toulouse em 1864, Nantes em 1866 etc.

A princípio, pode-se caracterizar o modelo haussmanniano como um acordo entre entidades públicas e privadas, cuja finalidade é realizar uma renovação urbana, concentrada na reprodução de um modo específico de intervenção: as aberturas no tecido construído, as percées. Nas outras cidades francesas, pequenas ou médias, as operações consistem em traçar grandes vias, classificadas como haussmannianas, com um duplo objetivo: permitir a circulação, transformando a morfologia urbana, e criar imóveis novos, para impedir a retirada da burguesia. (BOURILLON, 1992, p. 140)

A haussmannização sai da França para outros países da Europa. Iniciando a nossa exemplificação com a Itália, verificamos que suas cidades realizam intervenções na malha urbana, justificando os sacrifícios como necessários, pela importância das melhorias que se produzem. D. Calabi (1995, p. 67-72) analisa a fascinação pela capital francesa dos técnicos e políticos italianos, que a tomam como um exemplo de modernidade. Considera que Paris é o modelo aplicado a Milão, no projeto de Cesare Beruto, de 1884; a Florença, 
onde Giuseppe Poggi define cortes haussmannianos nas zonas centrais do Mercato Vecchio e do gueto; e a Roma, tanto no caso do quarteirão Prati di Castello, de 1872, como no projeto da Via Nazionale, de 1871. Em Turim, a influência dos trabalhos de Haussmann pode ser identificada na abertura da Via Micca de 1886. (GRAVAGNUOLO, 1998, p. 47)

Analisando as obras que se realizam entre 1865 e 1880, na parte baixa da cidade de Bruxelas, um tecido antigo e muito denso, habitado por uma população operária, Yvon Lebliq (1995, p. 80) busca estabelecer um paralelismo entre Bruxelas e Paris.

\footnotetext{
Com Anspach, assinala-se de fato a vontade política de fazer triunfar a haussmannização, e os trabalhos executados sob seu governo constituem certamente o exemplo mais próximo do modelo parisiense da haussmannização de uma cidade não francesa na época do Segundo Império e nos anos imediatamente posteriores, haussmannização que se acompanha, assim como no caso de Paris e arredores, de aspectos negativos do ponto de vista social.
}

Os motivos que justificam essa intervenção são a má situação do Rio Senne, muito poluído, um esgoto a céu aberto, e a necessidade de enlaçar as duas estações de trens construídas nas extremidades dessa parte da cidade. São, mais uma vez, utilizados os argumentos de circulação, saneamento e embelezamento.

A abertura das vias Kingsway e Aldwych em Londres, entre os anos 1889-1935, faz parte de uma nova fase do desenho urbano londrino, na qual se combina a estética francesa, a imagem britânica imperial e os novos métodos norte-americanos de construção de edifícios comerciais. (SCHBERT; SUTCLIFFE, 1996, p. 115-144) Ainda que as aberturas sejam similares a algumas executadas por Haussmann em Paris, têm o estilo e a monumentalidade vinculados ao movimento City Beautiful, além da intenção subjacente de transformar Londres numa poderosa capital do Império Britânico.

A imposição de um modelo francês na Indochina, colônia da França, deve-se à necessidade de unir as condições locais a um ambiente similar ao da Metrópole, criando um novo ambiente urbano, onde possam conviver a paisagem das cidades francesas e a arquitetura de pagodes neorregionais. (PÉDELAHORE-LORI, 1995, p. 126-131) Nesse sentido, as cidades têm a função de representar o poder da metrópole sobre a colônia e, para isso, concebe-se um espaço público totalmente controlável, organizado estrategicamente, através da localização dos estabelecimentos institucionais. O sistema viário compõe-se de ruas retas, perpendiculares, largas, com passeios arborizados, equipadas com as necessárias redes de infraestrutura 
de água, esgoto e iluminação pública. Entre os objetivos dessa reforma, está o de unir os monumentos aos lugares mais significativos da cidade colonial, como a Prefeitura ao rio que corta a cidade, o teatro à estação de trem, o Palácio do Governo ao Jardim Botânico em Saigon, ou o Phnom à Catedral, em Phnom Penh. (PEDELAHORE-LODI, 1995, p. 127)

Longe da Europa e de suas colônias, França e Paris seduzem outras cidades que querem implantar um projeto de reformas. Sawsan Noweir (1995, p. 149-155) não tem dúvidas ao afirmar que o Cairo sofre diretamente a influência dos trabalhos realizados por Haussmann em Paris, em meados do século XIX. A sedução começa com a visita do Khedive do Egito a Paris, para participar da Exposição Universal de 1867, quando a autoridade egípcia tem o próprio Haussmann como cicerone na cidade. Decide-se, assim, a adoção da imagem de Paris na modernização do Cairo, para as comemorações da abertura do Canal do Suez. O projeto concebe um sistema de ruas e praças que fazem a articulação entre os quatro centros ou confluências principais da cidade: a Estação Central, a Azbakiyya, a Cidadela e o Palácio Abdine. Dois bulevares cortam a cidade antiga em diagonal, junto com um sistema de novas ruas, sempre pensadas e orientadas para valorizar e deixar em perspectiva os monumentos notáveis, principalmente os do poder: a Cidadela e o Palácio Abdine.

Também o projeto de Sir Edouard Lutyens, de 1912, para a nova capital do Império das Índias, em Delhi, constitui um outro exemplo da adoção do modelo haussmanniano. Françoise Crémel (1995, p. 156-160) afirma que, nesse caso, o modelo não se revela tanto nos traçados, mas no processo e na maneira de realizá-lo.

Afinal, há um "modelo" haussmanniano ou um "tipo" haussmanniano? Qual a forma de influência de Paris sobre outras cidades? Seja como modelo ou como um tipo de cidade, o certo é que a Paris haussmanniana simboliza a experiência de uma intervenção autoritária, a imposição de um projeto urbano numa determinada realidade. Entretanto, cada vez mais se consolida a interpretação da haussmannização não apenas como símbolo de uma intervenção realizada sob o poder autoritário, mas sobretudo como a capacidade de intervir numa estrutura existente, seja para maquiá-la, seja para dialogar com ela, mas nunca para negá-la. (LOYER, 1991, p. 14) Nesse sentido, a haussmannização vincula-se à monumentalidade e ao embelezamento das cidades, à estética e à criação da cidade como uma obra de arte.

Seria possível associar a haussmannização ao processo de reforma urbana que se produz no Brasil, em princípios do século XX? Na busca de resposta a essa questão, vamos verificar a possibilidade de afirmar que, também no Brasil, a Paris do Segundo Império desperta fascínio e seduz. 


\section{Parte II Os Casos}

O largo do Pelourinho é a vista urbana que um brasileiro pode mostrar a um francês sem ter nenhuma dor de corno pela perspectiva dos Campos Elíseos ou da avenida da Ópera.

Carta de Manuel Bandeira a Mário de Andrade, em 18 de janeiro de 1927. 

Capítulo 3

O caso do

Rio de Janeiro

\section{A capital do País}

No século XIX, a cidade do Rio de Janeiro, então capital do Brasil, está longe de parecer-se com uma cidade norte-americana ou europeia. Os numerosos viajantes que a visitam descrevem-na de uma forma aproximada de outros arquétipos de cidade. No início desse século, mesmo reconhecendo as referências a uma cidade colonial portuguesa, ${ }^{1}$ outras ali existem que escapam à percepção desses viajantes.

Nessa época, a arquitetura das edificações do Rio de Janeiro lembra a de Lisboa e a do Porto, embora adaptada ao clima de um país tropical. Suas ruas caracterizam-se por uma vida intensa: gente em constante movimento, mercadorias expostas ao sol, ao alcance dos olhos e das mãos, como num bazar aberto, fortes olores, muito ruído, ruas estreitas, sujas e sem ordem. Se o viajante fecha os olhos, pode imaginar-se numa cidade árabe. Entretanto, quando os abre, dá-se conta de que a multidão à sua volta é composta, na sua maioria, por africanos. Numerosos negros - apenas se percebem alguns brancos - num eterno vaivém, enchendo as ruas de movimento e ritmo. Homens, mulheres e crianças, dispersos pelas ruas, despertando nos brancos 
${ }^{2} \mathrm{O}$ escravo de ganho é um cativo que procura trabalho pelas ruas, e uma parte dos benefícios que recebe fica em suas mãos, enquanto a outra parte, prefixado o valor, fica com o seu senhor.

${ }^{3}$ Maria Graham vem ao Brasil acompanhando seu marido, Thomas Graham, capitão da Marinha, no navio-escola Doris, como professora dos aprendizes de marinheiro. (MATTOSO, 1992, p. 700)

${ }^{4}$ Os exemplos citados encontram-se na Itália, Escócia, Índia e Sri Lanka, respectivamente. a insegurança e o medo de revoltas. São escravos domésticos, escravos de ganho, ${ }^{2}$ lavadeiras, negros livres. Dessa forma, o viajante pode equivocar-se e pensar que está numa cidade africana.

O que não se pode negar é que o Rio, nessa época, ainda é uma cidade colonial, mesmo depois da Independência do Brasil, da sua formação como Império e da instauração da República. Reinventando, nos trópicos, as tradições urbanísticas de Portugal, a cidade revela sua "herança urbana" numa forma-aparência marcada por traços característicos das fachadas das casas e pelo traçado das ruas.

Também é uma cidade que vive da mão-de-obra escrava, cuja existência é marcada pela opressão e exploração de homens, pelo trabalho a eles imposto - serviços urbanos, circulação de mercadorias e trabalho doméstico.

Se o Rio é uma mistura de todas essas cidades ou de nenhuma delas, conhecê-lo no século XIX é o primeiro passo para entender o processo de transformação urbana projetado e gerado durante todo o século XIX, que se faz realidade em princípios do século XX.

\section{Conhecendo a cidade do século XIX}

\section{Como é a cidade}

A cidade do Rio de Janeiro encontra-se às margens da Baía de Guanabara e, para os viajantes do século XIX, é uma das mais belas do mundo. A inglesa Maria Graham, ${ }^{3}$ que visita o Brasil em 1821, diz que sua beleza não se compara com nenhuma outra, nem com a da Baía de Nápoles, ou com a da Baía de Firth of Forth, nem com a do Porto de Bombaim, ou com a de Tricomalee. ${ }^{4}$ Ao descrever a Baía de Guanabara, ela afirma:

\footnotetext{
Altas montanhas, rochedos como colunas superpostas, florestas luxuriantes, ilhas de flôres brilhantes, margens de verdura, tudo misturado com construções brancas, cada pequena eminência coroada com sua igreja ou fortaleza, navios ancorados, ou em movimento, e inúmeros barcos movimentando-se em um tão delicioso clima, tudo isso se reúne para tornar o Rio de Janeiro a cena mais encantadora que a imaginação pode conceber. (GRAHAM, 1956 , p. 174-175)
}

Na descrição de Leblanc (1895, p. 28) do mesmo lugar, lemos: "O Rio de Janeiro, situado sob um clima magnífico e construído em anfiteatro, oferece à vista um panorama maravilhoso; tem o ar de uma cidade de lazer antes do que de comércio, [...] Sua baía é uma das mais belas do mundo inteiro [...]." 
A baía deixa impressionados todos os viajantes. A natureza é generosa, mas o feitiço se desfaz assim que chegam à terra. A realidade da cidade é outra, muito mais dura e muito menos poética.

Vista de bordo pela manhã, apresentava a cidade um aspecto imponente por sua posição e pelas numerosas casas e igrejas caiadas de branco: mas, olhadas de perto, desvanecia a ilusão. As ruas estreitas e sórdidas, a catinga de milhares de negros, as emanações dos armazéns de provisões, davam a impressão que podia ser tudo, menos agradável. (GARDNER, 1836 apud BARBOSA, 1990, p. 125)

Depois da expulsão do invasor francês em 1567, a pequena urbe, localizada na praia da Cara de Cão, na entrada da baía, translada-se para o Morro do Castelo, descendo depois em direção à planície e à praia. Desenvolve-se sobre pântanos e, ao final, localiza-se no quadrilátero formado por quatro morros: Morro do Castelo, Morro de Santo Antônio, Morro de São Bento e Morro da Conceição.

Submetido o francês invasor, surge São Sebastião do Rio de Janeiro.

Cresceu o povoado sôbre pauis infectos. A princípio, taba selvagem, onde o gentio sobrepujava o branco, depois aldeota africana, com o prêto dominando o luso e os nascidos na terra. Assim cresceu. Mas não mudou. Com a chegada do primeiro Vice-Rei, Conde da Cunha, em 1763, ainda estava no que era.

No quadro maravilhoso da natureza, a cidade é um tristíssimo contraste. Uma nódoa brutal na paisagem radiosa. A casa é feia. A rua é suja. 0 conjunto exaspera. Tudo conspira contra o povoado infeliz. Tudo. O clima, um clima abrasador e ardente, as montanhas que o cercam e o encantonam e o sufocam, o chão úmido e verde, paul onde êle se assenta, o desasseio gerado pelo próprio homem, que sorri das lições do bárbaro tamoio... (EDMUNDO, 1957 , v. 1, p. 18)

Até finais do século XVI, a maior parte da cidade ainda está sobre o morro. Pouco a pouco, começa a descer, com o aterramento de pântanos e lagoas. Na Rua Direita, a mais importante, ligando o Morro do Castelo ao Morro de São Bento, se encontram o Palácio do Governo, a Alfândega e Igrejas. O povoado muda seu aspecto. Nas construções, predomina o estilo colonial "feio e forte", com um só andar e entre empenas, sem espaço entre as construções. Em finais do século XVIII, são 43.376 habitantes (REIS, 1986, v. 40, p. 24), numa área restrita. As ruas são estreitas, muitas sem pavimentação, ou pavimentadas com pedra do tipo "pé-de-moleque". 
${ }^{5}$ Pela carta régia de 16 de dezembro de 1815, o Brasil foi feito Reino Unido de Portugal e Algarve. (TAPAJÓS, 1967, p. 252)
O Rio de Janeiro é a capital do Vice-Reino do Brasil desde 1763, quando Salvador perdeu essa prerrogativa. Em 1808, com a instalação da Corte Portuguesa - que fugia das guerras napoleônicas - o Rio de Janeiro transforma-se na sede da nova estrutura política, o Reino Unido de Portugal, Algarve e Brasil. ${ }^{5}$ A cidade não tem estrutura para receber as 20 mil pessoas, aproximadamente, que acompanham a Corte aos trópicos, quase um terço da sua população. Casas particulares, luxuosas e confortáveis residências, são requisitadas para acomodar a família real, que se instala no Convento do Carmo, na Casa de Câmara e Cadeia e nas melhores edificações perto do Paço. Nessa época, a cidade compõe-se de 75 espaços públicos: 46 ruas, 4 travessas, 6 becos e 19 praças.

A nova população que chega à cidade exige uma nova estrutura, já que a existente não a satisfaz por ser pobre, suja, sem encantos ou atrativos. Com a evidente intenção de transformar o Rio numa cidade europeia, são convidados numerosos artistas franceses, ansiosos por exilar-se da França após a ascensão ao trono de Luís XVIII. A Missão Francesa chega ao Rio em 1816 e, dez anos mais tarde, cria-se a Academia Imperial de Belas Artes, tendo início a influência da cultura francesa nos trópicos, que continuará até os anos 30 do século XX. Spix e Martius, em 1817 (1961, v. 1, p. 46), descrevem o impacto das contradições existentes na cidade:

\footnotetext{
Quem chega convencido de encontrar uma parte do mundo, descoberta só desde três séculos, com a natureza inteiramente rude, forte e não vencida, poder-se-ia julgar, ao menos aqui na capital do Brasil, fora dela; tanto fêz a influência da cultura da velha e educada Europa para remover dêste ponto da colônia os característicos da selvageria americana, e dar-lhe o cunho da mais alta civilização. Língua, costumes, arquitetura e afluxo dos produtos da indústria de tôdas as partes do mundo dão à praça do Rio de Janeiro feição européia.
}

O ambiente social transforma-se pouco a pouco. Os fazendeiros de café constroem casas confortáveis longe do Centro, em Botafogo ou São Cristóvão, e substituem a influência da arquitetura portuguesa pelo "estilo império": é a influência neoclássica. A cidade expande-se além de seus limites iniciais.

O espaço urbano, definido por Maria Graham como mais europeu do que o da Bahia e o de Pernambuco, continua mudando sua imagem durante todo o século XIX. Ao norte, a Cidade Nova, que surge depois da chegada da Corte, apresenta ruas mais largas, que orientam o crescimento da cidade. Para o sul, a cidade segue costeando a baía.

A parte mais antiga da cidade, a nordeste, é cortada por oito ruas direitas, bastante estreitas, paralelas, partidas por muitas travessas retangulares, em 
quadras. Uma grande praça a oeste da cidade velha, o Campo de Sant'Ana, separa-a da cidade nova. Esta última, na maior parte construída só depois da vinda da côrte [...]. A cidade mede, na sua maior extensão, meia milha. (SPIX; MARTIUS, 1961, p. 46-47)

No final do século XIX, o Rio já tem mais de 500 mil habitantes, mas ainda mantém a estrutura colonial, com ruas estreitas, das quais muitas ainda conservam a pavimentação do tipo "pé-de-moleque", com pouca iluminação, a maioria ainda com lampiões a gás, poucas diligências e bondes puxados por burros. É a partir desse momento, até os anos 30 do século XX, que o Rio se transforma numa cidade moderna, passando por reformas urbanas, ${ }^{6}$ mudando sua fisionomia, sua aparência, sua vida e a vida de seus habitantes.

\section{Quem vive na cidade}

Em princípios do século XIX, a estrutura social do Rio se compõe de plantadores de café, comerciantes, clero, portugueses que chegam com a Corte de D. João VI, imigrantes sem profissão definida e escravos. A maioria da população é constituída de portugueses e de seus descendentes, tanto brancos como mestiços. Os índios pouco são vistos, já que "[...] muito raramente aparecem, e só por acaso, como aves de arribação, no tumulto para êles estranho." (SPIX; MARTIUS, 1961, p. 50)

Antes da chegada da Corte Portuguesa, no início do século XIX, a cidade tem uma população aproximada de 50 mil habitantes, e os negros superam os brancos em número. Não existe nobreza. A classe que detêm essas prerrogativas é formada pelos religiosos, pelos funcionários públicos e pelas famílias abastadas que vivem no campo - os latifundiários e os donos das minas. Com a chegada da Corte, essa população rural desloca-se para a cidade do Rio em busca de títulos de nobreza e cargos, encantando-se com o novo estilo de vida europeu e instalando, definitivamente, suas residências na capital.

Além dos "nacionais", os imigrantes que vêm da Europa aumentam a população da capital. Ingleses, franceses, holandeses, alemães e italianos desembarcam no Rio depois da abertura dos portos às nações amigas em 1808 e unem-se aos cerca de 20 mil portugueses que chegaram com a Corte. Esses imigrantes instalam-se em diversos pontos da cidade, procurando, nos trópicos, locais mais agradáveis para viver.

Como capital de um Império que consegue sua independência política com o apoio dos latifundiários escravocratas, que se estabelece mantendo as estruturas coloniais e que se baseia na agricultura de exportação e na mão-de-obra escrava, o Rio de Janeiro é uma cidade em que se veem escravos por

\footnotetext{
${ }^{6}$ As intervenções são pontuais durante todo o século XIX, principalmente para a implantação dos serviços urbanos, chegando-se a uma grande reforma urbana entre os anos 1902-1906, o desmonte do Morro do Castelo em 1922 - uma intervenção que transforma a geografia da cidade -, além de propostas gerais como a de Alfred Agache em 1929 e a de Le Corbusier em 1930.
} 
toda parte: escravos domésticos, que levam mensagens ou compras, alugados por seus donos a comerciantes, ou até escravos de ganho.

\footnotetext{
No que concerne ao costume dos habitantes, o olhar, em vez de perceber num instante, como dentro dos bazares de Delhi ou de Benares, todas as gamas de cores, é obrigado a se contentar com duas notas extremas: [o branco] dos descendentes dos antigos colonos portugueses, plantadores, funcionários ou comerciantes, vestidos à última moda de Paris ou de Londres; e a negra na pele de ébano, uma pena, coberta com um farrapo de tela branca. (MOUSTIER, 1885, p. 7)
}

Esse contraste, essa mistura de costumes e de culturas, chama a atenção de todos os que por ali passam. Definitivamente, o Rio é uma cidade colonial, uma cidade escravista cujo funcionamento se baseia no trabalho escravo.

Muitos outros imigrantes chegam para trabalhar no campo. As fazendas de café, do vale do Paraíba, necessitam de mão-de-obra para trabalhar em suas lavouras, especialmente depois da abolição da escravidão, em 1888. Muitos abandonam as regiões rurais e vêm para as cidades, misturando-se aos pobres e aos ex-escravos e instalando-se em zonas degradadas do Centro, em habitações insalubres. O primeiro censo oficial, realizado no Brasil, em 1872, indica que, no Rio, no Município Neutro da Corte, existe uma população de 274.972 habitantes, 230.454 pessoas na área urbana e 41.518 na rural. (RENAULT, 1982, p. 27) Segundo o censo de 1890, há, no Rio, 522.651 habitantes, dos quais 34\% são negros ou mestiços. (CHALHOUB, 1986, p. 25) Um incremento de 90\%, entre 1872 e 1890.

\section{Como se vive na cidade}

A falta de infraestrutura é compensada pelo trabalho dos negros, que viabiliza desde o transporte de pessoas até o de dejetos urbanos. 0 africano chega ao Brasil, inicialmente, para trabalhar nas plantações de cana-de-açúcar, como opção econômica para o incremento da agricultura de exportação. Com o crescimento urbano, o trabalho dos negros volta-se para os serviços na cidade, em todos os setores da vida da urbe, seja nas ruas ou nas casas, utilizado tanto para permitir luxos da vida civilizada - como lacaios, por exemplo -, quanto para executar os mais vis serviços - como jogar as imundícies no mar ou nas lagoas.

O Centro, no século XIX, é uma área residencial, onde predominam as casas térreas e os sobrados, construídos no alinhamento da rua, onde convivem as mais variadas classes sociais. A forma da construção determina a distinção social no urbano, pois morar num sobrado significa olhar a rua de cima, muito diferente de morar numa casa térrea, onde a rua está no mesmo nível. 
Quando a cidade se expande, por volta do 1850, na direção norte, temos a Cidade Nova, e na direção sul, Botafogo e, depois, as praias de Copacabana e Ipanema. Os novos bairros, como Botafogo e São Cristóvão, apresentam construções diferentes das do Centro, com novas residências mais amplas, melhor construídas, arejadas e iluminadas. São as quintas, primeiramente usadas nos fins de semana e nas férias, que acabam se convertendo em moradias definitivas.

Daí em diante, para o sul, filas interrompidas de casas ocupam as duas enseadas em meio círculo, a do Catete e a de Botafogo, e casas isoladas aparecem espalhadas nos pitorescos vales vizinhos procedentes do Corcovado, e entre os quais o mais aprazível é o de Laranjeiras. (SPIX; MARTIUS, 1961, p. 47)

As classes abastadas deixam o Centro, abandonando seus antigos sobrados, os quais, após serem subdivididos, transformam-se em habitações coletivas, moradias para os pobres. São albergues ou casas de cômodos, que passam a ser alugados, pequenas habitações sem ventilação, banheiro ou cozinha. No Centro, assim como nos novos bairros, surge um novo tipo de residência popular para as classes de baixa renda, os cortiços, localizados nos fundos de antigas construções ou em terrenos adquiridos para essa finalidade. Luiz Edmundo (1957, v. 2, p. 364-367) nos descreve um desses cortiços:

Penetremos o cortiço que se esparrama diante de nós, sujo, feio e miserável, com a sua tôsca linha de casinholas sem luz, sem ar, sem confôrto, lembrando minúsculos oratórios, com o seu agressivo cheiro de sabão e a sua morrinha estonteante de suor. Aí, centenas de infelizes apodrecem às pilhas, aos montões, numa promiscuidade criminosa.

[...]

Em geral o cortiço é de um único pavimento: uma portinha e uma janela, uma portinha, uma janela... Há-os, porém, de dois e mais andares, com uma galeria avarandada, servindo a cada um dos pisos, e uma infalível grade de madeira pintada de amarelo.

[...]

0 arruamento é em forma de betesga: casinhas tanto à direita como à esquerda e, ao fundo, fechando-o, uma linha baixa de tabiques onde se instalam as imundíssimas retretas, sempre repletas e disputadíssimas. Êsse arruamento, todo êle, como largura pode ter, no máximo, obra de nove metros: três destinados ao trânsito dos moradores, ao centro, mas transformado sempre em coradouro de roupa e mais três de cada lado, atribuídos às residências e onde se aglomeram, num caos terrível: pranchas, cavaletes de madeira, tinas cheias d'água, bacias de enxaguar, alguidares para o preparo do anil, tábuas, mesas, bancos, cadeiras, todo um mundo de cacarecos, em meio a vasos com tinhorões, tinas com samambaias, gaiolas com passarinhos [...]. 
${ }^{7}$ Decreto do Legislativo de 9/12/1882, que dá isenção de impostos alfandegários, além de outros benefícios, às indústrias que construam casas higiênicas para seus empregados.

${ }^{8}$ Decreto de $1^{\circ}$ de junho de 1900 estabelece que: "A divisão de casas de vastas dimensões por cubículos de madeira, de modo a se estabelecerem sob o mesmo teto famílias diversas, é

terminantemente proibida, po contrária à higiene das habitações." (MOURA, 1995, p. 53)

${ }^{9}$ Postura Municipal de 1889. "[...] fica proibido o estabelecimento e a construção de cortiços, casinhas e outras edificações acanhadas para a habitação das classes menos favorecidas, e ainda mesmo nos quintais dos prédios." (MOURA, 1995, p. 52)
Esse tipo de residência prolifera na cidade. Normalmente, são moradias insalubres, possíveis focos de infecções e de epidemias. Em 1869, 3\% das edificações são cortiços, onde vivem $10 \%$ da população. Em 1888, as cifras sobem para $4 \%$ e $12 \%$, respectivamente. (SANTOS, 1981, p. 51) Neles, vive a população de baixa renda, perto do Centro, onde consegue os meios para sobreviver.

O governo, então, decide intervir no problema da insalubridade das residências dos proletários. Um decreto ${ }^{7}$ do Estado concede isenção de impostos às empresas que construírem moradias higiênicas para seus empregados, as vilas operárias. Ao mesmo tempo, proíbe-se a construção de cortiços em determinadas áreas da cidade, principalmente no Centro. 0 serviço de salubridade proíbe que mais de uma família viva sob o mesmo teto, ${ }^{8}$ e a legislação determina as condições para a construção de moradias proletárias, como a preparação do terreno, o traçado das ruas, a altura das divisões e as instalações higiênicas. ${ }^{9}$ As indústrias têxteis são as primeiras a construir as residências operárias, isolando seus empregados do resto dos trabalhadores que ainda vivem no Centro.

\section{De que vive a cidade}

Nas horas de ócio, os habitantes do Rio podem ir a um espetáculo no Teatro do Rossio ou no Teatro Imperial Pedro II (ou Lírico). Há os salões literários e as salas de baile, além das festas populares que, aos poucos, substituem as festas religiosas. A maior é o carnaval ou entrudo, nas ruas e nos teatros.

As praias começam a ser frequentadas em meados do século XIX, mas só para o banho de mar. Em finais do século, surgem os clubes de regata e as corridas de cavalo, essas últimas introduzidas por um prussiano, o Conde de Herzberg. Também há cafés, salas de chá e confeitarias, onde se pode passar o tempo. Os pobres divertem-se nos botequins ou nos quiosques, onde podem desfrutar uma xícara de café, uma cachaça ou uma cerveja, introduzida no Brasil por D. João.

$\mathrm{Na}$ economia urbana, diversas atividades desenvolvem-se na cidade. As ruas estão cheias de vendedores ambulantes, como o português que vende perus, o italiano que vende peixe e a turca dos fósforos. Há, ainda, o vendedor de vassouras, o de tecidos e artigos de armarinho, o de doces, o negro do sorvete, o que faz caldo de cana e o que vende leite com sua vaca pelas ruas. (EDMUNDO, 1957, v. 1, p. 55-58)

Os estrangeiros estão no comércio. Os ingleses, em geral, são atacadistas. Os nativos, com os franceses, dedicam-se às vendas a varejo. Esses 
últimos possuem lojas de tecidos, de moda e armarinhos. Há também comerciantes portugueses e espanhóis.

Nos tempos da colônia, o monopólio comercial da Metrópole determina um rígido controle da produção e da comercialização dos produtos. Esse quadro começa a mudar quando o Rio passa a ser a sede da Corte e a capital do Reino, a partir de 1808, com a abertura dos portos, a revogação da proibição de instalação de manufaturas no País, os acordos com a Inglaterra, a instalação da máquina burocrática portuguesa no Rio de Janeiro e, finalmente, com a autonomia política, que facilita a apropriação do espaço urbano pelo capital comercial. A cidade, então, beneficia-se da acumulação do excedente de capitais, investidos em funções urbanas, como os serviços portuários, os armazéns, os transportes e os equipamentos urbanos para atender ao seu crescimento, como representante do campo agroexportador.

A agricultura de exportação é a grande riqueza da província do Rio até meados do século XIX. O açúcar, que perde importância no âmbito nacional, continua forte na região. A cultura do café, que perde força no Rio, desloca-se, passo a passo, em direção a São Paulo, onde cresce o número de plantações, embora isso não afete a economia carioca. Segundo M. A. Leopoldi (1986, p. 64), o processo migratório do café para São Paulo acontece paralelamente ao florescimento econômico do Rio. 0 capital, antes investido no comércio de escravos, passa a ser aplicado em outros setores da economia que, direta ou indiretamente, incentivam o setor manufatureiro.

Até 1860 , o setor industrial tem uma importância pequena, caracterizando-se por uma dispersão regional, que atende às necessidades básicas da população local, nas áreas de alimentos, tecidos, guarda-chuvas, tabaco, sabão e velas. A proteção das tarifas, aliada à disponibilidade do capital que provém da agricultura, incentivam o crescimento industrial de tal maneira, que, entre os anos 1880 e 1895, ocorre a fase de maior desenvolvimento industrial. A cidade do Rio e seus arredores abrigam grandes estabelecimentos, principalmente os relacionados com a indústria têxtil. O porto mantém suas funções, e o setor financeiro estrutura-se a partir da metade do século XIX.

Quando a atividade industrial começou a se consolidar no Rio de Janeiro dos anos 1880, o cenário econômico, social e político estava em processo de mudança acelerada. 0 plantio do café na região fluminense declinava, e o porto do Rio começou a perder sua importância na exportação desse produto. Contudo, a despeito disso, a atividade portuária não decaiu. O Rio especializou-se na função de receptor e distribuidor de matéria-prima e maquinário para a indústria de artigos importados, consumidos na Capital e províncias vizinhas alcançadas pelas ferrovias. A praça do Rio ganhava também um novo perfil econômico e social. A Capital se firmava como o 
mais importante produtor de tecidos de algodão, superando a Bahia. O Rio de Janeiro era o centro financeiro mais importante, estando aí sediados os bancos estrangeiros e a única Bolsa de Valores do País. Constituía-se também num importante pólo comercial, envolvendo transações ligadas ao comércio local e inter-regional. Sendo a sede do Governo, tornava possível o contato entre os industriais e a burocracia governamental, sedimentando, desde o princípio da indústria carioca, a relação entre burguesia industrial e Estado. (LEOPOLDI, 1986, p. 56)

Em meados do ano de 1890, há sinais de uma recessão econômica e, em 1900, o Rio se vê afetado por uma séria crise financeira. O café tem uma superprodução e uma previsível baixa nos preços, causando um declínio nos investimentos da indústria, o que contribui para a desaceleração do crescimento, embora isso não seja suficiente para estancar o setor manufatureiro.

Em princípios do século XX, acaba a política de deflação, e a economia brasileira encontra-se em nova fase. 0 governo de Rodrigues Alves enfrenta a economia de recessão com um programa de obras públicas - o saneamento e a urbanização da Capital Federal, a melhoria dos portos e a construção de ferrovias. Para o Rio, isso significa dinamismo para a cidade e a saída da crise econômica.

\section{(Trans) formando a cidade}

\section{Configurando a cidade}

Após encerrar a ocupação francesa ${ }^{10}$ no Rio de Janeiro, os portugueses voltam-se para a expulsão dos índios Tamoios. Para conseguir a reconquista, fundam um núcleo urbano inicial em 1565, entre o Morro Cara de Cão e o Pão de Açúcar, ponto estratégico, com boa visibilidade da Baía de Guanabara. Quando os portugueses dominam totalmente o território, esse pequeno núcleo muda-se (1567) para o Morro de São Januário, mais tarde chamado Morro do Castelo, onde se instalam a Casa de Câmara e Cadeia, os armazéns da Fazenda Real, a igreja dos Jesuítas e a Catedral e onde também os habitantes constroem suas casas. A população está muito bem protegida por baluartes cheios de artilharias, pois o Rio é uma importante base naval no período colonial, além de porto da área de canaviais em volta da baía.

Se Salvador foi a Fortaleza Forte de que fala o Regimento de Tomé de Souza, o Rio foi o Castelo, de proteção da costa sul, ambos referidos nos documentos 
como praças fortes, o que equivale a dizer: com planos urbanísticos subordinados aos militares. (SANTOS, 1981, p. 17)

O local onde se instala a população não é apropriado, mas tem boas condições de defesa. Ali a cidade está rodeada por uma planície pantanosa, entre o maciço costeiro e o mar. A primeira ladeira dá acesso ao porto, mas é muito íngreme, e isso dificulta o transporte de materiais para cima. Logo se define uma outra ladeira, mais suave, e depois mais duas. Pouco a pouco, a cidade estende-se pelas encostas do morro em direção à planície. Os habitantes logo descem em direção ao mar, construindo suas casas sem nenhuma ordem e criando o primeiro caminho, o Caminho da Praia. São realizados aterros, cobrem-se as lagoas e dragam-se os pântanos.

Foi a princípio lento o crescimento da cidade mas, paulatinamente, venceu o colonizador árdua luta contra o brejo na pequena planície que medeia entre os morros do Castelo, de São Bento, de Santo Antônio e da Conceição. Ampliando-se o espaço urbano para oeste a partir da praia de Manuel de Brito; uma a uma foram sendo dessecadas as lagoas e aterrados os brejos, com esse fim tendo sido abertas valas de drenagem ou desmontadas as abas dos morros. (BERNARDES, 1990, p. 82)

A rua da praia segue reta à beira do mar, até o Morro de São Bento, onde se instala o mosteiro dos beneditinos. Dois morros, o da Conceição e o de Santo Antônio, formam os outros vértices que fecham o quadrilátero por onde se espalha a população. Se o traçado das ruas do Castelo é irregular, como nas cidades medievais portuguesas, embaixo, na planície, propõe-se uma demarcação, um alinhamento, uma regularidade que reflete as ideias do renascimento. As ruas desenham-se paralelas e perpendiculares ao mar, produzindo uma quadrícula irregular, que se compõe de lotes com frente estreita e compridos na longitude. Nesses lotes, são edificados sobrados e casas térreas, lado a lado, formando quarteirões não muito grandes. Nos sobrados, comércio e residência confundem-se numa mesma edificação.

Em direção ao oeste, o limite é o brejo de São Diogo. Em direção ao sul, a população chega até a lagoa do Boqueirão. Em princípios do século XVIII, a população cresce, e a cidade passa por uma nova expansão. Lentamente, aterram-se as lagoas e os pântanos, e criam-se áreas para a expansão urbana.

As lutas entre portugueses e espanhóis intensificam-se no Rio da Prata em meados do século XVIII. O Rio está mais perto da Colônia de Sacramento, a base brasileira no Prata, além de ser o porto mais próximo das recém-descobertas "minas gerais", no centro do País, o que representa uma melhoria na circulação do produto. Essas duas razões levam o Primeiro Ministro de 
${ }^{11}$ Nessa época, Portugal tem como Primeiro-Ministro Sebastião José de Carvalho e Melo, o Marquês de Pombal (1750-1777), responsável pela reconstrução de Lisboa depois do terremoto de 1755 , quando se adota, como forma do despotismo ilustrado, a projeção da imagem do poder no território e na cidade capital. 0 projeto da Baixa, uma solução racionalista, ilustrada e funcional, compõe-se de uma estrutura de eixos hierarquizados entre duas praças: a do Comércio, espaço simbólico do poder, e a do Rocio, mais popular, que se articula com o novo Passeio Público, um jardim fechado. (CALADO; LOBO; FERREIRA, 1994, v. 1, p. 100)

${ }^{12}$ Cada vez mais, deslocam-se para o sul, Botafogo e depois Copacabana, e para o norte, Tijuca e São Cristóvão.
Portugal, o Marquês de Pombal, ${ }^{11}$ a transferir a capital de Salvador para o Rio, em 1763. O Rio, nessa época, amplia extraordinariamente seu espaço urbano.

Durante o século XVIII: aterram-se pântanos, constroem-se pontes; proíbe-se (Correição da Câmara de 1735) que se atirem imundices na vala e obrigam-se que se desfaçam os monturos e se joguem as sujidades nas lagoas vizinhas; [...] cobre-se com lajões de pedra a Vala (Uruguaiana). [...] constrói-se na Praça do Carmo um cais de cantaria aparelhada com imponentes escadas e rampa de embarque e torneiras de bronze para aguada das embarcações [...] desmonta-se o Morro das Mangueiras, aterra-se a pestífera Lagoa do Boqueirão; abrem-se as ruas do Passeio e das Belas Noites (Marrecas); e, sob inspiração do Passeio Público projetado para Lisboa [...], constrói-se com aquele mesmo nome um jardim arborizado [...]. (SANTOS, 1981, p. 39)

O século XIX começa com a chegada da família real no Brasil, o que determina uma série de transformações na área central do Rio. As ruas continuam estreitas, mas as construções melhoram, são mais fortes e melhor edificadas. O quadrilátero central (Fig. 4) ainda mantém, em sua estrutura e em sua paisagem, o caráter colonial. A esse espaço se chama de Cidade Velha. No entanto, a área urbana prolonga-se em direção ao norte, para a Cidade Nova, até chegar a São Cristóvão e, para o sul, até Botafogo. As quintas e as fazendas dividem-se em lotes menores. Nos bairros, que se entranham pelos vales esculpidos no maciço do litoral, as construções têm mais área e jardins. 0 espaço urbano desenvolve-se ao longo de uma rua principal e outras transversais, que sobem pela floresta e pela montanha.

A Cidade Nova, continuação da Cidade Velha, mantém quase a mesma estrutura de divisão de lotes. Os novos bairros do século XIX, como Botafogo ou São Cristóvão, caracterizam-se por uma irregularidade, tanto na forma como no tamanho dos lotes e dos quarteirões. Ali a diversidade é constante. Ao passear por esses locais, podem-se encontrar amplas mansões com jardins em volta, ao lado de pequenas edificações, construídas em lotes simples e estreitos. Bem próximo pode haver um comércio, pequenas lojas ou estabelecimentos de serviços. Também se encontram moradias pobres e mesmo vilas operárias.

No núcleo central, a região perto do Paço Real, sede do governo e dos órgãos mais importantes do Reino, é o lugar preferido para residência das classes dirigentes, que ocupam sobrados nas ruas estreitas. Nas outras áreas, amontoam-se os demais grupos sociais.

No final da primeira metade do século XIX, a área urbana muda. O poder público abre e conserva caminhos para os arrabaldes, ${ }^{12}$ na mesma direção para onde se desloca a classe média - funcionários públicos, alguns profissionais liberais e uma minoria de comerciantes portugueses e brasilei- 


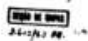

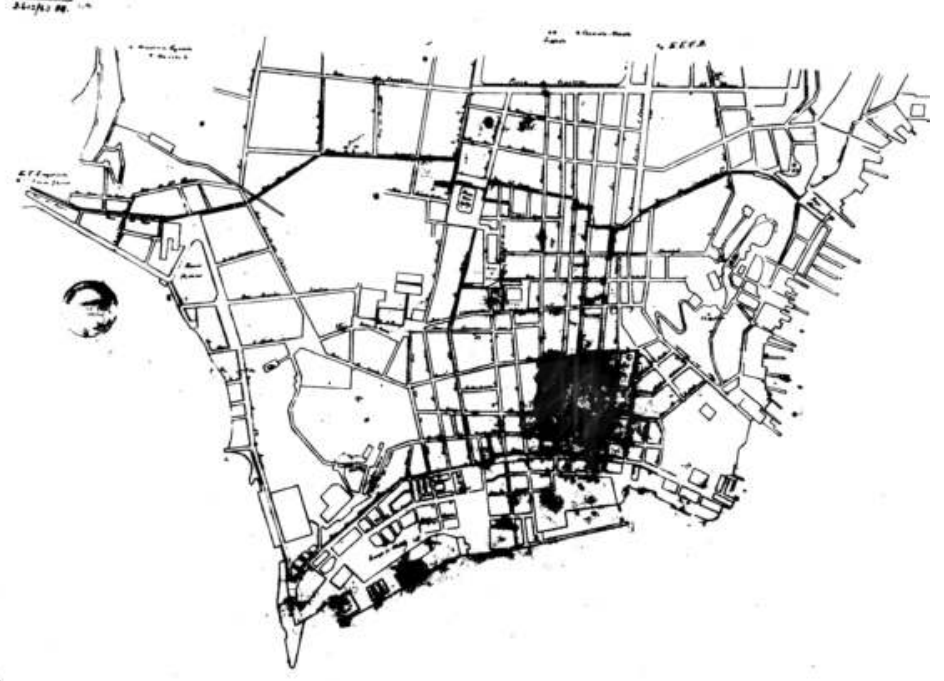

[i]

4. Plano do Rio de Janeiro no início do século XIX

ros - e a alta, enquanto a população de baixa renda se amontoa no Centro, perto do trabalho. Depois de 1850, ocorre um novo e importante período de expansão, não só pela anexação de novas áreas à capital como também pelo crescimento da população nas periferias.

Esse acelerado crescimento da malha urbana acarreta problemas relativos às distâncias. 0 caminhar e os transportes puxados por animais deixam de ser os meios de deslocamento mais adequados, e tem início a necessária implantação dos meios mecânicos: os bondes ${ }^{13}$ e os trens. Os que têm poder aquisitivo para utilizar os meios de transporte emergentes mudam-se para os novos bairros, longe do Centro, mais salubres e agradáveis. Nessa situação, encontram-se a classe rica e a média. Os que não têm acesso a esse serviço permanecem no Centro, que, pouco a pouco, vai se degradando.

A implantação dos novos meios de transporte no Rio revela-se importante por contribuir para as mudanças que acontecem em sua estruturação social e funcional, essa última expressa através da divisão da cidade em bairros residenciais e Centro, ficando o local de trabalho distante das residências. Se os bondes são associados a um modo de vida moderno nas áreas junto ao mar, os trens são associados aos subúrbios. 0 tipo de transporte está tão associado ao modo de vida ou a determinadas áreas, que não se permite a abertura de uma linha de trens para zonas nobres da cidade,
${ }^{13}$ São chamados bondes devido ao uso de bilhetes, usados para facilitar o acesso, bonds (bônus). 
${ }^{14}$ O Túnel Velho, hoje Alaor Prata, é aberto em 1892 e o Túnel Novo, ou do Leme, em 1904.

${ }^{15}$ Desde o século XVII, o Rio de Janeiro passa por sucessivos aterros de alagadiços, charcos e lagoas, conquistando áreas de expansão urbana. Os aterros na Baía de Guanabara iniciam-se em meados do século XIX. (BARREIROS, 1965)

${ }^{16}$ Vários morros foram desmontados no centro do Rio de Janeiro: Morro das Mangueiras, final do século XVIII; Morro do Senado, início do século

XX; e Morro do Castelo, em 1922.

O desmonte do Morro do Castelo é tema de item específico deste estudo, tratado adiante. apesar da existência de bairros operários nas proximidades da Lagoa Rodrigo de Freitas. A presença dos trens é fator de desvalorização dos terrenos.

A ocupação do litoral que margeia o Oceano Atlântico é feita com dificuldades, já que as rochas e as montanhas se interpõem no caminho. São abertos túneis, ${ }^{14}$ vencendo barreiras, conquistando planícies e praias, onde as ruas se multiplicam. Também se contornam os sopés do interior do maciço costeiro no sentido norte, o que impulsiona o crescimento dos subúrbios.

São agregados novos pedaços de terra para a população, não só pelo aterro de lagoas e alagadiços, mas também pela conquista da baía através de aterros sucessivos. ${ }^{15}$ No Centro, os contínuos aterros refazem o alinhamento da costa, o que permite a construção de um novo cais e de um mercado. O mesmo ocorre em todo o litoral da Baía de Guanabara, que se estende da Glória até Botafogo, assim como na Lagoa Rodrigo de Freitas, facilitando a circulação e criando áreas para a implantação de novos quarteirões. No lado do interior da baía, conquistam-se importantes áreas para a construção de um novo porto, à custa do aterro de muitas praias e enseadas. 0 desmonte de morros no Centro ${ }^{16}$ contribui, com suas terras, para facilitar os aterros que abrem espaços para novas divisões em lotes e novas ruas.

O processo de conquista de novas áreas para o espaço urbano não se orienta por um plano preconcebido. 0 traçado viário é o resultado da adaptação do urbano ao lugar.

Como no caso da maioria das cidades brasileiras, nenhum plano preconcebido orientou essa expansão que se fez ao sabor das circunstâncias do momento, resultando o traçado, no mais das vezes, da adaptação às injunções dos sítios difíceis. (BERNARDES, 1990, p. 86)

No cume dos morros, predomina o traçado sinuoso e labiríntico, muito característico das acrópoles do mundo mediterrâneo. Nos vales e planícies, há uma grande variedade de traçados, que dependem do terreno, de sua topografia e dos processos de crescimento. Nos vales, os velhos caminhos existentes dão origem à rua principal, normalmente sinuosa, no sopé dos morros, evitando-se, pelo perigo de inundações, o fundo do vale, em torno da qual se edifica o povoado. Os traçados regulares e projetados com antecedência são poucos, normalmente da iniciativa privada. Só em alguns bairros, como Vila Isabel e Lagoa, depois Ipanema e Leblon já no século XX, podemos identificar lotes mais amplos, com um caráter mais uniforme.

Na maior parte da cidade, portanto, refletindo o modo pelo qual se processou o crescimento urbano, pode-se reconhecer a dominância de um traçado quase espontâneo que, de certo modo, respeitou as imposições do meio 
e, mesmo nas planícies, desconheceu planos ou normas preconcebidas.

(BERNARDES, 1990, p. 86)

Ao longo do século XIX, a cidade se amplia. Surgem novos bairros e incorporam-se novos vales e planícies à área urbana. Enquanto isso, o Centro mantém suas antigas funções e sua imagem colonial. As primeiras transformações são produzidas depois de 1850, com a intervenção do Estado e a inversão do capital estrangeiro, que obtém concessões do Governo Imperial como provedor de serviços públicos.

\section{Equipando a cidade}

A primeira tentativa de abastecer a população do Rio com as águas do Rio Carioca acontece em 1673, mas o serviço é precário. A administração de Aires Saldanha (1719-1725) constrói o aqueduto entre dois dos vários morros do Rio, o Morro de Santa Teresa e o Morro de Santo Antônio, para a condução das águas do Rio Carioca até uma fonte no Largo da Carioca, ${ }^{17}$ no centro da cidade. Parte desse aqueduto, conhecido como Arcos da Lapa, é um símbolo da cidade, segundo um testemunho de Ferdinand Denis ([184-] apud CRULS, 1949, v. 1, p. 145) a respeito.

Cada capital na Europa tem qualquer monumento célebre, um edifício preferido, sua grande construção local que imprime a tôda a cidade um caráter peculiar de aspecto. No Rio é o aqueduto da Carioca, com suas ordens de arcadas, sua aparência de construção romana, sua forma ao mesmo tempo elegante e grandiosa, que de todos os lados a vista procura e gostamos de encontrar.

O sistema de abastecimento de água feito por escravos, que recolhem o líquido na nascente dos rios, em recipientes de barro, para vendê-lo na cidade, muda depois da instalação das fontes no Centro. O serviço passa a ser feito pelos chamados "aguadeiros", geralmente portugueses. Em 1840, uma empresa explora os serviços de abastecimento de água com a utilização de carros.

A modernização do sistema de abastecimento de água começa com a instalação de uma rede de canos de ferro e peças hidráulicas, importadas da Inglaterra depois da extinção do tráfico negreiro em 1850. É o início da comercialização da água, que beneficia primeiro as áreas ocupadas do Centro, cuja população tem maior poder aquisitivo, e, logo depois, os bairros, enquanto os pobres continuam se abastecendo nas fontes e chafarizes das ruas. Engenheiros do governo elaboram um projeto ${ }^{18}$ para a rede de distribuição a cargo da administração pública, mas, para a execução das obras necessárias, contrata-se a iniciativa privada.
${ }^{17}$ O chafariz da Carioca, inaugurado em 1725, tem 16 saídas de água. Outros chafarizes são abastecidos com a água proveniente do mesmo rio: o das Marrecas, o que se encontra no Largo do Paço e o chamado Moura. (GRAHAM, 1956, p. 184) 0 aqueduto da Carioca compõe-se de uma dupla fileira de arcos, com $64 \mathrm{~m}$ de altura e $270 \mathrm{~m}$ de comprimento. (CRULS, 1949, v. 1, p. 144)

18 Projeto elaborado por Jerônimo Rodrigues de Morais Jardim e Luís Francisco Monteiro de Barros, da Inspetoria Geral de Obras Públicas da Corte, e implantado pelo empreiteiro Antonio Gabrielli, em 1876. (BENCHIMOL, 1992, p. 70) 
${ }^{19}$ Segundo Benchimol (1992, p. 73), alguns autores afirmam que o Rio foi a terceira cidade, depois de Londres e Paris, a implantar os serviços de esgoto. Para outros, as primeiras cidades, antes do Rio, foram Hamburgo e as maiores cidades da Inglaterra. Em 1866, três distritos do Centro do Rio - Glória, São Bento e Gamboa - já estão conectados à rede de esgoto. Em 1890, mais de $60 \%$ das residências possuem esse serviço.
O suprimento d'água deverá ser obrigatório em todas as casas de habitação e edifícios de qualquer natureza, existentes na cidade e seus arrabaldes [...] Os jardins e hortas de certas dimensões, os hoteis, colégios, casas de banho, cocheiras, fábricas, estabelecimentos públicos etc. serão supridos d'água por meio de medidores. (FREITAS; MACEDO, 1874 apud BENCHIMOL, 1992, p. 69-70)

O novo conjunto é inaugurado em 1880, ano em que se celebra o início de uma nova etapa para a vida e a salubridade da cidade. Sem dúvida, alguns não se beneficiam do serviço, como os habitantes dos cortiços.

Os primeiros lampiões a gás são instalados no Centro a partir de 1854 , em substituição aos antigos, à base de óleo de peixe. Para o abastecimento de gás carbônico, produzido a partir do carvão, é construído o gasômetro em 1860. Pouco a pouco, esse novo tipo de iluminação chega até as residências e aos bairros mais afastados do Centro. Em alguns pontos da cidade, os lampiões a gás são usados até 1905.

A eletricidade começa a ser utilizada em 1882, com os primeiros experimentos na iluminação do Palácio da Exposição da Indústria Nacional. Depois, em 1883, no Largo do Machado e, em 1885, na Biblioteca Nacional, com motor próprio. Em 1891, substituem-se os lampiões a gás do Centro pelas primeiras lâmpadas elétricas. Os transportes também se beneficiam do novo sistema e os animais são substituídos pela força eletromotriz. A primeira linha de bondes elétricos é inaugurada entre o Centro e o Largo do Machado, em 1892.

A cidade do Rio chega à metade do século XIX sem um sistema de esgoto, já que os escravos são os responsáveis por recolher os dejetos em barricas para jogá-los em fossos e praias. Os primeiros movimentos de médicos e higienistas reivindicando as necessárias medidas para solucionar esse problema, apoiados pela opinião pública, surgem somente depois da primeira grande epidemia de febre amarela em 1849-1850.

O Coronel João Frederico Russel, titular da concessão para a implantação do sistema de esgoto no Rio, obtida em 1862, vende tal concessão a um grupo de capitalistas ingleses da Rio de Janeiro City Improvements. Segundo Benchimol (1992, p. 73), esses serviços são concedidos, sem questionamentos, à citada companhia em 1862 e, em 1864, já funcionam os primeiros segmentos da rede domiciliar.

Dessa forma, o Rio se torna uma das primeiras cidades do mundo a beneficiar-se desses serviços. ${ }^{19} \mathrm{Em}$ finais do século XIX, quase toda a área urbana está conectada à rede de esgoto. Entretanto, os serviços prestados não são satisfatórios, e são muitas as críticas, especialmente as que se referem ao 
problema da contaminação do subsolo e ao fato de ser a Baía de Guanabara usada como uma grande cloaca. 0 critério de definição das áreas prioritárias contribui para acentuar as diferenças entre os espaços urbanos.

Outros serviços são introduzidos na cidade, equipando-a com novas tecnologias surgidas nos últimos tempos. Em 1846, organiza-se o serviço postal em bases modernas, com um serviço de entrega em domicílio, que começa a funcionar a partir de 1852. O telégrafo chega no mesmo ano, com uma linha entre o Paço de São Cristóvão, onde vive o Imperador e sua família, e o Quartel Geral, ligando o Rio de Janeiro à Bahia, Pernambuco, Pará, e à Europa. Em 1854, são pavimentadas muitas ruas centrais. Os telefones começam a funcionar em 1877, nos serviços públicos situados no Centro. Em 1881, a Companhia Telefônica Brasileira e a Telegráfica Urbana principiam a instalação de suas linhas no comércio e nas residências.

São beneficiados outros locais que proporcionam à cidade novos espaços agradáveis para o lazer e o descanso. Desde o século XVIII, o Passeio Público, ${ }^{20}$ à beira da Baía de Guanabara, é um dos espaços para passear e passar horas de ócio, com sua forma trapezoidal e seu terraço voltado para a entrada da baía. Em 1808, por iniciativa do Príncipe Regente D. João VI, inaugura-se o Jardim Botânico para o cultivo de espécies de plantas exóticas, com uma alameda ladeada de palmeiras, assim descrita por Moustier (1885, p. 10), em 1879:

Por fim nos vimos diante da legendária alameda de palmeiras que conduz ao Jardim Botânico; é difícil de imaginar uma entrada mais majestosa: as árvores erguem-se de cada lado da via, como gigantescas colunas, depois desabrocham em leques que se juntam às hastes a 40 pés acima de nossas cabeças. Uma simplicidade grandiosa e uma profundidade misteriosa de um templo hindu, mas um templo de proporções, e ao mesmo tempo tão vasto e tão harmonioso que nenhum arquiteto certamente saberia construir um semelhante. $\mathrm{O}$ jardim oferece espécies de toda a flora dos países tropicais [...].

O Campo de Santana, ou Praça da Aclamação, um dos espaços públicos mais antigos da cidade, sofre transformações com a implantação de um jardim de tipo inglês, com veredas, grutas, pontes e riachos, elaborado por Auguste Glaziou e inaugurado em 1880.

\section{Movendo-se pela cidade}

Caminhar é o principal e mais comum meio de transporte até finais do século XVIII. Os mais abastados possuem escravos que os transportam de um lado para outro em cadeirinhas de arruar, palanquins, serpentinas e liteiras.
20 Inaugurado em 1783, sofre modificaçōes em torno de 1862 , com um projeto feito por Auguste Glaziou, paisagista francês, baseado no traçado do parque Des Buthes Chaumont de Paris. 
${ }^{21}$ Os automóveis só fazem parte da paisagem carioca depois de 1904 , quando 12 carros começam a circular por suas ruas.
Os veículos puxados por animais surgem aos poucos, a partir de finais do século XVIII: primeiro a traquitana, com duas rodas, e, logo depois, a sege, com quatro rodas. Comenta Gobineau (1936, p. 136), em 1870, “[...] que a cidade do Rio é uma cidade única no mundo. Imensa, precisa de mais de uma hora para ir de uma ponta à outra com excelentes cavalos [...]."

O século XIX é marcado por um grande desenvolvimento dos meios de transporte. Graças, em grande parte, a eles, a malha urbana expande-se, amplia-se, a população desloca-se mais rápido, conhece outros locais e pode residir longe de seu trabalho: as áreas nobres servidas pelos bondes e os subúrbio, pelos trens.

Os meios de transporte modernos, implantados pela iniciativa do poder público, transformam a cena urbana a partir de 1850. No final do Império e princípio da República, fala-se da "revolução dos transportes", pela introdução dos primeiros trens e das linhas de bonde, que ampliam e dividem a cidade, mudando decisivamente a distribuição da população e determinando áreas urbanas socialmente distintas. ${ }^{21}$

Os transportes marítimos, na Baía de Guanabara, são igualmente importantes na nova estruturação da cidade. A partir de 1834, cria-se uma empresa para fazer a travessia entre o Rio e Niterói, em barcos a vapor, além de outras linhas com destino a diferentes pontos da baía, como Saco do Alferes e Botafogo. A maior expansão desses serviços dá-se na década de 60 do século XIX, com a obtenção e a venda de concessões, a fusão de empresas, a tendência ao monopólio, e a presença da combinação dos capitais nacional e estrangeiro. (SILVA, 1992, p. 55) Muitas empresas obtêm a concessão para o serviço, mas a Cia. Cantareira e a Viação Fluminense dominam o mercado até meados do século XX, graças à fusão com outras empresas e à eliminação da concorrência.

Em 1862, inaugura-se o sistema de barcos a vapor, tipo ferry, como os utilizados nos Estados Unidos, cuja concessão pertence a Thomas Ragney e a W. F. Jones. São realizadas remodelações nos cais e outras obras necessárias para o início da circulação dos novos barcos.

As comunicações marítimas são superadas pelo desenvolvimento dos outros meios de transporte. A navegação para Botafogo se encerra, por força do progresso das linhas de bonde da Botanical Garden. O restante dos roteiros dos barcos, dentro da baía, acabam por desaparecer, com a implantação dos trens da Companhia Estrada de Ferro do Norte, da Melhoramentos e, inclusive, da Rio d'Ouro. Só se mantêm os serviços para Niterói e para Paquetá, uma ilha dentro da baía. 
Em 1868, começam a funcionar as primeiras linhas de bondes puxados por burros, da companhia norte-americana Botanical Garden Railroad Company, que cobrem os bairros das chamadas Zona Norte e Zona Sul. ${ }^{22}$ Animadas pelo sucesso dessa companhia, outras obtêm a concessão para prover, com esse serviço, outros pontos da cidade. É um meio de transporte que facilita o deslocamento, promove a ocupação dos bairros mais afastados e passa a ser considerado responsável pela renovação dos costumes. Muitas residências de fim de semana tornam-se as moradias principais de uma parte da população, que deixa de residir no Centro.

A acumulação de capital nacional e estrangeiro condiciona as decisões referentes ao caminho por onde devem passar os trilhos. O capital nacional, em grande parte oriundo do lucro da aristocracia do café, de comerciantes e de financistas, é investido, cada vez mais, em propriedades localizadas em áreas servidas pelos bondes. 0 capital estrangeiro multiplica-se, ao controlar as decisões sobre as áreas que devem ser contempladas com os serviços de bonde e de infraestrutura urbana em geral. Os dois, muitas vezes, vão juntos, valorizando áreas e criando novos bairros. Moustier (1885, p. 9) descreve em 1879:

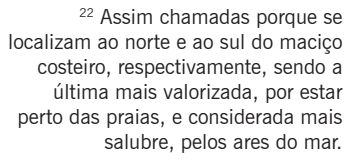

localizam ao norte e ao sul do maciço costeiro, respectivamente, sendo a última mais valorizada, por estar salubre, pelos ares do mar.

\begin{abstract}
Mas é necessário sair da cidade para apreciar este país privilegiado, e nada
é mais fácil, pois os arredores do Rio, assim como a cidade, ela mesma, são sulcados por bondes, descobertos a maior parte, e parecidos com os carros com bancos. Nada mais belo do que a rota que se dirige para o Jardim Botânico: é a rota da Corniche ou a de Castellamare, elevada à enésima potência. Nós vemos desfilar sob nossos olhos uma série de vivendas afogadas dentro da mata e das flores [...].
\end{abstract}

Como exemplos da criação de bairros em função da implantação dos trilhos do bonde, temos Copacabana na Zona Sul e Vila Isabel na Zona Norte. Em meados do século XIX, Copacabana é somente um balneário afastado, com poucas construções de boa qualidade e alguns casebres. Com a abertura do Túnel Velho, em 1892, faz-se a conexão entre Copacabana e a área urbana já consolidada. Com o propósito de "preparar" a área, implanta-se a infraestrutura urbana, para, posteriormente, venderem-se os terrenos, o que se revela uma ação de sucesso.

O caso de Vila Isabel não é muito diferente do de Copacabana. Quando, em 1872, foi concedida a permissão para implantar-se uma linha em direção a essa área, antiga parte de uma fazenda imperial, uma companhia do mesmo proprietário da concessão da linha prepara o terreno, com a divisão da área em lotes e ruas amplas, dentre as quais se destaca a Vinte e Oito de Setembro, um boulevard, que segue o exemplo das cidades europeias. 
${ }^{23}$ Os autores denominam de acumulação urbana a forma de acumulação que utiliza a cidade como matéria-prima de valorização do capital. Como exemplo, citam a forma como os capitalistas de serviços de infraestrutura organizam e distribuem seus serviços na cidade, valorizando ou desvalorizando determinadas áreas. Os trilhos dos bondes chegam a Ipanema em 1901 (já havia ali rede de esgoto, iluminação elétrica etc.), quando a área ainda está quase desabitada, enquanto o subúrbio de Inhaúma, com 3,5\% da população, em 1890, não dispõe dos mesmos serviços.
Diferentemente dos bondes, que seguem em direção às áreas onde já se processa a urbanização, as linhas de trem orientam-se para zonas ainda rurais, convertendo-se em responsáveis pela sua rápida transformação. 0 primeiro trecho da Estrada de Ferro Dom Pedro II é inaugurado em 1858 e, em 1861, já existem sete estações ao longo desse trecho. Em 1883, inaugura-se outra linha de trem, a Estrada de Ferro Rio d'Ouro, com a finalidade de transportar material para as obras da nova rede de abastecimento de água da cidade. Em 1884, constrói-se a Estrada de Ferro Corcovado e, em 1886, a Estrada do Norte, hoje chamada Leopoldina.

O trem contribui para o desenvolvimento dos núcleos rurais por onde passa e transforma-os em pequenos povoados. Alguns são pontos isolados de população rural, e outros, como Cascadura e Engenho Novo, são áreas que mantêm relações constantes com o Centro. A distância entre as estações e 0 Centro, não em extensão, mas em tempo de percurso, muda, inaugurando a relação entre o núcleo central e os subúrbios, o que aumenta o movimento de pessoas, incrementando a demanda e, consequentemente, o número de trens destinado a esses lugares.

Em 1870, por sua vez, a linha de Cascadura passou a ser servida por mais dois trens diários, inaugurando-se de fato o sistema suburbano de transporte, já que os horários dos trens passaram então a ser mais adequados às horas de entrada e saída dos locais de emprego do centro da cidade. (ABREU, 1988 , p. 50)

Como complemento às áreas servidas pelos trens, aparecem as indústrias, que atraem uma grande quantidade de operários e uma população de baixa renda.

A segunda metade do século XIX assiste à introdução dos novos serviços públicos e das novas tecnologias. A infraestrutura instala-se no espaço urbano, de acordo com o poder de influência da população. Até meados do século XIX, a infraestrutura existente está concentrada no centro da cidade, já que a periferia ainda é uma área rural. No último terço do século XIX, a infraestrutura expande-se e sai do núcleo central. Essa expansão não decorre da aplicação de critérios como quantidade de habitantes ou área ocupada, porém vincula-se a outras prioridades, como a especulação imobiliária, e a outros interesses dos governantes, ou das empresas responsáveis por sua implantação. Esses grupos privilegiam as áreas nobres da cidade com a implantação dos bondes, da iluminação, da rede de esgoto e do abastecimento de água, criando novos espaços mais valorizados. (SOLIS; RIBEIRO, 1985, p. 48-50)23 


\section{Alguns projetos para a cidade}

\section{Medicando a cidade}

Apesar dos serviços de abastecimento de água e da rede de esgotos, introduzidos na área urbana, a cidade mantém-se insalubre e suja. É foco de epidemias como o cólera, a malária, a febre amarela e a varíola. ${ }^{24} \mathrm{O}$ lixo é jogado nas ruas, e as praias são imundas. Em 1847, o serviço de limpeza urbana está a cargo da empresa do Sr. Júlio Gary, cujas funções são o recoIhimento do lixo doméstico, mediante o pagamento de uma taxa, e a limpeza dos espaços públicos da cidade. Mas o serviço é realizado de maneira irregular e imperfeita.

O problema das epidemias preocupa aos governantes desde o tempo da colônia. Em função de uma forte epidemia de febre amarela nos anos de 1849 e 1850 e da morte de centenas de pessoas, a Assembleia Geral reconhece a necessidade de intervir no estado de salubridade da capital do Império.

Dessa forma, uma Comissão de Engenheiros assume a missão de realizar as melhorias urbanas indispensáveis ao saneamento da cidade, e uma Junta de Higiene Pública responsabiliza-se por propor e executar as medidas necessárias à preservação da saúde pública na Corte. Em 1886, a Junta divide-se em Inspeção Geral de Higiene e Inspeção Geral de Saúde dos Portos. Introduz-se um novo tipo de medicina, a Medicina Social, que observa, inventaria e analisa o espaço, numa busca preventiva, para localizar o perigo e preservar a saúde dos habitantes da cidade.

Ao responsabilizar a desordem urbana pela degeneração da saúde não só física como 'moral' da população, a medicina social diagnosticava causas naturais, relacionadas às peculiaridades geográficas do Rio de Janeiro, e, sobretudo, causas sociais, tanto no nível do funcionamento geral da cidade como de suas instituições. (BENCHIMOL, 1992, p. 116)

A Medicina Social afirma que a geografia da cidade se constitui num dos fatores determinantes para a insalubridade urbana, pois considera que a localização numa planície baixa e pantanosa, quente e úmida, rodeada pelo mar e por montanhas, favorece o surgimento de enfermidades. Os pântanos são focos de exalação de miasmas, e os morros impedem a circulação de ventos purificadores. Por isso, os médicos defendem o aterro dos pântanos e o desmonte dos morros.

Causas sociais também são apontadas pela Medicina Social para a insalubridade urbana. Nesse âmbito, dirige suas críticas para as habitações, mais especificamente as coletivas, onde se amontoa a população pobre na área

\footnotetext{
${ }^{24}$ A primeira grande epidemia de febre amarela acontece entre 1849 e 1850. As outras sucedem-se, com anos de maior intensidade e outros de menor. Os anos epidêmicos são: 1891, 1892, 1894 e 1896 (febre amarela) e 1887. 1891, 1904 e 1908 (varíola). Mas é a tuberculose a principal causa de mortalidade no Rio entre 1860-1909. (BODSTEIN, 1986, p. 37)
} 
central da cidade. Os proprietários não respeitam as normas de construção relativas à higiene, especulando com a vida humana, ao alugar habitações sem condições de salubridade, pequenas, úmidas, sem ar e sem luz.

Esses argumentos fundamentam a tese da necessidade de remodelação da cidade, o que constitui também interesse de especuladores, mais interessados em seus lucros do que na saúde pública. 0 urbano precisa, pois, de uma intervenção cirúrgica, para a implantação de um plano geral de funcionamento e desenvolvimento. Nesse sentido, são formuladas as seguintes propostas: expansão urbana para bairros mais salubres, com o intuito de descongestionar o Centro; imposição de normas para a construção de casas higiênicas; alargamento e abertura de ruas e praças; arborização; instalação de rede de esgoto e água; manutenção do asseio nos mercados e matadouros; criação de locais próprios para a deposição dos dejetos, entre outras.

[...] [o discurso] infiltrou-se no senso comum das camadas dominantes e das camadas médias, culturalmente subalternas, que nos anos setenta já constituíam uma influente 'opinião pública', favorável a todo tipo de melhoramento que transformasse a capital do Império numa metrópole salubre e moderna. (BENCHIMOL, 1992, p. 118)

Esse discurso fundamenta as argumentações de engenheiros, políticos, governantes, jornalistas e capitalistas até o início do século XX.

\section{Projetando uma nova cidade}

Herdeiro de um espaço urbano confuso, o Rio é o reflexo de como os portugueses colonizaram o Novo Mundo. No início da colonização, predomina o interesse de exploração comercial, de tirar proveito da colônia, considerada apenas um local de passagem. Mesmo tendo um primeiro núcleo planejado, algumas das primeiras vilas e cidades brasileiras crescem de forma desordenada e sem planejamento. Isso pode ser percebido na desordem das ruas e das casas e nos elementos urbanos dispostos ao acaso. Nesses casos, os portugueses guiam-se mais pela rotina do que pela razão, estabelecendo planos sem nenhuma coordenação, sem seguir nenhum projeto predeterminado e são expressas pelas palavras de Holanda (1995, p. 110), nos anos 30 do século XX.

A cidade que os portugueses construíram na América não é produto mental, não chega a contradizer o quadro da natureza, e sua silhueta se enlaça na linha da paisagem. Nenhum rigor, nenhum método, nenhuma previdência, sempre esse significativo abandono que exprime a palavra 'desleixo' [...]. 
Com essa urbanística "desleixada", ${ }^{25}$ a cidade adquire um aspecto de sujeira e de desordem labiríntica. Na primeira metade do século XIX, os projetos destinam-se a solucionar problemas de salubridade, decorrentes, em primeiro lugar, da geografia da área e, depois, da situação do espaço construído. São projetos pontuais, que nem sempre se executam, geralmente realizados para controlar a natureza, como o aterro dos pântanos e das lagoas, as drenagens, os desmontes dos morros e o nivelamento do solo para melhor escoamento da água da chuva. A técnica serve para dominar a natureza, já que se acredita que os problemas de insalubridade se originam dos miasmas emanados do solo, principalmente dos terrenos alagados e encharcados.

As reflexões sobre o espaço construído e as intervenções do Estado, em âmbito urbano, durante esse período, guiam-se por dois eixos antagônicos, mas com pontos em comum. Um propõe tratar o espaço urbano como um monumento, através da sua "imutabilidade". O outro propõe sua transformação através do dinamismo, da noção de progresso e de circulação. ${ }^{26}$ Sem dúvida, os dois contêm uma crítica aos valores da sociedade colonial e um novo projeto social e urbano. A procura de uma "identidade nacional" condena a cidade herdada a buscar um modelo distinto do modelo colonial, um modelo próprio, embora baseado nos valores da sociedade europeia.

Exemplos de intervenção no espaço construído, em princípios do século XIX, são os projetos apresentados pelo francês Grandjean de Montigny, ${ }^{27}$ entre os anos 1825 e 1827, para o Largo do Paço e o Campo de Sant'Ana. Ele utiliza a noção de conjunto, propõe a abertura de ruas e preocupa-se com a salubridade e a circulação dentro da Cidade Velha, com uma proposta de articulação entre o núcleo central e as novas áreas de expansão, embora seu plano seja basicamente de reforma do Centro.

No Largo do Paço, o projeto, provavelmente de 1825, consiste na construção de um Palácio Imperial, que se abre para uma grande praça e para o mar, e na abertura de uma nova avenida, até uma interseção em semicírculo, que se conecta com as ruas dos quarteirões centrais e prolonga-se até a Praça do Rossio, no coração da cidade.

Em outro projeto, apresentado em 1827, Grandjean propõe a redução das dimensões do Campo de Sant'Ana, nessa época chamado de Praça da Aclamação, projetando uma nova praça inscrita na antiga, com uma rua entre elas "[...] com quatro entradas principais para a praça e, limitada no perímetro interno, por um correr de edifícios, de 15 braças de profundidade, circundados, do lado da praça, por pórticos, destinados a passeio do povo e ao comércio." (SANTOS, 1981, p. 49)

\footnotetext{
${ }^{25}$ Alguns autores, atualmente, discutem a questão do planejamento prévio de algumas cidades coloniais brasileiras e refutam a tese de Sérgio Buarque de Holanda

${ }^{26}$ Esses conceitos baseiam-se nas teorias do urbanismo culturalista e progressista. (CHOAY, 1979, p.1-56)

${ }^{27}$ Arquiteto, prêmio de Roma, que vem para o Brasil junto com a Missão Francesa, em 1816. Suas principais obras, no Rio de Janeiro, são a Academia Imperial de Belas Artes, - Mercado da Candelária, a Praça do Comércio, a adaptação do Seminário São Joaquim, para servir de sede ao Colégio Pedro II, o chafariz do Largo de Benfica e o da Praça do Mercado, além de várias casas residenciais, entre elas o palacete do Barão do Passeio e sua própria residência na Gávea.
} 
${ }^{28}$ Sobre esse projeto, ver Pereira (1988).
O projeto é, evidentemente, baseado na Rue de Rivoli em Paris, e tem a intenção de criar um centro novo, a partir do qual se faça a reestruturação da área urbana em moldes modernos.

O Engenheiro Militar Major Henrique de Beaurepaire Rohan, ${ }^{28}$ diretor de Obras Públicas em 1843, apresenta um relatório geral sobre a cidade, junto com a proposta de um projeto de intervenção urbana.

\footnotetext{
Aliás, seu Relatório permite uma leitura do Rio de Janeiro na metade do século, assim como as noções que guiam a ação e os discursos dos poderes constituídos da cidade. Através das mudanças e das permanências, ele nos apresenta uma atitude radicalmente nova, que proclama a condenação definitiva das cidades herdadas. (PEREIRA, 1988, p. 213)
}

Seu informe divide-se em duas partes: a primeira faz referência à salubridade pública, e a segunda ao embelezamento da cidade e à comodidade de seus habitantes. As sugestões da primeira parte referem-se à rede de esgoto - incluindo a de águas pluviais -, à zona pantanosa do Mangue, ao Morro do Castelo, ao matadouro, aos cemitérios, à arborização e aos dejetos urbanos.

Para resolver os problemas das águas pluviais, o projeto sugere elevar a caixa das ruas acima do nível do mar e construir sarjetas junto às calçadas. Para a área do Mangue, projeta um canal navegável, a partir de um braço de mar. Sobre o desmonte do Morro do Castelo, o autor argumenta que, desde o século XVIII, esse e outros morros são considerados fatores de insalubridade e barreiras para a expansão da cidade.

O autor prossegue com o problema do matadouro, que deve sair da praia de Santa Luzia, e o dos cemiterios, cuja localização propõe que seja fora dos limites da cidade. A arborização das ruas e das praças justifica-se como medida de saneamento, como um meio de purificação do ar e de embelezamento. Ao final da primeira parte do Relatório, propõe a criação de um serviço que se encarregue do recolhimento dos dejetos urbanos.

A segunda parte analisa as vias de comunicação, as praças, a pavimentação, as pontes, os cais marítimos, os mercados fechados e os cortiços. $\mathrm{O}$ autor propõe um plano radical de transformação do tecido urbano existente, justificando com a análise dos pontos anteriormente citados. É um plano de reforma que se destina a uma parte da cidade velha, onde se localizam 5.657 imóveis, aproximadamente um terço da cidade construída. "Eu não conto certamente com reconstruir toda a cidade, mas somente a parte que existe da Praça da Aclamação para baixo, aquela que é mais problemática." (ROHAN, 1943 apud PEREIRA, 1988, p. 221) 
O engenheiro sugere nivelar a cidade a partir da Praça da Aclamação até a praia, na direção leste, com novos quarteirões quadrados de 65 metros de lado e com ângulos chanfrados, as ruas com um mínimo de $17 \mathrm{~m}$ de largura e os lotes com $12 \mathrm{~m}$ de frente, pelo menos. Por trás de cada quarteirão, haveria uma rua de serviço, destinada à circulação dos veículos, dos escravos, dos vendedores ambulantes etc. As casas possuiriam água corrente, e uma parte do lote deveria ser destinado a um jardim.

As praças, cuja localização e dimensões não são definidas, destinam-se a distintos usos, umas públicas, outras para mercados e uma outra reservada para as edificações da administração pública.

Sob a influência da Beaux-Arts, o autor defende a construção de uma nova cidade sobre a velha, condenada por suas práticas, para reabilitá-la material, moral e economicamente. $\mathrm{O}$ argumento é o de recuperar a imagem do Rio de Janeiro, porque, desse modo, "[...] os milhares de artistas estrangeiros vão nos trazer suas manufaturas, seus atelieres, seus conhecimentos [...] que contribuirão enormemente a um desenvolvimento formidável de nossa população, a uma revolução de nossas indústrias [...]." (ROHAN, 1943 apud PEREIRA, 1988, p. 224)

Uma vez conhecidas as dificuldades para a implantação de seu projeto, o engenheiro relaciona as medidas que podem ser executadas num prazo mais curto, nem por isso menos contundentes: o prolongamento de 26 ruas, a abertura de outras 18 e a criação de 8 praças públicas somente na área urbana, além da abertura de outras ruas, em áreas semiurbanas e rurais.

O relatório contém também informações sobre a pavimentação, uma análise do estado de conservação das pontes e um relato sobre a necessidade de construção de novos cais, ao longo das margens da baía, e de mercados fechados.

Por fim, Beaurepaire Rohan oferece, pela primeira vez, uma proposta para as residências da população de baixa renda. Sugere a construção de uma edificação com comércio, serviços e em torno de 160 apartamentos, para alugar a preços baixos, promovida pelo Estado ou pela iniciativa privada.

Margareth Pereira (1988, p. 226-227) afirma que o relatório do Major Beaurepaire Rohan revela as contradições do funcionamento da cidade colonial e sugere meios de transformá-la, seja através de demolições em massa e da implantação de um novo modelo espacial sobre o vazio, seja pelas transformações progressivas na morfologia urbana, através de um plano de reformas. A autora acrescenta que as sugestões respondem às novas lógicas de organização, de regulamentação e de controle do espaço urbano pela administração pública. 
${ }^{29}$ Seu projeto, de 1843 , é anterior às principais intervenções em cidades europeias como Paris, Barcelona ou Viena.
As propostas feitas pelo Engenheiro Henrique de Beaurepaire Rohan não se baseiam em nenhum exemplo preciso, pois pretendem dotar a cidade do Rio de um modelo espacial totalmente novo. ${ }^{29}$ Ainda que esse modelo não chegue a ser implantado, alguns pontos da proposta transformam-se em alvo de discussões.

Até o ano de 1870, quando o espaço urbano construído é mais uma vez o centro das preocupações, propõe-se muito, mas pouco se faz. Entre 1870 e 1875, os projetos apresentados propõem uma mudança na organização urbana através da abertura de novas ruas (Fig. 5), do alargamento e da retificação das já existentes, com o objetivo de facilitar a circulação de ar e a dissipação dos miasmas. São propostas influenciadas pelo impacto que as obras realizadas por Haussmann, em Paris, provocam em muitos profissionais brasileiros. Mas Margareth Pereira (1988, p. 414) também considera que

[...] as experiências de organização urbana desenvolvidas nos Estados Unidos, sobretudo em Chicago e Nova York, são seguidas com interesse pelos especialistas cariocas e contribuem, elas também, com esta vontade de trazer as soluções à série de problemas colocados pela expansão urbana do Rio.

A autora continua sua argumentação sobre a influência que têm os Estados Unidos sobre o Brasil, ao considerar a existência de um jogo de olhares triangular entre Brasil, Europa - principalmente a França - e Estados Unidos. As informações sobre os trabalhos realizados nos Estados Unidos chegam à França, através das publicações francesas que não tardam a chegar ao Brasil.

[...] pouco depois da primeira metade do século XIX, podemos constatar, a propósito das discussões sobre a cidade, um interesse de engenheiros brasileiros pelos Estados Unidos. Este interesse se revela geralmente através do novo jogo de espelhos triangular: o Brasil olha a França, que se vira para a América do Norte. (PEREIRA, 1988, p. 450, nota 4)

Em 1874, o Imperador D. Pedro II designa uma comissão para elaborar um plano urbanístico para a capital do Império. É seu primeiro plano, que coincide com os anos prósperos, quando o cultivo do café chega ao seu apogeu, e o Rio impõe-se como o grande centro comercial do País, apesar de ser também um dos mais insalubres e epidêmicos.

A comissão, composta por três engenheiros - Jerônimo Moraes Jardim, Marcelino Ramos da Silva e Francisco Pereira Passos - propõe um plano de reformas, cujos pontos principais são a abertura de ruas e avenidas com até $40 \mathrm{~m}$ de largura e novas praças. 


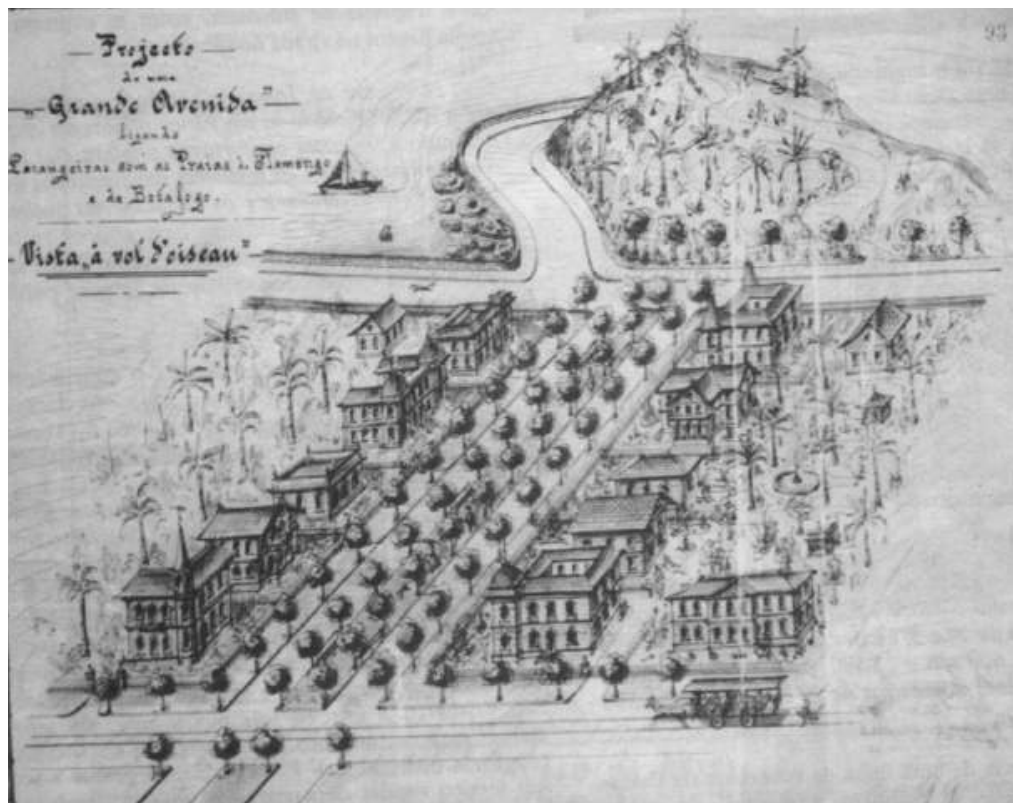

5. Projeto de uma grande avenida, em 1875

[...] um plano geral para o alargamento e rectificação de várias ruas desta capital e para a abertura de novas praças e ruas, com o fim de melhorar suas condições hygiênicas e facilitar a circulação entre seus diversos pontos, dando ao mesmo tempo mais beleza e harmonia às suas construcções.

(PASSOS, 1875, p. 1)

Nessa proposta, dá-se uma especial atenção à ventilação das casas, para melhorá-las, e ao deságue das águas pluviais. Os novos alinhamentos evitam a demolição de importantes edifícios públicos e privados. São regulamentadas a largura das calçadas e dos passeios laterais e a altura das arcadas e dos pórticos, sempre que for necessário cobri-las. Também são indicadas ruas e praças que necessitam alargamento ou retificação, e é projetada a implantação das melhorias necessárias à salubridade pública.

Trata-se, também, de um plano de expansão, por incluir os bairros mais próximos. No primeiro relatório, são apresentados os projetos referentes aos bairros existentes no vetor de expansão norte da cidade, da Praça da Aclamação até a raiz da Serra do Andaraí.

Os principais itens da proposta são a construção de uma avenida, que parte da Praça da Aclamação e vai em direção ao Andaraí e ao Engenho Velho, com 40m de largura (18 de rua e 11 de calçada de cada lado) e 4.870m de 
${ }^{30}$ Os principais pontos das normas de construção são relativos à higiene, tais como: a altura das fachadas vinculada à largura da rua; pé direito; aberturas para áreas livres; instalações sanitárias e depósitos de água. (PASSOS, 1875, p. 15) comprimento, e a execução de um tratamento higiênico - limpeza e prolongamento - do Canal do Mangue.

Segundo Benchimol (1992, p. 142), as avenidas propostas pelos membros da comissão alinham-se com as novas concepções urbanísticas em prática nas cidades europeias, adotando o modelo de Haussmann para Paris. A diferença é que, em vez de destruir o Centro, derrubando quarteirões operários, essas avenidas são projetadas para a periferia, áreas ainda pouco urbanizadas, orientando e criando condições para a expansão da malha urbana.

Nessa época, uma intervenção no Centro implicaria alto custo e alto preço político. Dessa forma, a Comissão deixa de especificar os trabalhos necessários nessa área, foco dos problemas mais graves, frente à impossibilidade de um orçamento preciso para as intervenções e desapropriações indispensáveis.

No traçado das novas ruas e avenidas a Commissão procurou conservar as direcções rectilineas tanto quanto o permitiam os accidentes do terreno e as construcções existentes, sem perder de vista as condições de belleza e as conveniencias da circulação. Extensas ruas em linha recta nem sempre produzem bom effeito, porque a uniformidade dá-Ihes geralmente, um aspecto monotono e triste, ou pelo menos fatiga a vista de quem as percorre. Algumas inflexões de alinhamento são necessarias para produzir variedade e mostrar os edificios sob angulos diversos; e determinam igualmente efeitos de sombra e de luz, que contribuem para realçar a belleza do panorama, oferecendo novos pontos de vista. (PASSOS, 1875, p. 7)

A Comissão preocupa-se com a estética das novas ruas e com a construção de edifícios particulares, mas é contrária a um tipo predeterminado de fachada, já que cada uma deve refletir sua função ou seu nível social, o que deixa abertura para uma ocupação diferenciada. Os engenheiros condenam os construtores sem formação profissional e aconselham a nomeação de um arquiteto ou engenheiro por distrito, para que examinem os projetos de construção e realizem a fiscalização das obras, assegurando o cumprimento das normas de construção. ${ }^{30}$

Na proposta para a execução dos projetos, sugere-se que o Estado não custeie as intervenções, já que se prevê uma forte oposição a custos considerados altos. A proposta é que seja confiada a execução do projeto a uma empresa capaz de torná-lo realidade.

O fato de o projeto da "Comissão de Melhoramentos" não ter sido executado estimula a apresentação de muitos outros, menos ambiciosos e mais pontuais, como o de Antônio Rebouças, que propõe uma avenida às margens da Baía de Guanabara. Em todos eles, podemos perceber tendências 
comuns, como a de voltarem-se, principalmente, para a parte antiga da cidade, situada dentro do quadrilátero formado pelos quatro morros - do Castelo, de São Bento, da Conceição e de Santo Antônio e a de promover a abertura de grandes avenidas em sentido norte-sul ou leste-oeste.

Uma das propostas apresentadas é um pedido de concessão ao corpo legislativo, feito por Giuseppe Fogliani e José Ferreira de Souza Araújo, em 1883, para a abertura de uma nova rua ${ }^{31}$ no centro da cidade, em sentido leste-oeste, argumentando a necessidade de uma melhoria no saneamento, para mudar

[...] a impressão desagradável que causa ao estrangeiro, que chega a esta Corte, o estado de desmazelo do serviço municipal e a incúria da administração que esta cidade denuncia. (FOGLIANI, 1903, p. 9)

Esse projeto pode ser comparado ao de Percier e Fontaine para a Rue de Rivoli em Paris, com arcadas somente num dos lados, e a Via Roma de Turim. Seus autores afirmam que a beleza e as perspectivas que a rua aporta são uma primeira etapa para que muitos outros pontos da cidade sigam o exemplo, transformando o aspecto e as condições gerais de higiene da área urbana. Apontam duas formas para a realização das reformas necessárias à cidade: a assunção pela municipalidade ou a delegação a empresas privadas, em troca de concessões.

Os autores pedem ainda a renovação da concessão em 1901, chamando essa nova rua de Grande Avenida (Fig. 6) e incluindo um projeto de alargamento de outras. Argumentam que São Paulo realiza obras e não projetos, e que Buenos Aires tem um novo aspecto depois das reformas de finais do século XIX.

Durante todo o século XIX, as propostas de intervenção na cidade partem de um arquiteto como Montigny, de um engenheiro militar como Beaurepaire Rohan, de um engenheiro civil como Pereira Passos e até de um empresário como Giuseppe Fogliani. Nesse contexto, os médicos sanitaristas têm um peso importante nas críticas sobre a cidade suja e com traçado confuso. Na segunda metade, são instituições intelectuais que contribuem com discussões, ideias e propostas para a reforma do espaço urbano do Rio, principalmente na que se produz em princípios do século XX. A Escola Politécnica, que se dedica à Engenharia Civil, é inaugurada em 1874 - após a transformação da Escola Central, que se voltava para a Engenharia Militar-, para suprir a necessidade de mão-de-obra especializada para as obras que se realizam no País.

Da Escola Politécnica, surge, em 1880, o Clube de Engenharia, onde alunos recém-saídos da escola, alguns industriais e comerciantes debatem assuntos os mais diversos, dentre os quais as reformas urbanas e as obras
310 projeto é de uma rua com $1.130 \mathrm{~m}$ de comprimento por $25 \mathrm{~m}$ de largura, dos quais $15 \mathrm{~m}$ são descobertos e $5 \mathrm{~m}$, de cada lado, cobertos por arcadas com altura de $8,50 \mathrm{~m}$. As edificações são compostas por um térreo com $4,50 \mathrm{~m}$ de altura para abrigar lojas de luxo, restaurantes, cafés, casas de leitura, exposições etc. A sobreloja, com uma altura de $4 \mathrm{~m}$, pode ser usada como depósito para as lojas ou como escritórios para advogados, médicos, companhias etc. Por cima das arcadas, três andares mais, chegando até o alinhamento da rua. (FOGLIANI, 1903, p. 90) 


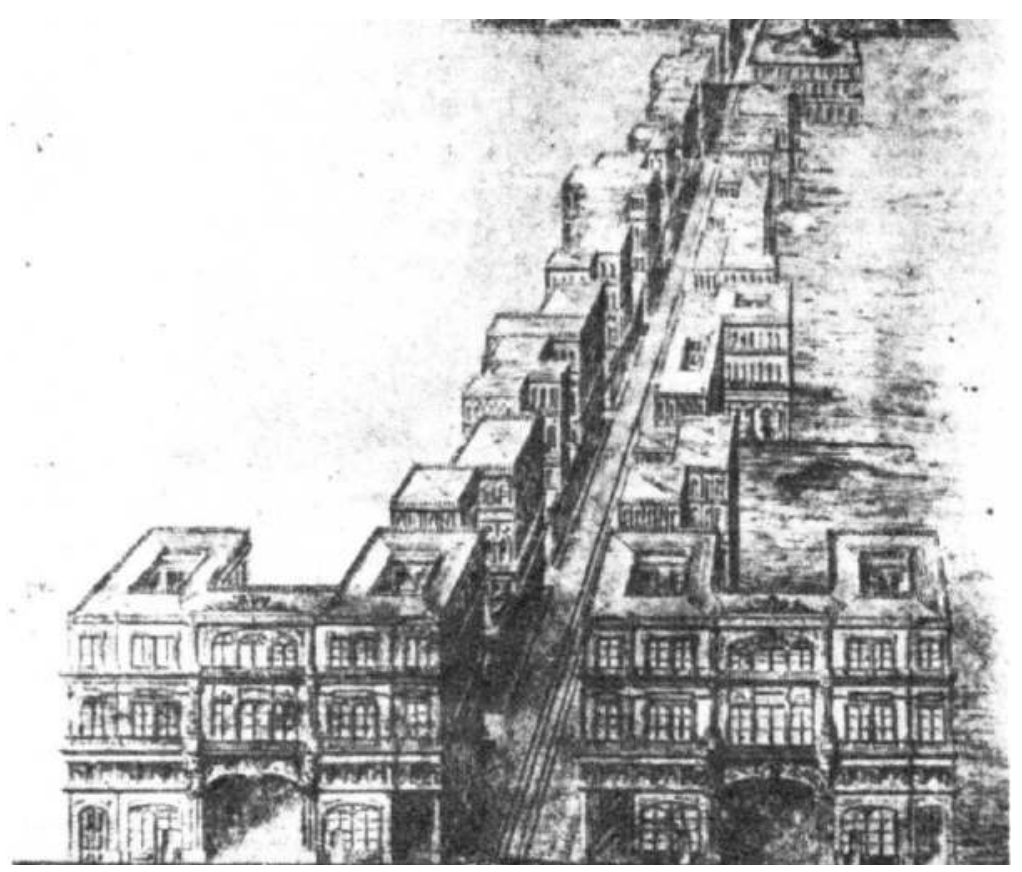

6. Projeto apresentado por Fogliani, em 1901

públicas do Rio de Janeiro, integrando-se ao debate sobre o saneamento da cidade. (ROCHA, 1995, p. 42-43)

O Congresso de Engenharia e Indústria (1901) realiza-se nesse Clube e tem como tema principal o embelezamento e o saneamento da Capital Federal. São propostas a abertura de ruas orientadas em função dos ventos dominantes, a definição da altura dos edifícios proporcional à largura da rua, a pavimentação com materiais de comprovada eficiência, a limpeza da cidade com lavagem das ruas, a retirada e incineração do lixo, a construção de uma avenida no litoral e novas avenidas com uma largura mínima de $17 \mathrm{~m}$, além de um novo alinhamento das edificações.

Depois de alguns projetos elaborados e não executados, de algumas pequenas intervenções para a melhoria da salubridade, da introdução dos novos serviços urbanos - iluminação a gás e elétrica, rede de esgoto e de abastecimento de água, bondes e trens -, assim como de novas tecnologias - o telégrafo e o telefone -, o Rio entra no século XX com muitos problemas ainda a resolver.

Seu aspecto não coincide com o status de capital do País. As comparações com as outras capitais, como Buenos Aires e Montevidéu, são constantes. 
Há uma necessidade de adequar a forma urbana às novas funções da cidade na República, com a integração do País no contexto capitalista internacional, o que exige uma nova organização de seu espaço. Mas a concretização dessas ideias só se tornaria possível quando à disponibilidade financeira se somasse a decisão política. Seria necessária a liderança de um administrador capaz de enfrentar as dificuldades e os problemas que um projeto desse porte acarretaria à vida da cidade e de seus habitantes. Pereira Passos, com sua forma ditatorial de administrar a cidade, iria consegui-lo.

\section{A reforma urbana de Pereira Passos}

Na segunda metade do século XIX, a Segunda Revolução Industrial na Inglaterra e nos outros países capitalistas tem como consequência o aumento da produção e do comércio internacional, além da exportação de capitais e inversões diretas que se refletem no setor de serviços e na infraestrutura urbana das sociedades periféricas. Por essa época, o Rio de Janeiro começa a ter um papel fundamental na inserção do Brasil no capitalismo internacional, ao transformar-se de porto exportador de café para centro distribuidor de produtos importados, tornando-se também um mercado consumidor. O Rio assume sua condição de centro cosmopolita e passa a receber inversões de capital estrangeiro, principalmente na implantação de sua infraestrutura.

Com a Proclamação da República em 1889, a cidade passa a ser o Distrito Federal, sede do Governo do Brasil. Sua administração faz-se primeiro através de um Conselho de Intendência Municipal, cujo presidente tem a função de administrar a cidade, e, depois, a partir de 1892, pelo prefeito, escolhido pelo Presidente da República.

Na primeira década da República, são produzidas grandes transformações na cidade, no âmbito socioeconômico, político e cultural. ${ }^{32}$ As transformações socioeconômicas associam-se à transição das relações sociais do tipo senhor/escravo para as do tipo burguês/capitalista. O regime republicano, baseado na ideologia do positivismo, tem o projeto de transformar o homem livre, imigrante ou ex-escravo, em trabalhador assalariado. O conteúdo negativo que tem o trabalho, porque se associa à escravidão, deve mudar e ter um valor positivo, propulsor da ordem e do progresso, e impulsionar o país para o novo e o civilizado, criando-se uma nova ordem burguesa. As portas abrem-se ao capital e à sociedade civilizada, com "[...] o projeto dos donos
${ }^{32}$ Alguns exemplos: a instauração de relações capitalistas, com a substituição da mão-de-obra escrava pela assalariada; a mudança da economia mercantil-exportadora pela capitalista-industrial; a decadência da cultura do café, baseada na escravidão; o desenvolvimento do setor secundário e terciário da economia urbana; o rápido crescimento da população urbana e a definição de novas categorias sociais; a transformação na organização política do Estado Brasileiro; a difusão dos valores burgueses. (Cf. VAZ, 1994, p. 50) 
do poder e do capital de fazer da jovem República um prolongamento tropical da civilização e da economia européia." (CHALHOUB, 1986, p. 29)

A burguesia e os médicos higienistas buscam mudanças para a cidade, que foi construída sem método, onde os pobres amontoam-se promiscuamente, a natureza dos morros impede a boa circulação de ar e o traçado das ruas prejudica a circulação de homens e mercadorias. Segundo Giovanna Del Brenna (1985c, p. 247), esse é um ambiente perfeito para a implantação de um projeto baseado no modelo adotado por Haussmann para Paris, em meados do século XIX, e que tem como objetivos principais o saneamento, o embelezamento e a circulação.

Em 1902, Rodrigues Alves assume a Presidência da República (19021906), com o projeto de modernizar o Brasil e sua capital, transformando seu aspecto colonial. Suas prioridades são o saneamento da cidade e a modernização do porto, o que facilita o comércio do café e a imigração da mão-de-obra necessária ao desenvolvimento econômico. O Presidente traz de São Paulo ideias novas para a urgente modernização da cidade e designa o Engenheiro Francisco Pereira Passos para a Prefeitura da capital entre os anos 1902 e 1906.

Pereira Passos, formado em Ciências Físicas e Naturais e depois em Engenharia Civil, frequentara a École des Ponts et Chausées de Paris, entre 1857 e 1860, onde assistiu a aulas de Arquitetura, Hidráulica, Construção de estradas de ferro, portos e canais, Direito Administrativo e Economia Política. Assistiu, ainda, às transformações de Paris implementadas por Haussmann e conheceu as intervenções em outras cidades. Tendo participado da elaboração do Plano de Melhoramentos da Cidade de 1875, conhece bem os problemas da cidade do Rio de Janeiro.

\section{A viabilidade da reforma urbana}

\section{Por que se faz a reforma}

Tudo começa quando o Rio de Janeiro se identifica como uma cidade feia, insalubre e sem dignidade, uma cidade que não está à altura de ser uma capital. (Fig. 7) Por não ter um porte que a distinga das demais cidades, surge a necessidade de mudar sua imagem para a de uma cidade capital que represente o novo País, a ponto de inseri-lo no capitalismo internacional e promover seu reconhecimento no exterior. Buenos Aires e Montevidéu já são cidades modernas, e é necessário igualar-se a elas, ou mesmo superá-las. 


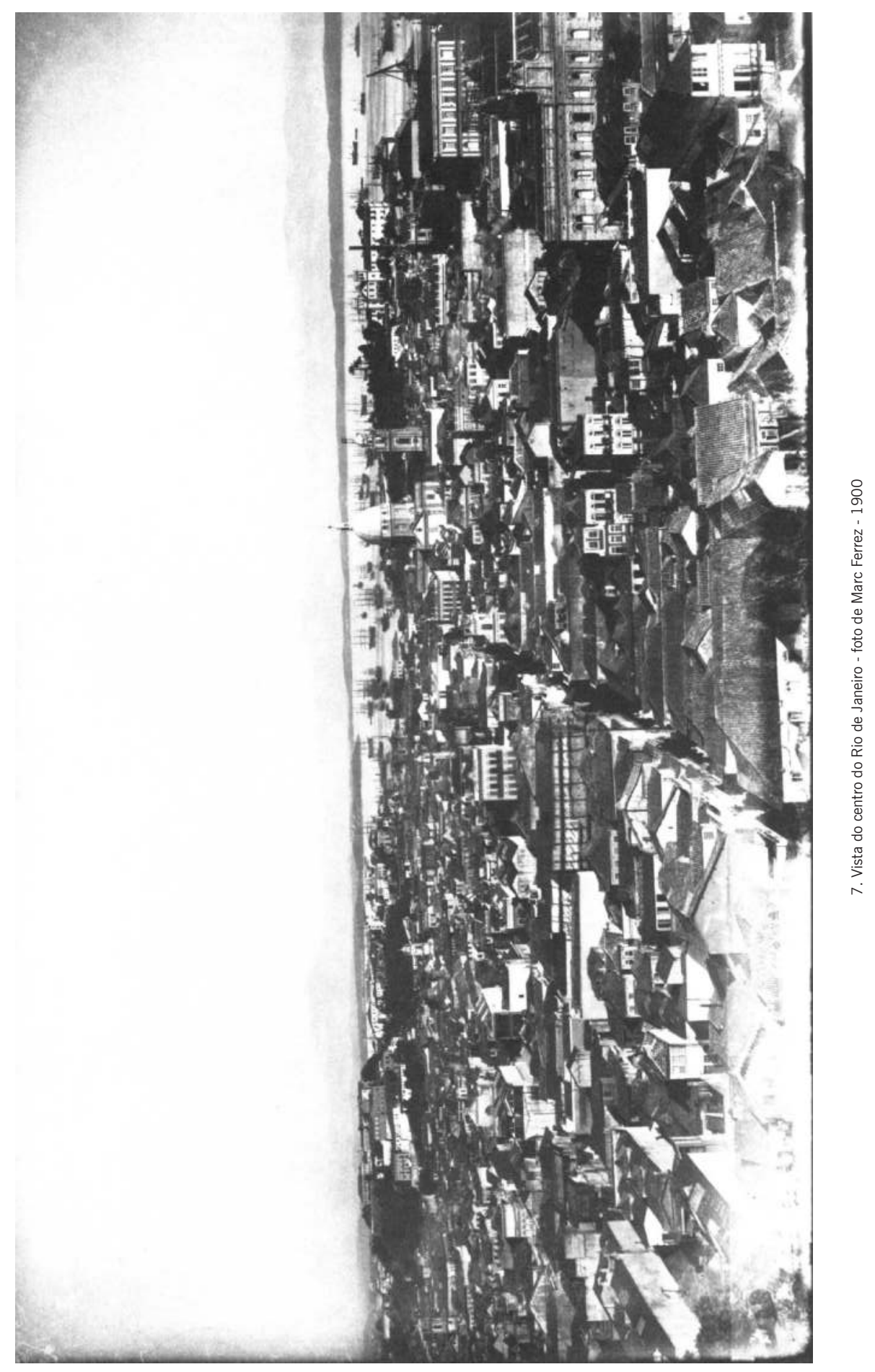


${ }^{33} \mathrm{O}$ Porto do Rio de Janeiro, um dos pilares da economia da capital, perde importância para o Porto de Santos, por onde escoa a produção de café. Além disso, há a crise que ameaça a economia, havia guerra civil no sul e percebia-se o risco de fragmentação do País. Havia dificuldades para administrar a dívida externa e necessidade de acabar com a instabilidade política. Todos esses pontos levam o Rio de Janeiro a perder hegemonia como capital
Outro ponto a ser destacado e que move a necessidade dessa transformação é a Constituição de 1891, que prevê a transferência da capital para uma nova cidade, a ser construída no interior do País. Após a Proclamação da República, o Rio de Janeiro perde a hegemonia ${ }^{33}$ e reduz suas funções tradicionais como cidade-porto, cidade capital, centro cultural, econômico e financeiro. Com as reformas ocorridas entre 1902 e 1906, a centralidade governamental e a centralidade territorial voltam ao Rio.

\begin{abstract}
Para a nova classe dominante que chegava ao poder [...] de extração nitidamente urbana, a cidade que herdara, além de não espelhar a sua imagem, representava ainda um sério empecilho para os seus negócios, tanto pela ameaça representada pelas epidemias quanto pela inexistência de uma estrutura urbana adequada, a suas novas necessidades. [...] Era preciso, portanto, no imaginário da burguesia cafeeira, construir-se uma nova cidade, à imagem e semelhança da imagem que esta classe fazia de si mesma. (PECHMAN, 1992, p. 35-36)
\end{abstract}

Para se obter a aparência desejada e as características de uma cidade moderna, racional e desenvolvida, que representasse um país reformado, capitalista, eram necessárias intervenções no tecido urbano e construções monumentais. As cidades europeias simbolizam esses novos tempos da burguesia e da modernidade, e têm, em Paris, a capital política e cultural, em Londres, a capital da economia política e, em Viena e Berlim, as capitais da filosofia.

Ao chegar à Presidência da República, Rodrigues Alves tem, entre seus projetos de governo, a intenção de apoiar a produção, estimular a imigração e a ocupação dos solos férteis, incrementar os transportes e a defesa da entrada de capital. Para alcançar tais metas, é necessário um programa para sanear e modernizar a capital. A pretendida inserção do Brasil no capitalismo supõe a adoção de novos valores, uma nova urbanidade em que se inclui uma nova cidade, com novos atores, novas atitudes e novos comportamentos. É preciso cambiar a "desordem" da cidade colonial pela "ordem" da cidade capitalista-burguesa.

\footnotetext{
A cidade tradicional e escravista contém a 'desordem', seja na venda de carne, na coleta de lixo, nas habitações, no vestuário ou na distribuição de água. Por isso mesmo os argumentos para a nova ordem estão expressos no próprio espaço urbano, na medida em que a desordem expressa na 'sujeira', na 'feiúra' e nas epidemias está presente neste espaço. (PECHMAN, 1992, p. 34)
}

Um dos objetivos do projeto de transformação do Rio é o de sanear a cidade, através de uma mudança urbanística. O projeto do poder público e da elite inclui retirar a população de baixa renda do Centro, reocupar seus espaços com novas construções e novos habitantes, embelezar e sanear, 
a partir de modelos modernos como o de Paris, e transformar a cidade em capital turística, comercial e financeira da América Latina. Seu saneamento e sua transformação são pontos fundamentais para a atração de mão-de-obra e do capital europeu.

É necessário criar um novo espaço urbano, com a finalidade de facilitar a circulação de pessoas e de mercadorias, através do controle urbanístico, que tem seu fim na reestruturação do porto, na abertura de avenidas e alargamento de ruas. É preciso simplificar o processo de importação/exportação de mercadorias, além de criar uma nova capital que represente o País, com valores e modos de vida cosmopolitas e modernos. A nova organização do espaço deve refletir o novo momento de organização social, adequando sua forma às necessidades de criação, concentração e acumulação de capital, uma vez que a economia brasileira se integra, cada vez mais, no contexto do capitalismo internacional. Por trás de todas essas necessidades, encontra-se a negação de sua herança colonial, de seu passado escravista, de sua negritude.

Ao prefeito Pereira Passos caberia a tarefa de modernizar a cidade, torná-la atraente aos olhos europeus, mas também a tarefa de domesticá-la, instaurando a ordem para que o Rio de Janeiro se apresentasse como uma cidade cartão postal da Belle-époque, onde não aparecesse, a turvar a imagem, o Brasil pobre, o Brasil negro, o Brasil mulato. (RESENDE, 1993, p. 39, grifos nossos)

A intervenção no espaço construído do Rio é conhecida como a "Reforma Passos", a "era das demolições" ou, mais popularmente, como o "bota-abaixo", realizada com a intenção de acabar com a corte colonial portuguesa, infecta, imunda e antiga, para dar passagem a um centro moderno, "afrancesado" e saneado.

O Brasil quer mudar sua imagem modificando as feições de sua capital e os costumes de seus habitantes. Com o início das reformas, em 1902, começa a transformação: o centro da cidade é o cenário de uma luta social, onde entra em cena um novo urbanismo, símbolo do progresso, da limpeza, da saúde, da beleza e da civilização, evidenciando-se, a partir desse momento, uma nova identidade nacional.

\section{Como se faz a reforma}

Para criar uma nova estrutura urbana, reorganizar seu espaço, melhorar a salubridade geral e realizar uma intervenção que a transforme na tão sonhada cidade burguesa, o Rio de Janeiro necessita de capital. Apesar de algumas melhorias implementadas ao longo do século XIX - como a introdução 
${ }^{34}$ Como exemplo, temos o programa sanitário de combate à febre amarela e à varíola, que prejudicam a imagem do País no exterior; entretanto, é a tuberculose, que mata mais pessoas nessa época.

${ }^{35}$ Em março de 1904, também Oswaldo Cruz, diretor geral da Saúde Pública, recebe autorização para invadir, inspecionar, condenar e demolir casas e construções consideradas insalubres. de novas tecnologias e a aplicação de capital estrangeiro em infraestrutura de iluminação, transportes, abastecimento de água e rede de esgoto - e dos vários projetos formulados, das ideias que circulam, a situação financeira não se ajusta à grandeza das inversões de capital necessárias, e falta decisão política para reformas de grande porte.

Foi possível ao governo de Rodrigues Alves tornar realidade a reforma urbana, por força da restauração do crédito do Brasil, realizada por seu antecessor, Campos Sales, o qual também deixa recursos nas reservas do Tesouro. Com essa situação financeira confortável, o governo pode endossar o empréstimo feito pela Prefeitura para seu programa de desenvolvimento urbano e, para reformas almejadas, comprometendo metade do orçamento do Estado no pagamento do empréstimo negociado junto ao grupo de banqueiros N. M. Rothschild and Sons de Londres. (ROCHA, 1995, p. 60) O governo inicia-se com uma moeda débil (1902-1904), mas, a partir de 1905, ocorre a sua valorização, seguindo-se anos de expansão no mercado mundial. (LOBO; CARVALHO; STANLEY, 1989, p. 74)

A chamada "Reforma Passos" é o resultado da ação conjunta dos governos Federal e do Distrito Federal. O processo empreendido constitui uma ruptura na cadeia do tempo, um novo começo e uma nova etapa, mais que uma melhoria na cenografia urbana e na vida social. Agora, as prioridades são diferentes das do século XIX, pois, além da falta de água e das más condições de higiene, está presente a questão da imagem. ${ }^{34}$

Assim, inicia-se a "era das demolições". Pereira Passos só aceita o cargo de prefeito com a condição de poder realizar uma administração eficaz, sem obstáculos políticos e com a garantia de leis federais para uma ação imediata na cidade. Em dezembro de 1902, o Prefeito recebe total poder para intervir no espaço urbano ${ }^{35}$ e, ao tomar posse, dissolve o Conselho Municipal por seis meses, obtendo plenos poderes para realizar seus projetos de transformação da cidade. Segundo Nestor Goulart Reis Filho (1994, n. 1, p. 29), Pereira Passos adota um estilo ditatorial de administração, semelhante ao de Haussmann em Paris. Com o respaldo do Presidente Rodrigues Alves, não atende a nada nem a ninguém, sequer às ordens judiciais, derrubando, à noite, edificações protegidas judicialmente. De todo modo, Passos tem uma grande aceitação popular e da imprensa em seus atos autoritários.

A elaboração do plano de intervenções está a cargo de uma comissão que, além da Carta Cadastral do Distrito Federal, projeta alinhamento de ruas, canalização de rios, prolongamento e abertura de novas avenidas, criação de redes de abastecimento de água e de esgoto. A Diretoria de Saúde Pública e Higiene, o Ministério de Obras e Vias Públicas e o Clube de Engenharia 
manifestam-se a favor das mudanças na cidade, influenciando o processo com suas ideias, o que os converte em corresponsáveis pelas intervenções.

Os trabalhos realizados baseiam-se num processo de destruição e reconstrução, até em áreas situadas fora do perímetro das reformas. As desapropriações e demolições são executadas para a abertura, alargamento e prolongamento de ruas e avenidas, mas também se impõem aos imóveis condenados pela Saúde Pública como insalubres. A higiene domiciliar e a transformação das edificações são pontos novos no saneamento da cidade.

Introduz-se um novo instrumento, conhecido como Projeto de Alinhamento (PA), que determina o alinhamento e a largura das vias, condenando muitas edificações à renovação. Desde a Constituição Política de 1824 , garante-se o direito à propriedade privada, com previsão de desapropriação em caso de necessidade pública, mediante o pagamento de uma indenização pelo valor da propriedade. Esse dispositivo é mantido na Constituição de 1891: "O direito de propriedade mantém-se em toda a sua plenitude, salvo a desapropriação por necessidade ou utilidade pública, mediante indenização prévia." (DALLARI, 1981, p. 34)

A desapropriação e a demolição ${ }^{36}$ são justificadas pela associação entre habitações populares, insalubridade e disseminação de epidemias, fatores de comoção social. Na verdade, o desaparecimento dessas edificações permite não só o controle das epidemias mas também das classes trabalhadoras. Ao final do período 1902-1906, entre as obras realizadas pela Prefeitura e pelo Governo Federal, as demolições de imóveis condenados pela Saúde Pública atingem um total de 2.240 edificações e de 36.900 desalojamentos. (VAZ, 1985, p. 226)

Segundo Gastão Cruls (1949, p. 451), cronista e historiador da cidade do Rio,

Impossível seria pormenorizar aqui o que foi a obra ingente dêsses dois homens, um [Oswaldo Cruz] em luta aberta contra o mal amarílico, isolando doentes, acabando com os mosquitos, mas também obstinado no extermínio dos ratos e na difusão da vacina antivariólica, ainda mesmo que fôsse de uma maneira compulsória; o outro [Pereira Passos], a secundar-Ihe a operosidade, tresdobrando-se no afã de remodelar completamente a cidade. Derrubavam-se quarteirões inteiros. As ruas estreitas e os becos escuros transformavam-se em avenidas largas e ruas bem arejadas. Ao golpe incessante dos alviões e das picaretas, esboroavam-se para sempre os pardieiros imundos e as pocilgas nauseabundas.

Sem dúvida, nem todos estão de acordo com as desapropriações e as demolições. Os donos de cortiços, de casas de cômodos, de lojas e de
${ }^{36}$ Um novo decreto, de 9 de setembro de 1903, regulamenta as desapropriações, dando amplos poderes ao Estado, mudando os cálculos das indenizações e facilitando a demolição em série. (VAZ, 1985, p. 224) 
${ }^{37}$ Um exemplo é a Revolta da Vacina, que ocorre em novembro de 1904 , quando milhares de pessoas saem às ruas e enfrentam as forças da polícia, do exército e até do corpo de bombeiros e da marinha, tendo como saldo, segundo jornais da época, 23 mortos, dezenas de feridos e quase mil presos, muitos deles enfrentando uma viagem sem regresso para o Acre. Sobre esse tema, ver Chalhoub (1996) armazéns situados no Centro protestam contra os valores das indenizações, conseguindo um valor mais alto, ou uma permuta por um lote em local valorizado. Por outro lado, os pobres, classificados como classe perigosa, que também não estão de acordo com as decisões do governo, sofrem a repressão do Estado quando manifestam seus protestos. ${ }^{37}$

Esta população poderia ser comparada às classes perigosas ou potencialmente perigosas de que se falava na primeira metade do século XIX. Eram ladrões, prostitutas, malandros, desertores do Exército, da Marinha e dos navios estrangeiros, ciganos, ambulantes, trapeiros, criados, serventes de repartições públicas, ratoeiros, recebedores de bondes, engraxates, carroceiros, floristas, bicheiros, jogadores, receptadores, pivetes (a palavra já existia). E, é claro, a figura tipicamente carioca do capoeira [...]. Morando, agindo e trabalhando, na maior parte, nas ruas centrais da Cidade Velha, tais pessoas eram as que mais compareciam nas estatísticas criminais da época, especialmente as referentes às contravenções do tipo desordem, vadiagem, embriaguez, jogo. Em 1890, estas contravenções eram responsáveis por $60 \%$ das prisões de pessoas recolhidas à Casa de Detenção. (CARVALHO, 1987, p. 18)

$\mathrm{Na}$ criação da cidade civilizada e salubre, os problemas sociais disfarçam-se, e os sinais de pobreza escondem-se. No Centro, habitado por uma população em busca de oportunidades de trabalho dia após dia, proíbe-se a circulação de mendigos e de vendedores ambulantes, excluindo-se a população que vive nos limites da legalidade e que sobrevive com biscates, mal remunerada, subempregada, sem ocupação fixa.

Essas pessoas são o alvo dos reformadores, já que sua presença no Centro não é compatível com a imagem da cidade civilizada e moderna que se pretende construir. Elas são as mais prejudicadas nessa renovação urbana que destrói suas formas de relação e de sobrevivência e que submete o proletariado a uma nova ordem social.

A retórica elitista que justificava essa remodelação, a estética art-nouveau dos edifícios e mansões, como as medidas que em nome da higiene e do saneamento urbano definem a demolição em massa, o 'bota-abaixo' dos cortiços e do antigo casario habitados por populares, e as campanhas de vacina obrigatória, se por um lado ajustam efetivamente a cidade às novas necessidades da estrutura política e econômica montada e aos valores civilizatórios da burguesia, por outro não consideravam os problemas de moradia, abastecimento e transporte daqueles que são deslocados de seus bairros tradicionais no Centro para a periferia, para o subúrbio e para as favelas que se formam progressivamente por todo o Rio de Janeiro, definindo um padrão de ocupação e de convívio das classes na cidade que vai se tensionando ao longo do século. (MOURA, 1995, p. 47) 
Com os argumentos de circulação, fluidez e saneamento, o poder intervém de forma contundente no espaço da cidade, realizando, por fim, a reforma urbana.

\section{A realização da reforma urbana}

\section{0 que se faz na reforma}

A reforma urbana do período Pereira Passos tem vários objetivos: a construção de um novo porto e de avenidas para uma melhor circulação de mercadorias; o saneamento da área central; o alargamento, alinhamento e pavimentação de ruas; a abertura de uma grande avenida em direção norte-sul e a construção de edifícios monumentais. Adota o modelo geométrico de planejamento urbano, com linhas retas e largas e uniformidade nas vias de circulação, o que combina com a expansão dos bondes.

Desde o dia de sua posse na Prefeitura, Pereira Passos determina que, em cada rua aberta, sejam feitas as instalações de esgoto e as tubulações de água e gás, além da pavimentação. São colocadas em prática medidas para o saneamento da cidade: retirada dos quiosques imundos, que se encontram em cada esquina; proibição da criação de animais no centro urbano; derrubada dos sujos mercados e impedimento do exercício do comércio ambulante. A reforma busca melhorar a higiene, tanto no espaço público como no privado, com a imposição de medidas de profilaxia, sob a supervisão da Diretoria de Saúde Pública, dirigida pelo médico sanitarista Oswaldo Cruz.

[Pereira Passos] Declara guerra aos bacalhoeiros da Rua do Mercado, aos tamanqueiros do Bêco do Fisco, aos mestres-de-obras que constroem no estilo compoteira e outros autores do atraso nacional; entra pelas casas que se fazem, ainda [...] sem luz, sem ar, dédalo de corredores e de alcovas; cria posturas alargando as suas divisões, manda rasgar janelas nos aposentos de dormir, enche a morada de luz, de ar, de vida e de saúde! Do fundo dos armazéns manda arrancar toneladas de lixo, derrubar construções arcaicas; nas lojas, manda substituir os assoalhos podres, [...], cria o Serviço de Assistência Pública, [...], primeiro serviço que tivemos; extingue a cainçaIha que vivia infestando as ruas da cidade; acaba com a gritaria colonial dos pregões, mete os mendigos em asilos, acaba com os ambulantes que vendem vísceras de rêses apodrecendo, ao sol, cercados pelo vôo contínuo do mosqueiro, alarga ruas, cria praças, arboriza-as, calça-as, embeleza-as, termina com a imundície dos quiosques e diminui a infâmia dos cortiços. (EDMUNDO, 1957, v. 1, p. 31-32) 
${ }^{38}$ Tem $5.200 \mathrm{~m}$ de extensão e $33 \mathrm{~m}$ de largura, dividida em duas vias para carros, com 9m cada uma, e um passeio central com $7 \mathrm{~m}$, adornada com árvores. Em cada lateral, uma calçada com $4 \mathrm{~m}$, com um guardacorpo de pedra do lado do mar.
O projeto de intervenção no traçado urbano inclui o alargamento de antigas artérias ou a abertura de novas que diminuam distâncias, contornem obstáculos naturais e unam pontos estratégicos da cidade. São aberturas norte-sul, leste-oeste, algumas em diagonal e outras de contorno do litoral. As mais importantes têm o objetivo de facilitar as comunicações e romper a intrincada trama colonial. (Fig. 8, ver caderno de imagens)

A opção é pelo sistema radial de avenidas. Duas avenidas que formam um "V" saem da margem da baía, ao sul do Centro. Uma delas une-se diretamente a uma das extremidades da nova avenida do porto, totalmente modernizado. Da outra extremidade da avenida do porto, sai uma larga avenida que se junta à segunda perna do "V", em direção aos bairros da Zona Norte e aos subúrbios, áreas de expansão urbana da classe média e do proletariado. Do vértice do "V", sai a avenida que segue pelo litoral que margeia a baía, em direção aos bairros burgueses da Zona Sul. São asseguradas, assim, as comunicações dentro da área do Centro: entre a zona portuária e o Centro; entre as zonas portuária, ferroviária e industrial de São Cristóvão; entre o Centro e os novos bairros da Zona Sul por um lado, e entre a Zona Norte e os subúrbios por outro; e, por fim, entre a Zona Sul e a Zona Norte.

São anos de muita agitação, de grandes mudanças, tudo se transforma. A cidade muda sua feição a cada dia que passa. A população sente-se perdida, sem poder encontrar as casas, as lojas, seus pontos de referência. Poder-se-ia ir um dia a um local e, no dia seguinte, ser incapaz de encontrá-lo. A cidade é um labirinto, um monumental canteiro de obras.

\section{A Prefeitura na reforma}

O plano de melhorias da Prefeitura inclui a abertura de grandes eixos de circulação, facilitando a comunicação entre os diversos bairros da urbe, o que constituirá a base da transformação da cidade e de seu saneamento. Cada vez mais, os bairros distinguem-se por suas funções e por sua população. O intercâmbio com o Centro é fundamental, já que, cada vez mais pessoas vivem e trabalham em locais distintos, e as mercadorias devem circular para abastecer o comércio em pontos distantes de sua origem. Uma cidade moderna exige rapidez em seus deslocamentos, tanto de pessoas, inclusive da mão-de -obra, como de mercadorias.

A Avenida Beira-Mar, ${ }^{38}$ que contorna a baía em direção à Zona Sul (Fig. 9), abre-se sobre terreno conquistado do mar, por meio de aterros. Da extremidade dessa avenida, no Centro, saem outras duas, uma em direção ao 
oeste, a Avenida Mem de Sá, e outra em direção ao norte, a Avenida Central, responsabilidade do Governo Federal.

A Avenida Mem de Sá (Fig. 10), com 1.500m de extensão e 17m de largura, passa onde antes estava o Morro do Senado, até juntar-se a outra avenida, Salvador de Sá, com 800m de comprimento e $17 \mathrm{~m}$ de largura, em direção à Rua Estácio de Sá, que se alarga e segue para a Zona Norte, formando uma das radiais leste-oeste.

Uma segunda radial leste-oeste abre-se mais ao norte do Centro, definida pelo alargamento de ruas existentes. São a Rua Visconde de Inhaúma, a Avenida Marechal Floriano (formada pelas Ruas Estreita de São Joaquim e Larga de São Joaquim), o Bulevar São Cristóvão e partes das Ruas Maris e Barros, Senador Eusébio e Visconde de Itaúna.

Outras ruas são alargadas nos sentidos norte-sul e leste-oeste, para comunicar melhor o Centro com as outras zonas da cidade. Para a realização de todas essas intervenções, derrubam-se quarteirões inteiros ou parte dos edifícios de um dos lados da rua. (Fig. 11 e 12)

Essas aberturas ${ }^{39}$ introduzem uma novidade: o perfil convexo da caixa da rua com as sarjetas nas laterais e os cruzamentos chanfrados ou em curvas. As calçadas são amplas e regulares, adornadas com árvores e postes de iluminação; as ruas são revestidas com asfalto e, por baixo, passam as tubulações de água, gás e esgoto, além dos coletores de águas pluviais.

A Prefeitura também realiza obras de canalização de diversos riachos, o ajardinamento e arborização de praças e ruas, a abertura de novas praças, a construção de três novos mercados, do Teatro Municipal, a remodelação do Paço Municipal, ${ }^{40}$ entre outras.

\section{O Governo Federal na reforma}

Os trabalhos realizados sob a responsabilidade do Governo Federal são, basicamente, dois: a abertura da Avenida Central e a modernização do porto e de suas avenidas complementares, a Rodrigues Alves e a Francisco Bicalho.

A Avenida Central rasga em diagonal o Centro, onde se concentram as atividades administrativas, comerciais e financeiras e onde se desenvolve grande parte do trabalho urbano, ligando, de mar a mar, em sentido norte-sul, duas das avenidas radiais: a Avenida Beira-Mar, ao sul, e a Avenida Rodrigues Alves, ao norte. É um dos acessos ao novo Porto do Rio e a mais importante artéria da zona central. Simboliza a cidade moderna, em oposição à cidade colonial, e é a principal responsável pela mudança da imagem geral do Centro, inclusive na alteração de hábitos. É considerada, ainda, o símbolo
${ }^{39}$ Os trabalhos são executados de forma sincronizada e rápida. Ao acabar a demolição das edificações, chega o grupo que define a largura da rua, demarcando o alinhamento das fachadas e a linha da calçada.

${ }^{40}$ Edíficio demolido com a abertura da Av. Presidente Vargas, em 1942. 


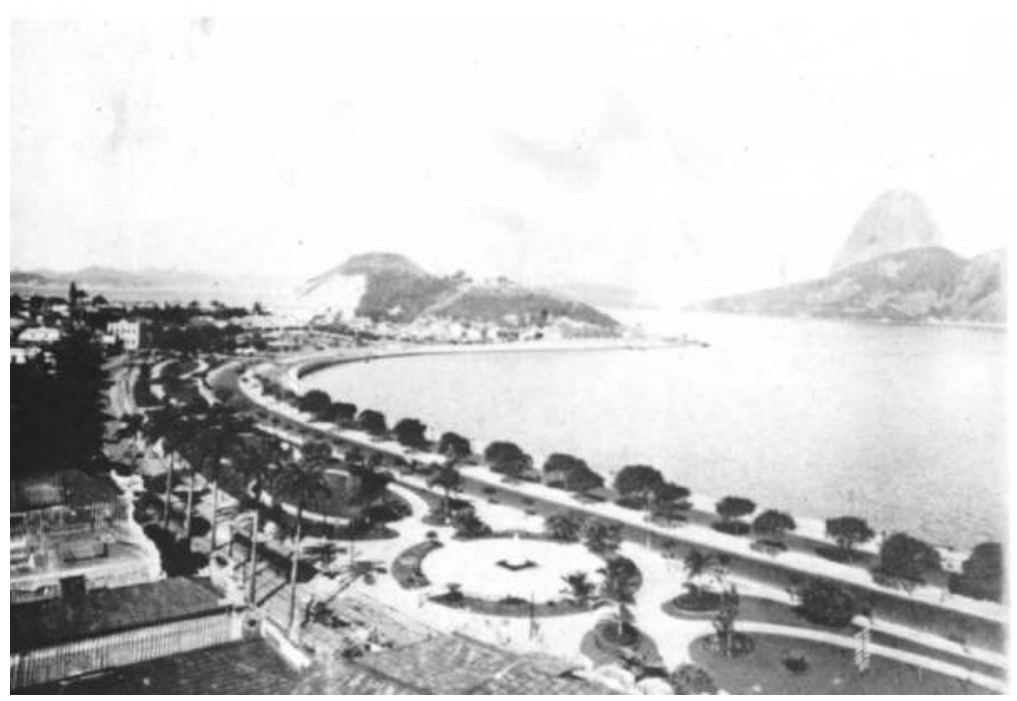

9. Vista da Avenida Beira Mar, em Botafogo - foto de A. Ribeiro - 1915

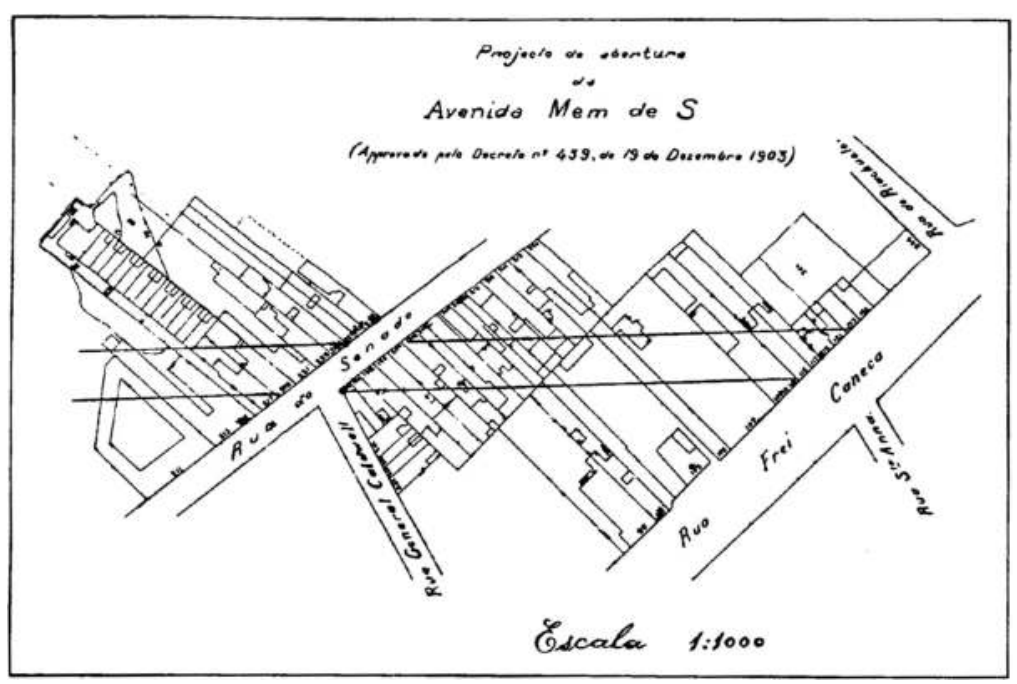

10. Projeto de abertura da Avenida Mem de Sá, no Rio de Janeiro, em 1903 


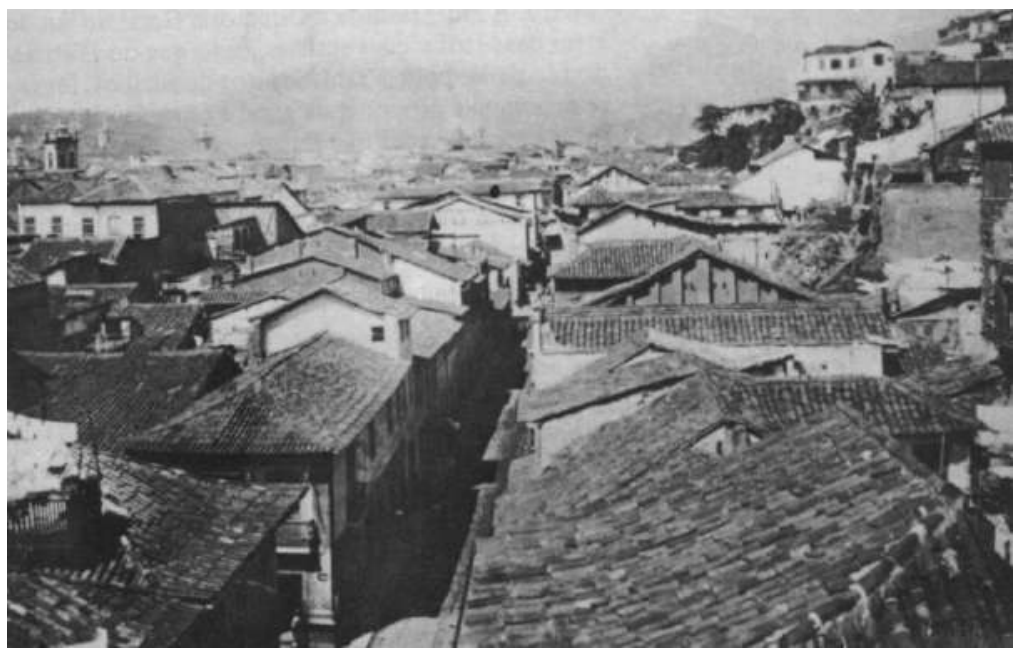

11. Rua da Prainha antes da reforma - foto de Augusto Malta - 1903

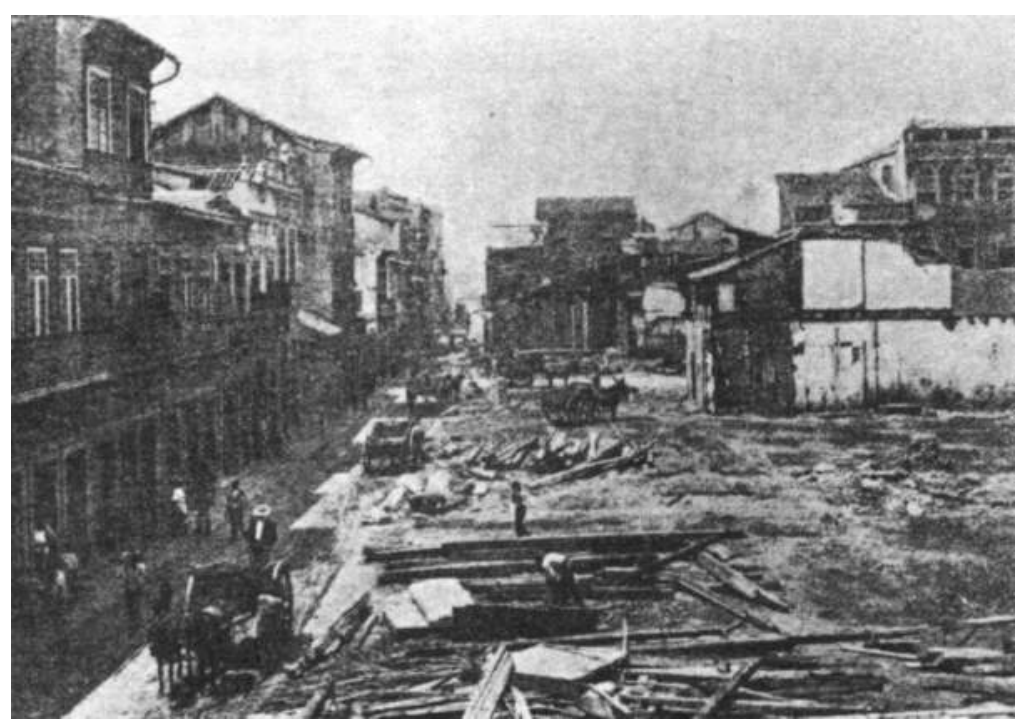

12. Rua da Prainha durante a reforma - foto de Augusto Malta - 1904 
${ }^{41}$ Cruls (1949) refere-se a $1.880 \mathrm{~m} \mathrm{e}$ Reis Filho (1994) a $1.795 \mathrm{~m}$.

42 O Engenheiro Morales de los Ríos comenta que a avenida deveria ter $50 \mathrm{~m}$ de largura, além de um rond point no cruzamento com a Rua 7 de Setembro, com 120 m de diâmetro como a Étoile de Paris, de onde partiria outra avenida, em sentido leste-oeste, com $40 \mathrm{~m}$ de largura. Para exemplificar sua opinião, compara-a com outras avenidas: a Avenida Waterloo em Bruxelas, com $84 \mathrm{~m}$, a des Arts em Antuérpia, com $60 \mathrm{~m}$, o Ring em Viena, com 57m, a do Bois de Boulogne e o Champs Elisées em Paris, com 142 e 77m respectivamente; e o Paseo del Prado, além de outros passeios com larguras variáveis mas sempre muito largos. № Brasil, as avenidas de Belo Horizonte têm 50m de largura. (SANTOS, 1981, p. 77) da inserção do Distrito Federal nos tempos modernos. A intervenção não traz hegemonia ao espaço; cria somente uma ilha de modernidade dentro de uma malha urbana ainda colonial. Mas, sem dúvida, muda a fisionomia da cidade.

Sua concepção parte da necessidade de criar uma avenida para viabilizar a circulação de mercadorias, do porto até as outras áreas da cidade, já que o intrincado traçado de ruas do Centro é um obstáculo. A ideia de embelezar a cidade também é um ponto importante para levar adiante o projeto, especialmente quando se vislumbra a possibilidade de criar uma avenida que possa rivalizar, ou mesmo superar, a tão falada Avenida de Mayo de Buenos Aires.

A Avenida Central tem $1.820 \mathrm{~m}^{41}$ de comprimento por $33 \mathrm{~m}$ de largura, dos quais 7,50m para cada lado são passeios. (REIS, 1977) Possui um refúgio central com $2 \mathrm{~m}$, onde se localizam árvores e colunas de iluminação. Sua abertura acarretou a demolição de aproximadamente 700 edificações. 0 traçado da nova avenida corta 21 ruas, alguns becos e parte dos Morros do Castelo e de São Bento. No total, são afetados 130 mil metros quadrados. (ATHAYDE, 1961, p. 100)

A construção da avenida representou, antes de tudo, um processo de expropriação ou segregação de determinadas frações sociais de uma área privilegiada, 'central', do espaço urbano, em proveito de outras frações sociais, atuando o Estado como executor do processo, através de mecanismos econômicos e jurídicos de expropriação e valorização. (BENCHIMOL, 1992, p. 228-229)

$\mathrm{Na}$ avenida, que se abre com 33m de largura, como os bulevares de Paris, ${ }^{42}$ instalam-se as principais casas comerciais, as sedes dos jornais, as grandes companhias, clubes, hotéis, e vários edifícios do governo, como o Palácio Monroe (1906), sede do Senado Nacional, a Escola Nacional de Belas Artes (1908) (Fig. 13), o Teatro Municipal (1909) (Fig. 14) e a Biblioteca Nacional (1910). São definidas três zonas distintas na avenida: a parte mais ao sul, da Avenida Beira-Mar até a Rua São José, abriga as edificações de estabelecimentos públicos, institutos e associações; no centro, entre as Ruas São José e General Câmara, estão as grande lojas de moda, confeitarias, cafés, jornais e bancos; e, na parte mais ao norte, da Rua General Câmara até a Praça Mauá, os comércios de importação e exportação, além dos grandes bancos do mercado financeiro.

O projeto e a construção estão a cargo da Comissão Construtora da Avenida Central (Fig. 15), cujo responsável, o Engenheiro Paulo de Frontin, já tinha em mente a ideia de abrir um bulevar no coração da Cidade Velha. Segundo Oswaldo Rocha (1995, p. 63-64), Paulo de Frontin esteve em Paris em 1902, e ficou tão impressionado com suas avenidas, que reproduziu 


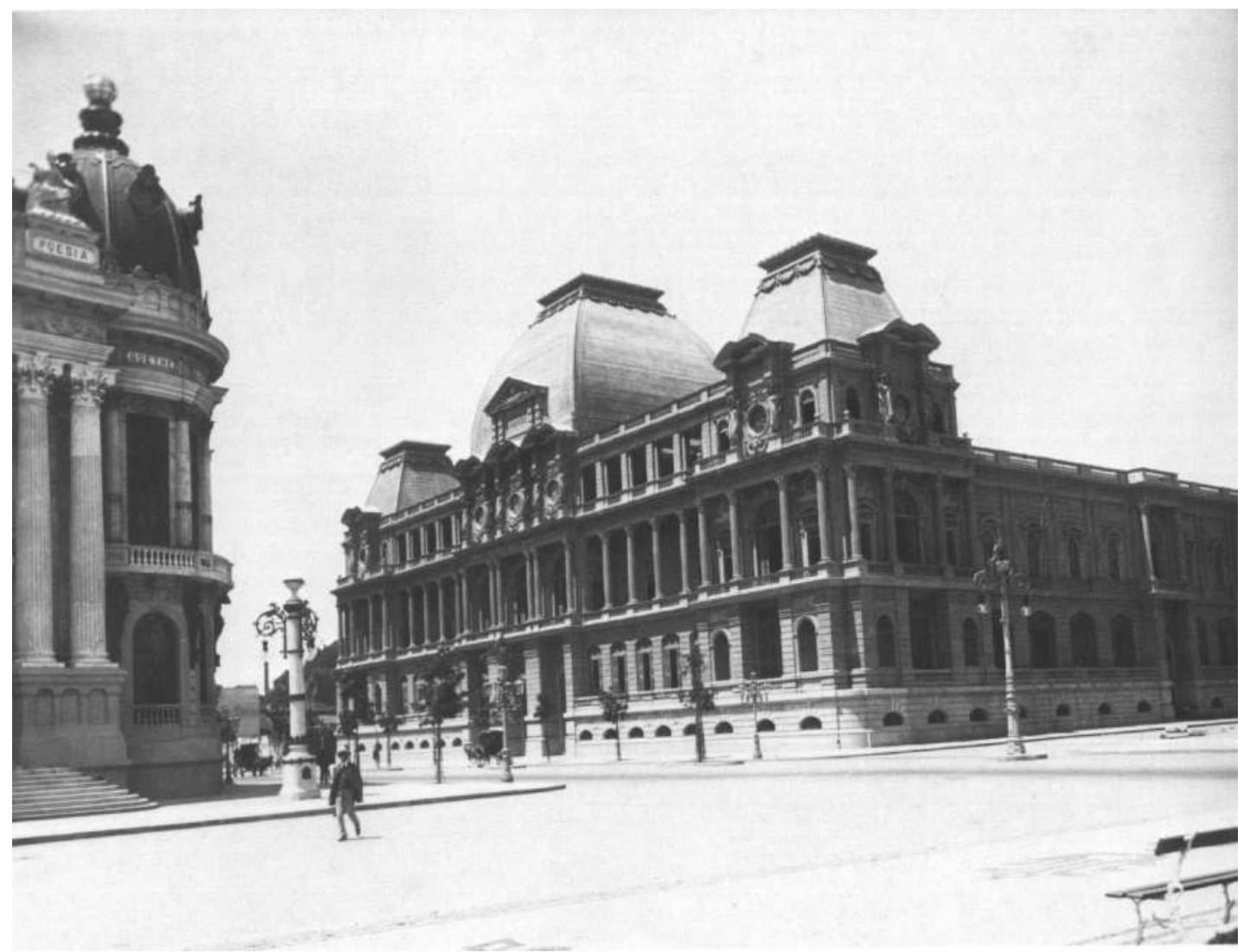

13. Escola Nacional de Belas Artes - foto de Marc Ferrz - 1910 


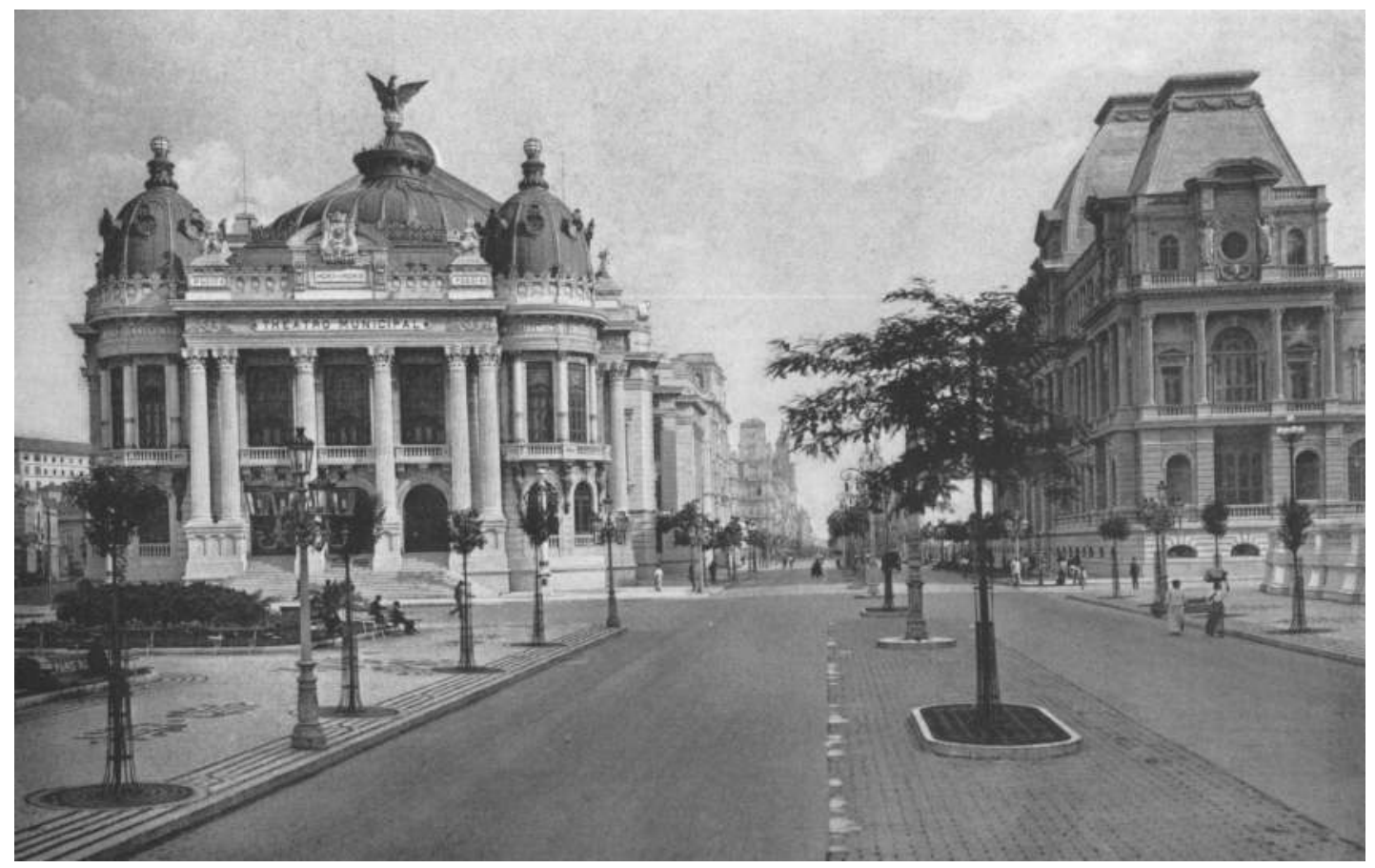

14. Teatro Municipal - foto de Marc Ferrez - 1910 
alguns de seus aspectos na Avenida Central. Uma legislação com influência claramente europeia é elaborada para as obras, e, nas construções, observa-se uma tendência de estilo belle époque. ${ }^{43}$ (Fig. 16)

O concurso de fachadas que se realiza pode ser comparado ao de Paris, em 1806, quando os arquitetos de Napoleão, Percier e Fontaine, projetam primeiro as fachadas e depois as plantas dos edifícios da Rue de Rivoli, da mesma forma como já havia acontecido na Place Vendôme, no final do século XVII. Como Haussmann, Frontin determina a altura e a largura de cada fachada, obrigando os arquitetos a submeter seus projetos a um júri. Apesar de existir liberdade de estilo, as fachadas da Avenida Central são um elogio ao ecletismo francês, uma expressão da École de Beaux-Arts. (NEEDELL, 1993, p. 62) Do concurso participam 107 inscritos com 138 projetos.

Maravilhosa e de grande aspecto com as numerosas construções de estilo, os magníficos palácios que a bordejam, sem deixar espaços vazios, que podem suportar a comparação com as mais esplêndidas avenidas das mais belas capitais europeias.

$[\ldots]$

Por toda parte, as construções que se elevam na Avenida Central são de estilos variados e todas de um belo efeito arquitetônico. (GEORLETTE, 1905, t. 29 , p. 451-452)

A Avenida Central é inaugurada no dia 15 de novembro de 1905, com pavimentação de asfalto, lâmpadas elétricas ao centro e lampiões a gás dos lados, com as calçadas concluídas, 30 edifícios acabados e 85 ainda em construção. Em cada uma das extremidades, encontra-se um monumento para obter boas perspectivas, como em Paris: ao norte, uma coluna com a estátua do Visconde de Mauá e, ao sul, um obelisco erguido em comemoração à sua conclusão. (Fig. 17)

A segunda obra executada pelo Governo Federal é a modernização do porto que, apesar de perder as exportações de café para o Porto de Santos, em São Paulo, recebe um incremento com o mercado de importações e o mercado costeiro, o que o converte no centro das operações com mercadorias estrangeiras. Suas instalações são antigas e precárias, além de ser muito estreito e pouco profundo, inadequado para receber os novos transatlânticos, que ficam ao largo e dependentes de um sistema de transbordo feito por embarcações menores.

A partir de meados do século XIX, o porto é objeto de preocupação por parte das autoridades brasileiras, devido às enfermidades que entram e saem através das embarcações, à precariedade de suas instalações e, finalmente, em função do aumento do movimento em seus cais, o que evidencia

\footnotetext{
${ }^{43} \mathrm{Em} 21$ de novembro de 1903 , Lauro Müller aprovou as instruções para o funcionamento da Comissão

Construtora da Avenida Central, conferindo-Ihe poderes para: organizar os projetos e planos da nova avenida, cuidando de todos os tipos de operação com as propriedades reloteadas, desapropriações, demolições, compras e vendas, permutas, cessões; dirigir as obras, quando realizadas por administração direta, e fiscalizá-las, quando realizadas por administração ou empreitada de terceiros; dirigir a venda dos materiais resultantes das demolições; estabelecer salários etc. A Comissão abre um concurso para projetos de fachadas para os prédios da nova Avenida em 27 de janeiro de 1904.
} 


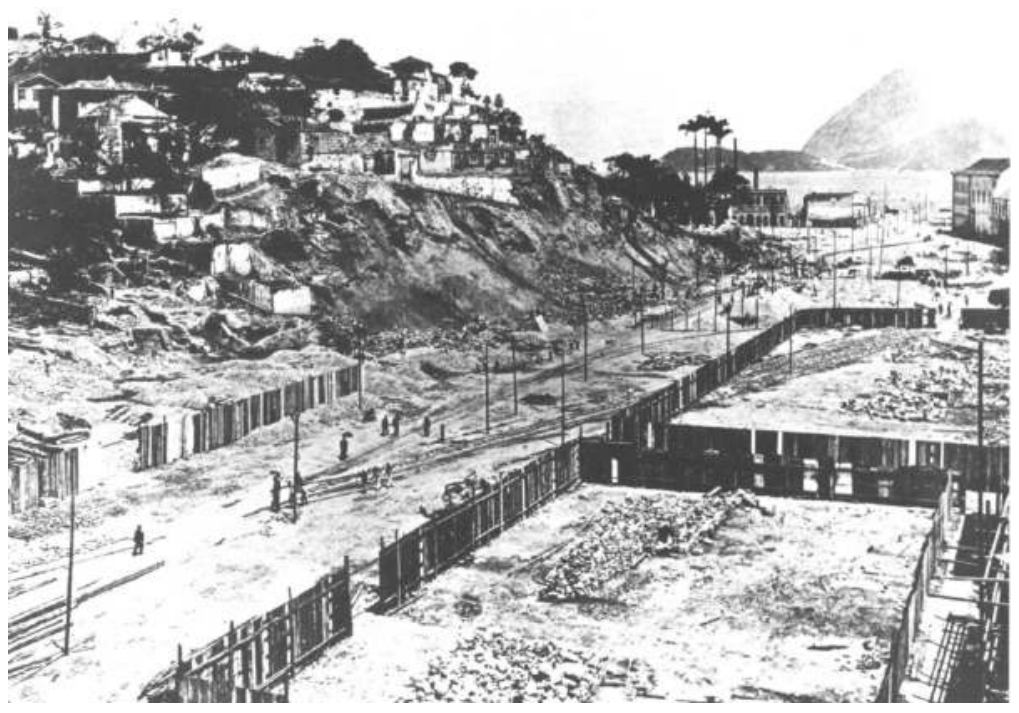

15. Obras de abertura da Avenida Central - foto de Marc Ferrez - 1904

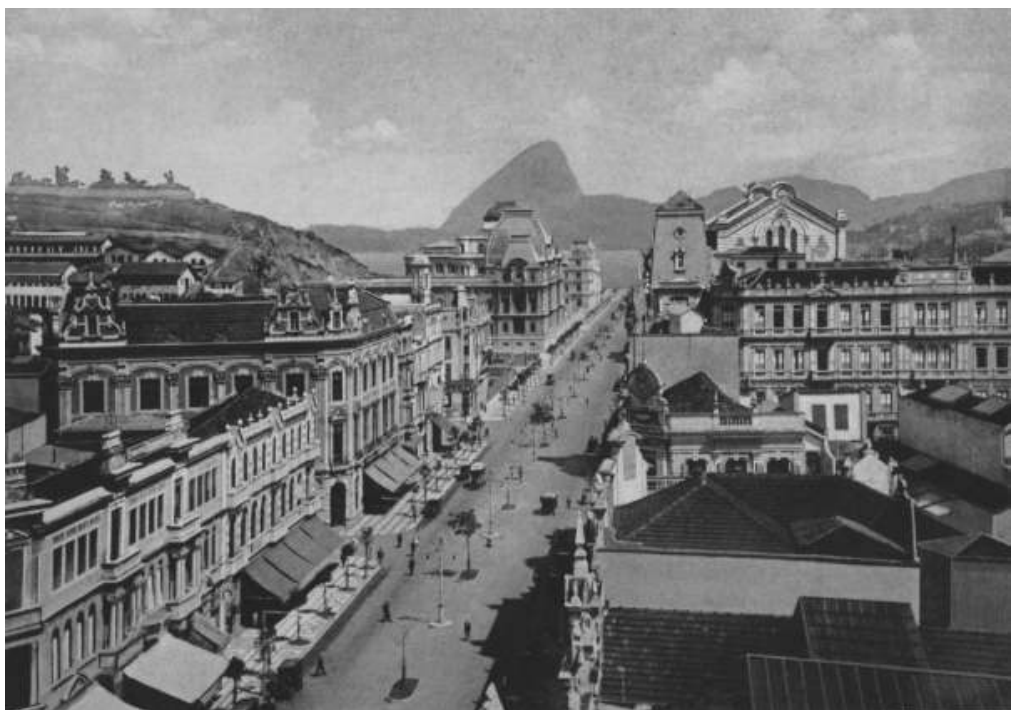

16. Avenida Central após a abertura - foto de Marc Ferrez - c.1910 


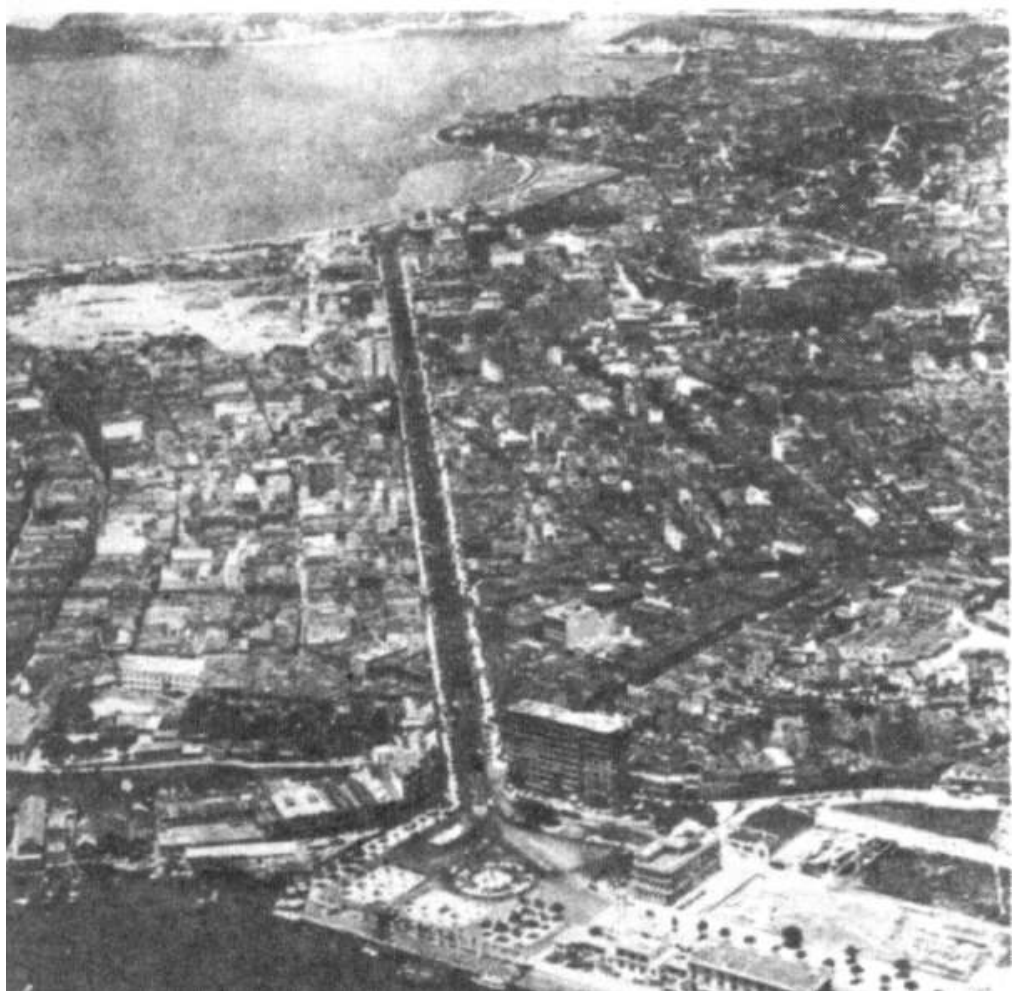

17. Vista do centro do Rio de Janeiro - 1930 
${ }^{44} \mathrm{~A}$ área que resulta dessa intervenção e do aterro divide-se numa faixa de $25 \mathrm{~m}$ de cais, onde os navios atracam diretamente com novas gruas elétricas e trilhos para trens; $25 \mathrm{~m}$ para a construção dos grandes armazéns, edifícios administrativos e outros complementares ao serviço do porto; uma avenida, a Rodrigues Alves, com $3.090 \mathrm{~m}$ de comprimento e $40 \mathrm{~m}$ de largura, com $14 \mathrm{~m}$ em cada uma das duas pistas, um refúgio central com $3 \mathrm{~m}$ para as árvores $\mathrm{e}$ a iluminação, um passeio com $5 \mathrm{~m}$ do lado do cais e com $4 \mathrm{~m}$ do outro lado. Da avenida para o interior, são construídas também duas séries de armazéns e uma linha de trens.

${ }^{45}$ Para o local do Morro do Senado, projeta-se um novo traçado viário, incluindo a Avenida Mem de Sá.

${ }^{46}$ Por onde passa a Avenida Central. Esse morro só será definitivamente derrubado nos anos 20 .

${ }^{47} \mathrm{~A}$ avenida tem uma extensão de $1.380 \mathrm{~m}$ por 95 de largura. No centro, fica o Canal do Mangue, com 23m e, de cada lado, duas pistas com $10 \mathrm{~m}$ de largura cada uma e um refúgio central arborizado com $6 \mathrm{~m}$. Os passeios laterais, arborizados com palmeiras imperiais do lado do canal e oitis do lado das edificações, medem 4,50m. a necessidade de uma reforma. A princípio, os trabalhos são orientados para a sua higiene, através da vigilância sanitária de mercadorias, das inspeções e da quarentena. Comissões estudam sua reforma. No que se refere a suas instalações, os estudos começam em 1880, com propostas e pedidos de concessão que são outorgados e adiados, sem saírem do papel.

$\mathrm{Na}$ luta pelas concessões para a reforma do porto, destacam-se duas importantes empresas. A Empresa Industrial de Melhoramentos do Brasil, presidida pelo Engenheiro Paulo de Frontin, obtém a concessão em 1890 para a construção de um cais entre o Arsenal da Marinha e o Saco do Alferes, e de outro da Ponta da Saúde até a Ponta do Caju. O projeto prevê um cais para atracação de grandes navios, armazéns, equipamentos modernos para carga e descarga, linhas férreas, serviços de gruas e uma artéria de ligação entre a Prainha e São Cristóvão.

Mais tarde, em 1899, a companhia britânica The Rio de Janeiro Harbour and Docks Company Limited obtém a concessão para a construção de uma enseada protegida ao sul da IIha das Cobras, com cais equipados de guindastes e elevadores hidráulicos, vias férreas, armazéns e depósitos. Em 1901, as duas empresas unem-se, formando a Companhia Docas do Rio de Janeiro.

Com a Presidência de Rodrigues Alves, seguem-se as negociações para a execução das reformas necessárias nas instalações portuárias. Em maio de 1903, é assinado o contrato de um empréstimo com a companhia inglesa Rotschild and Sons, para a execução das obras. A Comissão de Obras do Porto, responsável pelo desenvolvimento da reforma, sob a presidência do Engenheiro Francisco Bicalho, utiliza o projeto da Empresa de Melhoramentos do Brasil, com mudanças relativas à profundidade e ao alinhamento do cais. Com o projeto de um cais de $3.500 \mathrm{~m}$, o resultado do aterro da Baía de Guanabara são $175.000 \mathrm{~m}^{2}$, do Arsenal da Marinha até o Canal do Mangue, ${ }^{44}$ realizado com a terra do desmonte do Morro do Senado ${ }^{45}$ e parte da do Morro do Castelo. ${ }^{46}$

A articulação do porto com os demais pontos da cidade faz-se por ruas e avenidas abertas no tecido urbano. De uma das extremidades da Avenida Rodrigues Alves sai a Avenida Central, como já foi referido anteriormente, e, da outra ponta, sai a Avenida Francisco Bicalho, ${ }^{47}$ que é o resultado da retificação e do saneamento do Canal do Mangue, no sentido norte-sul.

Ao final da reforma, o porto articula-se com todas as áreas da cidade. A Avenida Rodrigues Alves conecta o porto com a zona industrial, em implantação, e com os eixos ferroviários, que se dirigem aos subúrbios; a retificação do Canal do Mangue e a Avenida Francisco Bicalho articulam o porto com a área industrial e o Centro; e a Avenida Central, além de unir o porto à Zona 
Sul, abriga as companhias marítimas, as atividades administrativas, comerciais e financeiras.

O novo Porto do Rio é inaugurado oficialmente, em julho de 1910, mas as obras não se concluem até 1911. (Fig. 18)

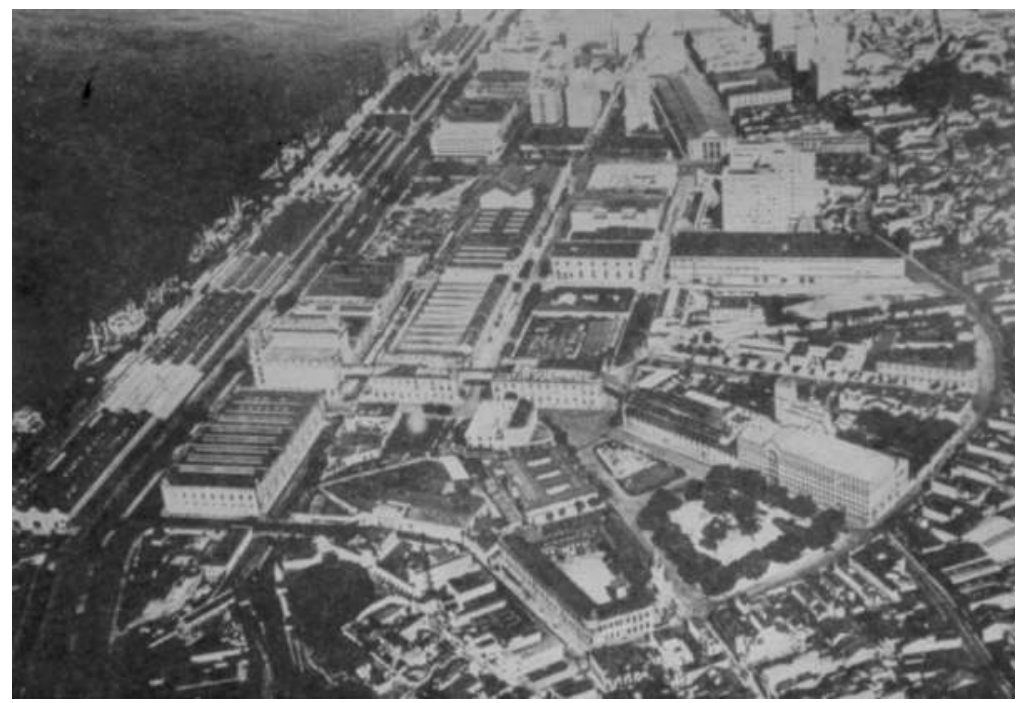

18. Vista aérea do Porto do Rio de Janeiro

\section{A interpretação da reforma urbana}

Três aspectos se destacam como os mais importantes da Reforma Passos. Ela constitui um exemplo típico de como uma nova conjuntura na organização social determina novas funções na cidade. É o primeiro exemplo de intervenção estatal na qual o urbanismo se reorganiza em novas bases, segundo as quais os pobres são expulsos da área mais valorizada da cidade. Finalmente, é uma demonstração de que a resolução das contradições do espaço gera outras novas contradições na organização social, como a nova estruturação espacial e a segregação social e funcional, a exemplo da formação das primeiras favelas, que se desenvolvem em consequência das reformas.

\section{Os argumentos da reforma}

O que existe de implícito nos discursos que justificam a reforma é uma condenação aos hábitos e costumes tradicionais, pelo receio de que qualquer traço da cultura popular possa "sujar" a imagem civilizada pretendida pela 
classe dominante. Há uma política de expulsão dos grupos populares do Centro, reservado, a partir de então, para desfrute exclusivo da burguesia, e a adoção de um cosmopolitismo agressivo, identificado com o modo de vida de Paris. (SEVCENKO, 1995, p. 30)

Como já foi analisado, os principais argumentos explícitos que o poder público e a elite utilizam para intervir no espaço urbano são o saneamento, a beleza e uma melhor fluidez de mercadorias e de pessoas. Essas são as expressões sempre presentes nos discursos formulados para a sociedade e que expressam e justificam a necessidade de intervenção nos espaços públicos e privados.

A boa circulação é sinônimo de controle da ordem, e o Poder Público deseja facilitá-la, extirpando do Centro todos os obstáculos existentes. O amontoamento é sinônimo de uma desordem que se expressa nos quiosques, na prostituição, nos jogos de rua. Sua eliminação, junto com os maus hábitos, os ruídos e os alvoroços é uma necessidade premente.

\footnotetext{
Este ato do 'progresso e da racionalidade' pressupunha eliminar os entraves espaciais à circulação de mercadorias e, por conseqüência, reorganizar o espaço urbano. E o espaço urbano criado e organizado pela hegemonia do capital mercantil se erguia como obstáculo. Ruas estreitas, vielas, becos, casario, armazéns e oficinas constituíam um aglomerado de formas urbanas incompatível com as novas demandas do capital na organização do espaço urbano. (BARBOSA, 1990, v. 2, p. 256)
}

O próprio espaço urbano é um obstáculo para a livre circulação. No Centro, as construções, os becos e os quiosques impedem o movimento dos novos meios de transporte e da nova população que dele deseja apropriar-se. Longe do núcleo central, há obstáculos naturais que precisam ser eliminados, como morros e pântanos, para a criação de novas áreas de expansão, novos lotes e novas vias que facilitem o crescimento da cidade nos sentidos sul e oeste.

As avenidas projetadas e abertas pelo Governo Federal e do Distrito Federal concorrem para tirar o tráfego do Centro, através das avenidas radiais, em direção aos novos bairros emergentes. Elas também permitem melhorar a circulação de mercadorias, através da vinculação entre o novo porto e as zonas suburbanas e industriais. No Centro, as ruas mais largas e retas facilitam o deslocamento da população e dos bondes. A grande artéria monumental, a Avenida Central, representa a nova cidade burguesa, pois nela os novos frequentadores do Centro exibem novas modas e novos hábitos.

Os meios de transporte estão incluídos também no projeto de reforma, para a garantia de uma melhor circulação. Os que já existem são melhorados, 
e as novas tecnologias são introduzidas, através dos bondes elétricos e dos automóveis. Cada vez mais, trabalhadores necessitam se deslocar entre suas residências e os locais de trabalho, o que aumenta a dicotomia entre o núcleo e a periferia, com uma cidade dividida social e funcionalmente.

A política higienista é um dos principais suportes argumentativos da reforma urbana, pois, em nome dela, destrói-se e derruba-se tudo que contraria seus pressupostos. A caracterização da área central, em comparação aos novos bairros que surgem na cidade, destaca sempre seus aspectos negativos. 0 Centro é identificado às cidades do Oriente, tristes e insalubres, ou a outras cidades marítimas, que têm suas ruas superpovoadas e imundas, cheias de habitações coletivas sem condições para abrigar um grande contingente de pessoas.

As casas populares são associadas à propagação de enfermidades e à insalubridade da cidade. As epidemias que surgem nos bairros pobres assustam a burguesia, que teme a propagação para seus espaços. Decorre daí o imperativo de limpar e desinfetar os espaços públicos, alargando ruas, alinhando construções, abrindo e arborizando praças. Ganha a Medicina Social, com seu discurso disciplinar de controle do espaço social e pessoal e de interferência na vida cotidiana do trabalhador, através de novos métodos de higiene pessoal e de vida.

Esse movimento de limpeza faz parte também de uma nova estética, pois há uma repulsa à arquitetura colonial, que representa o passado e dificulta a adoção de novos critérios urbanísticos. ${ }^{48}$ "Tudo o que não correspondesse aos padrões urbanísticos e arquitetônicos adotados em Paris, a partir de Haussmann, tendia a ser destruído, como símbolo do atraso." (REIS FILHO, 1994, p. 19)

O estilo oficial é o ecletismo historicista. A arquitetura recebe influência estrangeira, e o concurso de fachadas da Avenida Central dá o tom da nova arquitetura da cidade. As edificações dessa avenida representam a monumentalidade, e são projetadas com finalidades específicas, através das quais são reconhecidas. Contêm fortes elementos identificadores e são inspiradas em edifícios famosos, a exemplo do Teatro Municipal, inspirado na Opéra de Paris, ou a Escola Nacional de Belas Artes, ${ }^{49}$ inspirada nas alas de Lefuel e Visconti do Louvre.

Além dos argumentos da beleza, fluidez e saneamento, outros podem ser depreendidos, apesar de não tão explícitos, nos discursos dos governantes e interessados na realização da reforma urbana do Rio de Janeiro. Na expressão "embelezamento", por exemplo, presente em todos os discursos de apoio às

\footnotetext{
48 Uma nova estética possibilita a negação da história local e a inserção na história ocidental.

${ }^{49}$ Hoje Museu Nacional de Belas Artes.
} 
${ }^{50}$ Alguns exemplos nacionalistas são as crônicas de Lima Barreto, publicadas em jornais da época, que retratam os primeiros anos da República, o exercício do poder, as questões democráticas e o direito à cidadania.

${ }^{51}$ Um exemplo é a Pequena África, na Cidade Nova, um reduto de negros e nordestinos, com alternativas concretas de vizinhança, de vida religiosa, de arte, trabalho, solidariedade e consciência. reformas projetadas para a cidade, percebe-se que a referência não é apenas à estética ou ao valor arquitetônico da nova imagem da cidade, capital do País, mas aos valores de uma nova população, seus hábitos, a novas funções e novas exigências de acumulação e circulação do capital comercial e financeiro.

Revoltas, motins, greves e alvoroços marcam os primeiros anos da República. Nesse contexto, é preciso controlar a "classe perigosa" e restaurar a ordem pública, e esses também são argumentos que justificam as intervenções no tecido urbano. A "boa sociedade" vê esse segmento da população como remanescente do passado colonial e escravista, o qual quer esquecer, por considerar que o povo, com sua cultura própria, seus hábitos, seus ritmos e seus tipos, distancia-se em muito da estética "parisiense" que se pretende adotar. A "boa sociedade" considera, ainda, que a miséria é abrigo da criminalidade, devendo ser escondida, com os pobres distanciados desse novo contexto urbano que se inaugura.

Toda a transformação e todos os esforços para deixar no esquecimento a sociedade do passado contribuem para a "europeização" da cultura do Rio. Com a penetração dos novos valores culturais e a importação de uma cultura estrangeira, ficam latentes os antigos valores e a identidade cultural do passado. ${ }^{50}$

O Centro [...] é, a partir da reforma Passos, entregue às grandes companhias, aos bancos, jornais, hoteis, cafés de luxo e repartições públicas - e a Zona Sul - que avança do tradicional bairro de Botafogo para Copacabana e Ipanema, onde se constróem as novas casas da elite com sua infra-estrutura de serviços e abastecimento -, definitivamente se modernizam de acordo com os padrões de grande cidade ocidental moderna, mas as contradições sociais geradas pelo seu encontro com a outra cidade que dariam ao Rio de Janeiro um caráter próprio, pelo qual ficaria conhecido e mesmo dubiamente cultuado. (MOURA, 1995, p. 49)

Entretanto, esse processo de "eliminação" do passado gera algumas resistências. Enquanto alguns são desalojados e veem suas vidas desarticuladas, outros resistem e mantêm suas tradições, sua cultura e sua própria identidade. 0 esforço de modernização e de enquadramento da população nos parâmetros definidos para a vida numa cidade moderna não impede que alguns continuem vivendo sob suas próprias leis e costumes. O Centro muda, assemelhando-se a uma cidade europeia, mas, em seu entorno, a população expulsa do Centro mantém suas relações e suas tradições. ${ }^{51}$ 


\section{Depois da reforma ${ }^{52}$}

Ao final do período da Reforma Passos, a cidade tem um novo desenho, com uma nova hierarquia de espaços físicos e sociais. São novos habitantes, em novas áreas: uma área central, zonas industriais, áreas de lazer e bairros residenciais diferenciados. Essa nova organização do espaço urbano, com as áreas de trabalho separadas das residenciais, é defendida por sanitaristas e urbanistas. Desse modo, as intervenções servem como meio de depuração socioespacial, gerando uma reconfiguração do Centro, não mais caracterizado como área residencial e de circulação da população de baixa renda.

Essa nova distribuição espacial aponta para uma inversão de polaridade. A cidade da República dá as costas ao Palácio Imperial. O desenvolvimento da cidade, que antes se voltava para o interior, onde se localiza o Palácio Imperial, muda em direção às praias, onde antes se jogavam os dejetos. A área das praias, com seu ar mais saudável, começa a ser valorizada e a atrair uma população mais abastada, enquanto que o interior, para onde vão os trens, converte-se em zona industrial e residência do proletariado.

Pouco antes da reforma, o Estado e os capitalistas contribuem para a nova distribuição espacial da cidade. Exemplo disso é o caso de Copacabana, Ipanema e Leblon, com a implantação de sua infraestrutura (Fig. 19 e 20), enquanto que, mesmo depois da reforma, os subúrbios continuam sem pavimentação nas ruas, sem infraestrutura nem áreas de lazer, reservadas ao Centro e aos bairros da classe alta e média. (SOLIS; RIBEIRO, 1985, p. 48-50; ABREU, 1988)

Uma nova cidade, com novas construções e novos atores, com um estilo francês da belle époque, não pode conviver com a antiga população da cidade colonial. O Rio agora é uma cidade capitalista, onde não há lugar para os pobres. Todos os personagens que se afastam dos novos padrões exigidos, que não estão de acordo com o novo décor, são proibidos de circular. Separam-se, portanto, os espaços de circulação para os diferentes grupos sociais.

E os mendigos saem de cena rapidamente [...] do centro da cidade remodelada. Nela, imago de um país que se sonha em sintonia com o cosmopolitismo europeu, o capitalismo liberal e a modernidade, não cabem - senão à margem ou como mal a ser extirpado - trabalhadores, imigrantes, negros, mendigos e desempregados. Assim como casebres, pardieiros e ruelas. Ou qualquer outro elemento capaz de quebrar a tensa harmonia dessa miragem cosmopolita. (SÜSSEKIND, 1986, p. 57)

A reforma traz como consequência a exclusão das classes subalternas, da classe trabalhadora e de baixa renda, dos benefícios da urbanidade e dos

\footnotetext{
52 As obras previstas na administração de Pereira Passos têm continuidade com seus sucessores, sendo finalizadas na administração do Prefeito Serzedelo Correia - 1909-

1910. Mas seus efeitos se fazem sentir muito antes de estarem totalmente finalizadas.
} 


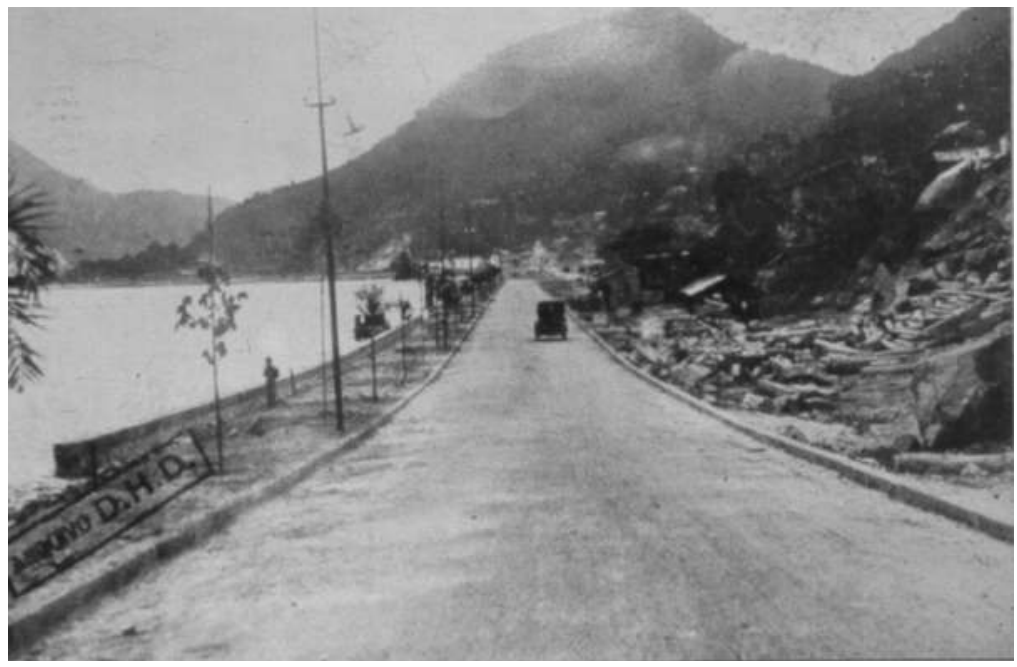

19. Lagoa Rodrigo de Freitas - foto autor desconhecido - início século XX

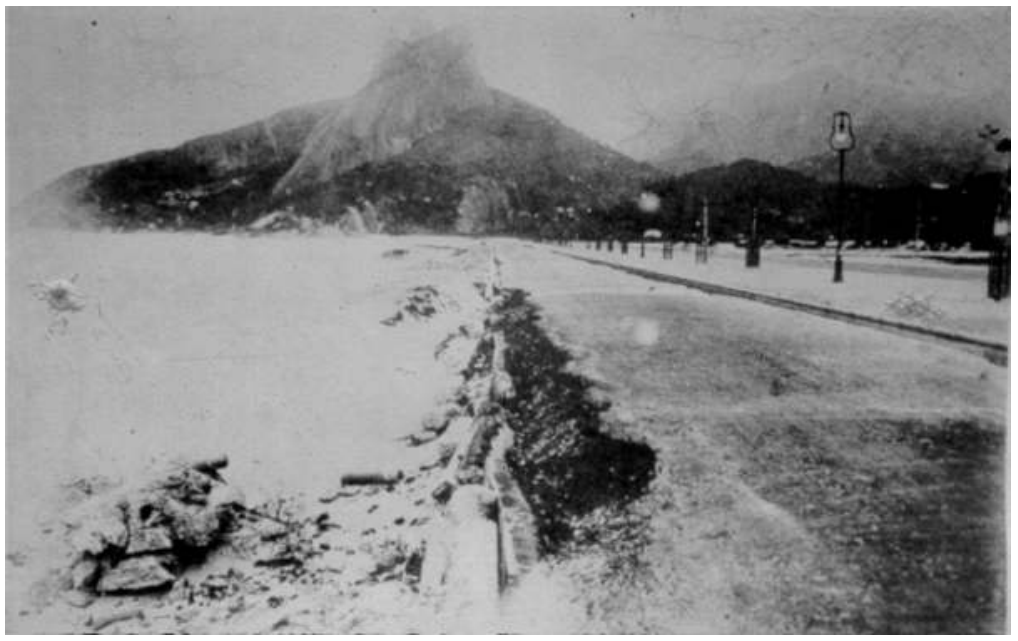

20. Praia do Leblon - foto autor desconhecido - início século XX 
direitos à cidadania. As maravilhas da capital constituem privilegio de uma minoria e da burocracia do Estado. Os trabalhadores moram mal, vivem mal, não fazem parte do novo projeto político e econômico da cidade.

Os bairros são classificados de acordo com o nível socioeconômico e o tipo de atividade de seus moradores. 0 proletariado ocupa as zonas suburbanas, ou os morros ${ }^{53}$ perto do Centro, enquanto que a classe abastada se apropria das zonas norte e sul. O núcleo central perde sua característica residencial, mas seu entorno mais imediato continua abrigando as moradias dos trabalhadores e da população de baixa renda. A área da Cidade Nova mantém, pois, seus cortiços e suas casas de cômodo.

A proposta de 'se civilizar' de um setor dominante da população, associada à sua necessidade de mão-de-obra barata para os objetivos e a manutenção 'do progresso', definia na prática uma nova ecologia social na cidade, um novo Rio de Janeiro subalterno, não mais o dos escravos, mas o das favelas e dos subúrbios que se expande em proporções inéditas, que se forma longe do relato dos livros e dos jornais, afastado e temido, visto como primitivo e vexatório. A cidade se reforma. A cidade se transforma. A cidade se transtorna.

O Rio de Janeiro moderno. (MOURA, 1995, p. 61)

Muda a cidade, muda o Centro, mas não muda o local de trabalho de uma parte da população expulsa de seus lares. Uns se mudam para a periferia, alguns disputam uma vaga num cortiço nos arredores do Centro e outros se apropriam de áreas livres perto de suas antigas residências, nas encostas dos morros, perto do centro - nas favelas. "A favela se ergue, então, como um contraprojeto de resistência dos dominados frente aos estratagemas sócio-espaciais dos dominantes." (BARBOSA, 1990, v. 2, p. 223)

Surgem as favelas, reeditando as antigas condições de sobrevivência, perto do Centro e dos bairros da classe abastada, que necessita da sua população para os trabalhos domésticos, única herança da escravidão que deseja manter.

\section{Os modelos da reforma urbana}

A Reforma Passos pode ser comparada aos trabalhos levados a cabo por Haussmann, na Paris do Segundo Império, entre 1853 e 1870, considerados por muitos autores como modelo utilizado em diversas cidades do mundo. Nessa perspectiva, algumas questões podem ser levantadas. Trata-se da

\footnotetext{
${ }^{53}$ A primeira ocupação das encostas de um morro acontece em 1893, no Morro de Santo Antônio, mas só a partir da ocupação do Morro da Providência ou da Favela é que o termo favela difundiu-se pela cidade.
} 
adoção plena de um modelo urbanístico, ou apenas da semelhança na forma utilizada para a sua implantação? Os problemas urbanos do Rio de Janeiro podem ser comparados com os de Paris? Se os problemas são diferentes, pode-se utilizar um mesmo modelo para resolvê-los?

Como foi visto anteriormente, diversos projetos de intervenção no Rio são elaborados ainda no século XIX, alguns, inclusive, em momentos anteriores ao das obras de Haussmann, embora com objetivos e propostas muito semelhantes aos do projeto de Pereira Passos.

\section{Uma revisão}

Quem primeiro compara o Prefeito Pereira Passos com Haussmann é o Ministro de Assuntos Exteriores do governo do Presidente Rodrigues Alves, o Barão do Rio Branco, que o qualifica de "Haussmann brasileiro". (CRULS, 1949, p. 451) Surgem, depois, outras denominações, como "Haussmann tropical", e a qualificação do Rio como "Paris da América". (DEL BRENNA, 1985b, p. 9)

É indiscutível a influência parisiense na Reforma Passos entre 1902 e 1906, mas não podemos esquecer que o predomínio da cultura francesa sobre o Rio remonta a princípios do século XIX. Desde a chegada da Missão Francesa e de Grandjean de Montigny, encontramos sinais dessa influência, a exemplo da compreensão do papel da praça como elemento de composição monumental e das ruas retas e ordenadas.

Margareth Pereira (1995, p. 143) afirma que, o Rio e Paris se unem mais a partir do ano de 1870, quando as exposições internacionais divulgam as técnicas e a cultura moderna. E o Rio, em crise com seu passado colonial, busca, na Europa, o exemplo de embelezamento. A admiração por Paris está presente no espírito da época, pois ali se encontra um modelo de civilização. Esse "modelo", francês, ou europeu, tem como suporte ideológico o discurso da modernização, contraponto ao "atraso" da sociedade e da cidade do Rio.

A respeito da intervenção prática que se produz entre os anos 1902 e 1906, diversos autores analisam o processo, o plano e suas formas de implantação, além das outras intenções que existem subjacentes ao projeto.

Com relação ao plano urbanístico em si, Giovanna Del Brenna (1985b, p. 8) afirma que o projeto realizado por Pereira Passos para o Rio não passa de uma montagem de planos e propostas anteriores, com alguns ajustes, mudança de traçados e novas orientações. 0 projeto do porto baseia-se no da Cia. de Melhoramentos do Brasil, elaborado entre 1890 e 1900; o da Avenida Central repete alguns projetos anteriores, com diversos traçados; 
o programa de melhorias da Prefeitura não é nada mais do que o da Comissão de 1875 , com pequenas modificações e a introdução de novos elementos, em função de críticas recebidas, como por exemplo, o projeto da Avenida Beira Mar, ideia de Antônio Rebouças, no século XIX.

A mesma autora, em outro de seus trabalhos (DEL BRENNA, 1985c, p. 249-250), afirma que o projeto de 1875 - segundo ela, base do de 1902 - é influenciado pelos trabalhos de Haussmann, uma vez que Pereira Passos assiste a algumas de suas intervenções entre 1857 e 1860. Atribui essa influência francesa nas ações da administração de Pereira Passos ao fato de ter ele assistido às intervenções haussmannianas, quando vivia em Paris como diplomata da delegação brasileira, momento em que se executavam algumas das mais importantes aberturas parisienses, como o bulevar Sébastopol, além de ter estudado na École des Ponts et Chaussés. Considera a Avenida Central, que corta a cidade de norte a sul, como a artéria monumental, comparando-a com a Avenida de Mayo, de Buenos Aires. Para a autora, o projeto inspira-se, quanto a conceito e método, na intervenção de Haussmann.

Fica clara, pelo menos na opinião de alguns autores, essa vinculação, já que o projeto elaborado em 1875 contém elementos muito evidentes de influência da abertura das ruas francesas. Em 1903, a influência persiste, apesar de haver, entre um período e outro, a divulgação de novas e numerosas teorias urbanísticas. ${ }^{54}$ Também não julgamos haver influência da Paris do princípio do século XX, pois as ideias de Eugène Hénard ${ }^{55}$ só são divulgadas a partir da sua publicação, em 1903, quando as obras do Rio já estão sendo realizadas.

Jeffrey Needell (1993, p. 55-58) afirma que a inspiração em Hauss-

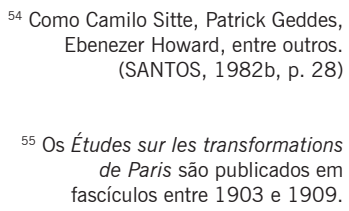
Ebenezer Howard, entre outros. (SANTOS, 1982b, p. 28)

${ }^{55}$ Os Études sur les transformations de Paris são publicados em fascículos entre 1903 e 1909. mann é consciente e bem fundamentada, decidida por um grupo de profissionais. Segundo o autor, documentos do engenheiro da reforma do Rio e publicações da época confirmam a importância de Haussmann, não só para Pereira Passos mas também para seus companheiros que participam das reformas. Needell, na sua análise, compara as ações da reforma do Rio às das obras parisienses. A demolição da Cidade Velha é comparada à destruição dos bairros proletários de Paris, efetivada por Haussmann. A melhoria da iluminação e da ventilação, por meio de ruas mais largas e novas vias, é parte fundamental nas duas reformas. Outra característica comum aos dois planos é o sistema viário, composto por ruas e avenidas que conduzem o tráfego dos limites da cidade até o Centro, e de outras que eliminam o tráfego no Centro.

O autor, na mesma obra, também cita o princípio das places-carrefours, ao considerar como tal alguns dos cruzamentos de avenidas do Rio, como os das extremidades da Avenida Mem de Sá, no cruzamento com a Rua Frei 
${ }^{56}$ Pensamos que não se pode "considerá-las como" ou "comparálas com" as places-carrefours, pois são simples cruzamentos de ruas ou como a Praça Mauá, um ponto final, onde termina uma avenida e começa outra, em outro sentido. As praças a que se refere o autor, não têm a forma nem a função das place-étoiles, tão conhecidas em Paris, como a Place Charles de Gaulle ou a Place de la Nation.
Caneca ou, no outro extremo, com a Avenida Beira-Mar e a Avenida Central, e o da Praça Mauá, onde as Avenidas Central e Rodrigues Alves se encontram. Compara ainda o grande cruzamento de Paris ao cruzamento da Avenida Central com a Rua Visconde de Inhaúma, duas avenidas que cortam o Centro e se encontram em ângulo reto. ${ }^{56}$

Norma Evenson (1973, p. 37-38) compara os dois projetos e observa que, em ambos os casos, o que mais se distingue são as avenidas monumentais, abertas depois da expulsão da população, das demolições e reconstruções. Comenta que o projeto de Haussmann inclui melhorias tecnológicas e modernizações, e o de Pereira Passos, uma reorganização geral da urbe; mas os dois são conhecidos por seus bulevares, largos, retos e arborizados - símbolos da modernidade e nova área da burguesia. A autora acrescenta que Pereira Passos se baseia não só no projeto e nas obras de Haussmann, mas também na forma ditatorial pela qual se vale para realizar seus planos, eliminando qualquer obstáculo, mesmo que para isso seja preciso dar as costas a uma população que fica órfã na cidade.

Bruand (1981, p. 334) considera que a obra de Pereira Passos não é um trabalho de urbanismo e afirma ser evidente a influência do modelo haussmanniano sobre ela. Faz uma análise de como as transformações permitem ao Rio um novo começo.

É indiscutível a imitação de Haussmann: mesma atividade transbordante, mesmo renome cuidadosamente cultivado de destruidor sistemático e sem escrúpulos [...], mesmo princípio das grandes artérias com árvores, arrasando impiedosamente tudo que estava no caminho e desembocando nos monumentos que servem como perspectivas finais; chegou-se até a retomar, para a largura da Avenida Central, peça chave do dispositivo, as dimensões dos bulevares parisienses (33 metros).

O historiador José Murilo de Carvalho (1987, p. 40) afirma que as obras de saneamento e embelezamento da cidade são executadas com a eficiência e a rapidez permitidas pelo estilo autoritário e tecnocrata inaugurado no Brasil pela República, estilo também adotado em Paris ainda no século XIX.

Pereira Passos não mede esforços nem se intimida ante as críticas e os ataques dos insatisfeitos ou dos prejudicados por suas ações. Tem apenas quatro anos para transformar a velha cidade colonial numa nova cidade moderna. Com todos os seus poderes, destrói e reconstrói a cidade segundo sua vontade.

No projeto de Haussmann, uma das estratégias básicas é a neutralização do proletariado revolucionário de Paris, que utiliza a estrutura urbana em 
seus motins. As ruas largas e retas, além de melhorar a circulação, facilitam o deslocamento das tropas, se necessário. "A Reforma Haussmann tornou-se 'o modelo dos modelos' de intervenção na estrutura urbana quando a luta de classes tornava-se acirrada e o urbano assumia a dimensão política dos confrontos abertos pelas insurreições proletárias." (BARBOSA, 1990, v. 2, p. 209).

No caso do Rio, subjacente a todo o discurso de modernidade e higiene, existe a decisão de tirar o proletariado do Centro e devolvê-lo à elite, renovado e valorizado, para seu desfrute. Em verdade, suspeita-se que a forma de vida dos pobres e sua concentração em determinada área possam gerar uma revolta, que são perigosos e que, portanto, devem ser dispersados, para desarticular uma possível manifestação popular. Barbosa (1990) afirma ainda que o caso do Rio não é uma transposição do modelo de Paris, mas a tradução de uma estrutura urbana que vai se tornando universal.

Não se pode negar que o caso do Rio tem uma particularidade. Enquanto, em Paris, Haussmann ataca a era das revoluções, ao incluir, em seus planos de eficiência, saúde e beleza, intenções de natureza contra-revolucionária, contra os baluartes da classe trabalhadora, no Rio, Pereira Passos golpeia a tradição da sociedade da casa-grande e dos sobrados, atacando os baluartes de um ambiente e de uma cultura afrobrasileira.

\section{Um comentário a mais}

Pode-se dizer que as reformas - tanto a de Paris como a do Rio - são conhecidas por suas novas avenidas, largas, arborizadas, abertas no centro da cidade, desvalorizado e abandonado, lugar de concentração de uma população pobre, sem higiene, foco de epidemias e de rebeliões.

As intervenções que se realizam em Paris são conhecidas como haussmannização, termo que reflete o aburguesamento da cidade, a produção de um conjunto coerente, construído sob o princípio da harmonia racional, uma forma urbana nova e original distinta da cidade clássica, ${ }^{57}$ ou colonial no caso do Rio. Sob essa ótica, concorda-se que o Rio passa por uma haussmannização, passa por um processo de aburguesamento da cidade, sob o comando de Pereira Passos à frente da Prefeitura.

Outras comparações são possíveis. Quanto aos objetivos das reformas, em Paris há o propósito de transformar a cidade na grande capital de um Império, destinado a expandir-se, valorizando sua vocação comercial e financeira. No Rio, o objetivo é transformar a cidade, para que assuma sua posição de capital de uma nova República, que quer esquecer seu passado colonial e inserir-se no capitalismo internacional, retomando sua hegemonia como
57 Segundo Marchand (1993), a cidade clássica define-se por um tecido variado, feito com retalhos, sem conexão uns com os outros, sem controle, com as construções erguidas sem normas, pondo um palácio ao lado de um casebre. 
cidade capital mais importante da América do Sul, com vocação financeira e comercial, centro de importação e exportação.

Nos dois casos, o projeto da rede viária é esquemático, sem vinculação direta com a cidade existente. As novas avenidas rasgam ruas, becos, praças e construções, formando uma nova rede viária, que se superpõe à antiga. Aproveitam-se algumas vias nesse processo, mas altera-se a largura e retifica-se ou modifica-se o seu traçado. Como elementos novos que se incorporam a um tecido já existente, as mudanças são realizadas somente nas novas ruas; as outras permanecem da mesma forma, com seu aspecto e seus traçados. Há, de todas as formas, uma clara intenção em fazer com que, no Centro, se consolidem as funções comerciais, financeiras e administrativas, ao lado das funções de lazer num espaço novo, com árvores, largas calçadas, cafés, modernas lojas, teatros e outros equipamentos de entretenimento.

Em outras partes da cidade, há uma nova orientação de funções, com a valorização dos bairros residenciais, providos da infraestrutura necessária. No caso do Rio, assim como no de Paris, pode-se dizer que, nos bairros burgueses e de classe alta, os benefícios são implantados muitas vezes antes da chegada dos novos habitantes; enquanto isso, os bairros proletários devem esperar sua vez.

A facilidade de circulação de pessoas ou de mercadorias, na cidade, é um ponto importante nos dois projetos. Em Paris, as gares - portas de entrada da cidade - são o meio de comunicação da capital com as demais províncias da França e com os outros pontos da Europa. No novo traçado das ruas, a conexão entre as gares tem um alto grau de importância, a mesma que têm as avenidas do Rio na conexão do porto com as zonas industriais, comerciais e financeiras. Aqui, a atividade econômica e uma boa circulação de mercadorias dão o tom fundamental da nova rede viária.

Outro ponto em comum entre a reforma de Haussmann e a de Pereira Passos é que ambas decorrem de projetos de terceiros. Em Paris, Napoleão III é o autor do projeto de abertura de ruas, e entrega a Haussmann um plano da cidade com as novas vias desenhadas em cores, segundo a prioridade. O plano de transformação do Rio é uma mistura de projetos anteriores, com complementos feitos por engenheiros do Governo Federal, como Paulo de Frontin e Francisco Bicalho.

Das diferenças entre os planos, destaca-se o espaço onde se produzem as intervenções. Paris é uma cidade amuralhada, uma cidade já construída, que, através de um plano de reforma, muda sua estrutura viária, funcional e espacial, redistribuindo sua população e hierarquizando seus espaços. No 
Rio, apesar das transformações na área central, há um novo alinhamento no crescimento urbano, um plano de expansão, com a inclusão, na nova estrutura urbana, de bairros ainda inexistentes, ou áreas quase desertas. A nova estrutura viária, funcional e espacial expande-se para fora do núcleo central, tornando fundamental a participação de novos meios de transporte e de empresas concessionárias dos serviços públicos.

Não discutimos ou discordamos da importância de Paris como modelo para o Rio de Janeiro, tampouco da influência de Haussmann sobre Pereira Passos. Mas acreditamos que o projeto do Rio não se resume a uma haussmannização.

Analisando os planos de Grandjean de Montigny, de Beaurepaire Rohan, da Comissão de 1875 e algumas das propostas pontuais do final do século XIX, percebe-se que muitas das obras realizadas por Pereira Passos já estavam ali concebidas. Durante todo o século XIX, as discussões em torno do urbano demonstram a necessidade de mudanças estruturais, de intervenções que só precisavam de condições para ser implantadas, condições políticas e financeiras.

São essas as condições de que dispõem os dois prefeitos, com uma total liberdade de ação para a implementação dos planos, mesmo que de forma ditatorial. Essa forma de impor as decisões e a brutalidade dos trabalhos são condições sine qua non para levar adiante o projeto de remodelação da cidade do Rio, esteja ele baseado ou não nas obras de Haussmann. O que há de semelhante nas obras do Rio e de Paris é o apoio das classes dominantes e a consequente dispersão da população que habita no Centro.

Entre 1853 e 1870, Paris já é uma cidade consolidada, com sua própria história, uma grande cidade, que já tem mais de um milhão de habitantes em 1850, e um importante centro econômico e cultural da Europa. O Rio, entretanto, em princípios do século XX, ainda é uma cidade que está por se fazer, com uma população, em 1906, de 811.443 habitantes. (CHALHOUB, 1986, p. 25-26) Sua pequena história envergonha a classe dominante, que busca, nas cidades já consolidadas, exemplos que permitam transformá-la, de forma a ser reconhecida por seus próprios méritos. Ao final, ela obtém êxito. Depois da Reforma Passos, o Rio passa a ser conhecido no mundo como a Cidade Maravilhosa. 
${ }^{58}$ Charles Edouard Jeanneret Gris Le Corbusier - formado pela Escola de Arte de La Chaux-de-Fonds, especializado em Arquitetura. Em 1922, apresenta seu estudo de urbanismo Ville Contemporaine pour trois millions d'habitants e, em 1925 o Plan Voisin para Paris.

${ }^{59} \mathrm{O}$ concurso para a nova sede do Chicago Tribune acontece em 1922 com a participação de 265 arquitetos de 23 países. 0 projeto vencedor, uma torre neogótica de autoria dos norte americanos John Mead Howells e Raymond Hood, foi construído na Michigan Avenue em 1923-5. (HITCHCOCK, 1993, p. 514)

${ }^{60}$ Agache, junto com Louis Bonnier e Marcel Auburtin, são os fundadores da Société Française des Architectes Urbanistes, criada em 1913. Em

1917, são professores da École d'Art Public, onde ensinam os princípios da organização de cidades e da formação de urbanistas. Sua formação é a da École des Beaux-Arts de Paris, onde termina seu curso em 1905. Agache participa da Société des Architectes Diplômés par le Gouvernement e integra a comissão organizadora do concurso para o projeto da nova capital do Equador, New Guayaquil. Também é membro do Musée Social de Paris e colabora nos trabalhos da Section d'Hygiène Urbaine et Rurale do Museu desde 1909. Sob a direção de Eugène Henard, e com o Arquiteto Henri Prost, contribui para o desenvolvimento do plano de Paris depois da demolição das fortificações entre 1909-1910. Os debates giram em torno de questões relativas aos espaços verdes e da regulamentação dos planos de ordenação e extensão. Para o estudo da trajetória de Agache Ver Bruant $(1994,1996)$.

\section{Outros projetos}

Acaba o período Pereira Passos e sua reforma urbana no Rio, mas não se encerra a fascinação que Paris e a França despertam na sociedade carioca. A segunda década do século XX não se caracteriza como um período de grandes intervenções no urbano, mas não significa que se tenha deixado totalmente de pensar a cidade e seus problemas. É na década de 20 que o Rio, uma vez mais, volta a ser o centro das atenções. Seu espaço urbano sofre drásticas cirurgias como, por exemplo, a conclusão do desmonte do Morro do Castelo. É ainda nessa época que renomados arquitetos e urbanistas convidados propagam soluções para a cidade.

Apesar de temas relativos às metrópoles europeias e norte-americanas estarem nos congressos e nas publicações, e de essas informações circularem pelo Brasil, a importância dos franceses no debate sobre a cidade continua tendo muita relevância na década de 20. (PEREIRA, 1996, p. 367-368) Com relação aos arranha-céus, são mais frequentes as referências à Ville Contemporaine pour trois millions d'habitants de Le Corbusier ${ }^{58}$ que ao Chicago Tribune, ${ }^{59}$ dos Estados Unidos.

Em finais da década de 20, Alfred Agache, ${ }^{60}$ arquiteto-urbanista francês, realiza um projeto de expansão, renovação e embelezamento para a cidade do Rio, segundo os princípios da Beaux-Arts, com claras influências do City Planning americano. Também segue o modelo haussmanniano, pois as avenidas que propõe têm relação com aquelas referidas no plano de Daniel $\mathrm{H}$. Burnham e Edward M. Bennet para Chicago e com o movimento City Beautiful, considerado como uma reinterpretação de Haussmann e Paris, feita pelos norte-americanos.

Le Corbusier, em 1929, passa pelo Rio e deixa o croqui de um projeto de ordenação para a cidade, baseado em quatro princípios fundamentais: o descongestionamento do centro da cidade; o aumento da densidade populacional; a ampliação dos meios de circulação; e a ampliação das áreas de parque. Seu projeto compõe-se de um edifício-viaduto, que cruza a malha urbana por cima das edificações existentes e que tem como jardim as encostas das montanhas e como panorama a Baía de Guanabara.

Com esses dois franceses, ou, melhor dizendo, um franco-suíço e um francês, podemos afirmar que se encerra uma etapa da influência do modelo urbanístico francês, e começa outra etapa, influenciada pelo modelo norte-americano e seus arranha-céus, influência que já se pode encontrar nos 
desenhos de Agache para a Esplanada do Castelo, área resultante do desmonte do morro de mesmo nome.

\section{De Pereira Passos a Agache}

Na década de 10, depois do período das demolições, da renovação urbana e da definição dos novos eixos de expansão da urbe, o Rio de Pereira Passos já é considerado obsoleto, ${ }^{61}$ velho, suas edificações começam a ser substituídas por novas construções mais altas, e a paisagem, ao estilo belle époque, começa "[...] a se desintegrar sob a pressão de novas forças transformadoras e propulsoras da expansão da cidade." (PEREIRA, 1996, p. 365)

Enquanto pensam e executam a reforma, no período 1902-1906, os técnicos e políticos não se dão conta dos novos desafios do crescimento urbano, e somente se ouve falar do debate sobre uma nova forma de ver a cidade, do nascimento de uma nova disciplina, o Urbanismo, e de um novo profissional, o urbanista. A Reforma Passos é feita sem um projeto geral para a cidade, sem técnicos especialistas, sem "urbanismo". O que faz Pereira Passos são intervenções pontuais na malha urbana, baseadas na higiene e na ciência positivista.

Entre nós, as ideias urbanísticas e os projetos para a cidade tiveram muito mais o caráter de resolução de 'problemas técnicos' e intervenção no equipamento de situações críticas da cidade do que o de uma política de reforma urbana baseada no pressuposto da necessidade de planejamento da cidade que enquadrasse seus problemas sociais derivados de uma 'má urbanização'.

(PECHMAN, 1996, p. 336)

O "urbanismo" de Pereira Passos apresenta-se como uma tradução das teorias higienistas/urbanísticas europeias, quer dizer, o enquadramento de tudo na lógica higienista da circulação e da diferenciação, a renovação urbana a partir dos princípios de melhoria e embelezamento do cenário urbano e a construção da imagem de uma cidade civilizada para ser admirada pelo país e pelo mundo.

As administrações que sucedem a de Pereira Passos têm como objetivo a consolidação da capital administrativa da República e de um centro de turismo. 0 polo industrial desloca-se para São Paulo e Minas Gerais. O Rio, enquanto isso, assume seu caráter de cidade balneário e de serviços.
${ }^{61} \mathrm{~A}$ valorização dos terrenos no Centro, a falta de espaços livres e os novos modelos norte-americanos fazem com que se considerem as construções da Avenida Rio Branco (a Avenida Central tem seu nome mudado depois da morte do Barão do Rio Branco em 1912) obsoletas, iniciando-se o processo de substituição das edificações belleépoque pelos arranha-céus. 


\section{De 1906 a 1930}

A transfomação urbana do Rio, no período 1906-1930, é o reflexo das contradições do sistema político-econômico do País. Os Governos Federal e do Distrito Federal, que representam a classe dominante, dão continuidade à reordenação urbana do Centro e ao embelezamento da Zona Sul. As cirurgias urbanas sucedem-se nos bairros pobres, e as indústrias dirigem-se para os subúrbios, criando áreas novas, atraindo infraestrutura e gerando empregos.

Na década de 10, a preocupação dos técnicos brasileiros é resolver a divisão da cidade, as diferenças de serviços, a distribuição de equipamentos públicos por diferentes zonas, o problema habitacional e o crescimento das favelas, a falta de investimentos em transportes de massa e a pressão imobiliária no Centro.

São feitas distintas propostas para intervir na estrutura urbana do Rio, mas poucas são realizadas. Os engenheiros, técnicos da Prefeitura, médicos-sanitaristas e intelectuais pedem uma solução para os problemas da cidade e sua falta de infraestrutura. São feitas pequenas intervenções pontuais, mas os problemas essenciais continuam sem solução: faltam habitações, água, luz, rede de esgoto e transportes.

A década de 20 traz uma mudança de postura, uma nova forma de vida urbana, que exige uma nova metodologia para intervir na cidade: é a vez dos urbanistas. A cidade deixa de ser pensada só em seu aspecto estético e espacial, para comportar, também, uma leitura social e moral. "Assim se começa a pensar a cidade como organismo, como um todo que precisa ser estudado globalmente por homens capacitados pela técnica e legitimados pela racionalidade da ciência." (STUCKENBRUCK, 1996, p. 22)

Existe uma mudança de relação entre o poder e o saber. Até a década de 20 , os arquitetos e engenheiros fazem parte de uma elite cujo ponto de distinção é a educação. Esses profissionais articulam-se com o poder pela sua origem social, mais do que pelo seu conhecimento e formação técnica. 0 processo de urbanização e a inserção da classe média mudam a concepção assistencial e a solução paternalista, voltando-se para o estudo dos problemas sociais.

A expansão da malha urbana, entre 1906 e 1930, segue dois vetores distintos: para as zonas norte e sul, bairros de classe média e alta, promovida pelo Estado e companhias concessionárias dos serviços públicos; e em direção aos subúrbios, local de residência do proletariado, excluído, sem dúvida, desse apoio institucional. A cidade funciona segundo duas lógicas distintas:

[...] um núcleo bem servido de infra-estrutura, onde a ação pública se fazia presente com grande intensidade e onde residiam as classes mais favorecidas, e uma periferia carente dessa mesma infra-estrutura, que servia de 
local de moradia às populações mais pobres, e onde a ação do Estado era praticamente nula. (ABREU, 1988, p. 82)

A diferença de tratamento contribui para a definição de um zoning, tanto funcional como social. Embora não constitua formalmente um projeto, essa definição pode ser percebida na distinção de funções para determinados espaços. Algumas são permitidas e prioritárias na zona sul, e outras são proibidas. É o caso das indústrias, proibidas em Copacabana, ou do comércio, vedado em algumas ruas do mesmo bairro.

Entre as realizações da década de 20, o desmonte do Morro do Castelo, realizado por Carlos Sampaio, à frente da Prefeitura do Rio (1920-1922), constitui um marco na mudança de pensamento dos engenheiros que "[...] com uma visão mais profissional do seu métier transcendem a velha visão de obra e avançam na direção da proposição de uma funcionalidade/racionalidade que sirva de base à reordenação do espaço." (PECHMAN, 1996, p. 355)

Durante o período de Carlos Sampaio, são elaborados quatro projetos ${ }^{62}$ para a cidade, e, apesar de não se realizarem, podem ser interpretados como indício de uma preocupação com a racionalidade e o planejamento da ordenação urbana.

Na sua administração, constrói-se um novo cais na parte sul do Centro, entre a Ponta do Calabouço e a Glória. Também é complementada a Avenida Beira-Mar, aberta por Pereira Passos, com o contorno do Morro da Viúva, entre Flamengo e Botafogo. Entre outras obras, dá-se o embelezamento e saneamento da Lagoa Rodrigo de Freitas, reconstrói-se a Avenida Atlântica em Copacabana e abre-se a Avenida Maracanã na Tijuca. Na opinião de Maurício de Abreu (1988, p. 78), o período Carlos Sampaio não passa de uma nova etapa no processo de depuração da área nobre da cidade dos usos e da população não desejada.

Alaor Prata, que governa o Rio entre 1922 e 1926, cria comissões que propiciam discussões entre arquitetos e engenheiros, divulgando a percepção da cidade como um organismo onde as partes devem articular-se para formar um todo. Essas comissões são as responsáveis pela formação do corpo de urbanistas da cidade, uma vez que os debates entre os profissionais fazem com que o poder público acabe por coordenar um novo campo do saber: o Urbanismo.

[...] com Alaor Prata o Poder Público tomou definitivamente as rédeas do processo de urbanização global que se pretendia para o Rio, e para tal empreitada seria absolutamente necessária a confecção de um plano geral de melhoramentos para a Cidade. (STUCKEMBRUCK, 1996, p. 60)
${ }^{62}$ Os projetos são de: Costa Moreira; Adamczky; Engenheiros Eugênio L. Franco e Augusto F. Ramos; Cortez e Bhruns. (SILVA, 1996) 
${ }^{63}$ Analisaremos Alfred Agache e seu projeto para o Rio mais adiante.

${ }^{64} \mathrm{O}$ projeto de Le Corbusier será analisado mais adiante.
Para fechar o período, Antônio Prado Júnior, prefeito entre 1926 e 1930, contrata o arquiteto-urbanista francês Alfred Agache, ${ }^{63}$ para elaborar um projeto de reordenação da cidade. Segundo Denise Stuckenbruck (1996, p. 25), o fato de Agache ter se instalado no Brasil é importante para a consolidação definitiva do Urbanismo, que, aos poucos, se desenha no Brasil como um novo campo do saber e do poder. Maurício de Abreu (1988, p. 86) considera a presença de Agache no Rio o exemplo mais importante da tentativa, por parte da República Velha, de controlar o desenvolvimento da forma urbana no Rio. Em 1929, o Rio de Janeiro também recebe a visita de Le Corbusier, ${ }^{64}$ que faz um projeto para a cidade.

\section{Do Morro do Castelo à Esplanada do Castelo}

Não se pode contestar que a obra mais importante do período de Carlos Sampaio foi o desmonte do Morro do Castelo. Sob o pretexto da necessidade de uma melhoria sanitária na cidade e de uma área para abrigar a Exposição Universal em comemoração ao Centenário da Independência do Brasil, em 1922, desaparece o morro onde se instalou a cidade, depois da expulsão dos franceses da Baía de Guanabara, no século XVI. O Morro do Castelo abrigou as grandes residências que se transformaram em cortiços em finais do século XIX, depois da saída da classe abastada em busca dos novos bairros, mais agradáveis.

\footnotetext{
A célebre montanha, histórica porque ali se fundou a cidade do Rio de Janeiro, sagrada com a existencia de um convento e duas igrejas e lendaria ou mesmo encantada em virtude dos tunneis subterraneos, onde dizia-se existirem thesouros consideraveis de ouro e de pedras preciosas, desafiava, ha mais de um século, os médicos que aconselhavam a sua demolição para melhorar as condições hygienicas da cidade, e punha a prova a vontade dos engenheiros que viam nessa obra gigantesca um trabalho téchnico de importancia, a par de uma operação lucrativa, já pela area da base do morro, já pela extensão da superficie ganha ao mar. (SAMPAIO, [192-], p. 4)
}

Discute-se sobre o desmonte do Morro do Castelo desde 1796, como uma proposta para a melhoria do espaço sanitário da já então capital do País. Em 1798, um informe médico condena a sua permanência, alegando que é uma barreira para a circulação de ar procedente do mar, com a qual se aumenta o calor da cidade, contribuindo para a proliferação de doenças. Outras vezes, o Morro do Castelo é tema de discussão, como em 1811 e 1843. Em 1891, o mesmo Carlos Sampaio obtém uma concessão à sua empresa para o arrasamento do Morro do Castelo, mas não segue com seu projeto de 
desmonte, por causa da crise da época. Só em 1922 realiza-se o projeto, eliminando uma enorme área residencial e o berço da cidade,

[...] porque formava um antepáro à ventilação que, durante o dia, se produz sempre pela entrada da barra. [...] e produzia, por seu aspecto inesthético e asqueroso uma má impressão ao viajante, que, ao entrar na esplendida bahia do Rio de Janeiro, tinha a mesma sensação que se teria ao ver uma linda bocca com o dente da frente cariado. (SAMPAIO, [192-], p. 4-5)

Ainda com o argumento da higiene e do arejamento, derruba-se o morro e, junto com ele, o bairro da Misericórdia, que se localiza em sua base, apagando-se os últimos vestígios do Rio colonial do passado. "Importava, a partir de então, dar as costas à história e caminhar rumo às promessas do futuro." (VAZ, 1994, p. 92)

A grande valorização do solo, no Centro, faz pressão que se amplie a sua área. 0 desmonte do morro abre a possibilidade de se criar um espaço, uma esplanada, e permite a utilização da terra para o aterro de parte da baía. Chega o momento de construir uma cidade moderna, sem os elementos tradicionais do passado, tirando de uma área valorizada as prostitutas, lavadeiras e vagabundos que moram no morro.

Para as elites era um absurdo que em menos de duas quadras do Municipal pudesse existir amontoados de casebres imundos.

[...] A presença física do Castelo era a negação de uma cidade moderna. O morro não só obstruía a circulação, elemento indispensável para o movimento; como explicitava a irracionalidade e o caos do espaço urbano. (SILVA, 1993, p. 194)

Nessa operação, o resultado financeiro já é razão suficiente para justificar o desmonte do morro, mas também há a higiene, a facilidade de circulação, a criação de um parque às margens da baía e as razões estéticas, argumentos idênticos aos de Pereira Passos. O Prefeito considera que o orçamento da Prefeitura deve ser investido em obras, cujo retorno financeiro seja viável, justificando que o desmonte do Castelo não só contribui para o desenvolvimento da cidade, então asfixiada, mas também, para a reprodução do capital.

0 processo de desapropriação e demolição do morro transforma a aparência do Centro, desaloja dezenas de famílias, destrói numerosas casas e suscita muitos elogios e muitas críticas. Cada intervenção no Centro expulsa uma parte de sua população, que se vê obrigada a mudar de domicílio. As ações da gestão de Pereira Passos contribuem para a formação das favelas, 
e, com o desmonte do Morro do Castelo, desaparece o mais antigo núcleo residencial da cidade.

Tudo delira e todos nós estamos atacados de megalomania. De quando em quando, dá-nos essa moléstia e nós nos esquecemos de obras vistas, de utilidade geral e social, para pensar só nesses arremedos parisienses, nessas fachadas e ilusões cenográficas. Não há casas, entretanto, queremos arrasar o morro do Castelo, tirando habitação de alguns milhares de pessoas. (LIMA BARRETO, 1920 apud NEVES, 1994, p. 144)

São vários os projetos apresentados para a realização do desmonte e a utilização de suas terras. O Engenheiro Paulo de Frontin propõe que se utilize a terra para o prolongamento do porto, em direção às praias de São Cristóvão e Caju. Há outro projeto para a construção de um grande porto entre a Ponta do Calabouço e a Ilha das Cobras. Jerônimo Teixeira de Alencar Lima projeta o prolongamento da Avenida Rio Branco, em direção à Ponta da Glória. (SAMPAIO, 1924, p. 58)

O que pretende o Prefeito Carlos Sampaio é utilizar o material do morro para o aterro da Ponta do Calabouço e o aterro de uma praia junto ao morro, economizando transporte de terra, projetando um novo traçado para o Saco da Glória e evitando, assim, problemas com a ressaca. Em seu projeto, uma parte da área destina-se a parques e jardins e outra a edificações. No total, obtém-se $384.424 \mathrm{~m}^{2}$ de área aterrada (REIS, 1977, p. 80) e $431.534 \mathrm{~m}^{2}$ de esplanada (NEVES, 1994, p. 144), para anexar ao Centro.

Depois de todo esse movimento, a Esplanada do Castelo (Fig. 21), assim como as áreas aterradas, abrigam, em 1922, a Exposição Universal, para comemorar o $1^{\circ}$ Centenário da Independência do Brasil. Nesse momento, o Rio é a "Porta do Brasil" e, como uma vitrina, tem que refletir a modernidade do País. Para isso, é necessário modernizar a cidade para receber os visitantes da exposição.

Para essa grande área, obtida com o desmonte do morro e o aterro da baía, necessita-se de uma proposta de ocupação que seja algo mais que uma simples trama de quadrículas. A cidade, a população e os técnicos exigem um plano especial. Prado Júnior, prefeito do Rio de 1926 a 1930, contrata Alfred Agache, que, em seu projeto, tenta transferir para o Rio um urbanismo de estilo ainda parisiense, com "[...] grandes perspectivas, baseado numa trama de boulevares, praças, roind-points e pontos focais, estruturada sobre um eficiente sistema de transporte e com cuidados especiais a certas áreas consideradas 'Marcos de Referência' urbana." (OLIVEIRA, 1978, p. 9) 


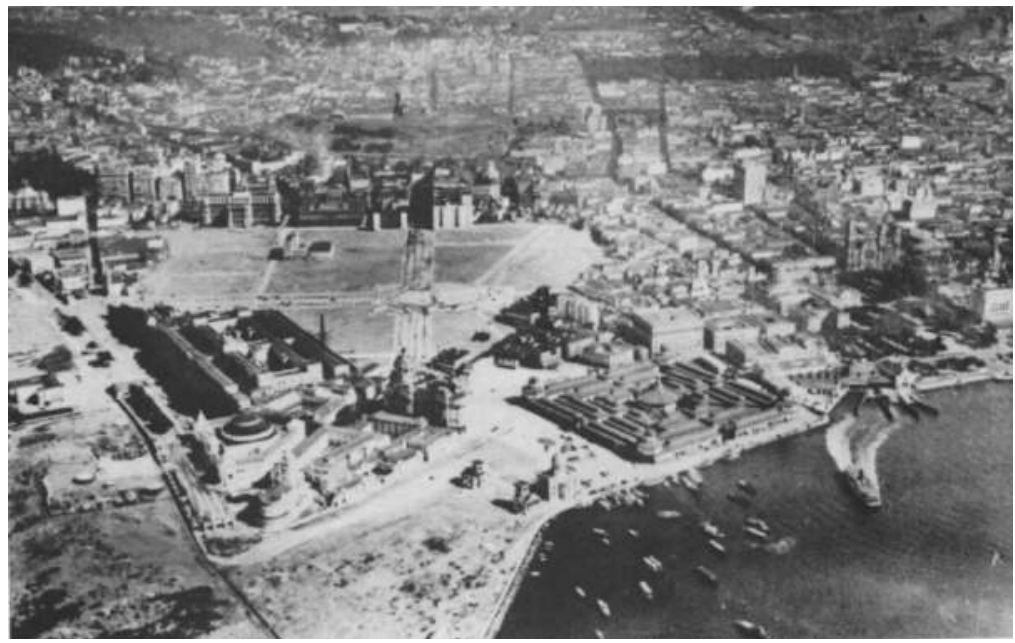

21. Vista aérea da Esplanada do Castelo após desmonte do Morro do Castelo - Rio de Janeiro foto de C. Kfuri - década de 20 do século XX

A área utilizada para os pavilhões da Exposição Universal de 1922 é, mais tarde, ocupada pela Feira de Mostras, que fica até 1930, quando, finalmente, urbaniza-se a Esplanada do Castelo, com largas avenidas e edificações monumentais, embora o projeto de Alfredo Agache não tenha sido considerado em sua totalidade.

\section{Agache e Le Corbusier}

Depois da Grande Guerra (1914-1918), a necessidade de reconstruir as cidades gera, em distintos países, debates sobre questões técnicas e competências administrativas, referentes à organização e à execução dos planos urbanísticos dos novos tempos. 0 movimento de reflexão sobre as cidades advém da cultura tecnológica moderna, industrial e urbana, sem nacionalismo.

Os franceses são importantes na internacionalização do tema e, como a França influencia o Brasil desde princípios do século XIX, era natural que profissionais de origem francesa viessem ao Rio para tentar resolver os problemas da cidade. Como já nos referimos anteriormente, um deles é Alfred Agache, arquiteto-urbanista com influência da Beaux-Arts, e outro é Le Corbusier, arquiteto autodidata que defende o "espírito novo". 
${ }^{65}$ Segundo Françoise Choay, o termo "urbanismo" foi proposto por Ildefons Cerda, em seu trabalho Teoría General de la Urbanización de 1867. e introduzido na França, na primeira década do século XX, por $\mathrm{H}$. Prost e um grupo de praticantes que atuavam em volta do Musée Social.

(CHOAY, 1994)
As discussões, no Brasil, sobre as cidades remontam ao século XIX, lideradas por médicos-sanitaristas e engenheiros. Em finais do século, projeta-se uma nova cidade - Belo Horizonte. Outras, como Rio de Janeiro, São Paulo e Recife, são objeto de projetos de reordenação e reforma urbana. O século XX muda um pouco o sentido do pensamento urbanista, deixando aos arquitetos a condução desse processo. Agache e Le Corbusier contribuem para a valorização do arquiteto, quando o elemento de discussão e intervenção é a cidade.

\section{0 projeto de Alfred Agache}

Em 1926, Prado Júnior é o novo prefeito do Rio, e tem o projeto de finalizar o desmonte do Morro do Castelo (interrompido pelo seu antecessor) e fazer um plano para reordenar a cidade. As discussões em torno do tema são muitas. Quem poderia conduzir esse processo? Arquiteto ou engenheiro, nacional ou estrangeiro, essas são algumas das dúvidas, e diferentes são as visões sobre o plano de que a cidade precisa. Os arquitetos pensam nos aspectos estéticos da materialidade da cidade. Os engenheiros incluem, no seu discurso higienista, uma apelação estética e a questão da circulação, já que a cidade cresce de forma desordenada, e o caos deve ser racionalizado através de um plano que prepare a cidade para o progresso e o futuro.

Não se pode dizer que é uma escolha tranquila e unânime. Muito se discute. Uns preferem a escolha de um profissional do País; outros argumentam que ainda não existem, no Brasil, profissionais com formação adequada para esse projeto. Enquanto a polêmica está na cidade, principalmente na imprensa, a Prefeitura precisa decidir o que fazer com o espaço vazio da Esplanada do Castelo.

Ao fim, decide-se por um estrangeiro, que pode ser, a princípio, Josef Stübben, Edward Bennett, Léon Jaussely ou Alfred Agache. (SILVA, 1995, p. 229) Ganha a Arquitetura, ganha Agache, que é contratado em 1927 para proferir, no Brasil, uma série de conferências sobre Urbanismo, e também para fazer um estudo do plano de reordenação, expansão e embelezamento para a cidade do Rio de Janeiro. A decisão por Agache deve-se ao conhecimento que se tem dos seus projetos, realizados em outras cidades, especialmente o de Canberra, Austrália, realizado em 1910, pelo qual obtém o terceiro lugar no concurso.

A Agache é atribuída a criação do termo "Urbanismo", ${ }^{65}$ em 1912, que, para ele,

\section{[...] é uma Sciencia e uma Arte, e sobretudo uma Philosophia social. Entende-}

-se por Urbanismo o conjuncto de regras applicadas ao melhoramento da 
edificação, do arruamento, da circulação e do descongestionamento de artérias públicas. E a remodelação, a extensão e o embelezamento de uma cidade levados a effeito mediante um estudo methódico da geografia humana e da topografia urbana sem descurar as soluções financeiras [...]. (AGACHE, 1930, p. 4)

Com base nas referências citadas, Prado Júnior anuncia oficialmente a contratação de Alfred Agache, que chega ao Rio em 25 de junho de 1927, para a realização das conferências sobre Urbanismo e também para a elaboração de uma proposta para a reordenação da cidade. Durante sua intervenção na Assembleia Legislativa, o Prefeito expressa os motivos que

[...] me levaram a convidar o célebre especialista Sr. Alfred Agache para vir ao Rio de Janeiro fazer algumas conferências sobre urbanismo, procurando, deste modo, despertar o interesse geral pela organização de um plano metódico de remodelação da Cidade.

[...] Julgo escusado esclarecer a necessidade urgente da organização do plano de remodelação do Rio de Janeiro, segundo os princípios desta ciência moderna que é o urbanismo. (PRADO JÚNIOR, 1927 apud REIS, 1977, p. 90)

As palestras de Agache, um total de três, realizam-se no Teatro Municipal. Ele também vai ao Liceu Francês e ao Automóvel Clube. Da Capital Federal, Agache vai a Recife, Belo Horizonte e, depois, a São Paulo, onde realiza conferências sobre Urbanismo. Enquanto isso, no Rio, a população desconfia de seu projeto, porque teme que objetive apenas o embelezamento da Zona Sul. Reclamações chegam até a imprensa, cobrando um plano geral, com infraestrutura para toda a cidade, independentemente da classe social que habita cada região.

Ao voltar ao Rio, Agache instala-se num escritório, na Avenida Rio Branco, com sua equipe, formada pelos Arquitetos E. de Groer e W. Palanchon, para as questões de urbanismo; Engenheiro A. Duffieux, para as de saneamento; e o Engenheiro-Arquiteto Arnaldo Gladosch, para as relativas às instalações industriais. Junto à sua equipe francesa, encontramos jovens arquitetos da Escola Nacional de Belas Artes do Rio de Janeiro: D. Albuquerque, Afonso Reidy, Santos Maya, Atílio Corrêa Lima, M. Barroso e H. Pelagion. (STUCKENBRUCK, 1996, p. 100)

Eis aqui a capital de um paiz que tem 40 milhões de habitantes cujo Senado está installado num antigo pavilhão de exposição. A Camara dos Deputados, edificada entre duas pequenas ruas, apesar de sua construcção recente apresenta-se já insufficiente. Afóra o Ministerio das Relações Exteriores e o dos Correios, installados in antigos palacios preparados para esse fim, 
os outros ministerios occupam locaes pouco apropriados e sem conforto e, para as paradas militares ou demonstrações patrioticas, a cidade não possúe uma praça de honra nem avenidas espaçosas e convenientemente traçadas. Se o porto está apetrechado da fórma mais moderna e é tido como um dos melhores, o centro dos negócios, pelo contrario, continúa a gravitar em volta das ruas estreitas e pouco extensas da antiga cidade colonial, tendo sido o unico melhoramento a abertura da Avenida Rio Branco, insufficiente já para o trafego sempre crescente da cidade. (AGACHE, 1930, p. 122)

Com essa visão da capital, Agache começa seus estudos para a elaboração de um plano de transformação da urbe, ao menos do Centro e da Zona Sul, numa cidade monumental, com o objetivo de ordená-la e embelezá-la, segundo critérios funcionais e de estratificação social do espaço.

Em seu plano, com a ideia de que urbanismo é como uma atividade integrada às outras numa cidade, pretende orientar o crescimento normal, sistematizar sua expansão, metodizar sua vida coletiva e organizá-la para as futuras necessidades. Considera, pois, os problemas da cidade de forma global.

[...] não é de conceber sómente um preparo mais ou menos feliz para o centro da cidade. $O$ verdadeiro problema consiste em dotar todo o conjunto de um vestuario bastante amplo de modo a lhe permitir um crescimento normal sem entraves e sem emmendas desastrosas. (AGACHE, 1930, p. 130)

Segundo Vera Rezende (1982, p. 40), o plano de Agache tinha o objetivo de reordenar a cidade, para que ficasse de acordo com os modelos modernos, aspiração da burguesia urbana. Também é uma concessão que essa burguesia, que se aproxima do poder, faz à oligarquia, resolvendo conflitos entre elas e restaurando a ordem.

De uma forma geral, o plano de Agache analisa o Rio como a capital do País, uma cidade com funções político-administrativas, econômicas e portuárias, além de mercado comercial e industrial. Com base nessas funções, seu plano inclui um zoneamento, para assegurar a existência e a localização dos equipamentos funcionais. Traça uma rede de comunicação, para que haja uma conexão fácil entre esses equipamentos e o resto da cidade. Propõe habitações confortáveis e agradáveis para as distintas classes sociais e estabelece regras para sua edificação. Também encontramos a preocupação com a higiene, a saúde da população e a ventilação. Há um cuidado especial com a estética e com os problemas construtivos. Podemos dizer, sobre seu projeto, que, como na Reforma Passos, as prioridades são a circulação, a higiene e a estética.

Ao considerar a cidade como um organismo vivo que nasce, cresce, vive, enfraquece e morre, compara os equipamentos da cidade com as funções 
orgânicas, como a circulação, a respiração e a digestão. A respiração se faz através dos espaços vazios, avenidas, praças e jardins; a circulação se faz pelo sistema viário que une toda a cidade, leva a vida dos pontos mais afastados para o Centro, o coração da cidade, e vice-versa; e o sistema digestivo, que é a rede de esgoto. Para que a cidade funcione bem é necessário que suas funções estejam bem cuidadas. Em seu diagnóstico, o Rio é

[...] um corpo que teve um desenvolvimento demasiado rapido, e cujos orgãos, que não tiveram ainda o tempo de se adaptar à nova estructura do conjunto, funccionam mal e não prestam os serviços necessarios. A necessidade de um tratamento racional impõe-se. (AGACHE, 1930, p. 122)

Para obter o resultado esperado, propõe a melhoria do saneamento, a expansão do porto, um novo desenvolvimento para a área central, a abertura de ruas e a reorganização do sistema de transportes. Agache ataca principalmente os problemas do trânsito, com grandes artérias de circulação e rond points. Entra com o zoning, definindo áreas e funções na cidade.

Com o objetivo de aumentar a eficiência, o esquema de circulação pretende chegar aos pontos mais afastados da urbe, com base num esquema de estrutura viária e de transportes que inclui também o metropolitano. Esse sistema é o "esqueleto do plano diretor", o sistema circulatório, uma função vital na vida da capital.

É a distancia que na realidade limita a extensão de uma agglomeração urbana. Mas a distancia que attenue ou supprime os phenomenos sociaes nascidos da vizinhança não é a distancia geographica absoluta, a que se exprime por um algarismo indicando um numero de kilometros, mas sim a distancia pratica, a que se exprime em algarismos que indicam o tempo necessario para effectuar um certo percurso. Essa distancia pratica varia segundo a maior ou menor rapidez dos meios de transportes dos quaes podem dispôr os habitantes da cidade. Assim, pois, os limites do 'Rio maior' dependem immediatamente da organização dos transportes. (AGACHE, 1930, p. 130)

Com relação ao zoning, Agache o integra em seu plano, especializando funções no espaço urbano, criando zonas de utilização distintas, com legislações específicas. Há uma visão estrutural, funcional e especializada. A cidade é dividida em cinco zonas distintas. A primeira é a zona central, que se divide em bairro comercial e bairro de negócios; a segunda é a zona do porto; a terceira, a residencial, subdividida em quatro categorias; a quarta é a suburbana; e a quinta, a zona rural. "Cada elemento desempenha uma determinada atividade no 'organismo' urbano e, dessa forma, se articula e integra a cidade." (REZENDE, 1982, p. 80) 
Agache estuda a questão do saneamento de forma técnica e com profundidade: o básico, como água, esgotos e drenagem, tem enfoque global na urbe, sem discriminação ou espaços privilegiados.

O plano (Fig. 22) é divulgado em junho de 1930, no IV Congresso Internacional de Arquitetura, realizado no Rio. São maquetas e planos relativos aos diferentes projetos propostos para a cidade. São eles: a nova localização da estação de trens, os novos bairros-jardins nos arredores da Lagoa Rodrigo de Freitas, a zona portuária com os quarteirões industriais e as vilas operárias, o projeto de um canal em Botafogo, o projeto do metrô e outro para resolver as inundações. Também apresenta projetos para as áreas da Esplanada do Castelo, da Ponta do Calabouço e dos novos aterros.

Para a Esplanada do Castelo são projetadas largas avenidas alinhadas, edifícios com galerias construídos em gradis, com 25, 60 e 90m de altura, destinados às grandes sedes de jornais, clubes importantes, grandes hotéis e comércio de luxo, entre outros. Aí se projeta o novo bairro de negócios. Da praça central, irradiam-se seis avenidas, para garantir uma boa e fácil comunicação com o resto da cidade.

A Ponta do Calabouço abriga um conjunto de suntuosas avenidas e jardins que levam a um terraço, onde se encontra uma basílica ou um panteão consagrado às grandes glórias nacionais. É um local para passear, um parque para o lazer.

A "Porta do Brasil" ergue-se numa nova área aterrada, que alinha o Saco da Glória, transformando-se numa praça circundada por edifícios monumentais. Para esse espaço, é projetado um local de honra, o centro governamental federal, o centro cívico que faltava à capital. Dessa praça partem avenidas que cortam o antigo Centro.

O Rio de Janeiro offerecerá, assim, á admiração do visitante chegado por mar, uma entrada monumental correspondente a importancia e aos destinos da capital. [...] É ahi que desfilarão os soldados em dias de parada; é ahi que as auctoridades receberão as personalidades eminentes que chegarem por vapor ou por hydro-avião, as quaes poderão desembarcar por meio de lanchas deante da escada de honra moldurada por duas grandiosas columnas rostraes. (AGACHE, 1930, p. 161)

Também são projetados o bairro dos Ministérios, o bairro das Embaixadas, o centro de negócios e o centro bancário, todos em pontos do Centro, onde é preciso que ocorram a desapropriação e a demolição de muitas edificações dos séculos anteriores, para a sua implantação. 


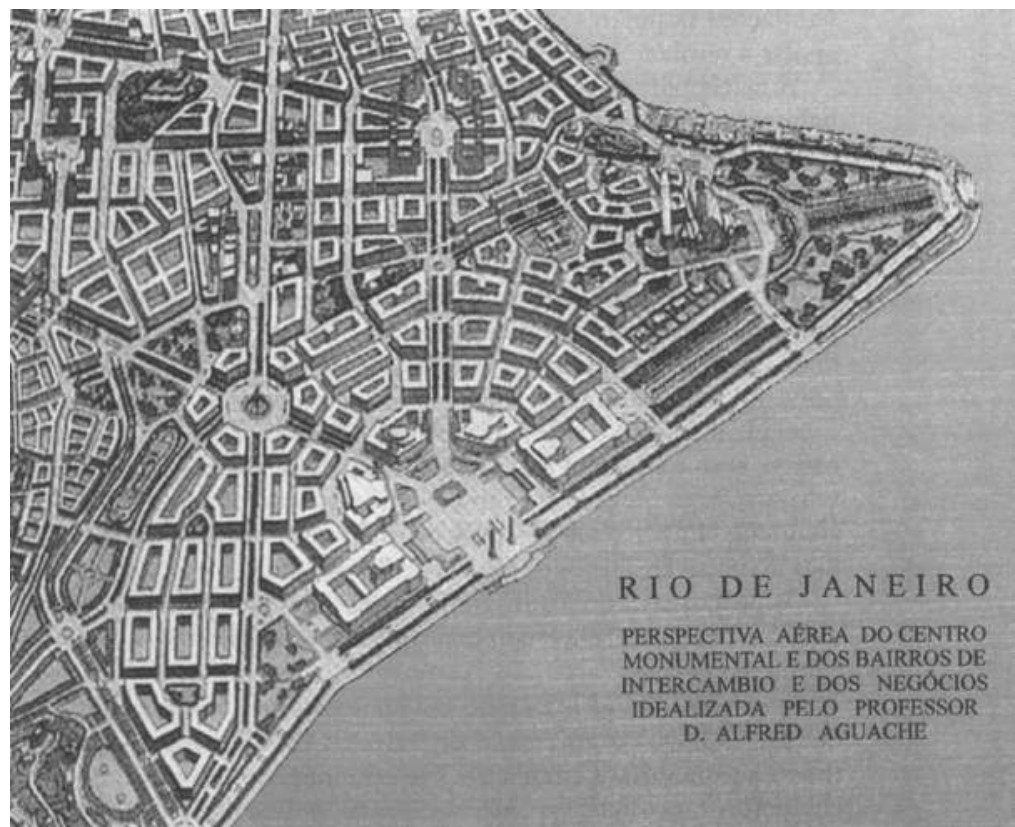

22. Projeto de Alfred Agache para o centro do Rio de Janeiro - 1930

Surgem muitas opiniões com relação a seu projeto, como as que criticam seu esquematismo, a rigidez que induz ao zoneamento e à segregação de grupos sociais. Porém não se nega seu caráter de modelo de metodologia e suas soluções em forma de dispositivos técnicos. Mais ainda que seu método, seu rigor técnico e sua formulação plástica impressionem as autoridades.

Mas Agache é acusado de plagiar outro projeto, que previa a construção da "Porta do Brasil", realizado pelo escritório Cortez \& Brunhs em 1921 e reelaborado em 1924. Em sua defesa, Agache alega a existência de planos mais antigos, como o dos franceses Viret e Marmorat, de 1919, e o do também francês Cuchet. A respeito desse tema, Margareth Pereira considera que

[...] quando Agache expunha idéias próprias estas eram extravagantes - como a via expressa Norte-Sul de $18 \mathrm{~km}$ de extensão ligando Copacabana à Ilha do Governador através de inúmeros túneis; como o canal em diagonal para Botafogo; como o túnel submarino... Quando expunha boas idéias, elas nada mais eram do que a reedição do que brasileiros ou estrangeiros, que haviam estudado 'de fato e profundamente' o Rio, já haviam pensado. (PEREIRA, [199-], p. 19) 
${ }^{66}$ Entende-se como plano diretor um plano vinculado ao planejamento racional que pressupõe 0

conhecimento completo do objeto.

Um plano que organiza os espaços e equipamentos urbanos para chegar à cidade ideal, onde não se encontram problemas de trânsito nem de habitações. 0 plano diretor ignora o social e o econômico, uma vez que o físico resolve todos os conflitos. "Ao ignorar o social e econômico, ignoram também a maioria dos conflitos urbanos. Ao ignorá-los, não se obrigam, portanto, a resolvê-los." (REZENDE, 1982, p. 32)
Independentemente da nacionalidade, o que se questiona é a forma como Agache utiliza o caráter comunicativo da Arquitetura; há uma falta de originalidade, aplicação de fórmulas já existentes e falta de percepção das diferenças entre a cidade americana e a europeia. Sobre sua proposta:

[...] à despeito dos diagnósticos minuciosos, ela [sic] não levava em conta a importância que a experiência americana atribuí ao sítio natural, apostando como configuração espacial falante em formas cristalizadas, grandiosas e construídas onde se privilegia a fluidez, um certo intimismo nos espaços públicos e o diálogo com a natureza. No que tange às construções mesmas, elas também se mostravam aquém da própria ‘imagem' de modernidade que localmente se discutia [...].

[...] trata-se, antes de tudo, de um equívoco de alvo na leitura do que localmente poderia ser potencializado como lugar da memória e emblema da unidade nacional. 'Modernos' e 'brasileiros' [...] foi a incapacidade de rememoração destas duas noções através de uma formulação discursiva e plástica o que em grande parte condenaria a realização do Plano de Agache não em termos de soluções técnicas [...] mas em sua configuração visível e poética. (PEREIRA, [199-], p. 16-17)

Ao final das discussões sobre o projeto, sobre a existência ou não de plágio, questiona-se a posição da França como condutora do urbanismo na cidade moderna, o que leva a diálogos França-Brasil mais sutis, mais complexos e ainda mais férteis. (PEREIRA, [199-], p. 20)

O Plano Agache é um típico plano diretor, ${ }^{66}$ que propõe transformações físicas para obter mudanças sociais, considerando que, para chegar à cidade ideal, basta seguir o plano e fazer as transformações propostas. Assim, faz-se a comparação com modelos ideais, detectam-se os problemas e propõem-se as soluções para chegar o mais próximo possível do modelo eleito.

Esse modelo continua sendo Paris. Agache segue a política de Pereira Passos, com mais coerência e de forma mais ampla. Não há dúvidas de que é um seguidor de Haussmann, um discípulo da escola francesa, mas seu plano é melhor definido, o sistema viário mais elaborado, a geometria mais pura. A diferença entre a obra de Agache e a de Pereira Passos é que a primeira é de um profissional e a segunda é de um amador. Seu projeto baseia-se na

[...] execução de grandes avenidas e praças cuidando-se das perspectivas terminais constituídas quer por monumentos modernos a serem erguidos, jardins à francesa completando uma arquitetura que desta vez deveria formar um todo majestoso, previsão de um zoneamento destinado a pôr em ordem a capital da época e assegurar um crescimento harmonioso da periferia por meio de uma acentuada especialização. (BRUAND, 1981, p. 335) 
O Plano Agache tem uma clara orientação da Beaux-Arts, inclui elementos do movimento City Beautiful, mas também incorpora, em sua configuração, o planejamento dos anos 20, a busca da cidade ideal com sua engenharia urbana, tráfego fluente e saneamento. Também encontramos nele a monumentalidade e o academicismo, características básicas da escola francesa. Os diversos autores (ABREU, 1988; BRUANT, 1996; DEL BRENNA, 1985b; EVENSON, 1973; PEREIRA, 1995; PEREIRA, [199-], SILVA, 1996; STUCKENBRUCK, 1996) que estudam o Plano Agache para a reorganização da cidade não questionam a influência da escola francesa, da Beaux-Arts e de Haussmann - um Haussmann revisto por Eugène Hénard.

Como um discípulo da Beaux-Arts, Agache projeta embelezamentos cívicos, com amplas avenidas, ordenação de conjuntos arquitetônicos clássicos, paisagens formais e eixos barrocos. 0 que pretende é transformar 0 centro do Rio num centro governamental monumental. Projeta uma proposta para o centro cívico, a "Porta do Brasil", numa escala megalômana, para um imaginário super-Estado, no sentido de construir-se um local de um nacionalismo disciplinado, destinado a desfiles militares e cerimônias. 0 projeto assemelha-se a um embrião do projeto cívico da Alemanha nazista, mas $\mathrm{N}$. Evenson (1973, p. 46) crê que a inspiração de Agache vem dos esquemas visionários de Claude-Nicolas Ledoux e Etienne-Louis Boullée, do século XVIII, e que a austera geometria dos seus edifícios está associada ao romantismo clássico do século XIX.

Mas Agache também sofre influência do movimento City Beautiful e do projeto de 1909 de Burnham e Bennett para Chicago, que também faz referência a Haussmann. ${ }^{67}$ Desse movimento, o Plano Agache incorpora a atitude clássica ancestral e a suntuosidade arquitetônica, com majestosos edifícios públicos e refinados parques, com grande ênfase no centro da cidade e no centro cívico.

Do urbanismo modernista, encontramos a divisão da cidade em elementos funcionais, o zoning, o interesse pelos esportes, com locais para a sua prática - piscinas, jardins e grandes parques. Os edifícios comerciais representam a estética da cidade moderna, dominando visualmente o urbano, como a igreja domina durante toda a Idade Média.

\section{O projeto de Le Corbusier}

Enquanto Agache está no Rio, Le Corbusier toma conhecimento da intenção do Brasil de construir uma cidade para ser sua nova capital, sendo uma grande oportunidade para pôr em prática suas ideias de urbanismo. Blaise
67 "O trabalho que Haussmann fez em Paris é o mesmo que devemos fazer em Chicago." (BURNHAM; BENNETT, 1996, p. 190) 
Cendrars e Fernand Léger, através de Paulo Prado, negociam para que ele venha ao Rio e apoiam sua indicação para autor do projeto da nova capital - Planaltina, além do que, ter Le Corbusier no Rio representa um estímulo para uma renovação cultural radical e mais fecunda. Paulo Prado "[...] apostava em novas formas de acolher a especificidade da história do país que fossem capazes de evitar os equívocos do movimento regionalista em curso - o neocolonial e que se inserissem num projeto contemporâneo." (PEREIRA, [199-], p. 6)

Le Corbusier começa sua viagem com uma visita a Buenos Aires, em finais de 1929, e abandona o projeto de uma nova cidade para se dedicar ao estudo das velhas cidades de Buenos Aires, Montevidéu, São Paulo e Rio de Janeiro. Das ideias urbanísticas de Le Corbusier, destaca-se a forma como retoma os traços do discurso utópico, a supervalorização do espaço e a sua importância terapêutica. Fundamenta suas intervenções evidenciando o lado negativo da cidade atual, faz tábula rasa e a substitui por uma cidade ordenada.

Os projetos de Le Corbusier são as respostas tradicionais de uma disciplina - a Arquitetura - e de suas ferramentas de planejamento - a geometria, a classificação. Indicam a crise de um saber que responde em termos de forma, de geometria [...], num mundo cujo movimento cresce excessivamente rápido e que não se sabe como deter ou canalizar, por ser muito complexo para ser fechado em uma forma ou submetido a um projeto único. (GUIHEUX, 1994, p. 290)

Em seu primeiro projeto urbanístico, a Ville Contemporaine pour trois millions d'habitants, a ênfase é dada à circulação e à velocidade. Seu ponto central é ver a cidade como uma máquina para circular. A cidade tem, agora, um novo papel, como máquina para viver e máquina de abastecimento de serviços. A casa e o conforto tomam a frente. A casa e a cidade são uma unidade, e seus estudos urbanísticos baseiam-se no estudo detalhado da casa, na atividade que se desenvolve nela, na comodidade que se deve procurar em seus complementos e em sua agregação.

Xavier Monteys (1996, p. 14) afirma que a cidade de Le Corbusier começa na casa e nas condições domésticas do homem, e nos seus complementos - a luz e o sol -, mesmo que esses complementos sejam obtidos de forma peculiar, através da janela. Propõe blocos de apartamentos isolados, em forma de "Y", escalonados ou laminados, utilizando-se as duas técnicas modernas: estrutura de aço e concreto. O bloco tipo "Y" também se encontra no projeto que faz para o Rio, em 1936.

Para o Rio, Le Corbusier pensa num urbanismo que não interfira na cidade existente, onde passado e presente se superponham como camadas da 
história. No total, elabora três planos: um, em 1929, depois de sobrevoar a cidade; um segundo, já em Paris, em 1930, como uma evolução do primeiro; e o terceiro, em 1936, em sua segunda visita ao Rio.

Do avião, projetei para o Rio de Janeiro uma imensa auto-estrada, enlaçando a meia altura os dedos dos promontórios abertos sobre o mar, de maneira que se pudesse chegar, rapidamente, à cidade, pela auto-estrada, desde os elevados das mesetas salubres. (LE CORBUSIER, 1979, p. 266)

Nos três projetos, a base é uma autoestrada, localizada a 100m do solo, que atravessa a cidade, saltando obstáculos, contornando barreiras ou rompendo bloqueios. A grande autoestrada une os principais pontos da cidade, a Zona Norte à Zona Sul, o Centro a Niterói, do outro lado da baía. Nos três projetos, são resolvidos os problemas de circulação e também de habitação, com a criação de edifícios onde são projetadas habitações até $30 \mathrm{~m}$ sobre o solo, sob a autoestrada.

No primeiro projeto (Fig. 23, ver caderno de imagens), o grande edifício-viaduto desenvolve-se paralelo à baía, com uma bifurcação até o Pão de Açúcar e outra até o centro de negócios, esse composto por edifícios perpendiculares à autoestrada. No segundo, mantém-se a mesma estrutura, mas sem a bifurcação para o Pão de Açúcar. A terceira proposta é totalmente distinta das outras, já que, por ela, o circuito da autoestrada se estende para o interior em direção à Cidade Universitária. As unidades residenciais existentes são substituídas por blocos em forma de "Y".

Já podem imaginar que em locais apropriados estarão as torres com os monta-cargas, os elevadores, parecidos com os das grandes garagens, que descem vosso carro 'até a cidade', embaixo, sobre o solo habitual e a rua normal, assim como dali o sobem até a auto-estrada. (LE CORBUSIER, 1979, p. 269)

Sem interferir na cidade construída, Le Corbusier pretende criar um contraste entre os picos das montanhas e a horizontal parede da construção. 0 resultado é o contraste entre a obra do homem e a da natureza. (Fig. 24, ver caderno de imagens)

Margareth Pereira ([199-], p. 25) considera que há uma influência do cinema, da visão aérea e de teorias como a tese do Park-movement, quando Le Corbusier integra o espaço construído, a paisagem da Baía de Guanabara e as encostas verdes das montanhas como um jardim natural.

[...] para Le Corbusier não é da cidade existente [...] que surgem as diretrizes e leis que engendram o projeto. Para Le Corbusier, a cidade existente é lida antes de tudo como fato poético - plástico - na forma que se relaciona com o seu sítio, com sua geografia. (PEREIRA, 1996, p. 372) 
Não se considera a doutrina de Le Corbusier apropriada para cidades antigas, com uma massa urbana constituída. Sua doutrina é pura e inflexível, suas propostas polêmicas e visionárias, jamais realistas. Assim, seu projeto para o Rio, seu edifício-viaduto, não tem possibilidade de triunfar.

\section{Entre Agache e Le Corbusier}

Existe algo de comum entre o projeto de Alfred Agache e o de Le Corbusier? A princípio, podemos dizer que o que têm em comum é o fato de seus autores serem franceses, e o Brasil sempre ter se interessado pelo que se passa na França e o que pensam os franceses.

Mas, ao analisar com cuidado os dois projetos, as duas visões de cidade, podemos encontrar pontos que os aproximam e outros em que divergem. A visão que os dois têm é a de um espaço urbano regulado por ritmos da circulação mecanizada e da possibilidade de integração centro-periferia. Em ambos, está presente a ideia de cidade como um parque. Os dois primeiros fundamentos baseiam-se nas reflexões de Eugène Hénard, e o último nas experiências anglo-saxônicas, ponto de interesse de ambos. Os grandes eixos de Agache e a autoestrada - o edifício-viaduto - de Le Corbusier são heranças de Haussmann, atualizadas por Hénard. A diferença está na concepção dos projetos.

Agache vê a cidade como uma colagem de fragmentos, integrados pelo automóvel e pelo trem, que fazem a associação do que está dissociado o Centro, os bairros e os subúrbios. Defende a expansão horizontal, a relação cidade-natureza, considera que os meios de circulação mecânica e a extensão de áreas periféricas são solidários.

Le Corbusier, por outro lado, trabalha a cidade em sua totalidade, com o automóvel como meio de regulação urbana. Nega a ideia de periferia como noção geográfica e social, quando seu edifício-viaduto flutua sobre a cidade existente. Projeta sua autoestrada como uma cidade-parque que usufrui da paisagem, da baía e das montanhas, assim como da cidade antiga.

Nas palavras de Margareth Pereira ([199-], p. 27), a diferença básica entre os dois arquitetos é,

[...] este agudo sentido de liberdade e história que Agache refreia e Le Corbusier manipula acreditando ser, em princípio, o que move todo homem. De fato, Agache mesmo após tantos anos continua marcado por uma 'visão evolucionista' e 'particularista' de arte e de sujeito, enquanto Le Corbusier opera a partir de uma 'reação estética' e de uma 'visão universalista'. 
É muito importante ressaltar a influência diversa desses dois profissionais sobre os arquitetos brasileiros. Enquanto os longos estudos, detalhados e ambiciosos, de Agache não os empolgam, os croquis de Le Corbusier têm uma grande repercussão entre os arquitetos e urbanistas locais. Na opinião de Yves Bruand (1981, p. 336), mesmo com uma visão superada, Agache prepara os brasileiros para a nova disciplina, o que facilita a assimilação das ideias de Le Corbusier. 

Capítulo 4

\section{O caso da \\ cidade do Salvador}

\section{A primeira capital do Brasil}

A cidade do Salvador é fundada em 1549, para ser a sede do Governo Geral do Brasil, então colônia de Portugal. Trata-se de uma decisão estratégica da Metrópole, para ter um melhor controle de sua maior colônia, fator que define as diretrizes de sua localização: a nova cidade tem de situar-se num ponto estratégico, de onde se possa controlar toda a extensão do litoral, e, ao mesmo tempo, deve estar bem protegida de possíveis ataques dos índios e de estrangeiros, por terra ou por mar.

O ponto definido para a construção da cidade encontra-se dentro da Baía de Todos os Santos, a $13^{\circ}$ de latitude sul e 38³0' de longitude oeste, e seu núcleo original localizado sobre uma falha geológica, a aproximadamente $60 \mathrm{~m}$ acima do nível do mar. O local, a nordeste do Brasil, é equidistante do norte e do sul do litoral brasileiro, o que permite melhor controle de qualquer ponto da costa. É um bom porto natural, parada obrigatória dos barcos que vêm da Metrópole em direção a outros pontos do Brasil, ou de passagem para as colônias portuguesas da África e da Ásia. 
${ }^{1} \mathrm{Em}$ sua fundação, Salvador recebeu um "termo", como todas as paróquias e cidades do Império Português -, que é a área sobre a qual se exerce a autoridade municipal, e um "rossio", que é uma área de expansão, criação de animais e hortas para o abastecimento da cidade. Segundo Mattoso (1992, p. 100) os limites do termo não se modificam até o século XIX.

${ }^{2}$ Freguesia é o termo utilizado para definir a divisão eclesiástica da cidade.

${ }^{3}$ Instituída em 1871.

${ }^{4}$ As sete freguesias suburbanas são: São Bartolomeu de Pirajá, N. S. do Ó de Paripe, São Miguel de Cotejipe, N.S. da Piedade do Matoim, N. S. da Conceição de Itapoã, Santana da Ilha de Maré e N. S. da Encarnação de Passé.
A primeira capital do País é projetada com um traçado em quadrícula e ruas ortogonais, que se adaptam ao relevo acidentado. Fora do perímetro do núcleo central, as ruas, becos e vielas reconciliam-se com a topografia acidentada, abandonando a regularidade pretendida. A "Cabeça do Brasil" - assim fica conhecida a cidade - é concebida como uma fortaleza, sendo o local escolhido de fundamental importância.

O núcleo matriz da cidade do Salvador divide-se em duas partes. Uma - a que está sobre a falha geológica e onde se encontra o centro administrativo, político e religioso, além das residências - é denominada de Cidade Alta, tendo a oeste a escarpa e abaixo a praia, duas gargantas ao norte e ao sul, o Taboão e a Barroquinha, e a leste o vale do Rio das Tripas. A outra parte, que se encontra no nível do mar, abriga o porto e seus armazéns e é conhecida como Cidade Baixa. Esse modelo de cidade, com uma parte alta e outra baixa, é amplamente utilizado pelos portugueses, assemelhando-se ao de Lisboa e do Porto, também divididas em Cidade Alta e Cidade Baixa.

A sua geografia condiciona sua forma, e a cidade desenvolve-se paralela ao mar. No século XIX, começa na ponta da baía, na Barra, onde se encontra um farol e a área da antiga Vila Velha, povoação já existente antes da fundação da capital. Desse ponto, sobe-se em direção à Cidade Alta, ou segue-se pela praia, por onde se desenvolve a Cidade Baixa, indo em direção ao interior da baía, até a península de Itapagipe e os bairros do Bonfim e Montserrat. A Cidade Alta segue paralela à Baixa, sobre a escarpa.

No século XIX, a Cidade Alta e a Cidade Baixa mantêm a mesma divisão funcional dos séculos anteriores, e os limites da cidade ${ }^{1}$ são os mesmos desde o século XVIII. Até 1871, Salvador divide-se, administrativamente, em dez freguesias ${ }^{2}$ urbanas e sete suburbanas. As freguesias urbanas são: Sé, Passo, Santo Antônio Além do Carmo, Santana, São Pedro, Vitória e Brotas, na Cidade Alta; e Conceição da Praia, Pilar, Penha e Mares, ${ }^{3}$ na Cidade Baixa. ${ }^{4}$

As freguesias do centro da cidade eram as de maior população: Sé, Passo, Santo Antônio Além do Carmo, Santana e São Pedro, na Cidade Alta; Conceição da Praia e Pilar, na Cidade Baixa. Mas o núcleo central, o coração de Salvador, para onde levam todos os caminhos, é a Sé, no alto, e a Conceição da Praia, embaixo. (Fig. 25)

Salvador se mantém como capital da colônia até 1763 , quando essa função é transferida para o Rio de Janeiro. Apesar disso, Salvador ainda é a capital de uma província importante, a Bahia, e uma cidade que passa por transformações significativas ao longo do século XIX. Entender como Salvador se transforma, como se adapta às novas tecnologias, como reage às mudanças 


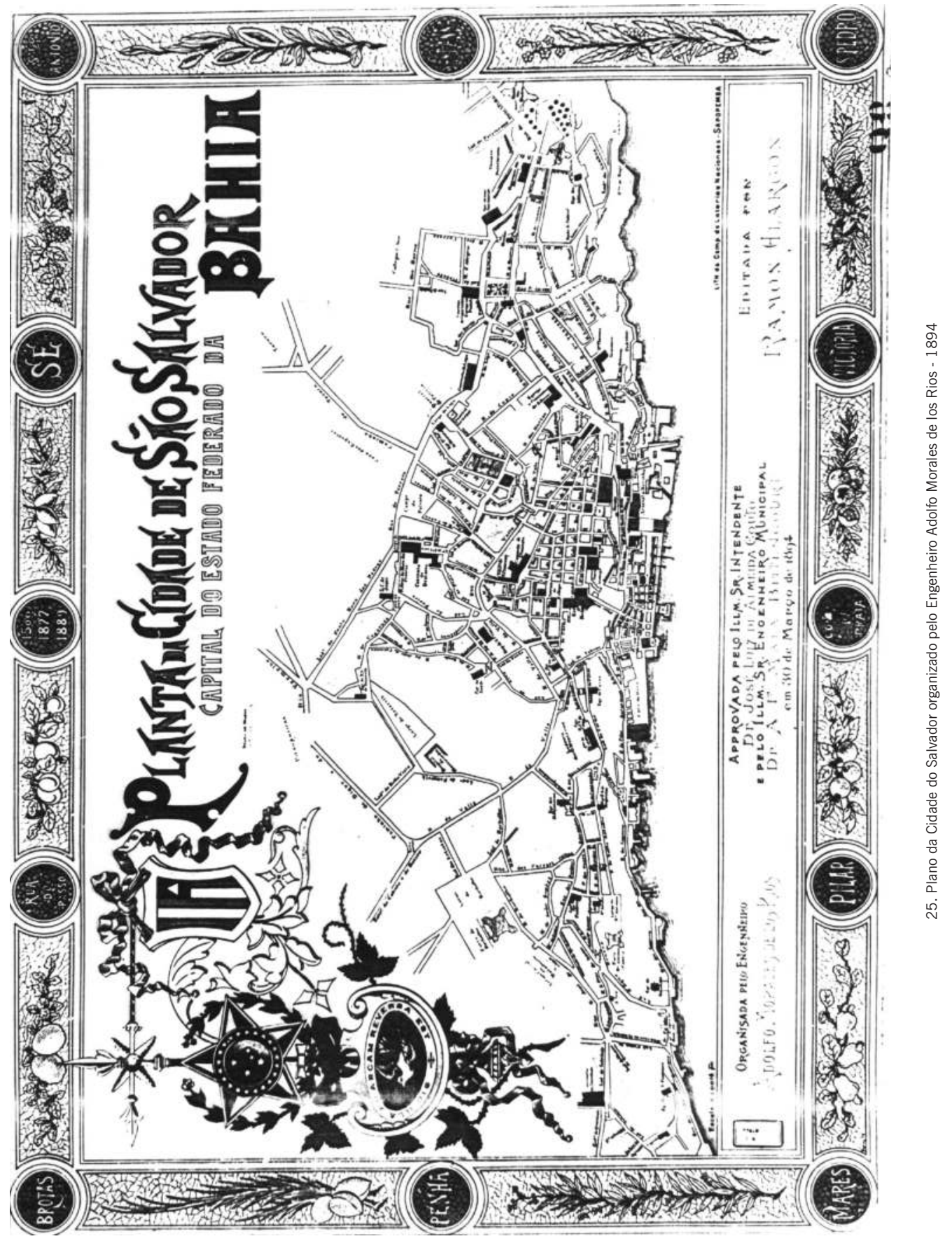


econômicas e à perda da posição de capital, é importante para conhecer a cidade do século XIX e entender o porquê de sua reforma urbana nos anos 1912-1916, um dos fatos relevantes na história da cidade.

\section{Conhecendo a cidade do século XIX}

\section{Como é a cidade}

Como o Rio de Janeiro, Salvador está localizada às margens de uma grande baía, já utilizada para os encontros das esquadras, antes mesmo da existência de qualquer núcleo urbano. Chegar a Salvador por mar provoca uma forte impressão, pela beleza de sua baía e a originalidade do lugar. Numerosas são as descrições de viajantes que a visitam ao longo de todo o século XIX, testemunhas do impacto que causa essa chegada.

A Baía de Todos os Santos pode ser considerada uma das maiores, das mais belas e das mais cômodas do mundo; ela pode abrigar mais de dois mil navios; o fundo é bom, e os ventos ali não assustam, pesca-se grande número de baleias, e constrói-se muitos bons barcos [...] (FROGER, 1700, p. 134)

Esse tipo de comentário, de 1695, repete-se ao longo dos séculos XVIII e XIX. Mas não é só a baía que encanta os viajantes. A cidade do Salvador, vista do mar, também se constitui numa bela paisagem. Em 1821, Maria Graham (1956, p. 144) emociona-se com o que vê.

Esta manhã, ao raiar da aurora, meus olhos abriram-se diante de um dos mais belos espetáculos que jamais contemplei. Uma cidade, magnífica de aspecto, vista do mar, está colocada ao longo da cumeeira e na declividade de uma alta e íngreme montanha. Uma vegetação riquíssima surge entremeada com as claras construções [...]. Aqui e ali o solo vermelho vivo harmoniza-se com o telhado das casas. O pitoresco dos fortes, o movimento do embarque, os morros que se esfumam a distância, e a própria forma da baía, com suas ilhas e promontórios, tudo completa um panorama encantador [...].

Esse encanto desfaz-se com a chegada à terra. Na Cidade Baixa, os estrangeiros constatam que "[...] não há nada da limpeza que se observa em nossa terra." (GRAHAM, 1956, p. 144) Essa parte da cidade vive em função do porto, mais ativa durante o dia. Numa reduzida faixa de terra, encontram-se edifícios de quatro, cinco andares, lojas e armazéns, que se localizam numa única rua longitudinal, tortuosa e estreita, que vai da Preguiça até a Jequitaia 
[...] a cidade na beira mar representava um impressionante conjunto arquitetônico e ao mesmo tempo um buliçoso labirinto de becos e ruas estreitas e tortuosas que vinham dos sopés dos morros e cortavam verticalmente a grande rua longitudinal. (MATTOSO, 1978, p. 173-174)

As construções erguem-se sem ordenação, as ruas são estreitas e sem alinhamento reto. Por ali se encontram o Arsenal da Marinha, a Alfândega, a Associação Comercial e os consulados, ao lado de armazéns, trapiches, mercados - inclusive o de escravos -, comércio atacadista e varejista, escritórios de importadores e exportadores, pequenas indústrias e agências marítimas. Nessa parte da cidade, o movimento de gente é constante. 0 ruído do comércio, dos barcos no porto, dos vendedores ambulantes e das negras que vendem comida mistura-se com a sujeira das ruas.

Cidade Baixa, cidade suja, mas cidade muito viva. Os pregões dos vendedores ambulantes se mesclavam à melopéia bem-ritmada dos carregadores negros curvados sob pesadas cargas, em seu vaivém. Cidade suja mas colorida, inclusive pelas roupas e as peles variadas da sua gente. Verdadeira cidade-porto, onde o mais humilde acotovelava o mais insigne nos afazeres da vida cotidiana. (MATTOSO, 1992, p. 438)

A estreita faixa de terra junto à montanha amplia-se no século XIX, através de aterros ${ }^{5}$ que conquistam cada vez mais uma parte do mar. Mas o caráter da Cidade Baixa permanece igual, com seu movimento constante, suas cores e ruídos.

Nas primeiras horas da manhã e ao final da tarde, há um grande intercâmbio de gente - comerciantes e trabalhadores - entre a Cidade Alta e a Baixa, através das ladeiras, do elevador e dos planos-inclinados que unem as duas "cidades". A Cidade Alta, onde reside a maioria da população, é mais bonita, mais limpa e mais acolhedora que a Baixa.

O Distrito da Sé é o centro administrativo, político e religioso da cidade. Desde a sua fundação, os principais edifícios públicos e religiosos localizam-se ali. Em torno da Praça do Palácio, para onde se dirige a população em momentos de crise e durante as festividades, estão a Casa de Câmara e Cadeia, o Palácio dos Governadores, a Casa da Moeda e a Casa da Relação. ${ }^{6}$ Podemos encontrar uma boa descrição de dois de seus edifícios - a Casa de Câmara e Cadeia e o Palácio dos Governadores - nos relatos do Príncipe Maximiliano de Habsburgo, que visita a cidade em 1860.

Um lado do Palácio Imperial estende-se ao longo da rua principal, a fachada de frente dá para a Praça do Paço Municipal e o terceiro lado, para a baía. O prédio, semelhante a um hospital, é da maior simplicidade, não demonstra
${ }^{5}$ De 1800 a 1860 , grandes aterros foram realizados pelo Governo: o aterro do Arsenal, deslocando a ribeira das Naus para o sul; 0 aterro da Alfândega; e o aterro que vai da Igreja do Corpo Santo até a prumada

da Ladeira do Taboão. De 1860 a

1894 , novos e significativos aterros se realizam: em frente a Igreja da Conceição da Praia; o Arsenal de Marinha avança a linha da costa até o alinhamento da rotunda da Alfândega; o cais Dourado avança mar adentro quase se alinhando com a Praça do Comércio e todo o cais desse ponto até a Alfândega. (CÂMARA, 1989, p. 123)

${ }^{6}$ A Casa da Relação e a Casa da Moeda foram demolidas em 1872 e 1875 respectivamente. 
o menor luxo, comparado aos prédios particulares, ressaltando-Ihe, apenas, o tamanho e a localização. As inúmeras janelas são todas em forma de portas, com pequenas balaustradas de ferro.

[...]

O Paço Municipal é um prédio grande, alto, imponente, dos velhos tempos dos reis de Portugal e sobressai da banalidade por uma espécie de galeria com arcadas e pequenas colunas maciças de granito. (HABSBURGO, 1982, p. 135-136)

Ao norte da Praça do Palácio, encontramos a Sé, também de construção austera, a Santa Casa de Misericórdia e o Palácio Arquiepiscopal. Uma vez superados, chega-se a uma segunda praça, o Terreiro de Jesus, na qual encontramos

[...] o famoso templo, e parte do Colégio, que foi dos Jesuítas [...]; e fronteira fica a igreja dos Terceiros de São Domingos, com sua casa de consistório nobre, e de gôsto moderno; e outra grande propriedade ao lado da igreja. Pela frente do Norte fica o templo da Irmandade dos Clérigos de São Pedro, [...]; e tudo o mais são casas pequenas, antigas e irregulares; a face oposta é mais regular, e tem melhores edifícios: comunica-se esta praça com os bairros da cidade tôda, por sete ruas, que nela vão sair. (VILHENA, 1981, p. 45)

No século XIX, o antigo prédio do Colégio dos Jesuítas passa a abrigar a Faculdade de Medicina. Essa praça, centro religioso de Salvador, é um lugar de passagem de pessoas que vão e vêm da Cidade Baixa para o Santo Antônio, o Passo e Santana.

Descendo do Terreiro de Jesus, ainda em direção ao norte, encontra-se o Pelourinho, um bonito espaço construído com sobrados de diversos andares e habitado, até meados do XIX, por uma classe abastada, que fazia dele um dos locais residenciais mais valorizados até então. As transformações sociais que começam em finais do século XIX convertem o Pelourinho numa área pobre, local de amontoamento da população que vem para a cidade, em plena crise da economia rural e depois da abolição da escravidão.

Ao caminhar em direção ao sul, saindo da Praça do Palácio, chega-se ao Largo do Teatro, onde está o Teatro São João, construído no limite da escarpa, com uma bela vista panorâmica da baía. Dali seguimos para o São Bento e o São Pedro. Por esse caminho, pode-se chegar a diversos pontos da cidade, como o Largo da Palma, o Largo do Desterro, Nazaré e Barris. Seguindo paralelo à baía, em direção ao litoral sul, chega-se ao Campo Grande, à Vitória, e até à Barra.

Da mesma forma que na Cidade Baixa, fora do núcleo central da Sé, as construções erguem-se sem alinhamento. Isso gera uma assimetria e converte 
a área em um labirinto de ruas, vielas e becos. Algumas têm pavimentação, porém muito mal feita, com pedras enormes intercaladas com pequenas, muitas soltas, e outras sem pavimentação alguma. As edificações, às vezes com vários andares, são construídas lado a lado e sem variedade, enquanto os edifícios públicos são ricos, além de arquitetonicamente belos e significativos. Os terrenos das edificações particulares são estreitos e longos. Tais construções têm fachadas tímidas, e portas e janelas dando para a rua, igualmente estreita, o que dificulta a penetração da luz do sol. Não há espaços livres na área central, densamente construída.

Nesse cenário, acontecem intervenções urbanas ao longo de todo o século XIX, o que permite mudar a imagem da cidade colonial, ainda baseada na estrutura escravista, pela introdução de novas tecnologias do mundo moderno e adaptações a um sistema capitalista de produção e de modo de vida.

\section{Quem vive na cidade}

Salvador não perde sua importância como polo de atração de população, depois que deixa de ser a sede do Governo do Brasil. O censo eclesiástico, realizado em 1805, registra 45.600 habitantes na cidade (AZEVEDO, 1969, p. 218) e, no de 1900, os residentes já são 205.813. (SILVA, 1985, v. 2, p. 239) Embora em menor escala que outras cidades brasileiras, mantém-se como centro de migração, seja da população das regiões rurais, seja de estrangeiros, principalmente de portugueses e de negros africanos trazidos como escravos. No século XIX, a urbe quadruplica sua população. Não é um aumento muito significativo, mas ocorre devido ao crescimento vegetativo e à migração rural dos deserdados do campo, seja pelos altos e baixos da cultura açucareira, seja pela ocorrência de uma das mais longas secas na Bahia, entre 1857 e 1860. (MATTOSO, 1992, p. 113)

Os imigrantes portugueses normalmente vêm para ficar, integram-se à sociedade local e casam-se com brasileiras quando não trazem as esposas de seu país. Depois de fixar residência e ter seu próprio negócio, trazem parentes, sobrinhos e, muitas vezes, rapazes da vizinhança, para trabalhar em suas empresas. Alguns vêm apenas para fazer fortuna e regressar à sua terra e, por isso, não se casam, não têm filhos, não se integram à sociedade baiana, mas nem sempre voltam a seu país. Os negros, ao contrário, não vêm por vontade própria. São capturados na África, trazidos ao Brasil e vendidos como escravos.

Por ter sido capital do Governo do Brasil e por sua economia agro-exportadora, baseada na mão-de-obra escrava, Salvador é um dos portos mais importantes do tráfico negreiro até 1850 - quando esse se torna ilegal - e, 
portanto, uma das cidades mais "negras". Estima-se que 300 mil africanos chegaram à Bahia só na primeira metade do século XIX. (COSTA, 1989, p. 23) A maioria trabalha na agricultura, apesar de muitos ficarem na cidade. O elevado número de negros que ocupa as ruas soteropolitanas surpreende e impressiona os visitantes da Bahia, como Ave-Lallemant (1961, v. 1, p. 20), em 1859.

Quando se desembarca na Bahia, o povo que se movimenta nas ruas corresponde perfeitamente à confusão das casas e vielas. De feito, poucas cidades pode haver tão originalmente povoadas como a Bahia. Se não se soubesse que ela fica no Brasil, poder-se-ia tomá-la sem muita imaginação, por uma capital africana, residência de poderoso príncipe negro, na qual passa inteiramente despercebida uma população de forasteiros brancos puros. Tudo parece negro: negros na praia, negros na cidade, negros na parte baixa, negros nos bairros altos. Tudo que corre, grita, trabalha, tudo que transporta e carrega é negro; até os cavalos dos carros na Bahia são negros. A mim pelo menos pareceu que o inevitável meio de condução da Bahia, as cadeirinhas, eram como cabriolés nos quais os negros faziam as vêzes de cavalos.

Os escravos urbanos costumam ser divididos em três tipos, segundo o trabalho que realizam.

O primeiro é o escravo exclusivo de seu senhor, que realiza tarefas domésticas, economicamente não produtivas, e pertence, principalmente, às famílias mais ricas.

O segundo tipo é o escravo de aluguel. O senhor aluga sua "propriedade" em troca de um valor predeterminado, e o escravo não recebe remuneração alguma. Esse é um negócio muito valorizado, numa sociedade em que não se encontram homens livres para executar o trabalho braçal, e onde fazer o menor esforço físico é considerado uma infâmia. É muito comum que a classe média possua escravos de aluguel, já que essa é uma boa forma de aumentar seu rendimento ou, no caso de algumas viúvas que possuem um ou mais escravos de aluguel, pode ser a única fonte de renda. Essa relação é contraditória, segundo Maria Inês C. de Oliveira (1988, p. 16).

Mas o que havia de mais sintomático era a profunda contradição que começava a se operar na relação de trabalho escravista: de um lado o locador, mantendo com o escravo uma relação escravista calcada na propriedade de outra pessoa, e de outro lado, o locatário, que se utilizava da força de trabalho não mais realizando uma inversão e sim preferindo alugá-la ao modo de um 'capitalismo embrionário'. A generalização do costume de alugar a mão de obra, ao invés de comprá-la, pode ser um fator elucidativo das primeiras manifestações de dissolução do sistema escravista e de transição para formas 
de trabalho assalariado, aceleradas especialmente a partir da perda de sua principal fonte de renovação, com o fim do tráfico.

O terceiro tipo de escravo é o de ganho. O cativo procura trabalho pelas ruas, e uma parte dos benefícios que recebe fica em suas mãos, enquanto a outra parte, prefixado o valor, fica com o seu senhor. Nessa relação, o escravo obtém liberdade de movimento e é o responsável pela venda de sua força de trabalho e em garantir seu sustento; em troca, dá a seu senhor um valor definido por dia ou por semana. Muitos desses escravos nem mesmo vivem nas casas de seus donos.

O que chama muito a atenção dos que passam por Salvador, além da superioridade numérica dos negros, é o seu comportamento. Em 1860, Maximiliano de Habsburgo estima que haja um total de 80 mil negros, frente a 40 mil brancos, e comenta como os negros andam pelas ruas.

É interessante, também, observar o povo negro passar pela rua, com cestas cheias das mais lindas frutas, sempre gritando, possuídos de uma incansável mania própria e cômica de tagarelar e de uma alegria que contrasta, de maneira estranha, com a idéia de escravidão. (HABSBURGO, 1982, p. 94)

Sobre os costumes dos negros na Bahia, é interessante o que comenta o Conde de Gobineau (1936, p. 54-55) com Marie, em uma carta de 24/03/1869.

[...] existem negros e negras em imensa quantidade. A Bahia é a cidade do Brasil onde os encontramos em maior quantidade, uns escravos, outros livres. [...] a vestimenta das negras é maravilhosa e de uma grande nobreza [...]. Uma longa camisa bem decotada [...] que cai sobre seu braço, de um lado; a camisa é ajustada na cintura; uma saia de cor luminosa e um tipo de abrigo, todos em algodão passando por baixo do busto e os corpos são envoltos com grandes pregas. Os braços nus; fortes colares, braceletes, brincos de ouro, às vezes maciço, ou bijuterias de vidro. É muito bonito. Todo esse pequeno mundo negro ri de garganta aberta mostrando os dentes brilhando de brancura no meio dos lábios vermelho-escuros, destacando-se sobre a pele negra. E é um burburinho e é uma algazarra como numa revolução.

Entretanto, muitas vezes, detectamos um certo racismo nas observações feitas pelos estrangeiros. Para muitos deles, os negros, que são muitos, são todos escravos, o que não é verdade. Por outro lado, supõem que os poucos brancos são todos senhores, o que também não é uma realidade. Um exemplo desse pensamento está nos escritos de Habsburgo (1982, p. 75): "Os negros são escravos, e, por isso, animais com alma humana. Os brancos são os senhores de escravos, portanto, seres humanos com alma animal." 
${ }^{7}$ Esses dados devem ser vistos com cuidado, pois o conceito de "branco" é muito relativo e amplo, já que a cor da pele torna-se cada vez mais "branca", quando se ocupa uma posição mais alta na sociedade.
Mas, na realidade, quantos são os negros e quantos são os brancos? O censo de 1807 (MATTOSO, 1988, p. 23-24) nos revela a existência de 51.112 habitantes na área urbana de Salvador, dos quais 28\% são brancos, $20 \%$ são mulatos e $52 \%$ são negros. Infelizmente, o censo não indica quantos deles são livres e quantos são escravos. De acordo com um segundo censo, realizado em 1872, a área urbana abriga 108.138 pessoas, divididas em $30,9 \%$ de brancos, $43,7 \%$ de mulatos, $23,5 \%$ de negros e $2 \%$ de caboclos. Esse censo nos informa que existem 95.637 "almas" livres.

Para melhor entendimento da estrutura social da cidade, seguimos a divisão de Kátia Mattoso (1978, p. 161-164), para quem os grupos sociais da capital da Bahia são quatro. No primeiro, estão os funcionários da administração real, militares de altas patentes, o alto clero secular e regular, os grandes mercadores e os grandes proprietários rurais. O segundo grupo é composto pelas mesmas categorias que o primeiro, mas com salário menor ou renda mais baixa, e por profissionais liberais e mestres de ofícios nobres como ourives, pintores, canteiros, torneiros e entalhadores de objetos de madeira. No terceiro grupo, misturam-se os funcionários subalternos da administração real, os militares de baixa patente, como sargentos, cabos e soldados, os profissionais liberais secundários, os oficiais mecânicos como pedreiros, carpinteiros, tanoeiros, sapateiros entre outros, e pequenos comerciantes. Nessa categoria, encontram-se homens e mulheres recém-saídos da escravidão, marinheiros, pescadores e provedores de gêneros alimentícios e pescados. O quarto e último grupo compõe-se de mendigos, escravos e desocupados, também considerados como "classe perigosa".

Os grandes proprietários rurais, os plantadores de cana-de-açúcar, chamados senhores de engenho, são os representantes da classe dominante, os "homens bons", os que tem o direito do voto, uma vez que têm o controle dos principais meios de produção e um enorme poder social, político e simbólico. Por outro lado, os escravos formam a principal categoria entre os trabalhadores, subordinados política, social e economicamente a seus senhores. Essa relação senhor/escravo é a base da sociedade e da economia.

A estrutura social também pode ser classificada por cores: a classe alta é toda branca, sejam brasileiros, portugueses ou europeus; na classe média, encontram-se mulatos e uns poucos caboclos, mas a grande maioria é branca; na classe baixa, há mulatos, caboclos, e poucos brancos; finalmente, os escravos, entre os quais não encontramos brancos, dividem-se em africanos, crioulos, cabras e mulatos. ${ }^{7}$ (REIS, 1987 , p. 20) 
Não há dúvida de que os "homens de cor" são mais numerosos que os brancos. No censo de 1872, constata-se que a população escrava é cada vez menor (12\%), em relação à livre, e a abolição definitiva da escravidão chega em 1888. 0 incremento das manufaturas e fábricas aumenta o trabalho livre e assalariado, formando um novo segmento social: o proletariado urbano.

Durante todo o século XIX, a população de Salvador cresce, os latifundiários fixam suas residências na cidade e ocorre a migração, do interior para o litoral, de pessoas que fogem da seca, em busca de melhores condições de trabalho e de vida. No século XX, a taxa de crescimento da população reduz-se de forma radical. ${ }^{8}$ Entre 1890 e 1940, a população cresce 66,53\%, um aumento insignificante, se compararmos com o de cidades como Rio e São Paulo. ${ }^{9}$ Essa estagnação é fruto de uma taxa de mortalidade alta e de migrações quase inexistentes. As altas taxas de natalidade são as responsáveis pela não diminuição da população. (SANTOS, 1990, p. 22-23) Entre 1920 e 1940, o seu crescimento reduz-se a uma taxa anual de 0,20\%. (SOUZA, 1980, p. 104).

O crescimento é tão pequeno, que Salvador perde posição na classificação das cidades brasileiras. Até 1890, Salvador encontra-se em segundo lugar em número de habitantes, enquanto o Rio encabeça a lista. Em 1900, passa para o terceiro, deixando seu posto para São Paulo. Mantém-se nessa posição até 1940, quando passa para o quarto lugar, com Recife à sua frente. Entretanto, embora perdendo sua posição quanto à população, Salvador não perde totalmente sua importância econômica. A cidade portuária mantém suas funções.

\section{Como se vive na cidade}

Como e onde vive essa população no espaço físico da cidade? A maioria concentra-se na Cidade Alta, em locais como Sé, Passo, Santo Antônio, Santana e São Pedro. A distribuição dos escravos e dos homens livres, dos brancos e dos "homens de cor" pela cidade não se produz de forma homogênea.

Até finais do século XIX, a população vive misturada. Ao lado de um sobrado, pode estar uma casa térrea, com uma porta e uma janela. Um sobrado pode abrigar uma única família, ou muitas. Os bairros abrigam escravos e libertos, mestres, artesãos e funcionários, burgueses e nobres. Podem ser residenciais e comerciais, ao mesmo tempo. Numa mesma área, podem realizar-se vários tipos de atividades. A partir do final do século XIX, percebe-se uma mudança progressiva nessa estrutura espacial e na estratificação social.

O núcleo da estrutura social é a família, normalmente numerosa, pelos muitos filhos e pelos que se juntam a ela como agregados. Existe o costume
${ }^{8} \mathrm{~A}$ taxa de crescimento, entre 1890 e 1920 , é de $38 \%$ e, entre 1920 e 1940 , é de $3 \%$.

${ }^{9}$ O Rio triplica sua população, passando de 522.651 habitantes em 1890 para 1.759 .277 em 1940. (ABREU, 1988, p. 67, 109). São Paulo tem um crescimento maior, pois aumenta sua população 20 vezes, passando de 64.934 habitantes em 1890 para 1,3 milhão em 1940. (BONDUKI, 1999, p. 18, 248) 
de amparar os pais quando mais velhos, as irmãs solteiras ou os parentes pobres. Muitas vezes, os filhos recém-casados continuam a viver com os pais, até conseguirem uma maior estabilidade. Outros agregados são ex-escravos da família, empregados do negócio familiar ou amigos pobres. Os escravos que, uma vez livres, transformam-se em empregados domésticos, também vivem com a família.

Ao longo do século XIX, a cidade muda, adaptando-se aos novos padrões de vida que se vão impondo na urbe. A Sé perde um pouco seu caráter residencial, ao deixar espaço para a instalação de um comércio varejista, até então concentrado na Cidade Baixa. Sua desintegração social e material começa com a saída das famílias mais ricas em busca de um novo estilo de vida, e a ocupação dos espaços vazios por uma nova população, composta de migrantes da zona rural e ex-escravos. São homens, mulheres e crianças que se amontoam onde podem, até transformarem a área num formigueiro humano. A situação chega a seu apogeu na década de 20 do século XX, quando se decide transferir todo o meretrício para uma área da Sé chamada Maciel, onde se "[...] liberou a prostituição e as atividades paralelas e derivadas que terminou por envolver toda área residencial - como forma de controle dessa prática, dentro da política higienista de então." (BOMFIM, 1994, p. 30-31)

A população de alta renda, que deixa seus sobrados na Sé, vai viver nas novas casas da Vitória, Canela, Graça e Barra, bairros que assumem um ar elitista e onde residem cônsules, latifundiários, além de grandes comerciantes nacionais e estrangeiros.

A classe média - funcionários públicos, alguns profissionais liberais e uma minoria de comerciantes portugueses e brasileiros - prefere instalar-se em Santo Antônio ou em Santana, onde também se encontram pequenos comerciantes, artesãos e artistas, inclusive muitos músicos. O Passo caracteriza-se pela presença de famílias grandes, que vivem em sobrados, e de uma classe média similar à de Santo Antônio. São Pedro abriga uma grande parte da elite intelectual e social da cidade.

Na Cidade Baixa, a Conceição da Praia abriga comerciantes, principalmente portugueses, que ainda vivem na mesma edificação do trabalho. Já os residentes do Pilar estão bem mais próximos da população pobre da Conceição da Praia.

Um dos pontos de diferenciação entre um distrito e outro é a quantidade de escravos, ou a relação entre brancos e negros que nela vivem. Os libertos e os escravos de ganho, que vivem por conta própria, preferem viver no Centro, pois ali estão as oportunidades de trabalho diário. Os que ainda são escravos concentram-se mais nos bairros ricos, já que vivem na casa de seus senhores, 
como na Sé, onde residem $16,8 \%$ de escravos, de acordo com o censo de 1872, ou São Pedro, com seus 18,8\% de cativos, e a Vitória, com 17,9\%.

Conceição da Praia e Brotas são bairros atípicos, pois, em ambos, o número de brancos supera o número de pessoas de "cor". O que explica essa diferença são as atividades que nesses locais se desenvolvem. Na Conceição da Praia, centro comercial da urbe, habitam $62 \%$ de brancos. Em Brotas, os motivos são outros: 50,9\% de brancos vivem ali, porque é um distrito ainda semirrural, onde os terrenos são arrendados a lavradores livres.

A distribuição da população e sua estrutura urbana não negam a característica de cidade colonial. Como o Rio de Janeiro, Salvador funciona com base no sistema escravista. Na cidade, ou nas casas, o motor que faz tudo funcionar são os escravos. Deles depende a distribuição de água, os transportes, o funcionamento de uma casa. Substituem os correios, os cavalos e as tubulações. Todo esse "equipamento" deve ser substituído, quando a escravidão entra em decadência e o trabalho livre e assalariado se instaura definitivamente na cidade.

No que se refere às casas, essas já não satisfazem às novas necessidades da população, e seus estilos arquitetônicos são obsoletos. O novo bairro burguês da Vitória surge com seus solares elegantes, arejados, iluminados, com jardins, com uma construção mais solta, muitos ornamentos, muitas janelas, terraços e galerias. Nos bairros antigos, as construções mais comuns continuam sendo os sobrados e as casas térreas.

No bairro do Comércio, a Conceição da Praia, encontramos um tipo de edificação muito típica, que continua a existir até os anos 30 do nosso século. São edifícios de três ou quatro andares, que abrigam no térreo o negócio, no segundo andar a família, sendo o terceiro (ou quarto) destinado a alguma finalidade relacionada com o negócio, como um depósito, por exemplo, além de alojamento para os empregados e escravos. ${ }^{10} \mathrm{Em}$ princípios do século XX, começa a mudança dessa estrutura. Os comerciantes trocam suas residências e instalam-se longe do trabalho, embora seus empregados continuem vivendo ali.

Estas formas de moradia revelam a permanência do antigo, paralelamente à renovação do espaço urbano, mediante a abertura das novas áreas residenciais. $[. .$.

A residência do empregado no local do trabalho dava ao patrão um reforço do controle de sua mão-de-obra sob dois aspectos. Em primeiro lugar, esta ainda estava na vigilância não remunerada após o expediente. Em segundo lugar, a obediência absoluta ao patrão era mais facilmente obtida com este tipo de moradia. Por outro lado, havia uma forte razão para muitos empregados preferirem tal modo de residir. Seus ganhos eram irrisórios e Ihes parecia mais
${ }^{10} \mathrm{Na}$ Conceição da Praia, segundo o Censo de $1872,21 \%$ de sua população é escrava. Infelizmente não há informações seguras de quantos vivem com seus senhores ou vivem por conta própria. Como já foi visto anteriormente, os escravos de ganho, normalmente, não vivem com seus senhores. 
${ }^{11}$ Na elevação traçada por José Antonio Caldas, em 1756, já se faz referência ao Mercado de Santa Bárbara, na Cidade Baixa. seguro ter teto e mesa garantidos pelo sistema de pagamento denominado 'a molhado' (com casa e comida). A alternativa era o pagamento 'a seco', apenas o ordenado. (SANTOS, 1992, p. 259-60)

Outra característica das casas que surpreende os viajantes é o fato de não serem um mundo fechado em si mesmo, devido ao clima de verão que prevalece durante quase todo o ano.

A casa no Brasil não é o ponto em volta do qual se concentra o mundo do proprietário; é, apenas, alternadamente, ora o guarda-sol, ora o guarda-chuva e, de noite, uma cama com dossel, onde se pode despreocupadamente, deixar arejar as roupas, para gozar a brisa fresca e reanimadora. (HABSBURGO, 1982, p. 113)

Como vimos, a forma de viver e de morar em Salvador não é diferente da que encontramos no Rio. As duas cidades têm populações e estruturas urbanas semelhantes, baseadas nos serviços da mão-de-obra escrava e, aos poucos, introduzem as novas tecnologias urbanas melhorando as condições da cidade, de suas ruas e da vida de seus habitantes. São cidades portuárias e, portanto, têm nessa atividade, ademais do comércio e dos serviços, suas mais importantes funções.

\section{De que vive a cidade}

O comércio é a principal atividade desenvolvida na cidade do Salvador. O movimento constante das pessoas - homens livres, libertos ou escravos, que vivem do comércio - junto com a oferta e a demanda de variados produtos, fazem de Salvador uma cidade viva, distinta e agitada. Esse movimento não passa despercebido aos estrangeiros que a visitam.

A variedade de produtos, as cores, os cheiros, a presença das mercadorias, tudo é exótico e novo para os que chegam de fora. As ruas estão cheias de vendedores ambulantes, as lojas estão por toda a parte e os mercados fechados. ${ }^{11}$ Não há comparação, aos olhos dos viajantes. Sobre isso, informa-nos Maximiliano de Habsburgo (1982, p. 138):

Uma cidade de barracas semelhante a um bazar, simétrica, com ruas que se cortam e que o circundam, forma o mercado de frutas da Bahia, que se assemelha muito ao de Gilbratar [...].

Quando se entra no mercado, fica-se, como no bazar do Cairo, atordoado, extasiado. Não se sabe para onde olhar primeiro, se para os vendedores ou para as mercadorias; se a atenção deve ser dedicada, primeiramente, às plantas ou aos animais. 
O comércio gira em torno da atividade agroexportadora, cujos produtos têm sua principal saída pelo cais de Salvador. Esse porto é um dos mais importantes da América portuguesa, desde os princípios da colonização do Brasil, quando Salvador ainda era a capital da colônia. A cidade organiza, pois, seu espaço, através da afirmação como praça comercial de uma grande área, e seu porto consolida-se como exportador dos produtos que vêm dali. ${ }^{12}$ O descobrimento de ouro na Chapada Diamantina, no interior da Capitania, e a multiplicação das fazendas de gado ajudam nessa consolidação.

Não se pode negar o abalo sofrido com a transferência da capital do Governo do Brasil para o Rio de Janeiro. Mas, nessa época, Salvador já se havia consolidado como uma grande praça comercial, exportadora de açúcar, algodão e tabaco, e importadora de produtos manufaturados. Tinha também se convertido numa distribuidora de mercadorias pelo interior da Capitania e por uma grande região à sua volta, chegando a pontos tão afastados como Piauí, Pernambuco, Sergipe, Minas Gerais e São Paulo, no Brasil, e também Uruguai e Argentina. A área de influência de Salvador chega, pois, além de seu entorno imediato. Com uma atividade econômica tão estruturada, Salvador não sente tanto a perda da função administrativa.

Um acontecimento importante vem agilizar as atividades na cidade: a abertura dos portos às nações amigas, em 1808, que põe fim ao monopólio de Portugal em relação ao comércio com o Brasil. Esse fato funcionou

[...] como resposta à necessidade de legalização de um imenso comércio clandestino para elevação de recursos da Metrópole, às pressões internacionais de liberdade de comércio, sobretudo da Inglaterra, e mesmo ao liberalismo econômico dos comerciantes nacionais potencializa a ampliação das trocas, dos contatos e das alianças internacionais, alicerçando concretamente um veio de ruptura com o passado colonial. Consolidam-se novas aspirações sociais, delineadas já desde as últimas décadas do século XVIII, e amplia-se o horizonte de referências da sociedade local. (FERNANDES; GOMES, 1992, p. 55)

Cria-se, então, a necessidade de a cidade ampliar as funções de seu porto, como centro de importação e exportação de mercadorias. Percebe-se a dependência de Salvador e da Capitania da Bahia em relação ao mercado externo em todos os momentos, seja em épocas de crise ou de prosperidade.

Em princípios do século XIX, a agricultura tem um novo estímulo, com o declínio das explorações na Chapada Diamantina e o retorno, à costa, da mão-de-obra que volta às plantações. Ao mesmo tempo, cresce o mercado europeu, favorecido pela Revolução Industrial. Além de produzir açúcar, tirando proveito da desorganização cubana e da subida dos preços no mercado 
internacional, a Bahia é uma grande produtora de café, algodão e cacau. Em Salvador também se realizam as transações financeiras e comerciais necessárias à expansão agrícola e à exportação dos produtos. "Assim sendo, continuava a cidade concentrando e usufruindo de todas as vantagens financeiras, econômicas, políticas e sociais decorrentes desta situação de 'metrópole regional'." (MATTEDI; BRITO; BARRETO, 1979, p. 349)

A cotação do açúcar no comércio internacional, o alto preço do algodão, a proibição do tráfico de negros e até mesmo a fuga dos negociantes portugueses depois da Independência do Brasil são fatos que influenciam no desenvolvimento da cidade, na transformação de sua estrutura, na sua entrada na era moderna e na implantação das novas tecnologias.

A partir de 1827, a Bahia disputa, com o Rio de Janeiro, a liderança na quantidade das exportações, em função do aumento da sua produção de açúcar. A produção do Recôncavo e do litoral chega a Salvador através de uma frota de veleiros, e busca-se uma melhor comunicação, por terra, com Feira de Santana e Xique-Xique, para, assim, ligar a bacia de São Francisco ao litoral. (SAMPAIO, 1999, p. 62-63)

Em meados do século XIX, a decadência de suas principais culturas, como a cana e o tabaco, não permite a diversificação de atividades produtivas, por causa da

\section{[...] insuficiente acumulação interna, reforçada principalmente pela evasão da maior parte do excedente gerado para outros espaços econômicos; a estrutura extremamente concentrada da renda e a conseqüente estreiteza do mercado interno; a inexistência de condições de infra-estrutura e a própria atuação do Estado, cuja proteção aos interesses do setor agro-exportador constituía um obstáculo a transformações que melhor o adaptassem às novas condições do mercado interno e externo. (CARVALHO; SOUZA, 1980, p. 73)}

Apesar disso, faz-se uma tentativa de industrialização - já que a proibição de instalação de manufaturas em terras brasileiras deixa de existir a partir de 1808 -, com a implantação das primeiras fábricas e manufaturas em Salvador, entre os anos 1840 e 1860 . A cidade converte-se num centro industrial. Essas manufaturas são o prolongamento do trabalho artesão tradicional, e a indústria têxtil é a mais importante. Essas atividades industriais são basicamente dependentes e/ou complementares do setor agroexportador, ou estão destinadas à população de baixa renda, uma vez que a classe dominante se abastece de produtos importados.

Com o fechamento das perspectivas internacionais, a partir de meados do século XIX, a produção fabril volta-se para o mercado interno, que não responde satisfatoriamente. É o primeiro fator que leva à estagnação do setor. 
O segundo fator é o crescimento acelerado da industrialização no centro-sul do País, sem que Salvador possa competir no processo de substituição das importações que lá se efetua.

O comércio, como função intermediária e instigadora do consumo, também impede o desenvolvimento do setor industrial, já que não se consegue criar um fluxo contínuo nas operações, na produção, tampouco nos benefícios. À falta de condições para o desenvolvimento de uma indústria de base, soma-se o significativo consumo de manufaturas estrangeiras.

Surge um dado novo na economia de Salvador, em finais do século XIX, com a cultura do cacau no sul da Província e sua produção em escala comercial. ${ }^{13}$ Esse fato muda o polo econômico da Bahia para lá, mas “[...] a cultura do cacau não estava em condições de permitir uma acumulação de capitais em favor da cidade do Salvador, cujo pôrto, contudo, concentrava tôda a exportação de cacau para o estrangeiro." (SANTOS, 1959a, p. 43)

O comércio ainda predomina na economia soteropolitana, mas não só aquele relacionado com a importação e a exportação. Há um comércio pequeno de grande poder e influência, onde, além de portugueses e brasileiros, encontram-se pessoas de muitas outras nacionalidades. 0 que não se pode negar, no desenvolvimento econômico de Salvador, é a importância do capital mercantil, que se diversifica e é investido em áreas de expansão e no melhor funcionamento da cidade.

Dadas as características da economia baiana, sem a possibilidade de se realizar a passagem do capital comercial a capital industrial, o primeiro terminou por se transformar na fonte por excelência dos investimentos internos, e seus detentores passaram a se comportar como uma 'burguesia de negócios' que investia em todos os campos. (SANTOS, 1994, p. 98)

Na primeira metade do século XX, Salvador vê reduzida sua área de influência, quando perde o domínio sobre os estados vizinhos e também sobre uma parte de seu próprio Estado. Devido à dificuldade de comunicação entre as cidades mais afastadas e a capital, essas estabelecem relações com cidades de estados mais próximos e de mais fácil acesso.

Uma questão crucial para a cidade nesse sub-período [1870-1950] vem do conjunto de fatores ainda pouco estudados e explicados, relacionado ao 'abortamento' das indústrias emergentes no Recôncavo e Salvador, cujo entendimento passa pela industrialização do Centro-Sul, muito mais forte e dinâmica, baseada nos excedentes do café, que vai deslocar a hegemonia do bloco do poder do Nordeste para o Sul. (SAMPAIO, 1999, p. 74)

\footnotetext{
${ }^{13}$ Essa produção aumenta de $811 \mathrm{t}$ em 1865 para 41 mil t em 1905 e daí para 53 mil t em 1920. Baixa de 70 mil em 1929 para 63 mil t em 1930. (TAVARES, 1987, p. 176)
} 


\footnotetext{
14 "A cidade se instalou num pequeno planalto, protegida de um lado por vales profundos e de outro por uma escarpa. Do núcleo inicial ela se estendeu a princípio para NE e $\mathrm{SW}$, ultrapassando as esplanadas com um plano em forma de 'pé de galinha', característico principalmente ao N. Logo após, sua expansão se fêz seguindo os espigões arejados, evitando os fundos dos vales que foram ocupados pelas hortas. [...] Tal forma de crescimento foi conseqüência das dificuldades naturais impostas pela distribuição do relêvo. Os bairros se desenvolveram isoladamente sôbre cada um dos elementos destacados da topografia, separados uns dos outros pelos vales, limitados por desníveis fortes que prejudicaram as ligações diretas entre as lombadas. As artérias principais se dispõem radialmente a partir da Praça da Sé [sic] em direção aos bairros seguindo os topos mais planos. As ligações entre as artérias principais são muito estreitas, sinuosas e enladeiradas."

(PEIXOTO, 1972, p. 3-4)
}

Esse período de letargia é conhecido como "enigma baiano", que decorre de sua descapitalização, da crescente deteriorização da indústria do açúcar na região e da mudança do eixo das decisões centrais do País no final do século XIX. Os produtos primários como açúcar, cacau, fumo e café, continuam a sofrer sobressaltos e flutuações devido às crises internacionais. Apesar disso, em 1907, a Bahia representa 13\% da circulação monetária brasileira, ficando atrás apenas de Minas e São Paulo, o que demonstra ainda sua importância a nível nacional.

Em meados do século XX, Salvador é a capital de um estado acanhado e subdesenvolvido, apesar de ser o mais rico do nordeste do Brasil. Sem dúvida, a cidade segue vivendo de suas glórias passadas, de seu antigo prestígio de metrópole comercial, centro administrativo e religioso. Sua perda do compasso chega a levá-la a não saber adaptar-se às novas exigências de um país independente, a não tentar investir em indústrias locais e a não tirar proveito de riquezas não agrícolas.

\section{(Trans) formando a cidade}

\section{Configurando a cidade}

Salvador tem a característica de ser cidade desde sua fundação. Como sede do Governo Geral do Brasil, em sua instalação já estão previstos todos os equipamentos administrativos, políticos e religiosos. Quando Tomé de Souza chega em 1549, traz consigo um "Regimento do Rei ao Primeiro Governador Geral", de 17 de dezembro de 1548, que determina as normas e regras de orientação para o processo de povoamento do Brasil. E são trazidas ainda traças e amostras recebidas em Lisboa, que deveriam ser obedecidas para a implantação da Fortaleza e povoação Grande e Forte.

A cidade está assentada num ponto da costa brasileira cujos elementos topográficos são os espigões, as lombadas prolongadas e as colinas. Entre esses elementos encontram-se os vales. A escarpa é outro componente da topografia que separa a cidade em duas: Cidade Alta e Cidade Baixa. Por último, há as baixadas do litoral. Com essa topografia, Salvador caracteriza-se por ser uma cidade alongada, de tipo linear, que se desenvolve em função da falha tectônica, o que a converte num exemplo de subordinação a um fator geológico. ${ }^{14}$

No primeiro período da evolução urbana da cidade, que se situa entre sua fundação em 1549 e a expansão inicial da capital em finais do século 
$X V I$, a urbe limita-se à plataforma do alto da escarpa. No segundo, do século XVII até meados do século XVIII, expande-se sobre as colinas, cruza o Rio das Tripas e chega à segunda linha de cumeada. É um crescimento lento, que reflete os primeiros esforços de incorporação de uma área em expansão.

O terceiro período, o da consolidação da cidade, de meados do XVIII até finais do século XIX, caracteriza-se pela formação de novos bairros, que se beneficiam dos novos transportes. A cidade estende-se em direção ao norte e ao sul, principalmente sobre as dorsais na Cidade Alta e para a península de Itapagipe na Cidade Baixa. A expansão acontece de forma rápida.

Um crescimento lento e reformas urbanas são os pontos-chave do quarto período, que vai do início do século XX até princípios da década de 50. Nessa fase, realizam-se aterros na Cidade Baixa e executam-se obras no porto, porém a área urbanizada aumenta lentamente. (SILVA; SILVA, 1991, p. 57)

Milton Santos (1959a, p. 56-63) constata três tipos de ocupação urbana da fundação até a década de 50 do século XX. Em sua análise, na primeira fase, de 1549 até finais do século XVI, Salvador goza de um centro de plano regular, onde as ruas se cruzam em ângulo reto, e adapta-se a topografia; na segunda etapa, entre o século XVII e finais do século XIX, a cidade cresce sem plano nenhum para o conjunto, disso derivando ruas sinuosas e pequenas praças; na terceira e última fase, no século XX, temos a ampliação das funções urbanas e a introdução dos transportes modernos, o que cria a necessidade de alargamento das ruas e de abertura de praças. Na Cidade Baixa, os aterros criam áreas para a ampliação do porto, a abertura de largas avenidas, a criação de grandes praças e a construção de edifícios modernos. Nessa fase, a cidade dispõe de capital e técnicas para adaptar-se às exigências do lugar e às modificações das condições topográficas da urbe.

Entre 1800 e 1850, a zona que vai da Preguiça até Água de Meninos e Jequitaia, na Cidade Baixa, transforma-se numa área moderna, como o resultado de uma ação que respeita a herança cultural recebida das gerações anteriores. A estreita faixa de terra amplia-se pouco a pouco, por meio de aterros que conquistam áreas ao mar, principalmente entre a Alfândega e a Associação Comercial. Nas áreas novas, são construídos novos quarteirões, e agora, além da rua que serpenteia junto à montanha, existem três ou quatro paralelas, a depender do trecho. A ocupação do trecho entre a Jequitaia e os Mares consolida o vetor de crescimento da cidade na direção de Itapagipe. ${ }^{15}$

A malha urbana está vinculada à irregularidade da superfície. Na primeira linha de cumeada encontra-se o núcleo original da cidade. Ao longo do século XIX, a Cidade Alta incorpora, em sua área urbanizada, os núcleos de povoamento dispersos. Os limites, que antes estavam entre as fortificações do
${ }^{15}$ Segundo Câmara (1989, p. 122125), o trecho entre a Igreja do Pilar e Água de Meninos se ocupa a partir de 1777 e até 1860 se estende até a Igreja de São Francisco, sendo interrompido até o Noviciado da Jequitaia, de onde toma forma contínua até a Calçada de Mares. 
Barbalho e Santo Antônio ao norte e a de São Pedro, ao sul, vão mais além. Passando pelo vale do Rio das Tripas, a cidade avança pela segunda linha de cumeada, onde se encontram Nazaré, Palmas e Desterro. Ultrapassa o limite do Dique do Tororó, e ocupa a terceira linha de cumeada. São ocupados, povoados e organizados núcleos populacionais em locais tão distantes como Brotas, Rio Vermelho ou São Gonçalo e Cabula. São conquistadas outras cumeadas no século XIX, como Matatu, Quinta das Beatas, Acupe de Brotas e Estrada de Brotas. No alto das colinas, as aglomerações urbanas formam-se como manchas, unidas por ruas longas e sinuosas.

Identificam-se três vetores de expansão além do da Cidade Baixa. A conquista do primeiro vale com a canalização do Rio das Tripas e a abertura da Rua da Vala é um dos vetores mais importantes de crescimento da cidade. Seu prolongamento possibilita a união com outros vales, gerando novas opções para o trânsito entre o centro tradicional e os diversos pontos periféricos, de forma suave, sem encostas abruptas. A canalização do rio também propicia a dissecação das áreas pantanosas, criando condições para a expansão urbana. O polo do Campo Grande ramifica-se, pela Estrada da Vitória, até a Barra e a Graça e, pelo Garcia, para o Canela, chegando até o Rio Vermelho seguindo pela cumeada. Um último vetor do sistema de expansão é a Estrada 2 de Julho que, partindo de um ponto da Rua da Vala, segue pelo Dique do Tororó até o Rio Vermelho.

A dificuldade de deslocamento entre os diversos pontos da cidade faz com que Salvador concentre funções em seus distritos centrais. A formação da área urbanizada não permite a organização de centros comerciais nos bairros, o que favorece o centro único, com concentração de atividades e transportes, situação que só muda a partir da segunda metade do século XX.

O crescimento urbano de Salvador é uma expansão física do tipo "mancha de azeite" (SILVA; SILVA, 1991, p. 61), primeiro de forma linear com relação a seu núcleo original e depois envolvendo-o. Em finais do século XIX, a cidade tem 800 hectares e chega aos 3 mil hectares de área urbanizada em 1940. (NEVES, 1985, p. 23)

\section{Equipando a cidade}

Durante todo o século XIX, implantam-se e inauguram-se, em Salvador, diferentes tipos de equipamentos, que introduzem hábitos distintos e um novo modo de vida. Desde 1799, o governo português tem a ideia de criar um jardim botânico na cidade, mas, só em 1810, o então Governador e Capitão-Geral da Capitania da Bahia, Marcos de Noronha e Britto, $8^{\circ}$ Conde dos Arcos 
(1810-1818), desapropria uma área perto do Forte de São Pedro, onde se implanta o Passeio Público e um obelisco, em comemoração à chegada da família real no Brasil em 1808.

Era um belo logradouro público, plantado de grandes árvores, palmeiras imperiais e dotado de gradil suspenso sobre a ribanceira, magnífico belvedere sobre o mar, a baía, [...]. Alamedas de laranjeiras, limoeiros, jambeiros, mangueiras, árvores de pão, densas e aparadas cercas de pitangueiras, flores ornamentais de toda parte [...] (PEIXOTO, 1980, p. 135-136)

Maximiliano de Habsburgo (1982, p. 97) também se maravilha com o Passeio Público e nos conta que

[...] fica situado em dois terraços, no alto da colina já muitas vezes mencionada, no estilo arquitetônico do Sul, no qual natureza e arte se unem, de maneira harmoniosa. Os terraços são maravilhosamente ornamentados com ricas balaustradas vasos e estátuas, de mármore de Carrara, no estilo barroco italiano. Fontes - em forma de monumentos - e terraços com muitos bancos enfeitam os pontos principais. Canteiros com as flores mais perfumadas, nas cores mais brilhantes, orlam os caminhos e demais áreas, enquanto as trepadeiras mais encantadoras pendem sobre as balaustradas das escadas.

Há outras obras realizadas pelo Conde dos Arcos: o Teatro São João, terminado e inaugurado sob sua administração, apesar de não ter sido iniciado por ele; o edifício onde funcionaria a Praça do Comércio - a partir de 1840, Associação Comercial da Bahia -, uma edificação destinada a servir de sede dos ajustes de negócios (SANTOS, 1985, p. 17-18); e a Biblioteca Pública, inaugurada em 1811, com algo como 4 mil volumes, a princípio no Salão do Dossel do Paço dos Governadores, mudando-se depois para um salão dos fundos da Catedral. Após uma rápida passagem pela Piedade, vai para o Palácio dos Governadores, onde incendiou-se em 1912, sendo, então, transferido, o que restou, para diversos pontos, até que, em 1919, instala-se em seu próprio edifício, na Praça Rio Branco, antiga do Palácio. (PEIXOTO, 1980, p. 250)

Também encontramos outros serviços, como o Corpo de Polícia, criado em 1825, e a Guarda Urbana de Salvador, de 1857. Para os incêndios, organiza-se um grupo chamado "Voluntários contra os Incêndios", de iniciativa privada. Os telefones são implantados em 1884, têm uma expansão lenta, e só há um aumento do número de aparelhos no século XX. Em 1833, o Hospital Militar, situado no antigo Colégio dos Jesuítas, cede lugar à Faculdade de Medicina. 
${ }^{16}$ Segundo Nascimento (1986, p. 46) só em 1836 há uma determinação legal para o fornecimento da iluminação com óleo de peixe.
Como outras cidades do Brasil, Salvador moderniza suas redes de infraestrutura ao longo do século XIX. A cidade, que funciona graças à mão-de-obra escrava, seja para o transporte de pessoas ou para o abastecimento de água, prepara-se para a introdução das novas tecnologias e do trabalho assalariado.

As novas exigências da população, a diminuição do número de escravos a partir da extinção do tráfico até a abolição total, a pressão internacional, entre outros fatores, levam a uma nova forma de ver a cidade e de nela viver. Há uma preocupação com a melhoria dos serviços públicos e a busca de uma qualidade de vida superior, com mais conforto e bem-estar. Esse processo faz com que as empresas responsáveis pelos serviços básicos introduzam novas tecnologias, cada vez menos dependentes da mão-de-obra escrava.

As condições para intervir no urbano, transformando-o e adaptando-o a uma nova era, surgem quando Salvador se reafirma como uma cidade comercial, com um porto de fundamental importância dentro da estrutura da Província. Cada vez mais, Salvador integra-se na estrutura capitalista internacional, assegurando um intercâmbio comercial contínuo com mercados mundiais e abrindo a possibilidade de ingresso do capital estrangeiro na cidade.

Os poderes públicos, sob a pressão dos empresários, que buscam melhor fluidez para suas mercadorias, e do capital internacional, pronto para ser investido na cidade, concorrem para uma renovação urbanística e uma modernização material, que se refletem na implantação dos serviços de infraestrutura como: abastecimento de água, iluminação - primeiro a gás e depois elétrica -, novos meios de transporte e inovações no setor das comunicações.

Até princípios do século XIX, não há iluminação nas ruas de Salvador. O primeiro projeto realizado para a implantação de lampiões é aprovado em dezembro de 1825, para o percurso entre São Pedro e a Praça do Palácio. 0 projeto define a quantidade de bicos que deve ter cada lampião e onde devem estar localizados, apesar de os primeiros lampiões, abastecidos com óleo de baleia, só serem instalados em 1829. (MATTOSO, 1992) ${ }^{16}$ De qualquer forma, a iluminação que se oferece ainda não é de boa qualidade. Como não se faz um bom controle do funcionamento dos lampiões, muitos deles param de iluminar no meio da noite. Algumas áreas ficam bem iluminadas, e outras não têm iluminação alguma.

Em 1847, começam as negociações para melhorar o serviço de iluminação, através de um abastecimento à base de gás carbônico, como se fez em Paris e em Londres. O serviço é contratado em 1858, e as obras são iniciadas em 1861, mas o resultado continua sendo insatisfatório. Esse tipo de iluminação é instalado inicialmente nas ruas, mas, aos poucos, é introduzido nas edificações públicas e nas particulares. 
Em 1903, inaugura-se a iluminação elétrica numa parte da cidade, e logo se expandem os serviços por toda a área urbanizada. A implantação fica a cargo da Compagnie d'Eclairage da Bahia, que, depois de dois testes, decide pela instalação em caráter definitivo. Uma das provas ocorre em 8 de dezembro de 1903, e a inauguração definitiva acontece em 24 do mesmo mês, em alguns pontos do Distrito da Sé. (PINHEIRO, 1992, p. 84-85)

Apesar de ser considerado um dos serviços mais regulares, o abastecimento de água em Salvador se faz através de fontes públicas. Em 1853, é criada a Companhia do Queimado, responsável pelo tratamento e distribuição de água potável, captada na Represa de Santa Luzia. São construídos uma estação de tratamento e um lago artificial, para o abastecimento dos diversos chafarizes instalados em vários pontos das freguesias da cidade. Os chafarizes e as fontes públicas, feitos de mármore e ferro fundido, são muito apreciados pelos viajantes que visitam a cidade e, inclusive, comparados com os do Rio.

Quando, há alguns anos, construíram novas canalizações de água, no Rio de Janeiro, não se pensou em ornamentação de fontes.[...]

Na Bahia empreenderam êsse trabalho com muito mais poesia. Nalguns pontos principais da cidade erigiram fontes, em parte talhadas no mármore e, em parte, de bronze fundido, que são realmente belas.

A obra-prima mais perfeita parece-me a fonte no Terreiro, diante da Igreja do Colégio ou Igreja dos Jesuitas, magníficas figuras de bronze de dimensões colossais, cuja aquisição faz honra à cidade. 0 monumento foi todo fundido na França. Uma das figuras é realmente de beleza perfeita, como quase não conheço igual. (AVÉ-LALLEMANT, 1961, v. 1, p. 23)

Apesar disso, até princípios do século XX, a população ressente-se da precariedade do serviço de distribuição de água, que não chega a funcionar de forma satisfatória. Em 1904, o município encampa a Companhia do Queimado, que, sob a direção do Engenheiro Theodoro Sampaio, realiza o projeto e as obras necessárias para o abastecimento - a construção de represas e de uma estação elevatória -, ampliando assim a rede de distribuição. Essas obras, que se inauguram em 1907 (QUATRO..., 1949, p. 209), abastecem a cidade até 1925 , quando se realiza um novo projeto para a ampliação da rede, a cargo do Engenheiro Saturnino de Brito.

Uma cidade sem rede de esgotos e sem cloacas é uma cidade suja, onde os detritos e as águas imundas são jogadas na rua, que se limpam somente quando chuvas torrenciais caem sobre a cidade. A princípio, deixa-se a limpeza da cidade nas mãos de particulares, serviço pelo qual, só em 1867, se responsabiliza a Câmara dos Vereadores. Os problemas de salubridade da 
${ }^{17}$ A autora não específica qual é a empresa citada. urbe só se evidenciam quando aparecem as epidemias de febre amarela e cólera, que matam centenas de pessoas.

A implantação da rede de esgoto já se discute em 1855 com a proposta da construção de um sistema geral de tubulações. Outra vez é discutida, em 1859 , mas nada se executa. É realizada mais uma tentativa em 1865 , quando o governo consegue a autorização para contratar um serviço de sumidouros de quem apresentar melhores condições. Uma vez mais, não se delibera sobre o tema e não se realiza a contratação.

Por fim, em 1869, as negociações seguem adiante com a apresentação de três propostas para a execução da rede de esgoto nas edificações e nas ruas, e um contrato é assinado com o Engenheiro Antônio Luís da Cunha Bahiano.

Em 1873, é assinado um novo contrato entre uma empresa e a Câmara dos Vereadores, mas fica em "letra morta", já que a Assembleia Legislativa não o aprova. ${ }^{17}$ (MATTOSO, 1992) E a cidade continua sem um serviço de boa qualidade até que se abre concorrência em 1893 e, por fim, são implantadas as tubulações em 1905, após a contratação do Engenheiro Theodoro Sampaio.

Não se pode dizer que não haja preocupação em efetuar o saneamento da cidade. Apesar dos diversos contratos assinados e os problemas com a execução do serviço, acabam sendo implantadas tubulações nas mais diversas partes da cidade e há uma preocupação com a manutenção dos condutores de águas sujas e também das águas das chuvas.

\section{Movendo-se pela cidade}

Na segunda metade do século XIX, ocorre uma significativa melhoria no sistema de transporte da cidade. Até então, numa cidade muito acidentada, cheia de ladeiras íngremes, com núcleos de povoação nas cumeadas das colinas, o meio de transporte mais comum são os pés, ou deixar-se levar por escravos nas cadeirinhas de arruar, palanquins, serpentinas e liteiras.

Como a cidade é dividida em alta e baixa, e por conseguinte a locomoção dos veículos ali são impraticáveis, os escravos têm a função de cavalos, e transportam de um lugar a outro os mercadores, inclusive os mais pesados. Por essa mesma razão o uso do palanquim é muito comum. Trata-se de uma rede coberta por uma pequena cortina bordada, levada por dois negros, que carregam um longo bastão, o qual é suspenso por duas pontas, e assim as pessoas de qualidade são transportadas à Igreja, em suas visitas, e mesmo ao campo. (FROGER, 1700, p. 134-135)

Os investimentos em transportes começam na década de 60 do século $\mathrm{XIX}$, tanto no que se refere às mercadorias como às pessoas. $\mathrm{O}$ desenvolvimento 
da área urbana impõe uma melhor comunicação entre a Cidade Alta e a Cidade Baixa, entre o Centro e os núcleos afastados, entre a capital e o interior da Província. Para tornar viáveis tais comunicações, concedem-se vantagens aos empresários que invistam na implantação dos transportes públicos.

A expansão e a modernização dos transportes, na segunda metade do século XIX, reflete-se na valorização do solo e no incentivo à especulação imobiliária. Bairros como Barra, Graça e Vitória urbanizam-se e recebem mais habitantes, enquanto o Rio Vermelho, afastado e despovoado, muda sua estrutura e comercializa seus terrenos, após a chegada das linhas de bonde.

Os bondes diminuem as distâncias e integram os diversos pontos da cidade. A dificuldade está nas ruas muito estreitas, que dificultam sua passagem, e é necessário o deslocamento por longos trechos, até chegar-se a uma artéria principal por onde circulam. A população, pouco a pouco, adapta-se a esse novo meio de transporte, que é introduzido em Salvador na segunda metade do século XIX.

Um empresário, Rafael Ariani, estabelece o primeiro serviço público em 1862, com as gôndolas, carros altos com molas, puxados por quatro animais, em que o cocheiro fica sobre um deles. No mesmo ano, o mesmo empresário introduz os bondes puxados por burros sobre trilhos de aço ou de madeira, que cobrem o trecho entre Coqueiros de Água de Meninos e o Bonfim. São criadas outras empresas para servir a outras partes da cidade.

Em 1871, é inaugurada uma nova linha, da Barroquinha até as Sete Portas, que integra as novas terras conquistadas depois da canalização do Rio das Tripas. Nesse mesmo ano, são introduzidos os transportes a vapor, cujos trilhos vão ainda mais longe.

As empresas existentes dividem a cidade em setores, e cada uma delas responsabiliza-se em levar e trazer a população do Centro até os bairros e vice-versa. A empresa Trilhos Centrais tem sua linha entre a Barroquinha e a baixada da Soledade; a Veículos Econômicos, entre o Largo da Conceição e a península de Itapagipe; finalmente, a Trilhos Urbanos leva os passageiros da Praça do Palácio até o Rio Vermelho e a Barra.

Quanto à eletrificação dos transportes urbanos, em 1897 é fundada a Companhia Carris Elétricos, pelo empresário Antônio Francisco Brandão que, com a empresa alemã Siemens \& Halske, eletrifica os trechos da Cidade Baixa. Um novo grupo, a Light and Power, norte-americana-canadense, estende a eletrificação às linhas Graça-Vitória, Barra, Rio Vermelho-Amaralina, Bonfim-Ribeira, Soledade-Liberdade e Retiro. Em 1920, todas as linhas já estão eletrificadas. 
Os trens são introduzidos na Bahia em meados do século XIX, quando surge a necessidade de conectar as regiões do interior do Estado com a capital, através de um melhor transporte de pessoas e de mercadorias. As primeiras linhas implantadas seguem os caminhos do gado, dos portos do Recôncavo, das zonas de cultivo de cana-de-açúcar, café e fumo, e das minas de exploração de diamante. 0 Estado da Bahia situa-se na vanguarda com relação a esse meio de transporte. (SANTOS, 1959a, p. 40-41)

A implantação das linhas depende do capital estrangeiro, já que o capital público nacional tem outras prioridades e oportunidades melhores. Por outro lado, nem toda a rede se constrói com o capital estrangeiro. Segundo Kátia Mattoso (1992, p. 470), podemos identificar duas fases: na primeira, entre 1856 e 1875, as linhas férreas são construídas com o capital inglês e, na segunda, entre 1875 e 1893, o governo da Província financia as construções, em sociedade com empresas privadas dos meios financeiros da Bahia. De todas as concessões obtidas entre 1856 e 1893, mais ou menos 50\% são exploradas adequadamente e outros $50 \%$ não são levadas adiante.

Tendo Salvador como ponto de partida, a Bahia and São Francisco Railway Company, com sede em Londres, faz a conexão entre a Jequitaia, em Salvador, e Juazeiro, às margens do Rio São Francisco. São construídas outras linhas que conectam cidades do interior da Bahia, complementando-se o trajeto para Salvador por via marítima e fluvial. Por exemplo, para ir da Chapada Diamantina até Salvador, é construída uma linha entre a Chapada e Cachoeira, para de lá se fazer o transporte pelo Rio Paraguassu, depois pela Baía de Todos os Santos, até se chegar à capital.

Os locais por onde passa o trem, ainda quase desertos, com pequenos núcleos de povoamento, recebem um impulso com a chegada desse meio de transporte, que propicia o deslocamento de pessoas do interior, além das facilidades para instalarem-se ao longo de suas linhas. Os trens, como vetor da expansão urbana de Salvador, não têm a mesma importância que o bonde. Entretanto, propiciam o desenvolvimento de alguns subúrbios ferroviários, como Periperi, Plataforma e Paripe, e, o mais importante, barateiam os custos da produção e melhoram o abastecimento da cidade.

Numa cidade dividida em parte alta e parte baixa, é fundamental que haja uma boa ligação entre elas. Durante todo o século XIX, os diversos governantes preocupam-se em facilitar esse deslocamento e, ao mesmo tempo, evitar os desmoronamentos da encosta sobre as casas da parte baixa. São propostas soluções como a construção de ladeiras, que sirvam também como elemento de contenção da montanha e a instalação de elevadores e planos inclinados. 0 grande problema encontra-se na inclinação das ladeiras que 
unem as duas cidades, que não permitem o uso de veículos com rodas, e, para realizar o trajeto, a única opção é a utilização das cadeirinhas de arruar, ou outros meios de transporte, sempre conduzidos por escravos.

Nas ladeiras íngremes, em parte calçadas de tijolos, o que impossibilita quasi andar-se a cavallo, o viajante encontra cadeiras de aluguel, em que dois robustos negros escravos podem transportal-o com presteza para a cidade alta, onde uma calma não comum o espera e as agradáveis brizas marinhas o reconfortam. (SPIX; MARTIUS, 1916, p. 53)

Desde a fundação da cidade, a diferença de nível entre as duas cidades converte-se num problema que merece muita atenção. Os primeiros jesuítas que chegam constroem uma espécie de monta-carga, para fazer subir os materiais de construção da igreja, do colégio e tudo o que se necessite na Cidade Alta. Implantam-se outros monta-cargas, mas essa comunicação continua a ser um problema até o século XIX. Para mudar essa situação, em 1873, inaugura-se um elevador hidráulico (Fig. 26) entre as duas partes da cidade, construído por Antônio Lacerda, gerente da empresa Hosting Machine. Na Cidade Alta, o elevador tem seu acesso pela Praça do Palácio e, na Cidade Baixa, por trás da Alfândega. Em 1897, constrói-se um segundo elevador hidráulico, o do Taboão.

Outra forma de unir a Cidade Alta à Baixa é por meio de planos inclinados: o Gonçalves (Fig. 27), inaugurado em 1889, e o do Pilar, cuja data de construção não é do nosso conhecimento. A eletrificação, tanto dos elevadores como dos planos inclinados, acontece entre 1907 e 1910.

A nova revolução dos transportes acontece com a introdução do automóvel em Salvador. O primeiro carro chega à cidade em 1902.

Quando a buzina fazia FON-FON toda a gente corria às portas e janelas para ver o automóvel passar. Quem transitava se detinha para apreciar o novo engenho, ou para esconjurar aquele Macaco Doido, que se metia a andar em semelhante invenção do diabo. (VIANNA, 1983, p. 48)

\section{Alguns projetos para a cidade}

\section{Medicando a cidade}

Salvador, uma cidade suja, como já foi referido, é uma capital enferma, com taxas de mortalidade muito altas, males epidêmicos e moléstias endêmicas. A população não respeita as leis e joga o lixo e os dejetos no meio das ruas. 


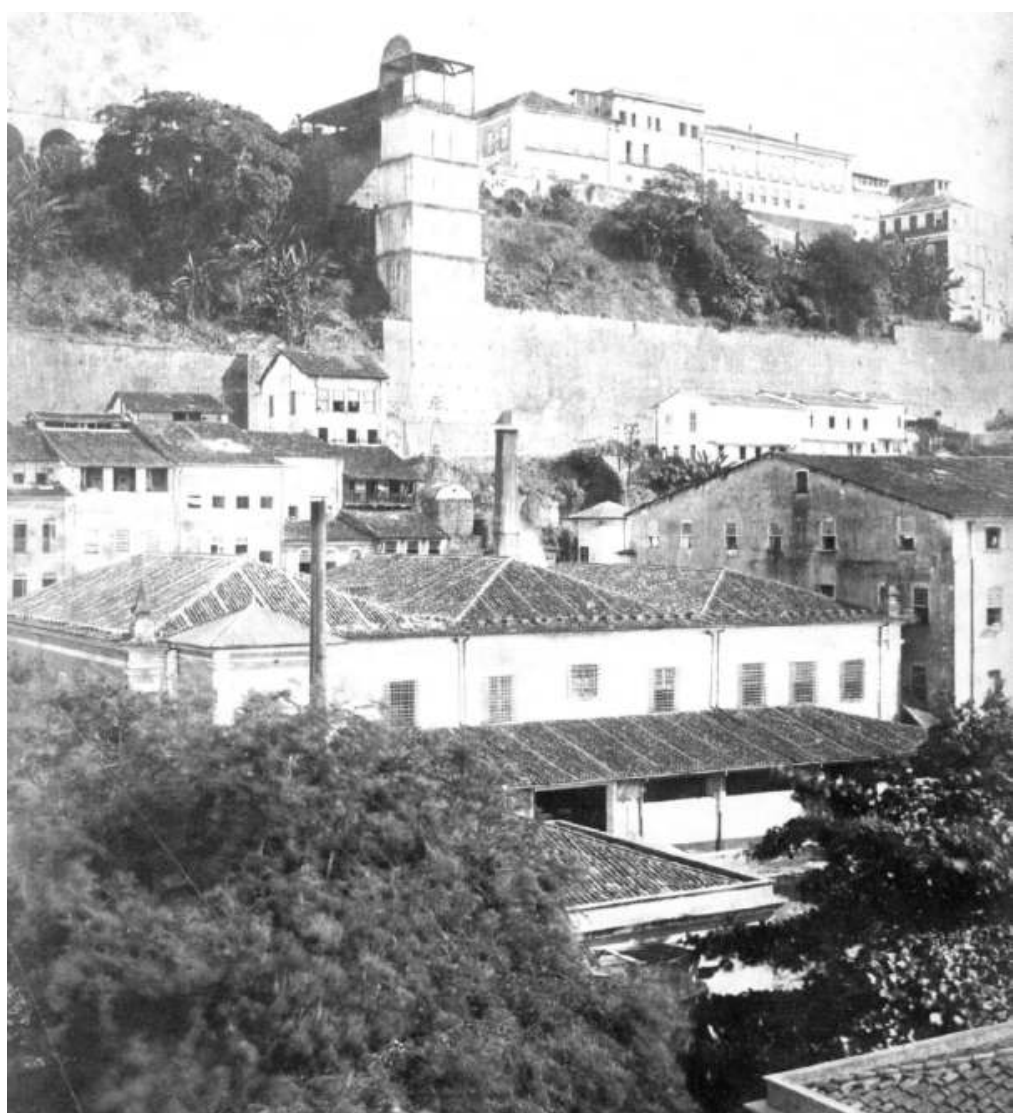

26. Elevador Lacerda - foto de Rodolfo Lindemann - 1885

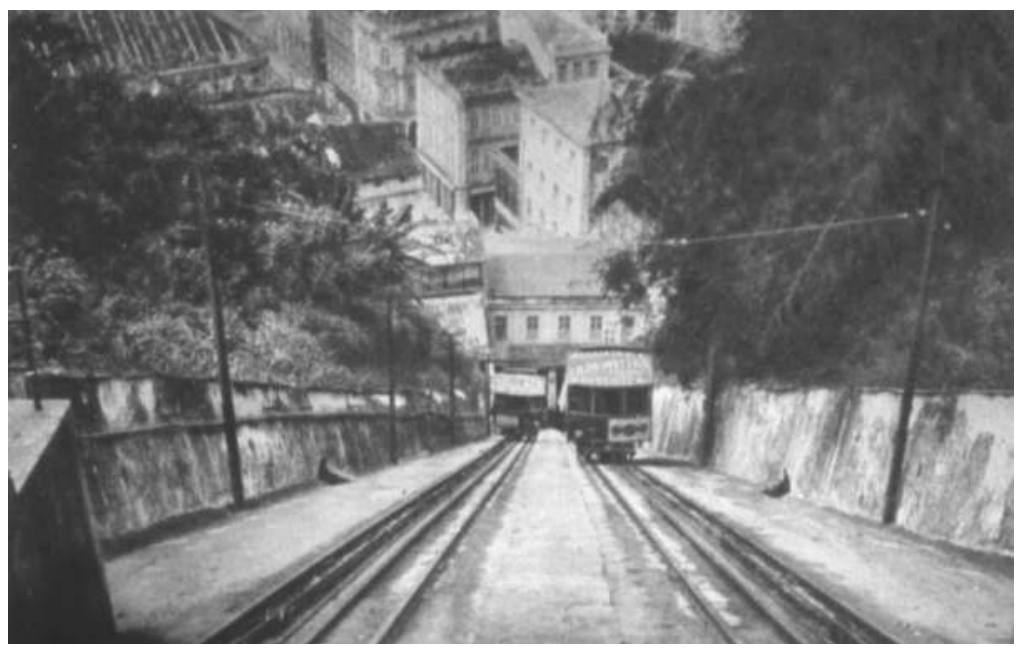

27. Plano Inclinado do Gonçalves, imagem atual 
A Câmara Municipal tenta mudar os maus hábitos dos habitantes da cidade, sistematizando, em 1831, um código de posturas, muitas delas já existentes, com um conjunto de normas para a orientação das obras públicas e privadas, além da orientação sanitária. Nesse código, encontramos muitos pontos relativos à higiene, à limpeza e à saúde pública, como por exemplo:

Todos são obrigados a ter sempre varrida a testada de sua casa, limpa, derramada a sua roça; Ninguém lançará de suas casas para as ruas águas de serviços delas ou qualquer corpos que possam enchuvalhar os viandantes; Todo despejo imundo das casas que não tiverem cloacas será levado ao mar, em vasilhas cobertas, somente depois das 9 horas da noite; Todos são obrigados a vacinar seus filhos ou dar remédios antes da idade de 2 meses.

(SIMAS FILHO, 1977, p. 190-110)

Porém há outros fatores que colaboram com a insalubridade. O problema não está só nas pessoas, que não respeitam as "posturas", mas também na própria cidade, que vive num estado precário de salubridade pública, com infraestrutura deficiente, sem higiene nas casas e numa situação de miséria, criando um ambiente propício para a aparição e a propagação de epidemias. A cidade construída impõe limites à higiene. Seu denso espaço está construído de maneira confusa, com um traçado e uma arquitetura que em nada ajudam à salubridade. Não obstante, as novas áreas têm um aspecto sanitário diferente dos antigos espaços já degradados.

A primeira grande epidemia que aparece é a de febre amarela, em 1850, deixando para trás uma enorme quantidade de mortos em Salvador e em toda a Bahia. Volta em 1852. O cólera, supõe-se, chega do Pará, a bordo de um navio, em 1855. Dessa vez, são cerca de 10 mil mortos, quer dizer, 16,8\% da população da capital. ${ }^{18} \mathrm{O}$ grande número de óbitos, nas duas epidemias, afeta a economia da Bahia, com a desorganização da produção de açúcar, uma comoção no comércio e uma crise no abastecimento alimentício.

Há um caos na cidade. Não há médicos nem hospitais. São tantas as vítimas, que não se pode inumar todas, e muitas nem mesmo são sepultadas. Os mortos são recolhidos em carros grandes e jogados em valas comuns, em locais afastados da cidade. A insalubridade é a origem do problema, e é necessário mudar esse quadro. Nesse momento, o poder público, por meio da máquina administrativa, cria hospitais de isolamento, cemitérios fora do perímetro urbano e mecanismos de saúde pública gratuita. Os serviços de limpeza urbana começam a funcionar mais regularmente em 1867, quando passam a ser responsabilidade da Prefeitura.

São tomadas muitas outras medidas para melhorar a higiene em Salvador, como a execução de obras de saneamento nos matadouros, nos mictórios
18 Dados obtidos através do documento da APEB Seção Histórica - Presidência da Província - Saúde Epidemia 1855-1889. (apud NASCIMENTO, 1986, p. 161) 
19 Entre 1715 e 1777, segundo Marcos Paraguassu Câmara, a linha da costa avança para o alinhamento da ribeira das Naus. (CÂMARA, 1989 , p. 120)

${ }^{20}$ Segundo Nestor Goulart, com base na elevação traçada por José Antonio Caldas, em 1756. (REIS FILHO, 1994b). Essa linha de cais transformou-se na Rua Nova do Comércio, hoje Rua Portugal e Rua Conselheiro Dantas.

${ }^{21}$ No desenho de 1786, de Manuel Rodrigues Teixeira, pode-se observar, na área anteriormente ocupada pelos jesuítas, já expulsos do Brasil, aparecem seis quadras, com edifícios de quatro andares e mansardas, entre o mercado de Santa Bárbara e o Cais do Sodré. (REIS FILHO, 1994b)

22 Essa linha de cais corresponde à atual Rua Miguel Calmon. públicos e nos serviços de recolhimento de materias fecais. Até finais do século XIX, estrutura-se melhor o serviço sanitário e criam-se muitos órgãos de defesa da saúde. São realizadas desinfecções em pessoas e cargas que chegam de navio ao porto e são incentivadas as investigações sobre vacinas.

Uma cidade civilizada e moderna tem de ser limpa e higiênica. Os engenheiros e os médicos estão à frente das transformações que se produzem na área urbana, para mudar as condições de salubridade de Salvador, incompatíveis com os ideais de uma sociedade civilizada. Mudar o aspecto de higiene da capital é um dos passos para atingir a modernidade.

\section{Projetando uma nova cidade}

O processo de modernização da cidade do Salvador não se limita ao período de sua mais importante reforma urbana, 1912-1916, pois se desenvolve ao longo do século XIX como resposta a uma necessidade de estruturar a urbe, ampliar sua área, acomodar uma população que cresce, aumentar o número de habitações, erradicar as epidemias, melhorar a salubridade, facilitar a circulação de pessoas e de mercadorias, implantar os transportes e os novos serviços urbanos. A idealização da cidade moderna está presente em Salvador sob a forma de uma preocupação com a estética e com elementos determinantes, como salubridade, setorização e fluidez.

Pode-se dizer que o primeiro planejamento urbano realizado na cidade do Salvador ocorre na Cidade Baixa. Por meio de aterros para ganhar terras ao mar, amplia-se, pouco a pouco, a estreita faixa de terra da parte baixa da cidade, a partir de meados do século XVIII. ${ }^{19}$ A evolução desse espaço começa no Cais da Farinha, onde aparecem três quadras, construídas com grandes sobrados de 4 andares, tendo ao alto, nos telhados, as janelas das cozinhas, com aparência de mansardas. ${ }^{20}$ Em finais do século, já são seis os quarteirões com aparência regular, entre o mercado de Santa Bárbara e o Cais do Sodré. ${ }^{21}$ Em 1811, é demolido o Forte de São Fernando, construindo-se, em seu lugar, o prédio da Praça do Comércio, inaugurado em 1816. Entre 1840 e 1870, cria-se uma nova linha de aterros, em frente à anterior, onde se projetam dez novos quarteirões, com a construção de sobrados de cinco andares e mansardas, três praças, além de uma rua larga e de uma nova linha de cais, chamada Cais do Pedroso, ou das Amarras. ${ }^{22}$ (Fig. 28)

[...] uma ampla avenida a beira mar, com excelentes edifícios, de altura uniforme, mas sem que o seu gabarito impedisse a visão, seja da encosta verde, seja do perfil da cidade alta, valorizando-se, assim, todo o conjunto, respeitando-se o antigo e nele integrando-se, adequadamente, o moderno. (SIMAS FILHO, 1977, p. 105-106) 


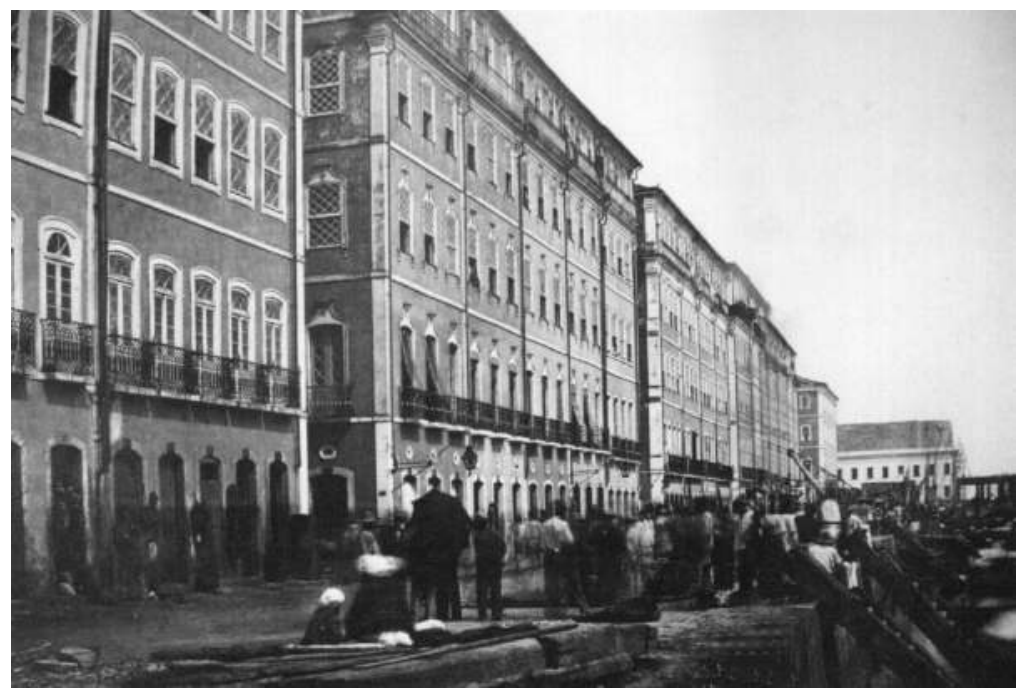

28. Cais das Amarras, na Cidade Baixa - foto de B. Mulock - 1860

Para as novas áreas, projeta-se um conjunto urbano com quarteirões regulares, compostos por edificações com o mesmo número de andares e o mesmo acabamento externo, diferenciando-se apenas pelos detalhes decorativos. Alguém que os observe de longe pode crer que se trata de um único edifício por quarteirão. ${ }^{23}$

Segundo Nestor Goulart (apud REIS FILHO, 1994b, p. 17), essa uniformidade nas fachadas, na altura, e até mesmo no tipo de ornamentação, dá monumentalidade ao conjunto, ainda que os edifícios, isoladamente, não tenham muita importância. Por um momento, pode-se pensar ter sido o modelo pombalino adotado em Salvador, não fosse a diferença entre as datas. Em 1756, o conjunto da Cidade Baixa de Salvador já existe enquanto a reconstrução de Lisboa ainda não havia começado. A hipótese que propõe o autor é a seguinte:

[...] as soluções adotadas na Baixa de Lisboa não teriam caráter tão circunstancial mas seriam fruto de uma consciência urbanística comum, dos principais construtores portugueses dessa época, que se vinham formando nas décadas anteriores. Nesse caso, o parentesco entre o conjunto da Bahia e o de Lisboa, como dos conjuntos posteriores de Belém, São Luís e Alcântara, seria uma relação com família mais ampla e não uma obra do acaso. (REIS FILHO, 1994b, p. 37)

Finalmente, o primeiro conjunto pode ser identificado como barroco, e o último, em frente ao anterior, obedece a padrões pombalinos, com algu-
${ }^{23}$ Podemos fazer uma comparação com as edificações da Place Vendôme, ou as da Rue de Rivoli, em Paris, que são construídas como um bloco único, com regras preestabelecidas. 
mas décadas de atraso. Mesmo com a mudança de estilo nas construções da Cidade Baixa, o modelo urbanístico permanece nas dimensões dos quarteirões e no alinhamento das edificações. 0 conjunto impressiona pela época de sua construção e por suas dimensões.

0 partido era necessariamente o de um conjunto do barroco tardio. Os edifícios, em sua parte, apesar do despojamento, exibiam vergas arqueadas nos vãos e detalhes decorativos de gosto rococó. Mesmo os construídos em meados do século XIX, frente ao Cais das Amarras, tinham marcas estilísticas do barroco tardio. Mas os edifícios públicos nas extremidades eram neoclássicos e as últimas obras ultrapassavam os limites cronológicos de cultura barroca e apresentavam alguns detalhes neoclássicos. Nem por isso o enquadramento urbanístico desses conjuntos deixava de ser barroco. (REIS FILHO, 1994b, p. 41)

Esse conjunto monumental representa a afirmação do poder de uma classe social que começa a dominar em finais do século XVIII e princípios do século XIX: a burguesia comercial. Se os latifundiários do século XVII e princípios do século XVIII constroem suas mansões com portadas barrocas, obras monumentais isoladas, e praças com edificações oficiais, os comerciantes constroem conjuntos urbanos e praças com edificações relacionadas com o comércio, como os mercados, a Associação Comercial e a Alfândega.

Entre 1810 e 1818, no governo do Conde dos Arcos - considerado o pioneiro na modernização da cidade do Salvador -, surge a ideia de transferir o centro administrativo para mais ao norte do bairro comercial, quer dizer, para a península de Itapagipe, aproveitando edificações existentes e abandonadas, e construindo outras para receber a Alfândega e os armazéns. Finalmente, o projeto não se concretiza, e o centro administrativo permanece na Cidade Alta.

Há outro projeto, no governo do Conde dos Arcos, que se inicia, mas não é concluído: o de um canal entre a Baía de Todos os Santos e a enseada de Itapagipe, cujo objetivo seria facilitar o acesso de barcos pequenos, que vêm do interior da baía para o porto principal e criar um ancoradouro público e seguro na península.

Encontramos outras iniciativas do Conde dos Arcos para a modernização da cidade, como a construção do Passeio Público, da Associação Comercial (Fig. 29), do Teatro São João e a organização da Biblioteca Pública, sobre as quais já nos referimos anteriormente. 0 governador tem a intenção de embelezar a capital e publica um código de "posturas", que têm como objetivo regulamentar as construções. A cidade muda seu aspecto com a introdução dos novos elementos, principalmente na Cidade Baixa. 


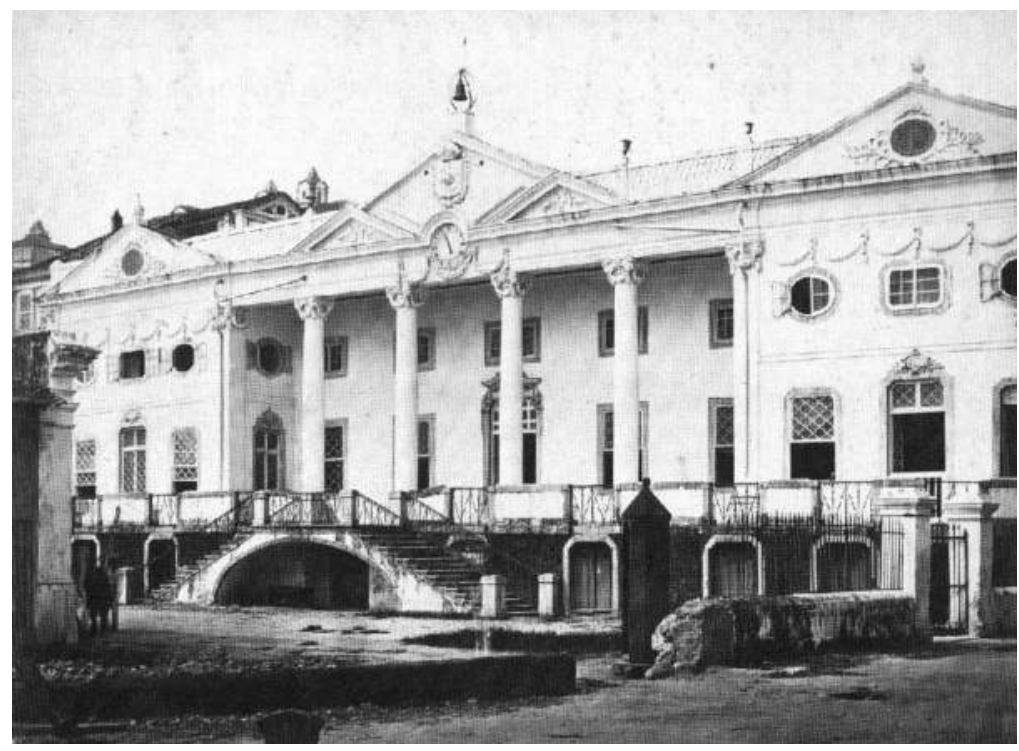

29. Sede da Associação Comercial na Cidade Baixa - foto de B. Mulock - 1860

Mas a cidade real ancora-se ainda e no entanto numa cidade eminentemente colonial. Tímida em suas características físicas, acanhada em sua economia urbana, dominada pelo espaço privado, gerida por precária estrutura administrativa e dependente do braço escravo para o seu funcionamento, ela é parte e condição da sociedade colonial e escravista. (FERNANDES; GOMES, 1992, p. 56)

Há necessidade de novas intervenções e de novos projetos para se obter a modernização e mudar a estrutura colonial-escravista por uma estrutura moderna. A administração da cidade preocupa-se com o sistema viário desde finais da década de 40 até o final do século XIX. São muitos os problemas que se apresentam referentes a esse sistema, já que Salvador cresce sem planejamento global nem organização, com ruas estreitas, sinuosas e com péssima qualidade de pavimentação.

A urbanização com a abertura de ruas, praças, ladeiras, becos, travessas e largos era feita sem a menor planificação, a não ser do primitivo núcleo do centro da cidade. A impressão que deixa o exame da documentação é de que, primeiro, existiam as casas, para que depois viessem a existir as ruas. Daí o desalinhamento destas. (NASCIMENTO, 1986, p. 30) 
Dentre as mudanças realizadas na estrutura viária, a canalização do Rio das Tripas, com a abertura da Rua da Vala, e a construção da Ladeira da Montanha são as duas obras urbanísticas mais importantes do século XIX.

A Rua da Vala representa não só a canalização de um dos rios mais infectos que cruzam a cidade, como a utilização, pela primeira vez, de um vale como forma de união entre os distintos núcleos existentes sobre as colinas que formam o espaço construído. Ao utilizar o macadame para a sua pavimentação, a Rua da Vala transforma-se numa das principais artérias, por onde transitam pesados veículos sobre rodas, como os de carga, que não conseguem passar pelas estreitas ruas da capital, e os bondes com tração animal, depois a vapor e, mais tarde, elétricos. Como já foi mencionado, a Rua da Vala é um dos vetores mais importantes, responsável pela expansão da cidade e pela conquista de novos espaços.

A Ladeira da Montanha (Fig. 30), construída na década de 70 do século XIX, começa na Rua dos Ourives, na Cidade Baixa, e chega até a Praça do Teatro, na Cidade Alta. Concebida para que veículos sobre rodas possam subir e descer sem problemas, sua leve inclinação facilita as comunicações entre as duas partes da cidade. Sua abertura para o trânsito acontece em 1878. Além de facilitar a circulação entre as duas partes da cidade, sustenta a escarpa, evitando os constantes deslizamentos de terra.

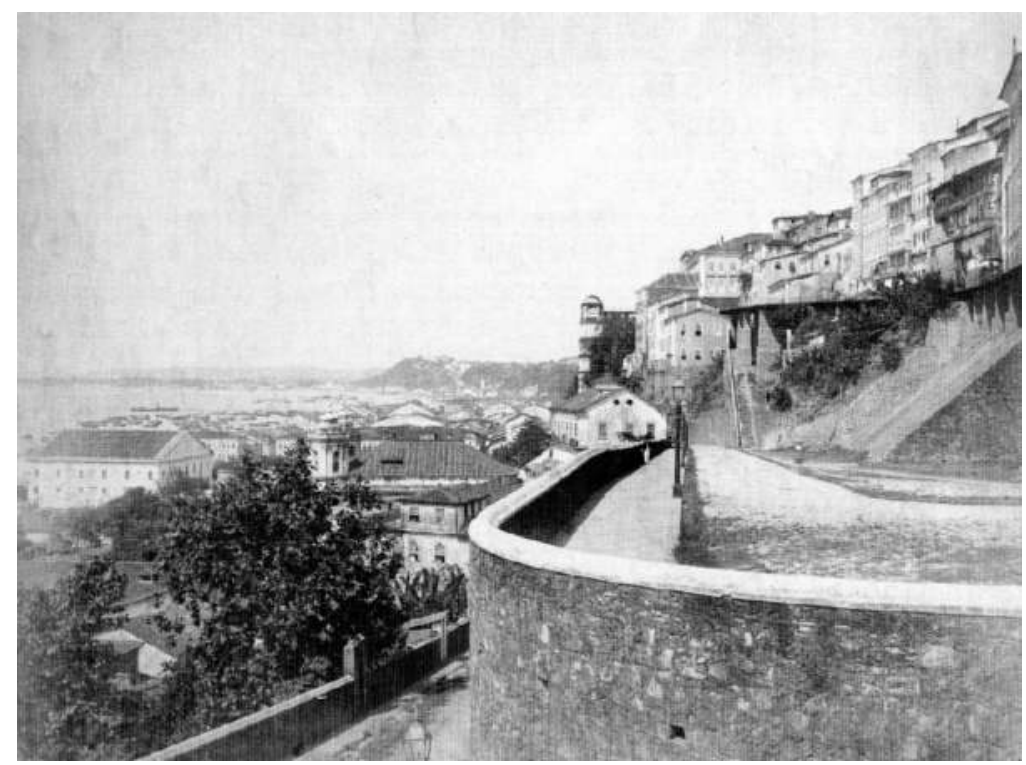

30. Ladeira da Montanha, ligação entre a Cidade Baixa e Cidade Alta - foto de R. LIndemann - c. 1880 
Entretanto, no século XIX, não apenas se criam essas duas novas artérias. A rede viária também passa por um processo de recuperação, com muitos alargamentos, retificações e pavimentações de ruas já existentes, e a abertura de novas, que muitas vezes vêm a orientar o crescimento da cidade.

A determinação das ruas que devem passar por uma reestruturação demonstra que há uma diferenciação entre os distintos bairros da cidade, pois as melhorias são mais frequentes nas áreas mais nobres. Em bairros como Sé, Conceição da Praia ou São Pedro, as intervenções atendem à intensificação do comércio; na Vitória, as melhorias são levadas a cabo porque é uma área nobre, cada vez mais ocupada pela classe alta.

As "Leis e Resoluções Municipais" de finais do século XIX fazem referência à abertura de novas ruas, à regularização de outras, à construção de calçadas, à implantação de infraestrutura, tanto no Centro como longe dele. Aí também percebemos um trato diferenciado entre os diversos bairros. Sobre o Distrito da Penha, há referência à construção de habitações operárias, caracterizando essa área como proletária. Ondina, bairro à beira do Oceano Atlântico, sempre aparece nas normativas como uma "cidade balneário". (CARDOSO, 1991, p. 83-84)

A Sé, centro político, administrativo e religioso de Salvador, merece uma atenção especial ao longo de todo o século XIX. Durante os anos 70, a área que compreende a Praça do Palácio e seu entorno, até o Largo do Teatro, é alvo das principais intervenções que pretendem uma mudança na estrutura urbana.

São introduzidos os serviços de infraestrutura: trilhos para os bondes, tubulações para o abastecimento de água, rede de esgoto e iluminação pública. As ruas são alargadas e pavimentadas, a maioria de paralelepípedos. São adicionados adornos e mobiliário urbano nas praças ampliadas.

A principal praça da capital, a Praça do Palácio, sofre uma total transformação, com a demolição de edifícios arruinados, o alinhamento de casas e a construção do elevador hidráulico, que faz a ligação com a Cidade Baixa (Fig. 31 e 32). Mudar o aspecto da cidade faz parte da transformação que se quer introduzir, para conseguir uma cidade moderna. É importante começar por ali para que "alargando a Praça acabasse com o cercado e tudo quanto empactando-a dava-Ihe aspecto pouco agradável e impróprio da principal praça desta Cidade." ${ }^{24}$

Na mesma praça, é construída uma balaustrada na parte oeste, onde se colocam colunas de iluminação feitas na Inglaterra e 19 estátuas de mármore, sendo que 11 delas representam a Pintura, a Escultura, a Música,
${ }^{24}$ Ofício n⿳0 93 expedido pela Diretoria de Obras Públicas em 20/04/1878. Arquivo Público do Estado da Bahia. 


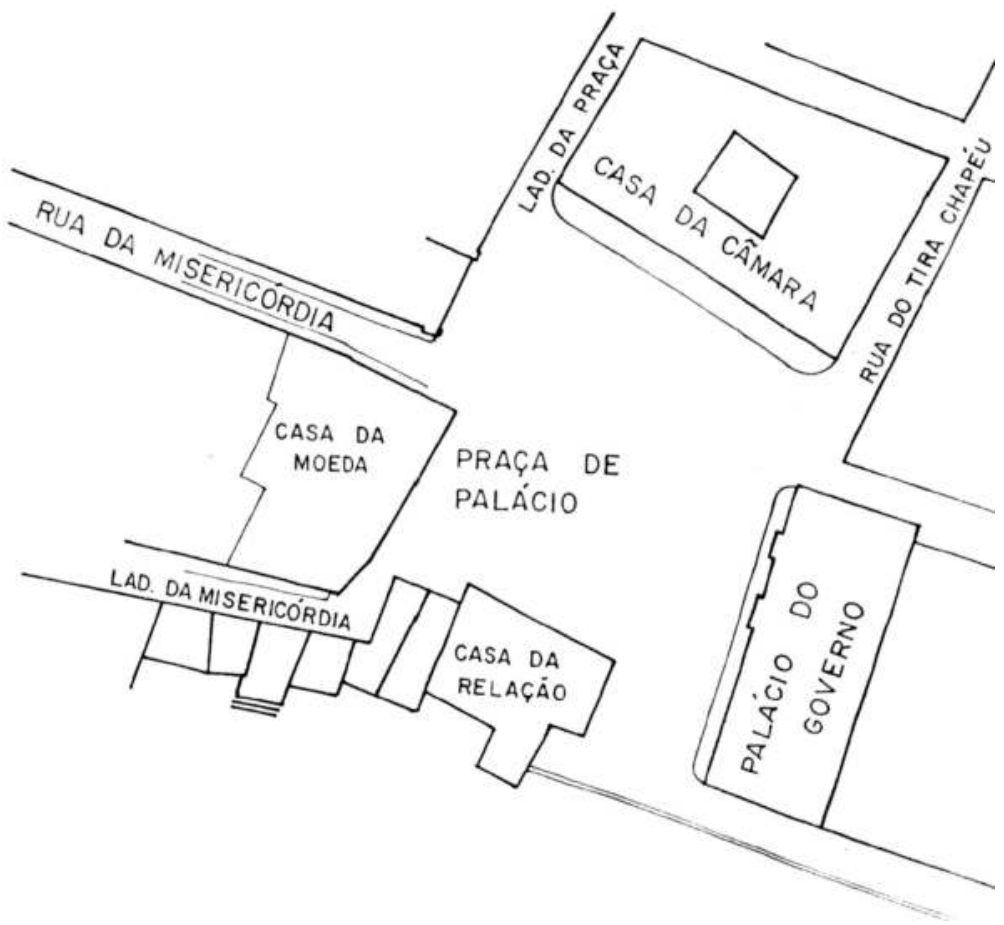

31. Praça do Palácio antes das intervenções realizadas no século XIX

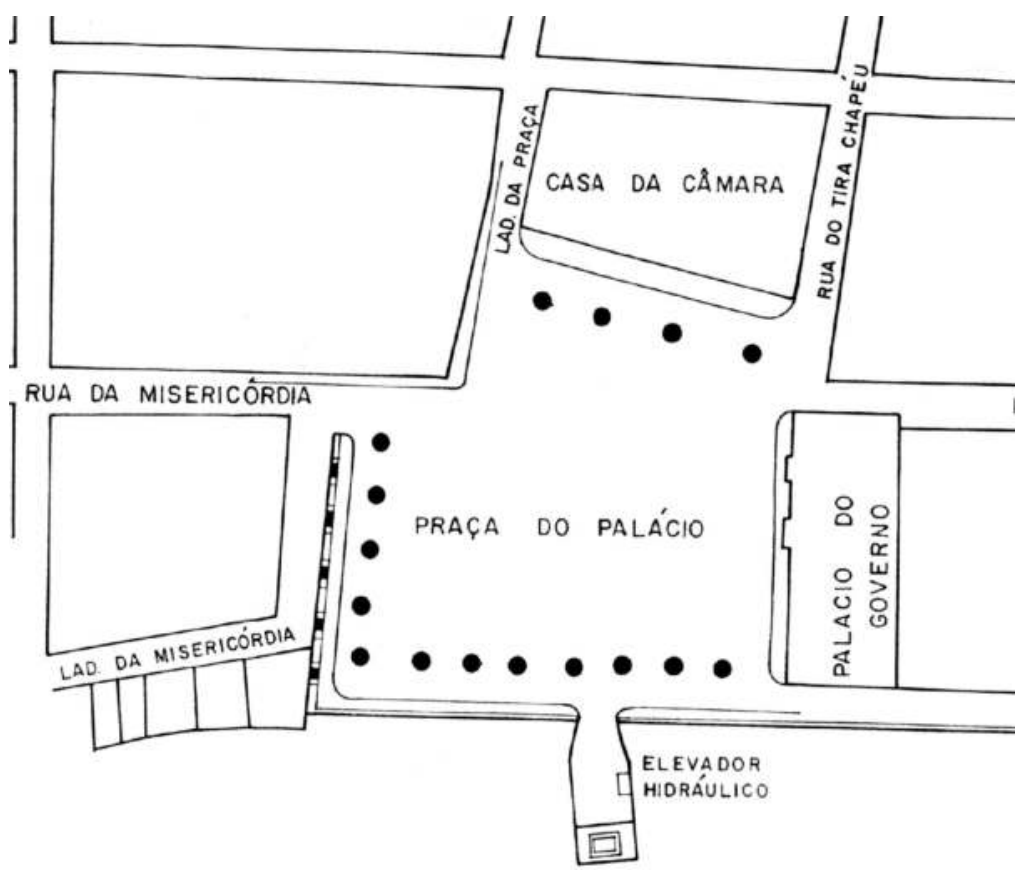

32. Praça do Palácio depois das intervenções realizadas no século XIX 
a Poesia, a Náutica, a Astronomia, a Agricultura, a Indústria, o Comércio, a Abundância e a Arquitetura. ${ }^{25} \mathrm{O}$ Largo do Teatro também sofre modificações, com a substituição de sua pavimentação, a colocação de um gradil de ferro com bancos e de colunas de iluminação.

No que se refere à Cidade Baixa (Fig. 33), o século XIX representa a consolidação dessa área como a zona comercial da cidade. Já que é o primeiro ponto visto pelos que chegam por mar, a Cidade Baixa tem de estar suficientemente cuidada, para impressionar. Depois dos aterros, seguidos da construção do conjunto harmonioso de edificações e da larga avenida do porto, pavimentam-se as outras ruas, a limpeza pública aos poucos se torna eficiente e a infraestrutura é devidamente implantada. A parte baixa continua crescendo, mas para o alto, devido a seu espaço reduzido.

Sendo uma cidade portuária, é importante modernizar seu porto, algo vital para o desenvolvimento do comércio de importação e exportação. Durante todo o século XIX, apresentam-se projetos de melhoria das instalações portuárias, ainda coloniais, que propõem a ampliação da área do porto mediante aterros, a construção de novos cais para navios de grande calado, atracadouros para embarque e desembarque de passageiros e mercadorias, além de grandes armazéns. As obras não se restringem à área entre a Alfândega e a Praça do Comércio, mas continuam até a Jequitaia.

A Bahia Docks Company Limited, fundada em Londres, em 1872, desenvolve um projeto para o porto, que não sai da mesa de trabalho. Em 1891, Frederico Merei e Augusto Cândido Harache obtêm uma nova concessão para essas obras, posteriormente transferida para a Companhia Docas e Melhoramentos da Bahia. ${ }^{26}$

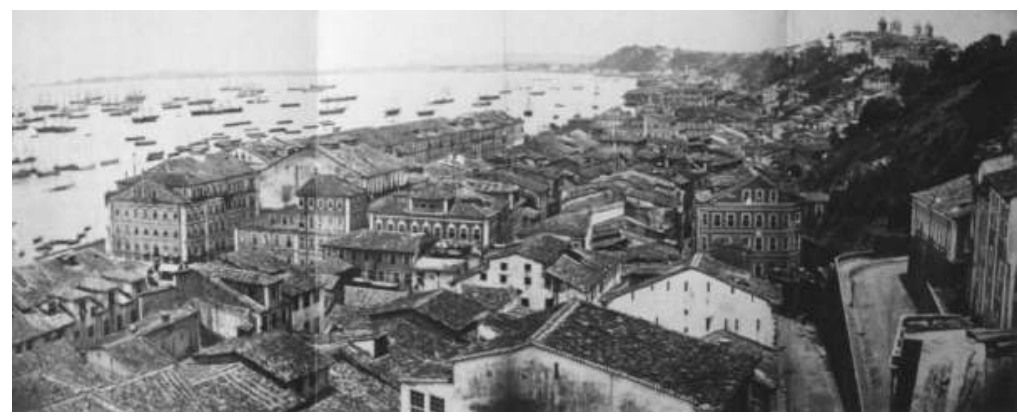

33. Vista da Cidade Baixa - autor desconhecido - c. 1880
${ }^{25}$ Em ofício n ${ }^{\circ} 247$ expedido pela Diretoria de Obras Públicas em 17/06/1876, comunica-se que o negociante Nicoláo Gavazza oferece uma coleção de estátuas de mármore, para serem colocadas na Praça do Palácio, mas são compradas oito, conforme ofício $n^{\circ} 627$, da mesma Diretoria, em 18/12/1876. Em 03/01/1881, através do ofício $n^{\circ}$ 01, foi autorizada, pela Diretoria de Obras Públicas, a compra de mais 11 estátuas de mármore. Arquivo Público do Estado da Bahia.

\footnotetext{
${ }^{26}$ Essa companhia muda seu nome para Companhia Internacional de Docas e Melhoramentos do Brasil, e depois para Companhia Concessionária das Docas
} do Porto da Bahia. 
Todo esse processo de pequenas intervenções, numa tentativa de transformar a estrutura colonial ao longo do século XIX, chega a seu apogeu na segunda década do século XX com a realização da reforma urbana promovida no período 1912-1916, sob a direção do Governador José Joaquim Seabra, um ex-ministro de Rodrigues Alves, Presidente da República entre 1902 e 1906, anos da reforma urbana realizada no Rio, conhecida como "Reforma Passos".

\section{Á reforma urbana
de José Joaquim Seabra}

Em princípios do século XX, a cidade do Salvador ainda mantém sua estrutura colonial, com desenvolvimento do setor industrial incipiente. Assim, seu papel limita-se ao de cidade portuária e comercial, de importância regional, aumentando sua área de influência quando o trem a conecta com as terras mais afastadas do interior. No início do século XX, o fumo e o cacau são os principais produtos da economia baiana.

[...] durante as primeiras décadas do presente século a situação econômica da cidade e de sua região de influência pouco se modificou em relação às últimas do século anterior. A falta de dinamismo do setor tradicionalmente vital da economia baiana se refletiu na cidade, que passou por um período de grande retração econômica ao tempo em que sofreu, inclusive, um certo amortecimento demográfico, devido em parte a um redirecionamento dos fluxos migratórios rumo ao sul do Estado, estimulados pelo desenvolvimento da economia cacaueira. (MATTEDI; BRITO; BARRETO, 1979, p. 351)

Não obstante, a cidade continua a expandir-se, e cresce a necessidade de obras urbanas, para a instalação de transportes, iluminação, redes de água e esgoto e para a melhoria do porto. Para tal empreitada, precisa dispor de capital para investir na criação da nova estrutura urbana.

Não foram poucos os capitais de origem externa obtidos pela administração pública para a implementação de suas obras; também nesse momento determinados tipos de serviços urbanos assim como insumos para a implantação dos mesmos eram importados, o que poderia, ao lado da penetração do capital internacional, constituir um estímulo para a intervenção no espaço físico-territorial de Salvador. (MATTEDI; BRITO; BARRETO, 1979, p. 352)

Nessa época, o bonde é o responsável pela maior parte dos deslocamentos da população, o que também promove o desenvolvimento e a ocupação de 
novos espaços. Os bairros crescem, o Centro torna-se cada vez mais denso, e surgem definições sociais e funcionais mais nítidas para a cidade. Na Penha, instalam-se as fábricas têxteis e outras manufaturas de produtos alimentícios. O bairro de Itapagipe caracteriza-se por ser proletário, e a Vitória, o local preferido pela elite. A Conceição da Praia mantém suas casas comerciais com negócios em atacado e continua sendo um dos pontos mais tumultuados da cidade, com grande quantidade de lojas e muita gente circulando durante 0 dia. A Cidade Alta não muda sua função de centro administrativo, religioso e, agora, também, comercial, prolongando-se em direção ao Campo Grande, além do qual estão os bairros ricos. A população que reside no Centro é cada vez mais pobre.

Apesar do surgimento de novas residências nos bairros ricos, a maioria das pessoas vive ainda em sobrados, ou em casas térreas. No Centro, seja na Cidade Baixa ou na Cidade Alta, os sobrados são subdivididos e alugados a muitas famílias. Mal conservados, encontram-se em péssimas condições de habitabilidade e higiene, muitos em ruínas. Normalmente, são habitados por uma população pobre, constituída de alforriados da escravidão, que conseguem a liberdade mas não recebem ajuda alguma, nem têm condições de sobrevivência. São eles os que vivem no Centro, em busca de uma oportunidade diária de trabalho.

A reforma urbana do período 1912-1916 realiza-se no Centro, um espaço densamente povoado, dividido em duas partes, com características e paisagens distintas. Também são dois os tipos de intervenção na cidade, objetivando introduzir a modernidade dentro de seus limites. Se a Cidade Baixa ganha terreno ao mar e constrói uma nova urbanização, a Cidade Alta inaugura largas avenidas, numa tentativa de romper com seu passado.

Até 1940, o crescimento urbano caracteriza-se pela expansão dos bairros afastados e a conquista crescente de terras ao mar, na Cidade Baixa. As intervenções são tópicas, pois ainda não se pensa a cidade como um todo.

\section{A viabilidade da reforma urbana}

\section{Por que se faz a reforma}

0 inchaço que a cidade sofre, com o grande afluxo de população, traz consequências lamentáveis, como a carência de habitações e a superpopula-

ção do Centro. A estrutura urbana colonial dificulta a circulação de pessoas e 
mercadorias, contribui para a incidência de epidemias causadas pela concentração urbana e pela insalubridade das ruas. Chega-se a uma situação limite, o que leva a nova burguesia emergente e as autoridades públicas a idealizarem uma cidade regular, higiênica, funcional, fluida, homogênea, equilibrada, sincronizada e bem administrada, argumenta-se a necessidade de intervir na cidade, mudando a estrutura colonial, para atender às novas necessidades, e de mudar a aparência da cidade, com a introdução de uma nova estética.

Já nos referimos às condições de salubridade (ou insalubridade) da cidade, onde as epidemias acometem a população várias vezes durante 0 século XIX e voltam em princípios do século XX. Referências a esse quadro são feitas nos comentários dos viajantes que a visitam, e a elite envergonha-se dessa situação, desejando mudar a imagem da cidade, aproximando-a do que se idealiza como "civilizada". Para atingir essa cidade limpa e higiênica tão desejada, é necessário intervir no espaço público, no espaço privado, e mudar os hábitos de vida.

Durante todo esse século, a salubridade e a higiene são uma preocupação constante, com pressões para que o poder público seja mais exigente no controle e na administração da cidade. Urge a elaboração de um projeto de saneamento para a capital.

Este projeto higienizador da cidade implicará em três planos: o do espaço público, o do espaço privado e o do modo de vida. Ele buscará a normatização das habitações, invadirá a vida familiar e tentará estruturar os comportamentos individuais e coletivos. (FERNANDES; GOMES, 1992, p. 61)

Uma cidade colonial, com seu típico traçado urbano, tem a circulação de pessoas e de mercadorias dificultada pelo intrincado de suas ruas e pela morosidade de seus meios de transporte. Com a introdução de uma nova ideologia capitalista, entende-se que Salvador tem de mudar essa estrutura, para facilitar a ligação entre o porto, elemento importante dentro de uma economia agroexportadora, e seu hinterland, através do trem e de avenidas que facilitem os acessos. 0 crescimento da área urbana também exige meios de transporte mais rápidos e a definição de novos vetores de expansão. Existe o ideal de converter Salvador numa cidade fluida, com possibilidade de deslocamentos rápidos, confortáveis e baratos.

[...] a necessidade de buscar uma melhor organização do porto e melhores articulações entre Cidade Alta e Cidade Baixa [...], entre o centro e os núcleos de povoamentos mais afastados e entre a cidade e seu interior já é demonstrada, num primeiro momento, pela preocupação do poder público em melhorar e ampliar o sistema viário da cidade, fluidificando o espaço na medida do possível. (FERNANDES; GOMES, 1992, p. 57) 
Também existe a pretensão de resolver os problemas de mobilidade urbana, uma vez que a classe dominante abandona o velho Centro, em busca de novos bairros para viver, e os trabalhadores têm de transportar-se até o trabalho diariamente. Para atingir esses objetivos, há que intervir nas ruas estreitas e sinuosas, melhorar a comunicação entre os distintos pontos da capital e facilitar a implantação dos novos meios de transporte.

A preocupação estética já vem do século XIX, com a chegada dos novos modelos estrangeiros, seus novos códigos estéticos e novos bens de consumo. Nos espaços públicos, trata-se de embelezar as ruas e praças, com a colocação de esculturas, graças a uma preocupação com a cenografia. Mendigos são retirados das ruas e internados em albergues. Nas construções, há a necessidade de mudar o contraste entre os edifícios religiosos, com sua forma rica e opulenta, e os residenciais, com sua falta de originalidade.

Aos poucos, uma nova linguagem arquitetônica chega da Europa, seja o neoclassicismo da Associação Comercial, seja o ecletismo das novas mansões da Vitória. A nova burguesia abandona os sobrados escuros e mal ventilados, passando a viver em novas mansões, que seguem os modelos vindos da Europa e dos Estados Unidos.

A elite crê que romper com o passado colonial, introduzindo novos modelos arquitetônicos, em moda na Europa, é a melhor maneira para se alcançar a modernidade e o progresso. Através de uma pesquisa feita pelo Jornal de Notícias, entre 18 e 25 de junho de 1912, podemos perceber a ansiedade da população por uma reforma geral na cidade e sua inserção numa nova estética. Alguns dos pedidos dos leitores são:

'Higgiene nas ruas', 'Saneamento geral e esthetico', 'Approvo o remodelamento completo de todo o districto da Sé', 'Ruas largas e iluminadas', 'Architectura, mas architectura de um novo estylo moderno', 'De tudo quanto precisa uma cidade moderna', 'Avenidas, calçamentos, edificios', 'Melhoramentos materiais' (JORNAL DE NOTÍCIAS apud PERES, 1974, p. 44)

A imprensa, favorável às reformas e sua fiel defensora, ajuda a doutrinar a população, apesar da necessidade de sacrificarem-se alguns conjuntos urbanos e monumentos isolados, o que revela uma insensibilidade e uma aversão em relação à Salvador colonial. Os modelos mudam, e a estrutura da primeira capital do Brasil também necessita mudar, pois há que seguir os passos da modernidade. "A Bahia material que guarda ainda todos os característicos de uma cidade colonial de três séculos atraz, vae desapparecer para ceder logar a uma cidade moderna construida sob os preceitos rigorosos do progresso." (GAZETA DO POVO apud PERES, 1974, p. 36) 
Nesse período, utiliza-se a estética na perspectiva de criação de uma nova cidade e de uma nova sociabilidade, importante na formação de um ambiente bom, que, consequentemente, originaria um homem bom. A estética une-se à técnica, representada pela salubridade e a fluidez, na construção desse novo ambiente. "No reino do visível (e do sensível) a estética complementa, portanto, a funcionalidade da técnica na adequação de um novo meio para o homem." (FERNANDES; SAMPAIO; GOMES, 1999, p. 168)

Esse processo remonta a meados do século XIX, mas, na segunda década do século XX, coincidem as condições financeiras e políticas favoráveis para realizar-se a desejada reforma urbana, em que "politécnicos do urbanismo", imbuídos de uma "ideologia do progresso" (PERES, 1974, p. 37), chegam com a ordem de demolir o passado, derrubar o antigo casario e os monumentos, abrir avenidas e conquistar espaços ao mar. Os distintos projetos urbanísticos apresentados, independentemente da ideologia de seu autor - seja Theodoro Sampaio, seja Jerônimo Teixeira de Alencar Lima -, defendem a higiene, a estética e a circulação.

\section{Como se faz a reforma}

O que percebemos, no princípio do século XX, é a tentativa de adequar a área urbana às demandas de uma sociedade que aprende a viver sem a mão-de-obra escrava, que tenta adaptar-se às novas tecnologias e às transformações sociais e estruturais ocorridas nos últimos anos do século anterior, como a Abolição da Escravatura e a Proclamação da República.

Para realizar as mudanças necessárias e intervir no espaço densamente construído, faltam, além de decisão política, condições humanas e uma situação economicamente confortável para cobrir os custos dessa grande empreitada. Ao tomar posse do Governo do Estado da Bahia, em 1912, José Joaquim Seabra reúne o desejo de mudança da cidade à sua força política, às condições econômicas favoráveis e a seus conhecimentos sobre intervenção em estruturas urbanas já consolidadas.

Para executar seu projeto, tem o apoio do Engenheiro Arlindo Coelho Fragoso, secretário do governo e coordenador de toda a ação executiva, do Prefeito Júlio Brandão e do Arcebispo Jerônimo Thomé da Silva. Uma parte dos trabalhos realiza-se sob a responsabilidade do Governo do Estado, com ou sem parceria com o Governo Federal, e outra parte fica a cargo do Governo Municipal.

Na modernização urbana e na implantação dos serviços de infraestrutura, a cidade sofre mudanças em sua antiga imagem, pelas demolição 
de velhas casas, construções antigas e alguns edifícios representativos da arquitetura civil e religiosa. Trata-se de um tipo de intervenção denominado "urbanismo demolidor". ${ }^{27}$ Conjuntos urbanos monumentais, que caracterizavam a área, são derrubados em nome do progresso. O que se constrói em séculos é derrubado em anos.

Nas obras de alargamento das Ruas da Misericórdia e Chile e construção da Avenida Sete de Setembro - da Ladeira de São Bento ao Forte de São Pedro - foram a régua e o esquadro os elementos preponderantes, destruindo-se monumentos importantes para a cultura nacional [...]. (CEAB, [197-], p. 494-495)

Como são financiadas todas essas intervenções? Graças aos contatos do Ministro de Estado Seabra ${ }^{28}$ com grandes empresários brasileiros e também com representantes do capital financeiro internacional, muitas das obras de melhoria realizadas no País são financiadas, desde o início do século. Ao tomar posse do Governo da Bahia, em 19 de junho de 1912, Seabra apoia-se numa lei que autoriza empréstimos estrangeiros, para aplicação em construções de avenidas ou estradas, e que permite a emissão de apólices estatais, cujos lucros complementam o custo das obras de melhoria da cidade. (PERES, 1974, p. 39)

Além disso, no início do século $\mathrm{XX}$, a Bahia vive um período de recuperação econômica, ocupando, em 1905, o primeiro lugar na produção de cacau, um novo produto de exportação. Todas essas condições - capital estrangeiro, nacional e local $^{29}$ - viabilizam a realização das tão desejadas reformas em Salvador.

Alguns empresários do Rio de Janeiro, como os Guinle, trazem capital nacional para o desenvolvimento de projetos, em circunstâncias um pouco suspeitas. Depois de anunciada a abertura, financiada por eles, de uma avenida litorânea entre o Rio Vermelho e o arraial de Itapoã, os mesmos, por intermédio da Companhia de Melhoramentos, compram terras de uma fazenda localizada no mesmo litoral, entre Barra e Ondina, por um valor muito baixo. Uma vez realizada a compra, muda-se a localização da avenida para o trecho do litoral entre Barra e Rio Vermelho, o que valoriza as terras recém-adquiridas por eles. Além desse fato, os Guinle, através da Linha Circular de Carris Urbanos, de sua propriedade, obtêm a concessão para instalar os trilhos dos bondes nessa nova avenida, embora as obras não sejam executadas de imediato.

Finalmente, a Companhia de Melhoramentos consegue realizar a abertura da grande Avenida, a Sete de Setembro, entre a Ladeira de São Bento e a Barra, enquanto o Município assume os custos da avenida do litoral. (Sá, 1918, p. 275)
${ }^{27}$ Termo utilizado por Pierre Lavedan (1952, p. 91) para descrever esse tipo de intervenção.

${ }^{28}$ Além de Ministro da Justiça e
Negócios Interiores no governo de
Rodrigues Alves (1902-1906), Seabra
foi o Ministro dos Transportes, de
1910 a 1912, no governo de Hermes
da Fonseca (1910-1914).
${ }^{29}$ P. ex., Crédit Mobilier,
Eduardo Guinle e Apólices
Populares, respectivamente.
(CEAB, [197-], p. 520)

${ }^{28}$ Além de Ministro da Justiça e (n) foi o Ministro dos Transportes, de 12, no governo de Hermes

${ }^{29}$ P. ex., Crédit Mobilier, Populares, respectivamente. (CEAB, [197-], p. 520) 
${ }^{30} \mathrm{O}$ início da Grande Guerra, em 1914 , prejudica as negociações com os capitalistas estrangeiros.
As obras de ampliação do porto e de reforma da Cidade Baixa realizam-se com a ajuda dos comerciantes, que aplicam um imposto em ouro a taxas de $2 \%$. A responsabilidade das obras está a cargo da Companhia Cessionária das Docas da Bahia, que tem um contrato assinado com o Governo Federal, desde o governo de Rodrigues Alves. Em 1911, entretanto, ainda continuam totalmente paralisadas. Seabra retoma essas e outras obras também na Cidade Baixa, promovendo desapropriações e demolições para o alargamento e o alinhamento de algumas ruas e a abertura de outras. "Não Ihe tivessem faltado os recursos, aggravados pela guerra europeia, e teria realizado todo o seu plano, de alto empreendimento, de remodelação desta capital, transformando a physionomia da colonial cidade de Thomé de Souza." (BOCCANERA JúNIOR, 1921, p. 182)

Os conflitos na Europa ${ }^{30}$ trazem dificuldades no desenvolvimento das negociações, gerando problemas para a finalização das obras iniciadas. Para não sustá-las, Seabra pede ajuda popular, através de apólices de baixo valor, arrecadando recursos para dar continuidade às intervenções.

\section{A realização da reforma urbana}

\section{0 que se faz na reforma}

Ao assumir o governo, J. J. Seabra tem como projeto prioritário introduzir a modernidade nas ruas da velha capital, em função das novas necessidades de circulação, atreladas a uma espacialização-modelo, um novo modo de vida, uma nova estética, um novo sentido público e uma civilização do espetáculo e da velocidade.

\footnotetext{
$\mathrm{Na}$ actividade febril de uma cidade que se renova, resgatando, pela ância de construir e edificar, a incúria do passado [...] tudo, onde descancem os olhos, são obras - avenidas que se rasgam, ruas que se alargam, paços que se levantam, casas, pavilhões e jardins que vão surgindo; [...] umas do Estado, outras da União; estas do Município e aquellas de particulares ou de emprezas diferentes; todas senão do povo, para o povo, para a sua alegria e para o seu trabalho, para a sua existência e para o seu orgulho; tudo é movimento... (MENSAGEM, 1914, p. 71-72)
}

As obras realizam-se em todas as partes. Renova-se o Distrito da Sé, orienta-se o crescimento da cidade em direção sul, com a abertura de uma grande avenida. Remodela-se e amplia-se o porto e alargam-se ruas da Cidade 
Baixa, uma nova avenida liga essa parte da cidade à península de Itapagipe. Conquista-se o litoral, constroem-se novos edifícios e incentiva-se a construção de casas para os operários. São tempos de mudança, tempos de novidades. Thales de Azevedo (1972, n. 7, p. 71-72) escreve sobre essa época:

Tempo foi aquele e a partir de então [...], das reformas da Capital com a Avenida Sete, rasgada através de São Pedro, do Rosário, das Mercês, do Viaduto, da Vitoria, da construção de vários edifícios públicos, imponentes, grandiosos, o Palácio Rio Branco, o Aclamação, a Imprensa Oficial [...] A Praça Deodoro plantada de oitizeiros já grandes, para a visita do Marechal Hermes, o começo do aterro das Docas, os primeiros grandes prédios do 'comércio', a reforma do Plano Inclinado, a garganta do Xixi, a agitada política dos tempos do legendário Seabra, a 'angú baiano', as obras do Intendente Júlio Brandão, os comícios políticos dissolvidos a bala ou a pata de cavalos, a febre amarela e a bubônica, o venerando Dom Jerônimo Tomé [...].

São elaborados alguns projetos antes das definições do que fazer e onde intervir (Fig. 34, ver caderno de imagens). Em 1910, Jerônimo Teixeira de Alencar Lima elabora seu Plano geral de melhoramentos em parte da cidade do Salvador, onde engloba questões centrais como a higiene, a estética e o trânsito urbano, utilizando como modelo a reforma do Rio de Janeiro (Fig. 35). Em sua exposição sobre o plano, considera

[...] mal approveitada a parte da Cidade que é a mais saudavel, mais alta e descampada, e a que melhor se presta, pelas suas condições de nivelamento e posição central, a bôas edificações em ruas largas e alinhadas.

Esse nucleo da Cidade Alta, [...] pode ser transformado radicalmente em outro de feições modernas desde que se aproveitem as ruas largas actuaes [...] uma vez corrigidos certos defeitos de alinhamento e que se façam as suas ligações por outras ruas largas com pontos de convergencia ou de partida d'aquellas praças citadas. (LIMA, 1910, p. 1-2)

O projeto apresentado se fundamenta na melhoria do saneamento, do conforto e da plástica arquitetônica, indispensáveis à vida moderna. Alega que, ao ter as ruas reformadas, as edificações também serão beneficiadas pela municipalidade. Suas propostas englobam abertura de avenidas, alargamento de ruas, nova pavimentação, além da construção de casas operárias e de edificações públicas. Também envolvem jardins, praças, parques abertos à população e banheiros públicos.

Até onde temos conhecimento, esse projeto tem três versões, das quais, a segunda, de 1912, é a mais ousada, ainda que todas tenham como ponto 


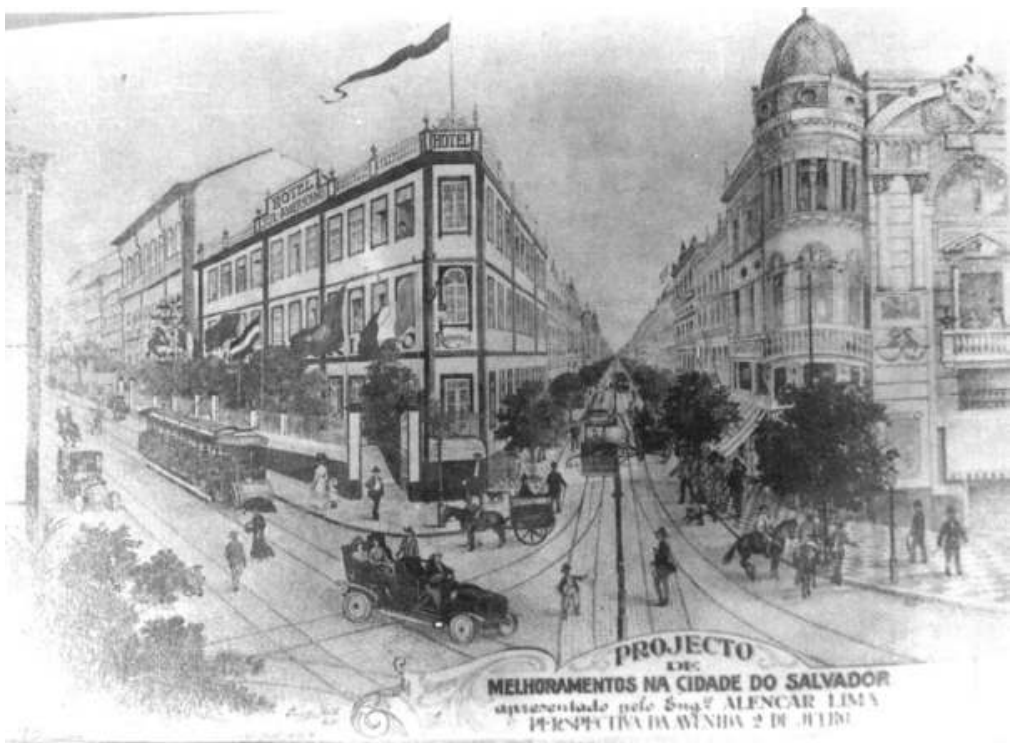

35. Projeto de melhoramentos na cidade do Salvador pelo engenheiro J. T. de Alencar Lima - perspectiva (1910)

central a abertura de uma grande avenida entre a Praça Castro Alves (antigo Largo do Teatro) e o Campo Grande.

Essa versão, apresentada aos Governos do Estado e do Município em dezembro de 1912, com o nome de Plano de Melhorias de Parte da Cidade de S. Salvador, recebeu um comentário cujo teor é importante ressaltar:

[...] o absurdo do projeto, concebido sem o menor respeito ao traçado existente e sem interesse na obtenção de algo aceitável. Unicamente o geometrismo o mais descabido, o alinhamento reto, os arcos de círculo, as formas dos esquadros e a completa destruição de uma estrutura urbana nascida e desenvolvida de forma orgânica no decorrer de mais de duzentos anos. (SALVADOR, 1979, p. 495)

Não é esse o projeto executado na reforma urbana de Salvador. Também não se executa outro (Fig. 36), de 1912, de autoria do engenheiro José Celestino dos Santos, apresentado para o Distrito de Santana, onde se prevê a abertura de uma avenida em linha reta, entre a Praça da Piedade e a Ladeira da Independência, com a destruição de uma malha urbana tradicional e pitoresca. (SALVADOR, 1979, p. 495-496)

O projeto executado é uma nova versão do projeto de Alencar Lima de 1910, a partir do qual apenas parte das intervenções previstas são realizadas, pois acabam-se os recursos financeiros. Ainda assim, destrói-se uma parte 
significativa do acervo construído na capital da Bahia. Para alargar as ruas, são derrubados exemplares da arquitetura dos séculos XVIII e XIX. Para a abertura da avenida principal - a Avenida Sete de Setembro - são demolidas igrejas inteiras e parte de outras, uma ala do edifício do Senado do Estado e muitas residências, o que provoca um problema habitacional que necessita solução.

Theodoro Sampaio ${ }^{31}$ considera que as modificações na cidade devem levar em consideração o relevo, a elegância e o conjunto, para a obtenção de um bom efeito estético, respeitando-se os monumentos de valor histórico e arquitetônico. A abertura das vias deve ser feita sempre em função da salubridade pública, do trânsito e da diminuição de distâncias. Em segundo plano está a abertura de estradas em direção aos subúrbios, a pavimentação das ruas, as árvores, os passeios, os jardins públicos, os monumentos, os mercados, os banheiros públicos e os locais para o ócio. Sua preocupação é a nova sociedade. Propõe uma cidade que tenha como base o jardim, onde se unam as vantagens do campo com as da cidade.

Em seu relatório de 1905,32 no capítulo sobre ruas, deixa entrever a necessidade de um plano para a cidade, em que o saneamento, o embelezamento e a comunicação sejam os três eixos de orientação dos trabalhos. Propõe basicamente um novo esquema viário, com um vetor de expansão sul, pela criação de uma Avenida Beira Mar, da Conceição da Praia até a Barra, um túnel na Barroquinha, fazendo a ligação entre a Cidade Alta e a Baixa, e uma avenida na Cidade Alta, entre a Praça Castro Alves e o Campo Grande.

Em todos os projetos, propostas e comentários que se fazem em relação às melhorias necessárias em Salvador, encontramos o registro da urgência em agilizar os deslocamentos, da mudança da estrutura viária tanto na Cidade Alta como na Cidade Baixa, e de uma mudança na estética, que não agrada a todos, sempre visando à modificação da aparência de cidade colonial. Em 1912, são aprovadas as mudanças necessárias.

Tenho a honra de communicar-vos que começaram hoje os estudos preliminares das obras de melhoramentos da Cidade do Salvador contractadas com o engenheiro Alencar Lima.

Os trabalhos de campo a cargo do engenheiro Souza Mendes tiveram inicio na Praça Castro Alves. ${ }^{33}$

Analisaremos em separado as distintas intervenções que se realizam na cidade do Salvador, dividindo-as em três partes: o Distrito da Sé, a Avenida Sete de Setembro, a Cidade Baixa e o porto.

\footnotetext{
${ }^{31}$ Theodoro Sampaio é o engenheiro responsável pela implantação de um moderno sistema de abastecimento de água e rede de esgoto para a cidade do Salvador, desde 1905. Suas ideias para a cidade estão num discurso proferido em 25 de agosto de 1912 , no Instituto Geográfico e Histórico da Bahia. (LEME, 1999, p. 260)

32 Este é o relatório elaborado sobre a necessidade de infraestrutura para a cidade, o "Relatório de 1905". (FERNANDES; SAMPAIO; GOMES 1999, p. 172)

${ }^{33}$ Documento $n^{\circ} 1443$, do maço 344 , da série Secretaria da Agricultura, da seção republicana, no Arquivo Público do Estado de Bahia.
} 


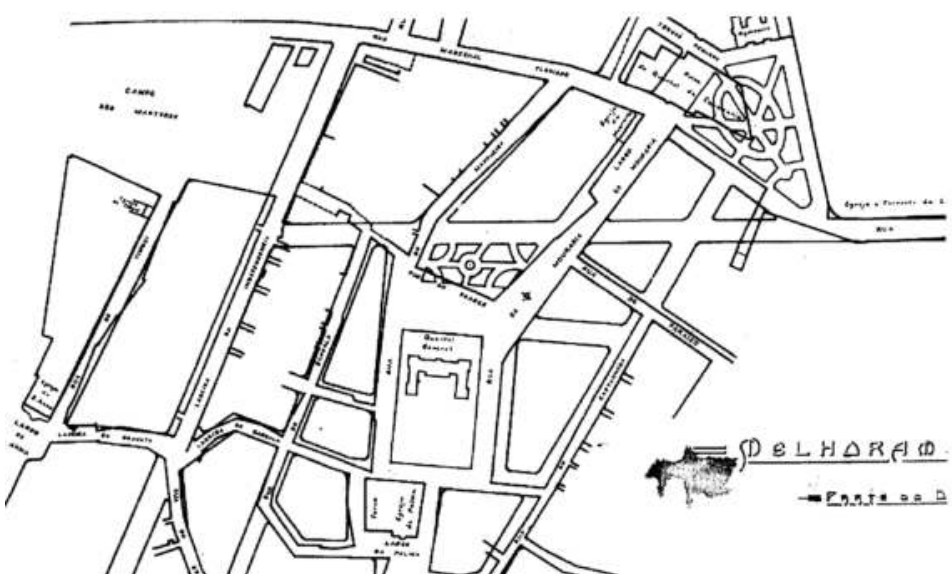

36. Melhoramentos municipais de parte do distrito de Sant'Anna - 1912

\section{O Distrito da Sé na reforma}

O Intendente Júlio Viveiros Brandão aprova, sob responsabilidade municipal, o projeto de melhorias para o Distrito da Sé (Fig. 37), através da Resolução nº 344 de 29/08/1912.

Neste afã modernizador a parte mais atingida será exatamente aquela do antigo miolo ou núcleo da velha capital, não só porque aí estavam concentrados os maiores problemas de estrangulamento da 'nova cidade' idealizada, mas também por ser aí onde a especulação imobiliária iria realizar os seus melhores negócios. (PERES, 1974, p. 37)

Nem todas as intervenções são realizadas. Tendo a Igreja da Sé como ponto de divisão do Distrito da Sé, promovem-se intervenções em direção ao sul, e, pelo menos nesse momento, não se realizam as reformas projetadas para a área ao norte. Para esse setor, estão projetadas mudanças no alinhamento das Ruas do Colégio, do Liceu e de dois quarteirões do Terreiro de Jesus, agora chamado Praça 15 de Novembro, além da demolição da Igreja da Sé e do Palácio Arquiepiscopal. Pelo plano, todas as edificações da Rua do Arcebispo devem ser demolidas, para abrir espaço a um terraço. Por falta de recursos, essa parte do projeto não foi executada.

O setor sul sofre as amputações previstas no projeto. Primeiramente, realizam-se as demolições de parte das edificações da Rua da Misericórdia, do lado da terra, e de parte das do lado esquerdo da Ladeira da Praça, ambas com a intenção de alargar as ruas. Na Praça do Conselho, antiga Praça do 


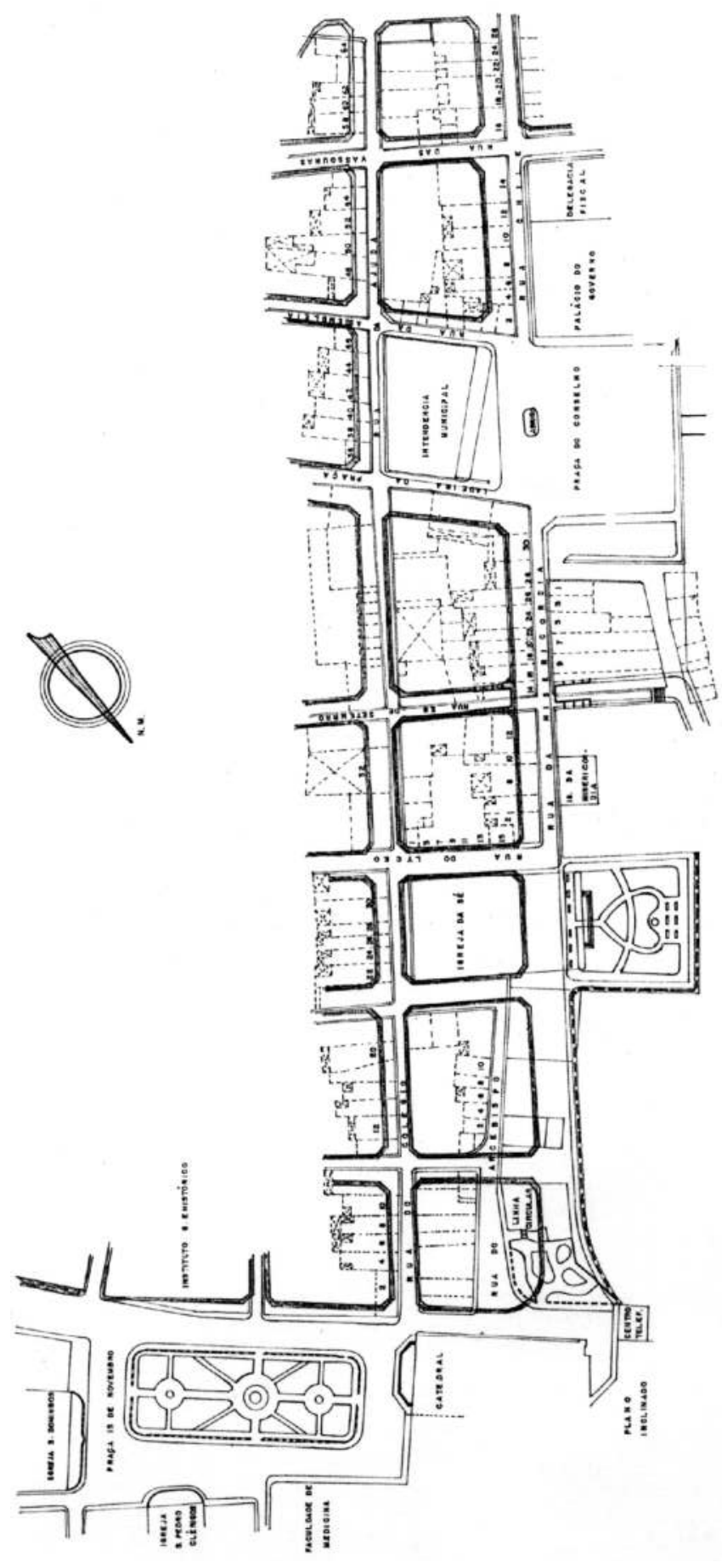

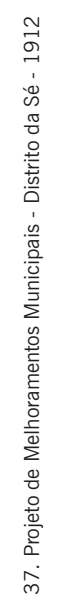


${ }^{34}$ Em 1900, o antigo edifício colonial foi reformado,

e inaugurado, em estilo moderno.

${ }^{35}$ A posse do governador J. J. Seabra não acontece de forma pacífica: um bombardeio, no dia 10 de janeiro de 1912, atinge o Palácio do Governo e algumas casas da Rua Chile, antiga Direita do Palácio.
Palácio, as principais intervenções são efetuadas no século XIX, de forma que, nesses primeiros anos do século $\mathrm{XX}$, só se acrescentam novas construções. O Palácio do Governo ${ }^{34}$ (Fig. 38 e 39) é afetado pelos bombardeios de 1912, ${ }^{35}$ que destroem toda a ala esquerda e a parte central, onde se encontra a $\mathrm{Bi}$ blioteca Pública. Por isso, passa por uma total reconstrução, que altera sua fachada e inclui ornamentos os mais variados (Fig. 40). Constrói-se ainda um edifício para a Biblioteca Pública do Estado (Fig. 41), ambos inaugurados em 1919. É criada a Imprensa Oficial do Estado (Fig. 42), mas sua sede só se inaugura na década de 30.

Entre a Praça do Conselho e a Praça Castro Alves, executam-se grandes demolições. Para o alargamento da Rua Chile (Fig. 43, 44 e 45), derrubam-se as partes frontais de todas as edificações dos quarteirões do lado da terra, até a Praça Castro Alves, que tem suas fachadas reconstruídas no estilo da época. Outra rua alterada é a Rua do Pão-de-Ló, onde também são demolidas algumas construções. Ainda no setor sul, derruba-se a Igreja da Ajuda, em 1912, para a retificação da rua de mesmo nome. A demolição ocorre de forma pacífica, ante a justificativa de que devem deixar passar o progresso.

São previstas as demolições de outros monumentos e edificações - como a Igreja da Sé, o Teatro São João, a estação do plano inclinado do Gonçalves e as edificações da Praça Castro Alves -, que, entretanto, não se realizam.

Os proprietários dos edifícios demolidos são indenizados, e a reconstrução fica sob sua responsabilidade. A pavimentação das ruas é refeita, por conta da Companhia Linha Circular, e a dos passeios laterais, a expensas dos donos dos lotes.

As mudanças são muitas e os jornais sempre fazem referências às obras em seus diários.

\section{NA RUA CHILE AS OBRAS DE MELHORAMENTOS ESTÃO EM PROGRESSO}

Na Rua Chile, que é realmente uma de nossas mais importantes vias públicas, as obras de melhoramentos vão a caminho de proxima realização.

Parte da dita rua ja se acha asphaltada e quasi promptos os novos trilhos por onde hão de trafegar mais duas linhas de bondes. (O CORREIO, 1914)

Durante o desenvolvimento do projeto, ruas são alargadas, construções são modificadas e exemplares da arquitetura civil, religiosa e pública demolidos. Mas a trama urbana continua sendo a tradicional, havendo simplesmente um processo de alargamento das vias, para facilitar a introdução de novos meios de transporte, propiciar melhor arejamento e um novo aspecto. 


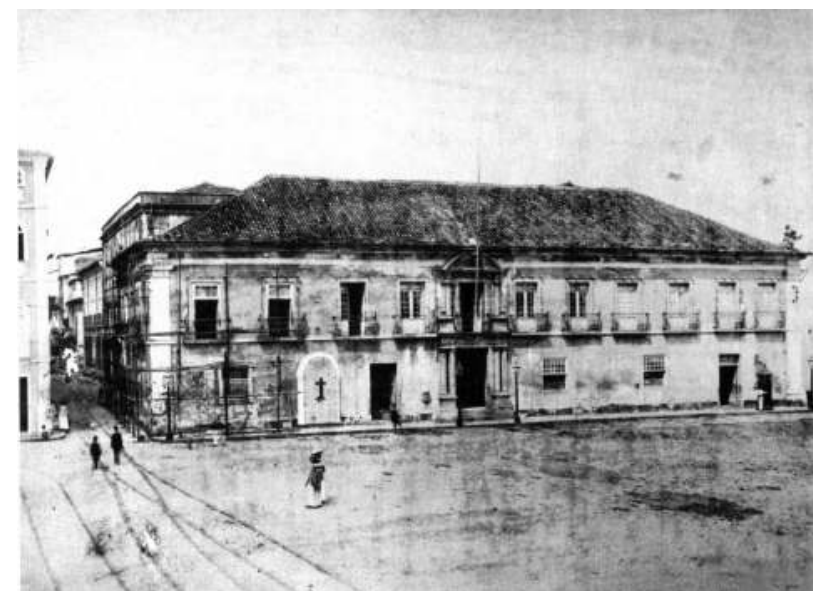

38. Palácio dos Governadores - c. 1871

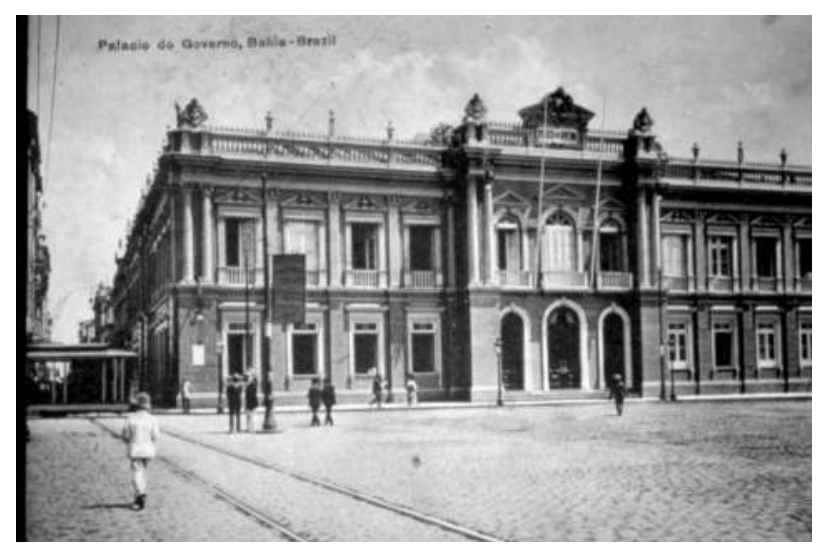

39. Palácio do Governo - 1900

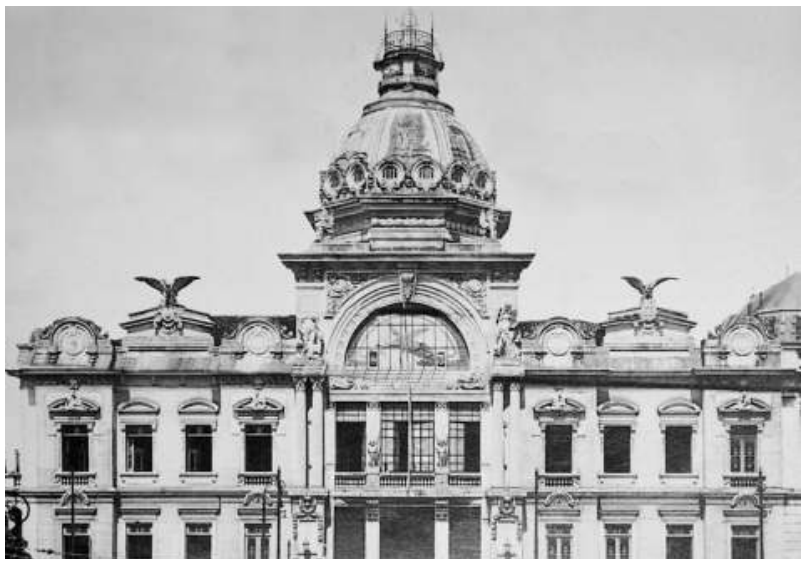

40. Palácio Rio Branco - 1919 


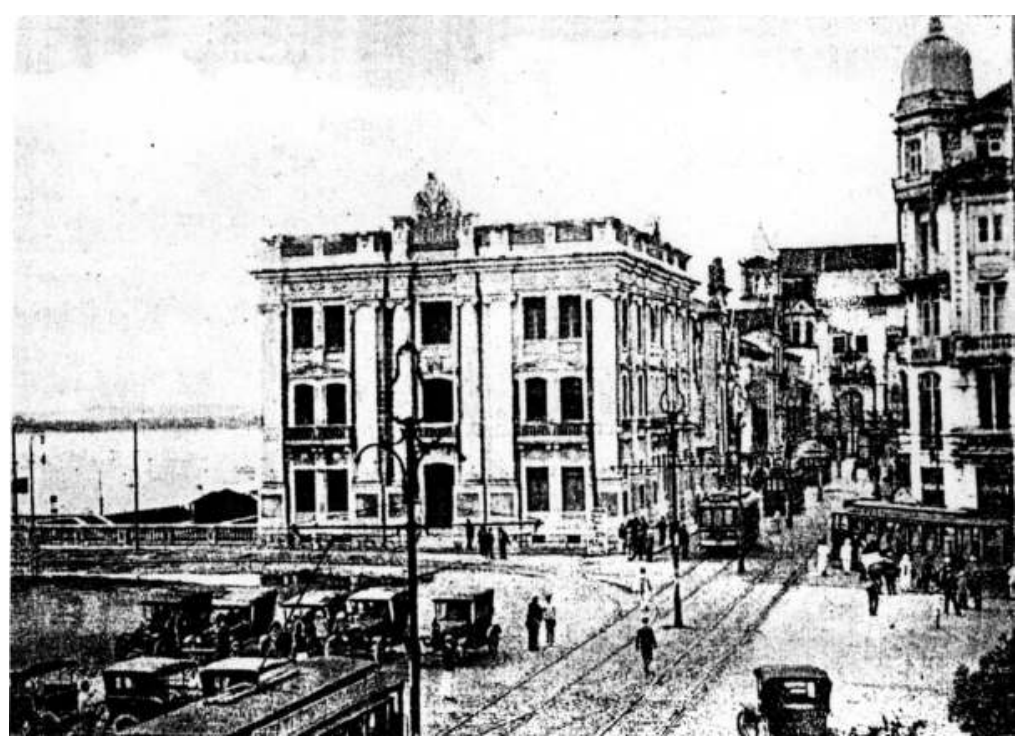

41. Biblioteca Pública - década de 20 do século XX

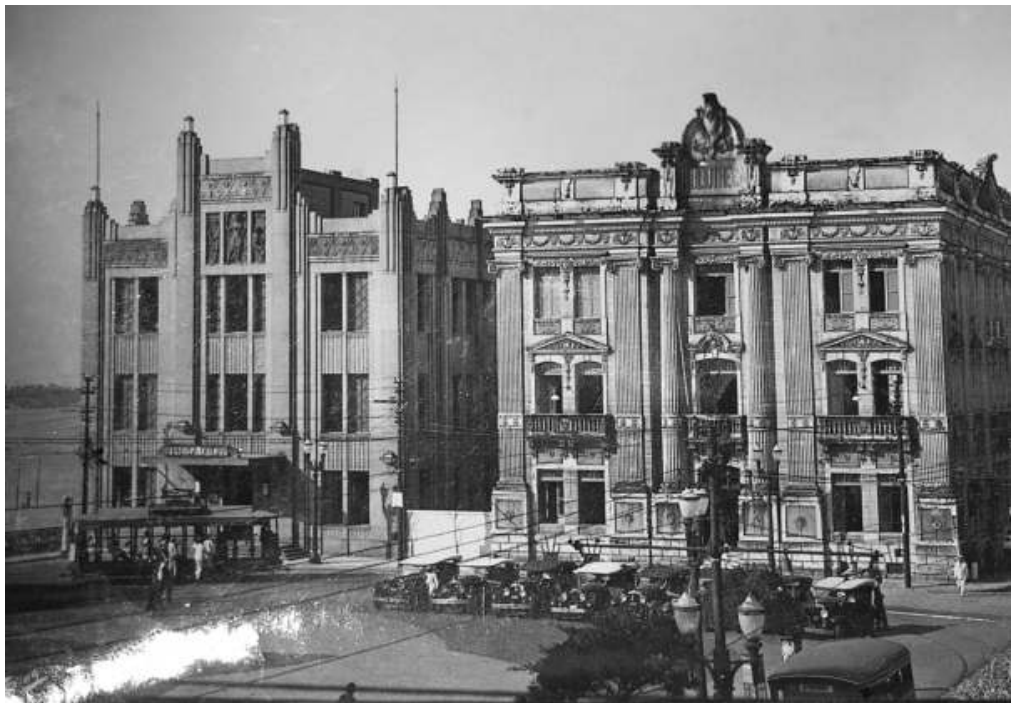

42. Imprensa Oficial e Biblioteca Pública - década de 30 do século XX 


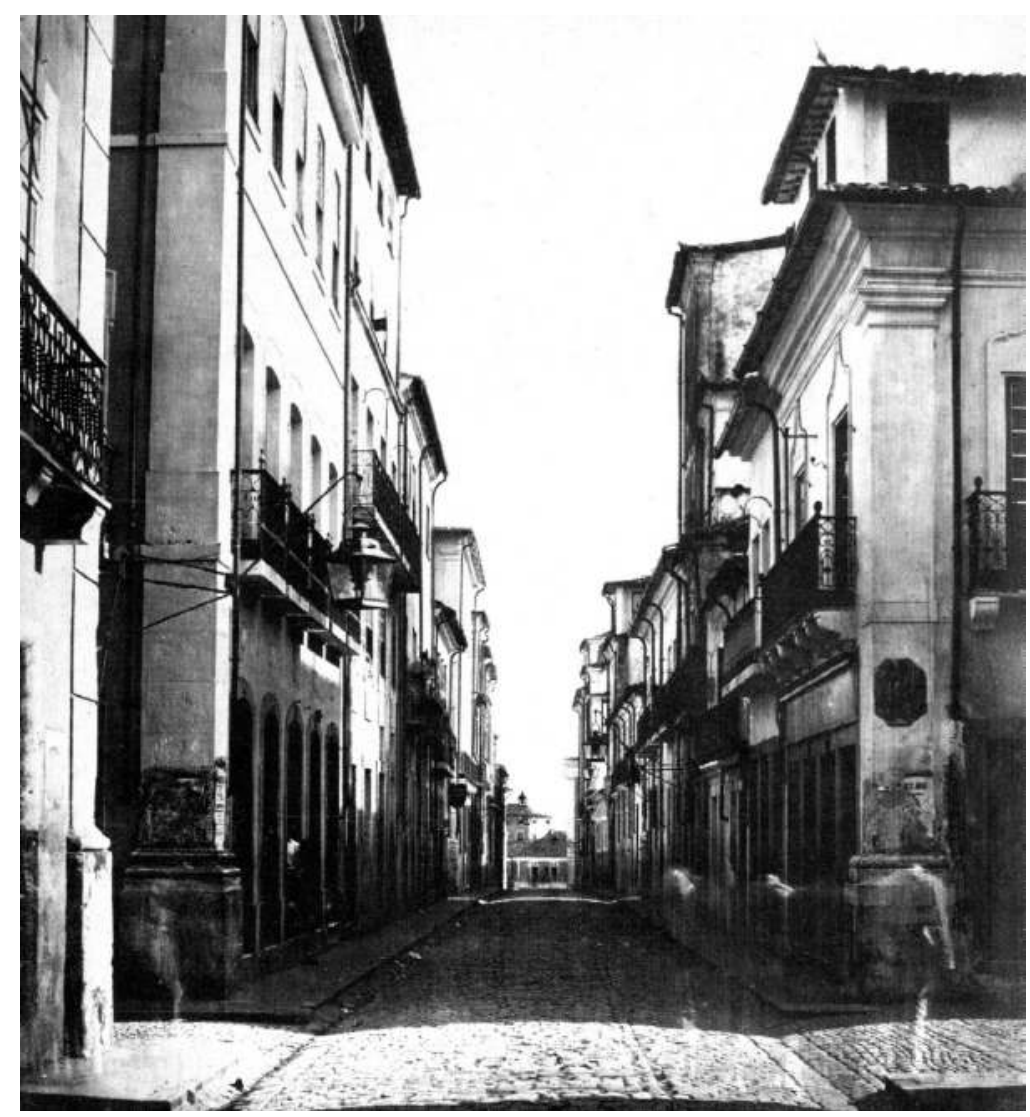

43. Rua Direita do Palácio, antes das intervenções - foto de B. Mulock - 1860

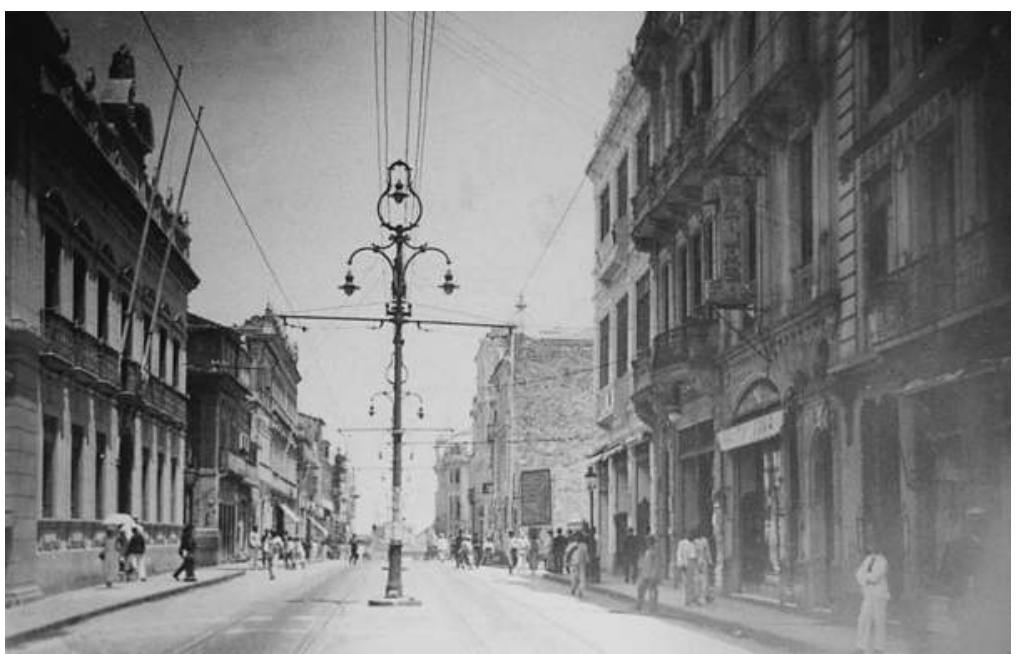

44. Rua Chile, antiga Direita do Palácio, depois das intervenções de 1912-1916 


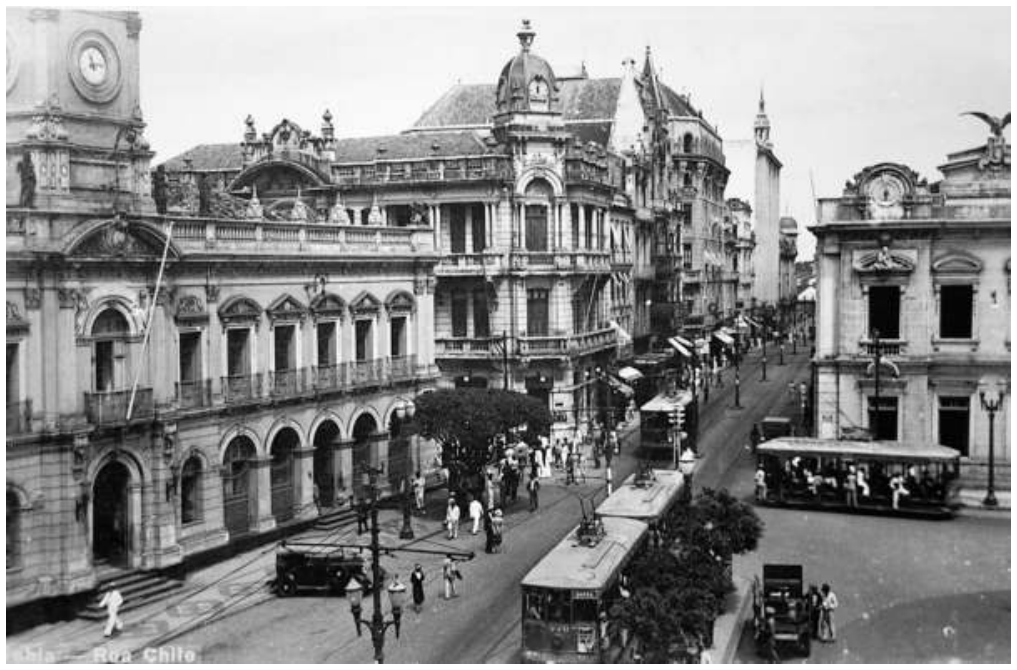

45. Rua Chile depois do alargamento realizado em 1912-1916

O plano de reformas também inclui as novas construções e as novas fachadas das edificações, mutiladas pelo alargamento das ruas. São modificadas, inclusive, construções que não são afetadas pela reforma, com o intuito de seguir o novo estilo em moda: o ecletismo. A legislação de construções da Prefeitura exige a introdução de novos elementos, como as bandeiras, em grades de ferro, sobre as portas. Mas, de um modo geral, a composição, a ordenação das janelas, o ritmo e a proporção das fachadas pouco se alteram.

O setor do Distrito da Sé é de grande valor, e as reformas provocam uma mudança nas atividades que ali se desenvolvem. As partes renovadas agora constituem um ambiente chic, e as pessoas circulam elegantemente vestidas pelas confeitarias e lojas de moda que se inauguram. As novas atividades que surgem no Distrito da Sé serão tratadas mais adiante.

\section{A Avenida Sete de Setembro na reforma}

A mais importante intervenção realizada em Salvador, durante o período estudado, é a abertura da Avenida Sete de Setembro, sob a responsabilidade do Governo do Estado da Bahia. A obra é o resultado da retificação e do alargamento de várias ruas e vielas, que se estendem da Praça Castro Alves até o Farol da Barra, e da demolição de importantes edifícios da cidade, entre eles a Igreja de São Pedro Velho, a ala esquerda do edifício do Senado do Estado 
e parte da Igreja do Rosário de João Pereira (ou dos brancos) e do Convento das Mercês. (Fig. 46, ver caderno de imagens)

Seu objetivo é a abertura de um vetor de expansão que desafogue o Distrito da Sé. $O$ traçado da avenida projetada tem um total de $4.600 \mathrm{~m}$ de extensão, $21 \mathrm{~m}$ de largura com $3 \mathrm{~m}$ de calçada, com exceção da ladeira que dá acesso à Barra, cuja largura permanece com as dimensões originais. ${ }^{36} \mathrm{Em}$ 1916 , a avenida tem $82.800 \mathrm{~m}^{2}$ de asfalto e está equipada com tubulações para as redes de água, esgoto, águas pluviais e instalações para a iluminação elétrica. Uma parte está localizada no Distrito de São Pedro, em seu eixo longitudinal, numa área antes ocupada por uma parte da elite econômica e intelectual da cidade, e que sofre um intenso processo de empobrecimento, com partes deterioradas e muitas edificações convertidas em cortiços. A outra parte se desenvolve sobre o eixo longitudinal do Distrito da Vitória.

Pelo traçado do projeto original, a grande avenida, que se abre no Distrito de São Pedro, passa sobre a área do Mosteiro de São Bento (Fig. 47 e 48), onde seria construído um conjunto de edifícios para abrigar as novas instalações do serviço público. O Mosteiro se salva de seu triste destino pela mobilização do Abade Dom Majolo de Caigny que, através de um "aviso ao povo baiano", distribuído pelas ruas, conquista a simpatia da população. Apesar disso, os jornais pensam ser essa ação em defesa do patrimônio um equívoco, pois a prioridade é a transformação da cidade.

OS FRADES DO S. BENTO E A REMODELAÇÃO

\begin{abstract}
Uma coisa que não se comprehende é que os srs. frades queiram entravar o nosso progresso, creando toda a sorte de difficuldades ao plano de meIhoramentos.

Homens extranhos ao movimento civilizador, pouco se Ihes dá que a Bahia seja eternamente a velha cidade da colonia infecta e africanizada, ou que se a queira remodelar dando-Ihe o molde das cidades europeias. (O CORREIO, 1913)
\end{abstract}

Mas a outra igreja, a de São Pedro Velho (Fig. 49 e 50), é derrubada em função da avenida (Fig. 51 e 52). As obras seguem demolindo outras edificações localizadas num dos lados das antigas ruas que se alargam. O trecho entre a Igreja de São Pedro e a Praça do Campo Grande é o mais afetado, no que diz respeito às demolições e intervenções no espaço construído.

Nesse trecho localizam-se outros edifícios religiosos e o Senado do Estado da Bahia, que são parcialmente demolidos e, depois, remodelados com novos estilos arquitetônicos. Do outro lado, não havia edificações importantes da cidade, que justifiquem a decisão sobre o partido adotado.

\footnotetext{
${ }^{36}$ Essa é a última parte da intervenção, quando os recursos financeiros escasseiam, e o projeto tem de mudar, mantendo a mesma largura da rua original.
} 


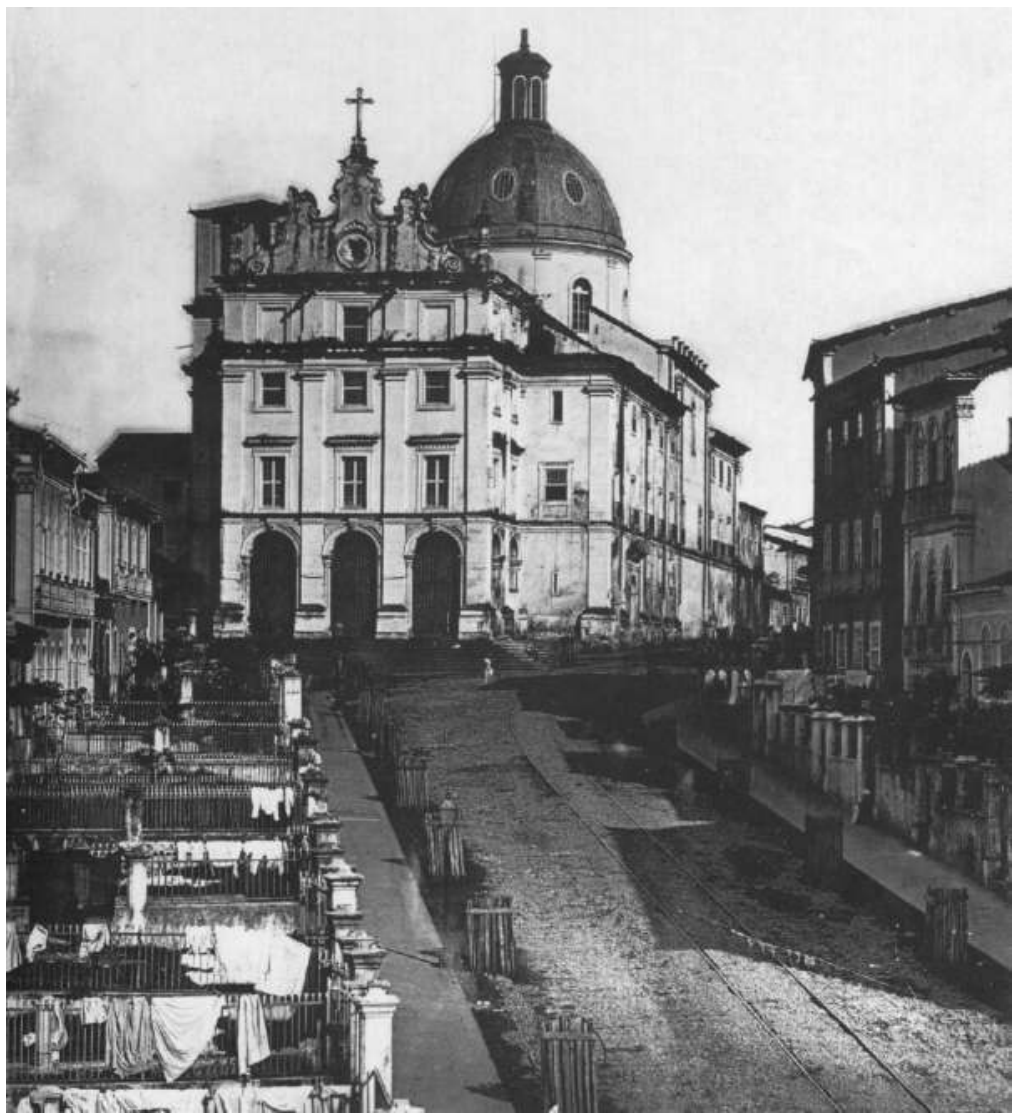

47. Ladeira de São Bento, antes das intervenções de J. J. Seabra - 1884 - foto de Marc Ferrez

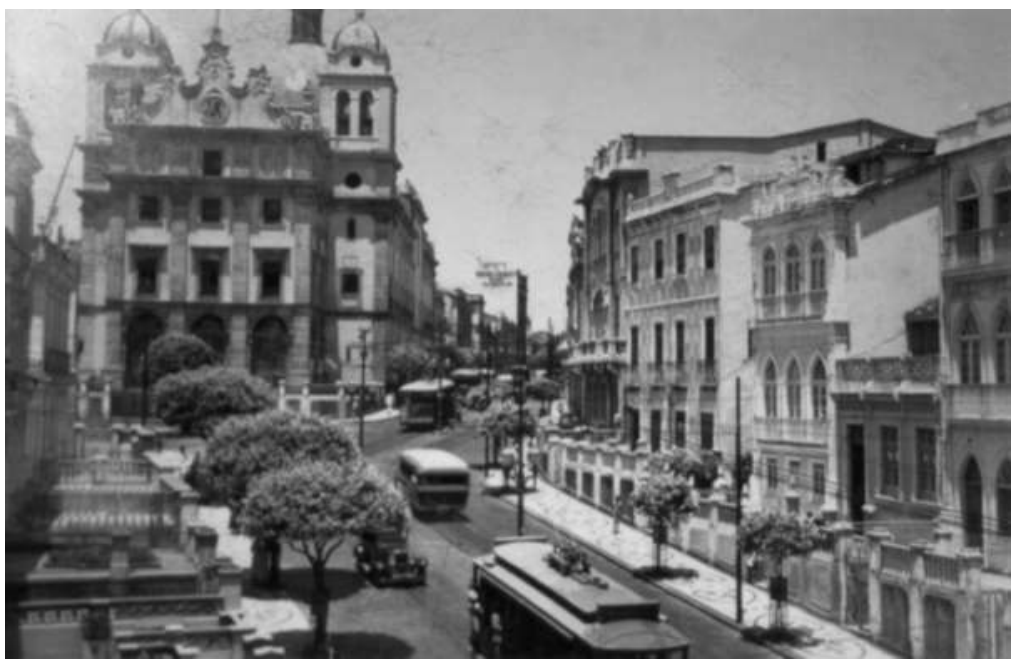

48. Ladeira de São Bento - meados do século XX 


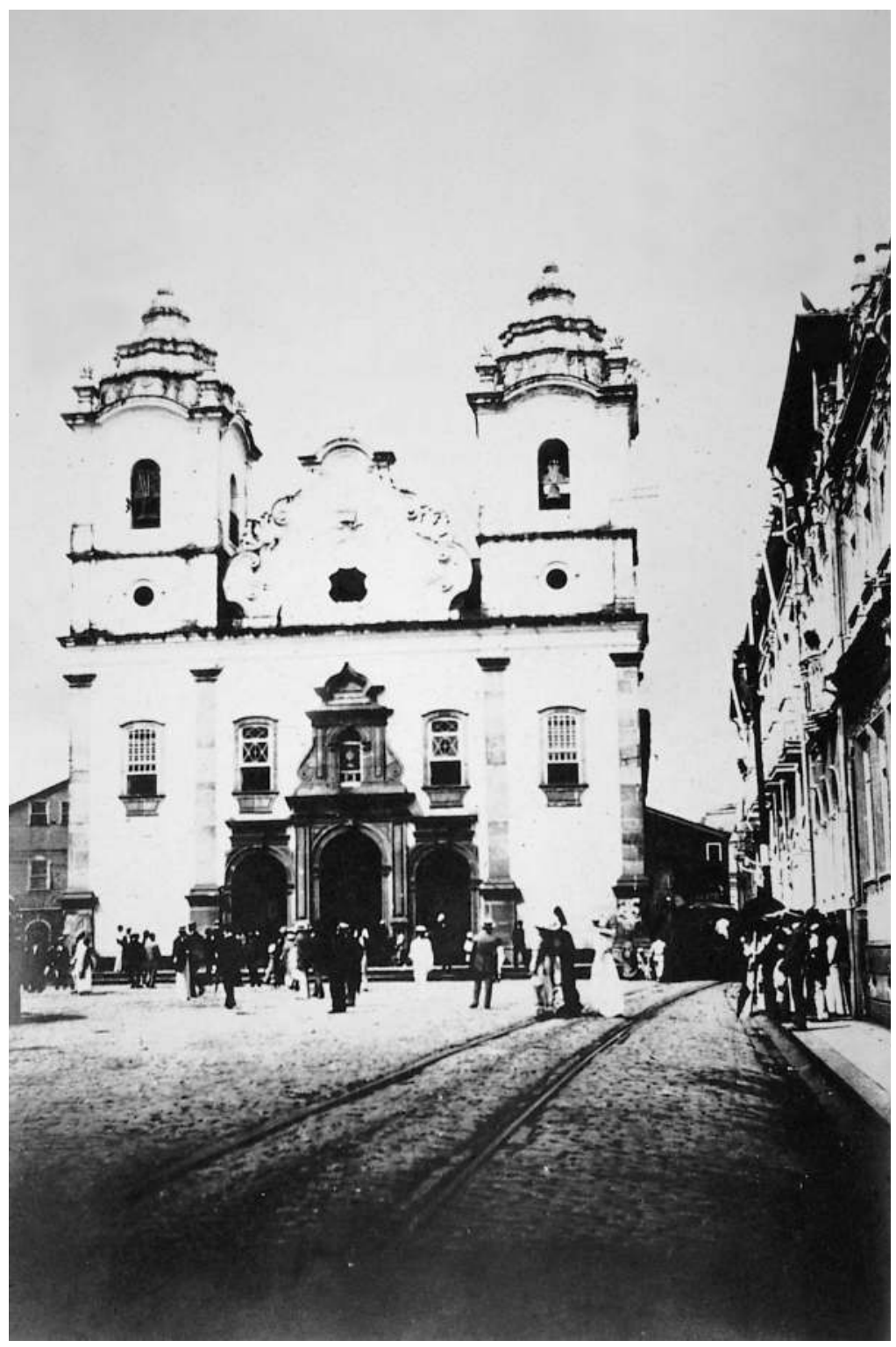

49. Igreja de São Pedro Velho 


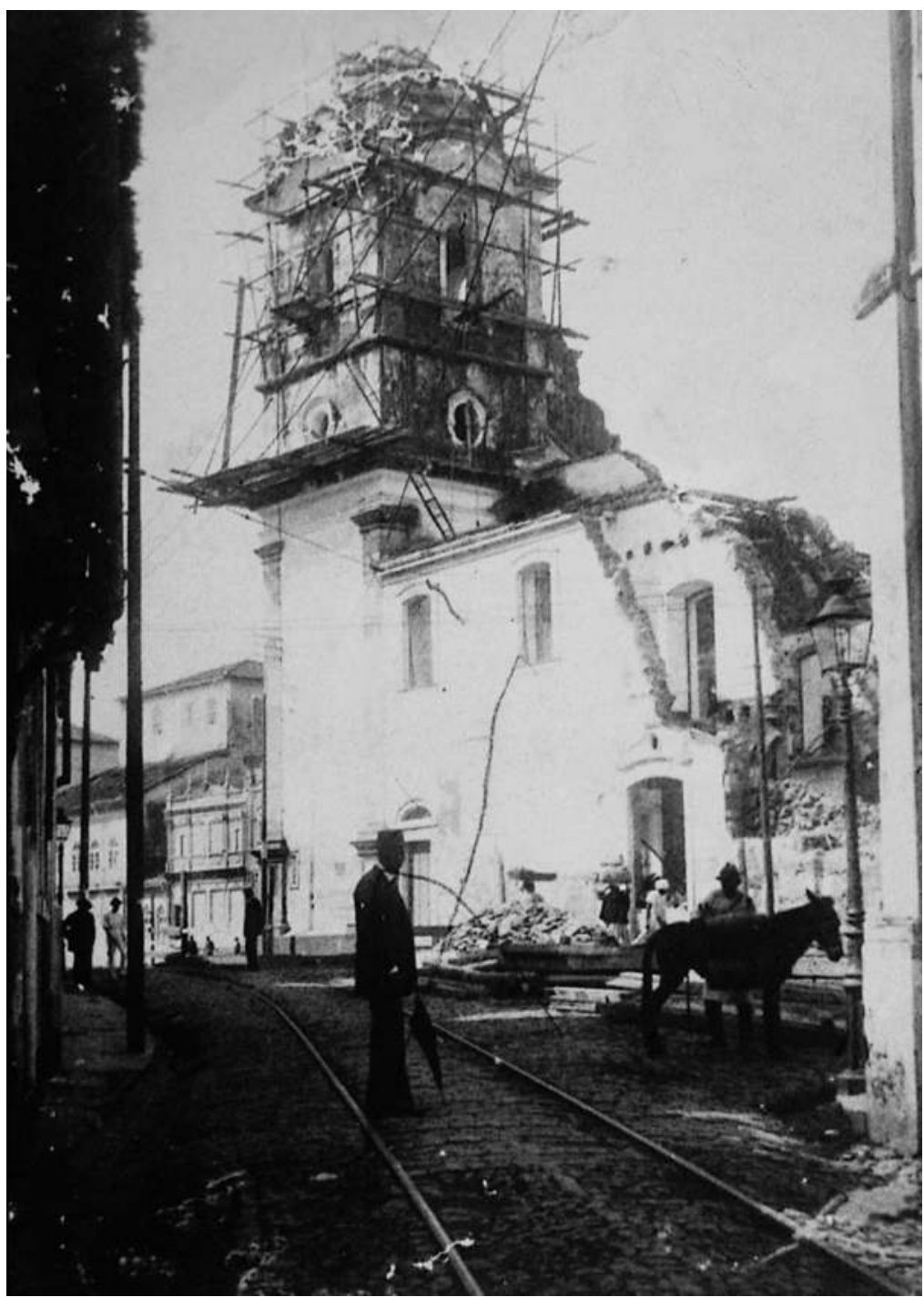

50. Demolição da Igreja de São Pedro Velho para abertura da Av. 7 de Setembro 


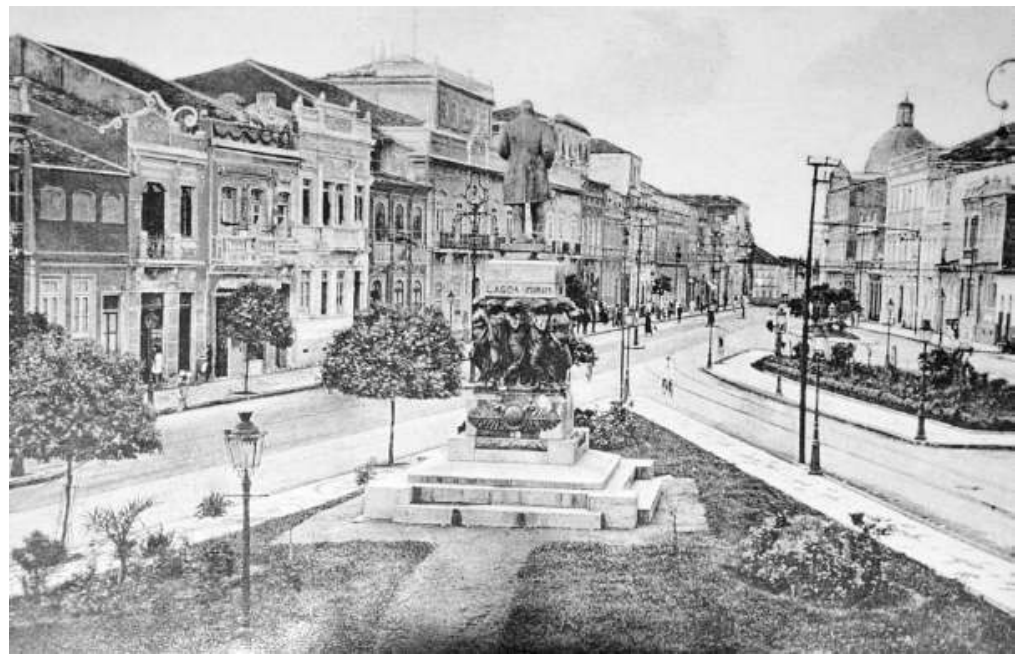

51. Avenida 7 de Setembro - Estátua do Barão do Rio Branco - local da antiga Igreja de São Pedro Velho

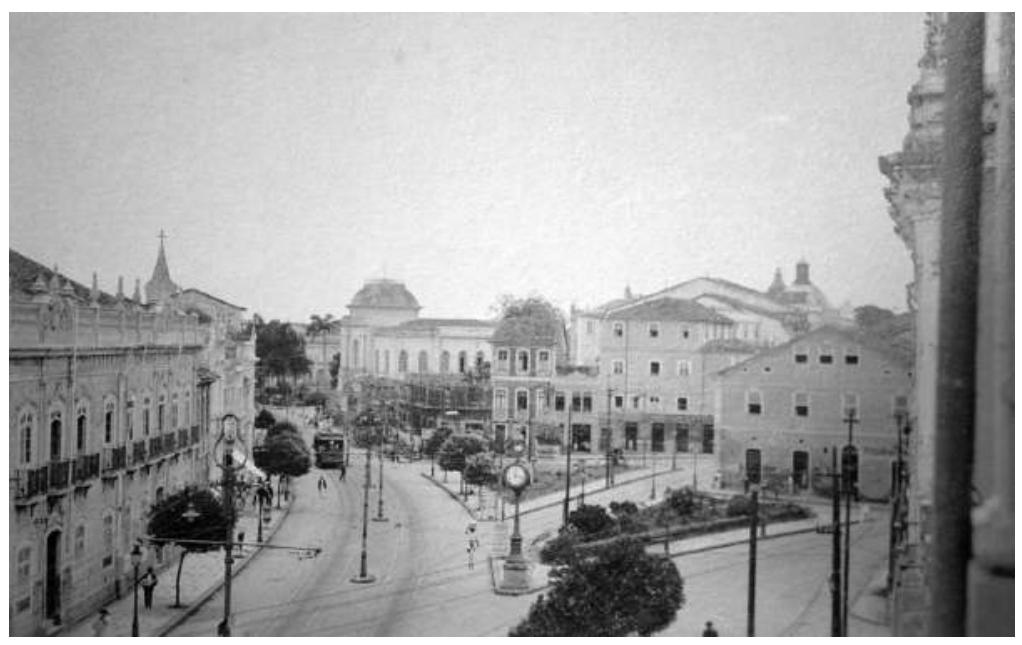

52. Avenida 7 de Setembro - Relógio de São Pedro - local da antiga Igreja de São Pedro Velho 
Os pontos do traçado da avenida menos afetados pelas obras, por já terem a rua mais larga, são os trechos entre a Ladeira de São Bento e a Igreja de São Pedro e o do Corredor da Vitória, além do da Ladeira da Barra, não alargado.

Para a abertura da Avenida Sete de Setembro, o tecido urbano não sofre alterações radicais, pois não se cortam ou derrubam quarteirões, como ocorreu na abertura da Avenida Central no Rio, ou do Bulevar Sébastopol, em Paris. O que percebemos, na Cidade Alta, em Salvador, é a confirmação de um eixo dinâmico, que orienta o crescimento da forma urbana da Igreja da Sé para a Barra, buscando o litoral sul e melhorando as comunicações nessa direção. Já se pode notar esse vetor desde os princípios da expansão da cidade, ligando o Centro à área nobre e definindo bairros para a classe abastada, locais mais agradáveis, arejados e saneados, com uma melhor qualidade de vida.

\section{A Cidade Baixa e o porto na reforma}

Como parte da reforma urbana, a transformação da Cidade Baixa (Fig. 53, ver caderno de imagens) tem o objetivo de criar um moderno centro de comércio, ampliar e equipar o porto e, em áreas conquistadas ao mar, construir quarteirões separados por amplas ruas que facilitem a circulação das mercadorias. As antigas ruas, estreitas, que serpenteiam a montanha, devem ter seus percursos corrigidos, atingindo-se uma dimensão mais espaçosa por meio da demolição de edifícios "[...] e que a Cidade Baixa da Bahia, profundamente modificada, e melhorada pelas novas construções e alargamentos de suas ruas, apresente, completamente diversas do que é hoje, as vantagens dos modernos centros de commercio." (MENSAGEM, 1912, p. 60-61)

As iniciativas de melhorar o Porto de Salvador começam com o Conde dos Arcos e, durante todo o século XIX, tenta-se levar adiante um projeto que o transforme num porto digno de sua importância. Esse porto, apesar de sua grande extensão, não funciona como uma unidade, pois está fracionado em pequenos atracadouros independentes, a maioria privados, pertencentes a comerciantes. Há que adaptá-lo também às novas embarcações de maior calado, que não podem chegar até o cais, o que prejudica os negócios. Os armazéns são velhos, precários, não adequados ao armazenamento das mercadorias.

Desde 1891, existe a ideia de reformar o porto, para ampliá-lo e equipá-lo. As promessas são muitas, mas, em 1904, as obras continuam paradas. Segundo as palavras do Governador Dr. Jose Marcelino de Souza, essa situação tende a solucionar-se e "[...] os melhoramentos há muito reclamados pelos poderes públicos e pelo comércio parece que caminham 
para sua solução segundo promessas e afirmações do Governo Federal." (MENSAGEM, 1905, p. 84)

Depois de muitas manobras, adiamentos e mudanças de concessão, por fim, a Companhia Cessionária de Docas da Bahia inicia as obras em 1908, com capital internacional, francês e inglês. Apesar de serem de fundamental importância para a exportação do cacau, que aumenta a cada ano, em 1911, as obras ainda continuam paradas. Um dos motivos é o bloqueio dos donos dos trapiches e armazéns, que resistem às desapropriações. Em 1913, as obras finalmente seguem adiante, paralisadas vez por outra por falta de recursos, e, entre os anos 1914 e 1918, em função da guerra na Europa.

Seabra contribui de forma decisiva nas intervenções do porto, seja como ministro em dois Governos Federais, ou à frente do Governo do Estado da Bahia. Ao tomar posse desse último, encontra as obras paradas desde 1911, com pouca coisa realizada, e decide levá-las adiante.

Em 1913 (Fig. 54), são inaugurados 532m de cais $-332 \mathrm{~m}$ para grandes barcos e o restante para os de cabotagem - e 3 armazéns. Em 1914, já são $750 \mathrm{~m}$ de cais aberto ao tráfego, o cais para cabotagem já está finalizado, o quebra-mar do sul está pronto e o do interior tem 120 m concluídos. Dos 7 armazéns construídos, 6 funcionam normalmente. Finalmente, em 1923, já são $1.378 \mathrm{~m}$ de cais para atracar, $220 \mathrm{~m}$ de cais de cabotagem, mais de $1.500 \mathrm{~m}$ de quebra-mar interno e externo. Dos equipamentos, há 8 armazéns internos, 1 externo, 1 para infláveis, 15 guindastes com $1.200 \mathrm{~m}$ de trilho e $3.450 \mathrm{~m}$ de linha de trem no cais, pavimentação, iluminação, rede de esgoto, rede de abastecimento de água, depósito de carvão etc. (CEAB, [197-] p. 538-542)

A Cidade Baixa passa por diversos aterros, que ampliam sua área ao longo do todo o século XIX. Em princípios do século XX, abrem-se duas novas ruas $^{37}$ sob as ordens do Intendente Municipal José Eduardo Freire de Carvalho Filho (1900-1903):

[...] soube o exmo. Sr. dr. Jose Eduardo Freire de Carvalho Filho, com admiravel e louvavel tino administrativo, abrir essas novas artérias para a expansão da actividade commercial, e progresso material da nossa urbes, a qual, igualmente, prestou relevantes serviços. (BOCCANERA JÚNIOR, 1928, p. 228)

Mas ainda fica muito por fazer. As obras do porto influenciam, de forma decisiva, na aparência da Cidade Baixa. É preciso acompanhar os novos tempos e também aderir à modernidade. Em 1912, J. J. Seabra comenta suas ações na mensagem apresentada à Assembléia Geral Legislativa: 
${ }^{38}$ Entre a Alfândega e o $7^{\circ}$ armazém, em frente ao prédio do Moinho da Bahia.

${ }^{39}$ Apenas nos anos 40 do século $X X$ os enormes vazios começam a ser preenchidos por uma nova geração de edifícios, com vários andares, e as casas mais antigas são demolidas.

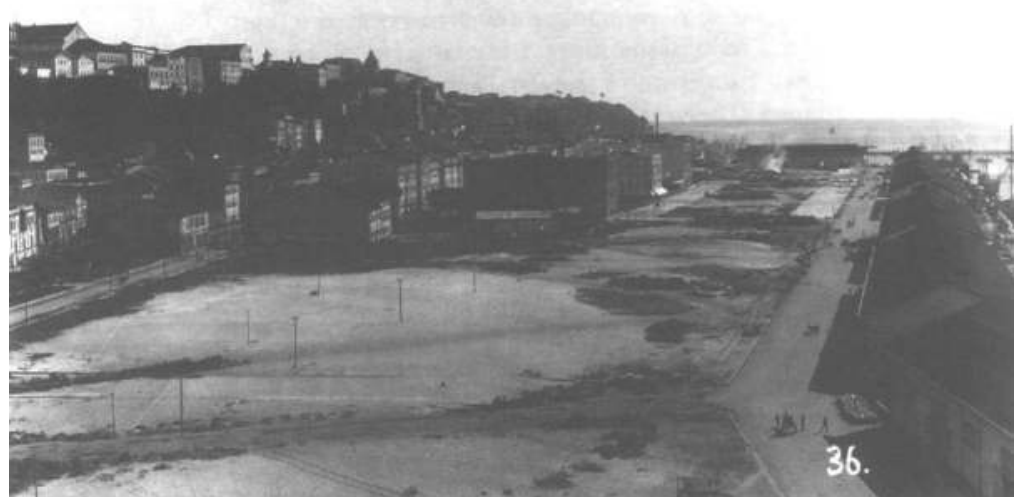

54. Ampliação do porto de Salvador - aterro e cais - c.1913

[...] iniciei a reforma desta cidade, absolutamente necessaria, maximé na parte baixa, onde a actividade mercantil, á falta de espaço, se sentia opprimida, e 0 aspecto da estreita faixa occupada entre a collina e o mar patenteava na conservação do passado, mais que atrazo, os testemunhos formaes de uma verdadeira decadencia. (MENSAGEM, 1912, p. 49)

A Companhia Cessionária vende a parte que conquista ao mar à Companhia Imobiliária da Bahia. ${ }^{38}$ Essa divide a área em quarteirões, separados por largas ruas, dando origem a uma nova urbanização, chamada Bairro das Nações. ${ }^{39}$ A companhia também tem a obrigação de fazer a pavimentação, os jardins e a arborização e de implantar a infraestrutura, como água, esgoto e iluminação.

Sob a responsabilidade do Governo do Estado e com o apoio dos comerciantes, representados pela Associação Comercial, o governo também intervém na parte construída da Cidade Baixa, demolindo edificações para ampliar as ruas e alinhar as construções, que, como em outras partes da cidade, mantém seu traçado urbano original.

Três de suas principais ruas passam por esse processo. Nas duas primeiras, a Nova das Princesas e a Nova do Comércio, sentido Alfândega/ Associação Comercial, derrubam-se as construções do lado da terra, pois as edificações do outro lado são do século XIX. Uma vez acabadas as obras, os edifícios são reconstruídos de acordo com o novo "espírito moderno". (Fig. 55 e 56) A Rua de Santa Bárbara, perpendicular às demais, é alargada para a obtenção de uma melhor união entre o porto, em construção, e a Cidade 
Alta, através da Ladeira da Montanha, que apresenta as melhores condições técnicas para se chegar ao alto da escarpa. O governo modifica a Cidade Baixa

[...] mudando-Ihe o aspecto antigo, embellezando-a, saneando-a, remodelando-a, alargando ruas, sendo, nessa grande obra de progresso, auxiliado, também, pela iniciativa particular, que modificou fachadas de velhos prédios e construio novas, de outra esthética, de feição toda moderna. (BOCCANERA JÚNIOR, 1921, p. 182)

A princípio, as melhorias limitam-se àquele espaço entre a Alfândega e a Associação Comercial. Porém não terminam aí, pois há a necessidade de ligar a área comercial da Cidade Baixa à península de Itapagipe, e o porto à Estação Ferroviária da Calçada. Não se pode continuar com uma única rua estreita e sinuosa que contorna a montanha, com habitações insalubres e de trânsito difícil. Para resolver esse problema, projeta-se uma avenida entre o Mercado do Ouro e a Jequitaia, com 20m de largura, que possibilite o fácil acesso de pessoas e mercadorias até a estação ferroviária e aos bairros da península. Essa obra se torna possível com os recursos que a Comissão Fiscal da Bahia obtém para as desapropriações, a renda do imposto de $2 \%$ em ouro e outras verbas consignados pela Companhia Cessionária.

O que muda na parte baixa da cidade do Salvador é a linha do mar. Alguns elementos, como armazéns antigos, trapiches, fortalezas e igrejas, que antes se localizavam à beira da baía, ficam longe do mar, depois dos aterros. 0 eixo da Preguiça, para o norte, é mantido, com mais uma rua. A nova urbanização amplia a malha urbana da Cidade Baixa com a introdução de um típico urbanismo em quadrícula, o que muda a aparência do bairro comercial, o Comércio, como se costuma chamar.

\section{A interpretação da reforma urbana}

\section{Os argumentos da reforma}

Se, na reforma urbana do Rio, encontramos fortes argumentos que fundamentam a ação dos governantes na cidade, em Salvador, isso não fica tão claro nem tão evidente. Sabe-se, porém, que as justificativas que apoiam as intervenções são a salubridade, a fluidez e a estética.

A rua Chile morosamente vae-se remodelando e quem por ella passar hoje, apesar dos montes de terra dos edificios que cahiram sob os golpes da picareta civilizadora, tem a impressão agradável de já estar transitando por uma via 


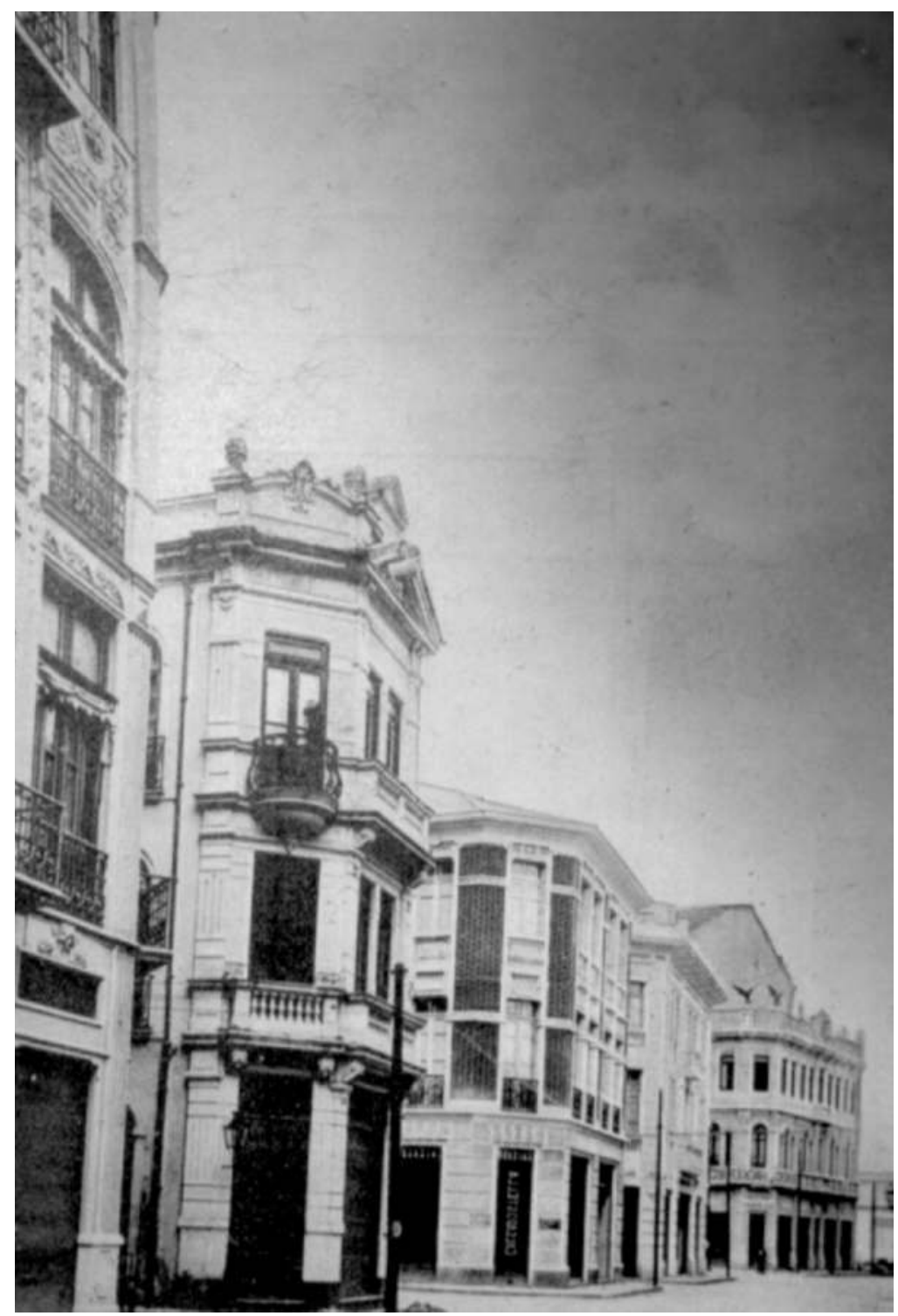

55. Comércio - Cidade Baixa 


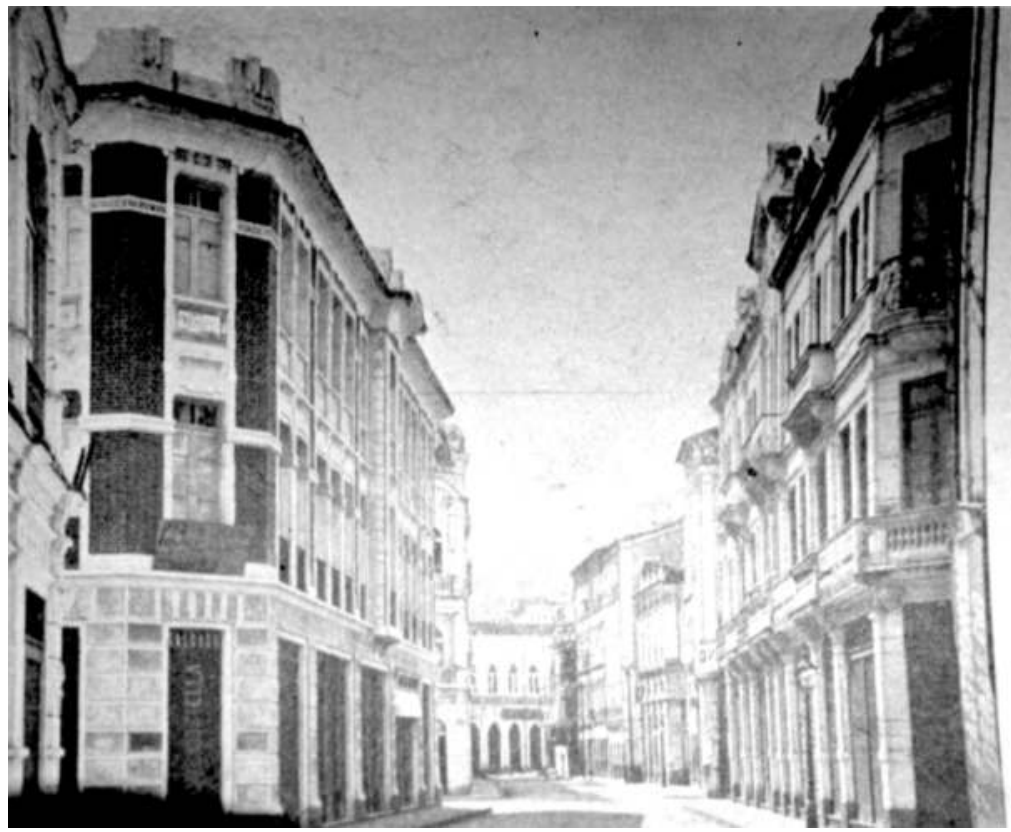

56. Comércio - Cidade Baixa

nova, transbordante de ar puro, clara, e pensa com indizivel satisfação de ver em dias próximos substituindo a apertada e escura viella de outrora, que todavia era uma das melhores de nossa patriarcal metropole uma outra via moderna, asphaltada, cujos edificios correspondem as exigencias da moderna esthetica architectural, e por onde passe uma multidão alegre e 'chic', pisando passeios alvos, com arabescos negros em suas curvas impeccaveis. (O Correio, 9 out. 1913, grifos nossos)

Esse é um exemplo do que pede a população, através da imprensa, e do que as reformas do governo de Seabra tentam implantar na cidade. Nesse texto, encontramos os argumentos da salubridade, através das referências à presença do ar puro, da fluidez, proporcionada pela circulação numa nova via, que substitui a estreita e escura, e da estética, pela moderna arquitetura dos edifícios. São as três grandes preocupações da época.

A reforma urbana de 1912-1916 garante a fluidez das mercadorias para o comércio internacional, e também para o abastecimento da capital, com a abertura da Avenida Jequitaia, que conecta o porto, ampliado e equipado, à estação de trens da Calçada. As reformas realizadas no conjunto da Cidade 
Baixa também facilitam o deslocamento de produtos e de pessoas, melhorando o comércio e agilizando as comunicações com a Cidade Alta.

No que se refere à ampliação da área urbana, a reforma define, ou meIhor, confirma os vetores de expansão, determinando novas áreas na cidade. A implantação de novos meios de transporte também impõe uma mudança na antiga estrutura urbana, adaptando-a às novas necessidades de deslocamento e às novas tecnologias.

A abertura da Avenida Sete de Setembro é a obra de maior impacto realizada na Cidade Alta, articulando o centro com a área nobre, em processo de formação desde o século anterior.

Seabra enfatiza a questão da salubridade em seu discurso, justificando o projeto de intervenção na malha urbana com a regularização dos serviços de higiene e com a organização do Serviço Geral de Saúde Pública do Estado. Ao intervir nas ruas, derrubando edificações e alargando os espaços públicos, procura a eliminação de tudo que possa contribuir para a contaminação, como águas paradas, lixo etc. Mas intervir no espaço público não é suficiente.

Na concepção dominante entre médicos, engenheiros e políticos, entretanto, esta ação sobre o espaço público será considerada necessária, porém insuficiente, posto que os espaços sob domínio dos particulares - as habitações e terrenos baldios em especial - serão igualmente considerados locus de contaminação que punham em risco a saúde dos habitantes da cidade como um todo. (FERNANDES; SAMPAIO; GOMES, 1999, p. 169)

A dificuldade de intervir no espaço privado para mudar hábitos e modos de vida faz com que o poder público, por meio das obras e da consequente valorização do solo na área central, retire dali a população pobre, que se desloca em direção a áreas específicas a ela destinadas. Para esse grupo, projetam-se, mas não necessariamente se constróem, conjuntos homogêneos de casas proletárias, dentro dos preceitos higiênicos, para deixar livre o centro, espaço apropriado pela burguesia. Esse constitui, pois, também um processo de exclusão na cidade.

A estética também é um instrumento de construção da nova cidade, de uma nova urbanidade, de uma nova identidade e de uma nova imagem. Os planos e projetos de embelezamento partem da construção de monumentos e edifícios isolados para o conjunto da cidade, que começa a ser questionada no âmbito da boa forma.

Os governantes afirmam a necessidade de embelezar as áreas sem atrativos, com ruas estreitas e sem arquitetura "moderna". Arquitetos, escultores, pintores e decoradores vieram de São Paulo, por decisão do Intendente 
Municipal, Júlio Viveiros Brandão, a partir de 1912, entre eles, Pasquale de Chirico, Júlio Conti, Filinto Santoro, Rossi Baptista, o engenheiro José Allioni e o pintor decorador Sercelli. (FLEXOR, 1999, p. 160)

A força de Salvador se mantém pela influência, na política nacional, dos senhores de engenho, chefes políticos regionais, que têm em Salvador sua sede residencial. Em princípios do século XX, a capital da Bahia perde o posto de segunda cidade para São Paulo, que vem desenvolvendo uma política industrial que atrai mão-de-obra em busca de emprego. Salvador também perde parte da população, que se dirige para o sul do Estado, onde o cacau começa a se destacar. Mesmo assim, o porto sustenta sua economia e seu posto de cidade capital, com um grande domínio sobre capitais sub-regionais e seu hinterland, que concentra funções e recursos, ficando cada vez mais forte com relação a outras capitais regionais.

Mas essas Capitais sub-regionais apenas fazem penetrar em meio rural as influências da Cidade do Salvador; centralizam a produção agrícola do Recôncavo e do Sertão e reenviam-na à Capital do Estado, donde ela é dirigida para a Europa. Essa organização de um espaço sub-regional reforça a dependência da região defronte em relação à cidade do Salvador. A cidade encontra, assim, a oportunidade de concentrar ainda mais os recursos financeiros, econômicos, sociais e políticos, concentração que vai prosseguir sempre. (SANTOS, 1959a, p. 41)

Ser uma cidade capital fundamenta a vontade dos governantes em adaptar o espaço urbano de Salvador às novas ondas de modernidade, justificando, assim, as intervenções dos anos 1912-1916 e as arbitrariedades cometidas para levá-las a cabo. Uma capital de sua importância, porto de comércio exterior de primeira linha, não pode manter suas ruas coloniais, seus hábitos tradicionais, nem ficar para trás das outras capitais de Estado, com estruturas já transformadas e modernizadas. ${ }^{40}$ Salvador quer ser uma cidade de seu tempo, com largas avenidas, um porto moderno e uma arquitetura que coincida com sua categoria de cidade capital, de cidade mais importante do nordeste do País.

\footnotetext{
${ }^{40}$ Alguns exemplos são Rio e sua "Reforma Passos", São Paulo, que realiza a sua reforma entre os anos 1910-1914, ao mesmo termpo que Recife, também reurbanizada entre 1910-1913.
}

\section{Depois da reforma}

As ruas de Salvador são beneficiadas com intervenções que, além de transformarem sua imagem, mudam também a localização das atividades nelas desenvolvidas. Não se pode dizer que é uma transformação homogênea, pois alguns pontos permanecem com seus usos tradicionais e outros alteram 
${ }^{41} \mathrm{O}$ primeiro setor localiza-se entre a Praça Castro Alves e a Igreja da Sé; o segundo, entre a Igreja da Sé e o Terreiro de Jesus; o terceiro, entre o Terreiro de Jesus e o Largo do Pelourinho; e o último, a Rua da Vala, apesar de pertencer ao Distrito de Santana.

${ }^{42}$ Por exemplo, as edificações das ruas do Pelourinho. suas funções. A Cidade Baixa se mantém como centro comercial e financeiro, e a Cidade Alta, como centro administrativo, político e religioso. Nessa época, a maioria das atividades permanece como antes, e apenas o comércio varejista sobe a encosta, em busca das ruas da Cidade Alta.

Na parte baixa, as obras do porto intensificam o comércio de importação e exportação, que atrai os novos bancos, sedes de empresas e casas comerciais, localizados em suas ruas reformadas, passando a área a ser conhecida definitivamente como o "Comércio". Ali se fazem os grandes negócios, ali está o centro financeiro e empresarial de Salvador.

Para melhor analisar a parte de cima, dividimos o Distrito da Sé em quatro setores, ${ }^{41}$ que se comportam de formas distintas. Há uns que mudam e outros que mantêm suas funções. São alargadas suas ruas e levantadas novas construções, mas uma parte da área mantém a estrutura colonial, com edificações dos séculos XVII e XVIII. ${ }^{42}$ As obras consolidam sua centralidade. De forma geral, o que se sucede no núcleo inicial de Salvador é a transformação de pequenos negócios locais para a criação de um "centro" urbano. Dentro do diminuto espaço do Distrito da Sé, as atividades ou ocupações desenvolvidas definem espaços frequentados por populações distintas. A Rua Chile abriga bonitas confeitarias e luxuosas lojas de moda, onde se encontram os últimos lançamentos da Europa, que atraem a classe mais rica, a elite social e intelectual da capital. A Rua da Vala é frequentada por uma população mais pobre e remediada, que busca lojas mais simples, oficinas e serviços mais humildes. Nas ruas do Pelourinho, há uma população pobre, que ainda vive em cortiços e casas de cômodo, muitos artesãos e prostitutas, com um comércio modesto.

Em resumo, o Distrito da Sé, assim como todo o resto da cidade, divide-se em zonas com distintas atividades e distinta estratificação social. O primeiro setor abriga um comércio fino e profissionais liberais; o segundo é especializado em serviços; no terceiro, um comércio menor, com artesãos ocupando suas ruas; e, no quarto setor, um comércio mais simples. (PINHEIRO, 1992, p. 58)

Da mesma forma que o Distrito da Sé, outros também se especializam progressivamente. A Liberdade se firma como um novo bairro proletário. Em direção à península de Itapagipe e aos subúrbios, ao longo da linha férrea, seguem as indústrias e o proletariado.

O comércio e os serviços dominam a parte mais central, e as novas áreas residenciais da burguesia seguem crescendo em direção ao sul, em busca do litoral, de locais mais agradáveis para viver. 0 eixo principal, a Avenida Sete de Setembro, depois de valorizada e reformada, é apropriada pelas classes dominantes, que ali fixam residências, instalam seus escritórios e estabelecem as 
melhores lojas da cidade. As obras expulsam a antiga população empobrecida, que vivia em edificações encortiçadas em partes do Distrito da Sé e do Distrito de São Pedro e que tem de buscar novos locais para acomodar-se. 0 projeto de abertura da Avenida Oceânica (Fig. 57), que liga a Barra ao Rio Vermelho, orienta a expansão da malha urbana, além de atender aos investimentos especulativos do solo urbano. A reforma de 1912-1916 confirma essa nova divisão espacial na cidade e a segregação social, dois processos que vinham sendo gerados desde meados do século anterior.

A elite idealiza uma cidade europeizada e "branca", mas encontra limites para sua materialização, por ser Salvador uma cidade composta por aproximadamente $75 \%$ de negros e mestiços. Como alternativa, a burguesia cria espaços onde possa fabricar essa cidade idealizada, europeizada - Barra (Fig. 58, 59, 60) e Ondina, além de Vitória (Fig. 61 e 62) e Graça. A classe média assenta-se predominantemente na segunda linha de cumeada, em bairros como Nazaré, Barris, Barbalho etc. Os mais pobres amontoam-se em áreas centrais não reformadas, ou se deslocam para bairros ao norte do centro, como Liberdade e São Caetano.

As intervenções introduzem outras formas de exclusão social, tais como a diversidade de tratamento quanto à implantação de infraestrutura nas áreas novas e nas antigas, essas últimas em processo de degradação. 0 custo dos aluguéis também define a permanência ou a expulsão da população dos seus locais de residência, pois o aumento do valor, nas áreas reformadas, leva a população de baixa renda a buscar habitações cada vez mais baratas e, portanto, mais insalubres, com péssimas condições de habitabilidade.

A nova distribuição da população na cidade é um projeto da burguesia, que até pouco tempo tinha interesse em conviver com as classes de baixa renda e os escravos, pois esses Ihe prestavam serviços fundamentais, como jogar fora os dejetos ou transportá-la de um lado ao outro. "Sua convivência é útil até quando se estabelecem novas relações sociais, quando a presença do pobre não é mais tolerada na paisagem urbana." (SOUZA, 1984, p. 87)

Com a introdução dos serviços de infraestrutura e dos transportes mecânicos, já não há a necessidade da presença tão constante de pessoas pobres e negras, que agora só atrapalham a idealização da cidade "branca" e de aparência europeia. Como no Rio, depois da nova estrutura espacial, surgem, em Salvador, os "guetos" da classe de baixa renda. São pessoas que necessitam viver perto do trabalho, muitas vezes na proximidade das casas da classe alta. São empregadas domésticas, jardineiros e indivíduos que prestam 
outros serviços domésticos. Nos bairros centrais, a população que não pode ou não quer se afastar concentra-se nos sobrados, cada vez mais subdivididos, ou em casebres colados uns aos outros, conhecidos como "avenidas".

A nova Salvador, a cidade moderna e capitalista, define novos espaços na capital, habitados por classes sociais distintas. A cada uma corresponde um novo lugar no novo espaço urbano, mesmo que alguns bairros mantenham uma população heterogênea.

As transformações nas áreas construídas e a formação de novos bairros estabelecem uma nova estrutura urbana que, por sua vez, define uma segregação socioespacial na cidade. Cada bairro de Salvador passa a ter uma função definida depois da reforma implantada nos tempos de Seabra. Pode-se observar, cada vez mais, a separação entre bairros residenciais e bairros comerciais, bairros pobres e bairros ricos. As alterações na estrutura urbana e a segregação social se complementam, porque ocorrem simultaneamente, e não se pode fazer referência a uma sem a outra. São processos siameses, já que a segregação social se produz com a introdução de uma nova maneira de estruturar a cidade.

A fuga das áreas centrais por parte dos setores mais ricos da população já delineia desde muito cedo uma nítida distinção, a nível de localização e aparência, entre bairros populares e burgueses, rompendo a superposição (ou proximidade) de classes sociais em um mesmo espaço, característica

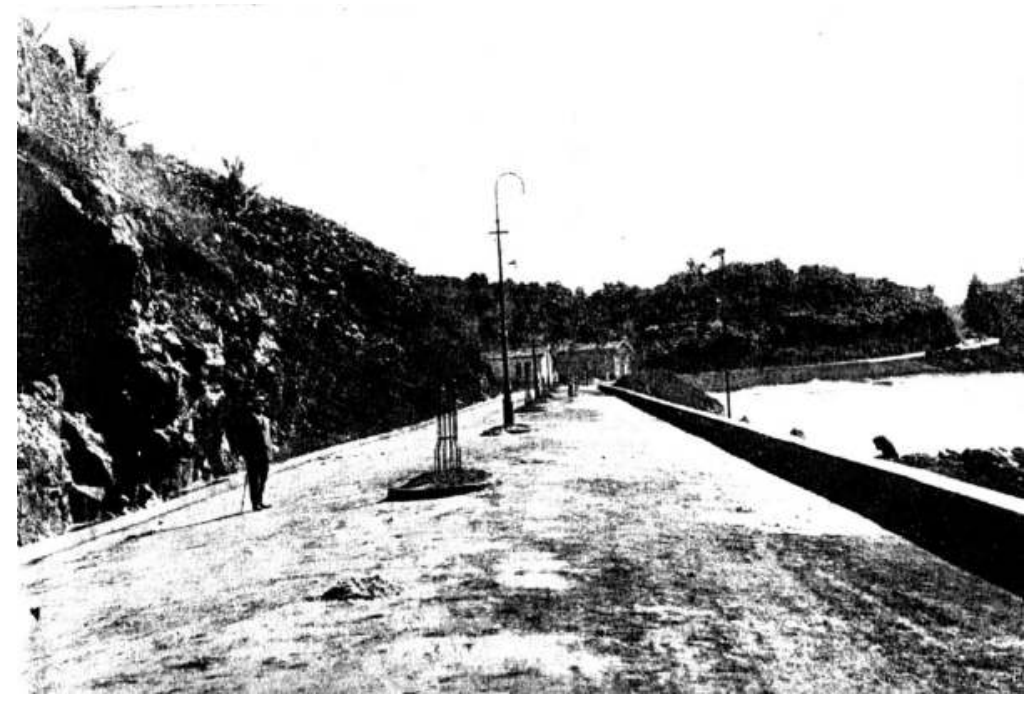

57. Avenida Oceânica no trecho entre a Barra e Ondina 


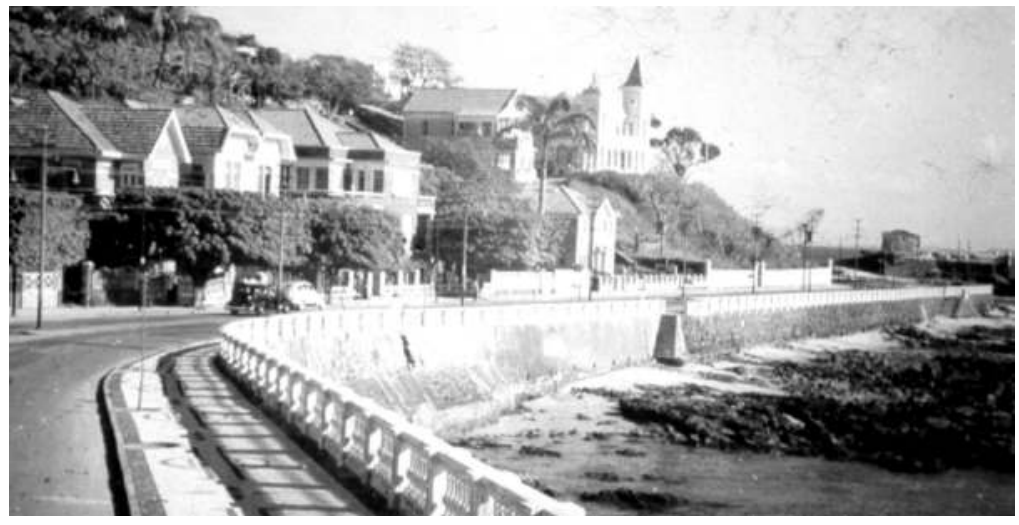

58. Avenida Sete de Setembro entre o Porto e o Farol da Barra

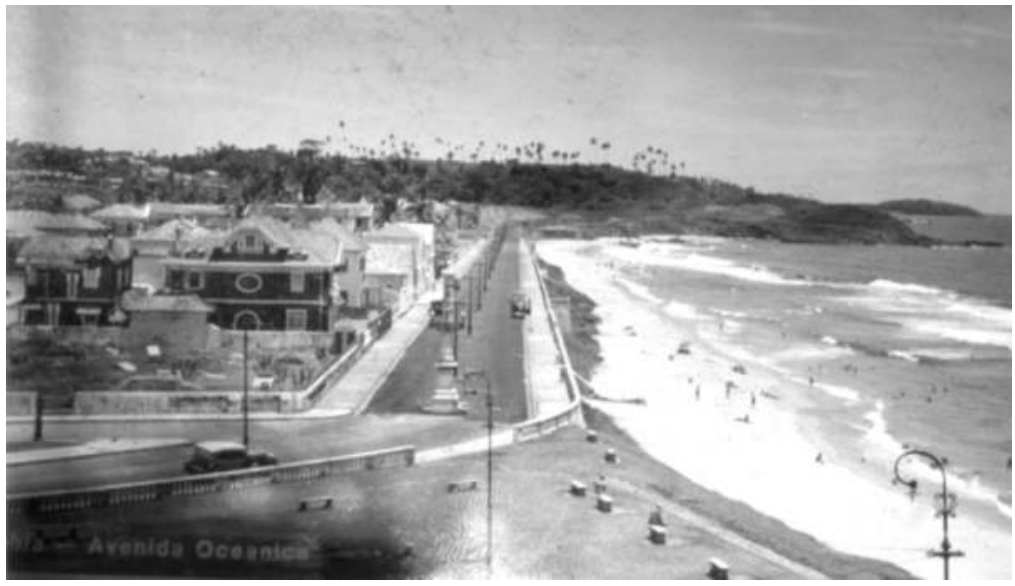

59. Vista da Barra e da Avenida Oceânica

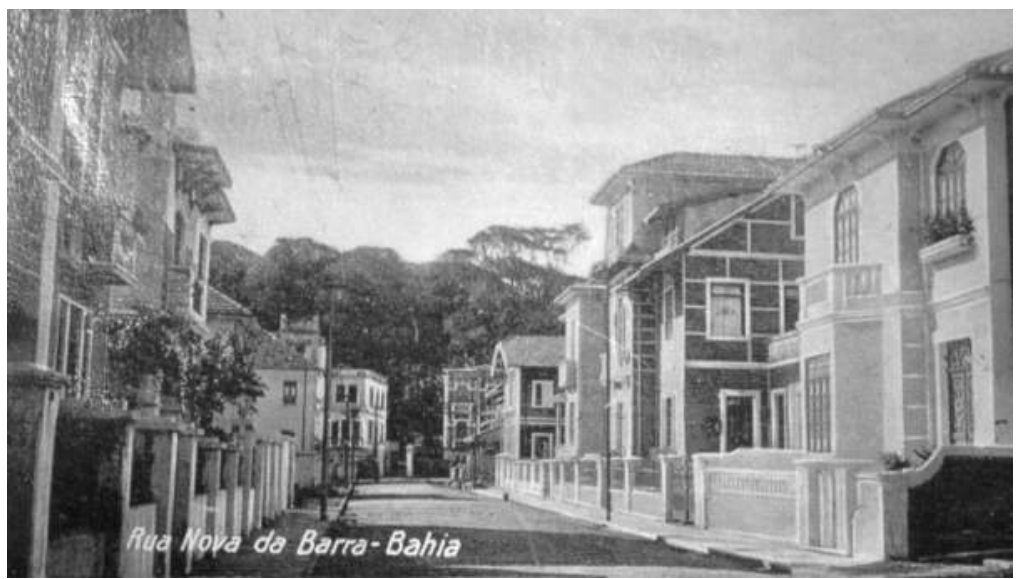

60. Uma rua na Barra 


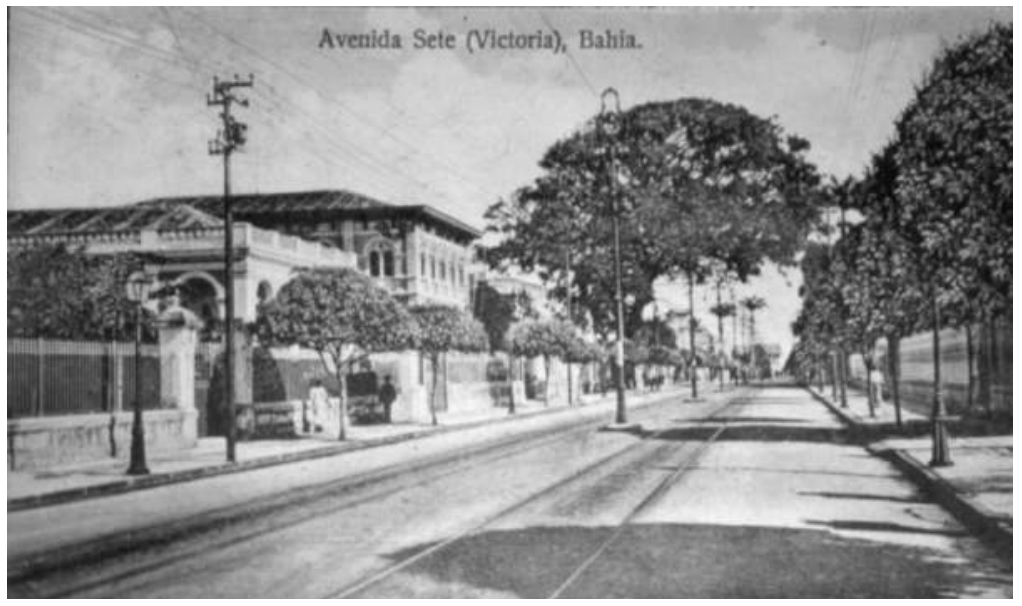

61. Avenida Sete de Setembro - Corredor da Vitória

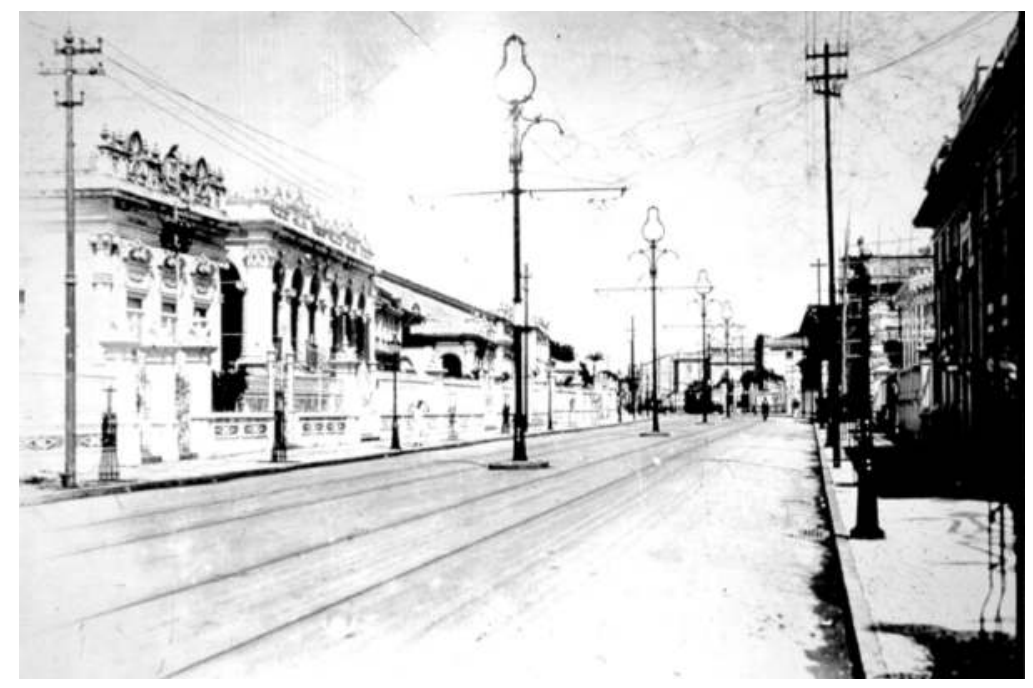

62. Avenida Sete de Setembro - Corredor da Vitória 
da cidade colonial. A nível da arquitetura, essa distinção completa-se pela exteriorização de códigos estéticos específicos, que podem ser esquematizados na contraposição entre, de um lado, o palacete neoclássico ou eclético e, do outro lado, o conjunto homogêneo de casinhas proletárias, onde a pobreza estética se 'justifica' diante dos avanços dos preceitos higiênicos. (FERNANDES; GOMES, 1992, p. 64-65)

A mudança na estrutura urbana começa em meados do século XIX, quando os comerciantes ricos abandonam o centro da cidade em busca de novos espaços para viver. É o primeiro passo para a separação entre o trabalho e a casa, com o surgimento de um bairro quase exclusivamente para a classe alta, enquanto que o Centro passa a abrigar uma população de classe social mais baixa e mais pobre. Aos poucos, a classe média também sai em busca de novas zonas exclusivas.

\section{Os modelos da reforma urbana}

Salvador também realiza sua reforma tendo como base intervenções urbanas anteriores, ocorridas em outras cidades brasileiras. Diferentemente das intervenções do Rio de Janeiro, no caso de Salvador há carência de uma bibliografia específica sobre a reforma urbana. Entretanto, autores que escrevem sobre esse período da cidade - jornalistas e cronistas da época referem-se às reformas de Seabra como inspiradas nas que ocorrem no período 1902-1906 na Capital Federal.

O plano das reformas urbanas, em princípios do século XX, no Brasil, faz parte de um projeto nacional de modernização de cidades, segundo o qual muitas cidades brasileiras reformam suas estruturas viárias, sob um novo modelo ideológico e cultural, vindo da Europa, para mudar a aparência das cidades. Podemos citar exemplos como São Paulo, Santos, Porto Alegre e Recife, entre outras capitais, que passam por processos de mudança. Salvador é uma capital importante e faz parte desse processo, em que as palavras de ordem são reformar, sanear, ordenar e modernizar.

\section{Uma revisão}

Já nos discursos sobre a cidade, em finais do século XIX e princípios do século XX, no que se refere ao traçado urbano e aos métodos de planeja- 
${ }^{43}$ Como Ministro do Interior do governo de Rodrigues Alves, contribui para a reconstrução da Faculdade de Medicina, inclui nas resoluções do Governo Federal as obras do porto (as docas); como Ministro da Viação e Obras Públicas do governo do Marechal Hermes da Fonseca, realiza o contrato da Rede Ferroviária Federal, assegurando melhorias nas comunicações na Bahia. mento, percebemos que Salvador segue o exemplo das cidades europeias e norte-americanas. E a reforma de 1912-1916, segue o modelo da reforma do Rio de 1902-1906, quando se transforma a capital do Brasil.

A capital federal tornara-se chic, fashionable, up-to-date (expressões correntes na imprensa da época). Era uma réplica tropical de Paris, que o barão do Rio Branco, ministro das Relações Exteriores, podia exibir com orgulho, uma cidade que suplantava Buenos Aires, que já era uma grande metrópole nas últimas décadas do século XIX. (BARBOSA, 1974, p. 16)

Segundo o mesmo autor, essa ideologia do progresso, que se produz no Rio, contagia a Bahia em 1912, quando assume o poder do Estado J. J. Seabra, que chega "[...] imbuído das mesmas idéias de reforma urbana à européia, de Pereira Passos. É a 'ideologia do progresso', que se preocupa tão somente em substituir o velho pelo novo, sem medir conseqüências [...]" (BARBOSA, 1974, p. 17)

No estudo sobre as transformações urbanas de Salvador, observamos que a remodelação da cidade tem sua gênese no Rio de 1902-1906, quando J. J. Seabra ocupa o Ministério da Justiça e dos Negócios Interiores e assiste às intervenções ${ }^{43}$ lá realizadas. É normal, portanto, que tente implantar em sua cidade, Salvador, as mesma ideias e técnicas que ajuda a introduzir no Rio.

Fernando Peres, em seu livro Memória da Sé, comenta a influência do sul do País, Rio e São Paulo, e de suas obras de engenharia, sobre Salvador, fazendo uma reflexão sobre o fato de dez anos depois de implantado no Rio, esse "urbanismo" chegar até o Nordeste, e Salvador passar por sua reforma urbana.

A liderança política e administrativa, assim como os órgãos de imprensa, serão responsáveis pela pregação e realização das ideias de reforma urbana. É certo que esta ânsia de progresso não surge, em nossa cidade, como por encanto, mas ela representa o reflexo de uma situação existente no sul do país, no Rio e S. Paulo, especialmente depois da realização de grandes obras de engenharia. Desde então a palavra dos homens públicos vai enfatizar que a cidade do Salvador carecia urgente de novos projetos viários e de saneamento, que o antigo burgo deveria ser convenientemente preparado para entrar, já com certo atraso, na mecânica do século. (PERES, 1974, p. 35)

Em sua análise, Peres segue comentando que a população quer algo similar ao Rio. Em reportagem do Jornal de Notícias, os leitores pedem, entre outras coisas, "um engenheiro Passos", ou "um Passos", o que demonstra a grande consideração que se tem ao referido engenheiro, uma personalidade 
capaz de mudar o aspecto de uma cidade, transformando-a numa nova. (PERES, 1974, p. 44)

Na bibliografia consultada, não encontramos nenhuma referência comparativa entre as obras em Salvador e as realizadas por Haussmann, em Paris, embora alguns autores classifiquem essas obras como "urbanismo demolidor".

Maria Helena Flexor (1998, p. 109-110) também considera que as ideias haussmannianas e as de progresso atingem a Bahia e seu Governador J. J. Seabra, conhecedor da Paris de Haussmann, por haver-se exilado na França em finais do século XIX.

\section{Um comentário a mais}

Desde finais do século XVIII, realizam-se intervenções no tecido urbano da cidade do Salvador, sendo a primeira década do século XX o período mais intenso dessa reestruturação urbana.

De uma forma geral, a cidade passa por transformações em sua estrutura socioeconômica e espacial, com a ampliação de sua área urbana, o incremento em sua população, a introdução dos novos serviços de infraestrutura e dos novos meios de transporte. Uma nova classe social tenta consolidar seu poder - a burguesia comercial -, procura formas de representação distintas das dos proprietários de terra e nega o passado colonial e escravista, identificando-se com a modernidade que as cidades europeias representam.

A rede viária passa por reformas pontuais durante todo o século XIX, entre as quais se destacam as tentativas de melhoria da ligação entre a Cidade Alta e a Cidade Baixa e a definição de eixos de expansão voltados para a conexão entre os núcleos edificados nas diversas cumeadas da Cidade Alta, melhoria essa atingida com introdução dos novos meios de transporte.

Apesar dessas intervenções no século XIX - quando foram dados passos visando à mudança da estrutura colonial, com o alargamento das ruas e praças, a pavimentação das principais vias e a introdução dos serviços de abastecimento de água, rede de esgoto, iluminação e transportes públicos -, a malha urbana como um todo mantém-se tipicamente colonial. Deve-ser pensar num projeto global, uma mudança estrutural mais profunda para toda a cidade, um projeto que ultrapasse as intervenções pontuais, e inaugure uma nova forma urbana, "moderna" e "civilizada".

A ideia de aberturas haussmannianas (percées) faz parte de um ambicioso projeto para Salvador, apresentado em 1912 pelo Engenheiro Alencar Lima, que propõe a construção de artérias largas e retas, com praças 
em elipse e circulares, com clara inspiração na rede viária implantada por Haussmann em Paris. Supõe-se que esse projeto não é implantado por seu alto custo, frente às parcas condições financeiras da cidade e do Estado. É necessária sua conversão num projeto possível, uma vez que Salvador não tem a mesma disponibilidade financeira que o Rio, para pôr em prática seus ideais de cidade moderna.

Para verificar até que ponto a realização dessas intervenções haussmannizam Salvador, são necessárias algumas comparações com o modelo de haussmannização definido no capítulo 2, numa tentativa de identificar as semelhanças e as diferenças. 0 primeiro ponto, e que nos parece muito significativo, é o fato de Salvador não mudar sua malha urbana, não introduzir elementos novos, alheios à sua configuração. 0 que acontece é o aproveitamento do tecido urbano existente e o alargamento de algumas de suas artérias principais, criando-se eixos de importância e orientando-se a expansão da cidade. Dois exemplos resultantes dessa forma de atuação são a Avenida Sete de Setembro, na Cidade Alta, e a Avenida Jequitaia, na Cidade Baixa.

Com isso, chama-se a atenção para um detalhe importante, que é o fato de a reforma urbana de Salvador não se realizar através de aberturas que rasgam os quarteirões, as percées. Por ser respeitado o traçado original das ruas, essas não resultam necessariamente em vias retas, nem há o objetivo de ressaltar determinados monumentos históricos, criando perspectivas monumentais. O novo alinhamento é conseguido pelo alargamento de ruas e becos existentes, mantendo-se o traçado original. As intervenções na rede viária são feitas através da demolição de partes das edificações de um dos lados da rua, com o intuito de alargá-la. Para a execução dos alargamentos, não é desapropriada toda a edificação, apenas a parte de que se necessita para a ampliação da via. Assim, não se faz um reparcelamento dos quarteirões. O resultado dessa forma de atuação são novas vias com o mesmo traçado das anteriores e a demolição completa de algumas edificações importantes como as Igrejas de São Pedro Velho e da Ajuda, já em 1912; e a previsão de demolição de uma terceira, a Igreja da Sé.

0 fato de em Salvador não se terem realizado as aberturas, os rasgos de quarteirões, as percées - uma forma radical de intervenção, descrita pelo próprio Haussmann como "regularização" - não significa que a reforma de Salvador tenha sido mais branda que as demais. Pode-se usar o termo regularização para caracterizar os chamados "planos geométricos", que se realizam em outras cidades através do alargamento e da retificação das ruas existentes. Dependendo da quantidade das intervenções realizadas, esse processo pode ser tão radical, ou mais, que o implantado em algumas reformas realizadas 
através da demolição total ou parcial dos quarteirões construídos. Pode-se mudar totalmente a fisionomia de uma cidade apenas com o alargamento de suas ruas e a reconstrução de seus edifícios.

As fachadas reconstruídas das edificações das ruas de Salvador são submetidas à análise, através dos requerimentos de aprovação e licença para construção, enviados à Intendência Municipal, que delibera sobre questões técnicas e também estéticas. 0 novo conjunto que se forma não resulta num espaço monumental estandardizado. Para completar as diferenças, temos a formação de novos núcleos urbanos, como o Bairro das Nações, na Cidade Baixa, e outros incentivados pela abertura dos novos eixos de expansão, os bairros do litoral sul e dos bairros ao norte do centro.

Dentre as características que aproximam a reforma de Salvador da reforma parisiense implantada por Haussmann, encontramos a forma autoritária de impor o projeto e de executar as intervenções. São realizadas demolições, desapropriações e a consequente expulsão de uma parte da população de baixa renda que habita no centro de Salvador. Os modernos serviços de infraestrutura e o novo mobiliário urbano são implantados nas novas vias, fazendo com que, na Cidade Alta, as ruas reformadas se transformem em cenário para a elite passar seus momentos de lazer, caminhando por entre as lojas de moda e as casas de chá ou de sorvetes. Em Salvador, a parte do centro afetada pelas intervenções, na Cidade Alta ou na Cidade Baixa, passa a ser a sede das atividades comerciais, financeiras e de serviços. Mas isso não significa que deixe de ser também residencial. Essa é uma grande diferença entre o centro de Paris, que abriga a burguesia, e a parte do centro de Salvador onde não se introduzem modificações, que continua mantendo as residências de uma população de baixa renda. O Pelourinho é um exemplo dessa permanência. Se, em Paris, os novos bulevares unem as gares e a Capital ao resto do país e à Europa, na Cidade Baixa, a nova avenida faz a ligação entre a estação ferroviária da Calçada e o porto, reformado, ampliado e dotado dos modernos equipamentos necessários para seu bom funcionamento, facilitando a conexão de Salvador com seu hinterland.

No capítulo anterior, ao comparar as ações realizadas no Rio com aquelas ocorridas em Paris entre os anos 1853 e 1870, concluímos que as intervenções na Capital Federal não se resumem a uma haussmannização, apesar das muitas semelhanças. Apesar disso, não negamos a importância de Paris e o fato de sua reforma ser um modelo urbano e de as ações de Haussmann terem influenciado diretamente as de Pereira Passos. 
${ }^{44}$ Os números são baseadas nos censos de 1920 e 1940 do IBGE, consultados no local.

${ }^{45}$ Como já foi mencionado anteriormente, o crescimento da população de Salvador aumenta $66,53 \%$ entre 1890 e 1940 , com um percentual muito baixo entre 1920 e 1940 , apenas $0,20 \%$ por ano, enquanto sua área urbana aumenta de 800 hectares, em finais do século XIX, para 3 mil hectares, em 1940. (SIMAS, 1937, p. 124-125)
Como já foi analisado, a reforma do Rio constitui-se basicamente de uma intervenção no centro da cidade, com a abertura de avenidas que derrubam quarteirões considerados insalubres, onde reside uma população que se deseja expulsar do Centro, e da criação de vetores de crescimento, em direção à Zona Sul e em direção às Zonas Norte e Oeste. Também ocorrem as obras de modernização do porto, com aterros que retificam a costa, onde são instalados novos equipamentos, e com a abertura de uma avenida paralela à costa. Nesse sentido, pode-se dizer que as duas intervenções, a do Rio e a de Salvador, são parecidas. Em Salvador, também se faz uma reforma em sua área central, tanto na Cidade Alta como na Cidade Baixa, com a criação de novas avenidas, mediante o alargamento de ruas estreitas e a definição de vetores de crescimento principalmente em direção ao sul, ao norte e ao leste. Ocupam-se novas cumeadas e executam-se obras de modernização do porto, com a criação de uma nova urbanização. Mas ainda é cedo para se afirmar que uma é a cópia da outra, ou o modelo.

\section{Outros projetos}

A cidade do Salvador não para depois da reforma do período 1912-1916 e continua a desenvolver-se, mas de forma lenta em relação a outras cidades brasileiras. Entre 1913 e 1940, o Rio e São Paulo têm uma expansão muito maior, um grande aumento populacional e de área urbana. O Rio já tem uma população de 984.370 habitantes em 1913, enquanto São Paulo possui aproximadamente 460 mil. As duas cidades chegam, em 1940, respectivamente, a cerca de 1,7 e 1,3 milhões de residentes, como já mencionado anteriormente. Se as comparamos com Salvador (283 mil em 1920 e 290 mil em 1940), ${ }^{44}$ podemos perceber que, nessa, o crescimento da população é pequeno, apesar de o crescimento da área urbana ${ }^{45}$ ter continuidade.

O aumento da área com baixo crescimento de população pode ser explicado pela criação de novos bairros afastados do Centro, já que este se transforma, mais e mais, num núcleo especializado em negócios e comércio, além de ser a sede administrativa. Por exemplo, no começo do século XX, implantam-se duas novas urbanizações afastadas do Centro, uma em finais dos anos 10 - a Pituba - e outra nos anos 20 - Montserrat. 0 número de edificações na cidade aumenta de 14.698, em 1893, para 44.610, em 1940. Com a especialização funcional do Centro, os banqueiros, pessoas enriquecidas 
pelo comércio e pela indústria, exportadores e importadores, mudam suas residências para áreas como Graça, Barra e o litoral de mar aberto, enquanto a classe pobre se dispersa pela cidade, criando novos aglomerados habitacionais em direção norte e leste de Salvador. (SANTOS, 1959a, p. 49-50)

Depois das reformas do período 1912-1916, os projetos não executados são arquivados. Na década de 30 do século XX, novas intervenções no Centro, como a demolição da Igreja da Sé, de alguns quarteirões próximos a ela, além do alargamento de outras ruas, buscam dar continuidade aos planos anteriores, mas ainda são intervenções típicas de um "urbanismo demolidor".

Calcado nas velhas e já mencionadas preocupações estético-viárias e sanitárias, este padrão de intervenção incorpora o fato de o funcionamento da cidade ter se tornado tributário de sistemas técnicos (transporte, distribuição de água, esgotamento, energia, telefone, etc.), embora ainda não incorpore a pretensão de pensar nem de intervir de uma forma global na cidade. (FERNANDES; SAMPAIO; GOMES, 1999, p. 174)

O aumento da área urbanizada pede novas soluções com relação ao saneamento da cidade e novos projetos urbanos que orientem o seu crescimento. A contratação de Saturnino de Brito, em 1925, para elaborar um projeto de saneamento para a capital, e a Semana de Urbanismo, que acontece em 1935, mudam a forma de pensar e intervir na cidade e em seu urbanismo. Em 1943, instala-se o Escritório do Plano de Urbanismo da Cidade do Salvador (EPUCS), com o objetivo de elaborar um plano diretor para Salvador. É o momento em que se começa a mudar o urbanismo tópico, passando a se pensar a cidade como um todo e tentando encontrar soluções para os problemas, tendo em vista mais o futuro do que o presente.

\section{De Seabra à Semana de Urbanismo}

\section{De 1916 a 1935}

As reformas urbanas planejadas por J. J. Seabra não se executam em sua totalidade, ante a dificuldade em obter financiamento, principalmente na ocasião da Grande Guerra, entre 1914 e 1918. No período imediatamente posterior à sua gestão, entre 1916 e 1920, sob a administração de Antônio Moniz, as ruas alargadas na reforma recebem novas construções de particulares e também do governo. A preocupação com a estética pode ser observada nas novas fachadas das casas, amputadas pelas reformas das 
46 Documento $n^{\circ} 633$ do maço 178 da série Secretaria da Agricultura da seção republicana, no Arquivo Público do Estado de Bahia.

${ }^{47} 0$ Teatro São João sofre um incêndio em 1923, e o que resta dele é derrubado para a construção do novo edifício. ruas. Os edifícios públicos seguem o mesmo estilo, como se afirma numa descrição de 1920 sobre o novo edifício que se constrói para ser a Secretaria da Fazenda e o Tesouro do Estado.

[...] compõem-se de três corpos: ala esquerda, corpo central e ala direita, todos elles reunidos num conjunto harmônico, formando um bello edificio de estylo moderno.

O corpo central e o ângulo da ala direita serão encimados por duas belas cúpulas, complementos indispensáveis, à esthetica do edificio. ${ }^{46}$

Seabra volta uma vez mais à administração do Estado, entre 1920 e 1924, buscando dar continuidade a seus projetos anteriores, não colocados em prática, mas não chega a executá-los. Até meados da década de 30 , não se produz um novo período de intervenções, embora se abram novas ruas no tecido urbano e se alarguem outras tantas, por exigência da circulação, que aumenta rapidamente.

Em princípios da década de 30, no Distrito da Sé, além da demolição da Igreja da Sé, que comentaremos mais adiante, são construídos novos edifícios públicos de grande importância, como o da Imprensa Oficial e o edifício para a Secretaria da Agricultura, Indústria, Comércio, Transportes e Obras Públicas, na Praça Castro Alves, onde antes se localizava o Teatro São João. ${ }^{47} \mathrm{O}$ Elevador Lacerda ganha uma nova torre, modificando sua imagem.

Ainda na década de 30 , continua a preocupação com a melhoria das comunicações entre a Cidade Alta e Cidade Baixa. A Ladeira do Taboão, talvez a mais usada pelos trabalhadores, é alargada para $10 \mathrm{~m}$ e pavimentada com paralelepípedos. São abertas outras ladeiras com essa finalidade, como a Rua Visconde de Mauá, ao sul do Centro, e a Rua Botelho Benjamin, ao norte.

$\mathrm{Na}$ tentativa de dar continuidade ao projeto de melhorias para o Distrito da Sé, elaborado em 1912, com Durval Neves da Rocha à frente da Prefeitura (1938-1942), realizam-se o alargamento já previsto de algumas ruas e a abertura de outras novas. São feitas algumas modificações no projeto original, no que se refere às demolições na Sé, entre a Igreja da Sé e a Catedral.

Outra intervenção importante, na mesma época, é a desapropriação e a demolição das casas do lado da terra para alargar a Rua Carlos Gomes, que começa na Praça Castro Alves e segue paralela à Avenida Sete de Setembro, e sua continuação. O prolongamento dessa rua se faz através dos pátios das casas da Avenida Sete de Setembro e do Largo Dois de Julho, de forma que não haja a necessidade de derrubar um só imóvel.

Nesse período, mais uma rua sofre intervenções: a Avenida Joana Angélica, no trecho entre a Praça da Piedade e a Lapa, com a derrubada de várias 
edificações, para o alargamento dessa via. Um pouco mais adiante, no Campo da Pólvora, derrubam-se alguns imóveis para abrir espaço e construir o Palácio da Justiça, o que não acontece por causa da implantação do Estado Novo, e somente se reforma o jardim existente, prejudicado pelas obras anteriores.

São feitas obras de reforma e embelezamento na península de Itapagipe, como as da Avenida do Bonfim, da Avenida Mem de Sá e da Praça General Osório, incluindo-se a construção de uma estação de hidroaviões. Além das intervenções no tecido construído, projetam-se duas novas urbanizações, executadas ao longo do período estudado: Pituba e Montserrat.

\section{Pituba}

A expansão da cidade em direção às praias do litoral sul transforma antigas aldeias de pescadores e fazendas em áreas urbanas. É o que acontece quando se contrata o Engenheiro Theodoro Sampaio para projetar e executar as obras de uma nova urbanização nas terras de Manoel Dias da Silva, uma antiga fazenda de cocos à beira do mar. Em 1919, o engenheiro apresenta o relatório dos "Estudos e Projetos para uma Cidade Nova, a Cidade Luz". (SAMPAIO, 1919)

O esquema apresentado (Fig. 63) tem como base avenidas, ruas, praças e jardins, que são complementados por redes de esgoto e de abastecimento de água, árvores, limpeza pública e incineração de lixo. No projeto, estão previstos um cemitério, exploração de pedreiras, uma capela nova, uma escola pública, um posto de saúde e uma delegacia de polícia. Pensa-se, inclusive, num balneário à Beira-Mar.

As ideias do engenheiro, que trabalha com a herança do século XIX, estão presentes no traçado das ruas, onde se impõe a importância do clima e da ventilação, sem deixar de lado a estética. 0 projeto compõe-se de quarteirões regulares com ruas retas e perpendiculares entre si, onde observamos cortes em ângulos. Os lotes também são regulares, com 10x30m ou 10x50m. No total, são 44 quarteirões completos e 16 incompletos, que ocupam uma área de $412.590 \mathrm{~m}^{2}$.

0 projeto se desenvolve em torno de um eixo principal, a Rua Manoel Dias da Silva, com $24 \mathrm{~m}$ de largura por $1.443 \mathrm{~m}$ de comprimento, paralelo ao mar. As demais ruas, com $16 \mathrm{~m}$ de largura, dos quais $4 \mathrm{~m}$ são de calçada de cada lado, são paralelas ou perpendiculares ao eixo. No total, são projetadas dez ruas longitudinais paralelas ao mar, incluindo a rua principal, e 15 transversais. Também fazem parte do plano de Theodoro Sampaio três praças, com a possibilidade de uma quarta e um jardim, "[...] a modo dos 


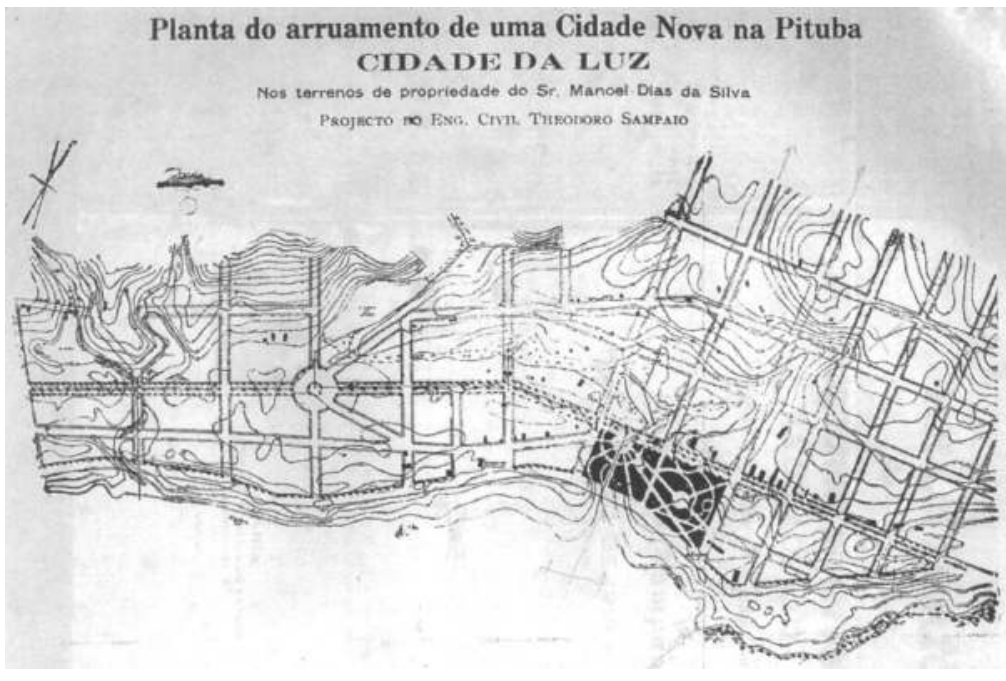

63. Planta do arruamento de uma Cidade Nova - Cidade Luz - 1919 - Projeto de Theodoro Sampaio

jardins inglezes com gramados extensos e arvoredos esparsos e destribuídos com arte, [...]" (SAMPAIO, 1919, p. 10)

Nesse projeto, está presente a preocupação do autor com a higiene, a fluidez e a estética, sem deixar de pensar no conforto ambiental da nova área urbanizada.

\section{Montserrat}

Sob a responsabilidade do Engenheiro Américo Furtado de Simas, em 1925, elabora-se o Projeto do Bairro de Montserrat, uma nova urbanização na península de Itapagipe, por encomenda do Estado. Esse plano é considerado como a primeira intervenção do poder público no planejamento para a criação de um novo bairro na cidade, já que todas as obras são realizadas em terrenos do Estado, com a desapropriação de somente cinco casas para um perfeito alinhamento das novas ruas projetadas.

Em princípios de 1925, em sua comunicação anual à Câmara dos Deputados, o Governador Francisco Marcusa de Góes Calmon faz referência à chácara de Montserrat, desocupada para a abertura de ruas, com terrenos a serem colocados à venda. A mansão existente transforma-se em dependências do Hospital de Isolamento, já instalado no local. Além da criação de instituições de saúde, são restaurados monumentos representativos da arquitetura militar - o Forte de Montserrat -, da arquitetura religiosa - a Capela e o Hospício de 
Nossa Senhora de Montserrat - e da arquitetura civil - a Casa da Ponta de Montserrat, construída no século XVII.

\section{Igreja da Sé}

A demolição da Igreja da Sé, já prevista desde a reforma de J. J. Seabra, realiza-se na década de 30 , por ser considerada um obstáculo à modernização da cidade. Argumenta-se a favor de sua eliminação com a necessidade de abrir espaço para dar continuidade ao eixo aberto na capital, composto pela Avenida Sete de Setembro, a Rua Chile e a Rua da Misericórdia. Resta eliminar a igreja, para que esse eixo siga até o Terreiro de Jesus, através da Rua do Arcebispo.

Outro argumento de grande importância para a sua demolição é o da companhia de bondes urbanos, que quer implantar um percurso econômico e ter, entre a Igreja da Sé e o Terreiro de Jesus, seu terminal na Cidade Alta. A pouca largura das ruas e a obstrução do eixo, causada pela presença da igreja, dificultam a circulação dos bondes.

Em 1916, o Cabido declara-se favorável à compra da Igreja da Sé pela companhia de bondes, a Companhia Circular de Carris da Bahia, e à sua demolição. Com isso, o Arcebispo D. Jerônimo Thomé da Silva pede permissão ao Vaticano para a demolição da igreja, concedida em 1919.

Durante o longo processo, há momentos em que pensamos que a igreja está salva, e outros em que se espera a sua demolição iminente. De um lado, está a defesa do monumento histórico da cidade e, do outro, a argumentação sobre a necessidade de modernizar a urbe. "[...] os sérios argumentos de preservação da igreja principal da Bahia, e não só dela, mas também, por extensão, de todo o conjunto arquitetônico colonial: é a luta do velho contra o 'moderno', do passado contra o 'progresso'." (PERES, 1974, p. 60)

Em 1928, a igreja ainda é um obstáculo para a passagem do progresso, e o Distrito da Sé mantém suas ruas estreitas e sua quadrícula, sem que se viabilize a finalização do projeto de Seabra. As discussões sobre o tema crescem com a imprensa, que se encarrega de demonstrar que a edificação não possui valor histórico ou artístico algum, e com as autoridades, que defendem a derrubada com o objetivo de dar continuidade às reformas. Por outro lado, a elite cultural mobiliza-se para salvaguardar a integridade e preservar os bens culturais arquitetônicos de conteúdo artístico e histórico.

Para evitar a demolição da igreja, apresentam-se alguns projetos com percursos alternativos para as linhas de bonde. Um dos projetos propõe, inclusive, a abertura de um túnel no corpo da igreja e a demolição de outras construções. 
${ }^{48}$ Em sua obra, encontram-se numerosas referências aos princípios de Camillo Sitte, apesar de muitos pontos de divergência. Para esse tema, ver Andrade (1996, p. 287-310)

${ }^{49}$ Alguns exemplos são: Belo Horizonte (1894-1895), Vitória (1896), Campos (1902-1903 e 1924-1929), São Paulo (1913 e 1924-1925), Santos (1905-1909), Recife (1909-1915), Curitiba (1921), Rio de Janeiro (1921), Salvador (1925)
A Igreja da Sé mantém-se como alvo de discussões desde as intervenções implementadas por Seabra, até que, em 7 de agosto de 1933, é demolida. Mais tarde, durante a gestão de Durval Neves da Rocha na Prefeitura, derrubam-se mais dois quarteirões (não os previstos no projeto de 1912), entre a Catedral e o antigo local da Igreja da Sé, abrindo-se espaço para uma praça, a Praça da Sé, ponto final de bondes. (Fig. 64, ver caderno de imagens)

\section{Saturnino de Brito e Semana de Urbanismo}

\section{0 projeto de Saturnino de Brito}

As ideias de Camillo Sitte, contra o isolamento de edifícios, a abertura de áreas e o esvaziamento dos espaços abertos, fatos ocorridos nas reformas urbanas do século XIX, chegam ao Brasil e influenciam os primeiros urbanistas modernos brasileiros, entre eles o Engenheiro Francisco Saturnino Rodrigues de Brito, ${ }^{48}$ responsável por dezenas de projetos de saneamento, melhoria e expansão das principais cidades e capitais brasileiras. ${ }^{49}$

Saturnino de Brito defende, com relação ao urbanismo, que os traçados em quadrícula ou artísticos não devem ser aplicados ou rechaçados a priori. Considera que o mais importante é a adaptação do desenho à topografia, sem esquecer o grande valor do traçado sanitário, admitindo concessões à estética. Critica o urbanismo baseado no alargamento de ruas, argumentando que, dessa forma, não se soluciona o problema da parte traseira das casas.

\footnotetext{
Destacamos, entre as posições de Saturnino de Brito, aquela marcada por uma visão holística do organismo urbano, que não tratava de realizar operações de remodelação urbana em escala pontual, mas sim planejar o conjunto da cidade. Portanto, longe de uma visão urbanística que buscava modificar exclusivamente certas áreas da cidade - como as reformas de Pereira Passos no Rio de Janeiro -, Brito preconizava o planejamento como modo de assegurar uma dinâmica de desenvolvimento harmônico do crescimento das cidades. (ANDRADE, 1992a, p. 77)
}

Saturnino considera a existência de três fases no desenvolvimento de uma cidade. A primeira é o acaso, a eventualidade, quando proprietários constroem suas casas em qualquer lugar e os terrenos são distribuídos aos interessados sem nenhum plano determinado, o que define um urbanismo sem traçado artístico, como em alguns caso no Brasil. Considera que isso se deve à lenta expansão urbana das cidades coloniais brasileiras. 
Na segunda fase, a situação dos terrenos já está consolidada, os interesses particulares são os prioritários e controlam as decisões administrativas, promovendo especulação com o solo urbano, principalmente no centro. Isso produz um ambiente insalubre e desordenado, o amontoamento da população e a proliferação de epidemias. Essa é a situação das cidades do século XIX.

Depois das fases anteriores, consideradas por Saturnino de Brito como "viciosas", vem a realização de um programa de obras de saneamento, baseadas num plano geral, com uma legislação adequada e, por fim, a construção de uma cidade ideal em termos da utopia sanitária, como "um corpo são e belo".

Seu plano de conjunto demonstra a preocupação de, através do pensamento racional, conseguir a ampliação da cidade em função de interesses públicos, sem conceder liberdades aos particulares. Propõe a aplicação dos princípios sanitários com uma morfologia própria e traçados que sigam as linhas de drenagem, os fundos dos vales e as vielas sanitárias. Introduz a avenida-parque, com largas áreas entre as vias de trânsito, onde se localizam os edifícios públicos, jardins e quadras de esporte. "A engenharia sanitária de Saturnino de Brito, ao propor um novo traçado para as cidades brasileiras, redesenha suas paisagens, criando uma imagem urbana moderna, radicalmente diversa da cidade colonial." (ANDRADE, 1996, p. 304)

Ao considerar o urbanismo de Saturnino de Brito como moderno, Fernando Moreira (1997, p. 55) cita alguns dos pontos que o caracterizam: (1) a visão global do espaço urbano, com a necessidade de um plano geral; (2) a preferência pelas formas ideais de traçado urbano; (3) os métodos de urbanismo sanitário; (4) as preocupações com relação à legislação e à regulamentação urbanística; (5) contribuições no âmbito da arquitetura, com sugestões de projetos e implantação das edificações nos terrenos, entre outras; (6) considerações sobre outros saberes que atuam no urbano.

Em seu urbanismo, destaca-se a preocupação com o saneamento e a necessidade de prever o crescimento da rede sanitária, subordinando a essa o traçado das futuras ruas.

Apesar de estar atento às novidades da Europa, principalmente às da França, com sua legislação estadista e intervencionista, tenta sempre adaptá-las às condições brasileiras. Propõe uma estética urbana sem a adoção do modelo haussmanniano. É um dos responsáveis pela introdução das ideias e pelo debate do urbanismo europeu, de concepções modernas, mas não se aproxima do urbanismo corbusiano racionalista, que chega ao Brasil em finais da década de 20 . 
Em 1925, Saturnino de Brito projeta a expansão do sistema de abastecimento de água e da rede de esgoto de Salvador. Antes disso, por duas vezes, rejeita convites para envolver-se no processo de expansão desses dois sistemas de infraestrutura da cidade. Em 1913, é convidado a unir-se a um grupo e participar de uma licitação, mas não aceita o chamado, por não concordar com a forma de implantação do projeto por empresas particulares, quando deveria ser de responsabilidade do poder público. Aceita apenas fazer uma visita a Salvador, para dar uma opinião técnica. Em 1915, é convidado a fazer um plano para a cidade, mas recusa o convite, por estar ocupado com o projeto de Recife.

Ainda em 1925, o Estado assume a responsabilidade pelo saneamento da capital e, uma vez mais o convida para estudar e executar os trabalhos. A cidade tem uma grande deficiência em seu sistema de abastecimento de água e em sua rede de esgoto. Do plano de saneamento de 1905, projetado pelo Engenheiro Theodoro Sampaio, só foram inauguradas as instalações de reforço de distribuição de água potável; as obras relativas ao serviço de rede de esgoto apenas foram iniciadas. A falta de dinheiro impede a continuidade dos trabalhos.

Em sua análise sobre a situação do estado sanitário da capital, Saturnino de Brito compreende que Salvador não avançou como outras cidades do País e ainda continua sendo uma cidade com 200 mil habitantes, sem esgoto. Critica a não implantação das tubulações nas ruas quando se realizaram as reformas, entre 1912 e 1916, época da introdução de algumas modernidades, como o alargamento e a pavimentação de ruas, a abertura de novas avenidas e a construção de edificações modernas. Segundo sua avaliação, Salvador é uma cidade atrasada.

Depois de um estudo sobre os problemas, contrata-se Saturnino de Brito para a elaboração do projeto. Ele aceita a convocação, mas não sem antes estabelecer algumas condições: (1) que se realizem trabalhos topográficos para a captação de água, que deve ultrapassar os $28 \mathrm{mil} \mathrm{m}^{3}$, com previsão de abastecimento futuro de até 400 mil habitantes; (2) que se faça revisão e ampliação da rede de esgoto, além de estudos e projetos para jogar os dejetos no oceano; (3) que os projetos de expansão da cidade, relativos às redes de água e de esgoto, tenham como base os planos topográficos da cidade.

Com relação ao projeto de abastecimento de água, o autor propõe a criação de novas represas, equipamentos de filtragem, instalações de elevação mecânica, condutores de recalque, construção de reservatórios, revisão da rede de distribuição existente e organização de um plano geral para o abastecimento de até 400 mil pessoas. 
Sobre a rede de esgoto, a proposta é a do aproveitamento e da adaptação ao novo projeto dos $27 \mathrm{~km}$ de coletores construídos por Theodoro Sampaio. ${ }^{50}$ Para o sistema público, projeta um separador absoluto, em que as águas da chuva não se misturam com os resíduos sanitários. Para as residências, que devem ser salubres, propõe um gabinete sanitário bem instalado, com água, luz direta, ventilação, revestimento em azulejo e equipamentos apropriados. Infelizmente, não temos informação precisa sobre a implantação do projeto.

\section{A Semana de Urbanismo de 1935}

As preocupações com o urbanismo da cidade do Salvador fazem com que o Governo do Estado da Bahia e o Governo Municipal organizem, em 1934, a Comissão do Plano da Cidade do Salvador, ${ }^{51}$ que tem a seu encargo a elaboração de projetos para a cidade, sua defesa e fiscalização. A comissão funciona até 1937.

A Semana de Urbanismo, organizada pela comissão, realiza-se de 20 a 27 de outubro de 1935, com uma série de conferências proferidas pelos organizadores, em que o tema principal está centrado na cidade, seus problemas, e as propostas de soluções. Sua realização faz parte de uma tentativa de popularizar o urbanismo e ratificar a necessidade de um plano urbano para a cidade, o que outras cidades brasileiras já possuem. ${ }^{52}$ Para Salvador, há que se elaborar um plano de conjunto, racional, inteligente e prático. A ideia é fazer um plano grandioso e, para tal empreitada, cita-se Burnham e seu projeto para Chicago. ${ }^{53}$ Essa iniciativa constitui um marco das discussões sobre as questões urbanas soteropolitanas.

A "Semana" é um momento de difusão do Urbanismo na sociedade de Salvador e de conscientização de sua importância para o desenvolvimento da cidade. O conjunto das conferências tenta demonstrar a necessidade da elaboração de um plano geral de intervenções e de expansão da cidade, assim como da discussão das soluções para os problemas detectados. As sugestões que se fazem são de um amplo estudo da situação industrial e seu futuro, das condições de vida e seus aspectos, e da legislação municipal.

Numa das conferências, $A$ cidade errada e a cidade certa, pronunciada pelo Engenheiro José Lourenço de A. Costa (1937a, p. 58-60), podemos perceber a intenção da "Semana" e da comissão. 0 autor considera que, para construir uma cidade equivocada, é suficiente deixá-la sem planejamento, sem fiscalização das construções, até chegar-se ao caos, e, assim, surgir a necessidade de intervir para consertá-la. Desse modo, o que se consegue é uma cidade sem estética, sem conforto, foco de epidemias e com dificulda-
${ }^{50}$ Em seu projeto, Theodoro Sampaio
prevê uma rede de $100 \mathrm{~km}$ de
coletores, dos quais só são construídos $27 \mathrm{~km}$.

${ }^{51}$ A comissão, dividida em 15 subcomissões, não é composta por políticos, mas por cidadãos que desejam colaborar com os poderes públicos, com o objetivo de transformar Salvador numa cidade mais bonita, mais sã, mais confortável, mais econômica, ou seja, numa cidade perfeita. (COMMISSÃO DO PLANO DA CIDADE DO SALVADOR, 1937)

${ }^{52}$ São citados os planos de intervenção para o Rio de Alfred Agache, onde se investe uma grande quantidade de dinheiro, para Belém, para Recife, além dos planos para novas cidades como Belo Horizonte e Goiânia. (COMMISSÃO DO PLANO DA CIDADE DO SALVADOR, 1937)

53 "Nada de planos acanhados! Nada de planos pequenos, elles não tem o previlegio de sacudir com os nervos dos homens e quase sempre ficam inacabados. Levantae pois planos grandiosos! Eu creio no futuro e no trabalho e, lembro que projectos nobres são como diagrammas logicos: nunca morrem, continuando a viver atravez dos tempos e ajustando-se sempre ás intensidades creadoras do progresso." Milton da Rocha Oliveira, citando Daniel Burnham, em sua conferência na "Semana de Urbanismo". (COMMISSÃO DO PLANO DA CIDADE DO SALVADOR, 
${ }^{54}$ Essas ideias só entram em prática com o EPUCS, no qual encontramos um novo discurso e uma nova prática urbanística. des de circulação. 0 que se sugere é que o processo de desenvolvimento da cidade dependa antes da elaboração de um plano com uma visão de conjunto e de futuro, baseado no bom senso. É mais fácil e barato prevenir do que corrigir. "Um plano da Cidade visa todas estas particularidades: a barateza da vida; a prophylaxia; a facilidade dos transportes; a localização das Escolas; o alargamento das ruas; a construcção de parques e jardins, enfim, todos os problemas urbanos." (COMMISSÃO DO PLANO DA CIDADE DO SALVADOR, 1937, p. XI)

As conferências realizadas visam a criar uma consciência urbanística, para que a população possa entender a necessidade de um plano geral para a expansão da cidade, com o objetivo de transformá-la numa cidade-modelo. Em seu crescimento, a cidade não pode esquecer-se de seu passado, de seu patrimônio, condição fundamental para um perfeito ajuste entre a cidade nova e a cidade velha. "Um plano de expansão e remodelação não é apenas uma reforma é a construcção duma cidade nova e a harmonização da parte velha com a nova." (COMMISSÃO DO PLANO DA CIDADE DO SALVADOR, 1937, p. XIII)

A Semana de Urbanismo pretende mudar a forma de pensar e de intervir na área urbana. Não mais se pode pensar num urbanismo tópico, pois é preciso considerar a cidade de uma forma global, como um organismo, com um plano para o futuro, da mesma forma que já se faz na Europa e nos Estados Unidos.

Segundo Fernandes, Sampaio e Gomes (1999, p. 175-176), são três os pontos das conclusões da "Semana" que demonstram essa ruptura com o passado do urbanismo tópico: (1) a defesa de um plano para controlar o crescimento da cidade em seu conjunto; (2) a defesa do Urbanismo como um novo campo de conhecimento e área de atuação, além da definição do zoning como algo fundamental para a ordenação das cidade; (3) a preocupação com o patrimônio histórico. ${ }^{54}$

Com relação às propostas concretas para um plano geral, algumas são feitas pelo Engenheiro Américo Furtado de Simas (1937, p. 117-126), em sua palestra. Os pontos estudados devem ser: (1) o centro da cidade; (2) artérias principais e secundárias; (3) parques, jardins e praças; (4) transportes coletivos; (5) quarteirões industriais; (6) escolas e universidades; (7) abastecimento de água, rede de esgoto e limpeza urbana; (8) energia para a indústria e iluminação pública; (9) residências proletárias; (10) plano financeiro.

Em seu esquema, o núcleo da cidade também é um ponto de convergência de artérias que enlaçam os arredores com o centro, que é a sede do governo e onde se localizam escolas, museus, teatros, cinemas, lojas de café 
etc. Há uma proposta para a abertura de uma avenida pela costa da Baía de Todos os Santos, que conecte o porto à estação de trens e às estradas que seguem para o interior do Estado. Está prevista a construção de pontes, viadutos, túneis e elevadores, para minimizar os problemas de circulação que existem em função da topografia.

Para uma melhor articulação entre a Cidade Alta e a Baixa, propõe-se a construção de edifícios para oficinas, com 20 andares, junto à encosta da montanha, de forma que se tenha acesso tanto por cima como por baixo. Seguindo com a melhoria da circulação na cidade, são propostas a construção de avenidas circulares e a utilização dos vales como vias de comunicação no interior, abrindo-se túneis e construindo viadutos sempre que sejam necessários. "Urge a ordem e harmonia entre os elementos estáticos e dinamicos da cidade: e isto é urbanismo [...]". (PINTO, 1937, p. 73)

As ideias que circulam entre os organizadores da "Semana", os membros da comissão, têm suas bases no urbanismo da Europa e dos Estados Unidos. Organiza-se, então, uma sociedade, a Sociedade dos Amigos de Alberto Torres, núcleo Bahia, muito similar a outras norte-americanas, como as Civic Associations, Civic Improvements Leagues, City Planning Associations ou Chambers of Civic Affairs, em que os cidadãos se propõem a trabalhar com o poder público em benefício do bem-estar coletivo. Em seus argumentos, encontramos referências a The Town Planning Act da Inglaterra, ou à lei Corbudet da França, mas a maior influência vem do Standart City Planning Enabling Act dos Estados Unidos, "[...] onde deveremos beber os ensinamentos para os nossos trabalhos, adaptando ao nosso meio as leis e methodos dos americanos do Norte, esses grandes fazedores de cidades." (COMMISSÃO DO PLANO DA CIDADE DO SALVADOR, 1937, p. 3)

No que se refere à contenção da migração do campo para a cidade, Milton da Rocha Oliveira propõe a criação de cidades-jardins no perímetro urbano de Salvador, formando parques onde se permita a criação de animais e pequenas hortas. Para as áreas suburbanas e rurais, propõe a implantação de cidades-jardins, de população limitada, com campos para agricultura e criação de animais para o abastecimento da capital e de seus arredores. $O$ projeto apresentado faz referência às cidades-jardins de Ebenezer Howard. (COMMISSÃO DO PLANO DA CIDADE DO SALVADOR, 1937, p. 113-114)

Nas conferências, há pontos que seguem as mesmas preocupações presentes nos projetos anteriores: circulação, higiene e estética. Porém, dentre as muitas preocupações discutidas na "Semana", a que parece mais importante, à parte de ser novidade, é a questão do zoning. Há que dividir a cidade em zonas, com funções determinadas 
${ }^{55}$ Entende-se por zonear a cidade 0 processo de dividi-la em setores, onde se localizam as distintas atividades, e onde são regulamentadas as alturas das edificações e as áreas que podem ser ocupadas.
[...] para que um egoista não edifique a sua casa, roubando a luz, o sol e o ar á do visinho ou não installe uma cocheira entre custosos bungalows ou, ainda, não occupe a superficie total dum lote em lugar onde todos reservam uma parte dos seus terrenos para ajardinamento e realce da belleza da paysagem. (COSTA, 1937a, p. 58)

O conferencista José Lourenço Costa (COSTA, 1937a, p. 62) justifica a necessidade de zoneamento ${ }^{55}$ da cidade, como uma forma de estabelecer ordem e método em seu desenvolvimento. Dessa maneira, estabiliza-se o custo das propriedades, protegem-se as residências e evita-se a destruição dos bairros.

Em outra conferência da Semana de Urbanismo, o Engenheiro Jayme Cunha da Gama e Abreu argumenta que zonear a cidade é fazer o mesmo que fazemos numa casa, onde cada espaço tem sua função determinada. 0 que caracteriza cada zona é sua atividade social e, para abrigá-la, é importante projetar a infraestrutura de acordo com suas necessidades.

Percebe-se o interesse pela melhoria da circulação na proposta de abertura de avenidas park-ways, como as dos Estados Unidos, aproveitando-se a natureza. Essas avenidas se caracterizam pelo aproveitamento das linhas de fundo dos numerosos vales que se encontram na área urbana, formando uma rede, e são projetadas para um tráfego especial, asfaltadas, munidas de trilhos para bondes e ladeadas de largas áreas com grama e arborização.

A higiene ainda é um problema, já que a cidade mantém as ruas estreitas, com as casas sem espaço entre si. As habitações continuam sem janelas, são mal ventiladas, úmidas, escuras e sem as necessárias instalações sanitárias. É uma questão que a Comissão considera de fundamental importância no planejamento global da cidade.

0 mesmo acontece em relação à estética. A cidade, com suas casas velhas e arruinadas pelo tempo, não está de acordo com a natureza. 0 contraste entre o espaço construído e a beleza da paisagem deixa evidente a falta de orientação e a negligência dos governantes e da população. "A nossa experiencia já nos deve ter ensinado que uma bôa apparencia influe na opinião que se forma duma cousa ou logar." (COSTA, 1937b, p. 96)

Uma vez mais se faz referência ao urbanismo dos Estados Unidos. O modelo adotado para a classificação dos setores baseia-se em cinco tipos, usados naquele país: (1) residencial, com casas isoladas, construídas lado a lado ou em blocos; (2) comercial, para comércio e negócio; (3) industrial, para pequenas ou grandes indústrias; (4) agrícola; (5) sem restrições. (ABREU, 1937, p. 47-48) 
O primeiro passo é a elaboração de um plano cadastral de toda a área da cidade, para uma avaliação da situação naquele momento, detectando-se as deficiências e projetando-se as necessárias correções.

Sobre esse mappa traçar-se-ão as partes novas da cidade, para que não sejam occupadas a tròche-môchè como antigamente se fazia e não tenham de ser modificadas subsequentemente com immensos prejuizos para a communa; desenhar-se-ão as modificações necessarias á cidade actual; collocar-se-ão os traçados das installações dagua, esgotos, de energia; das vias de communicação sobre trilhos ou de propulsão electrica; localisar-se-ão as escolas de modo a ficarem em pontos accessiveis a toda a população etc. Esse mappa ainda será dividido em secções, cujos melhoramentos serão executados em periodos successivos, precedendo os que forem de maior beneficio á collectividade. Em summa, não haverá duplicidade de melhoramentos nem descriminação de local. Não é preciso reflectir por muito tempo para avaliar da economia, resultante desse modo de proceder. (COSTA, 1937b, p. 106-107)

Os resultados da Semana de Urbanismo são os novos contatos da comissão com urbanistas para a elaboração do plano diretor para Salvador. No $1^{\circ}$ Congresso Brasileiro de Urbanismo, realizado em 1941, no Rio de Janeiro, são feitos contatos com a empresa de Coimbra Bueno, que elabora os planos para Curitiba e Goiânia, com a colaboração de Alfred Agache. Ele chega a Salvador em 1941 com uma proposta que define as áreas de expansão da cidade, cidades-satélites, sistemas de irradiação das vias de comunicação, e sugere lugares para agrupamentos humanos. Em 1943, organiza-se o Escritório do Plano de Urbanismo da Cidade do Salvador (EPUCS), como uma continuação da referida comissão e seguindo as recomendações finais da Semana de Urbanismo.

\section{Depois da Semana de Urbanismo}

A proposta apresentada por Alfred Agache não se desenvolve, pois prefere-se deixar a elaboração de um plano para a cidade a cargo do sociólogo sanitarista Mário Leal Ferreira, que, em 1943, assume a direção do EPUCS. Em suas ideias, percebe-se uma influência da Escola de Chicago, baseada na ecologia humana e nos trabalhos de Charles Darwin.

O plano que se elabora, seguindo indicadores da "Semana" de 1935, apoia-se na tese de Patrick Geddes sobre o conceito evolutivo da cidade, no modelo de Burgess do zoneamento em círculos concêntricos, vias expressas e áreas verdes e no centro urbano reformado, como recomenda a Carta de 
${ }^{56}$ Depois da morte de Mário Leal Ferreira, em finais dos anos 40, esse arquiteto assume a direção do EPUCS.

${ }^{57}$ Professor de Urbanismo na Escola Politécnica.
Atenas. Por fim, o plano assume o modelo radio-concêntrico, como os de Londres, Paris e Moscou. (SAMPAIO, 1992, p. 160)

O EPUCS tem o progresso como objetivo e a monumentalidade como uma marca. Com base no Congresso Internacional de Arquitetura Moderna (CIAM) e em Le Corbusier - que não vem a Salvador, mas suas ideias têm grande influência nos profissionais locais -, as intervenções nos centros históricos não são questionadas, pois o importante são os testemunhos isolados, sem se pensar ainda na preservação dos conjuntos urbanos. Salvador, por ter um único centro, não pode manter uma estrutura colonial em seu núcleo histórico. A adaptação das ruas para os modernos meios de transporte, como os automóveis, faz parte dos planos de transformação. Também na proposta da polarização para um centro principal, que abriga um "nó" ou complexo viário em vários níveis, denominado "base de tráfego", pode-se antever a noção de transbordo central, como previa Le Corbusier em sua Ville Radieuse.

Se nos anos 10, Seabra continua um adepto dos modelos franceses e de um "urbanismo demolidor", a Semana de Urbanismo de 1935 introduz as teorias da Escola de Chicago, e o urbanismo norte-americano começa a ter um forte peso entre nós. Os novos protagonistas da cidade - Mário Leal Ferreira, Diógenes Rebouças ${ }^{56}$ ou Jayme Cunha da Gama e Abreu ${ }^{57}$ - têm agora suas trajetórias voltadas para os Estados Unidos.

O que podemos concluir dos caminhos do urbanismo e de suas adaptações em Salvador é que, nos anos 30, uma nova forma de pensar e de intervir na cidade construída muda a direção do processo. Os modelos, nesse momento, vêm dos Estados Unidos, e não mais da França, e introduz-se, na cidade, o planejamento interdisciplinar, com a elaboração de um plano geral que olha para o futuro.

Pensamos que essa mudança de ideias começa a ocorrer com o projeto de saneamento de Saturnino de Brito para Salvador, centrado na implantação de um plano de saneamento, com abastecimento de água e rede de esgoto, mas sempre vinculado ao urbanismo geral da cidade. Pela primeira vez pensa-se num todo. Para Saturnino de Brito, os projetos caminham juntos, e um não se pode desenvolver sem o outro. Com a Semana de Urbanismo, percebemos a continuidade do pensamento sobre a necessidade de um plano geral, em que a cidade seja considerada como um todo, e as partes não possam ser tratadas isoladamente. É quando se introduz a ideia do plano diretor. 


\section{Um comentário final}

Dando continuidade às considerações feitas ao longo deste trabalho, voltamos à nossa questão inicial, para tecer alguns comentários finais sobre o tema. Optamos por "comentários", pois acreditamos que o tema não se conclui, não se esgota, e as reformas urbanas do Rio de Janeiro e de Salvador podem ser analisadas sob outros pontos de vista e através de outros eixos de discussão. 0 que pretendemos aqui é retomar a questão inicial: se as reformas urbanas das cidades do Rio de Janeiro e de Salvador, que se implantam entre 1902 e 1906 e entre 1912 e 1916, respectivamente, são uma variante do modelo haussmanniano, que adapta a malha urbana colonial às novas exigências da economia, a uma nova sociedade e a um novo modo de vida.

Os processos ocorridos em cidades como Rio de Janeiro e Salvador, que, de alguma forma, realizam reformas urbanas inspiradas nas de outras cidades, adaptando esses modelos à realidade local, não são casos isolados. Paris realiza intervenções radicais em sua estrutura medieval que se tornam referência em todo o mundo, e muitas cidades voltam-se para lá ao projetar suas próprias intervenções, embora cada uma as realize sempre de acordo com suas próprias necessidades e possibilidades. 0 tipo de intervenção que encontramos em Salvador pode ser comparado, por exemplo, com o de outras 
cidades europeias, capitais ou não, que, de alguma forma, adaptam o modelo parisiense, ou criam seus próprios modelos.

\section{Uma Revisão}

Cidades como Londres e Amsterdã realizam transformações em busca da cidade moderna, através de planos de expansão que incluem novas áreas urbanizáveis, para onde se desloca a população, convertendo núcleos antigos em centros de negócios e serviços. Em outras cidades, como Bruxelas e Paris, os planos de reforma superpõem uma nova cidade à antiga. $O$ centro continua sendo uma área comercial, mas também se torna local de habitação da burguesia. Muitas outras se valem dos dois tipos de intervenção e combinam reformas em seus núcleos centrais com projetos de novas áreas de expansão, como Madri.

Podemos associar as novas avenidas e ruas de Salvador - que não são retas como os bulevares parisienses e resultam do alargamento de vias já existentes - às que são criadas em cidades europeias que realizam suas reformas do mesmo modo. Em Roma, o Corso Vittorio Emmanuele, que se abre no meio do bairro do Rinascimento, a partir de 1884 , resulta numa via sinuosa (Fig. 65). Outra rua romana, o antigo Corso, intervenção papal dos séculos XV e XVI, alarga-se e transforma-se em polo de atividades diretivas e comerciais qualificadas. O mesmo ocorre na abertura da Gran Vía de Madri (Fig. 66), projeto de 1886, iniciado apenas em 1904, que é o resultado da demolição de uma centena de casas, após o despejo de sua população, para deixar lugar à nova via, que também não tem uma trajetória reta. Em Madri, também se realiza um ensanche, a urbanização de uma nova área, em 1860, para abrigar a crescente população que já não tem onde se alojar no antigo centro.

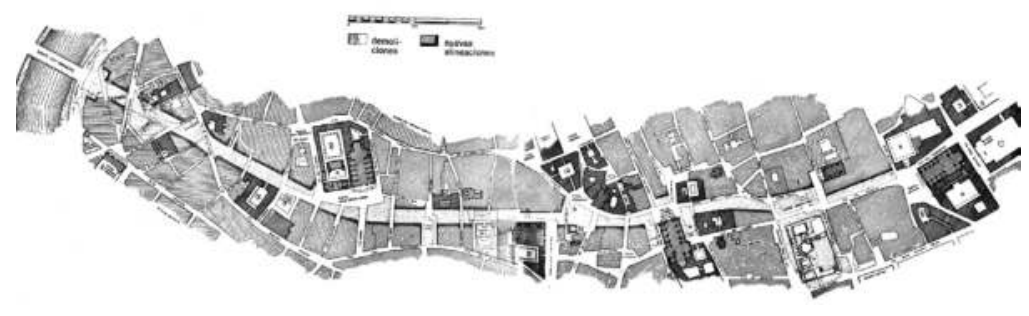

65. Projeto para a abertura do Corso Vittorio Emmanuele - Roma - 1884 


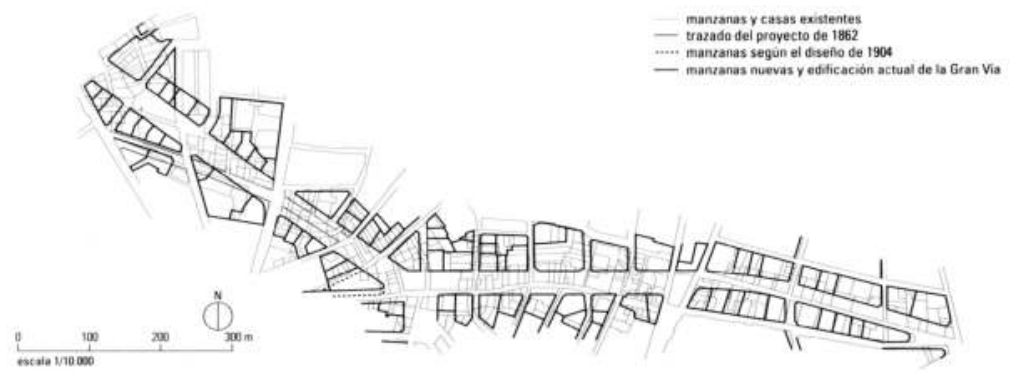

66. Projeto de abertura da Gran Via - Madrid - 1886

Em algumas outras cidades encontramos intervenções que se assemeIham às realizadas em Salvador. Marselha, portuária como Salvador, realiza suas transformações, ditas haussmannianas, a partir dos anos 50 do século XIX, segundo um projeto global, com o objetivo de adaptar o espaço à sociedade industrial, modernizando as construções, substituindo os equipamentos ultrapassados e adequando a rede viária às novas necessidades. A cidade velha se interpõe entre a cidade clássica dos negócios e o espaço industrial do novo porto.

Como em Salvador, as transformações de Marselha estão estreitamente associadas aos assuntos portuários e à especulação imobiliária, que se converte num prolongamento da iniciativa pública. À ampliação do porto, de 1847, sucedem-se outras, pois a expansão industrial requer obras de maior amplitude. Para a área urbana, dos projetos apresentados que pretendem substituir o tecido urbano por um novo, elege-se o municipal de 1858 , que se reduz a uma simples abertura cortando o tecido medieval. A principal via projetada, a Rue de la République, passa pelo meio do tecido medieval, mas também se prolonga em direção a uma área de expansão vinculada ao novo porto.

Longe do Velho Continente, nos países latino-americanos, novas Repúblicas que vão conquistando a independência, também se realizam intervenções nas capitais, para adaptá-las aos novos modelos vigentes, sempre com o olhar voltado para a Europa. Na Argentina, entre os anos 1883 e 1887, na nova capital, Buenos Aires, a Avenida de Mayo representa a intervenção mais significativa do século XIX. A abertura do eixo leste-oeste, que une a Casa Rosada, residência presidencial, ao edifício do Congresso, e a retificação de algumas artérias destroem ou mutilam monumentos coloniais, o que acarreta a perda de boa parte do patrimônio arquitetônico. 0 centro reformado abriga as atividades próprias de uma capital, os bancos, os escritórios das grandes 
empresas, as sedes dos diários e algumas residências de qualidade. Em volta da Plaza de Mayo, instala-se a city, o núcleo do poder econômico. Em 1887, apresenta-se o projeto das avenidas diagonais, que propõe a reestruturação da cidade, e que é realizado a partir da primeira década do século XX.

O mesmo acontece em Santiago do Chile, quando, a partir de 1872, são introduzidas transformações urbanas e de infraestrutura - a formação de novas praças e áreas verdes, o ajardinamento do Cerro de Santa Lucia, a estruturação do mercado de abastecimento e o alargamento de vielas. O processo modifica a estrutura de ocupação espacial, destruindo cortiços, o que ratifica o poder civil dos liberais. Obtém-se a imagem europeia nos delineamentos urbanísticos e também nos novos usos da cidade. Tudo o que lembra a tradição histórica tem o estigma de "barbárie", e é destruído para dar passagem à "civilização". Esse processo, na capital chilena, caracteriza-se mais como um produto de renovação do que de expansão planificada. A ideia não é integrar, e sim mudar a realidade existente, para que se introduzam as premissas cosmopolitas no antigo centro histórico.

Por fim, há que mencionar-se Caracas e o governo de Guzmán Blanco, com a implantação do urbanismo "guzmaniano" entre 1870 e 1888. Nesse período, na capital venezuelana, tenta-se criar uma imagem europeia, mediante a abertura de bulevares, a construção de monumentos, a colocação de estátuas, jardins e outros equipamentos, modificando-se o traçado hispânico da área central. Alguns autores, como Gasparini e Posani (1969), afirmam que Paris é o modelo para a capital. Outros, como Almandoz (1996), relativizam a utilização do modelo parisiense, considerando que o ecletismo do Segundo Império é certamente uma referência, mas que a morfologia haussmanniana não pode ser traçada em Caracas, nem as teorias de Haussmann e seu urbanismo regulador podem ser completamente entendidos no incipiente debate urbano "guzmaniano".

Nesse breve percurso pelas reformas urbanas de outras cidades europeias e latino-americanas, queremos demonstrar que o modelo haussmanniano se divulga, e as ideias haussmannianas se difundem em distintas direções, embora nem sempre seja possível sua adoção integral, pela necessidade de diversas adaptações a realidades distintas da parisiense. Nos casos da América Latina, no Brasil ou fora dele, o que mais se percebe é que, subjacente às intervenções, existe a vontade de mudar as estruturas coloniais de países cuja independência é recente, de repelir o passado e dar início à busca de novas representações, as quais, no final do século XIX e princípio de século $X X$, vêm da Europa. São processos que, muitas vezes, se produzem paralelamente aos europeus. 
Para caracterizar-se uma intervenção como um modelo haussmanniano, é necessário mais do que a presença de um prefeito autoritário, a abertura de novas ruas e a introdução de construções monumentais. Apesar de comportar esses traços, haussmannização apresenta outras características fundamentais. Sua forma de atuação baseia-se na capacidade de intervir num tecido urbano existente, introduzindo elementos novos, estranhos, na trama original, mudando sua imagem, expulsando a população que ali vive e dando monumentalidade ao espaço. A haussmannização engloba, além dos aspectos urbanos, os sociais, os econômicos e os políticos. A depender do rigor no uso do termo haussmannização, pode-se considerar a Paris haussmanniana como modelo para as intervenções em algumas cidades, ou afirmar serem essas apenas uma versão das intervenções realizadas na capital francesa. Questiona-se, nas discussões sobre o tema, se a aplicação de alguns critérios de Haussmann pode ser considerada como haussmannização, ou se o uso dessa marca implica a necessidade da utilização de todos eles. ${ }^{1}$

A cidade haussmanniana resulta ser o espaço da moderna sociedade burguesa, uma vitrine da modernização que se executa sob uma determinada conjuntura, criada quando se encontram a forma autoritária de gestão da cidade e as novas estruturas do capitalismo. 0 ciclo haussmanniano é um momento singular, que se produz num tempo determinado - nem antes nem depois -, através do qual se caracteriza. Assim o define M. Roncayolo (1983b, p. 93)

O ciclo haussmanniano integra assim fenômenos de momentos cronológicos diferentes. Ele é a conclusão de uma lenta renovação de conceitos e representações da cidade; ele herda a concentração mais recente dos homens, as tensões na cidade, uma primeira fase de altas violentas dos valores fundiários e imobiliários, a onda inicial das decisões no domínio dos equipamentos públicos e dos transportes. Faltavam ainda a vontade política e os meios jurídicos e financeiros. É o encontro de um urbanismo autoritário e das novas estruturas do capitalismo que deslancha o ciclo haussmanniano. Será em vão, então, opor o excesso de ideologia urbana aos 'interesses' e às estratégias sociais e, mais ainda, subordinar uns aspectos aos outros. $\mathrm{O}$ conjunto forma um sistema, inclusive naquilo que ele ignora, negligencia ou rejeita. Isso é que chamamos de haussmannização, cuja marca e expressão podem ser procuradas no elemento físico, social ou simbólico da cidade.

As intervenções urbanas formam um sistema novo que muda a ordem dos valores na cidade onde

[...] a rua ou o bulevar comandam o imóvel; a percée, o desenho das parcelas; a posição, as funções; o espaço público, o agenciamento dos espaços pri-
${ }^{1}$ Podemos fazer referência a discussões semelhantes sobre a cidade jardim de Ebenezer Howard, considerada modelo de outras cidades ou simples versões daquela. 0 mesmo se discute sobre o "ensanche" de Barcelona projetado por Ildefons Cerdà. (WARD, 1990) 
vados. 0 alinhamento não é mais um procedimento corretivo que respeita o plano. A nova rede viária transforma-se no princípio de organização que superpõe-se à cidade antiga ou que regula o agenciamento dos espaços conquistados. A projetação zenital, própria ao engenheiro, abstrai a rede da paisagem urbana e toma o caminho da perspectiva de estilo clássico e da harmonia dos volumes. (RONCAYOLO, 1983b, p. 102)

O sistema haussmanniano atua através de intervenções autoritárias sobre uma malha anterior, onde se sobrepõe uma nova rede viária, composta por ruas largas e retas, avenidas equipadas com modernos serviços de infraestrutura, largos passeios, um novo mobiliário urbano, adornadas com fileiras de árvores. As aberturas, as percées, são projetadas para destruir quarteirões onde se concentra uma população considerada "perigosa", pobre, que mora em habitações insalubres, as quais se quer destruir, expulsando, dessa forma, seus habitantes para longe do centro. As novas ruas são projetadas com monumentalidade, criam uma harmonia de grandes massas com construções uniformes, formam novas perspectivas, destacam os monumentos históricos existentes ou construídos. As consequências dessas intervenções são a segregação social e funcional, o aburguesamento do centro da cidade e a criação de um espaço monumental esteticamente estandardizado.

Essa é a forma como entendemos as intervenções que se realizam na Paris do século XIX durante os anos do Second Empire, sob o comando do Haussmann. Discute-se, atualmente, se a haussmannização é um modelo de intervenção urbana exportável, um tipo de cidade que se adapta a realidades distintas da parisiense. Seja um modelo urbano, seja um tipo de cidade, nossa questão é definir se a Paris haussmanniana inspira e seduz a Salvador de princípios do século XX.

\section{Um comentário a mais}

O propósito de identificar o modelo haussmanniano nas reformas carioca e soteropolitana e também de entender como a modernização do Rio de Janeiro influencia as intervenções urbanas de Salvador, implica comparações. Não se pode perder de vista que, em Salvador, a reforma permanece mais no âmbito das ideias e dos projetos do que de ações aplicadas ao urbano. Então, pode-se fazer uma análise das intenções dos governantes, pois sabe-se que tais ideias teriam sido implantadas, caso os recursos não houvessem escasseado.

O tecido urbano do centro de Salvador praticamente não muda (Fig. 67, ver caderno de imagens), após as intervenções. A abertura da Avenida Sete de Setembro e as intervenções em outras ruas produzem-se por meio 
do alargamento de vias já existentes, de forma que a malha urbana não sofre alterações. As novas ruas não são elementos estranhos ao traçado urbano, pois já existiam anteriormente, já faziam parte dele.

Esse é um traço que diferencia o processo empreendido em Salvador daqueles realizados no Rio e em Paris, já que, nessas duas últimas cidades, o tecido urbano sofre alterações com a introdução de ruas e avenidas que não pertencem ao traçado original, através da eliminação de obstáculos geográficos e da destruição completa de quarteirões. (Fig. 68) Assim ocorre no Rio, na abertura das Avenidas Central, Mem de Sá e Salvador de Sá. Assim acontece em Paris, na abertura do Bulevar Sébastopol, da Avenida de l'Opéra e nas aberturas da île de la Cité. Outra diferença evidente é a forma das novas vias, pois, enquanto no Rio e em Paris elas são retas e têm a mesma largura por toda a sua extensão, em Salvador, acompanham o traçado original, nem sempre reto, e não mantêm a mesma largura por todo o percurso.

$\mathrm{O}$ que as reformas urbanas, nas três cidades, apresentam em comum são os objetivos gerais das intervenções. Através do alargamento de ruas ou da abertura de novas vias, o que se busca é melhorar os deslocamentos, ligar pontos importantes da cidade de forma mais simples e facilitar a introdução dos modernos meios de transporte e das novas tecnologias. Nas três cidades, as intervenções se realizam através de demolições, desapropriações e expulsão da população residente, para obter-se, como resultado final, o aburguesamento do centro, tornando-o um conjunto urbano mais coerente, sem as características de cidades coloniais ou medievais.

Se, em Paris, o projeto tem a intenção de ligar as gares, no Rio, pretende-se conectar o porto com as zonas industriais, comerciais e financeiras, tornando-as mais fluidas. 0 mesmo acontece em Salvador, onde as novas ruas e avenidas têm a mesma função. Na Cidade Baixa, são abertas novas vias para a conexão do porto com a estação ferroviária, com a península de Itapagipe, que se desenvolve como área proletária, e com a Cidade Alta. Nessa última, a Avenida Sete de Setembro orienta a cidade em direção ao litoral sul, melhorando os acessos aos bairros burgueses já existentes e aos novos.

Contudo, é importante reiterar que o traçado desses vetores data de séculos anteriores, pois a cidade já se encaminha naturalmente nesses sentidos. $\mathrm{Na}$ Cidade Alta, a forma urbana segue as cumeadas das colinas e, na Cidade Baixa, sem muitas opções, apoia-se no sopé da montanha. Totalmente nova é a Avenida Oceânica que, às margens do mar, liga a Barra com o Rio Vermelho.

Em Paris, não se identifica um plano de expansão e, no Rio, os vetores também são de crescimento natural, ligando zonas desertas, ou quase, à área 
urbana. Surgem bairros novos, em função dessa expansão, beneficiados com a nova infraestrutura e a nova urbanização. Ocorre o mesmo em Salvador, onde, com a facilidade de acesso, surgem bairros como Pituba, na costa sul, e Montserrat na península de Itapagipe.

Finalmente, a intervenção urbana nas três cidades se concretiza sob um autoritarismo administrativo que introduz normas arquitetônicas, criando uma cidade que reflete o imaginário da burguesia, com uma estética nouveau riche. E a isso C. Blancot chama de haussmannização, como já foi mencionado anteriormente.

O Rio, como Salvador, é uma cidade que vive economicamente em função do porto e do comércio de importação e exportação. Sua trama colonial, seu aspecto insalubre e sujo, ao lado de sua condição de capital do País, demandam providências urgentes que a transformem numa capital moderna, dentro dos padrões estabelecidos pelas sociedades ditas "civilizadas". É, pois, a primeira cidade brasileira que passa por reformas urbanas, realizando uma intervenção solicitada pela sociedade e pela imprensa, que a compara, com desvantagens, a Buenos Aires e a Montevidéu, consideradas cidades "modernas" e "civilizadas".

Considerando o que se faz de concreto nas duas cidades, Rio e Salvador apresentam alguns pontos comuns e outros divergentes. As duas cidades têm estruturas muito semelhantes desde sua fundação, ambas são construídas no alto. Em diferentes momentos, as duas são capitais do País. Têm estrutura colonial, com seu funcionamento assentado na mão-de-obra escrava. Seus portos são importantes numa economia mercantil de importação e exportação. Suas ruas são estreitas, o sol penetra com dificuldade, a sujeira está por todas as partes e desenvolvem-se focos de epidemias. No século XIX, passam por um processo de inchaço, com a migração rural, principalmente depois da abolição da escravatura. $O$ centro das duas cidades está totalmente construído e ocupado. A população amontoa-se em sobrados e cortiços, que estão por toda parte. São centros empobrecidos, desvalorizados e sem atrativos.

Mais do que na reforma de Paris, as referências da reforma soteropolitana encontram-se na reforma que se realiza no Rio de Janeiro entre 1902 e 1906, pois as duas reformas urbanas possuem muitos pontos de contato. O Rio realiza a abertura da Avenida Central, de clara inspiração haussmanniana. Projeta-se uma nova rede viária, desvinculada da antiga malha colonial, que é introduzida na cidade. São novos eixos que derrubam edificações, rasgam quarteirões e destroem ruas e becos. Para a execução das intervenções, são realizadas muitas desapropriações e, ao final, os novos quarteirões são reparcelados. 

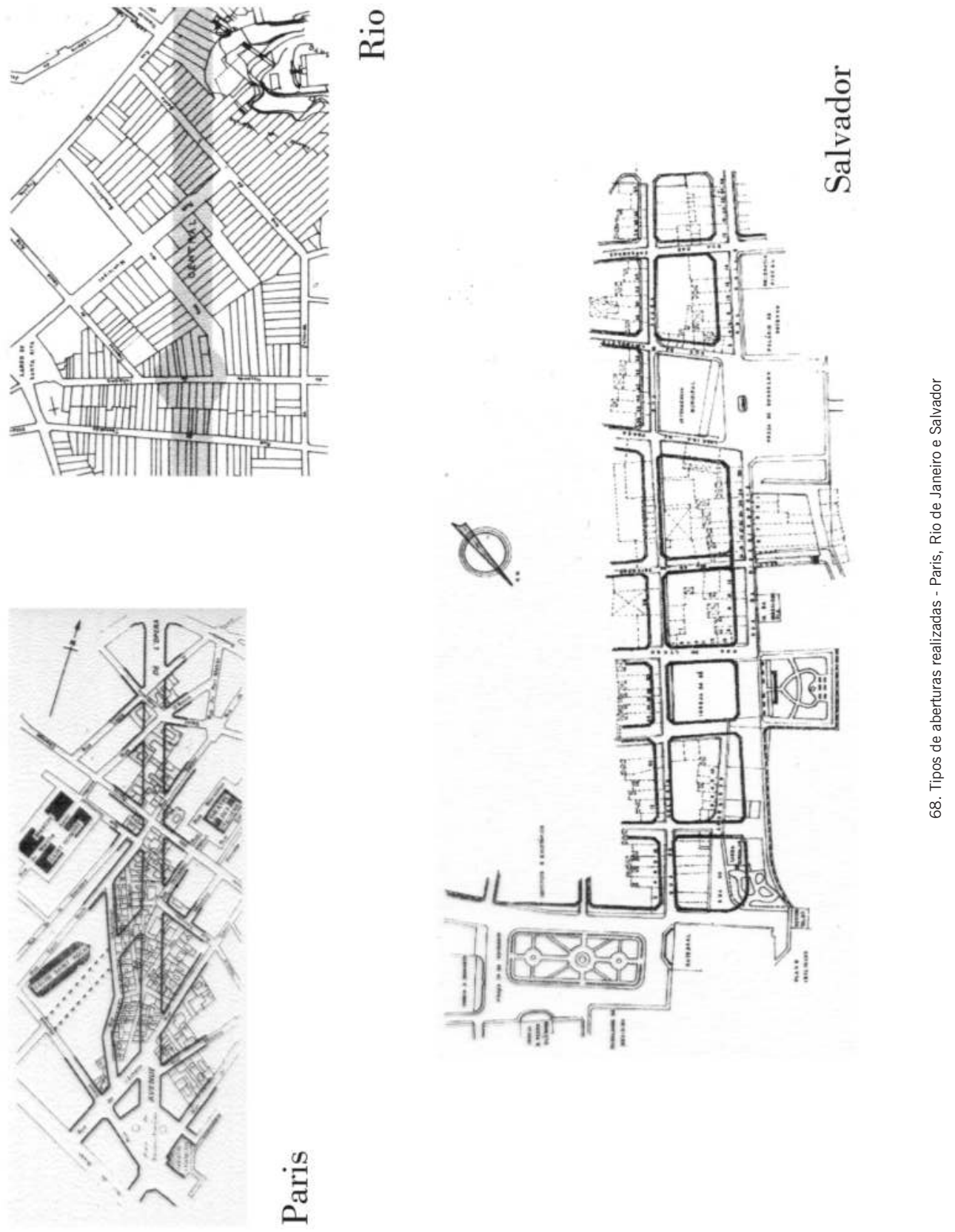
${ }^{2}$ De acordo com Francis Godard, as comparações não uniformizam, num mesmo patamar, as especificidades das condições históricas de cada espaço em questão. (GODARD, 1994, p. 6)
Para equipar as novas vias, são introduzidos modernos serviços de infraestrutura e, ao menos na Avenida Central, há uma tentativa de regulamentação estética das novas construções, através da instituição de um concurso de fachadas. Sem dúvida, a aparência final da Avenida Central assemelha-se muito à dos bulevares parisienses. Realizações desse tipo não são encontradas em Salvador.

Com todas essas mudanças introduzidas na Capital Federal, é lógico que Salvador, como a primeira capital do Brasil, não queira ficar em desvantagem e também realize sua reforma, inspirando-se no novo espaço urbano do Rio de Janeiro.

Tanto no Rio como em Salvador, são realizadas intervenções que não se identificam com a haussmannização, como os vetores de expansão da urbe e a modernização do porto, com áreas conquistadas ao mar, através de aterros, que se revertem em novas urbanizações, como o Bairro das Nações em Salvador. Esse é um processo muito semelhante nas duas cidades brasileiras, mas ainda faltam dados para afirmar que uma tenha sido o modelo da outra, já que ele remonta a épocas anteriores, intensificando-se no período das reformas urbanas.

Rio e Salvador são cidades que começam a sentir os efeitos de um rápido crescimento de população, com a decorrente necessidade de novas áreas urbanas, da definição de novos bairros e eixos que orientem a formação de novos terrenos urbanizados nos seus arredores. Tanto no Rio como em Salvador, além de um plano de reforma, executa-se um plano de expansão. As obras de modernização dos portos carioca e soteropolitano também fazem parte das reformas urbanas e, a partir delas, são realizadas intervenções nos bairros portuários, o que, sem dúvida, não encontramos similar na reforma de Paris, que não é uma cidade portuária.

$O$ objetivo a ser atingido, nas três cidades, é o aburguesamento do centro e a introdução de uma nova estética (Fig. 69). A sua consequência, a segregação social e funcional, além de uma nova estrutura do espaço urbano. Entretanto, as comparações não se podem fazer de forma linear.2 "Modelo dos modelos", a Paris de Haussmann é um modelo difundido em âmbito mundial. Da mesma forma, o Rio de Pereira Passos inaugura uma escola de urbanismo brasileiro, que passa a ser modelo para as demais cidades do Brasil, principalmente as do litoral, que adotam seus traçados, proporções, ideias e processos, principalmente por se tratar da Capital Federal, representante máxima do País. Entretanto, não podemos afirmar que se trate de um modelo para outras cidades. Preferimos considerar antes como uma referência, do que como um modelo. Um estímulo, mais do que algo a ser copiado. (Fig. 70) 


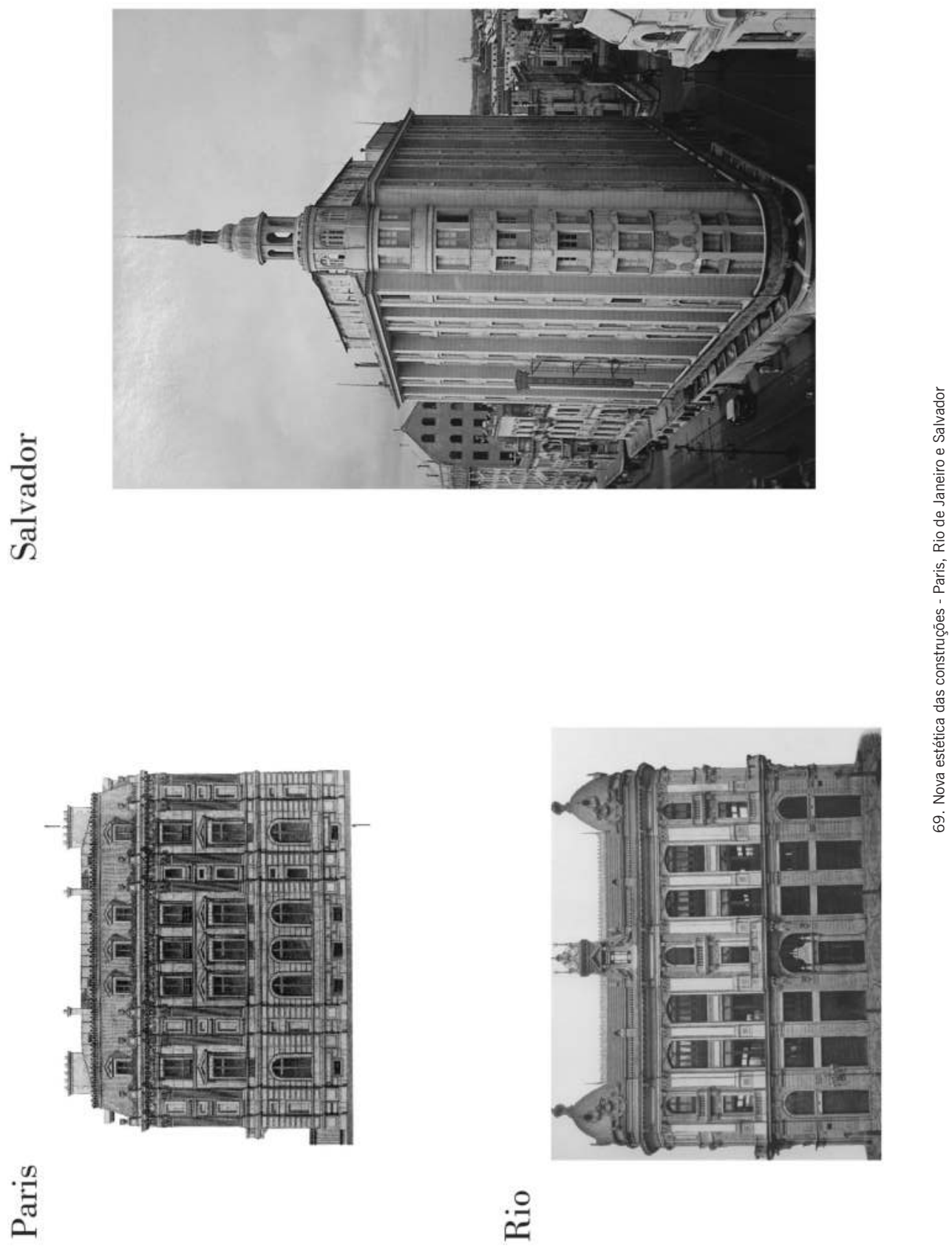




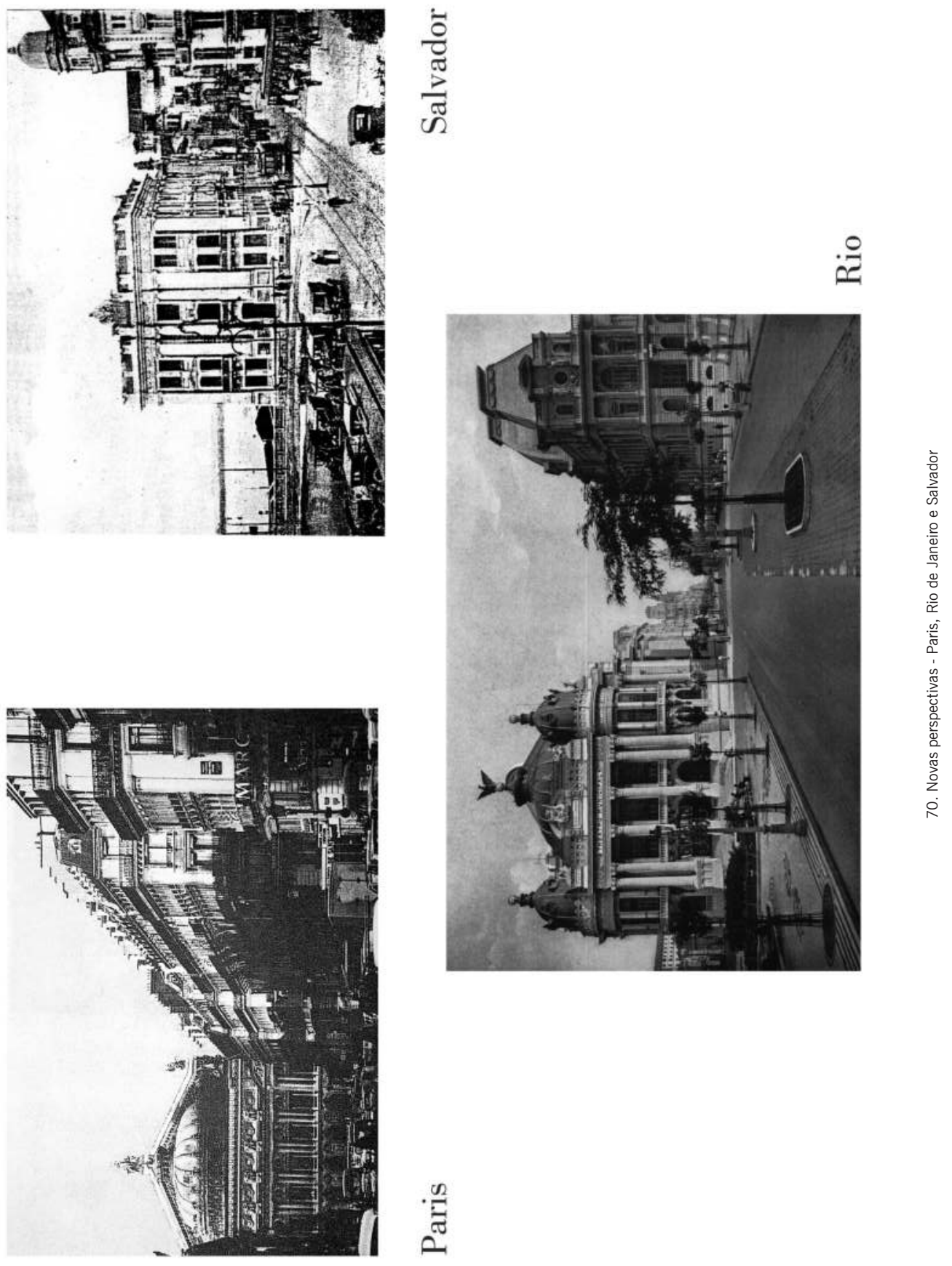




\section{Uma conclusão}

Não há dúvidas de que o modelo da Paris haussmanniana é reeditado em outras cidades europeias, impõe-se nas colônias francesas e seduz outras tantas cidades no mundo. O Rio faz parte das cidades seduzidas, mas seu processo não pode classificar-se simplesmente como haussmannização, por tratar-se de uma cidade cuja realidade é totalmente distinta da de Paris e por haver, em sua reforma, elementos que não se encontram na reforma parisiense. Preferimos afirmar que o processo de reformas urbanas do Rio de Janeiro constitui uma adaptação do modelo francês aos trópicos.

No caso da reforma de Salvador, não se identificam referências às obras de Paris, nem nos discursos dos governantes nem nas manifestações da imprensa. Muito mais próximo e mais acessível para Salvador está o Rio e sua reforma urbana, que irradia ares de nova civilização e modernidade. O Rio adapta o "modelo" haussmanniano às condições que se encontram na capital tropical, transformando seu traçado colonial e criando um novo modelo que se "exporta" para as outras cidades brasileiras. Salvador, ao realizar sua reforma urbana, adapta o modelo do Rio às suas condições estruturais e financeiras, pois também quer mudar sua imagem de cidade colonial. Mais uma vez, reafirmamos a tese de que, em Salvador, produz-se uma adaptação da malha urbana e de sua sociedade aos novos ventos que sopram e trazem os conceitos de modernidade, civilização e progresso, vindos do Rio de Janeiro, da reforma de 1902-1906, uma adaptação de modelos urbanos europeus. 

Posfácio

\title{
E assim, se passaram 100 anos...
}

\author{
Diga aí, diga lá \\ Você já foi à Bahia, nega? Não? \\ Então vá \\ Diga lá, diga aí \\ Você já foi até o Rio, nego? Não? \\ Tem que ir \\ (Lá e Cá - Lenine)
}

\section{Introdução}

0 renascimento dos centros urbanos tradicionais das grandes cidades passa a fazer parte do paradigma do desenvolvimento, dito sustentável, a partir do final do século XX. A revitalização das áreas centrais através da reutilização do patrimônio existente depende da viabilidade do sistema. Já nas intervenções nos waterfronts de Baltimore, de Boston e de Nova lorque, assim como nos casos europeus que se tornam paradigmáticos, buscam-se a recuperação de ambientes históricos existentes, por meio da criação de equipamentos culturais, como âncoras do projeto. Espaços públicos são objetos de projetos primorosamente desenhados, onde se realizam ações de animação cultural. (VAZ, 2004, p. 4)

Busca-se a espetacularização da cidade, das áreas revitalizadas,

[...] a que todos assistem, estupefatos, numa passividade consumista, alienante e sem participação. A proliferação de imagens, eventos, festivais, 
ícones arquitetônicos, espaços públicos renovados e primorosamente desenhados, cuja dimensão simbólica é potencializada e enobrecida pela cultura, se torna matéria prima para o marketing urbano. Anuncia-se a cultura e a cidade revitalizada - um espetáculo a ser consumido. (VAZ, 2004, p. 7)

No Brasil, as cidades de Salvador e do Rio de Janeiro, investem mais intensamente na revitalização de seus centros tradicionais, a partir da década de 1980, depois de várias tentativas e projetos em anos anteriores. No Rio, o Corredor Cultural ainda hoje em vigor, e em Salvador diversos planos e projetos se desenvolvem até o mais recente - Plano de Reabilitação do Centro Antigo de Salvador - sempre com o objetivo de revitalizar seus Centros Urbanos Tradicionais, áreas objeto de modernização nas duas primeiras décadas do século XX.

Como abordamos ao longo deste livro, as cidades de Salvador e do Rio de Janeiro no Brasil, têm histórias urbanas muito próximas. As duas se fundam a princípios da colonização portuguesa - a primeira foi fundada em 1549 e a segunda em 1565. Ambas já nascem com o título de cidade, dentro de baías, portos importantes, situadas em acrópole, mas que se desenvolvem também na parte baixa, com boa visibilidade, tanto para a proteção do que vem do mar como do que vem do interior, da terra. São fortalezas de proteção do território português e as duas foram capitais do Brasil, por aproximadamente, 200 anos cada uma - Salvador, de 1549 a 1763 e o Rio, de 1763 a 1960.

São cidades que, até o ano de 1888, tiveram a mão-de-obra escrava, como um importante componente da sua sociedade e da sua economia, iniciando no século XIX, um processo de industrialização que não se desenvolve. Cidades portuárias, cujo comércio de importação e exportação se constituía a base central da economia. Hoje, são cidades de grande atrativo turístico, capitais de seus estados, que mantêm suas funções administrativas, políticas, portuárias, comerciais, empresariais e de serviços.

A forma urbana das duas cidades é muito parecida com um vetor de crescimento que acompanha a linha da baía - em direção ao Oceano Atlântico segue a classe mais privilegiada e em direção ao interior da baía, a classe menos privilegiada - em função da barreira da sua topografia acidentada. Ambas mesclam natureza e urbanidade de forma singular. O Centro das duas cidades desenvolve suas funções principais no mesmo espaço, desde sua fundação até meados do século XX. Estes centros crescem, incorporam novos lugares - seja através de aterros da baía, desmonte dos morros ou por crescimento vertical - e continuam como espaços privilegiados dentro da 
urbe. Porém, na década de 1970, os centros das cidades de Rio e Salvador tomam rumos opostos, em função de decisões políticas distintas.

Seus centros tradicionais se tornam espaços públicos com funções diferentes. Enquanto uma, o Rio de Janeiro, prefere preservar seu centro como principal espaço empresarial, de negócios e administrativo, além de cultural e histórico; a outra, Salvador, decide apostar pela descentralização e por uma nova centralidade, separando o centro empresarial, do centro administrativo e do centro histórico, tendo atualmente, cada um, seu espaço específico.

\section{Relembrando a formação dos dois centros}

Como já analisamos neste livro, os centros do Rio e de Salvador foram objetos de reformas urbanas de caráter academicista ${ }^{1}$ no início do século XX.

\section{Rio de Janeiro}

Em 1902, Rodrigues Alves assume a Presidência da República (19021906), com o projeto de modernizar o Brasil e sua capital, desconstruindo seu aspecto colonial. Suas prioridades são o saneamento da cidade e a modernização do porto, o que facilita o comércio do café e a imigração da mão-de-obra necessária ao desenvolvimento econômico.

É imprescindível criar um novo espaço urbano, com a finalidade de facilitar a circulação de pessoas e de mercadorias, através dos controles urbanísticos, que têm seu fim na reestruturação do porto, na abertura de avenidas e alargamento de ruas, além de criar uma nova capital que represente o País, com valores e modos de vida cosmopolitas e modernos.

A nova organização do espaço deve refletir o novo momento de organização social, adequando sua forma às necessidades de criação, concentração e acumulação de capital, uma vez que a economia brasileira se integra, cada vez mais, no contexto do capitalismo internacional. Por trás de todas essas necessidades, encontra-se a negação de sua herança colonial, de seu passado escravista, de sua negritude.
${ }^{1}$ Entendendo aqui, o academicismo como o movimento que, no início do século XX representa a escola de Beaux-Arts de Paris, com reflexos nos principais países ocidentais. Assim, neste texto, considera-se o academicismo como formado por um acervo de conhecimentos teóricos e práticos herdados do passado e que proporciona a base da formação de arquitetos. 


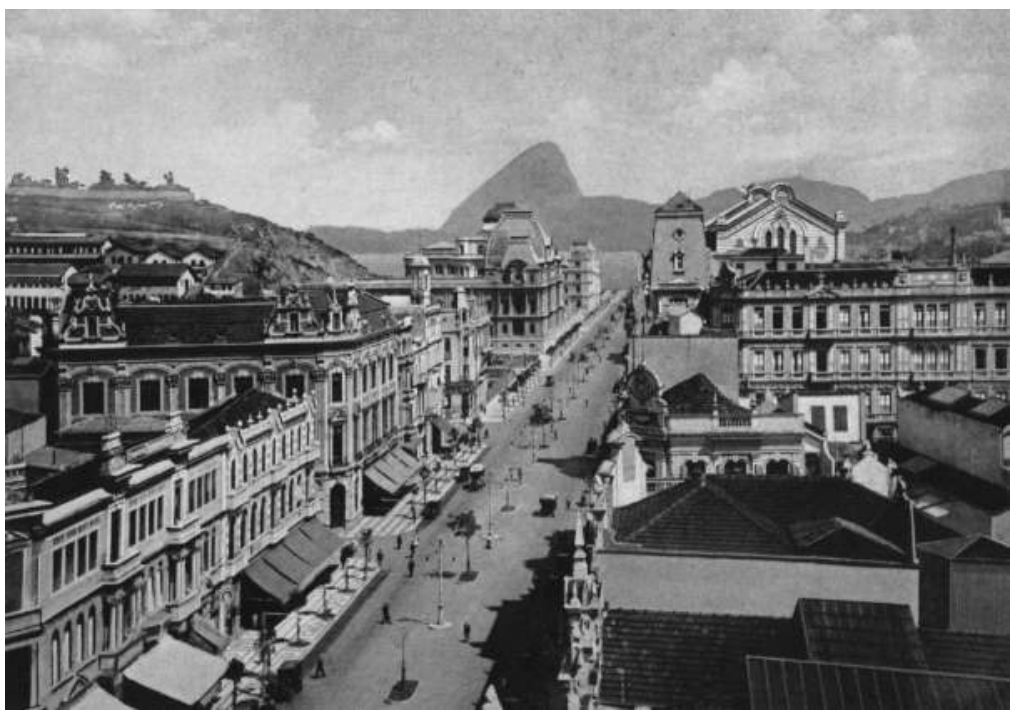

Figura 71 - Avenida Central, atual Rio Branco, foto de Marc Ferrez, em 1910.

Após as reformas, o novo centro do Rio já não abriga residências, a não ser em seus espaços periféricos como Gamboa, Santo Cristo, Cidade Nova, Lapa e outras, mas mantém todas as funções de centro e de capital do país. A grande valorização do solo, no Centro, faz pressão para que se amplie a sua área. E na década de 1920, a zona central do Rio, uma vez mais, volta a ser palco de intervenções. Seu espaço urbano sofre drásticas cirurgias como, por exemplo, a conclusão do desmonte do Morro do Castelo, que abre a possibilidade da criação de novos espaços - uma esplanada e a utilização da terra para o aterro de parte da baía. Chega o momento de construir uma cidade moderna, sem os elementos tradicionais do passado, tirando de uma área valorizada, as prostitutas, lavadeiras e vagabundos que moram no morro. É ainda nessa época que renomados arquitetos e urbanistas convidados, como Alfred Agache e Le Corbusier, propagam soluções para a cidade.

Grande parte da nova esplanada se utiliza para os pavilhões da Exposição Universal de 1922, comemorativa do Centenário da Independência do Brasil e, mais tarde, ocupada pela Feira de Mostras, até 1930, quando finalmente, urbaniza-se a Esplanada do Castelo, com largas avenidas e edificações monumentais, sendo o projeto de Agache, considerado apenas na construção de alguns quarteirões (Fig. 72, ver caderno de imagens).

Na década de 1940, a abertura de uma nova Avenida no Centro destrói alguns vestígios do Rio colonial. A Avenida Presidente Vargas, inaugurada em 
1950, reflete um novo modelo urbano e se ocupa com edifícios altos, agora muito mais vinculados à Escola de Chicago do que a Paris. A partir dessa época, as edificações ecléticas do centro do Rio passam a ser substituídas pelas representações do Movimento Moderno e do International Style, convertendo a Avenida Rio Branco num desfiladeiro de altas torres de aço e vidro. (Fig. 73, ver caderno de imagens).

Em 1960, a Capital Federal se muda para Brasília, transferindo as funções políticas e administrativas federais para aquela cidade. Tal fato traz mudanças no Centro, mas este não perde suas principais funções, como centro de um novo estado que se forma - o Estado da Guanabara. Já na década de 1970, com a fusão dos estados da Guanabara e do Rio de Janeiro, a cidade do Rio amplia sua função de capital para o novo estado fluminense.

A crise econômica dos anos 1980 e a estabilização do crescimento da população urbana levam ao estancamento da indústria imobiliaria que, no Centro, havia levado à substituição das edificações da Avenida Rio Branco. Dos edifícios do início do século XX, restam três ou quatro, enquanto outros terrenos já abrigam a quinta geração de prédios. (LIMA, 2005) (Fig. 74 e 75, ver caderno de imagens).

A partir dos anos 1980, o Centro do Rio volta a ser um espaço privilegiado para os investimentos da Prefeitura. Nesse período, surge o incentivo à recuperação do patrimônio histórico arquitetônico e a definição do projeto do Corredor Cultural, que detalharemos mais adiante. Por outro lado, também se incentiva a substituição de edificações e melhoria da infraestrutura existente, visando a inserção do Rio de Janeiro no cenário internacional, criando o ambiente necessário para transformar-se em cidade global. (MONTEIRO, 2009, p. 5)

Atualmente, o Centro se mantém como principal núcleo financeiro do Estado e o segundo do País. Em sua área podemos encontrar uma grande concentração de centros culturais, museus, bibliotecas, salas de teatro e cinema. É a área da cidade onde estão os melhores equipamentos culturais, mas também possui um amplo e diversificado comércio, além de serviços públicos e privados, universidades, sedes de empresas estatais, órgãos públicos e da sociedade civil. Entre outros equipamentos há um aeroporto, hotéis, restaurantes, botequins e bares. ${ }^{2}$
${ }^{2}$ Recentemente foi publicado no Jornal O Globo, de 18/02/2011, uma pesquisa feita pela empresa de consultoria imobiliária Global Cushman \& Wakefiel, em 132 cidades de 64 países. A pesquisa conclui que o aluguel comercial no Rio de Janeiro é o $4^{\circ}$ mais caro do mundo, ultrapassando Manhattan, em Nova Iorque, Milão e Paris. $\mathrm{O}$ aluguel comercial do Rio só perde para Hong Kong, Londres e Tóquio. Disponível em http://oglobo.globo.com/economia/ morarbem/mat/2011/02/17/aluguelcomercial-no-rio-o-4-mais-caro-domundo-923829750.asp. Acesso em 20/02/2011. 


\section{Salvador}

A cidade de Salvador, nos últimos 50 anos, passou por mudanças em sua forma urbana, devido ao seu crescimento acelerado que a transformou numa grande metrópole brasileira. Segundo o Censo 2010, de meados do século XX ao final da primeira década do século XXI, a cidade passa de pouco mais de 400.000 habitantes, em 1950, para 2.676.606 habitantes, com uma região metropolitana, criada em 1973, composta por 13 municípios, e 3.574.804 habitantes. (CENSO 2010)

Como pode ser observado nas ideias de Pedrão (2009, p. 9).

Para compreender a situação atual de Salvador será preciso rever as guinadas da urbanização desta cidade ao longo do tempo, para desenterrar os fios condutores das inter-relações entre esses fenômenos de criatividade na reprodução da pobreza e da expansão incontrolada de construções de 'alto padrão' que aparentemente, constituem uma grande bolha em formação.

Na década de 1910, a cidade de Salvador e seu centro passaram por reformas urbanas que iniciaram a transformação do centro tradicional. Ruas foram alargadas, avenidas foram criadas, direcionando cada vez mais a cidade rumo ao Oceano Atlântico por um lado, e à Península de Itapagipe por outro, bordejando a baía. Novas construções ecléticas substituíram antigas casas coloniais. Uma nova imagem se introduziu tanto na Cidade Alta como na Cidade Baixa.

Nesse momento, o crescimento urbano e a dificuldade de deslocamento entre os diversos pontos da cidade fizeram com que Salvador concentrasse funções em seus distritos centrais. A formação da área urbanizada não permitiu a organização de centros comerciais nos bairros, o que favoreceu o centro único com concentração de atividades e transportes, situação que só mudou a partir da segunda metade do século XX.

Por motivos diversos, a Cidade de Salvador sofreu uma estagnação no seu crescimento, entre os anos 1920 e 1940, sendo registrados 280 mil habitantes, em 1920 e 290 mil habitantes, em 1940. Porém, a movimentação do porto de Salvador se mantém, e são construídos os primeiros arranha-céus da cidade. O comércio se desenvolve colonizando a Rua Chile e a Avenida Sete de Setembro, como parte do comércio de luxo. (SANTOS, 2008, p. 48-49)

Na Cidade Baixa, a partir de 1940, os grandes vazios do último aterro começaram a ser construídos com uma nova geração de edificações, arranha-céus que diferiram do estilo do período precedente. Casas mais antigas das 
ruas Portugal e Conselheiro Dantas foram demolidas para dar espaço a novas construções.

Na Cidade Alta, após a demolição da Igreja da Sé, dois quarteirões foram derrubados ampliando o espaço vazio da Sé e deram origem a atual Praça da Sé. Também são alargadas algumas ruas, como, por exemplo, a Rua Carlos Gomes, onde edifícios de vários andares foram implantados, para desembaraçar a circulação. (SANTOS, 2008, p. 113-114)

Com o descobrimento do petróleo, no final da década de 1940, a implantação do Centro Industrial de Aratu (CIA), no final dos anos 1960 e o Complexo Petroquímico de Camaçari (COPEC), na década de 1970, Salvador assume o caráter de metrópole, o que incentiva o surgimento de novos centros comerciais. Assim, decide-se apostar pela descentralização e por uma nova centralidade, separando o centro empresarial, do centro administrativo e do centro histórico, tendo atualmente cada um seu espaço específico. Para isso são construídos, nos anos 1970, em área excêntrica e totalmente deserta, uma nova rodoviária, um shopping center e um novo acesso à cidade - Acesso Norte -, área hoje conhecida como Iguatemi e Avenida Tancredo Neves. Por conseguinte, uma nova via foi aberta, a Avenida Luiz Viana Filho, mais conhecida como Paralela, uma avenida que faz a ligação entre os dois extremos - da cidade ao aeroporto - e onde se instala o novo Centro Administrativo da Bahia (CAB); e a rede de avenidas de vale projetadas nos anos 1940, mas que, no entanto, só foram implantadas nas décadas de 1960 e 1970. (PINHEIRO, 2008, p. 10-11)

O Escritório de Planejamento Urbano da Cidade de Salvador (EPUCS), na década de 1940, teve como preocupação a forma da cidade e o seu ordenamento urbano. 0 objetivo era corrigir os defeitos da cidade, ordenar seu desenvolvimento e melhorar a qualidade de vida. Com influência da ideologia funcionalista de Le Corbusier - no plano de reforma do centro urbano e no zoneamento de funções urbanas específicas - e também das concepções da Escola de Chicago - em relação à valorização das áreas verdes e do esquema rádio-concêntrico -, além da proposta do Geddes - da visão da cidade como um todo -, a proposta do EPUCS muda a forma de se pensar o urbanismo em Salvador. (MENDES, 2006, p. 144-145) É o primeiro projeto que busca dotar a cidade de uma infraestrutura de circulação, implantada somente, com algumas modificações, nos anos 1960 e 1970. São projetadas parkways, as avenidas de vale ajardinadas e arborizadas, para o grande fluxo de veículos.

No final dos anos 1960, duas obras de grande porte ligando a Cidade Alta à Cidade Baixa são construídas em Salvador, com a finalidade de melhorar a circulação e desviar o trânsito do centro da cidade. A Avenida Contorno 
é projetada por Diógenes Rebouças, em 1958 e rodeia a encosta ligando o Vale do Canela à Conceição da Praia. E o Túnel Américo Simas, projetado por Theodoro Sampaio, que se constrói no final da década de 1960, conecta o Vale de Nazaré à região portuária, passando por baixo do Santo Antônio. Após o EPUCS, Salvador fica por quase três décadas sem planos ou projetos para a cidade, apesar do crescimento econômico da região com o planejamento industrial que tomou forma nos anos 1950 e que se afirma nos anos 1960 e 1970. (MENDES, 2006, p. 148)

O Plano de Desenvolvimento Urbano (PLANDURB) leva em consideração a nova estruturação urbana da cidade e seu entorno que foi definida pelo crescimento industrial com a instalação do CIA e do COPEC, além da abertura da Avenida Paralela, em 1973, que cria o vetor norte de crescimento. O Plano rompe com o urbanismo modernista e teve a função de planejar a organização do novo espaço urbano da cidade de Salvador, diferenciando-se do EPUCS. (MENDES, 2006, p. 170) A cidade toma a forma polinuclear, descentralizando seu centro com destaque para a região do Iguatemi, com atividades econômicas de comércio e serviço, assim:

[...] o modelo físico territorial adotado para a cidade neste plano indica os dois principais vetores (em direção ao norte) de expansão urbana - a BR-324, a Av. Paralela, recém inaugurada - e a grande área do 'miolo' [...] como de ocupação prioritária. (MENDES, 2006, p. 170)

A partir da década de 1970, tanto a Cidade Alta como a Cidade Baixa sofrem as consequências da formação de novas áreas comerciais e de negócios na cidade. O desenvolvimento da área do Iguatemi, onde foram construídos o shopping center lguatemi, a nova rodoviária e o novo acesso à cidade, em meado da década de 1970, além da abertura das avenidas de vale, principalmente da Avenida Paralela e a construção do novo Centro Administrativo da Bahia, que facilitam o acesso em direção norte, deslocam as funções administrativas, comerciais e empresariais criando novas centralidades administrativas, comercias e empresariais, contribuindo para a decadência do Centro. (Fig. 76, ver caderno de imagens)

Nas últimas três décadas, podemos perceber o crescimento da área urbana de Salvador, que se dá em forma de ilhas seja em torno de novos centros de consumo ou de conjuntos habitacionais fechados e novos loteamentos. Essa dinâmica de crescimento e de migração de funções, principalmente as centrais, desfigurou a cidade. As novas centralidades surgem sob o argumento da obsolescência da estrutura urbana central, usando o slogan de "A Bahia constrói o seu futuro sem destruir o seu passado". (PINHEIRO, 2008, p. 11) 


\section{Duas trajetórias diferentes}

A partir dos anos 1980, para a reabilitação, requalificação e restauração do patrimônio arquitetônico e histórico, e do espaço urbano dos dois centros, que ficam abandonados por distintas razões, são elaborados programas na tentativa de sua recuperação como ambiente público, visando à reapropriação dos seus espaços públicos e privados tanto pela população local como por visitantes.

Com seu centro antigo tombado como patrimônio histórico pelo Instituto do Patrimônio Histórico e Artístico Nacional (IPHAN), em 1984, e reconhecido pela United Nations Educational, Scientific and Cultural Organization (UNESCO), como Patrimônio Cultural da Humanidade, em 1985, Salvador apostou pela descentralização e por uma revitalização do seu Centro Histórico. Para tanto, o poder público permanece por trás da transformação de suas ruas em um destino turístico, nos anos 1990, retirando de suas edificações os moradores, uma vez que os usos tradicionais de centro de cidade já haviam se estabelecido em outra parte do município. Por outro lado, no Rio, a Prefeitura elabora um projeto denominado de Corredor Cultural que, através de intervenções de caráter cultural e em conjunto com proprietários e investidores, decide atrair para a área central teatros, cinemas, centros culturais, comércio de alta qualidade e restaurantes, sem deixar de atender aos usos tradicionais.

\section{Rio de Janeiro}

O centro do Rio sempre se configurou pelas funções empresariais, financeiras, comerciais, políticas, administrativas, bancárias e recreativas. Não tem um caráter turístico, pois outras localidades têm maior apelo nesta área e os principais hotéis se instalam ao longo da baía, na orla do Oceano Atlântico e na Zona Sul de forma geral. Desde o século XIX, que o Centro, a exceção da região da Lapa e outras regiões periféricas centrais, não é mais uma área residencial. A partir da década de 1990, esta estrutura começa a mudar com o projeto de revitalização do Centro Histórico e também o incentivo à construção habitacional em algumas áreas predefinidas.

Após a mudança da capital para Brasília, em 1960, o Centro perde vitalidade, que se acentua com o deslocamento da população para novas áreas, como a Barra da Tijuca, cada vez mais afastadas do núcleo central. Apesar de ser um Centro ativo durante o dia, até a década de 1990, à noite 
${ }^{3}$ Baseado na Carta de Nairobi, de 1976, quando a UNESCO adota uma recomendação relativa à proteção dos conjuntos históricos tradicionais e ao seu papel na vida contemporânea, que continua sendo a exposição de motivos e a argumentação mais complexa em favor de um tratamento não museográfico das malhas urbanas contemporâneas.

${ }^{4} \mathrm{O}$ projeto que começou a ser discutido em 1979 tem como primeiras áreas de atuação a Lapa-Cinelândia; Praça XV; Saara; e Largo de São Francisco. e nos fins de semana a população local não considera suas ruas atrativas, tornando-se um espaço vazio de atividades nesse período.

Já na década de 1970, através de posturas municipais, identificam-se algumas ações preservacionistas. Em 1978, são regulados gabaritos, impedidas reunificações de lotes e desmontes que interferissem no perfil natural da encosta do Morro do Pinto, Providência, Conceição e Santa Teresa. Em 1979, por meio de decreto, ficaram protegidas, a Cinelândia, a Rua da Carioca, a Rua República do Paraguai e a Rua Sete de Setembro. (MOREIRA, 2009, p. 11)

A partir dos anos 1980 dá-se início ao projeto do Corredor Cultural, ${ }^{3}$ um projeto da Prefeitura da Cidade do Rio de Janeiro que se desenvolve desde 1984 (Lei no 506, de 17/01/84, que reconhece o Corredor Cultural como Zona Especial do centro histórico do Rio de Janeiro) e está sob responsabilidade da Fundação Rio Arte, da Secretaria Municipal de Cultura. O Corredor Cultural é fruto de uma política que vem no bojo da redemocratização do país e a introdução do planejamento participativo. A aprovação da lei em 1984 preservou cerca de 1.300 edificações no centro da cidade.

\footnotetext{
A introdução quase obrigatória de práticas de consulta à população na tomada de decisões governamentais subverteu a lógica supostamente 'científica' dos documentos do urbanismo, politizando-os, sintetizando neles a mudança na correlação de forças ocorrida na sociedade brasileira naquele momento. $\mathrm{Na}$ cidade do Rio de Janeiro, desde 1983, governada pelo Partido Democrático Trabalhista (PDT) [sic], este período foi marcado pela absorção das reivindicações formuladas pelas associações comunitárias, refletindo-se na elaboração de um conjunto de regulamentos restritivos à especulação imobiliária e na adoção de uma política contundente de recuperação e preservação do centro histórico e adjacências. (COMPANS, 2004, p. 49-50)
}

O Corredor Cultural tem o objetivo de preservar e revitalizar o Centro, ${ }^{4}$ procurando desenvolver parte de seu antigo esplendor como área de lazer e cultura. De uma forma integrada, o Projeto une a preservação do patrimônio histórico e cultural, a recuperação e a renovação de bens arquitetônicos e urbanísticos em conjunto com a revitalização social e econômica. (Fig. 77, ver caderno de imagens)

O projeto que começa a ser discutido em 1979, no interior da Secretaria Municipal de Planejamento e Coordenação Geral, tem a participação da comunidade local como ponto fundamental da política adotada. 0 êxito da implantação da proposta dependia da conscientização dos proprietários da importância da preservação do acervo arquitetônico e fazer com que participassem das etapas de elaboração e acompanhamento do projeto. Para sua implantação foi elaborado um manual (Como recuperar, reformar ou 
construir seu imóvel no Corredor Cultural) para informar, divulgar os novos procedimentos e normas e, principalmente, orientar os usuários nos trâmites administrativos e procedimentos técnicos. (INSTITUTO MUNICIPAL DE ARTE E CULTURA, 2002)

Iniciado através de ações da Prefeitura, desde a sua origem, o Projeto Corredor Cultural considerou quatro aspectos fundamentais na requalificação urbana: a história, a memória, a preservação e a participação comunitária. O projeto buscou conciliar modelo histórico e arquitetônico com viabilidades econômicas e construtivas, além de favorecer a ocupação de áreas livres com novas construções que promovessem uma releitura das edificações históricas com uma linguagem contemporânea. (ALCANTARA; BARBOSA; RHEINGANTZ, 2006) A participação dos proprietários foi fundamental para a viabilidade do processo uma vez que os instrumentos urbanísticos existentes - zoneamento e tombamento - não garantiam a conservação e preservação do imóvel, podendo o mesmo ser abandonado até seu arruinamento e desabamento.

Com uma área territorial de 1.294.625m² a implantação do Corredor Cultural foi dividida em duas subzonas - preservação ambiental e renovação urbana. Na primeira, não se admite modificações em fachadas e telhados, apenas internas, mantendo as características arquitetônicas, artísticas e decorativas e novas construções devem obedecer a parâmetros fixados no projeto. Na segunda, as novas edificações devem obedecer ao projeto integrado no conjunto arquitetônico onde se inserem e manter alturas preestabelecidas. (COMPANS, 2004, p. 50-51)

A revitalização do Centro faz parte do Plano Estratégico, objetivando revigorar áreas urbanísticas, ambiental e economicamente estagnadas. Assim, visa criar novas infraestruturas e o desenvolvimento do mercado de produção e bens culturais através da renovação dos equipamentos existentes. No enfoque não se priorizam somente os aspectos estéticos e físicos, mas também os de ordem social e econômica.

Desde 1988, nota-se no Centro a instalação de diversos Centros Culturais e recuperação de museus, ${ }^{5}$ em cerca de 15 prédios históricos que foram restaurados, reciclados e administrados por organismos federais, estaduais e municipais. O projeto toma novo impulso, a partir de 1993, quando se implantou um programa de recuperação dos espaços públicos, através de parceria público/privado. Neste momento, se desenvolveu o programa Rio Cidade com intervenções em várias áreas da cidade, como Copacabana, Ipanema, Leblon, Flamengo, Botafogo, Tijuca, Méier, Penha, Campo Grande, Madureira e Ilha
${ }^{5}$ Entre os mais significativos se encontram: Paço Imperial, os Centros Culturais do Banco do Brasil, da Light, dos Correios, Casa França Brasil, Centro de Artes Hélio Oiticica, Espaço Cultural da Marinha e os Museus Histórico Nacional, Nacional de Belas Artes e de Arte Moderna. 
do Governador, além de áreas no centro da cidade. São iniciativas concretas de intervenções pontuais no espaço urbano.

Todo esse movimento possibilita que outras instituições não governamentais, por exemplo, as associações de amigos de ruas, também se mobilizem e se transformem em novos focos de intervenção como na Feira do Lavradio, a Praça Tiradentes, os bairros portuários através do Projeto SAGAS, a Lapa e a Cidade Nova.

O Projeto SAGAS que abrange três bairros antigos da zona portuária - Saúde, Gamboa e Santo Cristo, parte da iniciativa das associações de moradores que criam o Grupo de trabalho Comunitário e Institucional de Proteção e Valorização do Patrimônio Cultural dos bairros da Saúde, Gamboa e Santo Cristo que, diferente do Corredor Cultural, se concentra na definição de parâmetros para a ocupação por meio da elaboração de legislação de uso do solo. Para a área portuária, também foram executados outros programas. Segundo Sirkis (2004, p. 66),

O programa de revitalização da área portuária, da Praça Mauá ao Gasômetro, incluindo os morros da Conceição, da Providência, os bairros da Gamboa, Santo Cristo, Saúde e Caju, desdobra-se em quase vinte projetos todos dentro de uma mesma filosofia: qualificar a vida dos moradores desses bairros, combinar, cautelosamente, a recuperação do antigo - casario colonial português, armazéns de cais e galpões industriais ou construções públicas de valor histórico - com investimentos novos em escritórios, equipamentos culturais, serviços e residências, assegurando uma ampla participação comunitária em todo o processo.

A área da Lapa sofreu uma grande intervenção na reforma de Pereira Passos com o desmonte do Morro do Senado e a abertura das ruas Mem de Sá e Estácio de Sá, que cortam diagonalmente a área, ligando a Avenida Beira Mar à Cidade Nova em direção à Zona Norte da cidade. Com o desenvolvimento de novos bairros na faixa litorânea, os antigos sobrados e palacetes da Lapa são abandonados pela população de renda mais alta e ocupados por uma classe mais pobre, passando a fazer parte do cinturão de pobreza que circunda o centro da cidade, chegando até a zona portuária. (DUARTE, 2009, p. 7)

Reduto da música, dos intelectuais e da boemia, a Lapa, nas décadas de 1930 e seguintes é um lugar considerado como território do pecado e das transgressões. Porém, a área entra em decadência no período da Ditadura Militar, voltando ao cenário apenas a partir do final da década de 1990, quando antiquários se reúnem para realizar uma feira aos sábados, dando início do que vai ser o renascimento da área. 
A partir dos anos 90, no entanto, a Lapa ressurge das cinzas, pronta para a festa. Ocorre uma 'redescoberta da Lapa' e de seus predicados mais secretos. Um dos marcos decisivos foi a iniciativa dos antiquários localizados na Rua do Lavradio, em promover uma feira de antiguidades nos fins de semana. 0 sucesso alcançado foi largamente incrementado e potencializado pela transformação de várias lojas de antiguidades em casas de shows com música ao vivo, ambientadas com os próprios móveis e objetos antigos em exposição. (DUARTE, 2009, p. 10)

Assim, a Lapa, que ao longo do século XX foi objeto de vários projetos urbanísticos - como a demolição de várias casas para dar maior visibilidade aos Arcos -, passa por um processo de desarticulação do seu traçado urbano e a destruição do patrimônio. Com o projeto do Corredor Cultural, várias casas passam por restauração e algumas áreas do bairro são reconstruídas. Próximo aos Arcos se abre uma grande praça que permite a apresentação de espetáculos e concentrações populares. Esse espaço, junto com o Circo Voador e a Fundição Progresso, dá origem ao retorno da música para as ruas da Lapa, desencadeando um movimento de retorno das rodas de samba e o incentivo para abertura de bares e restaurantes.

$\mathrm{Na}$ área da habitação, os cortiços, que são a primeira modalidade de moradia de aluguel do Rio, passam a ser objeto de revitalização através da Secretaria Municipal de Habitação, a partir de 1996, principalmente, na zona portuária. Após adquirir os imóveis, a Prefeitura os moderniza com mais ventilação e iluminação, instalações elétrica e hidráulica novas e os moradores passam a pagar aluguel. O projeto piloto reformou casarões da Travessa do Mosqueira, da Rua Sacadura Cabral e da Rua Cunha Barbosa.

Dois outros programas de habitação no centro vêm sendo implementados - Morando no Centro, que prioriza construção de uso misto no centro, e Novas Alternativas, que atua na reabilitação, recuperação e construção de imóveis em vazios urbanos. Por exemplo, o empreendimento Santana, com 13 moradias e cinco salas comerciais, na Rua de Santana, 119. Outro exemplo é a recuperação do primeiro cortiço que se tem notícia no Brasil, com 120 anos, localizado na Rua Senador Pompeu 34, e tombado pelo Patrimônio Cultural do Município, onde foram construídas 23 moradias. (ROSSI, 2004, p. 86-87)

$\mathrm{Na}$ Cidade Nova, a instalação do Teleporto ${ }^{6}$ reforça a vocação do Centro como principal área de negócios do Rio. Sua implantação inicia-se em 1993 e prevê a construção de 29 edifícios inteligentes interligados por anéis de fibra ótica numa extensão territorial de 250 mil m² e área construída de 450 mil $\mathrm{m}^{2}$. O objetivo principal é transformar o Rio num centro terciário internacional.
${ }^{6} \mathrm{Um}$ porto de Telecomunicações dotado dos mais avançados meios de telecomunicações que permite um fluxo de informações quase que instantâneo proporcionado por uma infraestrutura dedicada 24 horas por dia à transmissão e recepção de sinais de voz, dados e imagem com o mundo inteiro, com segurança, eficiência e custos operacionais reduzidos dentro dos padrões competitivos a nível internacional. 
O primeiro empreendimento no Teleporto do Rio de Janeiro é o Centro Empresarial Cidade Nova (CECN), inaugurado em junho de 1995. Um Plano Diretor da Prefeitura da Cidade do Rio de Janeiro define o tipo e a volumetria das edificações em cada lote. 0 projeto envolve a instalação de atividades complementares e de moradia que inclui 36 quadras, onde se melhora o sistema viário, se recuperam residências e se revisa a legislação urbanística.

Porém, este projeto não se tornou, ainda, realidade por falta de investidores, do fechamento da Bolsa de Valores e da transferência de muitas empresas do setor financeiro para São Paulo. Dos 29 edifícios estimados para a área, apenas dois prédios foram construídos, e quatro estão em fase finalização.

\section{Salvador}

Em função dos diversos projetos realizados para a cidade e o redirecionamento do crescimento para a região nordeste de Salvador, da migração das principais atividades administrativas, comerciais e serviços e da facilidade de acesso à nova área do Iguatemi e da Avenida Tancredo Neves, o centro tradicional entra em decadência, transformando-se numa área residencial de baixa renda, marginalidade e prostituição e numa área comercial para as classes baixas - Avenida Sete de Setembro e a Baixa dos Sapateiros. Diante do quadro que se apresenta vários projetos são elaborados para o Centro na tentativa de revitalizar social e economicamente requalificando o espaço urbano arquitetônico da área central. (Fig. 78, ver caderno de imagens)

$\mathrm{Na}$ Cidade Alta, na busca de recuperação do centro tradicional, são construídos shoppings centers de caráter especializado para um público usuário de transporte coletivo. Para facilitar a circulação nas áreas centrais, terminais de ônibus urbano são construídos na periferia do centro - Lapa, Barroquinha, Aquidabã, e da França, na Cidade Baixa.

Porta de entrada e de saída dos negócios realizados no Estado, até a década de 1980, o Comércio possui alguns dos principais monumentos marcos do turismo, religiosidade e desenvolvimento econômico da cidade. A expansão em direção norte e nordeste, para a região do Iguatemi e das avenidas Tancredo Neves, Antonio Carlos Magalhães e Paralela, levam, também, à decadência dessa área da cidade. 0 resultado é uma acentuada depreciação do valor urbano de toda a área, uma imagem de degradação e deterioração da paisagem urbana com a maioria dos imóveis abandonados e degradados. Apesar da grande movimentação ainda existente nas ruas da área, 
os principais serviços e a sede das instituições financeiras e de importação e exportação são substituídos por outras funções de caráter mais local e de menor porte. (Fig. 79, ver caderno de imagens)

Muitas sedes de empresas e bancos abandonam suas ruas, pela lógica da não adaptação ao uso generalizado do automóvel, e os grandes equipamentos, como os trapiches, passam a abrigar novas funções como restaurantes, locais para festas e até estacionamentos. 0 antigo porto se destina à construção de marinas e para ancoradouro de barcos de passeio e de navios de cruzeiro. A estrutura existente no Comércio, as construções modernistas das décadas de 1940 e 1950, torna-se obsoleta e os edifícios são abandonados. Incentiva-se a instalação de instituições de ensino privado e órgãos públicos em edificações abandonadas buscando o retorno da vitalidade perdida.

As tentativas de recuperação do Centro Histórico de Salvador (CHS), área delimitada no Centro Antigo de Salvador, podem ser divididas em três momentos, conforme descreve Ângela Gordilho (2010, p. 90-95): primeiro momento, até o final da década de 1980, com tombamento e recuperação de monumentos e edificações históricas de uso institucional; segundo momento, a partir do início da década de 1990, quando do Governo de Estado inicia uma grande intervenção na área do Pelourinho, com ênfase às atividades voltadas ao turismo, eventos festivos, musicais e outras atividades de entretenimentos; e o terceiro momento, no início dos anos 2000, que se caracteriza pela busca de inserção de moradias.

Muitas políticas de preservação foram elaboradas para as áreas tombadas do Centro de Salvador, sendo que, a maioria privilegia as imediações do Pelourinho e do Terreiro de Jesus, seja por sua importância histórica paisagística, seja pelo apelo turístico e pelo seu avançado estado de degradação. Já a partir dos anos 1960, pensa-se na recuperação dos velhos casarões e edificações monumentais isoladas da Cidade Alta, deteriorados com o passar dos séculos, pelo Estado e com financiamento federal.

A revitalização do Pelourinho, a partir da década de 1970, tem caráter assistencialista e concentra-se no saneamento do local e na reeducação da população pobre que havia transformado em cortiço os casarões, antigas moradias da classe alta, dos latifundiários e do clero. A população residente é alvo de intensa política do atual Instituto do Patrimônio Artístico e Cultural da Bahia (IPAC), na época, conhecido como Fundação Pelourinho. (CARDOSO, 2010, p. 64) Mas estas ações de desenvolvimento social e econômico são pequenas em relação às propostas de incentivo ao turismo e atividades terciárias na área. Cardoso (2010, p. 64) afirma que as ações da Fundação Pelourinho, por um lado, abriram canais de atendimento mais facilitado para 
as demandas da população residente, por outro, "[...] contribuíram para o acirramento do isolamento e distanciamento do CHS em relação às ações governamentais implementadas no contexto da cidade."

Essa política adotada contribuiu para o processo de guetificação da área, principalmente entre o Terreiro e o Largo do Carmo, dissociando os projetos de desenvolvimento urbano do CHS do resto da cidade e sua área metropolitana. No Plano de Desenvolvimento Urbano da Cidade de Salvador, dos anos 1970, a área tombada do CHS não faz parte das propostas elaboradas para as demais áreas da cidade para ser objeto de um plano diretor específico, a ser elaborado pela Fundação Pelourinho - Plano Diretor do Pelourinho (PLANDIP), paralisado no final dos anos 1970.

Na década de 1980, constata-se um aumento acentuado de degradação. As causas apontadas são as intervenções pontuais, que procuram salvar um ou outro prédio, sem uma concepção que considere a totalidade do tecido urbano dos séculos XVII e XVIII. No início dos anos 1980, registra-se uma tentativa de implantação de um programa habitacional na área, que busca disponibilizar moradias de baixo custo para a população com financiamento do Banco Nacional da Habitação (BNH). Algumas dificuldades, como a transformação de antigas edificações unifamiliares em imóveis multifamiliares, e questões operacionais levaram à paralisação do projeto após a finalização de alguns imóveis.

Ainda nos anos 1980, verifica-se a primeira proposta elaborada pelo governo municipal para a área. Com o esvaziamento do $\mathrm{CHS}$, ocasionado pela transferência das instituições do Governo Estadual para o Centro Administrativo da Bahia, construído na Avenida Paralela, o município propõe o Projeto CAMI - Centro Administrativo Municipal Integrado. O Projeto prevê a transferência das sedes dos órgãos do governo municipal para a área central, apostando que a requalificação da área seria uma decorrência do processo. (CARDOSO, 2010, p. 66) Mas apenas a restauração do Solar São Dâmaso, para abrigar o Arquivo Público Municipal, foi executada.

A partir de 1986, com a eleição do prefeito por eleição direta, o governo municipal cria um ambicioso programa com o objetivo de recuperar o centro da cidade. O Programa Especial de Recuperação e Revitalização dos Sítios Históricos de Salvador (PERSH), busca recuperar o centro como área de trabalho, moradia, encontro e lazer da cidade, articulando a preservação do seu patrimônio arquitetônico, urbano paisagístico e cultural. Dentro de suas propostas está o Parque Histórico do Pelourinho (PHP), uma área de 30,8 ha, e se defende a ideia de Parque Construído, constituído de edificações e logradouros urbanizados. (CARDOSO, 2010) 
A partir desse quadro, a construção de um modelo de desenvolvimento a partir do turismo foi assumindo um caráter hegemônico na sociedade soteropolitana, tendo como base a ideia de vocação natural da cidade para o turismo. Assim, desde 1991, o governo estadual tem estimulado a indústria do turismo de forma nítida, tendo esta atividade econômica como um dos pilares para o desenvolvimento do estado. (MENDES, 2006, p. 199)

No auge do abandono, em 1992, se insere a área num grande projeto de reestruturação intitulado Projeto de Reforma e Recuperação do Centro Histórico de Salvador, do Governo do Estado, cuja execução se realiza por meio de diversas desapropriações, fundamentada sob o indeterminado conceito jurídico de "utilidade pública". O Estado usa esse instituto público invocando a propriedade sobre bens tombados para dar uso privado, atendendo assim aos interesses da especulação imobiliária. No fundo, se descartam os grupos indesejáveis, descartáveis por sua posição social e, em seu lugar, impõe uma cultura folclorizada da baianidade, com amostras dos modos de viver no local. (PUGLIES, 2005)

Após tirar a titularidade dos prédios residenciais tombados e tomando-a para si, o poder público concedeu o uso dos imóveis a outros com destinação comercial. Aos empresários, que obtêm anistia de dívidas e incentivos fiscais, não interessam a manutenção das famílias nem dos grupos culturais, dos personagens históricos e suas tradições, pois esses não engendram o grupo dotado de potencial de consumo.

O programa de restauro, dividido em sete etapas, envolve medidas urbanísticas que partem de um zoneamento de quarteirões inteiros cuja recuperação envolve quase mil imóveis, o saneamento básico (água, esgoto, fiação de luz, telefone, cabos de internet etc.) da zona contemplada e o cadastramento dos habitantes num total de quase 4 mil pessoas. O Projeto do IPAC, ainda foi apoiado pelo IPHAN e pelo Banco Nacional de Desenvolvimento Econômico e Social (BNDES).

A partir de 1993, quando se conclui a primeira etapa de intervenção no Pelourinho, inicia-se a intervenção maciça por parte do Governo Estadual justificada pela necessidade de atender à demanda em atrair o maior número de turistas para a cidade. A mudança vem de cima. O Estado intervém no espaço público para transformá-lo em shopping e área de lazer impondo uma nova dinâmica de uso, mediante a expulsão da população tradicional e dando subsídios para as novas funções culturais e comerciais turísticas. (MUÑOZ, 1999) 
As novas funções favorecem a concessão de créditos para lojas de artesanato, butiques, joalherias, restaurantes, cafés, bares, entre outros. O Estado e o Município instalam bancos, escolas primárias e profissionalizantes bem como instituições públicas (IPAC, Museu da Cidade e outros), correio, posto de saúde e de polícia. O trânsito dentro do Pelourinho se limita se são construídos estacionamentos privados, sendo um deles com sete andares para carros, acessível pela Baixa dos Sapateiros, dando acesso ao pedestre na Rua das Laranjeiras. Planos inclinados e o elevador Lacerda são recuperados para facilitar a ligação entre Cidade Alta e Baixa. Ao mesmo tempo, a discussão do Plano Estratégico para a cidade de Salvador incluiu intervenções de privatização do espaço público para o lazer dirigido e pago dos parques temáticos, como política municipal de concessão de áreas públicas. Água, shopping, alimentação e exotismo produzindo uma alegoria do outro, uma cidade que se transforma em alegoria do visitante, seja ele estrangeiro ou nacional. Áreas de recuperação urbana, como a recente na orla da Barra, produzindo, assim como nas cores do Pelourinho, um cenário ao visitante. (VICENTINI, 2001)

As intervenções se valem de disposições patrimoniais, atendendo ao apelo do mercado imobiliário e do turismo. Em ambos os casos a manutenção das populações originais não foi uma premissa das intervenções. Com a indenização de 99\% dos inquilinos da área e a mudança realizada em caminhões da Prefeitura para áreas da periferia, a recuperação do Centro Histórico representa uma operação duvidosa do ponto de vista social e cultural.

Essa política do governo baiano é, até hoje, constantemente citada como o exemplo brasileiro mais bem acabado de preservação do patrimônio histórico que provocou elitização, exclusão da população mais pobre e a reprodução de desigualdades sociais. (CANTARINO, 2005)

Sem estudos mais profundos que determinassem a solução de problemas estruturais da decadência do centro, surgem muitas dificuldades para a implantação e manutenção do modelo adotado e, a partir de 1999, mudanças são necessárias no programa. Se antes a ideia era criar um shopping ao ar livre, com o critério político mais do que econômico na escolha da exploração dos empreendimentos instalados que logo fecharam suas portas, agora a habitação ganha força nas mudanças feitas no programa em 1999. Sendo assim,

A recuperação do Centro Histórico da cidade aparecia então como uma importante alternativa para o incremento das atividades turísticas em Salvador, ao ser levado em conta, uma tendência internacional, que via na cultura, uma vertente com grande capacidade de agregar valor ao 'produto turístico' a ser disponibilizado no mercado. (CARDOSO, 2010, p. 68) 
A sétima etapa de intervenção no Pelourinho conta com a participação do Programa Monumenta ${ }^{7}$ e da Caixa Econômica Federal, tendo com foco prioritário, a habitação, sendo previsto um total de 332 unidades habitacionais distribuídas em 76 casarões. (GORDILHO, 2010, p. 93) Com a participação desses novos agentes e por se estruturar em estudos técnicos, essa etapa pode ser considerada um avanço, se comparada com as anteriores.

\section{Dois centros diferentes}

Preservar e restaurar bens não quer dizer cristalizá-los como peças ou museus. O cerne da questão é justamente a forma de dar uso aos bens preservados sem retirar o significado destes. Ao proteger os bens culturais de uma sociedade, visa-se na realidade preservar-Ihe a identidade cultural, pois, ao perder ou ver alteradas expressivas manifestações arquiteturais e paisagísticas, o indivíduo perde também os referenciais que permitem sua identificação com a cidade em que vive, em especial quando tecidos antigos são arrasados e novos objetos urbanos passam a compor a paisagem, com maciças alterações na escala do lugar. (LIMA, 2005)

Diante das duas políticas diferentes, em relação aos seus Centros Históricos, os resultados podem ser considerados antagônicos. No Rio, cada vez mais a população da cidade, os cariocas da gema, ${ }^{8}$ conhecem seu centro e voltam a frequentá-lo, não só em horário comercial, mas também pela noite, nos fins de semana, ocupando espaços públicos e privados, trazendo para o Centro a vida animada do resto da cidade. Já em Salvador, a população soteropolitana cada vez mais se afasta do Centro, não mais se reconhece nas ruas centrais e deixa-o para os turistas que se encantam com as ruas de um parque temático, que reproduz a cidade do século XVIII.

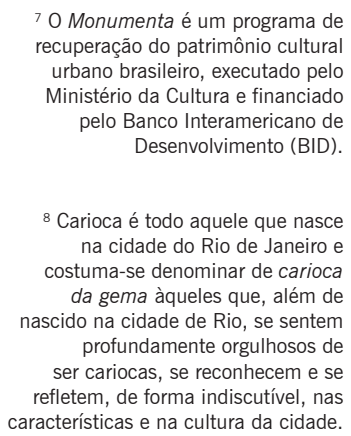

${ }^{7}$ O Monumenta é um programa de recuperação do patrimônio cultural urbano brasileiro, executado pelo Ministério da Cultura e financiado pelo Banco Interamericano de Desenvolvimento (BID).

${ }^{8}$ Carioca é todo aquele que nasce na cidade do Rio de Janeiro e costuma-se denominar de carioca da gema àqueles que, além de nascido na cidade de Rio, se sentem profundamente orgulhosos de

ser cariocas, se reconhecem e se refletem, de forma indiscutível, nas características e na cultura da cidade.

\section{Rio de Janeiro}

E o Centro revitaliza-se. Fazendo uma paródia da famosa expressão que foi usada no início do século XX, para ilustrar a construção da Av. Central, o centro da cidade vive hoje uma nova fase. São diversos empreendimentos imobiliários, como hotéis, novas construções residenciais e comerciais, novos bares e restaurantes que ilustram o grande potencial econômico e residencial 
que o Centro da Cidade, conhecido pela sua boemia, há muito resgatou.

(REVITALIZAÇÃ̃...., 2007)

O desenvolvimento do projeto Corredor Cultural se divide em quatro períodos - implantação, consolidação, estruturação (incorporação dos espaços públicos e das melhorias incrementais) e integração. A área denominada de Corredor Cultural apresenta uma população usuária de cerca de 2 milhões de transeuntes, pertencentes a diferentes camadas sociais, que circulam nas avenidas, ruas, praças e becos, onde edifícios de diferentes períodos abrigam usos comerciais e institucionais diversos. 0 poder público municipal investiu maciçamente nas obras de requalificação urbana, reurbanizando ruas, largos e praças e investindo na iluminação dos edifícios mais significativos. (LIMA, 2005) (Fig. 80 e 81 , ver caderno de imagens)

Um comércio de qualidade, principalmente na área da moda e livrarias, volta a se instalar nas ruas do Centro, atraindo não só a população que trabaIha na região, como também aqueles que frequentam as diversas instituições culturais e de lazer. Teatros e cinemas são reformados, modernizados e reabertos, além de novas salas que se abrem principalmente nos muitos centros culturais. Muitos bares e restaurantes, que antes fechavam suas portas ao final do expediente, agora mantêm suas atividades à noite, com happy hours e música, mesas na calçada e muita animação. O movimento nos fins de semana, pouco a pouco, vai crescendo em função da abertura das galerias de arte, centros culturais, bares, restaurantes, cinemas e teatros.

No caso da Lapa, área residencial no centro do Rio que sofreu um forte processo de decadência tem seu cotidiano transformado quando volta o interesse do público, principalmente, vinculados com a área da música. Em 2000, se cria o Distrito Cultural da Lapa e inicia-se o processo de restauração dos prédios antigos. (Fig. 82, ver caderno de imagens)

A novidade da revitalização da Lapa é ela acontecer pela vontade da iniciativa privada. Casas de espetáculo, bares e atividades culturais atraem jovens de variadas idades e de perfis socioeconômicos distintos. 0 samba divide espaço com o hip hop, com o reggae, com o rock'n roll e com a música eletrônica. (DURÃES, 2007) O acesso fácil, tanto da Zona Norte como da Zona Sul possibilita a frequência de usuários de distintas classes sociais e oriundos dos mais diversos bairros.

Outra consequência da revitalização da Lapa é o retorno dos empreendimentos imobiliários voltados para a classe média, atraindo inclusive, empresas de outros estados. Por exemplo, o empreendimento Cores da Lapa foi um sucesso de vendas, com seus 668 apartamentos vendidos rapidamente. 
(SIRKIS, 2005) Com isso, começa um processo de requalificação do comércio, uma melhora dos serviços e dos espaços públicos. Apesar de algumas críticas do tipo de empreendimento, que muito lembra os condomínios fechados da Barra da Tijuca, é o incentivo à moradia que demonstra a vitalidade da área.

A área portuária e os bairros adjacentes também já sentem as mudanças após algumas intervenções realizadas, como a instalação da Cidade do Samba e o uso de antigos armazéns para festas, desfiles de moda etc, além da atuação de ONGs locais. Atualmente, para a área portuária, desenvolve-se o projeto Porto Maravilha, cuja principal intervenção é a retirada do viaduto da Perimetral que corta a zona por cima da Avenida Rodrigues Alves.

\section{Salvador}

Após os primeiros investimentos de revitalização da região do Pelourinho, no início dos anos 1990, com clara intenção de transformá-la em área essencialmente turística, como já foi dito anteriormente, começa-se a notar um esvaziamento do local por parte da população residente na cidade, seja pela dificuldade de acesso - uma vez que os ônibus urbanos não chegam até ali - seja pelo deslocamento da população que antes habitava os casarões restaurados. A preferência por um local turístico, de lazer, que pouco incentiva a presença dos soteropolitanos, se reflete hoje, quando apenas as classes de renda mais baixa e alguns intelectuais ainda frequentam as ruas do Pelourinho, principalmente em dias de festa e shows, mas não no dia a dia. (Fig. 83, ver caderno de imagens)

Após a intervenção, o ímpeto esteticista adotado no Pelourinho, a partir dos anos 1990, desfigura os velhos rostos e símbolos do Centro - pequenos comerciantes, sapateiros, prostitutas, músicos, capoeiristas, terreiros - para imprimir-Ihe uma nova imagem - empresários, donos de joalherias, casas de show, franquias de lojas de grifes, restaurantes etc. Mas esses novos usos e franquias, destinados a uma classe de renda mais alta, pouco a pouco se retiram e não resta muito dessa primeira ocupação pós-reforma. A população a qual se destinam esses empreendimentos não adota as ruas reformadas do Pelourinho como seu espaço de compras e lazer, preferindo um dos tantos shoppings centers construídos em outras áreas da cidade.

Por outro lado, no Pelourinho as fachadas, pintadas de um colorido excessivo, deterioram-se rapidamente, haja vista a má qualidade das obras 
de recuperação. Já os moradores expulsos, também não tardam a voltar a circular pelas ruas, como pedintes, ambulantes, vendendo drogas aos turistas ou prostituindo-se.

Após quase 20 anos do início da sua execução, dividido em sete etapas, o Projeto de Reforma e Recuperação do Centro Histórico mantém os seus contornos iniciais, visando a atração de grandes empreendimentos voltados para a indústria do turismo em detrimento da preservação dos habitantes. $\mathrm{Na}$ decisão de criar uma representação da história para o Centro, os nativos da terra se exibem em shows ou andando pelas ruas, fantasiados ao gosto do turista, exóticos e pitorescos, sempre prontos para uma foto

[...] de uma cultura vilipendiada na sua autenticidade e na sua espontaneidade. [...] O Centro Histórico de Salvador que o Governo do Estado planejou é uma fábula: o Pelô da fantasia, o museu para o turista, sem conflitos, sem drogas, sem violência. (PUGLIES, 2005)

Hoje ainda se encontram galerias de arte, lojas de artesanato, ONGs variadas, museus e bares com mesas de plástico no meio da rua. A população residente em Salvador, normalmente, ao frequentar as ruas do Centro Histórico, se sente turistas em sua própria terra. (Fig. 84, ver caderno de imagens)

No caso do Comércio - que até meados dos anos 1970, tinha suas ruas fervilhando com lojas de eletrodomésticos, moda, decoração, tabacarias e bancos - e que já assegurou a Salvador o título do mais importante entreposto comercial do Atlântico Sul. O que era um verdadeiro shopping center ao ar livre, muito antes de o conceito ser introduzido entre os baianos, perde importância no contexto urbano. O Comércio, dessa forma, misturando construções de diferentes períodos permitindo uma viagem pelo passado arquitetônico da cidade, também revela como políticas públicas equivocadas podem encerrar prematuramente, um ciclo de prosperidade. Hoje o local não é mais o centro financeiro da capital e do Estado que se transferiu em direção à Avenida Tancredo Neves e a região do Iguatemi de onde convergem novos bairros. Em seu traçado ortogonal, encontramos uma sucessão de edifícios destruídos pelo tempo, prédios que retratam uma era, boa parte dos quais semiocupados ou inteiramente vazios. (Fig. 85, ver caderno de imagens)

Pelos últimos números da Associação dos Empresários do Comércio são 101 prédios abandonados ou vazios. A prefeitura, por sua vez, no final de 2008 constata que, dos 252 imóveis precários ou em processo de deterioração na área histórica da cidade (entre o Largo Dois de Julho e a Cidade Baixa), 113 estão situados na área do Comércio. 
Hoje ainda vemos as ruas do Comércio, assim como a Baixa do Sapateiro e a Avenida Sete de Setembro, fervilhando de pessoas que vão e vêm o tempo todo. $\mathrm{O}$ que mudou nessas regiões foram os tipos de serviços oferecidos e a mudança no tipo de comércio, cada vez mais dirigido a uma classe social de menor poder aquisitivo.

\section{0 anos depois}

Após 100 anos das reformas urbanas realizadas nos centros das cidades do Rio de Janeiro e Salvador, como andam suas avenidas, símbolo da modernidade no início do século XX?

No Rio, a Avenida Rio Branco, que comemorou 100 anos em 2005, mantém sua dinâmica de principal avenida. Sendo considerado o segundo centro mais importante do Brasil, a área central do Rio mantém suas ruas congestionadas de transeuntes, ornadas tanto por edificações remanescentes da sua abertura quanto por construções do século XXI. No seu entorno, o comércio de luxo, os restaurantes finos, livrarias, confeitarias e muitos centros culturais voltam a fazer parte da vida do Centro, trazendo frequentadores de todas as partes da cidade.

Por outro lado, a Rua Chile, que fará 100 anos em 2015, perde o glamour para novas áreas da cidade. Seu comércio fino, suas livrarias e confeitarias, hoje estão nos inúmeros shoppings centers espalhados pela área urbana de Salvador. A Avenida Sete de Setembro, a principal intervenção realizada na reforma de J. J. Seabra perde seu posto para nova Avenida Tancredo Neves, deslocada do centro urbano tradicional de Salvador, e para outros bairros soteropolitanos. 0 mesmo aconteceu com a área do Comércio, onde se localizava o centro financeiro da capital e do Estado, quando suas antigas funções se estabelecem na região do Iguatemi, deixando para trás os prédios modernistas construídos nos anos 1940 e 50.

Assim, dois centros que no início do século XX têm características muito semelhantes 100 anos depois são dois centros com dinâmicas e funções bem diferentes. 



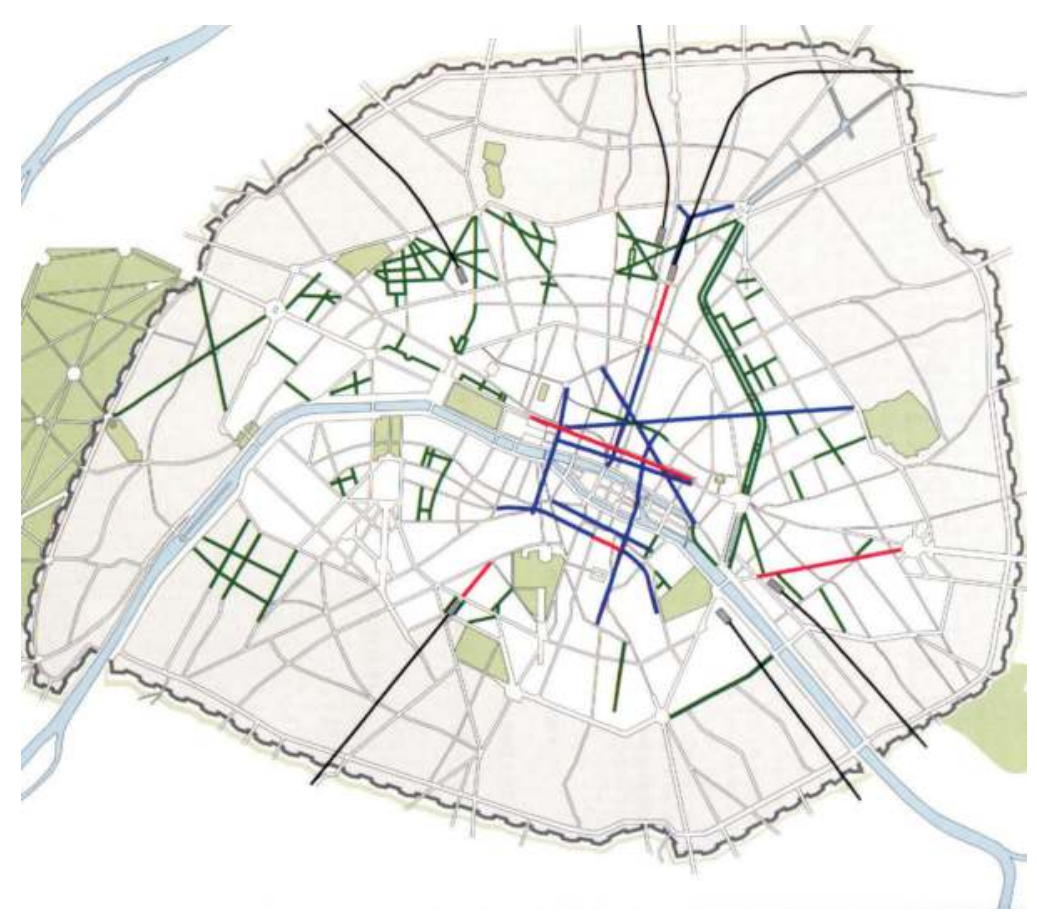

2. Intervenções realizadas em Paris entre 1815 e 1848, antes do período de Haussmann

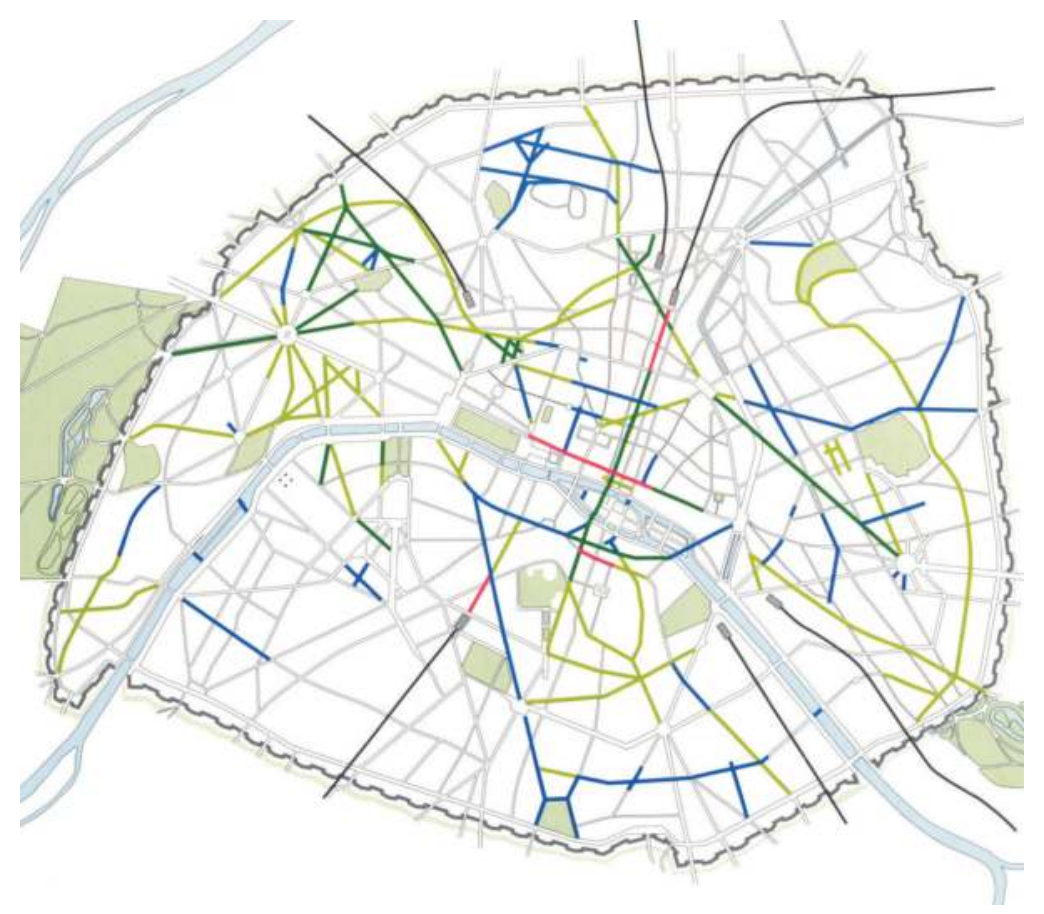

3. Intervenções realizadas em Paris de 1853 a 1870, durante o período de Haussmann 


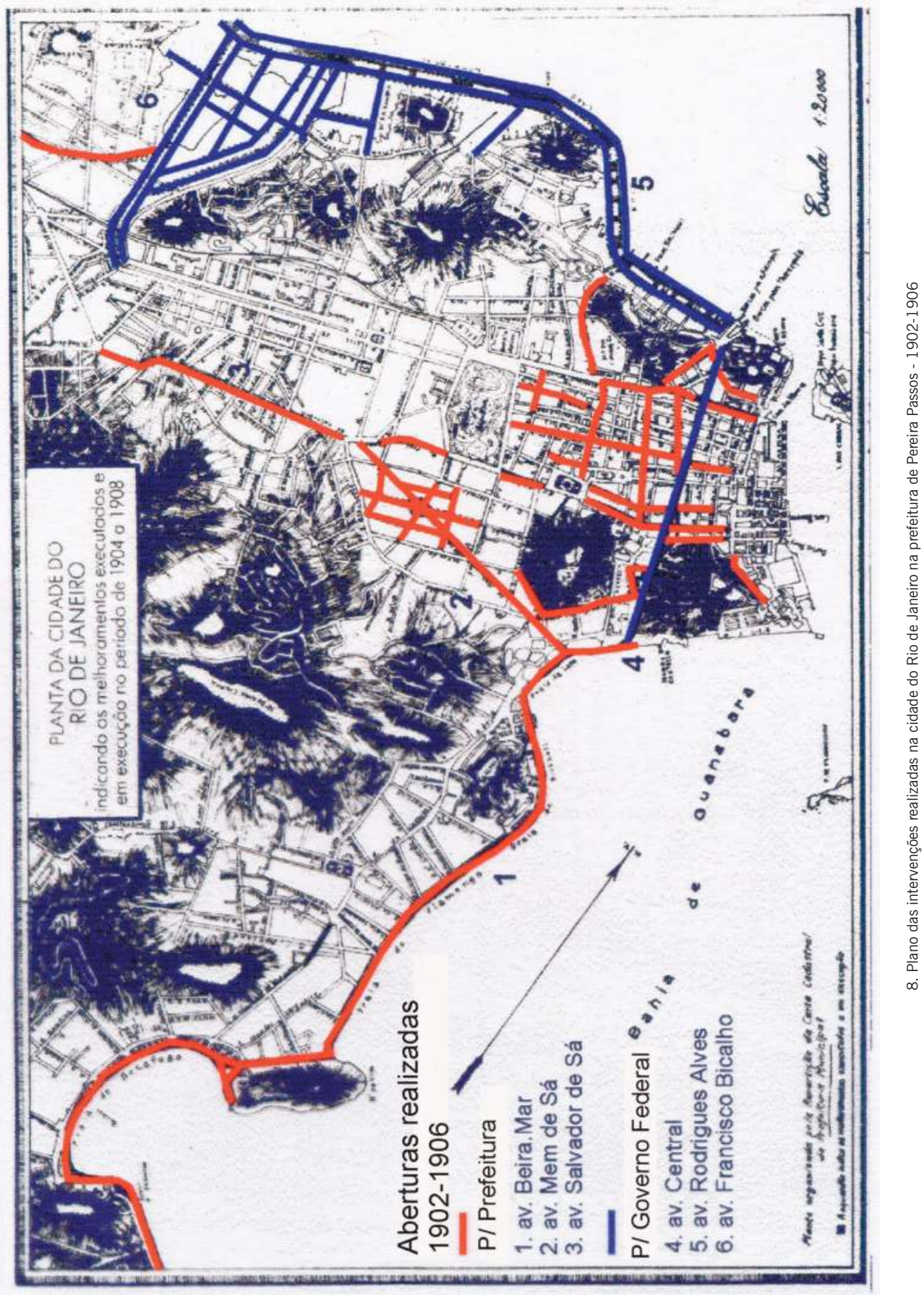




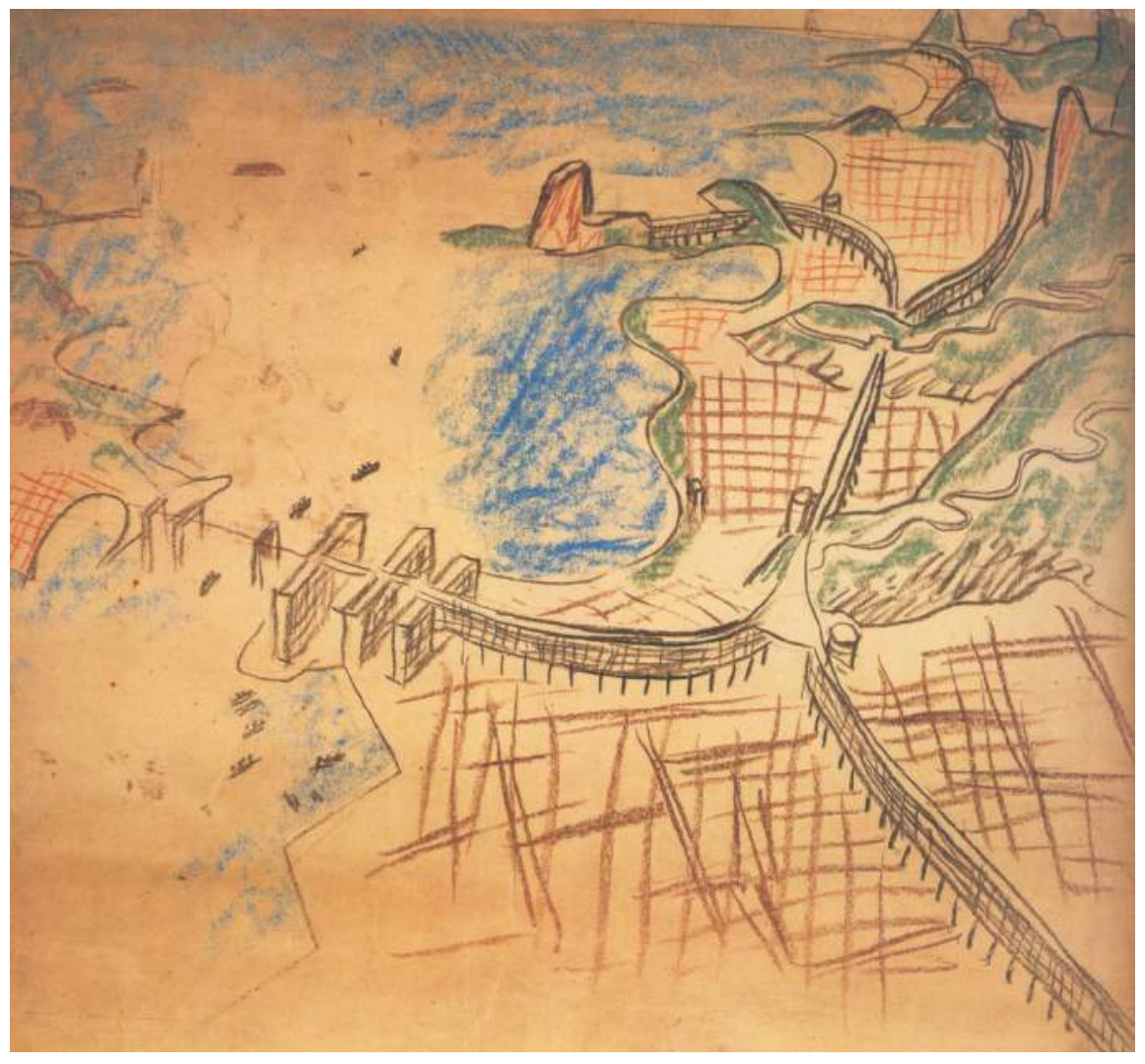

23. Esboço do projeto de Le Corbusier para o Rio de Janeiro - 1929

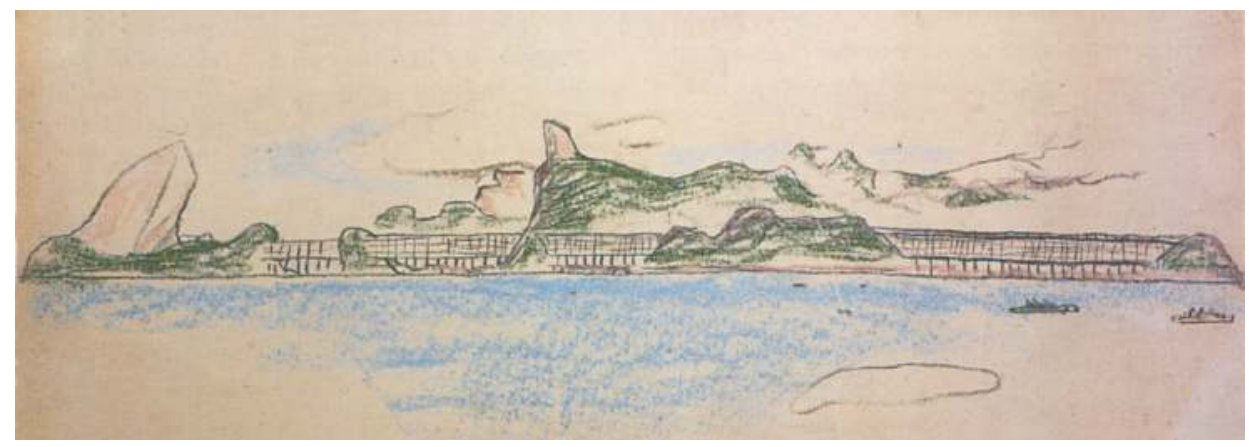

24. Elevação do projeto de Le Corbusier para o Rio de Janeiro - 1929 


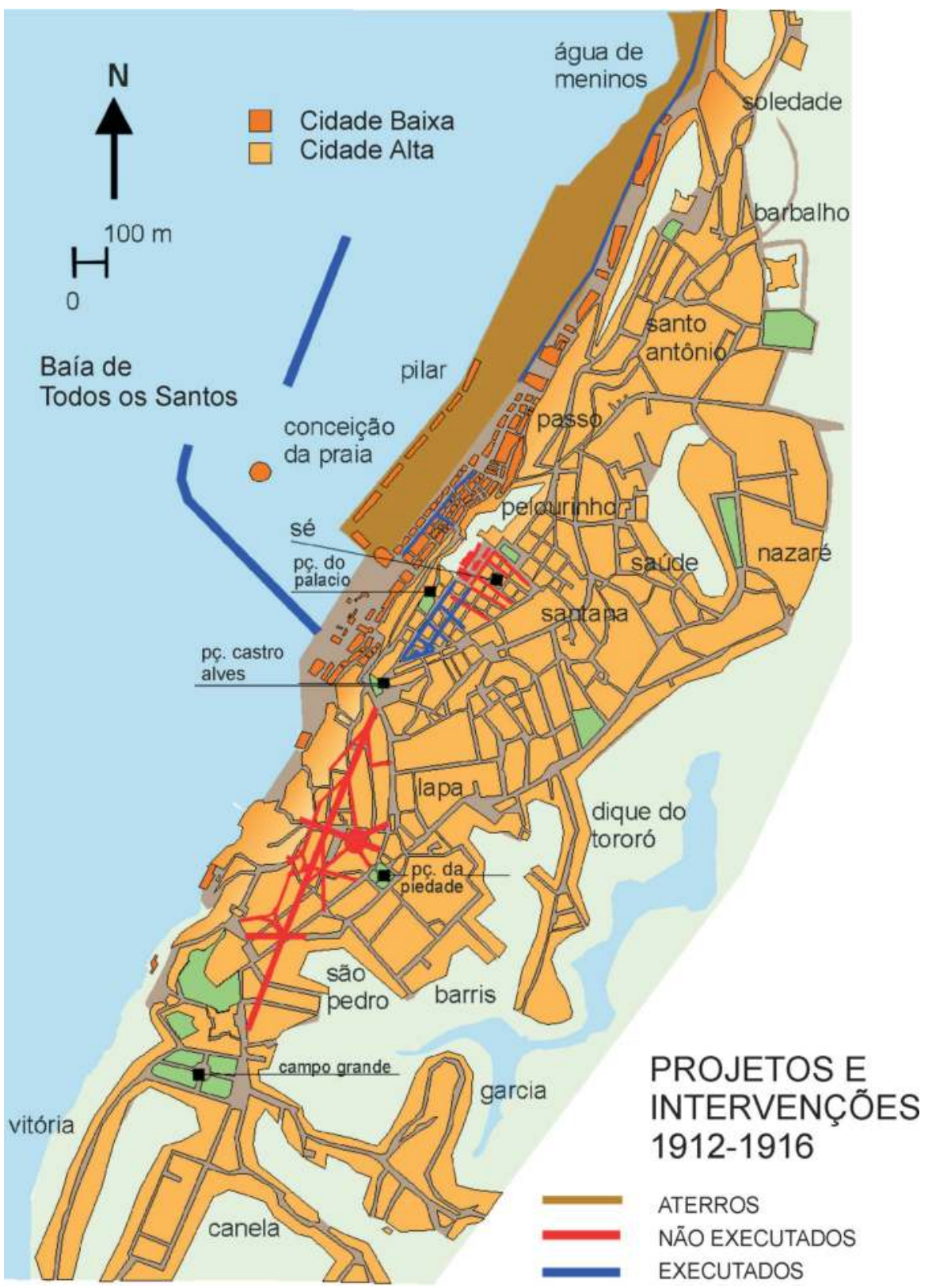

34. Projetos das intervenções propostas no governo de J. J. Seabra - Salvador - 1912-1916 


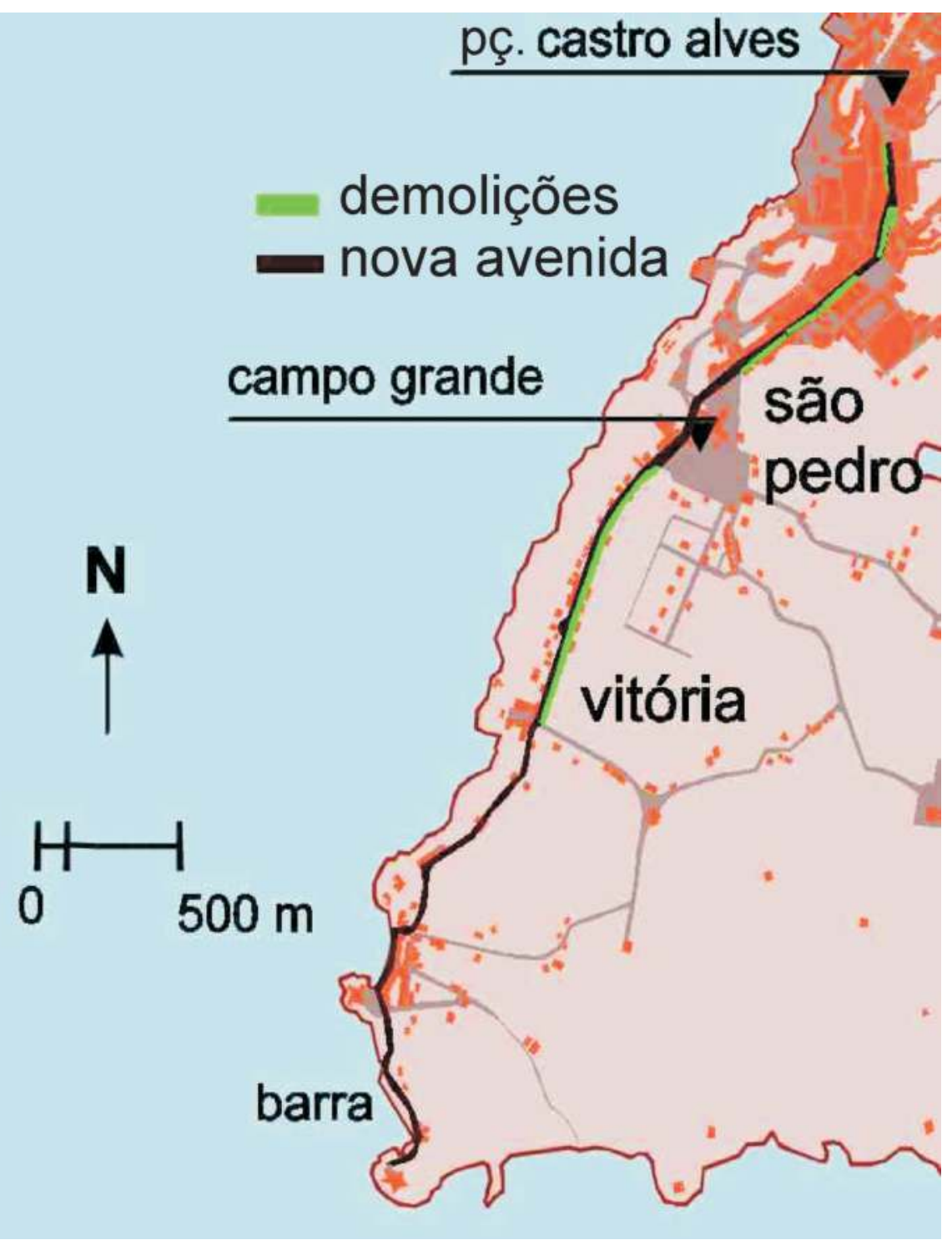

46. Projeto para a abertura da Avenida Sete de Setembro - Salvador - 1912-1916 


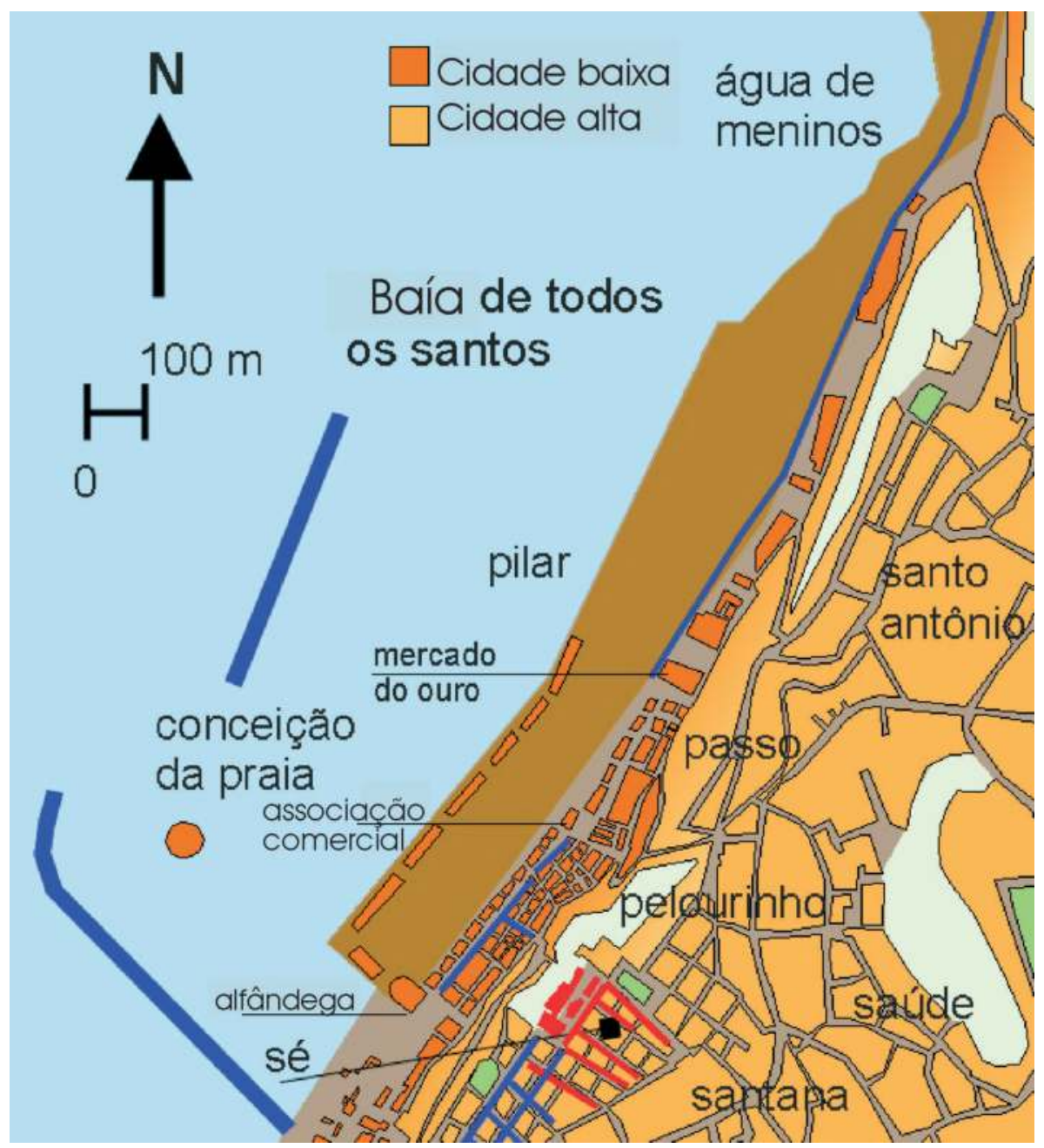

53. A Cidade Baixa e o porto de Salvador em 1920 


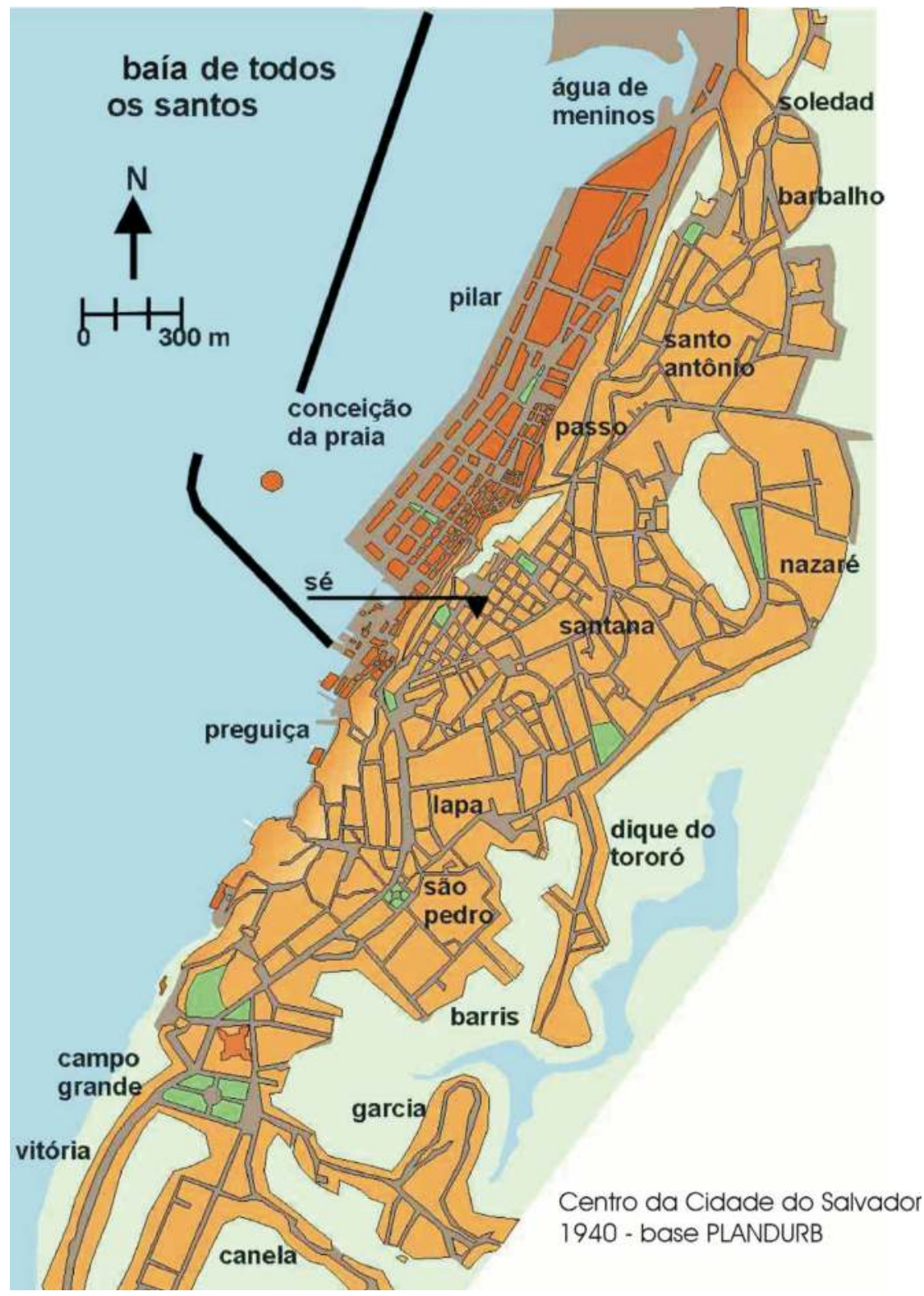

64. Planta do centro da Cidade do Salvador - 1940 

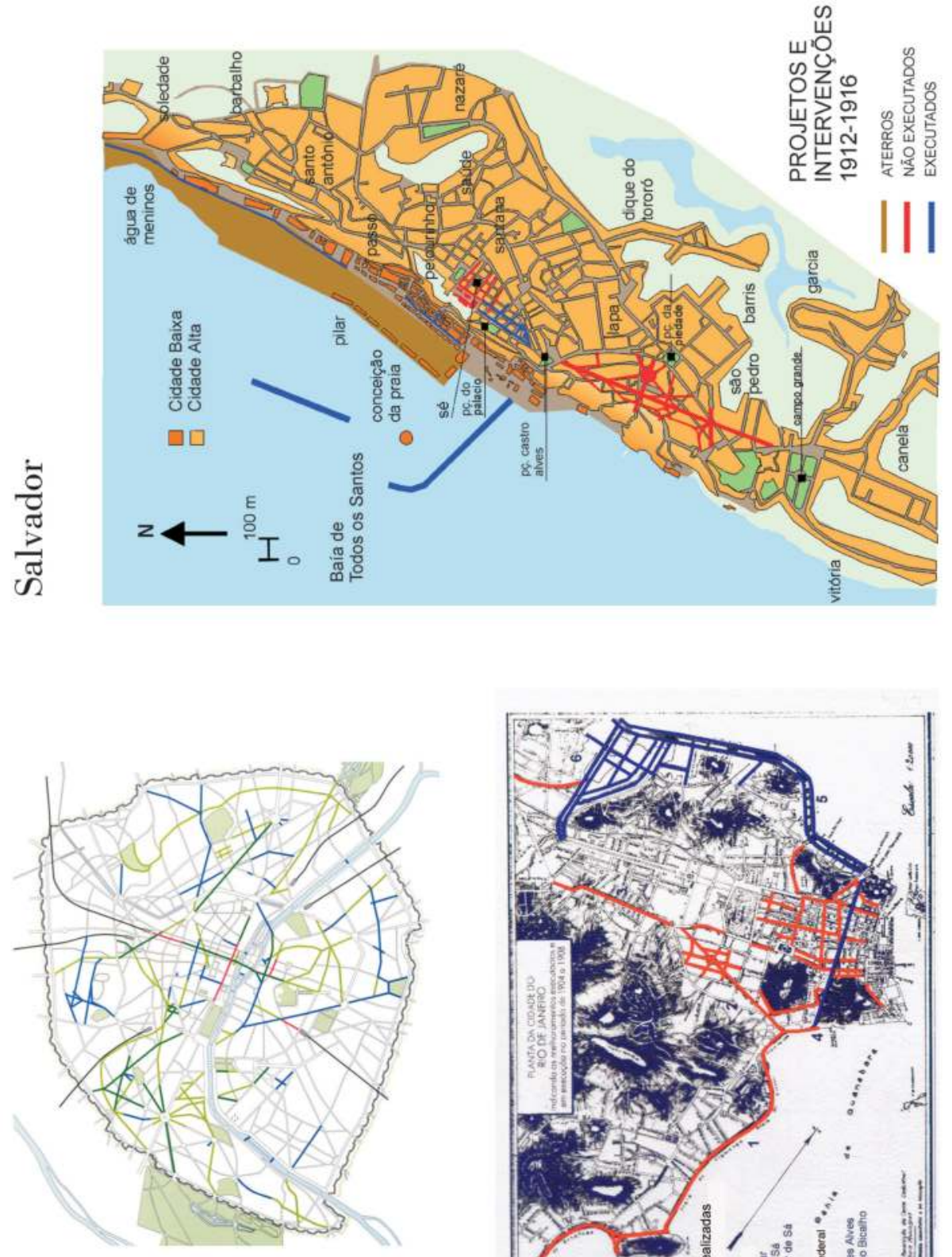

م

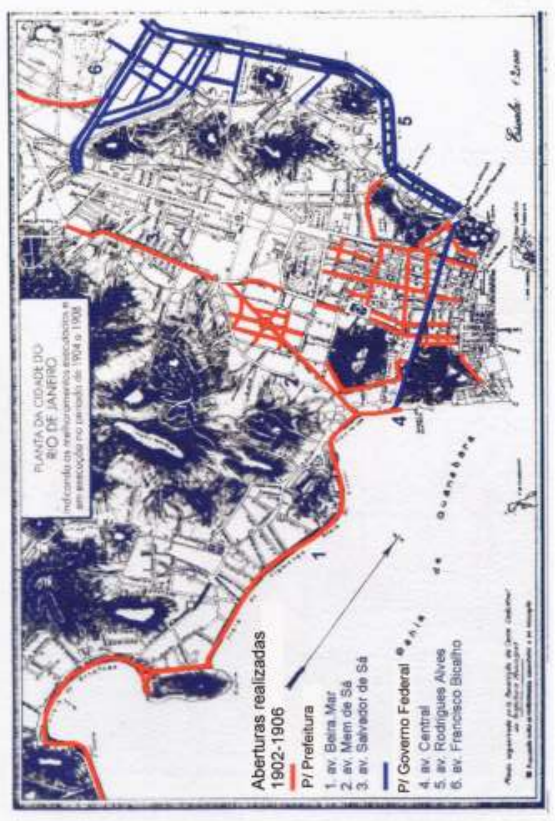




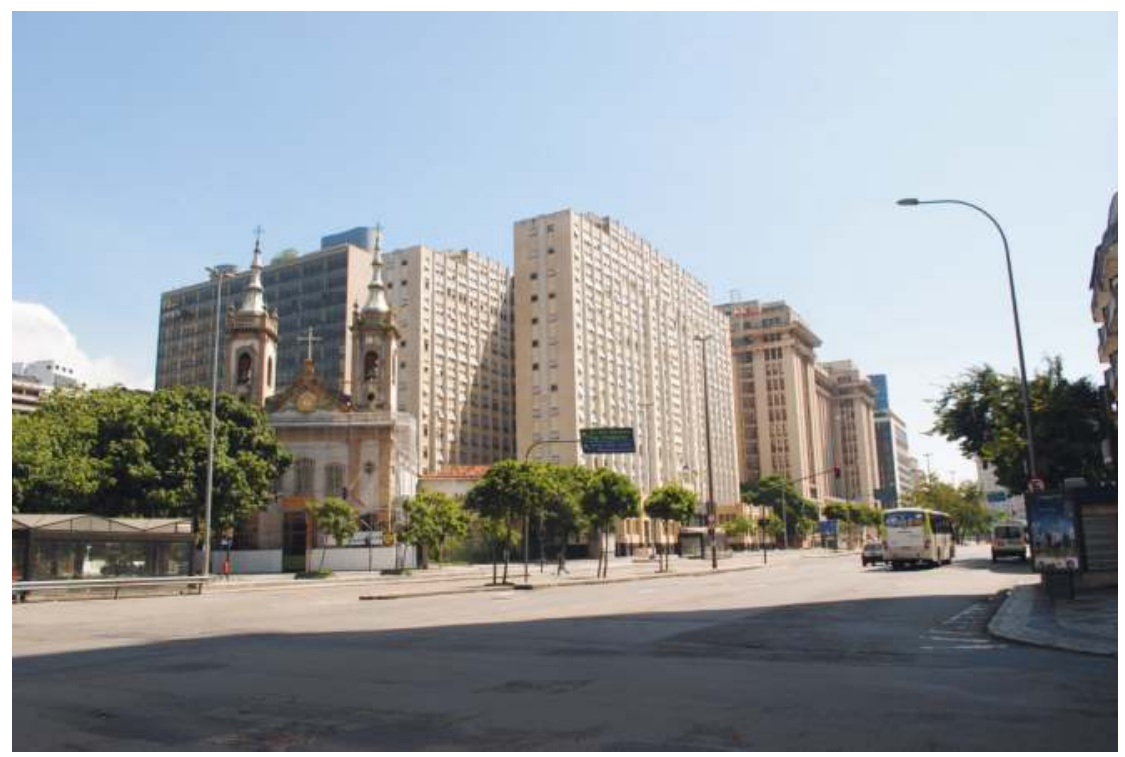

Figura 72. Centro do Rio após desmonte do Morro do Castelo

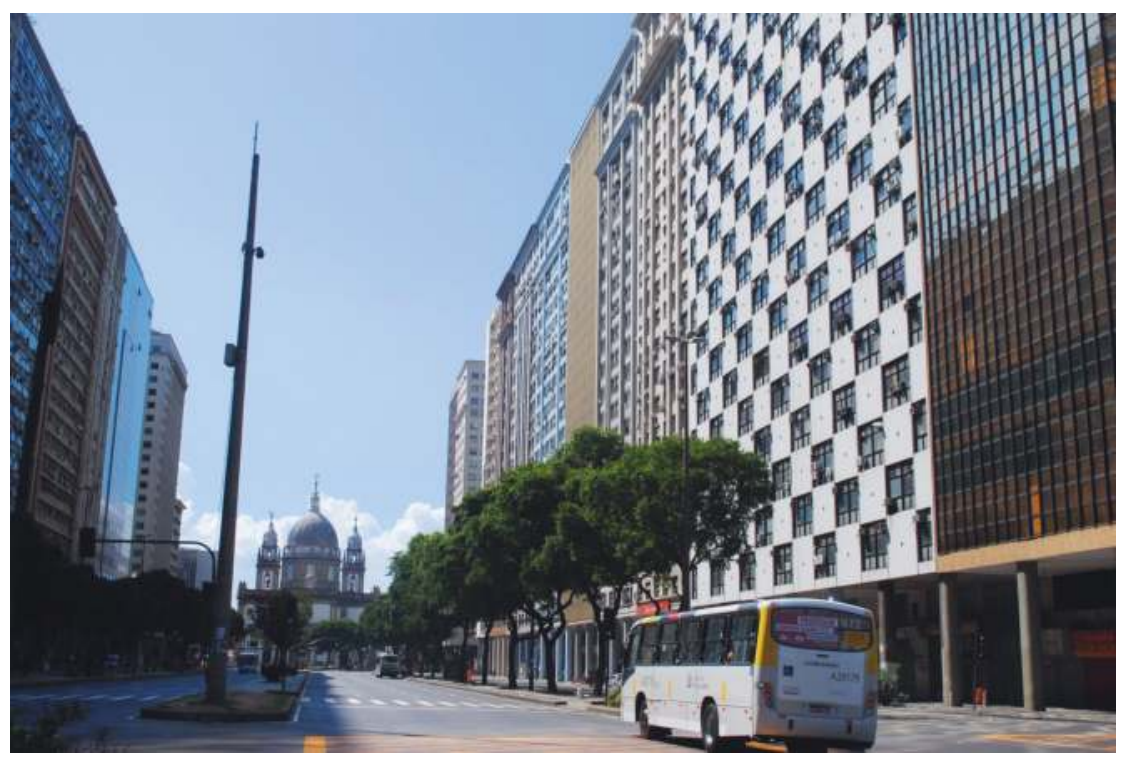

Figura 73. Vista da Avenida Presidente Vargas 

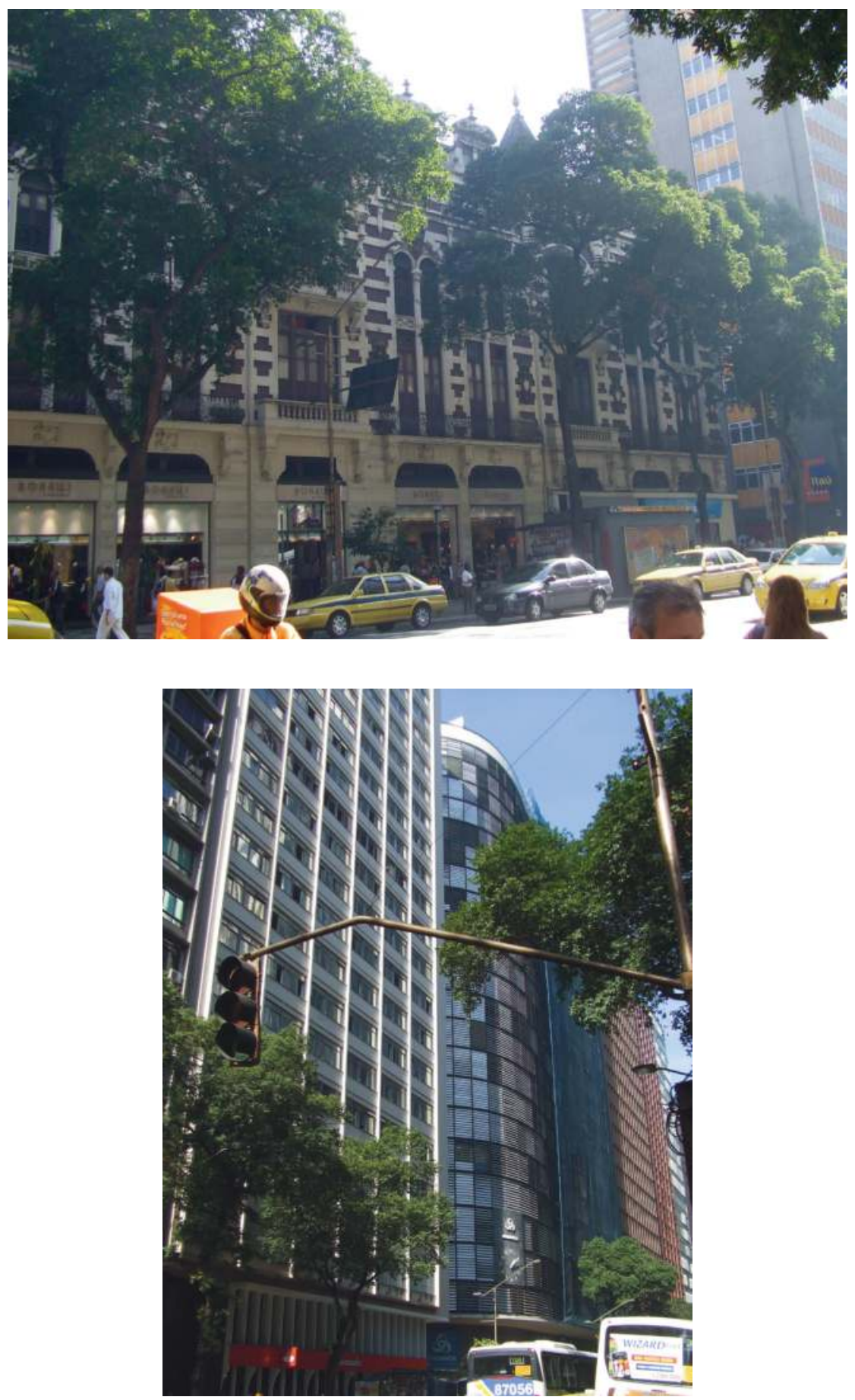

Figura 74 e 75. Prédios da Avenida Rio Branco 


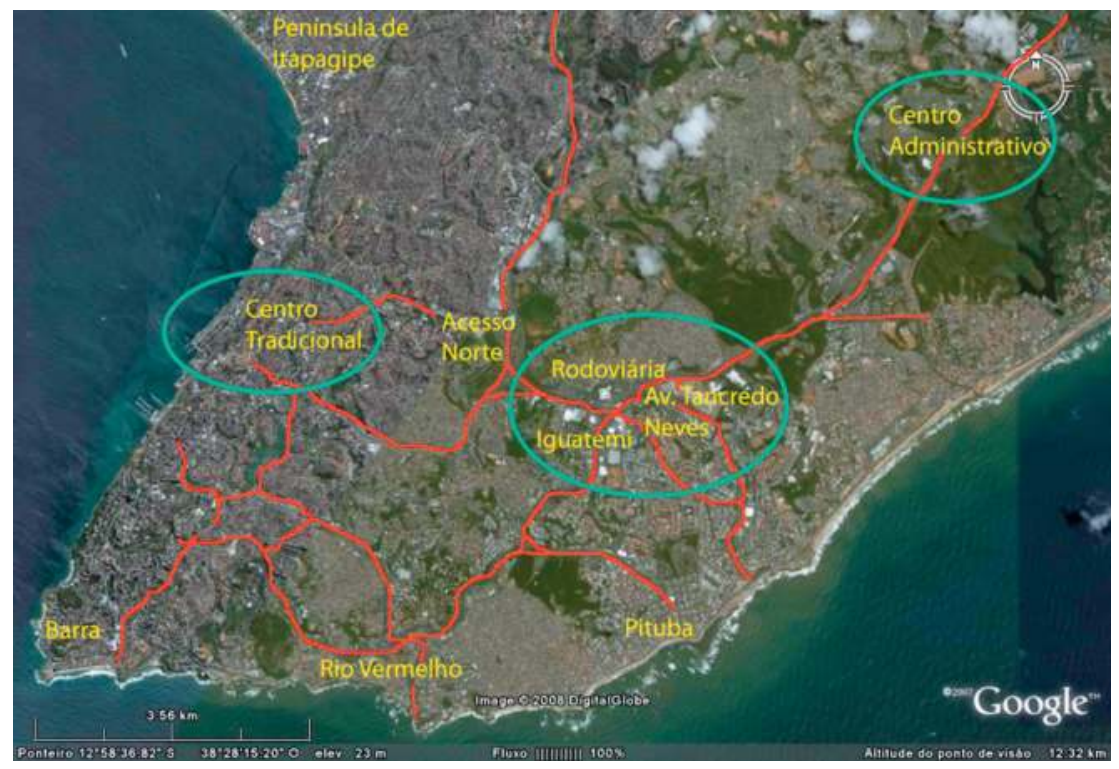

Figura 76. A Cidade de Salvador e seus centros e as avenidas de vale

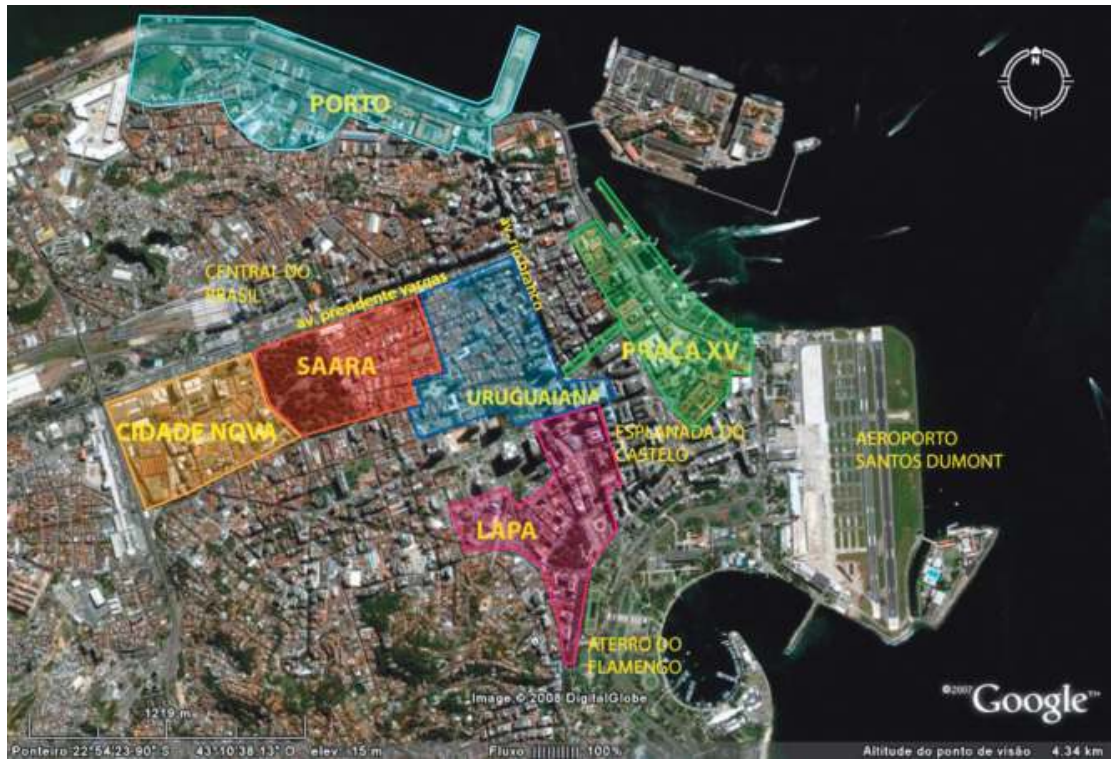

Figura 77. Áreas do Corredor Cultural e outras áreas de revitalização. 


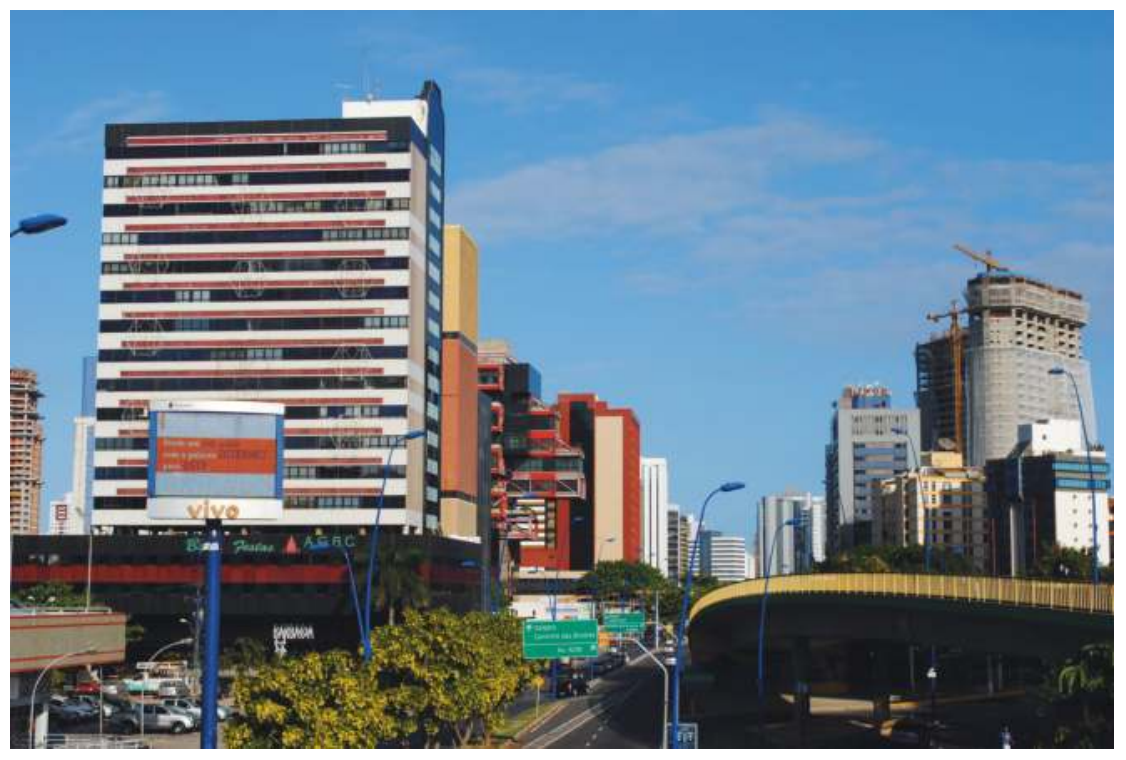

Figura 78. Avenida Tancredo Neves na região do Iguatemi atualmente

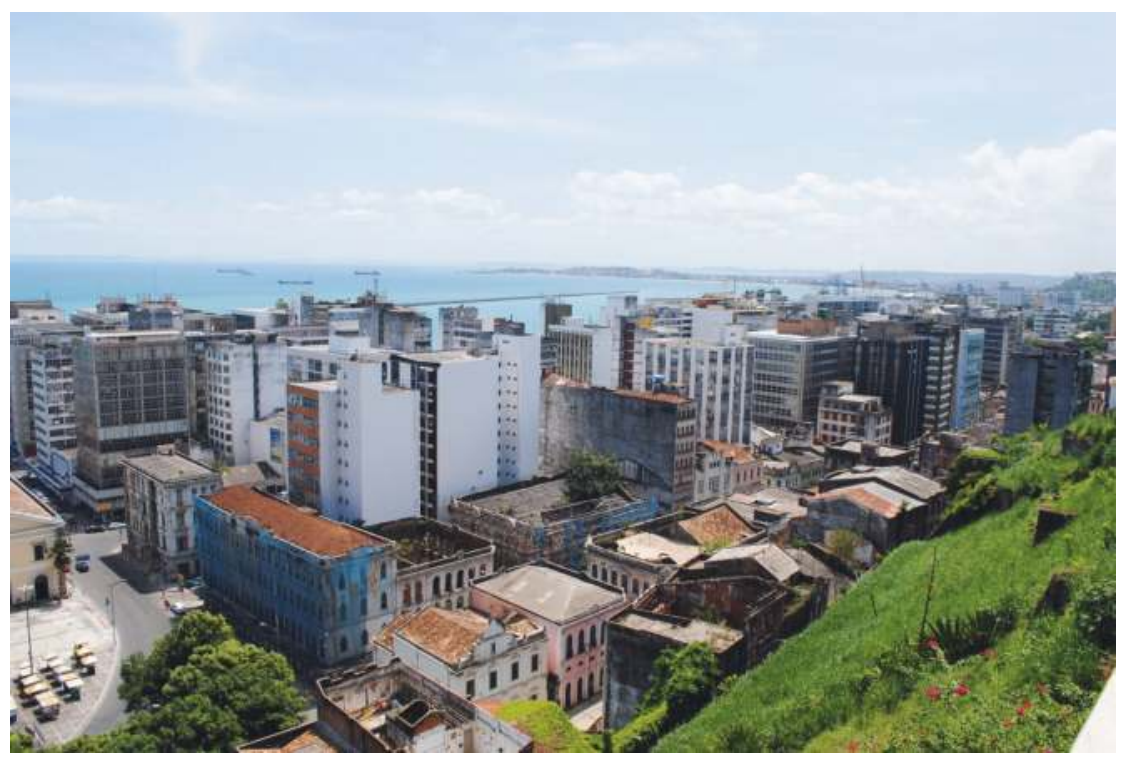

Figura 79. Vista atual do Comércio 

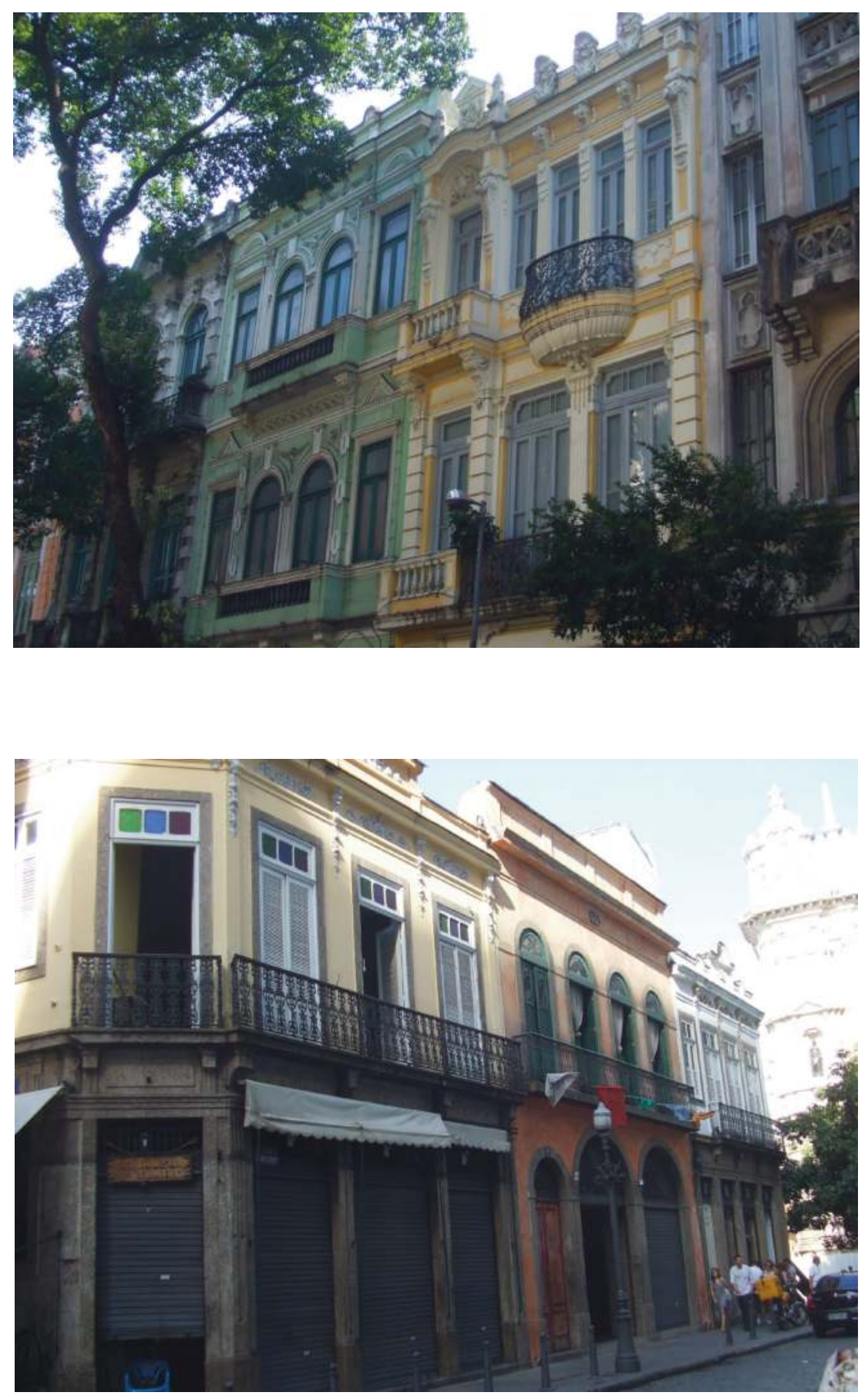

Figuras 80 e 81 . Espaços revitalizados - Rua da Carioca e Rua dos Mercadores 


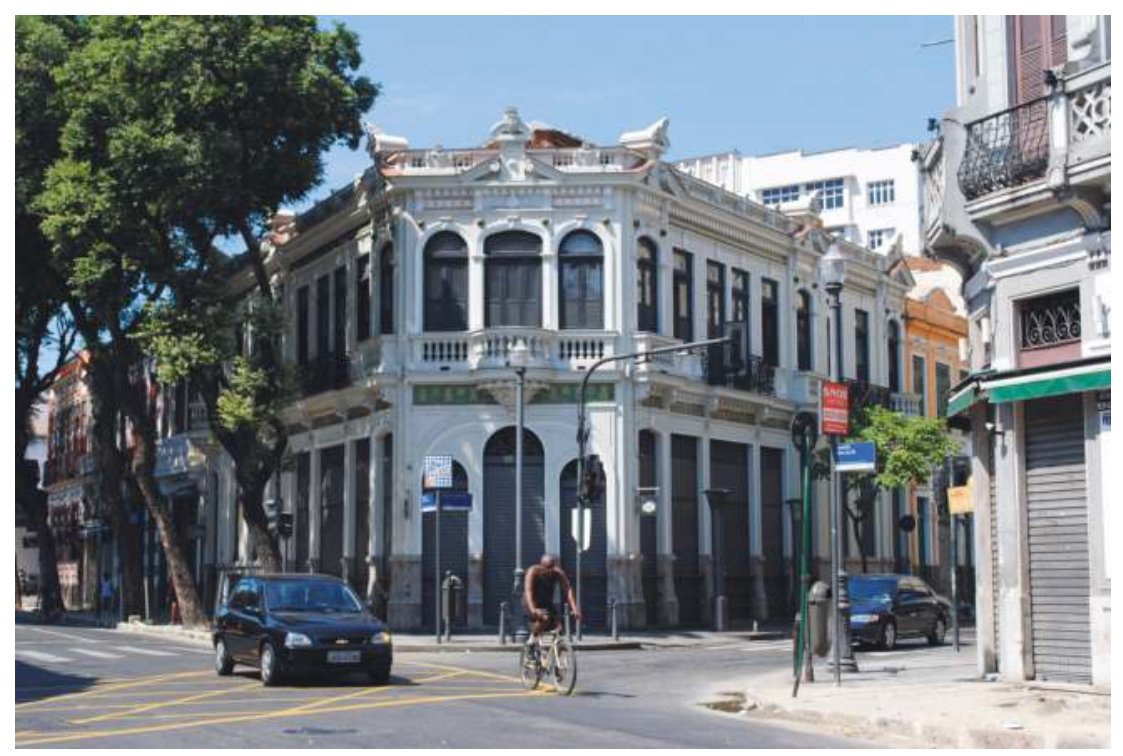

Figura 82. Prédios restaurados na Lapa

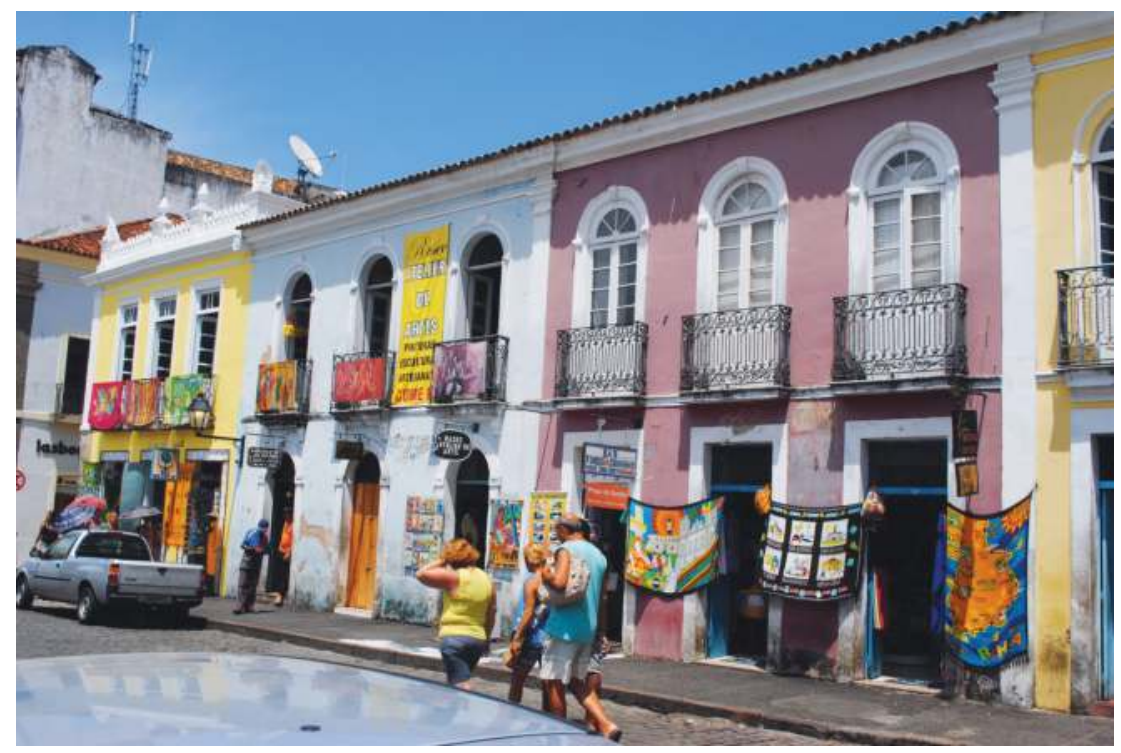

Figura 83. Típico comércio do Pelourinho 


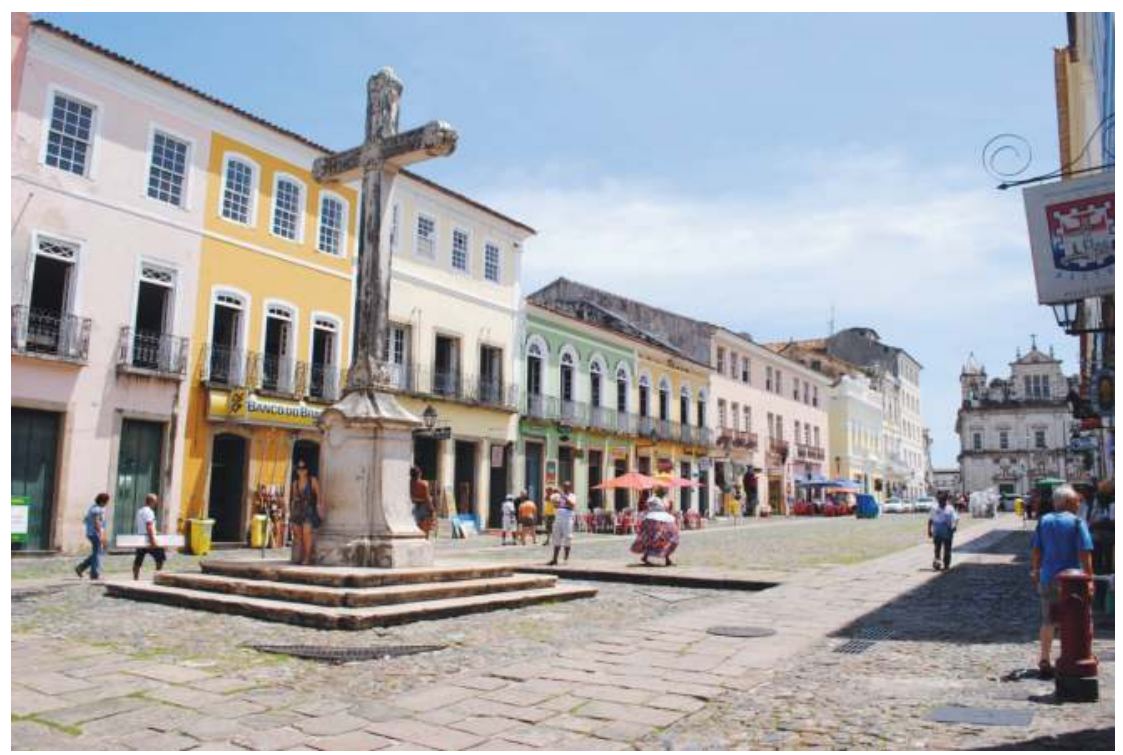

Figura 84. Vista do Cruzeiro de São Francisco e da Catedral ao fundo.

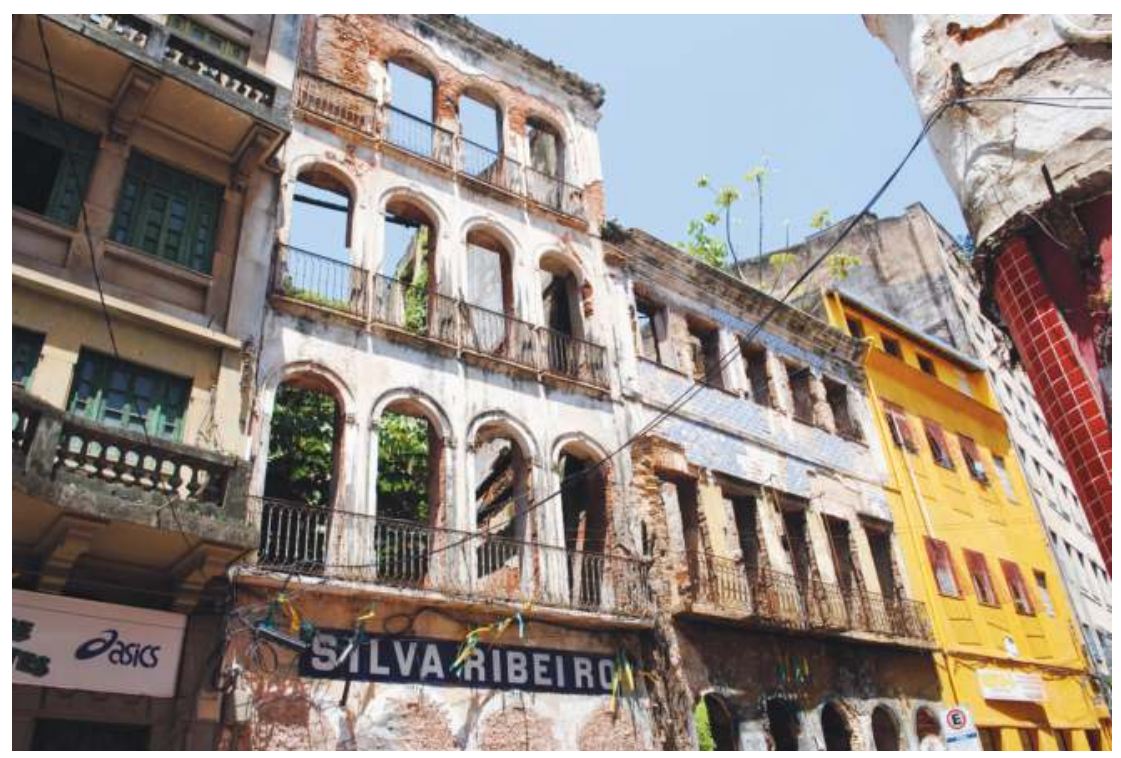

Figura 85. Vista de prédios abandonados no Comércio 



\section{Referências}

ABREU, Jayme Cunha da Gama e. Contribuição por melhoria. Arquivos da Universidade da Bahia. Escola de Belas Artes, Salvador, v. 2, p. 127-136, 1954/1955. Separata.

. Zoneamento nas Cidades. In: COMMISSÃO DO PLANO DA CIDADE DO

SALVADOR. "Semana de Urbanismo" 20 a 27 de outubro de 1935. Conferências. Bahia: Graphica da Bahia, 1937. p. 41-56.

ABREU, Mauricio de Almeida. Da habitação ao habitat: a questão da habitação popular no Rio de Janeiro e sua evolução. Revista Rio de Janeiro, Niterói, v. 1, n. 2, p. 47-58, jan./abr., 1986. 1988.

. Evolução urbana do Rio de Janeiro. 2.ed. Rio de Janeiro: IPLANRIO; ZAHAR,

Sobre a memória das cidades. In: V SEMINÁRIO DE HISTÓRIA DA CIDADE E DO URBANISMO. Campinas, 1998. Anais... Campinas: Pontifícia Universidade Católica. 1998. 1 CD

AGACHE, Alfred H. D. Cidade do Rio de Janeiro, extensão, remodelação, embellezamento. Tradução de Francesca de Souza. Paris: Foyer Brésilien, 1930.

ALCANTARA, Denise de (1); BARBOSA, Alexandre (2); RHEINGANTZ, Paulo A.(3). Percursos à deriva na investigação do lugar: 0 caso do Corredor Cultural, Rio de Janeiro. Anais do NUTAU, 2006.

ALMANDOZ, Arturo. European urbanism in Caracas (1870s-1930s). Planning History, Caracas, v. 18, n. 2, p. 14-19, 1996. 
ANDRADE, Carlos Roberto Monteiro de. Camillo Sitte, Camille Martin e Saturnimo de Brito: traduções e transferências de ideias urbanísticas. In: RIBEIRO, Luiz Cesar de Queiroz; PECHMAN, Robert. (Org.). Cidade, povo e nação: gênese do urbanismo moderno. Rio de Janeiro: Civilização Brasileira, 1996. p. 287-310.

A cidade como um corpo são e belo: o pensamento urbanístico do engenheiro Saturnino de Brito. In: FERNANDES, Ana; GOMES, Marco Aurélio A. de Filgueiras. (Org.). Cidade \& história: modernização das cidades brasileiras nos séculos XIX e XX. Salvador: MAU/FAUFBA; ANPUR, 1992a. p. 77-81.

A peste e o plano: o urbanismo sanitarista do eng. Saturnino de Brito. 1992b. Dissertação (Mestrado em Arquitetura) - Faculdade de Arquitetura e Urbanismo da Universidade de São Paulo, São Paulo.

ANTUNES, Paranhos. Estudos de história carioca. Rio de Janeiro: Prefeitura do Distrito Federal; Secretaria Geral de Educação e Cultura, [195-]. (Coleção Cidade do Rio de Janeiro, 8)

ARAÚJO FILHO, J.R. Alguns aspectos da cidade do Salvador. In: CIDADE do Salvador: aspectos geográficos, históricos, sociais e antropológicos. Salvador: IOBa, 1960. p. 9196. (Coleção Estudos Baianos, 1)

ASSOCIAÇÃO COMMERCIAL DA BAHIA. Relatório da Directoria (exercício 1915). Bahia: Duas Américas, 1916.

Relatório da Directoria (exercício 1925). Bahia: Duas Américas, 1926.

Relatório da Directoria (exercício 1912) Bahia: Almeida, 1913.

ATHAYDE, Raymundo A. de. Paulo de Frontin, sua vida, sua obra. Rio de Janeiro: Secretaria Geral de Educação e Cultura, 1961. (Cidade do Rio de Janeiro)

. Pereira Passos, o reformador do Rio de Janeiro: biografia e história. Rio de Janeiro: A Noite, [196-].

AVÉ-LALLEMANT, Robert. Viagem pelo norte do Brasil no ano de 1859. Tradução de Eduardo de Lima Castro. Rio de Janeiro: MEC; INL, 1961. v. 1. (Coleção Obras Raras, 7)

AYMONINO, Carlo et al. Città capitali del XIX゚ secolo. Roma: Edizioni, 1975.

. Origines y desarrollo de la ciudad moderna. Barcelona: Gustavo Gili, 1972.

AZEVEDO, Aluisio. O cortiço. São Paulo: Circulo do Livro, ca 1990. (Grandes da Literatura Brasileira, 2) 1 ed. 1890.

AZEVEDO, Aroldo de. Fisionomia da cidade do Salvador. In: CIDADE do Salvador: aspectos geográficos, históricos, sociais e antropológicos. Salvador: IOBa, 1960a. p. 49-54. (Coleção Estudos Baianos, 1)

AZEVEDO, Paulo Ormindo de. Bahia, hacia la recuperación de un centro histórico subdesarrollado. In: SOLANO, Francisco de (Org.) Historia y futuro de la ciudad Iberoamericana. Santander: Universidad Internacional Menéndez Pelayo; Madrid: Centro de Estudios Históricos, 1985. p. 147-161.

. O caso Pelourinho. In: ARANTES, Antonio Augusto. (Org.) Produzindo o passado: estratégias de construção do patrimônio cultural. São Paulo: Brasiliense, 1984. p. 219-255.

AZEVEDO, Thales de. Bahia: retrato de uma terra cercada de encantos por todos os lados, Revista Cultural da Bahia, Salvador, n. 7, p. 69-73, jan./dez. 1972. 
- A cidade do Salvador no comêço do século XIX. In: CIDADE do Salvador: aspectos geográficos, históricos, sociais e antropológicos. Salvador: IOBa, 1960b. p. 69-75. (Coleção Estudos Baianos, n.1) Povoamento da Cidade do Salvador. 3.ed. Salvador: Itapuã, 1969. (Coleção Baiana)

BAHIA. Brasil. Cartilha histórica da Bahia. Registro político do Estado. A República e seus governadores. 5.ed. Salvador: Ed. Salvador, 1990.

BAHIA. Brasil. A portfolio. Containing interesting information about the development, geology, agricultural, products, cacao industry and other resources of this opulent state of Bahia, Brasil. Bahia: The Companhia Energia Elétrica da Bahia, [s.d.] 4v.

BAIROCH, P. De Jericó a México: historia de la urbanización. México: Trillas, 1990.

BARBOSA, Francisco de Assis. Prefácio. In: PERES, Fernando da Rocha. Memória da Sé. Salvador: Macunaíma, 1974. p. 13-26.

BARBOSA, Jorge Luiz. Modernização urbana e movimento operário. 1990. 2v. Dissertação (Mestrado em Geografia) - Universidade Federal do Rio de Janeiro, Rio de Janeiro.

BARREIROS, Eduardo Canabrava. Atlas da evolução urbana da Cidade do Rio de Janeiro: ensaio - 1565-1965. Rio de Janeiro: Instituto Histórico e Geográfico Brasileiro, 1965.

BAUDELAIRE, Charles. As flores do mal. Tradução de Jamil Almansur Haddad. São Paulo: Círculo do Livro, 1995.

El pintor de la vida moderna. Murcia: Colegio Oficial de Aparejadores y

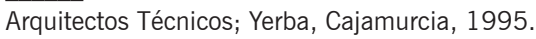

. O spleen de Paris: pequenos poemas em prosa. Tradução de Leda Tenório da

Motta. Rio de Janeiro: Imago, 1995. (Coleção Lazuli)

BENCHIMOL, Jaime Larry. A modernização do Rio de Janeiro. In: DEL BRENNA, Giovanna Rosso (Org.) O Rio de Janeiro de Pereira Passos: uma cidade em questão. Rio de Janeiro: INDEX, 1985. p. 599-611.

- Pereira Passos, um Haussmann tropical: a renovação urbana do Rio de Janeiro no inicio do século XX. Rio de Janeiro: Secretaria Municipal de Cultura, Turismo e Esportes; DGDIC - DE, 1992.

BENÉVOLO, Leonardo. La captura del infinito. Traducão de Margarita Garcia Galán. Madrid: Celeste, 1994.

. La ciudad y el arquitecto. Traducão de Rosa Premat. Barcelona: Paidós, 1985.

. La ciudad europea. Traducão de Maria Pons. Barcelona: Crítica, 1993

. História da cidade. Tradução de Silvia Mazza. São Paulo: Perspectiva, 1983.

$\overline{1992 .}$

. Orígenes del urbanismo moderno. Tradução de Floreal Mazia. Madrid: Celeste,

BENJAMIN, Walter. I/uminaciones //. Baudelaire, un poeta en el esplendor del capitalismo. Madrid: Taurus, 1972.

. Parigi capitale del XIX secolo. Torino: Einaudi, 1986.

BERGERON, Louis (Ed.). Paris: génèse d'un paysage. Paris: Picard, 1989. 
BERMAN, Marshall. Tudo que é sólido desmancha no ar: a aventura da modernidade. Tradução de Carlos Felipe Moisé e Ana Maria L. Ioriatti. São Paulo: Companhia das Letras, 1986.

BERNARDES, Lysia M.C. Expansão do espaço urbano no Rio de Janeiro. In: BERNARDES, Lysia M.C.; SOARES, Ma Therezinha de Segadas. Rio de Janeiro: cidade e região. Rio de Janeiro: Secretaria. Municipal de Cultura; DGDICI - DEd., 1990. p. 81-104. (Biblioteca Carioca, 3)

BLANCOT, Christiane. Actualité Haussmann. In: DES CARS, J.; PINON, P. (Ed.) ParisHaussmann. "Le pari d'Haussmann". Paris: Pavillon de l'Arsenal-Picard, 1991. p. 210219.

BOCCANERA JUNIOR, Silio. Bahia epigráphica e iconográphica (resenha histórica). Bahia: [s.n.], 1928.

- Bahia histórica: reminiscencias do passado, registro do presente. anotações (1549-1920). Bahia: Ed. Bahiana, 1921.

BODSTEIN, Regina Cele de A. Práticas sanitárias e classes populares do Rio de Janeiro. Revista Rio de Janeiro, Niterói, v.1, n.4, p. 33-43, set./dez.,1986.

BOMFIM, Juarez Duarte. Políticas públicas para o Centro Histórico de Salvador. O caso do parque histórico do Pelourinho: investigação de originalidade numa ação do governo local. 1994. Dissertação (Mestrado em Administração) - Escola de Administração da Universidade Federal da Bahia, Salvador.

BONAPARTE, N.-L. Des Idées Napoléoniennes. Paris: [s.n.], 1839.

BONDUKI, Nabil Georges. Origens da habitação social no Brasil: arquitetura moderna, lei do inquilinato e difusão da casa própria. 2.ed. São Paulo: Estação Liberdade; FAPESP, 1999.

BOURILLON, Florence. L'Haussmannisation: une solution à la crise urbaine du milieu du XIXe siècle?, Histoirens-Geographes, Paris, n.338, p. 131-149, 1992.

BRANDÃO, Maria David de Azevedo. Estrutura física, organização social, e dinâmica do crescimento de Salvador. In: CIDADE do Salvador: aspectos geográficos, históricos, sociais e antropológicos. Salvador: IOBa, 1960. p. 97-112. (Coleção Estudos Baianos, 1)

BRAUDEL, Fernand. Escritos sobre a história. São Paulo: Perspectiva, 1978. (Coleção Debates, 131)

BRESCIANI, Maria Stella. A Cidade das Multidões, a cidade aterrorizada. In: PECHMAN, Robert Moses (Org.) Olhares sobre a cidade. Rio de Janeiro: ed. UFRJ, 1994. p. 9-42.

(Org.) Imagens da cidade séculos XIX e XX. São Paulo: ANPUH, Marco Zero, 1994. 1990.

. Londres e Paris no século XIX. O espetáculo da pobreza. São Paulo: Brasiliense,

Permanência e ruptura no estudo das cidades. In: FERNANDES, Ana; GOMES, Marco Aurélio A. de Filgueiras. (Ed.) Cidade \& história: modernização das cidades brasileiras nos séculos XIX e XX. Salvador: MAU/FAUFBA; ANPUR, 1992. p. 11-26.

BRITO, Cristóvão de Cássio da Trindade. A produção da escassez de terrenos urbanos em Salvador e suas consequências na reprodução futura do espaço urbano. 1997. Dissertação (Mestrado) - Instituto de Geociências da Universidade Federal da Bahia, Salvador. 
BRITO, Saturnino de. Obras completas. Rio de Janeiro: Imprensa Nacional, 1943. v. 15

BRUAND, Yves. Arquitetura contemporânea no Brasil. São Paulo: Perspectiva, 1981.

BRUANT, Catherine. Donat Alfred Agache: urbanismo, uma sociologia aplicada. In: RIBEIRO, Luiz Cesar de Queiroz; PECHMAN, Robert. (Org.) Cidade, povo e nação: gênese do urbanismo moderno. Rio de Janeiro: Civilização Brasileira, 1996. p. 167-202.

. Louis Bonnier, Donalt-Alfred Agache, Marcel Auburtin. In: DETHIER, J.; GUIHEUX, A. (Eds) Visiones urbanas. Europa 1870-1993. La ciudad del artista. La ciudad del arquitecto. Madrid: Electa; CCCB, 1994. p. 158-160.

CALABI, Donatella. La professione dell'urbanistica. In: IL 'MALE' città: diagnosi e terapia: didattica e istituzioni nell'urbanistica inglese del primo 900. Roma: Officina, 1979. p. 92-123.

CALADO, M.; LOBO, M. de S.; FERREIRA, V. M. El terremoto, el poder ilustrado y la ciudad. In: GUARDIA, M.; MONCLÚS, F.J.; OYÓN, J.L. (Ed.). Atlas histórico de ciudades europeas. Península Ibérica. Barcelona: CCCB; Salvat, 1994. p. 100-101.

CALVINO, Italo. As cidades invisíveis. Tradução de Diogo Mainardi. São Paulo: Companhia das Letras, 1990.

CÂMARA, Antonio Alves. A Bahia de Todos os Santos com relação aos melhoramentos de seu porto. 2.ed. Rio de Janeiro: Denzinger, 1911.

CÂMARA, Marcos Paraguassu de Arruda. Conceição e Pilar. Freguesias seculares do centro econômico e do porto de Salvador até o século XIX. 1989. Dissertação (Mestrado em Ciências Sociais) - Faculdade de Filosofia e Ciências Humanas da Universidade Federal da Bahia, Salvador.

CAMPOS, Márcio C. Dois concursos, dois buracos, duas cidades. Vitruvius, Minha Cidade, 039, dez. 2001. www.vitruvius.com.br/minhacidade/mc039/mc039.asp

CAMPOS JÚNIOR, Carlos Teixeira de. O novo arrabalde. Vitória: Prefeitura Municipal de Vitória; Secretaria Municipal de Cultura e Turismo, 1996.

CANNADINE, D. Residencial segregation in victorian towns: form shapes in the ground to shapes in society. In: JOHNSON, J.H.; POOLEY, C.G. (Ed.) The structure of nineteenth century cities. London: Croom Helm, 1982. p. 235-251.

CANTARINO, Carolina. Monumenta muda pelos moradores dos centros. Revista do IPHAN n. 2, nov./dez. 2005. Disponível em: <http://www.revista.iphan.gov.br/materia. php?id $=103>$

CAPEL, Horacio. Capitalismo y morfología urbana en España. Barcelona: Libros de la Frontera, 1975.

CARDOSO, Elizabeth Dezouzart; SANTOS, Alexandre Antonio de Mello. Evolução urbana e aspectos da questão ambiental no Rio de Janeiro através dos planos e projetos dos séculos XIX e XX. In: SIMPÓSIO NACIONAL DE GEOGRAFIA URBANA, 3. 1993, Rio de Janeiro. Anais... Rio de Janeiro: IBGE, 1993. p. 206-207.

CARDOSO, Luiz Antonio F. A legislação de proteção no CAS e as políticas públicas visando à sua recuperação. In: BAHIA. Governo do Estado. Secretaria de Cultura. Escritório de Referência do Centro Antigo. UNESCO. Centro antigo de Salvador: Plano de Reabilitação Participativo. Salvador: Secretaria de Cultura, Fundação Pedro Calmon, 2010, p. 60-71.

CARDOSO, Luiz Antônio F. Entre vilas e avenidas: habitação proletária em Salvador na Primeira República. 1991. Dissertação (Mestrado em Arquitetura e Urbanismo) Faculdade de Arquitetura da UFBA, Salvador. 
CARVALHO, Anna Dias da Silva. O crescimento recente da cidade do Salvador. In: CIDADE do Salvador: aspectos geográficos, históricos, sociais e antropológicos. Salvador: Imprensa Oficial da Bahia, 1960. p. 77-89. (Coleção Estudos Baianos, n.1)

CARVALHO, Inaiá Maria Moreira de; SOUZA, Guaraci Adeodato Alves de. A produção nãocapitalista no desenvolvimento do capitalismo em Salvador. In: SOUZA, Guaraci Adeodato A. de; FARIA, Vilmar. (Org.) Bahia de todos os pobres. Petrópolis : Vozes, CEBRAP, 1980. p. 71-101.

CARVALHO, José Murilo. Os bestializados: o Rio de Janeiro e a República que não foi. São Paulo: Companhia das Letras, 1987.

. A formação das almas: o imaginário da República no Brasil. São Paulo: Companhia das Letras, 1990.

. O Rio de Janeiro e a República. Revista Brasileira de História, São Paulo, v. 5, n. 8/9, p. 117-138, 1985.

CARVALHO, Lia de Aquino. Contribuição ao estudo das habitações populares: Rio de Janeiro: 1886-1906. 2.ed Rio de Janeiro: Secretaria Municipal de Cultura; DGIC - DEd., 1995.

CARVALHO, Maria Alice Rezende de. Quatro vezes cidade. Rio de Janeiro: Sette Letras, 1994.

CASTELLS, Manuel. La urbanización dependiente en América Latina. In: CASTELLS, Manuel (Ed.) Imperialismo y urbanización en América Latina. Barcelona: Gustavo Gili, 1973. p. 7-26.

CAVALCANTE, Berenice de O. Beleza, limpeza, ordem e progresso: a questão da higiene na cidade do Rio de Janeiro, final do século XIX. Revista Rio de Janeiro, Niterói, v. 1, n. 1 , p. $95-103,1985$.

CEAB-FAUFBa CENTRO DE ESTUDOS DE ARQUITETURA DA BAHIA. Evolução física de Salvador. Salvador: CEABa; Centro Editorial e Didático da UFBA, 1979. 2v.

. Evolução fisica de Salvador. Salvador: [s.n.], [197-], v.4 (não publicado)

CENTRO DE ESTATÍSTICA E INFORMAÇÕES. CONDER. Informações básicas dos municípios baianos: Região Metropolitana de Salvador. Salvador: CEI/CONDER, 1994.

CERDÀ, Ildefons. Las cinco bases de la teoría general de la urbanización. Compilação de Arturo Soria y Puig. Barcelona: Electa, 1996.

CHALHOUB, Sidney. Cidade febril: cortiços e epidemias na Corte Imperial. São Paulo: Companhia das Letras, 1996.

CHALHOUB, Sidney. Trabalho, lar e botequim: o cotidiano dos trabalhadores no Rio de Janeiro da Belle Epoque. São Paulo: Brasiliense, 1986.

. Trabalho, lar e botequim: o cotidiano dos trabalhadores no Rio de Janeiro da Belle Epoque. São Paulo: Brasiliense, 1986.

. Visões da liberdade: uma história das últimas décadas da escravidão na corte. São Paulo: Companhia das Letras, 1990.

CHIAVARI, Maria Pace. As transformações urbanas do século XIX. In: DEL BRENNA, Giovanna Rosso (Org.) O Rio de Janeiro de Pereira Passos: uma cidade em questão. Rio de Janeiro: INDEX, 1985. p. 569-598. 
CHOAY, Françoise. A regra e o modelo: sobre a teoria da arquitetura e do urbanismo. São Paulo: Perspectiva, 1985. (Coleção Estudos, 88)

. El reino de lo urbano y la muerte de la ciudad. In: DETHIER, J., GUIHEUX, A. (Ed.), Visiones urbanas. Europa 1870-1993. La ciudad del artista. La ciudad del arquitecto. Madrid: Electa, CCCB, 1994.

. The modern city: planning in the 19th century. London: Studio Vista, [197-].

O urbanismo: utopias e realidades - uma antologia. São Paulo: Perspectiva, 1979. (Coleção Estudos, 67)

COARACY, Vivaldo. Memórias da Cidade do Rio de Janeiro. 3.ed. Belo Horizonte: Itatiaia; São Paulo: EDUSP, 1988.

COHEN, J-L. La temptació d'Amèrica: ciutat i arquitectura a Europa 1893-1960 Barcelona: Diputació de Barcelona; CCCB, 1996.

COLLINS, George R., COLLINS, Christiane C. Camillo Sitte y el nacimiento del urbanismo moderno. Traducción Rosa Barba. Barcelona: Gustavo Gili, 1980.

COMMISSÃO DO PLANO DA CIDADE DO SALVADOR. "Semana de Urbanismo" 20 a 27 de outubro de 1935. Conferências. Bahia: Graphica da Bahia, 1937.

COMPANS, Rose. Intervenções de recuperação de zonas urbans centrais: experiências nacionais e internacionais. In: CONIN, Álvaro et al. Caminhos para o centro: estratégias de desenvolvimento para a região central de São Paulo. São Paulo: UNESP, 2004, p. 23-60.

COREAL, François. Voyages de François Coreal aux Indes Occidentales, contennant se qu'il y a vû de plus remarquable pendant son séjour depuis 1666, jusqu'en 1697. Amsterdan: Chez J. Frederic Bernard, 1722. t.1

CORREIA, Roberto Lobato. O espaço urbano. São Paulo: Ática, 1989. (Série Principios, 174)

O CORREIO. Bahia, 01 set. 1913; 26 set. 1913; 01 out. 1913; 09 out. 1913; 27 jan. 1914.

COSTA, Ana de Lourdes R. da. Ekabó! Trabalho escravo, condições de moradia e reordenamento urbano em Salvador no séc. XIX. 1989. Dissertação (Mestrado em Arquitetura e Urbanismo) - Faculdade de Arquitetura da Universidade Federal da Bahia, Salvador.

Moradia de escravos em Salvador no século XIX. CLIO. Revista de Pesquisa Histórica. Recife. n. 11, p. 95-104, 1988. Separata.

COSTA, Emilia Viotti da. Urbanización en el Brasil del siglo XIX. In: SOLANO, Francisco de (Ed.) Estudios sobre la ciudad iberoamericana. 2.ed. Madrid: CSIC, 1983. p. 399-432.

COSTA, José Lourenço de A. A cidade errada e a cidade certa. In: COMMISSÃO DO PLANO DA CIDADE DO SALVADOR. "Semana de Urbanismo" 20 a 27 de outubro de 1935. Conferências. Bahia: Graphica da Bahia, 1937. p. 57-64.

. Propaganda de Urbanismo. In: COMMISSÃO DO PLANO DA CIDADE DO SALVADOR. "Semana de Urbanismo": 20 à 27 de outubro de 1935. Conferências Bahia: Graphica da Bahia, 1937b. p. 91-108.

CREMEL, Françoise. Paris-New Delhi: aller simple. In: LORTIE, A. (Ed.) Paris s'exporte: architecture modele ou modeles d'architectures. Paris: Pavillon de l'Arsenal-Picard, 1995. p. 157-160. 
CRULS, Gastão. Aparências do Rio de Janeiro (notícia histórica e descritiva da cidade). Rio de Janeiro: J. Olympio, 1949. 2v. (Coleção Documentos Brasileiros, 60)

DALLARI, Adilson Abreu. Desapropriações para fins urbanísticos. Rio de Janeiro: Forense, 1981.

DATO, Giuseppe (A cura di). L'urbanistica di Haussmann: un modello impossibile? Roma: Officina, 1995.

DE LOS RIOS FILHO, Adolfo Morales. Dois notáveis engenheiros. Rio de Janeiro: A Noite, 1951.

DE VRIES, Jan. La urbanización de Europa 1500-1800. Tradução de Ramon Grau. Barcelona: Crítica, 1987.

DEL BRENNA, Giovanna Rosso. Ecletismo no Rio de Janeiro (séc. XIX-XX). In: FABRIS, Annateresa (Org.) Ecletismo na arquitetura brasileira. São Paulo: Nobel; EDUSP, 1987. p. 29-67.

O projeto. Uma cidade em questão: duas etapas de uma proposta interdisciplinar. Revista Rio de Janeiro, Niterói, v. 1, n. 1, p. 7-13, 1985 b.

O Rio de Janeiro de Pereira Passos. In: (Org.) O Rio de Janeiro de Pereira Passos: uma cidade em questão. II Rio de Janeiro: INDEX, 1985. p. 7-565.

. Rio de Janeiro tra ottocento e novecento: una capitale nei tropici e il suo modelo europeo. In: DE SETA, Cesare (A cura di) Le città capitali. Roma: Laterza, 1985. p. 243252.

DEL RIO, Vicente. Em busca do tempo perdido. O Renascimento dos centros urbanos, Vitruvius, arquitextos. Texto Especial 028, nov. 2000. Disponível em: <www.vitruvius. com.br/arquitextos $>$.

DES CARS, J. Haussmann, la gloire du Second Empire. Paris: [ s.n.], 1978.

DES CARS, Jean, PINON, Pierre. Paris-Haussmann. "le pari d'Haussmann" Paris: Pavillon de l'Arsenal-Picard, 1991.

DIAS, Maria Lúcia R. Desenvolvimento urbano e habitação popular em São Paulo 1870-1914. São Paulo: Nobel, 1989.

DUARTE, Cristóvão Fernandes. A Lapa, abrigo e refúgio da cultura popular carioca. Anais da XIII ENANPUR. Florianópolis: UFSC, 2009. (CD-ROM)

DURÃES, Aline. Lapa: o bairro que renasceu. Olhar Virtual. Edição 175, set. 2007. Disponível em: <http://www.olharvirtual.ufrj.br/2006/>.

DYOS, H. J. The study of urban history. London: Edward Arnold, 1971.

DYOS, H. J.; WOLFF, M. (Eds.) The victorian city. London: Routledege and Kegan Paul, 1973. 2v.

EDMUNDO, Luiz. Recordações do Rio antigo. 2.ed. Rio de Janeiro: Conquista, 1956.

. O Rio de Janeiro do meu tempo. 2.ed. Rio de Janeiro: Conquista, 1957. 5v.

ENGELS, Friedrich. A situação da classe trabalhadora na Inglaterra. Tradução de Rosa Camargo Artigas e Reginaldo Forti. São Paulo: Global, 1985. (Coleção Bases, 47)

ESTIENNE, Gustavo. A reconstrução do Rio de Janeiro: a questão do patrimònio municipal. Rio de Janeiro: Jornal do Commércio, 1904. 
EVENSON, Norma. Two Brazilian capitals architecture and urbanism in Rio de Janeiro and Brasilia. New Haven and London: Yale University, 1973.

FAORO, Raymundo. Os donos do poder: formação do patronato político brasileiro. 8. ed. São Paulo: Globo, 1989. 2v.

FAUSTO, Boris. Trabalho urbano e conflito social 1890-1920. São Paulo; Rio de Janeiro: DIFEL, 1976.

FEITOSA, Maria José Gomes. Constituição do Terreiro de Jesus na Bahia. 1993. 2v. Tese (Doutorado em Arquitetura) - Faculdade de Arquitetura e Urbanismo da Universidade de São Paulo, São Paulo.

FERNANDES, Ana. Projeto Pelourinho: operação deportação x ampliação do direito. Curso de Capacitação - Programas de reabilitação de áreas urbanas centrais. Disponível em: <http://www.cidades.gov.br/secretarias-nacionais/programas-urbanos/biblioteca/ reabilitacao-de-areas-urbanas-centrais/materiais-de-capacitacao/curso-de-capacitacaoprogramas-de-reabilitacao-de-areas-urbanas-centrais-lab-hab/textos/T_Ana_Fernandes. pdf $>$.

FERNANDES, Ana; GOMES, Marco Aurélio A. de Filgueiras. Idealizações urbanas e a construção da Salvador moderna: 1850-1920. In: (Org.) Cidade \& história: modernização das cidades brasileiras nos séculos XIX e XX. Salvador: MAU/FAUFBA; ANPUR, 1992. p. 53-68.

FERNANDES, Ana; SAMPAIO, Heliodório; GOMES, Marco Aurélio A. de Filgueiras. A constituição do urbanismo moderno na Bahia (1900-1950): construção institucional, formação profissional e realizações. In: LEME, Maria Cristina da Silva (Org.). Urbanismo no Brasil - 1895-1965. São Paulo: Studio Nobel; FAUUSP; FUPAM, 1999. p. 167-182.

FERREIRA, Marieta de Moraes. Política e poder no Estado do Rio de Janeiro na República Velha. Revista Rio de Janeiro, Niterói, v. 1, n. 1, p. 115-120, 1985.

FERREZ, Gilberto. Bahia: velhas fotografias 1858/1900. Rio de Janeiro: Kosmos; Salvador: Banco da Bahia Investimentos, 1988.

- As cidades do Salvador e Rio de Janeiro no século XVIII álbum iconográfico comemorativo do bicentenário da transferência da sede do Govêrno do Brasil. Rio de Janeiro: Instituto Histórico e Geográfico Brasileiro, 1963.

FERREZ, Marc. O álbum da Avenida Central. Rio de Janeiro: Ex Libris; João Fortes Engenharia, 1982.

FLEXOR, Maria Helena Ochi. J. J. Seabra e a reforma urbana de Salvador. In: BATISTA, Marta Rossetti; GRAF, Márcia Elisa de Campos. Cidades brasileiras: políticas urbanas e dimensão cultural. São Paulo: Instituto de Estudos Brasileiros; Universidade de São Paulo, 1998. p. 108-119.

A mudança do desenho urbano de Salvador: principais agentes no século XIX e princípios do XX. In: BATISTA, Marta Rossetti; GRAF, Márcia Elisa de Campos. Cidades brasileiras /l: políticas urbanas e dimensão cultural. São Paulo: Instituto de Estudos Brasileiros; Universidade de São Paulo, 1999. p. 102-114.

FOGLIANI, Giuseppe. Projecto de Melhoramentos na Cidade do Rio de Janeiro. Rio de Janeiro: Borgonovo, 1903.

FONSECA, Antonio Angelo Martins da. A produção do subúrbio ferroviário de Salvador: os exemplos de Paripe e Periperi. 1991. Monografia, Instituto de Geociências UFBA, Salvador. 
FOOT, F.; LEONARDI, V. História da indústria e do trabalho no Brasil: das origens aos anos 20. São Paulo: Global, 1982.

OS FRADES do S. Bento e a remodelação. O Correio, Salvador, $1^{\circ}$ out. 1913.

FREITAG, Bárbara. O Pelourinho: Centro Histórico de Salvador. Correio Braziliense, $18 / 12 / 05$.

FREYRE, Gilberto. Casa grande \& senzala: formação da família brasileira sob o regime da economia patriarcal. 20. ed. São Paulo: Círculo do Livro, ca.1990. 1 ed. 1933.

Sobrados e mucambos: decadência do patriarcado rural no Brasil. 3.ed. Rio de Janeiro: J. Olympio, 1961. 2v. 1. ed. 1936.

. Vida social no Brasil nos meados do século XIX. Rio de Janeiro: Artenova; Recife: Instituto Joaquim Nabuco de Pesquisas Sociais, 1964.

FREZIER, M. Relation du voy age de la mer du sud aux côtes du Chily et du Perou fait pendant les années 1712, 1713 \& 1714. Paris: Chez Nyon, Ddidot, Quillau, 1732.

FRIDMAN, Fania. Propriedade fundiária, habitação e processo de urbanização no Rio de Janeiro. Cadernos IPPUR/UFRJ, Rio de Janeiro, v. 3, n. 2/3, set./dez., p. 79-93, 1994.

FRITSCH, Lilian de Amorim. Palavras ao vento: a urbanização do Rio imperial. Revista Rio de Janeiro, Niterói, v. 1, n. 3, p. 75-85, 1986.

FROGER, Sieur. Relation d'un voyage fait en 1695, 1696 \& 1697 aux côtes d'Afrique, Détroit de Magellan, Brésil, Cayenne, \& isles Antilhes par une escadre des vaisseaux de Roy, commandée par Monsieur de Gennes. Paris: Chez Nicolas le Gras, 1700.

FROTA, Guilherme A. Apontamentos para um guia histórico do Rio de Janeiro. Rio de Janeiro: Americana, 1971.

Noções da história da cidade do Rio de Janeiro. Rio de Janeiro: Secretaria de Administração; Divisão de Treinamento Descentralizado, 1969.

FURTADO, Celso. Formação econômica do Brasil. Rio de Janeiro: Fundo de Cultura, 1959.

GAILLARD, Jeanne. Paris, la Ville. 1852-1870. L'urbanisme parisien à l'heure d'Haussmann. Lille: Université de Lille III, 1976.

GAILLARD, Marc. Paris au XIXe siècle. Marseille: AGEP, 1991.

GARCIA ESPUCHE, A. El centre residencial burguès. In: LA FORMACIÓ de l'Eixample de Barcelona. Barcelona: L'Avenç-O.C., 1990. p. 203-221.

. (Ed.). Ciudades: del globo al satélite Barcelona: Electa, 1994.

GARCÍA, José Miguel L. Las ciudades europeas en la transición al capitalismo: Urbanización o urbanizaciones? Historia Urbana, Valencia, n. 2, p. 71-83, 1993.

GARDEN, Maurice. La apuesta de Haussmann: remodelar París. In: GUARDIA BASSOLS, M.; MONCLÚS FRAGA, F. J.; OYÓN BAÑALES, J. L. (Ed.). Atlas histórico de ciudades europeas. Francia. Barcelona: CCCB; Salvat, 1996. p. 46-47.

El esbozo de una nueva capital. In: GUARDIA BASSOLS, M.; MONCLÚS

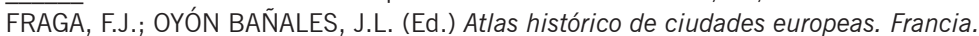
Barcelona: CCCB; Salvat, 1996. p. 44-45.

GASPARINI, G.; POSANI, J. P. Caracas a través de su arquitectura. Caracas: Fundación Fina Gómez, 1969. 
GAUDIN, J. P. Desseins de villes. Art urbain' et urbanisme. París: L'Harmattan, 1991.

- Política de la memoria sobre la ciudad en la primera mitad del siglo XX. Historia Urbana. Valencia: Universidad Politécnica de Valencia; Institució Valenciana d'Estudis i Investigació, 1994. p. 61-70. (Colección, 3)

GEORLETTE, F.A. Les travaux de transformation de la Ville de Rio de Janeiro et de construction du Port. Bulletin de la Société Royale de Géographie d'Anvers sous le patronage de sa Majesté le Roi, Anvers, t. 29, p. 421-464, 1905.

GERSON, Brasil. História das ruas do Rio de Janeiro. Rio de Janeiro: Prefeitura do Distrito Federal; Secretaria-Geral de Educação e Cultura, [195-]. (Coleção Cidade do Rio de Janeiro, 9)

GIEDION, Siegfried. Espacio, tiempo y arquitectura (el futuro de una nueva tradición). 2.ed. Barcelona: Hoelpi, 1958.

GIROUARD, Mark. Cities \& people: a social and architectural history. New Harven: Yale University, 1989.

GOBINEAU, Comte de. Lettres a deux athéniennes.(1868-1881). Paris: Bernard Grasset, 1936.

GODARD, Francis. Les comparaisons internationales. Le Courier du CNRS. La ville, Paris, n. 81, 1994. p. 6.

GORDILHO, Walter. Contribuição ao estudo da evolução urbana da cidade do Salvador. Salvador: Era Nova, 1942.

GORDILHO-SOUZA, Ângela. Ocupação urbana e habitação. In: BAHIA. Governo do Estado. Secretaria de Cultura. Escritório de Referência do Centro Antigo. UNESCO. Centro antigo de Salvador: Plano de Reabilitação Participativo. Salvador: Secretaria de Cultura, Fundação Pedro Calmon, 2010, p. 72-101.

GOULART, R. processo de reabilitação e renovação urbana na cidade do Rio de Janeiro e suas perspectivas. Scripta_Nova. Revista electrónica de geografía y ciencias sociales, Barcelona: vol. IX, n. 194 (44), ago. 2005. Disponível em: <http://www.ub.es/geocrit/sn/ sn-194-44.htm>

GRAHAM, Maria. Diário de uma viagem ao Brasil e de uma estada nesse país durante parte dos anos de 1821, 1822 e 1823. São Paulo: Nacional, 1956.

GRAHAM, Richard. Grã-Bretanha e o inicio da modernização no Brasil. Tradução Roberto Machado de Almeida. São Paulo: Brasiliense, 1973.

GRAHAM, Sandra Lauderdale. House and Street: the domestic world of servants and masters in 19th century. New York; Melbourne; Cambridge: Cambridge University, 1988.

GRAVAGNUOLO, Benedetto. Historia del urbanismo en Europa 1750-1960. Tradução de Juan Calatrava. Madrid: Akal, 1998.

GUIHEUX, Alain. El arquitecto del Universo. In: DETHIER, J.; GUIHEUX, A. (Ed). Visiones urbanas. Europa 1870-1993. La ciudad del artista. La ciudad del arquitecto. Madrid: Electa; CCCB, 1994. p. 290-292.

GUTIÉRREZ, Ramón. Arquitectura y urbanismo en Iberoamérica. Madrid: Cátedra, 1983. Buenos Aires: evolución histórica. Buenos Aires: Escala, 1992.

HABSBURGO, Maximiliano de. Bahia 1860. Esboços de viagem. Tradução de Antonieta da Silva Carvalho e Carmem Silva Medeiros. Rio de Janeiro: Tempo Brasileiro; Bahia: Fundação Cultural do Estado da Bahia, 1982. 
HALL, Peter. Ciudades del mañana.: historia del urbanismo en el siglo XX. Tradução de Consol Freixa. Barcelona: Serbal, 1996. (Colección La Estrella Polar)

HARDOY, Jorge Enrique. Dos mil años de urbanización en América Latina. In: HARDOY, Jorge E.; TOBAR, Carlos (Eds.) La urbanización en América Latina. Buenos Aires: Ediciones del Instituto, 1969.

. Impacto de la urbanización en los centros históricos de América Latina. Lima: PNUD; UNESCO, 1981.

HARDOY, Jorge E.; MORSE, R. P. (Ed.) Nuevas perspectivas en los estudios sobre historia urbana de Latinoamérica. Buenos Aires: Instituto Internacional del Medio Ambiente y Desarrollo IIED, Latinoamérica; Grupo Editor Latinoamericano, 1989.

HARDOY, Jorge E.; MORSE, R. P.; SCHAEDEL, R. P. Ensayos histórico-sociales sobre la urbanización en América Latina. Buenos Aires: CLCASO-CEUR; Siap, 1978.

HARDOY, Jorge E.; SCHAEDEL, Richard P. (Ed.). El proceso de urbanización en América desde sus orígenes hasta nuestros días. Buenos Aires: Editorial del Instituto, 1969.

HAUSSMANN, Georges-Eugéne. Mémoires du Baron Haussmann: grands travaux de Paris: 1853-1870. Paris: Guy Durier, 1979. 2 v.

HITCHCOCK, Henry-Russell. Arquitetura de los siglos XIX y XX. Tradução de Luis E. Santiago. Madrid: Cátedra, 1993.

HOBSBAWM, Eric J. A era do capital 1848-1875. 5.ed. Tradução de Luciano Costa Neto. São Paulo: Paz e Terra, 1996.

HOHENBER G, P.; LEES, L.H. The making of urban Europe, 1000-1950. Cambridge: Harvard University, 1985.

HOLANDA, Sergio Buarque de. Raízes do Brasil. 26.ed. São Paulo: Companhia das Letras, 1995. 1 ed. 1936.

HYGIN-FURCY, Charles. Guide universel de l'émigrant, Amérique du Sud, Empire du Brésil. Bruxelles: Universelle de Rozez, 1885.

INSTITUTO Municipal de Arte e Cultura (Rio de Janeiro, RJ). Corredor Cultural: como recuperar, reformar ou construir seu imóvel. 4 ed. Rio de Janeiro: Prefeitura da Cidade do Rio de Janeiro, 2002.

JOHNSON, James H.; POOLEY, Colin G. The internal structure of the nineteenth-century british city - an overview. In:_. (Eds.) The structure of nineteenth century cities. London: Croom Helm, 1982. p. 3-35.

JONES, Francis M. The aesthetic of nineteenth-century industrial town. In: DYOS, H. J. The study of urban history. London: Edward Arnold, 1971. p. 171-182.

KOHLSDORF, Maria Elaine. Breve histórico do espaço urbano como campo disciplinar. In: FARRET, Ricardo Libanez (Ed.). O espaço da cidade: contribuição à análise urbana. São Paulo: Projeto, 1985, p. 15-72.

KOSTOF, Spiro. The city assembled: the elements of urban form through history. London: Thames and Hudson, 1992.

. The city shaped: urban patterns and meanings through history. London: Thames and Hudson, 1991.

LADD, Brian. Urban planning and civic order in Germany, 1860-1914. Cambridge: Harvard University, 1990. 
LAMARÃO, Sérgio Tadeu de Niemeyer. Dos trapiches ao porto: uma contribuição ao estudo da produção da área portuária do Rio de Janeiro. 1984. Dissertação (Mestrado em Engenharia) - COOPE - Universidade Federal do Rio de Janeiro, Rio de Janeiro.

LANNA, Ana Lúcia Duarte. Uma cidade na transição. Santos: 1870-1913. São Paulo: HUCITEC; Santos: Prefeitura Municipal, 1996. (Coleção Estudos Históricos, 25)

LAVEDAN, P. Histoire de l'urbanisme. Epoque contemporaine. Paris: Henri Laurens, 1952.

. Nouvelle histoire de Paris: histoire de l'urbanisme à Paris. Paris: Hachette, 1975.

LE CORBUSIER. Precisiones respecto a un estado actual de la arquitectura y del urbanismo. 2.ed. Barcelona: Poseidon, 1979.

LEBLANC, William. Rècits de ma vie d'aventures et de navigation. Souvenirs d'un vieux normand. Paris: Plon, 1895.

LEBLIQ, Yvon. Belgique et le modèle haussmannien. In: LORTIE, A. (Ed.) Paris s'exporte: architecture modele ou modeles d'architectures. Paris: Pavillon de l'Arsenal-Picard, 1995. p. 73-81.

LEES, Andrew. Cities perceived: urban society in European and American thought, 18201940. Manchester: University Manchester, 1985.

LEME, Maria Cristina da Silva. A formação do pensamento urbanístico, em São Paulo, no início do século XX. Espaço \& Debates, Revista de Estudos Regionais e Urbanos, São Paulo, n. 34, p. 64-70, 1991.

O plano de avenidas e a formação do pensamento urbanístico em São Paulo nas primeiras décadas do século XX. In: FERNANDES, Ana; GOMES, Marco Aurélio A. de Filgueiras. (Orgs.) Cidade \& história: modernização das cidades brasileiras nos séculos XIX e XX. Salvador: MAU/FAUFBA; ANPUR, 1992. p. 69-76.

. (Org.) Urbanismo no Brasil - 1895-1965. São Paulo: Studio Nobel; FAU/USP; FUPAM, 1999.

LEMOS, Carlos A.C. Arquitetura brasileira. São Paulo: Melhoramentos; EDUSP, 1979.

LEOPOLDI, Maria Antonieta P. Crescimento industrial, políticas governamentais e organização da burguesia: o Rio de Janeiro de 1844 a 1914. Revista Rio de Janeiro, Niterói, v. 1, n. 3, p. 53-73, maio/ago. 1986.

LEPETIT, Bernard. Des capitales aux places centrales: mobilité et centralité dans la pensée économique française (1820-1850). In: JORNADA INTERNACIONAL DE HISTÓRIA URBANA. Belo Horizonte: o nascimento de uma capital. Cidades-capitais do século XIX: racionalidade, cosmopolitanismo e transferência de modelos, Belo Horizonte, 1996. (não publicado)

. Les villes dans la France moderne (1740-1840). Paris: Albin Michel, 1988.

LIMA, Evelyn Furquim Werneck. Avenida Presidente Vargas: uma drástica cirurgia. Rio de Janeiro: Secretaria Municipal de Cultura; DGDIC/DEd., 1995.

LIMA, Evelyn Furquim Werneck. Preservação do patrimônio: uma análise das práticas adotadas no centro do Rio de Janeiro. Patrimônio - Revista Eletrônica do IPHAN, Dossiê, n. 2, nov./dez. 2005. Disponível em: < http://www.labjor.unicamp.br/patrimonio/print. php?id=120>. Acesso em: 18 mar. 2008.

LIMA, Jeronimo Teixeira de Alencar. Plano geral de melhoramentos em parte da cidade do Salvador. Bahia: Central, 1910. 
LOBO, Eulália Maria Lahmeyer. História do Rio de Janeiro: do capital comercial ao capital industrial e financeiro. Rio de Janeiro: IBMEC, 1978. 2 v.

LOBO, Eulalia Maria Lahmeyer; CARVALHO, Lia A.; STANLEY, Miriam. Questão habitacional e o movimento operario. Rio de Janeiro: UFRJ, 1989.

LODDER, Celsius A. O processo de crescimento urbano no Brasil. In: TOLEDO, Ana Maria Pompeu de; CAVALCANTI, Marly. Planejamento urbano em debate. São Paulo: Cortez \& Moraes, 1978. p. 3-18.

LORTIE, André (Ed.). Paris s'exporte: architecture modele ou modeles d'architectures. Paris: Pavillon de l'Arsenal-Picard, 1995.

LOU, Maria Asunción Martín; BENASAYAG, Eduardo Múscar. Proceso de urbanización en América del Sur. Modelos de ocupación del espacio. Madrid: Mapfre, 1992.

LOYER, François. Avant-propos. In: DES CARS, J.; PINON, P. (Ed.) Paris-Haussmann. "Le pari d'Haussmann". Paris: Pavillon de l'Arsenal-Picard, 1991. p. 9-14.

. Le Paris d'Haussmann. In: COHEN, J-L.; FORTIER, B. (Eds.) Paris: la ville et ses projets. Paris: Babylone, 1992. p. 192-200.

Paris XIXe siècle, I'immeuble et la rue. Paris: Hazan, 1987.

LUBAMBO, Catia Wanderley. A reforma urbana no bairro do Recife no início do século: intervenção pública ou privada? Recife: Departamento de Estudos Populacionais da Fundação Joaquim Nabuco, 1991.

Reforma urbana: o que há de novo depois de um século? (a experiência do Bairro do Recife). In: FERNANDES, Ana; GOMES, Marco Aurélio A. de Filgueiras (Org.) Cidade \& história: modernização das cidades brasileiras nos séculos XIX e XX. Salvador: MAUFAUFBA; ANPUR, 1992. p. 117-123.

LUZ, Madel T. O corpo da cidade. In: PECHMAN, Robert Moses (Org.) Olhares sobre a cidade. Rio de Janeiro: EDUFRJ, 1994. p. 181-193.

MALET, Henri. Le Baron Haussmann et la renovation de Paris. Paris: Municipales, 1973.

MANCUSO, F. La consolidación del modelo y los problemas del zoning. Barcelona: Gustavo Gili, 1980.

MARCHAND, Bernard. Paris, histoire d'une ville (XIX-XXeme siecle). Paris: Seuil, 1993.

MARTIN, G.H. The town as palimpsest. In: DYOS, H. J. The study of urban history. London: Edward Arnold, 1971. p. 155-169.

MARX, Murilo. Cidade no Brasil terra de quem? São Paulo: Nobel; EDUSP, 1991. . Cidade brasileira. São Paulo: Melhoramentos; EDUSP, 1980. $\overline{\text { Desenho) }}$ . Nosso chão: do sagrado ao profano. São Paulo: EDUSP, 1988. (Série Espaço e

MAS, Rafael. La expansión de la ciudad. In: GUARDIA BASSOLS, M.; MONCLÚS FRAGA, F.J.; OYÓN BAÑALES, J.L. (Ed.) Atlas histórico de ciudades europeas. Península Ibérica. Barcelona: CCCB; Salvat, 1994. p. 42-44.

. Las reformas internas. In: GUARDIA BASSOLS, M.; MONCLÚS FRAGA, F.J.; OYÓN BAÑALES, J.L. (Ed.) Atlas histórico de ciudades europeas. Península Ibérica. Barcelona: CCCB; Salvat, 1994. p. 44-45. 
MATTEDI, Maria Raquel Mattoso; BRITO, Marusia Rebouças de; BARRETO, Sueli Santos. Salvador: o processo de urbanização. In: BAHIA. Secretaria de Planejamento, Ciência e Tecnologia. Fundação de Pesquisas. Habitação e urbanismo em Salvador. Salvador: SEPLANTEC, 1979. p. 337-364.

MATTOS, Waldemar. Evolução histórica e cultural do Pelourinho. Rio de Janeiro: Barbero, 1978.

MATTOSO, Kátia M. de Queiroz. Bahia: a Cidade do Salvador e seu mercado no século XIX. São Paulo: HUCITEC; Salvador: Secretaria Municipal de Educação e Cultura, 1978.

1992.

. Bahia, século XIX. Uma província no Império. Rio de Janeiro: Nova Fronteira,

Família e sociedade na Bahia do século XIX. Tradução de James Amado. São

Paulo: Corrupio; Brasília: CNPq, 1988.

MAUL, Carlos. O Rio da Bela Época. Rio de Janeiro: São José, 1967.

MAURO, Frédéric. O Brasil no tempo de Dom Pedro // (1831-1889). São Paulo: Companhia das Letras: Círculo do Livro, 1991. (Coleção. A vida cotidiana)

McKAY, J. P. Tranway and trolleys: the rise of the urban mass transport in Europe. Princeton: University of the Princeton, 1976.

MENDES, Victor Marcelo Oliveira. A problemática do desenvolvimento em Salvador: Análise dos planos e práticas da segunda metade do século XX (1950-2000). Tese de doutorado, IPPUR, 2006.

MENDONÇA, Jair. Prédios em ruínas degradam o Comércio. Jornal A Tarde, Salvador, 23 out. 2000. Disponível em:<www.atarde.com.br/fw/cp/2007/05/imprimir.

jsf?id $=588662>$.

MENDONÇA, Jair. Reocupar o Comércio sem gerar tráfego é desafio. Jornal A Tarde, Salvador, 16 dez. 2003. Disponível em:<www.atarde.com.br/fw/cp/2007/05/imprimir. jsf?id $=626067>$.

MENSAGEM apresentada a Assembléia Geral Legislativa do Estado da Bahia na abertura da 1 a. sessão ordinária da 8a. legislatura pelo Dr.Jose Marcelino de Souza, governador do Estado. Bahia: Diario da Bahia, 1905.

MENSAGEM apresentada a Assembléia Geral Legislativa do Estado da Bahia na abertura da 2a. sessão ordinária da 7a. legislatura pelo governador do Estado, Severino Vieira.

Bahia: Diario da Bahia, 1904.

MENSAGEM apresentada a Assembléia Geral Legislativa do Estado da Bahia na abertura da 2a. sessão ordinária da 11 a. legislatura pelo Dr. J.J. Seabra, governador do Estado.

Bahia: Secção de obras da 'Revista do Brasil', 1912.

MENSAGEM apresentada a Assembléia Geral Legislativa do Estado da Bahia na abertura da 1a. sessão ordinária da 12a. legislatura pelo Dr. J.J. Seabra, governador do Estado.

Bahia: Secção de obras da 'Revista do Brasil', 1913.

MENSAGEM apresentada a Assembléia Geral Legislativa do Estado da Bahia na abertura da 2a. sessão ordinária da 12a. legislatura pelo Dr. J.J. Seabra, governador do Estado. Bahia: Secção de obras da 'Revista do Brasil', 1914.

MENSAGEM apresentada a Assembléia Geral Legislativa do Estado da Bahia na abertura da 1a. sessão ordinária da $11^{\text {a }}$ legislatura pelo Exmo. Sr. Dr. João Ferreira de Araujo Pinho, governador do Estado da Bahia. Bahia: Ed. "A Bahia", 1911. 
MENSAGEM apresentada pelo Exmo. Sr. Dr. Vital Henriques Baptista Soares, governador do Estado da Bahia a Assembléia Geral Legislativa por ocasião da abertura da 1a. reuniao ordinária da 20a. legislatura, em 7 de abril de 1929. Bahia: IOBa, 1929.

MIRALLES i GUASCH, Carme. Transport i ciutat: una reflexió sobre la Barcelona contemporània. Barcelona: Universitat Autònoma de Barcelona, 1997.

MONCLÚS FRAGA, Francisco Javier. Arte urbano y estudios histórico-urbanísticos: tradiciones, ciclos y recuperaciones. 3 ZU, Barcelona, n. 4, p. 92-101, 1995

. Barcelona: ideas de ciudad y estrategias urbanísticas (1897-1923). In: Arturo Soria y el urbanismo europeo de su tiempo. Madrid: Colegio de Arquitectos de Madrid, 1997. p. 67-84.

Teorías arquitectónicas y discurso urbanístico. De las operaciones de 'embellecimiento' a la reforma global de la ciudad en el s. XVIII. Ciudad y Territorio, Madrid, n. 79, p. 25-40, ene./mar. 1989.

MONCLÚS FRAGA, Francisco Javier; OYÓN BAÑALES José Luis. La aproximación espacial en la historia urbana. In: HISTORIA urbana del pla de Barcelona. Barcelona: Instituto Municipal d'História, 1990. v. 2

Eixample i suburbanització. Trànsit tramviari i divisió social de l'espai urbà a Barcelona, 1883-1914. In: LA FORMACIÓ de l'Eixample de Barcelona. Barcelona: L'Avenç-O.C., 1990a.

Espacio urbano y sociedad: algunas cuestiones de método en la actual historia urbana. In: SEGUNDO SIMPÓSIO URBANISMO E HISTORIA URBANA EN EL MUNDO HISPANO, 1982, Madrid. Anais.... Madrid: A. Bonet; Universidad Complutense de Madrid, 1985.

MONTEIRO, João Carlos C. dos Santos. Transformações e perspectivas a área central do Rio de Janeiro: a ação do poder público municipal. In: ENANPUR, 8., 2009. Anais... Florianópolis: UFSC, 2009. (CD-ROM)

MONTEYS, Xavier. La gran máquina. La ciudad en Le Corbusier. Barcelona: Demarcación de Barcelona del Colegio de Arquitectos de Cataluña; Serbal, 1996. (Colección Arquitectura/teoría, 4)

MOREIRA, Fernando Diniz. A formação do urbanismo moderno no Brasil: as concepções urbanísticas do engenheiro Saturnino de Brito. Espaço \& Debates: Revista de Estudos Regionais e Urbanos, São Paulo, n. 40, p. 55-69, 1997.

MORRIS, A. E. J. Historia de la forma urbana: desde sus orígenes hasta la Revolución Industrial. Tradução de Reinald Bernet. 4. ed. Barcelona: Gustavo Gili, 1992. (Colección Arquitectura/ Perspectivas)

MORSE, Richard M. Cities and society in 19th century Latin América: the illustrative case of Brasil. In: HARDOY, Jorge E; SCHAEDEL, Richard P. (Ed.) El proceso de urbanización en América desde sus orígenes hasta nuestros días. Buenos Aires: Editorial del Instituto, 1969. p. 303-322.

MOURA, Roberto. Tia Ciata e a Pequena África no Rio de Janeiro. 2. ed. Rio de Janeiro: Secretaria Municipal de Cultura, DGDIC - DEd., 1995. (Coleção Carioca, v. 32, série publicação científica)

MOUSTIER, Renaud de. Une étape a Rio de Janeiro. Paris: Jules Gervais, 1885.

MUMFORD, Lewis. A cidade na história: suas origens, desenvolvimento e perspectivas. Tradução de Neil R. da Silva. 2. ed. São Paulo: Martins Fontes, 1982. 
MUÑOZ, Alexandra. Modernismo tardio nas transformações do centro de Salvador nos anos 60. Anais do 3०. DOCOMOMO, São Paulo, 1999. Disponível em: <www.docomomo. org.br/seminario\%203\%20pdfs/subtema_A2F/Alejandra_\%20munoz.pdf > .

NA RUA Chile as obras de melhoramentos estão em progresso. O Correio, Salvador, 27 jan. 1914.

NASCIMENTO, Ana Amélia Vieira. Dez freguesias da Cidade do Salvador: aspectos sociais e urbanos do século XIX. Salvador: Fundação Cultural do Estado da Bahia; EGBA, 1986.

NEEDELL, Jeffrey D. Belle Époque tropical: sociedade e cultura de elite no Rio de Janeiro na virada do século. Tradução de Celso Nogueira. São Paulo: Companhia das Letras, 1993.

NEVES, Laert Pedreira. O crescimento de Salvador e das demais cidades baianas. Salvador: Centro Editorial e Didático da UFBA, 1985. (Estudos baianos,15)

NEVES, Margarida de Souza. O povo na rua um 'conto de duas cidades'. In: PECHMAN, Robert Moses (Org.) Olhares sobre a cidade. Rio de Janeiro: EDUFRJ, 1994. p. 134-155.

NOWEIR, Sawsan. La modernisation du Caire. In: LORTIE, A. (Ed.) Paris s'exporte: architecture modele ou modeles d'architectures. Paris: Pavillon de l'Arsenal-Picard, 1995. p.149-155.

OLIVEIRA, Liana Silvia de Viveiros e. Relatório de Trabalho ( $n^{\circ} 1$ ). Salvador, 1990. Relatório apresentado ao MAU/UFBA como requisito de Bolsista de Iniciação Cientifica CNPq. Não publicado.

OLIVEIRA, Ligia Gomes de. Desenvolvimento urbano da cidade do Rio de Janeiro. Uma visão através da legislação reguladora da época - 1925-1975. Rio de Janeiro, 1978. Dissertação (Mestrado em Engenharia) - COPPE, Universidade Federal do Rio de Janeiro.

OLIVEIRA, Maria Ines Côrtes. O liberto: o seu mundo e os outros. Salvador 1790/1890. São Paulo: Corrupio; Brasília: CNPq, 1988. (Baianada, 7)

OLSEN, D.J. The city as a work of art. London, Paris, Vienna. New Haven; London: Yale University, 1986.

OUTTES, Joel. O corpo de um herói esquartejado: a reforma urbana do bairro de Santo Antônio em Recife no Estado Novo. In: FERNANDES, Ana; GOMES, Marco Aurélio A. de Filgueiras. (Org.) Cidade \& história: modernização das cidades brasileiras nos séculos XIX e XX. Salvador: MAU/FAUFBA; ANPUR, 1992.

. Les urbanistes sud-américains dans les congrès internationaux pour la réforme urbaine en Amérique Latine (1909-1941). Trabalho apresentado ao Seminário Origens das políticas urbanas modernas: Europa e América Latina, empréstimos e traduções. Itamonte, 1994. Não publicado.

PADILHA, Sylvia F. Da Cidade Velha à periferia. Revista Rio de Janeiro, Niterói, v. 1, n. 1, p. 15-23, 1985.

PANERAI, Philippe. Um reencontro insólito (notas para o teatro da Arquitetura). AU Arquitetura e Urbanismo, São Paulo, v. 4, n. 16, p. 100, out./nov. 1987.

PANERAI, Philippe R.; CASTEX, Jean; DEPAULE, Jean-Charles. Formas urbanas: de la manzana al bloque. Tradução de Santiago Castán. Barcelona: Gustavo Gili, 1986.

PASSOS, Francisco Pereira. Primeiro Relatorio da Comissão de Melhoramentos da Cidade do Rio de Janeiro. Rio de Janeiro: A Comissão, 1875. 
PECHMAN, Robert Moses. Os excluidos da rua: ordem urbana e cultura popular. In: BRESCIANI, Maria Stella (Org.) Imagens da cidade séculos XIX e XX. São Paulo: ANPUH, Marco Zero, 1994a. p. 29-34.

. Um olhar sobre a cidade: estudo da imagem e do imaginário do Rio na formação da modernidade. In: FERNANDES, Ana; GOMES, Marco Aurélio A. de Filgueiras. (Orgs.) Cidade \& História: modernização das cidades brasileiras nos séculos XIX e XX. Salvador: MAU/FAUFBA; ANPUR, 1992. p. 33-43.

. Olhares sobre a cidade. In: (Org.) Olhares sobre a cidade. Rio de Janeiro: EDUFRJ, 1994b. p. 3-8.

. O urbano fora do lugar? Transferências e traduções das ideias urbanísticas nos anos 20. In: RIBEIRO, Luiz Cesar de Queiroz; PECHMAN, Robert. (Org.) Cidade, povo e nação: gênese do urbanismo moderno. Rio de Janeiro: Civilização Brasileira, 1996. p. 331-362.

PECHMAN, Robert Moses; RIBEIRO, Luis César Queiroz. A Companhia de Saneamento do Rio de Janeiro: contribuição à história da formação do capital imobiliário. Revista Rio de Janeiro, Niterói, v. 1, n. 1, p. 105-113, 1985.

PECHMAN, Sérgio; FRITSCH, Lilian. A reforma urbana e seu avesso: algumas considerações a propósito da modernização do Distrito Federal na virada do século. Revista Brasileira de História, São Paulo, v. 5, n. 8/9, p. 139-195, 1985.

PEDELAHORE-LODI, Christian. Tracés parisiens et Paris immatériels d'Asie. In: LORTIE, A. (Ed.) Paris s'exporte: architecture modele ou modeles d'architectures. Paris: Pavillon de l'Arsenal-Picard, 1995. p. 126-131.

PEDRÃO, Angela West. Relatório de Trabalho ( $n^{\circ} 1$ ). Salvador, 1990. Relatório apresentado ao MAU/UFBA como requisito de Bolsista de Iniciação Cientifica CNPq. Não publicado.

PEDRÃO, Fernando. A urbanização voraz em Salvador. Revista VeraCidade, Salvador: Ano IV, n. 5, out. 2009. Disponível em: <http://www.veracidade.salvador.ba.gov.br/v5/pdf/ artigo1.pdf>. Acesso em: 15 dez. 2010.

PEIXOTO, Afrânio. Breviário da Bahia. 3.ed. Rio de Janeiro: Conselho Federal de Cultura, 1980.

PEIXOTO, Célia Simões. O sítio urbano do Salvador e seus problemas. Geografia urbana. São Paulo: 1972. p. 1-13.

PEÑA, Jorge Villota. A imagem ambiental urbana do comércio no século XIX. 1994. Dissertação (Mestrado em Arquitetura e Urbanismo) - Faculdade de Arquitetura da Universidade Federal da Bahia, Salvador.

PENZO, P.P. Parigi dopo Haussmann: urbanistica e politica alla fine dell'Ottocento (18711900). Firenze: [s.n]., 1990.

PEREIRA, Margareth da Silva. A americanização da América: os planos de Agache e Le Corbusier para o Rio de Janeiro 1927-1936. [199-] Não publicado.

L'entreprise 'The Rio de Janeiro Tramway Light and Power Company' à la naissance de la Rio de Janeiro moderne, 1890-1930. In: ÉLECTRICITÉ et électrification dans le monde. Paris: PUF, 1992. p. 379-399.

. Paris-Rio: le passé américain et le goût du monument. In: LORTIER, Andre (Ed.) Paris s'exporte: architecture modele ou modeles d'architectures. Paris: Pavillon de l'Arsenal-Picard, 1995. p. 140-148. 
- Pensando a metrópole moderna: os planos de Agache e Le Corbusier para o Rio de Janeiro. In: RIBEIRO, Luiz Cesar de Queiroz; PECHMAN, Robert (Org.) Cidade, povo e nação: gênese do urbanismo moderno. Rio de Janeiro: Civilização Brasileira, 1996. p. 363-376.

Rio de Janeiro: l'éphémère et la pérennité - Histoire de la Ville au XIXème siècle. 1988. Tese (Doctorat en Sciences Sociales) - École des Hautes Études en Sciences Sociales, , Paris.

PERES, Fernando da Rocha. Memória da Sé. Salvador: Macunaíma, 1974.

PERROT, M. (Ed.) História da vida privada, 4: da Revolução Francesa à Primeira Guerra. São Paulo: Companhia das Letras, 1991.

PESAVENTO, Sandra Jatahy. O imaginário da cidade: visões literárias do urbano - Paris, Rio de Janeiro, Porto Alegre. Porto Alegre: UFRGS, 1999.

PICCINATO, Giorgio. La construcción de la urbanística - Alemania 1871-1914.

Barcelona: OIKOS-TAU, 1993. (Colección de Urbanismo, n 12)

PIERSON, Donald. Brancos e Pretos na Bahia: estudo de contacto racial. São Paulo: Ed. Nacional, 1945.

PINHEIRO, Eloísa Petti. Dois centros, duas políticas, dois resultados. Scripta Nova. Revista Electrónica de Geografía y Ciencias Sociales. Barcelona: UB, 2008, Número extraordinario dedicado al X Coloquio Internacional de Geocrítica, 2008, n. 137. Disponível em: <http://www.ub.edu/geocrit/sn/sn-270/sn-270-137.htm>. Acesso em: 10 dez. 2010.

. Europa, Francia y Bahía: la difusión y adaptación de los modelos urbanos europeos. 1998. Tese (Doctorado en Arquitectura) - Escuela Técnica Superior de Arquitectura de Barcelona; Universidad Politécnica de Cataluña, Barcelona.

. Europa, França e Bahia: difusão e adaptação de modelos urbanos. Salvador:

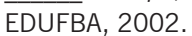

. Intervenções públicas na freguesia da Sé em Salvador de 1850 a 1920: um estudo de modernização urbana. 1992. Dissertação (Mestrado em Arquitetura e Urbanismo) - Faculdade de Arquitetura da Universidade Federal da Bahia, Salvador.

PINHEIRO, Paulo Sérgio. Classes médias urbanas: formação, natureza, intervenção na vida política. In: FAUSTO, Boris (Org.). O Brasil republicano. 2. Sociedade e instituições (1889-1930). 4.ed. São Paulo: DIFEL, 1985. v.2, t.3. p. 7-37. (História Geral da Civilização Brasileira, 9)

PINKNEY, David H. Napoleon III and the rebiulding of Paris. Princeton, New Jersey: University Press, 1972.

PINON, Pierre. L'haussmannisation: réalité et perception en Europe. In: LORTIE, A. (Ed.), Paris s'exporte: architecture modèle ou modèles d'architectures. Paris: Pavillon de l'Arsenal-Picard, 1995. p. 43-48.

. Le plan des artistes entre grands axes et opportunités foncières. In: PINON,

Pierre. Les traversées de paris: deux siècles de révolutions dans la ville. Paris: Moniteur; La Grande Halle - La Villette, 1989. p. 145-154.

. Le projet de Napoléon III et d'Haussmann. La "transformation de Paris". DES

CARS, Jean, PINON, Pierre. Paris-Haussmann. "Le pari d'Haussmann". Paris: Pavillon de l'Arsenal-Picard, 1991. p. 73-80. 
PIÑON. Juan Luis. Reflexiones sobre la comparación y la generalización en la historia urbana. Historia Urbana, Valencia, n. 2, p. 5-20, 1993.

PINTO, Nelson de Almeida. Contribuição á Semana de Urbanismo. In: COMMISSÃO DO PLANO DA CIDADE DO SALVADOR. "Semana de Urbanismo" 20 a 27 de outubro de 1935. Conferências. Bahia: Graphica da Bahia, 1937. p. 65-73.

PITTE, Jean-Robert (Ed.) Paris. Histoire d'une ville. Paris: Les Atlas Hachette, 1993.

PRADO JUNIOR, Caio. Formação do Brasil contemporâneo - colônia. 3.ed. São Paulo: Brasiliense, 1948. (Coleção Grandes Estudos Brasilienses, 1)

. História econômica do Brasil. 2.ed. São Paulo: Brasiliense, 1949. (Coleção Grandes Estudos Brasilienses, 2)

PUGLIES, Vanessa Souza. Patrimônio, resistência e memórias indesejáveis no Centro Histórico de Salvador. Revista Eletrônica Urbanidades, n. 3, 2005. Dossiê Salvador e outras cidades. Disponível em: <www.unb.br/ics/sol/itinerancias/urbanidades $>$. Acesso em: 20 mar. 2008.

QUATRO séculos de história da Bahia. Revista Fiscal da Bahia. Salvador, 1949.

QUIJANO, A. Dependência, mudança social e urbanização na América Latina. In: ALMEIDA, F. L. de. A questão urbana na América Latina: textos. Rio de Janeiro: Forense Universitária, 1978. p. 9-59.

RAGO, Margareth. Do cabaré ao lar - a utopia da cidade disciplinar no Brasil 18901930. 2. ed. Rio de Janeiro: Paz e Terra, 1987.

REIS FILHO, Nestor Goulart. Algumas experiências urbanísticas no início da República: 1890-1920. Cadernos de Pesquisa do LAP, São Paulo, n. 1, jul./ago. 1994. (Série Urbanização e Urbanismo) . Evolução urbana do Brasil (1500/1720). São Paulo: Pioneira, 1968. . Habitação popular no Brasil: 1880-1920. Cadernos de Pesquisa do LAP, São Paulo, n.2, set./out., 1994a. (Série Habitação Popular) . Notas sobre o urbanismo barroco no Brasil. Cadernos de Pesquisa do LAP, São Paulo, n.3, nov./dez., 1994b. (Série Urbanização e Urbanismo) Debates, 18)

. Quadro da Arquitetura no Brasil. São Paulo: Perspectiva, 1987. (Coleção

REIS, João José. Rebelião Escrava no Brasil: a história do levante dos malês (1835). São Paulo: Brasiliense, 1987.

REIS, José de Oliveira. História urbanística do Rio de Janeiro. O Rio: cidade dos pântanos e lagoas. Revista Municipal de Engenharia, Rio de Janeiro, v. 40, p. 3-25, jan./mar. 1986.

. O Rio de Janeiro e seus prefeitos: evolução urbanística da cidade. Rio de Janeiro: Prefeitura da Cidade do Rio de Janeiro, 1977.

RENAULT, Delso. O dia-a-dia no Rio de Janeiro segundo os jornais, 1870-1889. Rio de Janeiro: Civilização Brasileira; Brasilia: INL, 1982.

. Industria, escravidão, sociedade: uma pesquisa historiográfica do Rio de Janeiro. Rio de Janeiro: Civilização Brasileira; Brasília: INL, 1976. (Retratos do Brasil, 103)

. O Rio antigo nos anúncios de jornais. Rio de Janeiro: J. Olympio, 1969. 
RELATÓRIO apresentado ao Conselho Municipal na sessão de 3 de fevereiro de 1906 pelo pharmaceutico Leopoldino Antonio de Freitas Tantú presidente do conselho substituindo o intendente do Municipio da Capital da Bahia. Bahia: Ed. A Bahia, 1906.

RESENDE, Beatriz. Lima Barreto e o Rio de Janeiro em fragmentos. Rio de Janeiro: EDUFRJ; UNICAMP, 1993.

Rio de Janeiro, cidade de modernismos. In: PECHMAN, Robert Moses (Org.)

Olhares sobre a cidade. Rio de Janeiro: EDUFRJ, 1994. p. 121-133.

REVITALIZAÇÃO da Rua do Riachuelo e Bairro de Fátima atraem investimentos. Folha do Centro do Rio, edição n. 132, set 2007. Disponível em: <http://jornalfolhadocentro.com. br/index4.php>.

REZENDE, Vera. Planejamento urbano e ideologia: quatro planos para a cidade do Rio de Janeiro. Rio de Janeiro: Civilização Brasileira, 1982. (Coleção Retratos de Brasil, 159)

RIBEIRO, Ana Clara Torres. Urbanidade e vida metropolitana. Rio de Janeiro: JOBRAN, 1996.

RICHARDSON, Robert Jarry. Pesquisa social: métodos e técnicas. São Paulo: Atlas, 1985.

RIO, João do. A alma encantadora das ruas: crônicas. Rio de Janeiro: Secretaria Municipal de Cultura, DGDIC - DEd., 1995. (Biblioteca Carioca, v.4. Série Literatura)

RIO DE JANEIRO. Prefeitura da cidade do Rio de Janeiro. O bonde na paisagem carioca. Rio de Janeiro: Secretaria Municipal de Educação e Cultura; Departamento Geral de Cultural, 1984.

RIO DE JANEIRO. Prefeitura da cidade do Rio de Janeiro. Revitalização do Centro. Disponível em: <www.rio.rj.gov.br/planoestrategico/old/plano93_96/pl_proje5.html>.

RIO DE JANEIRO. Prefeitura do Distrito Federal. Rio de Janeiro. Melhoramentos da cidade projectados pelo Prefeito do Distrito Federal Dr. Francisco Pereira Passo. Rio de Janeiro: Gazeta de Notícias, 1903.

ROCHA, Oswaldo Porto. A era das demolições: cidade do Rio de Janeiro: 1870-1920. 2.ed. Rio de Janeiro: Secretaria Municipal de Cultura; DGDIC; DEd., 1995.

ROLNIK, Raquel. História urbana: história na cidade? In: FERNANDES, Ana; GOMES, Marco Aurélio A. de Filgueiras. (Org.) Cidade \& história: modernização das cidades brasileiras nos séculos XIX e XX. Salvador: MAU/UFBA; ANPUR, 1992. p. 27-29. 203) . O que é cidade. 3.ed. São Paulo: Brasiliense, 1994. (Coleção Primeiros Passos,

ROMERO, José Luis. Latinoamérica: las ciudades y las ideas. México: Siglo Veintuno, 1976.

RONCAYOLO, Marcel. La ciudad. Tradução de Beatriz E. Anastasi de Lonne. Barcelona: Paidós, 1988.

. La croisssance de la ville. Les schémas, les étapes. In: BERGERON, Louis. (Ed.) Paris. Génèse d'un paysage. Paris: Picard, 1989. p. 217-261.

. Mutaciones del espacio urbano: la nueva estructura del París haussmanniano. In: DETHIER, J.; GUIHEUX, A. (Eds), Visiones urbanas: Europa 1870-1993. La ciudad del artista. La ciudad del arquitecto. Madrid: Electa, CCCB, 1994. p. 57-59.

. Nouveau cycle ou fin de l'urbanization? In: DUBY, Georges (Ed.). Histoire de la

France Urbaine 4. La ville aujourd'hui. Paris: Du Seuil, 1983A. v.5. p. 13-131. 
. La production de la ville. In: DUBY, Georges (Ed.) Histoire de la France Urbaine 4. La ville del âge industriel: le cycle haussmannien. Paris: Du Seuil, 1983b. v.4. p. 73-155.

. Las transformaciones haussmannianas. In: GUARDIA BASSOLS, M.; MONCLÚS

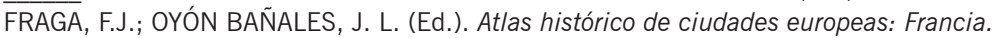
Barcelona: CCCB; Salvat, 1996. p. 188-189.

RONCAYOLO, Marcel; PAQUOT, Th. (Eds.) Villes et civilizations urbaine XVIII-XX siècle. París: Larousse, 1992.

ROSADO, Rita de Cassia Santana de Carvalho. O Porto de Salvador: modernização em projeto 1854-1891. 1983. Dissertação (Mestrado em Ciencias Sociais) - Faculdade de Filosofia e Ciências Humanas da UFBA, Salvador.

ROSSI, Aldo. La arquitectura de la ciudad. Tradução de Josep Maria Ferre-Ferre e Salvador Tarragó Cid. 8. ed. Barcelona: Gustavo Gili, 1992.

ROUGERIE, Jacques. Paris des barricades, un espace populaire. In: PINON, Pierre. Les traversées de Paris: deux siècles de révolutions dans la ville. Paris: Moniteur, La Grande Halle - La Villette, 1989. p. 47-54.

ROULEAU, Bernard. Le tracè des rues de Paris: formaction, typologie, fonctions. Paris: CNRS, 1983.

ROZZI. R. Ciudad y plano en la Italia del final del XIX. Historia Urbana, Valencia, n. 3, p. 91-107, 1994.

RUGENDAS; DEBRET, J.B. Paisagem colonial. Rio de Janeiro: Difusão Nacional do Livro,[s.d.]. (Série Documentos Históricos, 7)

SÁ, José de. O bombardeio da Bahia e seus efeitos: registro político e histórico. Bahia: Diário da Bahia, 1918.

SAHIB. La fregate L'Incomprise. Voyage autour du Monde. Paris: Albert Messein, 1924.

SALVADOR. PREFEITURA DA CIDADE DO SALVADOR. OCEPLAN. Evolução física da cidade do Salvador. Salvador: PLANDURB - Plano Diretor de Desenvolvimento Urbano, 1979. 4v. (Série de Estudos Informativos, 2)

SALVADOR. PREFEITURA MUNICIPAL DO SALVADOR. Álbum-lembrança da Exposição Iconográfica e Bibliográfica Bahiana. Salvador: Prefeitura Municipal do Salvador, 1951.

SAMPAIO, Antonio Heliodório Lima. Em busca da modernidade: três desenhos para Salvador metrópole. In: FERNANDES, Ana; GOMES, Marco Aurélio A. de Filgueiras. (Orgs.) Cidade \& história: modernização das cidades brasileiras nos séculos XIX e XX. Salvador: MAU/FAUFBA; ANPUR, 1992. p. 159-167.

. Formas urbanas: cidade real \& cidade ideal; contribuição ao estudo urbanístico de Salvador. Salvador: Quarteto; PPG: AU, Faculdade de Arquitetura da UFBa., 1999.

SAMPAIO, Carlos. O arrazamento do morro do Castelo. Paris: Société Française d'Imprimerie, [192-.]

- Memória histórica: obras da Prefeitura do Rio de Janeiro. 8 de junho de 1920 a 15 de novembro de 1922. Rio de Janeiro: Empresa Internacional, 1924.

SAMPAIO, Nelson de Sousa. Salvador em 60 anos. Revista Cultural da Bahia, Salvador, n. 7, p. 15-20, jan./dez. 1972.

SAMPAIO, Theodoro. Relatório dos estudos e projectos para uma cidade nova (a cidade luz). Salvador: Imprensa Official, 1919. 
SANTANA, Lídia. Revitalização de áreas portuárias: referências para Salvador. BAHIA ANÁLISE \& DADOS. Salvador, v. 13, n. 2, p. 225-238, set. 2003.

SANTOS, Mário Augusto da Silva. Associação Comercial da Bahia na Primeira República: um grupo de pressão. Salvador: Secretaria da Indústria, Comércio e Turismo do Estado da Bahia, 1985.

. Crescimento urbano e habitação em Salvador. (1890-1940). RUA: Revista de Arquitetura e Urbanismo, Salvador, v. 3, n. 4/5, p. 20-29, 1990.

. Habitação em Salvador: fatos e mitos. In: BRESCIANI, Maria Stella (Org.)

Imagens da cidade, século XIX e XX. São Paulo: ANPUH; Marco Zero, 1994. p. 93-110.

. Novas e velhas ocupações na Salvador republicana (1890-1930). In: FERNANDES, Ana; GOMES, Marco Aurélio A. de Filgueiras (Org.) Cidade \& história: modernização das cidades brasileiras nos séculos XIX e XX. Salvador: MAU/FAUFBA; ANPUR, 1992.

p. 257-262

SANTOS, Milton. O centro da Cidade do Salvador. Salvador: Universidade da Bahia, 1959a.

SANTOS, Milton. O centro da Cidade do Salvador: estudo de geografia urbana. 2 ed. São Paulo: EDUSP; Salvador: EDUFBA, 2008.

Contribuição ao estudo dos centros de cidades: o exemplo da cidade do Salvador. Separata de: Boletim Paulista de Geografia, São Paulo, n. 32, p. 17-30, jul. 1959b. . Ensaios sobre a urbanização Latino-americana. São Paulo: HUCITEC, 1982a.

Salvador: centro e centralidade na cidade contemporânea. In: GOMES, Marco Aurélio A. de Filgueiras. (Org.) Pelo Pelô: história, cultura e cidade. Salvador: Universidade Federal da Bahia; MAU/FAUFBA, 1995. p. 11-29.

5) . A urbanização brasileira. 3.ed. São Paulo: HUCITEC, 1996. (Estudos Urbanos,

SANTOS, Paulo F. Arquitetura e urbanismo na avenida Central. In: FERREZ, Marc. 0 Álbum da Avenida Central. Rio de Janeiro: Ex. Libris; João Fortes Engenharia, 1982b.

- Quatro séculos de arquitetura. Rio de Janeiro: Instituto dos Arquitetos Brasileiros, 1981. (Coleção IAB, 1)

SCHBERT, Dirk; SUTCLIFFE, Anthony. The "Haussmannization" of London? The planning and construction of Kingsway-Aldwych, 1889-1935. Planning Perspectives, London, v. 11 , n. 2, p. $115-144,1996$,

SCHNOOR, J. A harmonia do desenvolvimento urbano em função da rede de transportes coletivos de massa. Rio de Janeiro: B.N.H., 1975.

SCHORSKE, Carl E. Viena fin-de-siècle: política e cultura. Tradução de Denise Bottmann. São Paulo: Companhia das Letras, 1988.

SCHTEINGART, Martha, TORRES, Horacio. Processos sociais e estruturação metropolitana na América Latina: estudo de casos. In: ALMEIDA, Fernando Lopes de. A questão urbana na América Latina. Textos. Rio de Janeiro: Forense Universitária, 1978. p. 125-163. (Col. Ensaios de Economia)

SCOBIE, James. Buenos Aires del centro a los barrios. 1870-1910. Buenos Aires: SolarHachete, 1977. 
. Changing urban patterns: the porteño case 1880-1910. In: HARDOY, Jorge E.; SCHAEDEL, Richard P. (Ed.). El proceso de urbanización en América desde sus orígenes hasta nuestros días. Buenos Aires: Editorial del Instituto, 1969. p. 323-341.

SEABRA, Paulo Sérgio de Almeida. As visões ideológicas contemporaneas da reforma urbana do prefeito Pereira Passos. 1902-1906. 1989. Monografia. IPPUR/UFRJ, Rio de Janeiro.

SECRETARIA MUNICIPAL DE CULTURA, TURISMO E ESPORTES, DEPARTAMENTO GERAL DE PATRIMÔNIO CULTURAL. Rio de Janeiro, uma cidade no tempo. Rio de Janeiro: Diagraphic Projetos Gráficos, 1992.

SEGRE, Roberto. Rio de Janeiro metropolitano: saudades da Cidade Maravillosa. Vitruvius, arquitexto 046, mar/04. Disponível em: <http://www.vitruvius.com.br/ arquitextos/arq046/arq046_01.asp>.

SEVCENKO, Nicolau. Literatura como missão: tensões sociais e criação cultural na Primeira República. 4 ed. São Paulo: Brasiliense, 1995.

SICA, Paolo. Antologia di urbanistica. Bari: Laterza, 1980.

. Historia del urbanismo - el sig/o XIX. 2.ed. Madrid: IEAL, 1981a. 2v. . Historia del urbanismo - el siglo XX. Tradução de Joaquín Hernández Orozco.

Madrid: IEAL, 1981b. v.6. . Historia del urbanismo - el sig/o XVIII. Madrid: IEAL, 1982. . L'immagine della città da Sparta a Las Vegas. Roma; Bari: Laterza, 1991. (Colección. Biblioteca Universale Laterza,342)

SILVA, Barbara-Christine Nentwig, SILVA, Sylvio Carlos Bandeira de Mello e. Cidade e região no Estado da Bahia. Salvador: Centro Editorial e Didático da UFBA, 1991.

SILVA, César Henriques Matos e. Relatório de trabalho $n^{\circ} 1$. Salvador, 1990. Relatório apresentado ao Mestrado de Arquitetura e Urbanisno da UFBA como requisito de Bolsista Iniciação Cientifica CNPq. Não publicado.

SILVA, Eduardo. A República comemora o Império: um aspecto político-ideológico da crise dos anos 20. Revista Rio de Janeiro, Niterói, v. 1, n. 2, jan./abr., p. 59-70, 1986.

SILVA, Lúcia Helena Pereira da. A Cidade do Rio de Janeiro e a reforma urbana de Carlos Sampaio 1920/1922. In: SIMPÓSIO NACIONAL DE GEOGRAFIA URBANA, 3, 1993. Anais... Rio de Janeiro: IBGE, 1993. p. 193-194.

. O Plano Agache nos diários cariocas: leituras da cidade. In: MONTEIRO, Circe (Org.) SEMINÁRIO INTERDISCIPLINAR CIDADE E PRODUÇÃO DO COTIDIANO, 1995. Anais... Recife: UFPE; MDU., 1995. p. 221-235.

. A trajetória de Alfred Donat Agache no Brasil. In: RIBEIRO, Luiz Cesar de Queiroz; PECHMAN, Robert. (Orgs.) Cidade, povo e nação: gênese do urbanismo moderno. Rio de Janeiro: Civilização Brasileira, 1996. p. 397-410.

SILVA, Maria Lais P. da. Os transportes coletivos na cidade do Rio de Janeiro: tensões e conflitos. Rio de Janeiro: Secretaria Municipal de Cultura, Turismo e Esportes, DGDICultural - DEd., 1992.

SILVA, Marilene Rosa Nogueira da. Negro na rua: a nova face da escravidão. São Paulo: HUCITEC; Brasília: CNPq, 1988. (Estudos Históricos)

SILVA, Sylvio Bandeira de Mello e. Processo de crescimento espacial de Salvador/Brasil. In: CONGRESSO INTERNACIONAL DE AMERICANISTAS - AMSTERDAM, 46, Holanda. 
Trabalho apresentado no $46^{\circ}$ Congreso Internacional de Americanistas, Amsterdam/ Holanda, 1988. Não publicado.

. O sistema urbano de Salvador e sua inserção no contexto nacional. Debates, Salvador: Centro de Projetos e Estudos, 1985. v. 2, p. 233-257.

SIMAS, Américo Furtado de. Suggestões para o plano director da Cidade do Salvador. In: COMMISSÃO DO PLANO DA CIDADE DO SALVADOR. "Semana de Urbanismo" 20 a 27 de outubro de 1935. Conferências. Bahia: Graphica da Bahia, 1937. p. 117-126.

SIMAS FILHO, Américo. A cidade do Salvador antes e depois da independência. In: CICLO DE CONFERÊNCIAS SOBRE O SESQUICENTENÁRIO DA INDEPENDÊNCIA NA BAHIA EM 1973. Salvador: [s.n.], 1977. p. 99-115.

SIMÕES JUNIOR, José Geraldo. O setor de obras públicas e as origens do urbanismo na cidade de São Paulo. In: FERNANDES, Ana; GOMES, Marco Aurélio A. de Filgueiras. (Orgs.) Cidade \& história: modernização das cidades brasileiras nos séculos XIX e XX. Salvador: MAU/FAUFBA; ANPUR, 1992, p. 125-130.

SINGER, Paul. O Brasil no contexto do capitalismo internacional 1889-1930. In: FAUSTO, Boris (Org.) O Brasil republicano: estrutura de poder e economia (18891930). 4. ed. São Paulo: DIFEL, 1985. v.1, t.3, p. 355-390. (História Geral da Civilização Brasileira, v.8) Economia politica da urbanização. 11.ed. São Paulo: Brasiliense, 1987. . Urbanización, dependencia y marginalidad en América Latina. In: CASTELLS, Manuel (Ed.). Imperialismo y urbanización en América Latina. Barcelona: Gustavo Gili, 1973. p. 287-312.

. O uso do solo urbano na economia capitalista. In: MARICATO, Erminia. A produção capitalista da casa (e da cidade) no Brasil industrial. São Paulo: Alfa-Ômega, 1979.

SIRKIS, Alfredo. A revitalização do centro da cidade do Rio de Janeiro e da zona portuária. In SCHWEIZER, Peter José; CESARIO, Sebastiana (Org.) Revitalização de centros urbanos em áreas portuárias. Rio de Janeiro: 7letras; AFEBA, 2004, p. 60-68.

SIRKIS, Alfredo. A revitalização do Centro: vitória na Lapa, algum avanço na área portuária. Comunicação Sirkis. Rio de Janeiro, 2005. Disponível em: <http://www2. sirkis.com. br/noticia.kmf?noticia $=3913122 \&$ canal $=260>$.

SOARES, Maria Therzinha de Segadas. A integração do recôncavo da Guanabara na área metropolitana do Grande Rio de Janeiro. In: BERNARDES, Lysia M.C.; SOARES, $M^{a}$ Therezinha de Segadas. Rio de Janeiro: cidade e região. Rio de Janeiro: Secretaria Municipal de Cultura; DGDIC - DEd., 1990. p. 42-67. (Biblioteca Carioca, n.3)

SOLÁ-MORALES, M. de. Los ensanches. In: L.U.B. Los ensanches (I). El ensanche de Barcelona. Barcelona: ETSAB, 1978. p. 9-25.

SOLANO, Francisco de (Ed.) Historia urbana de Iberoamérica. Madrid: Testimonio; Consejo Superior de los Colegios de Arquitectos de España, 1987. 5 v.

El proceso urbano iberoamericano desde sus orígenes hasta principios del siglo XIX.: estudio bibliográfico. In: SOLANO, Francisco de (Ed.) Estudios sobre la ciudad iberoamericana. 2. ed. Madrid: CSIC, 1983.

SOLIS, Sidney Sérgio F.; RIBEIRO, Marcus Venício T. O Rio onde o sol não brilha: acumulação e pobreza na transição para o capitalismo. Revista Rio de Janeiro, Niterói, v. 1, n. 1, p. $45-59,1985$ 
SOUZA, Guaraci Adeodato Alves de. Urbanização e fluxos migratórios para Salvador. In: SOUZA, Guaraci Adeodato A. de; FARIA, Vilmar. (Org.) Bahia de todos os pobres Petrópolis: Vozes; CEBRAP, 1980. p. 103-128.

SOUZA, Luiz Antonio de. Configuração espacial de Salvador. 1984. Dissertação (Mestrado em Planejamento Urbano e Regional) - PROPUR/UFRGS, Porto Alegre.

SPIX, Johann Baptist von, MARTIUS, Carl Friedrich Philip von. Através da Bahia. Bahia: Imprensa Oficial do Estado, 1916.

. Viagem pelo Brasil 1817-1820. 2.ed. Tradução de Lucia Furquim Lahmeyer. São Paulo: Melhoramentos,1961. 2v.

STUCKENBRUCK, Denise Cabral. O Rio de Janeiro em questão: o Plano Agache e o ideário reformista dos anos 20. Rio de Janeiro: Observatório de Políticas Urbanas; IPPUR; FASE, 1996.

SÜSSEKIND, Flora. As Revistas do Ano e a invenção do Rio de Janeiro Rio de Janeiro: Nova Fronteira; Fundação Casa de Rui Barbosa, 1986.

SUTCLIFFE, Anthony. Du cheval au tranway: la mécanisation des transports urbains 1850-1900. Les annales de la recherche urbaine, Paris, n. 23-24, p. 5-17, 1984. . Introduction: the debate on nineteenth-century planning. In: SUTCLIFFE, A.(Ed.) The rise of modern urban planning, 1800-1914. London: Mansell, 1980. p. 1-10. El nacimiento de una disciplina. In: DETHIER, J.; GUIHEUX, A. (Ed.). Visiones urbanas. Europa 1870-1993. La ciudad del artista. La ciudad del arquitecto. Madrid: Electa, CCCB, 1994. p. 121-128.

- Ocaso y fracaso del centro de Paris. Tradução de Antonio J. Desmonts Gutiérrez. Barcelona: Gustavo Gili, 1973. . Paris: an architectural history. New Haven; London: Yale University, 1993. . Planificació urbana al segle XIX: continuïtat o discontinuitat? Història urbana $i$ intervenció en el centre históric. Barcelona: Institut Cartogràfic de Catalunya, 1989.

. Towards the planned city: Germany, Britain, the United States and France, 1780-1914. Oxford: St. Martins, 1981.

SZILARD, Adalberto; REIS, José de Oliveira. Urbanismo no Rio de Janeiro. Rio de Janeiro: O Constructor, 1950.

TAVARES, Luis Henrique Dias. História da Bahia. 8.ed. São Paulo: Ática, 1987.

TEIXEIRA, Cid. Bahia em tempo de Província. Salvador: Fundação Cultural do Estado da Bahia, 1985.

TERAN, Fernando de. La ciudad hispanoamericana. El sueño de un orden. Madrid: CEHOPU, 1989.

TOLEDO, Benedito Lima de. São Paulo: três cidades em um século. 2.ed. São Paulo: Duas Cidades, 1983.

TOLEDO, Roberto Pompeu de. Sobre ônibus, metrô e ordem social. As eleições para prefeito são uma oportunidade para pensar na sociedade que queremos. Veja, São Paulo, 22 maio 1996. p. 142.

TOUTTAIN, P. A. Haussmann: artisan du Second Empire, créateur du Paris moderne. Paris: [s.n.], 1971. 
VASCONCELOS, Pedro de Almeida. A “idade de ouro" de Salvador (1650-1800). In: SIMPÓSIO NACIONAL DE GEOGRAFIA URBANA. 3, 1993. Anais... Rio de Janeiro: IBGE, 1993, p. 191-192.

O trabalho irregular urbano: escravidão e república. In: FERNANDES, Ana; GOMES, Marco Aurélio A. de Filgueiras. (Org.) Cidade \& história: modernização das cidades brasileiras nos séculos XIX e XX. Salvador: MAU/FAUFBA; ANPUR, 1992. p. 247-256.

VAZ, Lilian Fessler. A "culturalização" do planejamento e da cidade: novos modelos? Anais IPHS2004. Barcelona: UPC. 2004.

. Contribuição ao estudo da produção e transformação do espaço da habitação popular: as habitações coletivas no Rio antigo. 1985. Dissertação (Mestrado em planejamento urbano) - IPPUR -Universidade Federal do Rio de Janeiro, Rio de Janeiro.

. História da habitação coletiva na cidade do Rio de Janeiro: estudo da modernidade através da moradia. 1994. Tese (Doutorado em Arquitetura) - Faculdade de Arquitetura da Universidade de São Paulo, São Paulo, 1994.

. Modernização excludente e moradia no Rio de Janeiro. In: FERNANDES, Ana, GOMES, Marco Aurélio A. de Filgueiras. (Org.) Cidade \& história: modernização das cidades brasileiras nos séculos XIX e XX. Salvador: MAU/FAUBA;ANPUR, 1992. P. 197203.

VAZ, Lilian Fessler; CARDOSO, Elizabeth Dezouzart. Obras de melhoramentos no Rio de Janeiro: um debate antigo e um previlégio concorrido. In: DEL BRENNA, Giovanna Rosso (Org.) O Rio de Janeiro de Pereira Passos: uma cidade em questão II. Rio de Janeiro: INDEX, 1985. p. 613-622.

VAZ, Lilian Fessler; SILVEIRA, Carmen Beatriz. A área central do Rio de Janeiro: percepções e intervenções - uma visão sintética no decorrer do século XX. Cadernos IPPUR/UFRJ, Rio de Janeiro, v. 8, n. 2/3, p. 95-105, set./dez., 1994.

. A área central do Rio de Janeiro: percepções e reformas urbanas. In: SIMPÓSIO NACIONAL DE GEOGRAFIA URBANA, 3, 1993. Anais... Rio de Janeiro: IBGE, 1993. p. 215-217.

VERGER, Pierre. Notícias da Bahia - 1850. Salvador: Corrupio, Fundação Cultural do Estado da Ba., 1981.

VIANNA, Hildegardes. Breve notícia sobre acontecimentos na Bahia no inicio do século XX. Salvador: Centro de Estudos Baianos da Universidade Federal da Bahia, 1983.

VICENTINI, Yara Teorias da cidade e as reformas urbanas contemporâneas.

Desenvolvimento e Meio Ambiente, n. 3, p. 9-31, jan./jun. 2001.

VILHENA, Luis dos Santos. A Bahia no século XVIII. Salvador: Itapuã, 1969. 2 v.

VINHAES, Nathalia Gomes da Costa. O açúcar, o fumo e o cacau como principais fatôres econômicos da Bahia. In: CONGRESSO DE HISTÓRIA DA BAHIA, 1. 1950. Anais... Salvador: Beneditina, 1950, v.4. p. 241-261.

VISTAS da Cidade do Salvador. Rio de Janeiro: Pimenta de Mello \& C.,[19-]

WAGENAAR, M. Centros monumentales, alrededores pintorescos: contrastes entre paisajes urbanos y diferentes usos del suelo en seis capitales europeas, 1850-1914. Historia Urbana, n. 4, p. 27-47, 1997.

Conquest of the center or flight to the suburb? Divergente Metropolitan strategies in Europe, 1850-1914. Journal of Urban History, London, v. 19, n. 1, p. 60-83. 1992. 
WARD, Steven (Ed.) The garden city: past, present and future. London: Spon, 1992.

WILSON, William H. The City Beautiful moviment. Baltimore; Londres: Johns Hopkins University, 1989.

. The ideology, aesthetics and politics of the City Beautiful movement. In: SUTCLIFFE, Anthony (Ed.) The rise of modern urban planning - 1800-1914. London: Mansell, 1980. p. 165-198.

YAGO, G. Transportation politics: the case of Frankfurt am Main. In: The decline of transit. Cambridge: Cambridge U. P., 1984. p. 77-130.

YUJNOVSKY, Oscar. La estructura interna de la ciudad. El caso latinoamericano. Buenos Aires: Siap, 1971.

ZUCCONI, G. (Org.). Camillo Sitte e isuoi interptreti. Milán: Franco Angeli, 1992.

ZYLBERBERG, Sonia. Morro da Providência: memórias da Favela. Rio de Janeiro: Secretaria Municipal de Cultura, Turismo e Esportes, DGDIC, 1992. 


\section{Lista de Imagens}

1. Plano de Paris - 1787 - indicando as sucessivas muralhas da cidade, sendo a última a Fermiers Généraux

Fonte: BERGERON, Louis (ed.) Paris. Génèse d'un paysage. Paris: Picard, 1989.

2. Intervenções realizadas em Paris entre 1815 e 1848, antes do período de Haussmann Fonte: DES CARS, Jean, PINON, Pierre. Paris-Haussmann. "Le pari d'Haussmann" Paris: Editions du Pavillon de l'Arsenal-Picard, 1991.

3. Intervenções realizadas em Paris de 1853 a 1870, durante o período de Haussmann Fonte: DES CARS, Jean, PINON, Pierre. Paris-Haussmann. "Le pari d'Haussmann" Paris: Editions du Pavillon de l'Arsenal-Picard, 1991.

4. "Planta da Cidade do Rio de Janeiro e subúrbios (cópia do "Plan der Stadt Rio de Janeiro und Umgebung" da B.E.G.) [S.n.]"

Fonte: Arquivo Nacional - Seção de Mapas

5. Projeto de uma grande avenida, em 1875

Fonte: ABREU, M. Evolução urbana do Rio de Janeiro. 2.ed. Rio de Janeiro: IPLANRIO; ZAHAR, 1988.

6. Projeto apresentado por Fogliani, em 1901

Fonte: DEL BRENNA, Giovanna. Rosso. (Org.) O Rio de Janeiro de Pereira Passos: uma cidade em questão. II Rio de Janeiro: INDEX, 1985.

7. Vista do centro do Rio de Janeiro - foto de Marc Ferrez - 1900

Fonte: FERREZ, Marc. O álbum da Avenida Central. Rio de Janeiro: Ex Libris; João Fortes Engenharia, 1982. 
8. Plano das intervenções realizadas na cidade do Rio de Janeiro na prefeitura de Pereira Passos - 1902-1906

Fonte: ABREU, M. Evolução urbana do Rio de Janeiro. 2.ed. Rio de Janeiro: IPLANRIO; ZAHAR, 1988, com intervenções nossas.

9. Vista da Avenida Beira Mar, em Botafogo - foto de A. Ribeiro - 1915

Fonte: SECRETARIA MUNICIPAL DE CULTURA. Rio de Janeiro, uma cidade no tempo. Rio de Janeiro: Diagraphic Projetos Gráficos, 1992

10. Projeto de abertura da Avenida Mem de Sá, no Rio de Janeiro, em 1903

Fonte: REIS, J. de O. O Rio de Janeiro e seus prefeitos: evolução urbanística da cidade. Rio de Janeiro: Prefeitura da Cidade do Rio de Janeiro, 1977.

11. Rua da Prainha antes da reforma - foto de Augusto Malta - 1903

Fonte: DEL BRENNA, Giovanna. Rosso. (Org.) O Rio de Janeiro de Pereira Passos: uma cidade em questão. II Rio de Janeiro: INDEX, 1985.

12. Rua da Prainha durante a reforma - foto de Augusto Malta - 1904

Fonte: DEL BRENNA, Giovanna. Rosso. (Org.) O Rio de Janeiro de Pereira Passos: uma cidade em questão. II Rio de Janeiro: INDEX, 1985.

13. Escola Nacional de Belas Artes - foto de Marc Ferrz - 1910

Fonte: FERREZ, Marc. O álbum da Avenida Central. Rio de Janeiro: Ex Libris; João Fortes Engenharia, 1982.

14. Teatro Municipal - foto de Marc Ferrez - 1910

Fonte: FERREZ, Marc. O álbum da Avenida Central. Rio de Janeiro: Ex Libris; João Fortes Engenharia, 1982.

15. Obras de abertura da Avenida Central - foto de Marc Ferrez - 1904

Fonte: FERREZ, Marc. O álbum da Avenida Central. Rio de Janeiro: Ex Libris; João Fortes Engenharia, 1982.

16. Avenida Central após a abertura - foto de Marc Ferrez - c. 1910

Fonte: FERREZ, Marc. O álbum da Avenida Central. Rio de Janeiro: Ex Libris; João Fortes Engenharia, 1982.

17. Vista do centro do Rio de Janeiro - 1930

Fonte: SICA, P. Historia del urbanismo - el siglo XIX. 2.ed. Madrid: IEAL, 1981.

18. Vista aérea do Porto do Rio de Janeiro

Fonte: ABREU, M. Evolução urbana do Rio de Janeiro. 2.ed. Rio de Janeiro: IPLANRIO; ZAHAR, 1988.

19. Lagoa Rodrigo de Freitas - foto autor desconhecido - início século XX

Fonte: ABREU, M. Evolução urbana do Rio de Janeiro. 2.ed. Rio de Janeiro: IPLANRIO; ZAHAR, 1988.

20. Praia do Leblon - foto autor desconhecido - início século XX

Fonte: ABREU, M. Evolução urbana do Rio de Janeiro. 2.ed. Rio de Janeiro: IPLANRIO; ZAHAR, 1988.

21. Vista aérea da Esplanada do Castelo após desmonte do Morro do Castelo - Rio de Janeiro - foto de C. Kfuri - década de 20 do século XX

Fonte: SECRETARIA MUNICIPAL DE CULTURA. Rio de Janeiro, uma cidade no tempo. Rio de Janeiro: Diagraphic Projetos Gráficos, 1992.

22. Projeto de Alfred Agache para o centro do Rio de Janeiro - 1930

Fonte: AGACHE, Alfred H. D. Cidade do Rio de Janeiro, extensão, remodelação, embellezamento. Paris: Foyer Brésilien, 1930. 
23. Esboço do projeto de Le Corbusier para o Rio de Janeiro - 1929

Fonte: GARCIA ESPUCHE, A. El centre residencial burguès. In: LA FORMACIÓ de I'Eixample de Barcelona. Barcelona: L'Avenç-O.C., 1990.

24. Elevação do projeto de Le Corbusier para o Rio de Janeiro - 1929

Fonte: DETHIER, J., GUIHEUX, A. (Eds). Visiones urbanas. Europa 1870-1993. La ciudad del artista. La ciudad del arquitecto. Madrid: Electa; CCCB, 1994.

25. Plano da Cidade do Salvador organizado pelo Engenheiro Adolfo Morales de los Rios - 1894

Fonte: Arquivo Nacional - Seção de Mapas

26. Elevador Lacerda - foto de Rodolfo Lindemann - 1885

Fonte: FERREZ, Gilberto. Bahia: velhas fotografias 1858/1900. Rio de Janeiro: Kosmos; Salvador: Banco da Bahia Investimentos, 1988.

27. Plano Inclinado do Gonçalves

Fonte: IFB - Instituto Feminino da Bahia

28. Cais das Amarras, na Cidade Baixa - foto de B. Mulock - 1860

Fonte: FERREZ, Gilberto. Bahia: velhas fotografias 1858/1900. Rio de Janeiro: Kosmos; Salvador: Banco da Bahia Investimentos, 1988.

29. Sede da Associação Comercial na Cidade Baixa - foto de B. Mulock - 1860

Fonte: FERREZ, Gilberto. Bahia: velhas fotografias 1858/1900. Rio de Janeiro: Kosmos; Salvador: Banco da Bahia Investimentos, 1988.

30. Ladeira da Montanha, ligação entre a Cidade Baixa e Cidade Alta - foto de R. LIndemann - 1880

Fonte: FERREZ, Gilberto. Bahia: velhas fotografias 1858/1900. Rio de Janeiro: Kosmos; Salvador: Banco da Bahia Investimentos, 1988.

31. Praça do Palácio antes das intervenções realizadas no século XIX

Fonte: CEAB - Centro de Estudos de Arquitetura da Bahia da Universidade Federal da Bahia

32. Praça do Palácio depois das intervenções realizadas no século XIX

Fonte: CEAB - Centro de Estudos de Arquitetura da Bahia da Universidade Federal da Bahia

33. Vista da Cidade Baixa - autor desconhecido - c. 1880

Fonte: FERREZ, Gilberto. Bahia: velhas fotografias 1858/1900. Rio de Janeiro: Kosmos; Salvador: Banco da Bahia Investimentos, 1988.

34. Projetos das intervenções propostas no governo de J. J. Seabra - Salvador - 1912-1916 Elaboração da autora

35. Projeto de melhoramentos na cidade do Salvador pelo engenheiro J. T. de Alencar Lima - perspectiva (1910)

Fonte: CEAB - Centro de Estudos de Arquitetura da Bahia da Universidade Federal da Bahia

36. Melhoramentos municipais de parte do distrito de Sant'Anna - 1912

Fonte: CEAB - Centro de Estudos de Arquitetura da Bahia da Universidade Federal da Bahia

37. Projeto de Melhoramentos Municipais - Distrito da Sé - 1912

Fonte: CEAB - Centro de Estudos de Arquitetura da Bahia da Universidade Federal da Bahia

38. Palácio dos Governadores - c. 1871

Fonte: FERREZ, Gilberto. Bahia: velhas fotografias 1858/1900. Rio de Janeiro: Kosmos; Salvador: Banco da Bahia Investimentos, 1988.

39. Palácio do Governo - 1900

Fonte: IFB - Instituto Feminino da Bahia 
40. Palácio Rio Branco - 1919

Fonte: IFB - Instituto Feminino da Bahia

41. Biblioteca Pública - década de 20 do século XX

Fonte: VISTAS da Cidade do Salvador. Rio de Janeiro: Pimenta de Mello \& C.,[19—]

42. Imprensa Oficial e Biblioteca Pública - década de 30 do século XX

Fonte: IFB - Instituto Feminino da Bahia

43. Rua Direita do Palácio, antes das intervenções - foto de B. Mulock - 1860

Fonte: FERREZ, Gilberto. Bahia: velhas fotografias 1858/1900. Rio de Janeiro: Kosmos; Salvador: Banco da Bahia Investimentos, 1988.

44. Rua Chile, antiga Direita do Palácio, depois das intervenções de 1912-1916

Fonte: IFB - Instituto Feminino da Bahia

45. Rua Chile depois do alargamento realizado em 1912-1916

Fonte: IFB - Instituto Feminino da Bahia

46. Projeto para a abertura da Avenida Sete de Setembro - Salvador - 1912-1916

Elaboração da autora

47. Ladeira de São Bento, antes das intervenções de J. J. Seabra - 1884 - foto de Marc Ferrez Fonte: FERREZ, Gilberto. Bahia: velhas fotografias 1858/1900. Rio de Janeiro: Kosmos; Salvador: Banco da Bahia Investimentos, 1988.

48. Ladeira de São Bento - meados do século XX

Fonte: IFB - Instituto Feminino da Bahia

49. Igreja de São Pedro Velho

Fonte: IFB - Instituto Feminino da Bahia

50. Demolição da Igreja de São Pedro Velho para abertura da Av. 7 de Setembro

Fonte: CEAB - Centro de Estudos de Arquitetura da Bahia da Universidade Federal da Bahia

51. Avenida 7 de Setembro - Estátua do Barão do Rio Branco - local da antiga Igreja de São Pedro Velho

Fonte: VISTAS da Cidade do Salvador. Rio de Janeiro: Pimenta de Mello \& C.,[19—]

52. Avenida 7 de Setembro - Relógio de São Pedro - local da antiga Igreja de São Pedro Velho Fonte: IFB - Instituto Feminino da Bahia

53. A Cidade Baixa e o porto de Salvador em 1920

Elaboração da autora

54. Ampliação do porto de Salvador - aterro e cais - c.1913

Fonte: CEAB - Centro de Estudos de Arquitetura da Bahia da Universidade Federal da Bahia

55. Comércio - Cidade Baixa

Fonte: IFB - Instituto Feminino da Bahia

56. Comércio - Cidade Baixa

Fonte: IFB - Instituto Feminino da Bahia

57. Avenida Oceânica no trecho entre a Barra e Ondina

Fonte: VISTAS da Cidade do Salvador. Rio de Janeiro: Pimenta de Mello \& C.,[19_]

58. Avenida Sete de Setembro entre o Porto e o Farol da Barra

Fonte: IFB - Instituto Feminino da Bahia

59. Vista da Barra e da Avenida Oceânica

Fonte: IFB - Instituto Feminino da Bahia 
60. Uma rua na Barra

Fonte: IFB - Instituto Feminino da Bahia

61. Avenida Sete de Setembro - Corredor da Vitória

Fonte: IFB - Instituto Feminino da Bahia

62. Avenida Sete de Setembro - Corredor da Vitória

Fonte: VISTAS da Cidade do Salvador. Rio de Janeiro: Pimenta de Mello \& C.,[19—]

63. Planta do arruamento de uma Cidade Nova - Cidade Luz - 1919 - Projeto de Theodoro Sampaio

Fonte: CEAB - Centro de Estudos de Arquitetura da Bahia da Universidade Federal da Bahia

64. Planta do centro da Cidade do Salvador - 1940

Elaboração da autora

65. Projeto para a abertura do Corso Vittorio Emmanuele - Roma - 1884

Fonte: SICA, P. Historia del urbanismo -el siglo XIX. 2.ed. Madrid: IEAL, 1981.

66. Projeto de abertura da Gran Via - Madrid - 1886

Fonte: GUARDIA, M., MONCLÚS, F.J., OYÓN, J.L. (Eds.). Atlas histórico de ciudades europeas. Península Ibérica. Barcelona: CCCB; Salvat, 1994.

67. Planos das reformas urbanas de Paris, Rio de Janeiro e Salvador

Aberturas realizadas em Paris por Haussmann- 1853/1870

Fonte: DES CARS, J., PINON, P. Paris-Haussmann. "le pari d'Haussmann" Paris: Pavillon de l'Arsenal-Picard, 1991.

Plano das intervenções realizadas no Rio de Janeiro

Fonte: ABREU, M. Evolução urbana do Rio de Janeiro. 2.ed. Rio de Janeiro: IPLANRIO;

ZAHAR, 1988, com intervenções nossas.

Projetos de intervenção em Salvador

Elaboração da autora

68. Tipos de aberturas realizadas - Paris, Rio de Janeiro e Salvador

Paris - Abertura da Avenue de l'Opéra

Fonte: DES CARS, Jean, PINON, Pierre. Paris-Haussmann. "le pari d'Haussmann" Paris: Pavillon de l'Arsenal-Picard, 1991.

Rio de Janeiro - Abertura da Avenida Central

Fonte: ABREU, M. Evolução urbana do Rio de Janeiro. 2. ed. Rio de Janeiro: IPLANRIO; ZAHAR, 1988.

Salvador - Aberturas no Distrito da Sé

Fonte: CEAB - Centro de Estudos de Arquitetura da Bahia da Universidade Federal da Bahia

69. Nova estética das construções - Paris, Rio de Janeiro e Salvador

Paris - Exemplo de fachada haussmanniana

Fonte: PITTE, Jean-Robert (ed.) Paris. Histoire d'une ville. Paris: Les Atlas Hachette, 1993.

Rio de Janeiro - Exemplo de fachada na Avenida Central

Fonte: FERREZ, Marc. O álbum da Avenida Central. Rio de Janeiro: Ex Libris; João Fortes Engenharia, 1982.

Salvador - Exemplo de fachada na Rua Chile

Fonte: IFB - Instituto Feminino da Bahia

70. Novas perspectivas - Paris, Rio de Janeiro e Salvador

Paris - Avenida da Ópera

Fonte: LOYER, F. Paris XIXe siècle, l'immeuble et la rue. Paris: Hazan, 1987.

Rio de Janeiro - Avenida Central

Fonte: FERREZ, Marc. O álbum da Avenida Central. Rio de Janeiro: Ex Libris; João Fortes Engenharia, 1982.

Salvador - Praça Rio Branco (antiga do Palácio)

Fonte: VISTAS da Cidade do Salvador. Rio de Janeiro: Pimenta de Mello \& C.,[19_] 
Figura 71. Avenida Central, atual Rio Branco, foto de Marc Ferrez, em 1910. Fonte: Ferrez (1982).

Figura 72. Centro do Rio após desmonte do Morro do Castelo

Fonte: Acervo da autora (2011).

Figura 73. Vista da Avenida Presidente Vargas

Fonte: Acervo da autora (2011).

Figura 74 e 75. Prédios da Avenida Rio Branco

Fonte: Acervo da autora (2011).

Figura 76. A Cidade de Salvador e seus centros e as avenidas de vale Fonte: Adaptado do Google Earth.

Figura 77. Áreas do Corredor Cultural e outras áreas de revitalização. Fonte: Adaptado do Google Earth.

Figura 78. Avenida Tancredo Neves na região do Iguatemi atualmente Fonte: Acervo da autora (2011).

Figura 79. Vista atual do Comércio Fonte: Acervo da autora (2011).

Figuras 80 e 81 . Espaços revitalizados - Rua da Carioca e Rua dos Mercadores Fonte: Acervo da autora (2011).

Figura 82. Prédios restaurados na Lapa Fonte: Acervo da autora (2011).

Figura 83. Típico comércio do Pelourinho Fonte: Acervo da autora (2011).

Figura 84. Vista do Cruzeiro de São Francisco e da Catedral ao fundo Fonte: Acervo da autora (2011).

Figura 85. Vista de prédios abandonados no Comércio Fonte: Acervo da autora (2011). 


\section{Índice Remissivo}

$190229,30,95,122,124,125,126,134,148,149,201,212,217,267$, $274,283,306,344$

$1902-1906122,127,155,247,248,279,283$

$190629,30,95,124,134,148,153,156,212,217,267,274,306,326$, 341,344

$191230,87,155,162,215,216,217,219,220,221,222,223,224$,

$227,228,234,236,241,248,249,250,254,258,260,267,3$ $08,309,335$

1912-1916 31, 178, 204, 212, 213, 239, 241, 243, 248, 252, 253

$191630,31,201,227,228,229,253,257,260,267,308,309,346$

\section{A}

academicismo 169, 283

academicista 283

Acesso Norte 287

Agache 154, 155, 158, 161, 162, 163, 164, 165, 166, 167, 168, 169, 172, $173,284,338,339,344,346$

Alencar Lima 160, 216, 219, 220, 221, 249

Alfred Agache 95, 154, 158, 160, 161, 162, 163, 167, 172, 261, 265, 284, 325

ambientes urbanos 39,48

ambiente urbano $41,49,57,58,86$

América Latina 26, 40, 41, 42, 43, 45, 47, 52, 55, 57, 125, 270, 326, 332, $340,343,345$ 
Amsterdã 54, 268

Arcos da Lapa 105

áreas centrais 72, 81, 243, 244, 281, 294

áreas revitalizadas 281

áreas urbanas 28, 108, 255, 276

áreas urbanizadas 26,73

área urbana 43, 45, 46, 55, 56, 96, 102, 105, 106, 109, 111, 114, 115, $119,184,199,204,214,216,240,249,252,262,264,269,274$, 288,303

Argentina 45, 189, 269

arte urbana 68

Arte Urbana 51

Avenida Beira Mar 292

Avenida Beira-Mar 130, 131, 132, 134, 149, 150, 157, 221

Avenida Central 131, 134, 137, 138, 140, 142, 143, 148, 149, 150, 155, 234, $274,276,329,343$

Avenida Contorno 287

Avenida de Mayo 134, 149, 269

Avenida Francisco Bicalho 140

Avenida Luiz Viana Filho 287

Avenida Mem de Sá 131, 132, 140, 149

Avenida Paralela 288, 296

Avenida Presidente Vargas 284, 313

Avenida Rio Branco 155, 160, 163, 164, 285, 303

Avenida Rodrigues Alves 131, 140, 301

avenidas de vale 287, 288, 315

Avenida Sete 217, 219, 221, 228, 234, 240, 242, 245, 246, 250, 254, 257, $272,273,303,309$

Avenida Sete de Setembro 245, 246, 286, 294, 303, 309. See also Consulte Avenida Sete

Avenida Tancredo Neves 287, 294, 302, 303, 316

\section{B}

Bahia 31, 32, 53, 94, 100, 107, 176, 181, 182, 183, 184, 188, 189, 190, $191,192,194,195,197,200,203,205,215,216,217,218,221$, 224, 228, 229, 234, 235, 236, 241, 248, 249, 257, 261, 263, 281, 287, 288, 295, 296, 324, 325, 326, 327, 329, 331, 334, 335, 336, 337, 338, 339, 340, 341, 342, 343, 344, 345, 346, 347

Baía de Guanabara 92, 100, 104, 107, 108, 118, 140, 154, 158, 171

Baía de Todos os Santos 175, 178, 200, 206, 263

bairros burgueses 44, 130, 152, 273

bairros haussmannianos 81

bairros operários 44, 45, 104

Barão do Rio Branco 148, 155

Barcelona 26, 27, 31, 55, 59, 60, 65, 116, 271, 325, 326, 327, 328, 330, $331,332,333,334,335,336,337,339,341,342,345,346$

Beaurepaire Rohan 114, 115, 116, 119, 153

Beaux-Arts 115, 154, 161, 169

Biblioteca Nacional 32, 106, 134

bombardeio de 1912195

bota-abaixo 125, 128

boulevards 69 
Brasil 26, 28, 29, 30, 31, 40, 42, 45, 46, 51, 52, 53, 55, 56, 87, 91, 92, $94,96,98,102,113,116,121,122,124,125,126,134,150,154$ $158,160,161,162,168,169,172,175,181,182,183,188,189$, $190,192,195,196,204,215,247,248,258,259,270,276,282$, $284,293,303,324,325,326,327,329,330,331,332,333,334$, $335,336,339,340,341,344,345,346$

Brasília 26, 27, 285, 289, 335, 337, 341, 344

Buenos Aires 40, 52, 57, 60, 119, 120, 122, 134, 149, 170, 248, 269, 274, $331,332,336,343,348$

bulevar $76,77,83,134,149,271$

bulevares $26,47,51,58,59,61,63,64,65,67,70,72,73,76,77,78$, $79,83,84,87,134,150,251,268,270,276$

C

CAB 287

Cabeça do Brasil 176

Camillo Sitte 26, 51, 258, 327, 348

Canal do Mangue 118, 140

Capital Federal 30, 100, 120, 163, 247, 251, 276, 285

Caracas 60, 270, 330

Carlos Sampaio 157, 158, 160, 344

Carta de Nairobi 290

casas de cômodo 58, 147, 242

casas higiênicas 98, 112

cena urbana 108

Centro Administrativo da Bahia 287, 288

Centro Antigo de Salvador 282, 295

centro histórico 45, 78, 85, 270, 283, 287, 290

Centro histórico 289

Centro Histórico 289, 295, 297, 298, 302

Centro Industrial de Aratu 287

centros históricos 53, 85, 266, 332

Centros Históricos 299

centros tradicionais $80,282,283$

centros urbanos 26,281

Centros Urbanos 282

centro tradicional $80,194,286,294$

centro urbano 54, 129, 242, 265, 287, 303

Cerro de Santa Lucia 270

Chile 45, 52, 60, 217, 237, 270

CHS 295, 296

CIA 287, 288

Cia. de Melhoramentos do Brasil 148

cidade $26,27,28,29,30,31,32,35,37,38,39,40,41,43,44,45,46$, $47,48,49,50,51,52,53,54,55,56,57,58,59,60,61,62,63$, $64,65,67,68,69,70,71,72,73,74,75,76,77,78,79,80,81$, $82,83,84,86,87,92,93,94,95,96,97,98,99,100,101,103$, $104,105,106,107,108,109,110,111,112,113,114,115,116$, $117,119,120,121,122,124,125,126,127,128,129,130,131$, $134,140,141,142,143,144,145,147,149,150,151,152,153$, $154,155,156,157,158,159,160,161,162,163,164,165,166$, $169,170,171,172,175,176,178,179,180,181,182,184,185$, 
$186,188,189,190,191,192,193,194,196,197,198,199,200$, $201,203,204,206,207,208,209,211,212,213,214,215,216$, $217,218,219,220,221,228,229,234,236,237,239,240,241$, $242,243,244,247,248,249,250,251,252,253,255,256,257$, $258,259,260,261,262,263,264,265,266,269,270,271,272$, $273,274,279,281,282,283,284,285,286,287,288,289,290$, 291, 292, 294, 296, 297, 298, 299, 301, 302, 303, 306, 324, 326, $327,328,331,332,333,334,336,337,338,339,340,341,342$, $343,344,345,347$

Cidade 30, 32, 40, 41, 298, 300, 301

Cidade Alta 176, 179, 185, 192, 193, 199, 201, 206, 208, 213, 214, 219, $221,234,237,240,242,249,250,251,252,254,257,263,273$, $286,287,288,294,295,298$

cidade antiga 43, 77, 87, 172, 272

cidade árabe 91

Cidade Baixa 176, 178, 179, 180, 186, 188, 192, 193, 194, 199, 201, 204, $205,206,207,208,209,211,213,214,218,219,221,234,235$, $236,237,238,239,240,242,249,250,251,252,254,273,286$, $287,288,294,302,310$

cidade balneário 209

cidade burguesa $46,57,59,62,64,68,82,125,142$

cidade capital 102, 122, 124, 152, 241

cidade colonial $30,31,45,87,91,92,96,115,124,131,145,150,164$, $181,187,214,215,221,247,279$

cidade colonial e escravista 31

cidade comercial 196

cidade do Salvador 31

Cidade do Salvador. See Consulte Salvador

Cidade do Samba 301

cidade escravista 96

cidade européia 94, 144

cidade haussmanniana 76, 77, 271

cidade ideal $49,75,168,169,259,342$

cidade industrial $44,45,48,49,58,60$

cidade jardim 271

cidade latino-americana 45

cidade liberal 59,83

cidade medieval 45

cidade moderna $57,75,95,124,130,131,144,150,159,168,169,204$, $209,215,244,250,268,284$

cidade nova 26

Cidade Nova 94, 97, 102, 144, 147, 256, 284, 292, 293, 294

cidade portuária $211,212,276$

cidade pós-liberal 59

cidades $25,26,27,28,29,30,31,32,37,38,39,40,41,42,44,45,46$, $47,48,49,51,52,53,54,55,56,57,58,59,60,61,65,68,71$, $73,76,82,83,85,87,92,96,106,114,122,143,147,153,154$, $161,162,170,176,179,182,185,188,191,200,201,247,250$, $258,259,260,261,263,268,269,270,271,273,274,276,281$, $282,283,303,324,325,329,333,334,337,338,341,342,343$,

Cidades 52 $345,346,347$

cidades anglo-saxônicas 54

cidades antigas 172

cidades brasileiras 28, 104, 112, 181, 185, 247, 252, 259, 261, 276, 279, $324,329,333,334,337,338,341,342,343,345,347$ 
cidades capitais 57

cidades coloniais 258, 273

cidades europeias 229

cidades européias 44, 47, 51, 53, 54, 56, 60, 109, 116, 118, 124, 248, 249, 268,279

cidades francesas $84,85,86$

cidades industriais 37

cidades industrializadas 54

cidades-jardins 263

cidades latino-americanas 55

cidades medievais 63, 65, 101

cidades modernas 122

cidades portuárias 37,188

Cidades portuárias 282

cidade suja 119, 197, 201

Cidade Velha 102, 113, 128, 134, 149, 337

City Beautiful 51, 52, 85, 86, 154, 169, 348

City Planning 50, 154

classe perigosa $128,144,184$

classes populares 38, 324

classes sociais $26,44,45,46,48,96,164,244,300$

Comércio 294, 295, 302, 303, 316, 319

Comissão Construtora da Avenida Central 134, 137

Comissão de 1875 149, 153

Comissão de Melhoramentos 118, 337

Comissão de Obras do Porto 140

Companhia Docas do Rio de Janeiro 140

Complexo Petroquímico de Camaçari 287

conjunto urbano 205

COPEC 287, 288

Corredor Cultural 282, 285, 289, 290, 291, 292, 293, 300, 315

Corso Vittorio Emmanuele 268

cortiço 45, 97, 147, 293, 295

cortiços 54, 64, 97, 98, 106, 114, 127, 128, 129, 147, 158, 229, 242, 270, $274,293,326$

crescimento urbano 37, 40, 43, 46, 52, 96, 104, 153, 155, 194, 213

D

desenho urbano 85,86

desenvolvimento urbano 48, 296

Diógenes Rebouças 266, 288

discurso urbanístico 38, 336

Distrito da Sé 179, 197, 218, 221, 222, 223, 228, 229, 242, 243, 254, 257

Distrito Federal 121, 126, 134, 142, 156, 331, 338, 340

Docas da Bahia 235

\section{E}

Ebenezer Howard 149, 263, 271

École de Beaux-Arts 137 
edifício-viaduto $154,171,172$

embelezamento $51,54,65,72,73,84,86,87,114,120,122,143,148$, $150,154,155,156,157,162,163,221,240,255$

embelezamentos haussmannianos 85

Empresa de Melhoramentos do Brasil 140

EPUCS 262, 265, 266, 287, 288

equipamentos urbanos 43, 63, 99, 168

era industrial $41,48,50,59$

Escola de Chicago 265, 266, 285, 287

Escola Nacional de Belas Artes 53, 134, 135, 143, 163

escravos de ganho 92, 96, 186, 187

escravos domésticos 92, 96

Escritório de Planejamento Urbano da Cidade de Salvador 287

espaço haussmanniano 77

espaços públicos 54, 78, 94, 107, 111, 142, 143, 168, 215, 240, 282, 283, $289,291,299,300,301$

Espaços públicos 281

espaços urbanos 54,107

espaço urbano $28,29,30,37,38,41,44,56,64,65,72,78,84,85,94$, $99,101,102,104,110,112,113,115,116,119,124,125,126$, $134,142,145,154,159,165,172,187,241,244,259,276,283$, $284,288,289,292,294$

Esplanada do Castelo 155, 158, 160, 161, 162, 166, 284

Estado da Guanabara 285

Estados Unidos 40, 50, 51, 53, 85, 108, 116, 154, 215, 262, 263, 264, 266

estética 50, 51, 52, 54, 57, 59, 65, 77, 78, 80, 83, 86, 87, 118, 128, 143, $144,162,164,169,172,204,214,215,216,218,219,221,237$, $239,240,247,253,255,256,258,259,261,263,264,274,276$, 277

estratégia urbanística 62

estruturação urbana $28,45,46$

estrutura social $46,95,184,185$

estruturas sociais 44

estruturas urbanas $54,71,188,216$

estrutura urbana $39,41,43,44,45,47,78,79,82,85,124,125,150,151$, $153,156,187,209,212,213,220,240,244,247,288$

Estrutura urbana 44

Europa 26, 37, 40, 50, 51, 52, 53, 54, 55, 69, 70, 75, 85, 87, 94, 95, 105, $107,116,148,152,153,215,218,235,241,242,247,251,259$, $262,263,269,270,325,327,328,331,339,341,346$

evolução urbana $52,156,192,248,331$

expansão urbana 81,101,104, 112, 116, 130, 194, 200, 258, 288

Exposição Universal 87, 158, 160, 161, 284

exposições universais 83

$\mathbf{F}$

fato urbano 48

favela 147

favelas $45,128,141,147,156,159$

fenômeno urbano 38, 39, 40

formas espaciais 44

forma urbana $28,43,82,83,121,151,158,234,249,273,336$ 
Francisco Bicalho 131, 140, 152

Fundação Pelourinho 295, 296

\section{G}

gestão urbana 50

Giuseppe Fogliani 119

Grandjean de Montigny 113, 148, 153

Gran Vía de Madri 268

\section{H}

Haussmann 25, 26, 29, 32, 46, 49, 51, 55, 61, 62, 63, 67, 68, 71, 76, 77, $78,80,82,83,84,86,87,116,118,122,126,137,143,147$, $148,149,150,151,152,153,154,168,169,172,249,250,251$, $270,271,272,276,305,324,328,330,332,334,338,339,346$

haussmannianas $51,85,249,269,270,342$

haussmannização $25,29,30,32,55,68,78,79,80,83,84,85,86,87$, $151,153,250,251,271,272,274,276,279$

história da cidade $28,38,39,41,48,178,330$

História da Cidade 30, 40, 41, 44

história do urbanismo 48, 50

História Urbana 40, 41

\section{I}

ideologia do progresso 216, 248

Igreja da Sé 222, 234, 242, 250, 253, 254, 257, 258, 287

Iguatemi 287, 288, 294, 302, 303, 316

Ildefons Cerdà 48, 271

industrialização 39, 40, 41, 50, 54, 190, 191, 282

infra-estrutura $25,43,55,61,62,72,76,86,96,109,110,121,126,144$, $145,152,156,163,190,196,203,209,211,216,221,236,243$, $249,251,260,264,270,272,274,276$

Inglaterra 40, 50, 51, 61, 74, 99, 105, 106, 121, 189, 209, 263, 328

insalubridade 48, 57, 61, 63, 64, 98, 111, 113, 114, 127, 143, 203, 214

Instituto do Patrimônio Histórico e Artístico Nacional 289

International Style 285

intervenção 30, 48, 49, 50, 53, 54, 55, 56, 59, 60, 61, 64, 67, 70, 73, 78, $79,80,81,84,85,86,87,95,105,112,113,114,118,119,125$, $130,134,140,141,142,148,149,151,155,159,162,163,212$, $213,216,217,228,229,240,250,252,253,254,256,261,267$, $268,269,271,272,274,292,295,297,299,301,334,339$

intervenções $25,26,28,29,30,31,38,39,49,50,53,54,55,59,60,61$, $62,63,64,65,67,69,70,71,75,76,77,79,80,82,84,85,95$, $113,116,118,120,122,124,126,131,144,145,149,151,152$, $153,154,155,156,170,181,207,209,210,212,213,217,218$, 220, 221, 222, 224, 227, 229, 230, 235, 237, 241, 243, 247, 248, 249, 250, 251, 252, 253, 254, 255, 258, 261, 266, 267, 269, 270, $271,272,273,274,276,306,308,347$ 
intervenções haussmannianas 77, 83, 149

intervenções públicas 28,29

IPAC 32, 295, 297, 298

IPHAN 289, 297

J

Jerônimo Teixeira de Alencar Lima. See Consulte Alencar Lima J. J. Seabra 303. See also Consulte Seabra

José Joaquim Seabra. See Consulte Seabra

$\mathbf{L}$

Ladeira da Montanha 208, 237

Lapa 254, 284, 289, 290, 292, 293, 294, 300, 318

Le Corbusier 30, 95, 154, 158, 161, 162, 169, 170, 171, 172, 173, 266, $284,287,307,336,338,339$

limpeza urbana $111,203,262$

Lisboa 54, 91, 102, 176, 192, 205

Londres 40, 41, 51, 54, 55, 57, 59, 60, 63, 64, 65, 68, 74, 75, 82, 86, 96, $106,124,126,196,200,211,266,268,324,348$

Lúcio Costa 26, 27

Luís Napoleão 59, 68, 74, 75

M

Madri 268

malha urbana $80,85,103,108,118,134,154,155,156,193,220,237$, $240,243,249,250,267,273,279$

mão de obra escrava 282

mão-de-obra escrava 29, 31, 92, 95, 121, 181, 188, 196, 216, 274

Marselha 269

Medicina Social 111,143

meio de transporte 107, 109, 198, 199, 200

meios de comunicação 42, 56

meios de transporte 43, 54, 57, 63, 103, 108, 142, 153, 196, 201, 214, 215, $224,240,249,266,273$

metrópoles latino-americanas 42

Missão Francesa 53, 94, 113, 148

mobiliário urbano 49, 209, 251, 272

modelo 25, 29, 30, 31, 32, 45, 51, 52, 55, 59, 61, 67, 68, 69, 75, 76, 82, $83,84,85,86,91,113,115,116,118,122,147,148,151,153$, $154,167,168,176,206,218,219,247,248,250,252,262,264$,

$265,270,271,272,276,279,288,291,297,298,327,328,334$

modelo francês 86,279

modelo geométrico 129

modelo haussmanniano $80,84,85,87,150,154,259,267,270,271,272$, 279

modelo parisiense 268,270

modelo pombalino 205 
modelos 31, 39, 49, 54, 68, 125, 147, 151, 155, 164, 168, 215, 247, 266, $267,269,276,333,334,339$

Modelos 51

modelos urbanos 29, 279, 339

modelo urbano 29, 251, 272, 285

modernidade $45,47,57,83,85,124,134,145,150,151,160,168,204$, $213,215,218,235,241,249,279,303,338,342,347$

modernização $28,29,30,31,40,78,79,82,87,105,122,131,137,144$, $148,196,199,204,206,207,216,247,252,257,271,272,276$, 282, 283, 324, 329, 331, 333, 334, 337, 338, 339, 341, 342, 343, 345,347

modo de vida 37, 38, 77, 103, 142, 181, 194, 214, 218, 267

modos de vida 28, 31, 45, 56, 125, 240

morfologia 43, 81, 115, 259, 270

Morfologia 43

morfologia urbana 85

Morro do Castelo 93, 95, 100, 104, 114, 140, 154, 157, 158, 160, 161, 162, 284

movimento moderno 26

Movimento Moderno 17, 18, 285

N

Napoleão III 25, 62, 63, 66, 67, 68, 75, 152

negros livres 92

novas urbanizações 45, 252, 255, 276

núcleo urbano 100, 178

\section{0}

Opéra $81,143,273$

organização espacial 40, 44, 48

o século XIX 25, 26, 39, 45, 46, 48, 59, 282, 289, 325

$O$ século $X I X 38$

\section{$\mathbf{P}$}

paisagem urbana $46,65,71,77,272,294$

países latino-americanos 42, 269

Paralela 287, 294

Paris $25,26,29,30,31,32,40,46,47,49,50,51,54,55,57,59,60$, $61,62,63,64,65,66,67,68,69,70,71,72,73,74,75,76,78$ $79,82,83,84,85,86,87,96,106,107,114,116,118,119,122$, $124,125,126,134,137,142,143,147,148,149,150,151,152$, $153,154,168,169,171,196,205,234,248,249,250,251,266$, 267, 268, 270, 272, 273, 274, 275, 276, 277, 278, 279, 285, 305, $312,324,327,328,330,331,332,333,334,336,337,338,339$, $340,341,342,346$

Paris haussmanniana 26, 46, 55, 68, 79, 84, 87, 271, 272, 279

parkways 287 
Parque Histórico do Pelourinho 296

Patrimônio Cultural da Humanidade 289

patrimônio histórico 262, 285, 289, 290, 298

Paulo de Frontin 134, 140, 152, 160

Pelourinho 89, 180, 242, 251, 295, 297, 298, 299, 301, 318

Pereira Passos 30, 31, 116, 119, 121, 122, 125, 126, 127, 129, 145, 148, $149,150,151,152,153,154,155,157,159,168,248,251,258$, $276,292,306,326,328,344,347$

perímetro urbano 203, 263

período colonial 42, 100

Place Vendôme 70, 137, 205

PLANDURB 288

planejamento urbano 50, 129, 204

Planejamento Urbano 32, 287

Plano Agache 168, 169

Plano de Desenvolvimento Urbano 288, 296

plano de expansão 117, 153, 262, 273, 276

plano de extensão 55, 56

Plano de Melhoramentos da Cidade 122

Plano de Reabilitação do Centro Antigo de Salvador 282

plano de reforma 55, 114, 152, 276, 287

Plano Estratégico 291, 298

plano regulador 50,55

planos de reforma 55, 268

planos de regularização 54

planos urbanísticos $61,71,101,161$

plano urbanístico 116, 148

plano urbano 261

Plaza de Mayo 270

população urbana 42, 121, 285

Porta do Brasil 160, 166, 167, 169

Porto do Rio 124, 131, 141

Porto Maravilha 301

Prado Júnior 158, 160, 162, 163

Pré-urbanismo 49

processo de urbanização 38, 39, 41, 42

processos urbanos 30, 39, 40, 42

Programa Monumenta 299

Projeto de Alinhamento 127

Projeto de Reforma e Recuperação do Centro Histórico 297, 302

Projeto SAGAS 292

projetos urbanísticos 31, 216, 293

projeto urbano 50,87

proletariado urbano 185

\section{Q}

questão urbana $30,39,53,56,340,343$

questões urbanas 50, 52, 261

questões urbanísticas 37 


\section{$\mathbf{R}$}

Rambuteau 67, 73, 75

redes urbanas 41

reforma carioca 31

reforma parisiense $30,68,251,279$

reforma Passos 144

Reforma Passos 125, 126, 141, 145, 147, 148, 153, 155, 164, 212, 241

reformas haussmannianas 82

reformas parisienses 30,67

reformas urbanas $25,29,30,37,39,53,54,55,56,57,60,65,66,68,85$, $95,119,193,247,253,258,267,270,273,274,276,279,312$, 347

reforma urbana $25,28,29,30,31,56,68,87,95,121,122,126,129,141$, $143,147,154,155,162,178,204,212,213,216,218,220,234$, $237,239,247,248,250,279,329,334,337,338,344$

renovação urbana $85,128,155,291$

residências operárias 44,98

Revolução Industrial 26, 37, 48, 58, 76

Rio 29, 30, 31, 32, 53, 92, 94, 95, 96, 98, 99, 100, 102, 103, 105, 106, $108,109,111,112,116,119,120,123,124,125,127,132,139$, $141,144,145,148,149,150,151,152,153,154,155,156,157$, $158,159,160,161,162,163,164,165,166,167,169,170,172$, $185,188,197,212,225,233,234,237,241,243,248,250,251$, $252,261,273,274,275,276,277,278,279,281,282,283,284$, $285,289,293,299,300,306,307,312,324,325,326,327,328$, $329,330,331,333,334,335,336,337,338,339,340,341,342$, $343,344,345,346,347,348$

Rio Cidade 291

Rio de Janeiro 26, 29, 30, 31, 32, 40, 52, 53, 57, 60, 84, 91, 92, 93, 94, $95,99,100,103,104,106,107,111,113,114,115,120,121$, $122,123,124,125,128,132,139,141,143,144,147,148,153$, $158,159,161,162,163,166,167,170,171,176,178,187,189$, 190, 197, 217, 219, 247, 258, 265, 267, 272, 274, 275, 276, 277, $278,279,282,283,285,289,290,294,299,303,306,307,312$, $324,325,326,327,328,329,330,331,333,334,335,336,337$, $338,339,340,341,342,343,344,345,346,347,348$

Rodrigues Alves 100, 122, 124, 126, 131, 140, 148, 150, 212, 217, 218, 248,283

Roma 40, 54, 65, 68, 72, 86, 113, 119, 268, 325, 328, 344

Rua Chile 224, 227, 228, 242, 257, 286, 303

Rua da Vala 194, 208, 242

ruas haussmannianas 79

Rue de Rivoli 64, 67, 71, 72, 75, 85, 114, 119, 137, 205

\section{S}

salubridade $68,72,98,106,111,112,113,114,117,120,125,197,203$, $204,214,216,221,237,239,240$

Salvador $29,30,31,32,40,52,53,60,94,100,102,175,176,177,178$, $180,181,183,184,185,187,188,189,190,191,192,193,194$, $195,196,197,199,200,201,203,204,205,206,207,209,212$, $214,215,217,219,220,221,228,234,236,237,241,242,243$, $244,247,248,249,250,251,252,253,258,260,261,263,265$, $266,267,268,269,272,273,274,275,276,277,278,279,282$, 
283, 286, 287, 288, 289, 294, 295, 297, 298, 299, 301, 302, 303, $308,309,310,311,312,324,325,326,327,329,331,333,334$, $335,337,338,339,340,341,342,343,344,345,346,347$

saneamento $37,53,75,86,100,111,114,119,120,122,125,127,128$, $129,130,140,142,143,150,157,163,165,166,169,198,203$, $214,219,221,248,253,258,259,260,266,283,295,297$

Saturnino de Brito 26, 56, 197, 253, 258, 259, 260, 266, 336

Sé 176, 180,185, 186, 187, 192, 209, 222, 224, 254, 287, 339

Seabra 31, 212, 216, 217, 218, 219, 224, 230, 235, 239, 240, 244, 247, $248,249,253,254,257,258,266,308,329,335$

século XIX 25, 26, 28, 29, 30, 31, 37, 38, 39, 40, 42, 44, 45, 46, 47, 48, $49,51,54,55,56,57,58,59,60,61,62,63,65,68,72,77,81$, $83,85,87,91,92,95,96,98,99,102,103,104,105,106,108$, $109,110,113,116,119,121,122,125,126,128,137,148,149$, $150,153,158,161,162,169,176,178,179,180,181,182,185$, $186,189,190,191,192,193,194,196,198,199,200,204,206$, $207,208,209,210,212,215,216,224,236,247,248,249,252$, $255,258,259,269,270,272,274,282,289,324,326,327,329$, $330,333,335,337,338,343$

século XVIII 37, 39, 51, 54, 65, 70, 71, 73, 79, 81, 93, 101, 102, 104, 107, $114,169,176,189,193,204,206,249,299,329,347$

século XX 25, 26, 28, 29, 30, 31, 39, 40, 42, 46, 47, 48, 50, 51, 55, 84, $87,92,94,95,100,104,108,112,119,120,146,149,153,154$, $161,162,185,186,187,191,192,193,194,195,197,212,214$, $216,217,224,226,230,235,241,247,249,252,253,270,272$, $281,282,283,285,286,293,299,303,333,347$

segregação espacial 43,45

segregação social 44, 45, 82, 141, 243, 244, 272, 276

Semana 261, 262, 263, 265

Semana de Urbanismo 52, 253, 258, 261, 262, 264, 265, 266, 327, 340, 345. See also Consulte "Semana"

serviços urbanos 56, 92, 95, 120, 204, 212

sistema urbano 41

Sisto 54

Sisto $\mathrm{V} 68$

sociedade burguesa $82,84,271$

sociedade industrial $48,49,56,269$

sociedade urbana 43,44

\section{T}

Teatro Municipal 131, 134, 136, 143, 163

tecido urbano $25,30,53,60,61,76,78,80,114,124,140,144,234,249$, $250,254,271,272,273,296$

Teleporto 293, 294

teoria dos miasmas 39

teorias urbanas 29

teorias urbanísticas $39,47,51,149$

teoria urbanística 50

Theodoro Sampaio 197, 198, 216, 221, 255, 256, 260, 261, 288

tipo haussmanniano 84

traçado colonial 29, 279

traçado urbano 130, 214, 236, 247, 259, 273, 293

tradições urbanísticas 30, 92 
trama urbana 224

transformação urbana 43, 47, 50, 54, 92

transformações urbanas 47, 85, 270, 326

Túnel Américo Simas 288

\section{U}

UNESCO 289, 290

urbanismo 27, 31, 48, 49, 50, 51, 52, 53, 55, 65, 71, 82, 113, 125, 141, $150,154,155,160,162,163,164,168,169,170,216,237,248$, $253,258,259,261,262,263,264,266,271,287,288,290,325$, $327,329,331,332,333,335,336,338,339,340,343,344,345$ Urbanismo 32, 38, 39, 40, 47, 48, 49, 52, 53, 155, 157, 158, 162, 163, $261,262,322,325,327,329,333,337,338,339,340,343,346$

urbanismo brasileiro 53, 276

urbanismo demolidor 217, 249, 253, 266

urbanismo europeu 31, 259

urbanismo guzmaniano 270

urbanismo haussmanniano 67

urbanismo moderno 48, 65, 169, 327, 329, 336, 338, 339, 344

Urbanismo moderno 48

urbanismo regulador 270

urbanística 37, 48, 49, 50, 53, 55, 62, 67, 70, 73, 113, 124, 196, 205, 258, $259,262,339,340$

urbanística moderna 50, 55

urbanização 26, 38, 39, 40, 41, 42, 45, 46, 50, 52, 58, 100, 110, 155, 156, $157,207,213,236,237,252,255,256,268,274,286,330,335$, $340,343,345$

Urbanização 41

urbanização brasileira 42

urbano $43,44,46,47,48,49,50,52,53,54,55,56,57,58,60,64,65$, $67,68,72,75,80,96,112,113,126,128,131,151,153,154$, $155,169,196,243,259,269,270,272,273,282,286,287,288$, $289,293,294,296,302,324,327,328,329,332,334,336,338$, $339,341,343,345,347$

uso do solo $37,43,44,58,292,345$

\section{V}

vida urbana 40, 47, 54, 56, 76, 83, 156

Viena $51,55,57,59,60,65,116,124,134,343$

vilas operárias $98,102,166$

Z

Zona Norte 109, 130, 131, 171, 292, 300

zonas industriais $45,48,145,152,273$

zona sul 289

Zona Sul 109, 130, 141, 144, 156, 163, 164, 171, 252, 300

zoning 51, 157, 165, 169, 262, 263, 334 
Esta obra foi publicada no formato $180 \times 230 \mathrm{~mm}$ utilizando a fonte NewsGoth e Bodoni Impressão e Acabamento da Cian Gráfica Papel Pólen Soft $80 \mathrm{~g} / \mathrm{m}^{2}$ para o miolo e Papel Triplex $350 \mathrm{~g} / \mathrm{m}^{2}$ para a capa Tiragem de 600 exemplares 